\title{
Publiekrechtelijke grensoverschrijdende samenwerking tussen decentrale overheden : juridische aspecten van publiekrechtelijke afspraken tussen Nederlandse decentrale overheden en hun 'counterparts' in Belgie en Duitsland
}

Citation for published version (APA):

Seerden, R. J. G. H. (1993). Publiekrechtelijke grensoverschrijdende samenwerking tussen decentrale overheden : juridische aspecten van publiekrechtelijke afspraken tussen Nederlandse decentrale overheden en hun 'counterparts' in Belgie en Duitsland. [Doctoral Thesis, Maastricht University]. Maklu. https://doi.org/10.26481/dis.19931217rs

Document status and date:

Published: 01/01/1993

DOI:

10.26481/dis.19931217rs

Document Version:

Publisher's PDF, also known as Version of record

Please check the document version of this publication:

- A submitted manuscript is the version of the article upon submission and before peer-review. There can be important differences between the submitted version and the official published version of record. People interested in the research are advised to contact the author for the final version of the publication, or visit the DOI to the publisher's website.

- The final author version and the galley proof are versions of the publication after peer review.

- The final published version features the final layout of the paper including the volume, issue and page numbers.

Link to publication

\footnotetext{
General rights rights.

- You may freely distribute the URL identifying the publication in the public portal. please follow below link for the End User Agreement:

www.umlib.nl/taverne-license

Take down policy

If you believe that this document breaches copyright please contact us at:

repository@maastrichtuniversity.nl

providing details and we will investigate your claim.
}

Copyright and moral rights for the publications made accessible in the public portal are retained by the authors and/or other copyright owners and it is a condition of accessing publications that users recognise and abide by the legal requirements associated with these

- Users may download and print one copy of any publication from the public portal for the purpose of private study or research.

- You may not further distribute the material or use it for any profit-making activity or commercial gain

If the publication is distributed under the terms of Article $25 \mathrm{fa}$ of the Dutch Copyright Act, indicated by the "Taverne" license above,

Download date: 26 Apr. 2023 
Publiekrechtelijke grensoverschrijdende samenwerking tussen decentrale overheden 
Van dit proefschrift verschijnt een handelseditie in de lus Commune Reeks onder ISBN $9062154085, \mathrm{D} / 1993 / 1997 / 31$, NUGI 692 


\title{
Publiekrechtelijke grensoverschrijdende samenwerking tussen decentrale overheden
}

\author{
Juridische aspecten van publiekrechtelijke afspraken \\ tussen Nederlandse decentrale overheden en \\ hun "counterparts" in België en Duitsland
}

\section{PROEFSCHRIFT}

ter verkrijging van de graad van doctor aan de Rijksuniversiteit Limburg te Maastricht, op gezag van de Rector Magnificus, Prof.dr. H. Philipsen, wolgens het besluit wan het College van Dekanen, in het openbaar te verdedigen op vrijdag 17 december 1993 om 12.00 uur

door

Renế Jacques Gerardus Helène Seerden 
Promotor: $\quad$ Prof.mr. A.Q.C. Tak

Beoordelingscommissie: Prof.mr. C. Flinterman (voorzitter)

Prof.mr. M.G. Faure

Prof.mr. J.H. Jans 
Ter raogedachtenis aan mièn wader Vasor mien moder

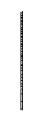


De tekst van dit proerschrift is afgesloten begin augustus 1993. 


\section{Inhoud}

Inhoudsopgave $\ldots \ldots \ldots \ldots \ldots \ldots \ldots \ldots \ldots \ldots \ldots \ldots$ VII

Lijst van afkortingen $\ldots \ldots \ldots \ldots \ldots \ldots \ldots \ldots \ldots \ldots$ XVII

\section{Hoofdstuk I}

Algemene inleiding $\ldots \ldots \ldots \ldots \ldots \ldots \ldots \ldots \ldots \ldots \ldots$

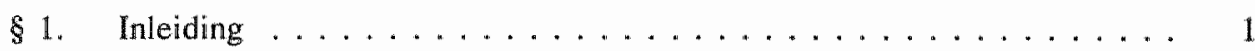

§ 2. Probleemstelling . . . . . . . . . . . . . . . 3

A. NADERE TOELICHTING BI DE PROBLEEMSTELLING . . . . . . 4

B. DEFINIËRING VAN DE BELANGRIJKSTE BEGRIPPEN

UIT DE PROBLEEMSTELLING $\ldots \ldots \ldots \ldots \ldots \ldots \ldots$

\$3. Plan van behandeling $\ldots \ldots \ldots \ldots \ldots \ldots \ldots$

\section{Hoofdstuk 2}

Internationaalrechtelijke aspecten van grensoverschrijdende samenwerking tussen decentrale overheden $\ldots \ldots \ldots \ldots \ldots \ldots \ldots \ldots \ldots$

$\$ 1$ Inleiding $\ldots \ldots \ldots \ldots \ldots \ldots \ldots \ldots \ldots \ldots \ldots \ldots \ldots$

\$2. Decentrale overheden en het internationale recht $\ldots \ldots \ldots \ldots \ldots$

A. DECENTRALE OVERHEDEN ALS (PARTIËLE) SUBJECTEN VAN INTERNATIONAAL RECHT . . . . . . . . . . . 13

B. DECENTRALE OVERHEDEN EN HET GRONDWETTELIJK STELSEL VAN DE EXTERNE BETREKKINGEN . . . . . . . . . . . 18

\&3. Grensoverschrijdende overeenkomsten tussen decentrale overheden en het Weens verdrag inzake het verdragenrecht (WVV) . . . . . 21

4. Grensoverschrijdende publiekrechtelijke afspraken tussen decentrale overheden en internationale administratieve akkoorden 

A. INTERNATIONALE ADMINISTRATIEVE AKKOORDEN

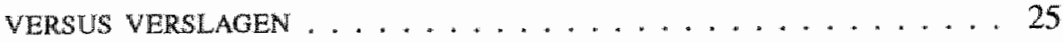
B. BEVOEGDHEID OM INTERNATIONALE ONEREENKOMSTEN

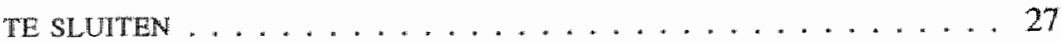
C. DE BNDENDE INTERNATIONAALRECHTELUKE STATUS VAN INTERNATIONALE ADMINISTRATIEVE AKKOORDEN . . . . . . . 31

\$ 5. Samenvatting en conclusies $\ldots \ldots \ldots \ldots \ldots$

\section{Moofdstuk 3}

Europese grondslagen voor decentrale grensoverschrijdende samenwerking . . . 39

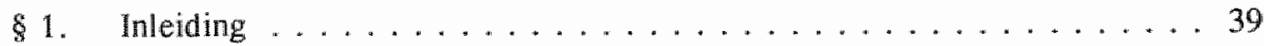

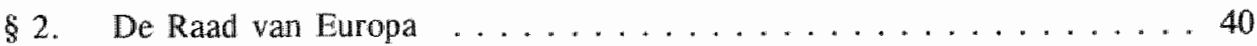

A. EUROPEAN OUTLINE CONVENTION OF TRANSFRONTIER CO-OPERATION BETWEEN TERRITORIAL COMMUNTTIES OR, AUTHORTTES (EOC) ........................ 40

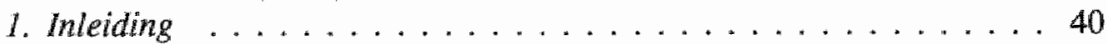

2. Ontstaan van de European Outline Convention .............4 41

3. Inhoud van de European Outline Convention ............. 42

4. Juridische siatus wan de European Outline Convention,

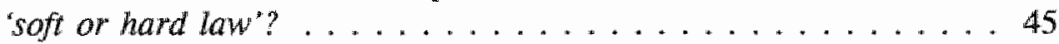

5. Inter-en nationaalrechtelijke dimensies van de European Outline Convention ................. 49

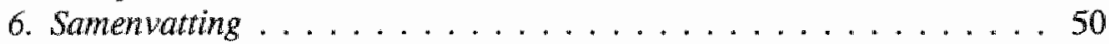

B. HET EUROPEES HANDVEST INZAKE LOKALE AUTONOMTE . . . . . . 51

\$3. De Europese Gemeenschappen $(\mathbb{E G}) \ldots \ldots \ldots \ldots \ldots$

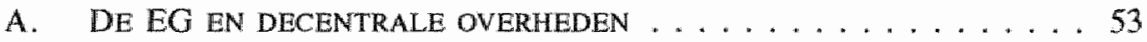

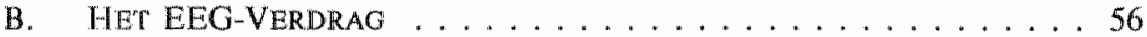

C. HET Verdrag betreffende de EuRopese UNIE . . . . . . . . . 58

D. HET SECUNDAIRE EG-MILIEURECHT .................. 59

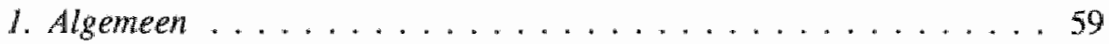

2. Decentrale grensoverschrijdende samenwerking inzake

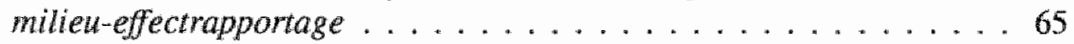

a. De richdijn inzake milieu-efiectrapportage . . . . . . . . 65

b. Nationale utvoeringswetgeving . . . . . . . . . . . . 66

E. ALGEMENE EUROPESE REGELGEVING INZAKE DECENTRALE GRENSOVERSCHRIJDENDE SAMENWERKING? . . . . . . . . 70

\$ 4. De Economische Commissie voor Europa van de Verenigde Naties (ECE) en de Organisatie voor Economische Samenwerking

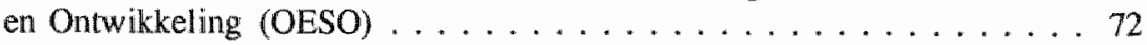

$\$ 5 . \quad$ Samenvatting en conclusies $\ldots \ldots \ldots \ldots \ldots$ 


\section{Hoofdstuk 4}

Het Belgische, Duitse en Nederlandse organieke recht

inzake decentrale overheden

\$1. Inleiding

\$ 2. Het Belgische organieke recht inzake decentrale owerheden . . . . . . . 78

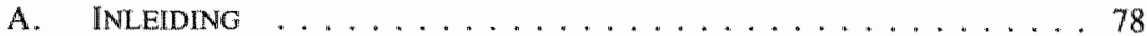

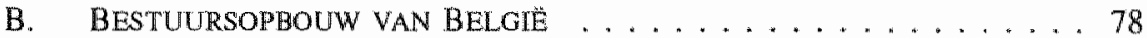

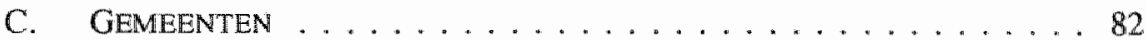

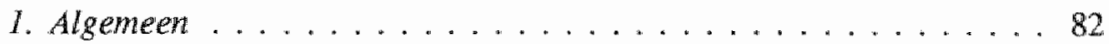

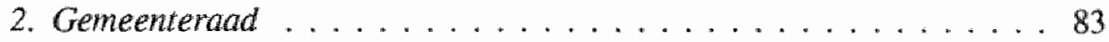

3. College van burgemeester en schepenen .............. 84

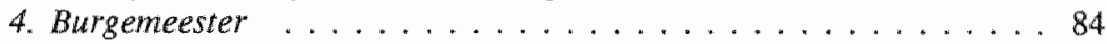

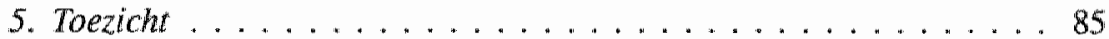

a. Vlaanderen ............................ 85

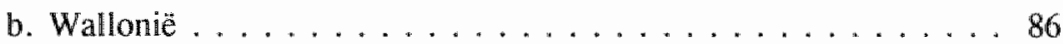

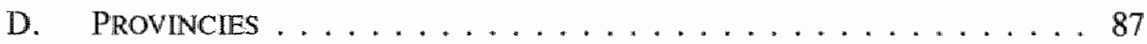

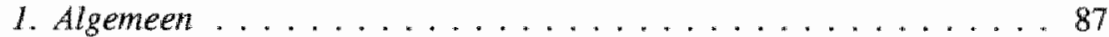

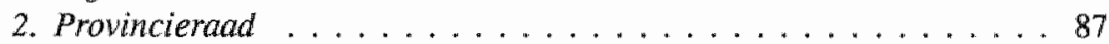

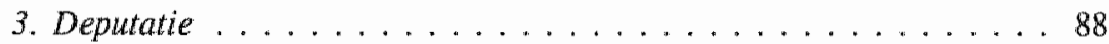

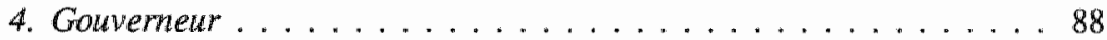

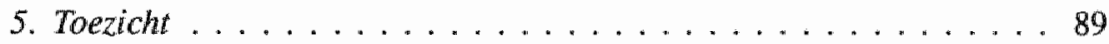

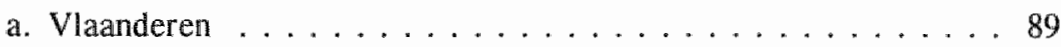

b. Wallonië . . . . . . . . . . . . . . . . . . . . . 89

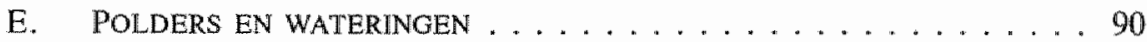

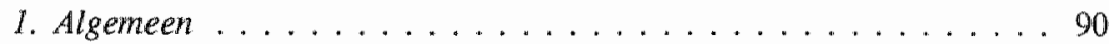

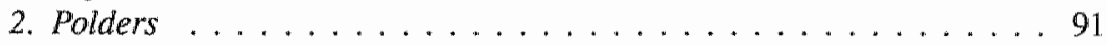

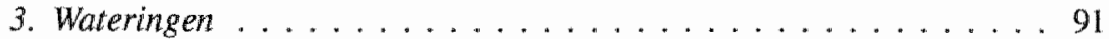

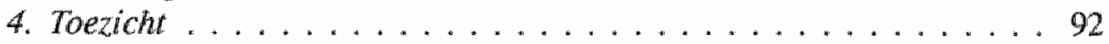

F. OPENBARE CENTRA VOOR MAATSCHAPPELIK WELZUN (O.C.M.W.'S) 92

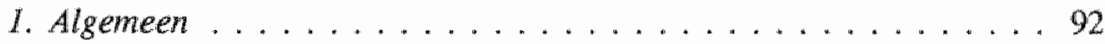

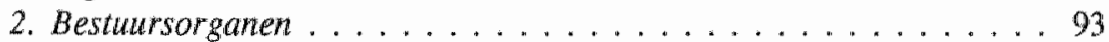

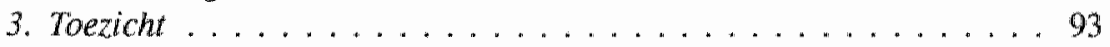

\$ 3. Het Duitse organieke recht inzake decentrale overheden . .......... 94

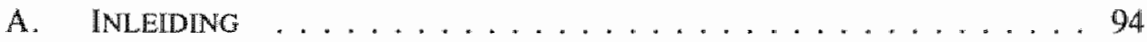

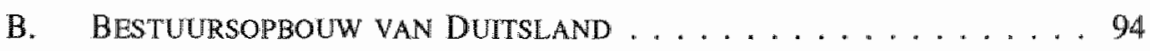

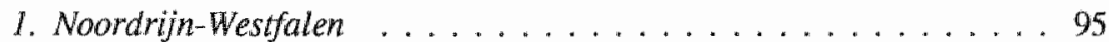

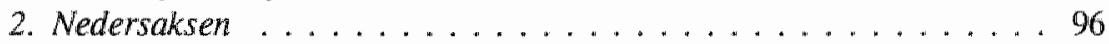

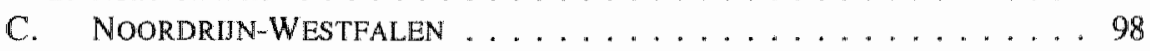

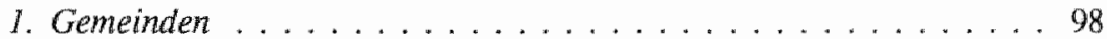

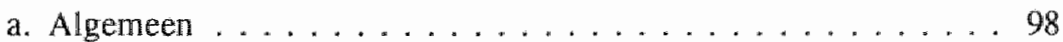

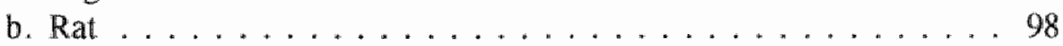

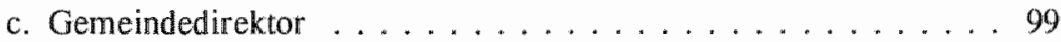

d. Toezicht ............................ 100 
2. Kreise .................... 101

a. Algemeen ....................... . . 101

b. Kreistag . . . . . . . . . . . . . . . . 101

c. Kreisausschuss . . . . . . . . . . . . . . . 102

d. Oberkreisdirector . . . . . . . . . . . . . 102

e. Toezicht ......................... . 102

3. Landschaftsverbände . . . . . . . . . . . . 102

a. Algemeen ....................... 102

b. Landschafts versammlung . . . . . . . . . . . . 103

c. Landschaftsausschuss . . . . . . . . . . . . . . 103

d. Direktor des Landschaftsverbandes . . . . . . . . . . . 103

e. Toezicht . . . . . . . . . . . . . . . . . . . . . . . 104

4. Kommunalverband Ruhrgebiet . . . . . . . . . . . . . 104

a. Algemeen ... . . . . . . . . . . . . . . . . . . . 104

b. Verbandsversammlung ............... 105

c. Verbandsausschuss . . . . . . . . . . . . . . 105

d. Verbandsdirektor . . . . . . . . . . . . . . . 105

e. Toezicht . . . . . . . . . . . . . . . . . . 106

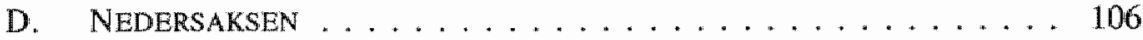

1. Gemeinden ... . . . . . . . . . . . . . . . . 106

a. Algemeen . . . . . . . . . . . . . . . . 106

b. Rat . . . . . . . . . . . . . . . . . . . 107

c. Verwaltungsausschuss $\ldots \ldots \ldots \ldots \ldots \ldots \ldots$

d. Gemeindedirektor . . . . . . . . . . . . . . . . . . . 108

e. Toezicht . . . . . . . . . . . . . . . . . . . . . . 108

2. Landkreise . . . . . . . . . . . . . . . . . . . 109

a. Algemeen . . . . . . . . . . . . . . . . . . . . . 109

b. Kreistag . . . . . . . . . . . . . . . . . . . . 109

c. Kreisausschuss . . . . . . . . . . . . . . . . 110

d. Oberkreisdirektor .................. 110

e. Toezicht . . . . . . . . . . . . . . . . . . . . 110

\$4. Het Nederlandse organieke recht inzake decentrale overheden $\ldots . .111$

A. INLEIDING . ....................... 111

B. BESTUURSOPBOUW YAN NEDERLAND ........... 111

C. GeMEenten . . . . . . . . . . . . . . . . . . . 112

1. Algemeen ........................ 112

2. Raad ........................... 113

3. College van burgemeester en wethouders $\ldots \ldots \ldots \ldots \ldots 114$

4. Burgemeester . . . . . . . . . . . . . . . . . 114

5. Toezicht . .................... 115

D. ProvincIes ..................... 116

1. Algemeen ...................... 116

2. Provinciale staten ................ 116

3. Gedeputeerde staten . . . . . . . . . . . . . . . . 117

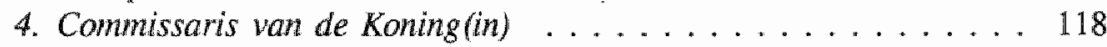




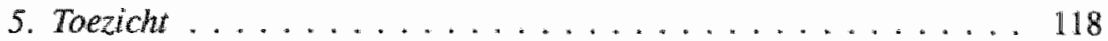

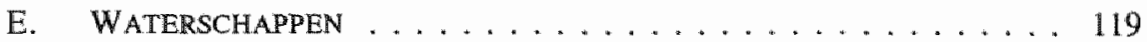

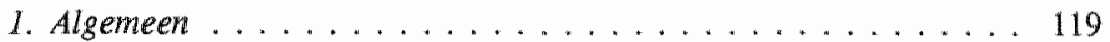

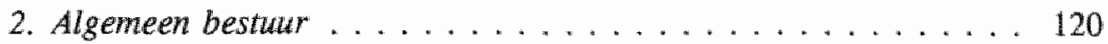

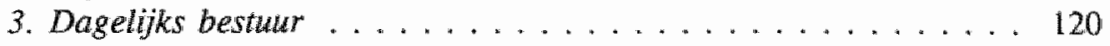

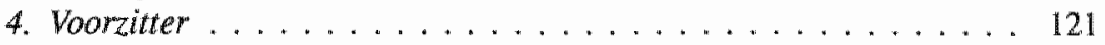

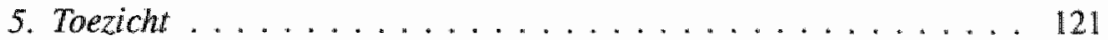

\& 5. Samenwattende vergelijking België, Duitsland en Nederland . . . . 122

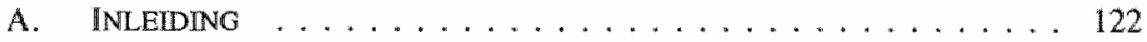

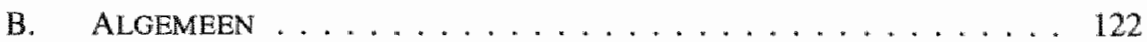

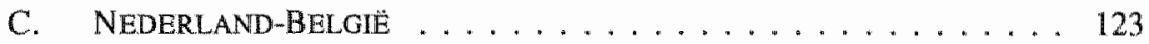

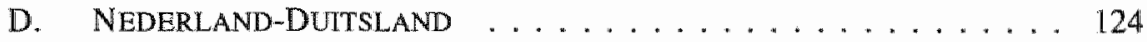

\section{Hoofdstuk 5}

Nederland-België . . . . . . . . . . . . . . . . . . . 127

1. Inleiding ......................... 127

\$2. Het Nederlandse recht inzake samenwerking tussen decentrale overheden 128

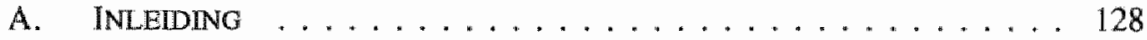

B. SAMENWERKING TUSSEN GEMEENTEN, PROVINCIES

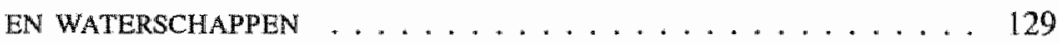

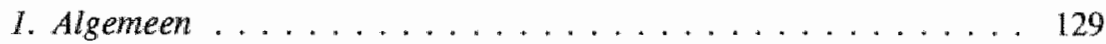

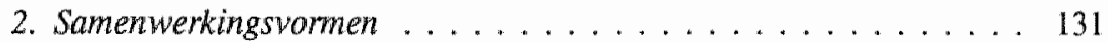

3. Toezicht en geschillenbeslechting ..............133

4. Wijziging van de Wet gemeenschappelijke regelingen ........ 134

\$3. Het Belgische recht inzake samenwerking tussen decentrale overheden . 135

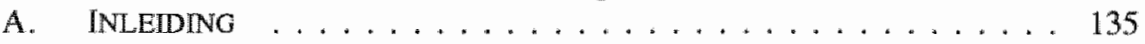

B. SAMENWERKING TUSSEN GEMEENTEN (EN PROVINCIES) . . . . . 136

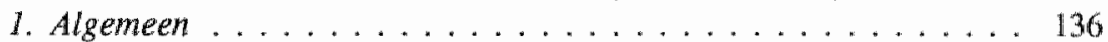

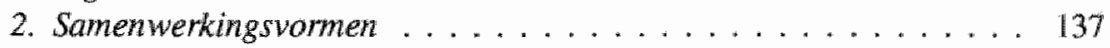

3. Toezicht en geschillenbeslechting ................ 139

C. SAMENWERKING TUSSEN POLDERS EN WATERINGEN ........ 140

D. SAMENWERKING TUSSEN OPENBARE CENTRA YOOR MAATSCHAPPELUKE WELZIJN $($ O.C.M.W.'S) . . . . . . . . . 141

E. AGGLOMERATIES EN FEDERATIES VAN GEMEENTEN . . . . . . . . 141

F. GEWESTEN (GEMEENSCHAPPEN) EN INTERCOMMUNALES . . . . . 142

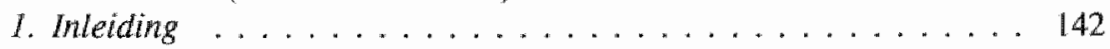

2. Algemeen ..................................... 143

3. Samenwerking tussen Vlaanderen en Wallonië ........... 143

4. Gewestgrenzen overschrijdende intercommunales .......... 145

G. WUZIGINGEN IN HET BELGISCHE DECENTRALE SAMENWERKIINGSRECHT $\ldots \ldots \ldots \ldots 6$ 
84. Samenwattende vergelijking decentrale samenwerking Nederland België

85. Benelux-Overeenkomst inzake grensoverschrijdende samenwerking tussen territoriale samenverwerkingsverbanden of autoriteiten (Benelux-Overeenkomst) . . . . . . . . . . . . . . . . . . . . 149

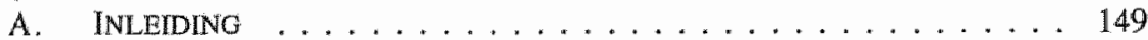

B. ONTSTAAN VAN DE BENELUX-OVEREENKOMST $\ldots \ldots \ldots \ldots 150$

C. INHOUD VAN DE BENELUX-OVEREENKOMST . . . . . . . 151

D. JURIDISCHE REIKWUDTE VAN DE BENELUX-OVEREENKOMST . . 152

1. Tot samenwerking gerechtigde overheden . . . . . . . 152

2. Samenwerkingsvormen .................. 153

3. Verwijzing naar het interne recht . . . . . . . . . . 159

4. Aanvullende werking .................. 161

5. Confrontatie van rechtsstelsels .............. 163

6. Geschillenbeslechting en (uniforme) interpretatie ......... 165

a. Geschillen tussen overheden ............... 165

b. Geschillen ussen overheden en burgers . . . . . . . . . . 169

c. Uniforme interpretatie van de Benelux-Overeenkomst . . . . 171

7. Benelux-Overeenkomst en de bepalingen in de Belgische Grondwet inzake externe betrekkingen en verdragssluiting . . . 173

a. Inleiding . . . . . . . . . . . . . . . . 173

b. De bepalingen in de Belgische Grondwet inzake externe betrekkingen en verdragssluiting . . . . . . . . . . 173

c. De Benelux-Overeenkomst en de bepalingen in de Belgische Grondwet inzake externe betrekkingen en verdragssluiting ... 174

d. De gewijzigde bepalingen in de Belgische Grondwet inzake externe betrekkingen en verdragssluiting $\ldots \ldots \ldots$.

$\$ 6 . \quad$ Overige tussen België en Nederland geldende regels inzake (decentrale) grensoverschrijdende samenwerking . . . . . . . 181

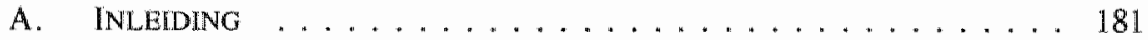

B. Overeinkomst TUSSEN HET Koninkritk DER NeDERLANDEN, HET KONINKRIJK BELGIË EN HET GROOTHERTOGDOM LUXEMBURG TOT INSTELLING VAN DE BENELUX-ECONOMISCHE UNIE (BENELUX-UNIEVERDRAG) . . . . . . . . . . . . . . .

C. OVEREENKOMST TUSSEN HET KONINKRIIK DER NEDERLANDEN, HET KONINKRIJK BELGIË EN HET GROOTHERTOGDOM LUXEMBURG OP HET GEBIED VAN NATUURBEHOUD EN LANDSCHAPSBESCHERMING ................

D. OVEREENKOMST TUSSEN HET KONINKRIK DER NEDERLANDEN EN HET KONINKRUK BELGIË INZAKE WEDERZUDSE BIJSTANDSVERLENING BIJ HET BESTRUIDEN VAN RAMPEN EN ONGEVALLEN $\ldots \ldots \ldots \ldots \ldots \ldots \ldots$ 
E. EERSTE AANVULLENDE OVEREENKOMST TER UTTVOERING VAN DE OVEREENKOMST TUSSEN HET KONINKRUK DER

NEDERLANDEN EN HET KONINKRUK BELGIË INZAKE

WEDERZIDDSE BISTANDSVERLENING BIJ HET BESTRUDEN

VAN RAMPEN EN ONGEVALLEN . . . . . . . . . . . 184

F. BESCHIKKINGEN/AANBEVELINGEN WAN HET COMITEE VAN

MINISTERS, WAARUIT INFORMATE/OVERLEGVERPLICHTINGEN

VOOR DECENTRALE OVERHEDEN VOORTVLOEIEN $\ldots \ldots \ldots \ldots . \ldots 184$

G. ONTWER MAASVERdRAG/SCHELdEVERDRAG .......... 185

$\S 7$. Samenvatting en conclusies $\ldots \ldots \ldots \ldots \ldots \ldots \ldots \ldots$

Hoofdstuk 6

Nederland-Duitsiand . . . . . . . . . . . . . . . . . . . . . 187

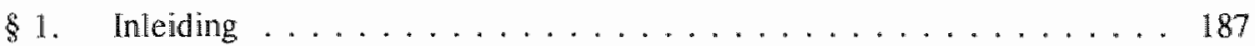

82. Het Duitse (Noordrijn-Westfaalse en Nedersaksische) recht inzake samenwerking tussen decentrale overheden . . . . . . . 188

A. HET NOORDRINN-WESTFAALSE RECHT INZAKE SAMENWERKING

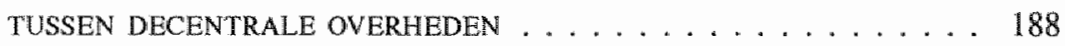

1. Inleiding . . . . . . . . . . . . . . . . 188

2. Samenwerking tussen Gemeinden en Kreise ........... 188

a. Algemeen . . . . . . . . . . . . . . . . . 188

b. Samenwerkingsvormen . . . . . . . . . . . . . 189

c. Toezicht en geschillenbeslechting . . . . . . . . . . . 191

B. HET NEDERSAKSISCHE RECHT INZAKE SAMENWERKING

TUSSEN DECENTRALE OVERHEDEN . . . . . . . . . . . 192

1. Inieiding . . . . . . . . . . . . . . . . . . . . . 192

2. Samenwerking tussen Gemeinden en Kreise .......... 192

a. Algemeen . . . . . . . . . . . . . . . . . . . . . . . 192

b. Samenwerkings vormen . . . . . . . . . . . . . . 192

c. Toezicht en geschillenbeslechting . . . . . . . . . . . 194

d. Vergelijking decentrale samenwerking Nedersaksen-

Noordrijn-Westfalen . . . . . . . . . . . . . . . . 194

C. LANDER EN DECENTRALE SAMENWERKNNG . . . . . . . . . 195

1. Inleiding . . . . . . . . . . . . . . . . . . . . 195

2. Samenwerking tussen Noordrijn-Westfalen en Nedersaksen ..... 195

3. Ländergrenzen overschrijdende decentrale samenwerking . . . . 196

\$3. Samenvattende vergelijking decentrale samenwerking

Duitsland-Nederland . . . . . . . . . . . . . . . . . . . 198 
\$4. Overeenkomst tussen het Koninkrijk der Nederlanden, de Bondsrepubliek Duitsland, het Land Nedersaksen en het Land Noordrijn-Westfalen inzake grensoverschrijdende samenwerking tussen territoriale gemeenschappen of autoriteiten (Duits-Nederlandse Overeenkomst) . . . . . . . . . . . 200

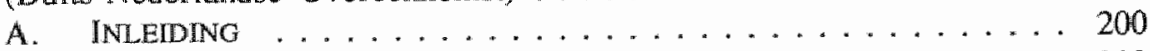

B. OntSTAAN VAN DE DUTTS-NEDERLANDSE OVEREENKOMST . . . . 200

C. INHOUD VAN DE DUITS-NEDERLANDSE OVEREENKOMST . . . . 201

D. JURIDISCHE REIKWUDTE VAN DE DUITS-NEDERLANDSE OVEREENKOMST . . . . . . . . . . . . . . 202

1. Tot samenwerking gerechtigde overheden . . . . . . . . 202

2. Samenwerkingsvormen . . . . . . . . . . . . . . 204

3. Verwijzing naar het interne recht .............. 208

4. Aanvullende werking . . . . . . . . . . . . . . 208

5. Confrontatie van rechtsstelsels . . . . . . . . . . . 209

6. Geschillenbeslechting .................. 211

a. Geschillen tussen overheden $\ldots \ldots \ldots \ldots \ldots \ldots \ldots 211$

b. Geschillen tussen overheden en burgers . . . . . . . . 212

7. De Duits-Nederlandse Overeenkomst en de bepalingen in het Grundgesetz inzake externe betrekkingen en verdragssluiting . . 214

a. Inleiding . . . . . . . . . . . . . . . . . . . 214

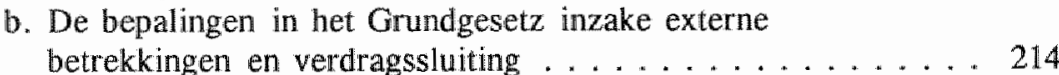

c. De Duits-Nederlandse Overeenkomst en de bepalingen in het Grundgesetz inzake externe betrekkingen en verdragssluiting . 219

d. De gewijzigde bepalingen in het Grundgesetz inzake externe betrekkingen en verdragssluiting $\ldots \ldots \ldots \ldots \ldots$

§5. Overige tussen Duitsland en Nederland geldende regels

inzake (decentrale) grensoverschrijdende samenwerking

A. VERdRAG TUSSEN het KONINKRIJK DER NEDERLANDEN EN DE BONDSREPUBLIEK DUITSLAND NOPENS HET VERLOOP VAN DE GEMEENSCHAPPELIJKE LANDSGRENS, DE GRENSWATEREN, HET GRONDBEZIT IN DE NABIHHEID VAN DE GRENS, HET GRENSOVERSCHRIJDENDE VERKEER OVER LAND EN VIA BINNENWATEREN EN ANDERE MET DE GRENS VERBAND HOUDENDE VRAAGSTUKKEN, MET BLLAGEN EN SLOTPROTOCOL (GRENSVERDRAG) . . . . . 223

B. EEMS-DOLLARDVERDRAG . . . . . . . . . . . . . . 227

C. OVEREENKOMST TUSSEN HET KONINKRUK DER NEDERLANDEN EN DE BONDSREPUBLIEK DUITSLAND INZAKE SAMENWERKING OP HET GEBIED VAN DE RUMMTELIJKE ORDENING . . . . . . 228

D. OVEREENKOMST TUSSEN HET KONINKRIJK DER NEDERLANDEN EN DE DEELSTAAT NOORDRINN-WESTFALEN BETREFFENDE SAMENWERKING BIJ DE STICHTING EN INRICHTING VAN EEN GRENSPARK MAAS-SWALM-NETTE . . . . . . . . . . 
E. OVEREENKOMST TUSSEN HET KONINKRIK DER NEDERLANDEN

EN DE BONDSREPUBLIEK DUTTSLAND INZAKE WEDERZUDSE BUSTANDSVERLENING BIJ HET BESTRIJDEN VAN RAMPEN, ZWARE ONGEVALLEN DAAR ONDER BEGREPEN, MET PROTOCOL . . . . . 229

\$6. Samenvatting en conclusies . . . . . . . . . . . . . . . . 229

\section{Hoofdstuk 7}

Samenvatting, conclusies en aanbevelingen $\ldots \ldots \ldots \ldots \ldots \ldots \ldots$

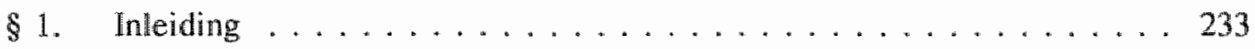

$\$ 2$. Samenvatting en conclusies . . . . . . . . . . . . . . 234

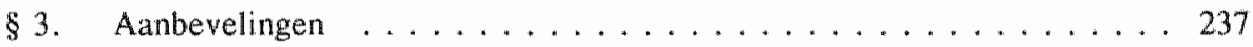

Bijlage 1: European Outline Convention on Transfrontier Co-operation between Territorial Communities or Authorities (alsmede) Nederlandse vertaling en Additional Protocol) . . . . . . . . . 241

Bijlage 2: Benelux-Overeenkomst inzake grensoverschrijdende samenwerking tussen territoriale samenwerkingsverbanden of autoriteiten (alsmede Franse vertaling) . . . . . . . . . 253

Bijlage 3: Overeenkomst tussen het Koninkrijk der Nederlanden, de Bondsrepubliek Duitsland, het Land Nedersaksen en het Land NoordrijnWestfalen inzake grensoverschrijdende samenwerking tussen territoriale gemeenschappen of gemeenschappen of autoriteiten (alsmede Duitse vertaling) . . . . . . . . . . . . . 263

Bijlage 4: Wet gemeenschappelijke regelingen Wet betreffende de intercommunales Zweckverbandgesetz Gesetz über kommunale Gemeinschaftsarbeit . . . . . . . . . 277

Bijlage 5: Samenwerkingsbepalingen Europese milieu-richtlijnen ..... . 305 Bijlage 6: Overeenkomsten op basis van artikel 59 Grensverdrag . . . . . . 31.

Literatuurlijst . . . . . . . . . . . . . . . . 31.3

Zusammenfassung ......................... 323

Summary $\ldots \ldots \ldots \ldots \ldots \ldots \ldots \ldots \ldots \ldots \ldots \ldots \ldots \ldots \ldots \ldots$

Résumé $\ldots \ldots \ldots \ldots \ldots \ldots \ldots \ldots \ldots \ldots \ldots \ldots \ldots \ldots \ldots \ldots \ldots$

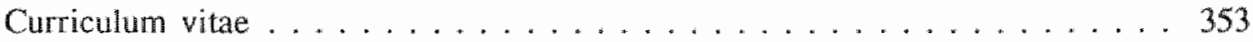





\section{Lijst van afkortingen}

$A B$

AFDI

AGRS

AJIL

AöR

AVR

Arob

ARRS

art.

a.w.

Awb

B

Benelux

Benelux-Overeenkomst

BGBI.

Bijzondere wet

B.S.IM.B.

Bull. Vr en A

b.v.

BVerfG

BVerfGE

BVerwG

c.q.

D
Administratiefrechtelijke beslissingen

Annuaire Français de Droit International

Afdeling voor de Geschillen van Bestuur van de Raad van

State

American Journal of International Law

Archiv des öffentliches Rechts

Archiv des Völkerrechts

Administratieve rechispraak overheidsbeschikkingen

Afdeling Rechtspraak. van de Raad van State

artikel

aangehaald werk

Algemene wet bestuursrecht

België

Belgisch Nederlands Luxemburgse (Economische) Unie

Benelux-Overeenkomst inzake grensoverschrijdende samenwerking tussen territoriale samenwerkingsverbanden of autoriteiten

Bundesgesetzblatt

Bijzondere wet tot hervorming der instellingen

Belgisch Staatsblad/Moniteur belge

Bulletin Vraag en Antwoord

bijvoorbeeld

Bundesverfassungsgericht

Entscheidung des Bundesverfassungsgerichts in der amtlichen

Sammlung

Bundesverwaltungsgericht

casu quo

Duitsland 
Duits-Nederlandse Overeenkomst

DVBI.

ECE

(E)EG

ed.

e.d.

EOC

EPL

et al.

ETS

e.W.

Gedr.St.

$\mathrm{GkG}$

GV.NW

$\mathrm{HR}$

Hrsg.

HvJ(EG)

ILC

ICJ(reports)

ILM

Interreg

$\triangle P O$

Jur.

12

$\mathrm{KB}$

LIIL

M.B./B.S

M en $R$

MvT

MvA

NDS/nds

Nieders. GVBI.

$\mathrm{NJ}$

NJB

NJCM

NJW

NL
Overeenkomst tussen het Koninkrijk der Nederlanden, de Bondsrepubliek Duitsland, het Land Nedersaksen en het Land Noordrijn-Westfalen inzake grensoverschrijdende samenwerking tussen territoriale gemeenschappen of autoriteiten Deutsches Verwaltungsblatt

Economic Commission for Europe (Europese Commissie voor Europa van de Verenigde Naties)

Europese (Economische) Gemeenschap(pen)

editor

en dergelijke

European Outline Convention on Transfrontier Co-operation between Territorial Communities or Authorities

Environmental Policy and Law

et alia

European Treaty Series

en verder

Gedrukte Stukken

Gesetz über kommunale Gemeinschaftsarbeit

Gesetz- und Verordnungsblatt Nordrhein Westfallen

Hoge Raad der Nederlanden

Herausgeber(s)

Hof van Justitie (Europese Gemeenschappen)

International Law Commission

(Reports of Judgments, Advisory Opinions and Orders of the)

International Court of Justice

International Legal Materials

Financieringsinstrument van de $\mathrm{EG}$ inzake interregionale samenwerking

Interprovinciaal Overleg

Jurisprudentie wan het Hof van Justitie van de Europese

Gemeenschap(pen)

Juristen Zeitung

Koninklijk Besluit

Leiden Journal of International Law

Moniteur belge/Belgisch Staatsblad

Tijdschrift voor millieu en recht

Memorie van Toelichting

Memorie van Antwoord

Niedersaksen/niedersächsisch

Niedersächsisches Giesetz- und Verornungsblatt

Nederlandse Jurisprudentie

Nederlands Juristemblad

Nederlands Juristen Comité voor de Mensenrechten

Neue Juristische Wochenschrift

Nederland 
NTB

$\mathrm{N}(\mathrm{R}) \mathrm{W} / \mathrm{n}(\mathrm{r}) \mathrm{W}$

NVIR

NVWZ

NWVbl.

o.a.

O.c.m.w.

OECD/OESO

ÖZöVR

PB

PCIJ

$\mathrm{Rbb}$

RCADI

red.

RDP

RFDA

RGDIP

RIDC

RMC

RvE

RvS

S.

SGV NW

Stb.

TBP

TGEM

TMA

Trb.

TVO

UPR

$\mathrm{vgl}$.

VN

VNG

Wgr

Wic

Wm

WVV

ZAöRV

ZWVG
Nederlands tijdschrift voor bestuursrecht

Nordrhein-Westfalen/nordrhein-w estfälisch

Nederlandse Vereniging voor Internationaal Recht

Neue Zeitschrift für Verwaltungsrecht

Nordrhein-Westfälische Verwaltungsblätter

onder andere

Openbaar centrum voor maatschappelijk welzijn

Organisation for Economic Co-operation and Development/Organisatie voor Economische Samenwerking en Ontwikkeling

Östereichische Zeitschrift für öffentliches Recht und Völkerrecht.

Publicatieblad van de Europese Gemeenschap(pen)

(Publications of the) Permanent Court of International Justice

Raad voor het binnenlands bestuur

Receuil des Cours de l'Academie de Droit International redactie/redacteur

Revue de Droit Public et de la science politique en France et à l'étranger

Revue Française de Droit Administratif

Revue Générale de Droit International Public

Revue Internationale de Droit Comparé

Revue du Marché Commun

Raad van Europa

Raad van State

Satz/Seite

Sammlung des bereinigten Gesetz- und Verordnungsblatt für das Land Nordrhein-Westfalen

Staatsblad

Tijdschrift voor bestuurswetenschappen en publiekrecht

Tijdschrift voor Gemeenterecht

Tijdschrift voor Milieuaansprakelijkheid

Tractatenblad

Tijdschrift voor Openbaar bestuur

Umwelt und Planungsrecht

vergelijk

Verenigde Naties

Vereniging Nederlandse Gemeenten

Wet gemeenschappelijke regelingen

Wet betreffende de intercommunales

Wet millieubeheer

Weens Verdrag inzake het verdragenrecht

Zeitschrift für Ausländisches öffentliches Recht und Völkerrecht

Zweckverbandgezetz 



\section{Algemene inleiding}

\section{\$. Inleiding}

Vele Nederlandse decentrale overheden grenzen met hun territoir direct aan de landsgrens met België of Duitsland. Het gaat hierbij om meer dan de helft van de Nederlandse provincies, ongeveer een achtste deel van de Nederlandse gemeenten, circa een vijfde deel van de Nederlandse waterschappen en ruim een derde deel van de samenwerkingsgebieden op basis van de Wet gemeenschappelijke regelingen. Tot nu toe zijn er tussen de provinciale, lokale en regionale overheden en hun 'counterparts' aan de andere kant van de grens nauwelijks publiekrechtelijke afspraken gemaakt. De nationale grens vormt blijkbaar een barrière in deze, aangezien binnen de betreffende landen veelvuldig samenwerking van publiekrechtelijke aard voorkomt. ${ }^{1}$ Nog steeds is de grensoverschrijdende samenwerking tussen decentrale overheden grotendeels ambtelijk en bestuurlijk en zo te zeggen feitelijk van aard. Daarbij manifesteert die grensoverschrijdende samenwerking zich op verschillende overheidsniveaus: tussen enkele gemeenten, tussen een groot aantal gemeenten en eventueel provincies (grens/euregio's ${ }^{2}$ ) en op het hogere interregionale niveau tussen Nederlandse provincies en Belgische Gewesten/Gemeenschappen alsmede Duitse Länder. In de praktijk wordt de laatste jaren een steeds groter aantal grensoverschrijdende initiatieven genomen in het kader van publiekrechtelijke taken en bevoegdheden. Zo kunnen in het gebied van de Euregio Maas-Rijn, voor een deel ook ingegeven door subsidiemogelijkheden vanuit de Europese Gemeenschappen, de volgende (lopende) projecten genoemd worden: het Europees bedrijventerrein Heerlen-Aken, het ruimtelijk ontwikkelingsperspectief Maastricht/Heerlen, Aachen, Liège, Hasselt/Genk (MHAL),

1. Voor een overzicht van het rume seala aan (juridische) vragapunten, verband houdend met gremsoverschrijdende sannenwerking, zie b.v.: 'Déclaration sur les aspects juridiques do la coopération transfrontalière', Symposium universitaire eturopén sur la coopération transfrontalière, Jaca (Esparne), 29-31 aoû 1987.

2. De belangrijkste grensoverschrijolende besturlijke overlegstructuren op dit moment tussen decentrale overheder, (met name) gemeentenen provincies, zijn de zagenatumde grens-/euregio"s. Zij bevinden zich langs de hele Duits-Nederlandse grens en de Belgisch-Nederlandse grens. Langs de Duits-Nederlandse grens zijn het de Eems-Dollard Regio, de Euregio, de Regio Rijn-Waal, de Grensregio Rijn-Mads-Noord en de Euregio Maas-Rijn. Langs de Belgisch-Nederlandsegrens is er de Euregio Scheldemond, het Benelux-Middengebied en het Belgisch Nederlands Grensoverleg (Benego). 
het grensoverschrijdend Ecologisch Basisplan, het grensoverschrijdende landschap Stramproyerbroek e.o., de bescherming van de St. Pietersberg (Mergelland).

Uit deze groeiende praktijk van decentrale grensoverschrijdende samenwerking en de toenemende behoefte tot juridisch verdergaande afspraken is reeds een deel van her belang van een nader onderzoek naar juridische grondslagen en juridisch kader in deze gegeven. Het schetsen van bevoegdheidsgrondslagen en het aangeven van mogelijke samenwerkings vormen is evenwel om een aantal andere redenen van (maatschappelijk) belang.

Allereerst is de decentrale grensoverschijdende samenwerking in het perspectief van de internationalisering alls gevolg van het verdwijnen van de Europese binnengrenzen te plaatsen. Juist samenwerking inzake publiekrechtelijke bevoegdheden op het niveau van de overheden die het dichtst bij de burger staan, kan een bijdrage leveren aan de verdere opbouw van één Europa. "Daarnaast neemt in verband met het verdwijnen van de landsgrenzen de onderlinge afhankelijkheid tussen overheden in grensgebieden toe. Voor het optimaal oplossen van problemen zal samenwerking met 'buitenlandse' overheden aan de orde kunnen zijn. Hierbij valt te denken aan het gezamenlijk opstellen van plannen en het verlenen van vergunningen, maar ook aan de mogelijkheid de uitoefening van dergelijke bevoegdheden over te dragen aan nieuw op te richten samenwerkingsverbanden. Mogelijk zal er een institutionalisering plaatsvinden in grensoverschrijdende regio"s. "Juist de mogelijkheid gezamenlijk op (bepaalde) beleidsterreinen vergaand samen te werken, zal het instellen van dergelijke grensoverschrijdende regio's kunnen versnellen en de interne en externe positie ervan versterken. ${ }^{5}$ Deze internationaliseringstendens zou b.v. ook betrokken kunnen worden in de discussie over de reorganisatie van het binnenlands bestuur in Nederland. Voorts kan hier nog op het volgende gewezen worden. De juridische reikwijdte van de grensoverschrijdende samenwerking gaat tot nu toe nog niet zover als de samenwerking tussen decentrale overheden binnen de desbetreffende landen. Zo kennen Nederland en Duitsland en in mindere mate Belgié wetgeving inzake decentrale samenwerking. Daarin is geregeld dat de decentrale overheden publiekrechtelijke bevoegdheden kumen overdragen aan in te stellen openbare lichamen. Ook kunnen zij een nabuurgemeente de uitoefening van publiekrechtelijke bevoegdheden mandateren en anderszins afspraken maken in het kader van de invulling van hun discretionaire bevoegdheden. Omdat dit onderzoek een vergelijking bevat van het Belgische, Duitse en Nederlandse recht inzake decentrale overheden en decentrale

3. "In de komende tjen jaar kan de positie wan de interne grensgebieden en-steden aanzienlijk verbeteren, doordat deze gebieden nu interne gebieden worden van een eengemaakte Europese Gemeenschap.", Commissie พan de Europese Gemeenschappen, Europa 2000, Perspectieven voor de ruimtelijke ontwikkeling van de Gemeenschap, 1992, p. $167 \mathrm{e.v.} \mathrm{Zie} \mathrm{ook:} \mathrm{Grenzibergreifende} \mathrm{Raumplanumg.} \mathrm{Erfahrung} \mathrm{und}$ Perpektiven der Zusanmenarbeit mit den Nachbarstaaten Deutschlands, Akademie fur Raumforschung
und Iandesplanung, (188), 1992 . 4. Zie b.v.: A. Bend, Regionen als Machtfaktor in Europa?, Verwaltungs-Archiv, 84. Band 3 , Heft 3 ,
1993. p. 328 e.v.

5. Zie b. .: Provincie Limburg. Notitie Priorittiten internationalisering juni 1993; Gemeente Maastricht, Notitie Herstructurering Euregio Maas/Rijnalsmede institutionalisering Euregio Adwiesraad/Euregional Parlement, juni 1993: Ruimtelijk ontwikkelingsperspectief MHAL, juni 1993.

6. Vgl. ook: A.A.L.G.M. Kessen, Besturijke verwieuwing in grensgebieden, Intergemeentelijke grensoverschrijdende samenwerking, 1992, p. 11 e. v. 
samenwerking kan op deze punten een al dan niet gemeenschappelijkheid van recht geconstateerd worden. Aangetoond zou kunnen worden of die gemeenschappelijkheid van recht de (Europese) integratie kan bevorderen. Juist daar waar er sprake is van overeenstemmend recht zal samenwerking makkelijker van de grond kunnen komen dan bij divergentie van rechtsstelsels. Overigens dient (gemeenschappelijkheid van) recht als mogelijke katalysator voor integratie mijns inziens niet overschat te worden. Overeenkomsten/verschillen in taal, bestuurscultuur, belangentegenstellingen e.d. zullen de samenwerking wellicht sterker kunnen beïnvloeden dan overeenkomsten/verschillen in regelgeving. Anderzijds zal een institutional isering en formalisering van grensoverschrijdende samenwerking (en dus het opstellen van regels hiervoor) een bijdrage kunnen leveren om tot afstemming van overheidsbeleid en bevoegdheden te komen ten aanzien van knelpunten en kansen in grensgebieden. ${ }^{7}$

Een ander belang voor het aangaan van grensoverschrijdende samenwerking is thet woorkomen van aansprakelijkheid, indien die samenwerking achterwege blijft. In deze dient gewezen te worden op de reflex-werking van regelgeving. In de Nederlandse rechtspraak is b.v. aangenomen, dat in de besluitvorming (met name inzake milieuvergunningen en -plannen) door overheden buitenlandse effecten c.q. gegevenheden meegewogen moeten worden. ${ }^{8}$ In het kader van deze plicht tot bescherming van buitenlandse rechten en belangen ligt samenwerking in de zin van wederzijdse afstemming (door afspraken tussen overheden) vóóraf voor de hand. Juist de mogelijkheid tot het maken van ver gaande publiekrechtelijke afspraken kan er voor zorgen dat er ook verplichtingen (niet alleen rechten) voor b.v. buitenlandse overheden/burgers kunnen ontstaan. Overigens bestaan er naast genoemde rechtspraak in Nederland enkele wettelijke bepalingen waarin afstemming met buitenlandse overheden expliciet is geregeld. ${ }^{9}$

Overigens geldt voor samenwerking altijd het voordeel dat deze efficiënter is dan dat ieder voor zich bepaalde dingen (anders) doet of de een wel maar de ander juist niets doet.

\section{\$2. Probleemstelling}

In de inleiding in $\S 1$ van dit hoofdstuk is de maatschappelijke relevantie aangegeven van grensoverschrijdende samenwerking c.q. het maken van publiekrechtelijke afspraken tussen decentrale overheden. Op dit moment is het juridisch regime met betrekking tot de mogelijkheden van grensoverschrijdende publiekrechtelijke afspraken tussen decentrale overheden zich aan het uitkristalniseren. Het doel van dit proefschrift is het geven van

7. Over de meer besmurskundige aspecten, zie: Th.A.J. Toonen, De Nederlandse sentyeid sstatatin Europeses. vergelijkend perspectief, Internationalisering en het binnendands bestuur, 1991; J.I.P. Hinssen, H. wan How en J. Maessen-van Adst, Grensoverschrijdende bestuurlijke samerwerking en milieuproblematiek, Bescuurswetenschapper, 1993 , nr.. 1. p. 32 e. W.

8. Zie b.Y.: Vz AGRS 20-2-1985. M en R 1986/1, p. 19-20; Hof "s-Grawenhage 3-5-1990, M en R 1991/9, p. 498-502 (ook: NJ 1991, 194). Vgl, ook: A. Rest, Berücksichtigung grenzibersinchitender Unweltaspekte in Recht der Bundesrepublk Deuschiand, OZOWR, 32, 1981, p. 59 a. .

9. Zie b.v. artikel 2 lid 2 Besluit houdende de woorbereiding en inichting van waterkwaliteitsplanmen, 7.6-1982, Stb. 347. Het Beslluit zonering buitenlandse luchtwaartreinen Noord- en Midden Limburg is een voorbeeld van een regeling als gevolg van activiteiten in het buiteriland (Noordrijn-Westfalen), 19-12-1983, Stb. 657 . 
een analyse van de juridische mogelijkheden (formele bevoegdheid tot samenwerking en juridisch kader van samenwerking) woor het maken wan grensoverschrijdende publiekrechtelijke afspraken tussen Nederlandse decentrale overheden en hun 'counterparts' in Belgiè en Duitsland.

In het licht van de decentrale grensoverschrijdende samenwerking zal hier de volgende vraag centraal staan:

Hebben Nederlandse decentrale overheden bevoegdheden om met hun "counterparts" in België en Duitsland publiekrechtelijke afspraken te maken en, zo ja, binnen welk juridisch kader manifesteren zich die publiekrechtelijke afspraken?

\section{A. NADERE TOELICHTING BIJ DE PROBLEEMSTELLING}

Voor afspraken inzake de overdracht van (geattribueerde) bestuurs- en zeker regelingsbevoegdheden van organen wan het ene openbaar lichaam op die wan een ander openbaar lichaam, is, woor de samenwerking binnen de eigen staat, woorzien in een wettelijke basis. ${ }^{10} \mathrm{Zo}$ geldt b.v. voor deze samenwerking tussen decentrale overheden in Nederland de Wet gemeenschappelijke regelingen, is in Belgie de Wet betreffende de intercommunales alsmede de Wet houdende organisatie van agglomeraties en federaties van gemeenten opgesteld en gelden in Noordrijn-Westfalen en Nedersaksen het Gesetz über kommunale Gemeinschaftsarbeit respectievelijk het Zweckverbandgesetz. Deze wetten bevatten een aantal samenwerkingsmogelijkheden tussen decentrale overheden, die als publiekrechtelijke afspraken gekwalificeerd kunnen worden. Deze publiekrechtelijke samenwerking is beperkt tot het betreffende nationale territoir. De desbetreffende (organieke) wetgeving en ook vaak andere (sector) wetgeving regelt in beginsel slechts de interne samenwerking en zegt niets over vergelijkbare samenwerkingsmogelijkheden tussen decentrale overheden over de grenzen heen. Incidenteel bestaan er op basis van richtlijnen wan de Europese Gemeenschappen en internationale verdragen samenwerkingsbevoegdheden voor decentrale overheden. Deze bevatten, op enkele uitzonderingen na, slechts overlegverplichtingen. In verdergaande vormen van samenwerking, analoog aan die in de genoemde nationale wetgeving, voorzien deze niet. Recentelijk zijn er tussen Nederland en België en Nederland en Duitsland verdragen inzake decentrale samenwerking gesloten. Zij werken de in het kader van de Raad van Europa gesloten European Outline Convention on Transfrontier Co-operation between Territorial Communities or Authorities (Madrid 1980) uit. De doelstelling van deze verdragen is publiekrechtelijke afspraken tussen decentrale overheden mogelijk te maken. Het betreft voor de Belgisch-Nederlandse decentrale samenwerking de Benelux-Overeenkomst inzake grensoverschrijdende samenwerking tussen territoriale samenwerkingsverbanden of autoriteiten (Brussel 1986). Voor de Duits-Nederlandse decentrale samenwerking gaat het om de Overeenkomst tussen het Koninkrijk der Nederlanden, de Bondsrepubliek Duitsland, het Land Nedersaksen en het Land Noordrijn-Westfalen inzake grensoverschrijdende samenwerking tussen territoriale gemeenschappen of autoriteiten (Isselburg-Anholt 1991).

10. Vgl. ook ten aanzien van de wens wan een wettelijke grondslag voor "privaatrechtelijke" vormen van overheidshandelen, De Grondwet, onder redactie van P.W.C. Akkermans, A.K. Koekkoek, 2 druk, 1992 , p. 791 . 


\section{B. DEFINIERING VAN DE BELANGRUKSTE BEGRIPPEN UIT DE PROBLEEMSTELLING}

\section{- publiekrechtelijke afspraken}

Samenwerking is in velerlei vormen mogelijk. Er valt b.v. te denken arn informatieverschaffing, consultatie, coördinatie. Een qua juridische reikwijdte verdergaande vorm van samenwerking is die, waarbij wederzijds rechten en plichten in het leven geroepen worden. Ik zou deze worm van samenwerking als publiekrechtelijke afspraak willen betitelen. Als instrument voor grensoverschrijdende samenwerking staat hier de publiekrechtelijke afspraak centraal. Afspraken ontstaan uit de wederzijdse behoeften van de partijen, die ze aangaan. Zij zijn bij uitstek een instrument om de wederzijdse belangen van de contractanten op elkaar af te stemmen. Partijen maken afspraken on ze in principe ook na te komen. In dat verband staat een vrijwilligheid voor het maken van afspraken in beginsel voorop. Worden afspraken niet nagekomen, dan ontstaat afdwingbare aansprakelijkheid. Onder publiekrechtelijke afspraken wordt hier verstaan: meerzijdige rechtshandelingen tussen (organen van) decentrale overheden omtrent de overdracht c.q. uitoefening van publiekrechtelijke bevoegdheden. Publiekrechtelijke bevoegdheden zijn die bevoegdheden waar alleen overheden bij of krachtens wettelijk voorschrift over kunnen beschikken. De belangrijkste kenmerken van publiekrechielijke bevoegdheden betreffen de eenzijidigheid van het gebruik ervan door de overheid (jegens de burger) alsmede de erga omnes werking, anders gezegd: overheden kunnen op bas is van publiekrechtelijke bevoegdheden ultra vires handelen door rechtsgewolgen voor de burger in het leven te roepen. Hier verschillen zij van privaatrechtelijke bevoegdheden. "Het gaat bij publiekrechtelijke bevoegdheden on die inzake regeling en bestuur. Zoals aangegeven is de uitoefening van publiekrechtelijke bevoegdheden slechts mogelijk op basis van een wettelijke grondslag. Voor het maken van afspraken over (de overdracht/uitoefening van) publiekrechtelijke bevoegdheden is dit in beginsel niet anders. Publiekrechtelijke samenwerking van deze aard is in België, Duitsland en Nederland gebaseerd op (grond)wettelijke grondslagen. De voornaamste vormen van afspraken tussen overheden, die hier als publiekrechtelijk worden aangemerkt en die als zodanig zijn aangegeven in de desbetreffende nationale wetgeving zijn:

- de oprichting van een nieuw gemeenschappelijk openbaar hichaam met regelings. en/of bestuursbevoegheden;

de overdracht van publiekrechtelijke bevoegdheden wan de ene overheid aan de andere overheid (delegatie):

- de overdracht van de witoefening van publiekrechtelike bevoegdheden van de ene overheid aan de andere overheid (mandaat).

Voorgaande wettelijke samenwerkingsmogelijkheden zijn territoriaal gebonden. Daar waar dergelijke publiekrechtelijke afspraken het territorium van de staat overschrijden is het vereiste van die wettelijke basis nog pregnanter aanwezig. In dit perspectief lijkt het zelfs zo te zijn, dat feitelijke dan wel privaatrechtelijke samenwerking tussen overheden van dezelfde staat als publiekrechtelijk wordt aangemerkt, zo gauw die samenwer-

11. Vgl. P. Nicolai, B.K. Olivier, L.J.A. Damen H. Troostwijk, Bestuursrecht, 4e herziene druk, 1993, p. 4 e. . . 
king plaats vindt tussen overheden uit verschillende staten. In dit opzicht kan b.w. gedacht worden aan het instellen van gemeenschappelijke overlegfora. Mijns inziens gaat het hier veelal om feitelijke samenwerking, waarvoor geen juridische grondslag is vereist. Ook kan b.v. gedacht worden aan afspraken, waarvoor in het nationale recht niet zonder meer een (additionele) wettelijke grondslag (naast de privaatrechtelijke contractsvrijheid) noodzakelijk wordt geacht. Het gaat hierbij b.v. om afspraken tussen overheden over hoe bepaalde publiekrechtelijke bevoegdheden worden uitgeoefend, over coördinatie van besluiten, e.d. Veelal vinden dergelijke afspraken hun grondslag in discretionaire publiekrechtelijke bevoegdheden. Om die reden zou ik voorshands deze laatste categorie van afspraken, vooral als afbakening ten aanzien van privaatrechtelijke afspraken, eveneens als publiekrechtelijk willen aanmerken.

\section{- decentrale overheden}

Onder de term decentrale overheden zouden in beginsel alle subnationale openbare lichamen van staten kunnen vallen. Hierbij dient wel het wolgende opgemerkt te worden. Nederland is een eenheidsstaat. Beigië en Duitsland zijn federale staten. De positie van de deelstaten in Duitsland (de Länder) en in België (de Gewesten en Gemeenschappen) is een andere dan die van b.v. de Nederlandse provincies. Voor een deel staan de deelstaten namelijk op thetzelfde niveau als de federale staat. Als het gaat om de grensoverschrijdende samenwerking tussen Nederland en België respectievelijk Nederland en Duitsland is het dan ook beter de Länder en Gewesten/Gemeenschappen als centrale overheden te betitelen. Als het gaat om grensoverschrijdende samenwerking lijken, evenals de eenheidsstaten ten aanzien van de gedecentraliseerde overheden, de federale staten problemen te hebben met activiteiten op dit wlak door de deelstaten. Zo zijn de Länder uitgezonderd van de werking van de reeds genoemde Duits-Nederlandse Overeenkomst inzake decentrale grensoverschrijdende samenwerking en vallen de Gewesten/Gemeenschappen evenmin onder de werking van de reeds genoemde Benelux-Overeenkomst inzake decentrale grensoverschtijdende samenwerking. Hier zij nog opgemerkt dat het niet noodzakelijk om decentrale overheden in het grensgebied dient te gaan. Omdat de nabijheid van overheden vaak de reden is om publiekrechtelijk samen te werken, zullen de afspraken zich in de praktijk veelal tot die tussen aan elkaar grenzende overheden in grensgebieden beperken.

\section{\$. Plan van behandeling}

In hoofdstuk 2 worden algemeen volkenrechtelijke aspecten van grensoverschrijdende publiekrechtelijke afspraken tussen decentrale overheden beschreven. ${ }^{12}$ Territorialiteit en soevereiniteit impliceren dat iedere staat op zijn eigen territoir zijn eigen (publiek)recht voor de eigen onderdanen hanteert. Het staat vast dat staten op hun territoir in beginsel exclusieve bevoegdheden hebben wat betreft het stellen, doorvoeren en

12. Zie b.*. ook: R.J.G.H. Seerdem, The Public International Law Character of Transironter Agreements between Decentrallised Authorities, LJIL, Vol. 5, Number 2, 1992, p. 187-213. 
afdwingen van regels. ${ }^{13}$ Bij grensoverschrijdende afspraken tussen decentrale overheden inzalke bestuurs- en regelingsbevoegdheden kan de soevereiniteit van de staat in het geding zijn. Daar waar soevereiniteitsaspecten in het geding zijn, beschikken decentralle overheden in tegenstelling tot staten in beginsel niet over de mogelijkheid bindende grensoverschrijdende afspraken te maken. Slechts staten, subjecten van volkenrecht, kunnen zonder meer dergelijke grensoverschrijdende afspraken, verdragen, met elkaar sluiten. Daarbij wordt de totstandkoming, de inhoud alsmede de nakoming van deze verdragen (grotendeels) beheerst door het volkenrecht. Overigens verzet het volkenrecht zich er niet tegen dat decentrale overheden bevoegd worden verklaard grensoverschrijdend te handelen. De centrale vraag in hoofdstuk 2 is of de soevereiniteits/territorialiteitsproblematiek meebrengt dat het maken van publiekrechtelijke afspraken, betreffende de uitoefening/overdracht van eigen bevoegdheden, tussen decentrale overheidsorganen aan weerszijden van de grens onderworpen zijn aan het volkenrecht. Daarbij is van belang dat er op centraal niveau een praktijk is ontstaan inzake het sluiten van de zogenaamde administratieve akkoorden, zonder dat altijd een expliciete bevoegdheid tot "buitenlands' handelen is gegeven. Met name waar het gaat om de overdracht van (burgers en overheden bindende) bestuurs- en regelingsbevoegdheden van binnenlandse aan buitenlandse decentrale overheden c.q. aan gezamenlijk op te richten grensoverschrijdende samenwerkingsverbanden, lijkt men er niet aan te ontkomen dat de betreffende staten, als subjecten van volkenrecht, b.v. via een verdrag daartoe de juridische grondslag creëren. Het volkenrecht erkent (nog) niet dat decentrale overheden rechtstreeks over de grenzen kunnen handelen (geattribueerde bewoegdheid), waartoe dan ook nog een eigen binding en daarmee eigen aansprakelijkheid op basis van het wolkenrecht voor de decentrale overheden zou behoren. De rol van staten ten aanzien van het al dan niet verschaffen van een juridische grondslag voor grensoverschrijdende samenwerking tussen decentrale overheden en een mogelijke toepasselijkheid van het volkenrecht ten aanzien van decentrale grensoverschrijdende publiekrechtelijke afspraken wormen een belangrijk onderdeel van bespreking. Gaat het in het vorenstaande vooral om de volkenrechtelijke aspecten van decentrale grensoverschrijdende samenwerking, van belang is ook de daarmee samenhangende staatsrechtelijke dimensie betreffende de bevoegdheid tot het voeren van buitenlandse betrekkingen. In beginsel wordt er hier vanuit gegaan dat publiekrechtelijke afspraken tussen nabuuroverheden in grensgebieden niet zonder meer binnen het grondw ettelijk kader inzake buitenlands beleid te plaatsen zijn. " Hier" op wordt in hoofdstuk 6 ingegaan.

13. P.H. Kooijmans, Internationaal publiekrecht in vogelwhoht, vierde druk, 1993, p. 44. Wgl, C.A.J.M. Kortmann, Constitutioneel recht, 1990 , p. 45; Th. wan Bellekom, A.W. Heringa, T. Kooprnans, R. E. de Winter Koopmans" Compendium van het Staatsrecht, 6e drulk, 1992, p. 8 e.v.; L. Brownlie, Princil ples of Public Intermational Law, 1990, 4h. edition, deel III, hoofdstuk 6.

14. Vgl. ook: L. F. M. Besseling, Statustecht en buitenlands beleid, Ars Acqui Cralliers, 1991, p. 14 15. Woor de Nederlandse Grondwet kan gewezen worden op artikel 91 Grondwet, dat een centrale rol arn de regering toekent (het artikel 58 van wốr de Grondwetsherziening van 1983 werwootdde het primal van de Koning in deze overigens veel duideliker). Voor Duitsland voert de Bond (de Bondspresident) de buitenlandse betrekkingen ex artiket 32 juncto Grundgesetz. In België is in het licht van artikel 68 Grondwet de Koning de centrale figuur in deze. 
In hoofdstuk 3 wordt ingegaan op de bemoeienis van een aantal Europese instanties met het fenomeen van decentrale grensioverschrijdende publiekrechtelijke samenwerking. De Raad van Europa heeft tot nu toe de meeste aandacht besteed aan decentrale grensoverschrijdende samenwerking. Om die reden ligt het zwaartepunt van hoofdstuk 3 bij deze intergouv ernementele organisatie. De reeds genoemde European Outline Convention on Transfrontier Co-operation en een daarbij behorend in voorbereiding zijnde Protocol alsook het Europees Handvest woor de Lokale Autonomie zijn in het kader van de Raad van Europa tot stand gebracht en worden in dit verband beschreven. Daarbij staat centraal in hoeverre beide verdragen daadwerkelijk bevoegdheden inhouden voor decentrale overheden om met hun "counterparts" publiekrechtelijke afspraken te maken. De rol van de Europese Gemeenschappen, een supranationale organisatie, waaraan de Lid-staten een aantal wan hun bevoegdheden (een gedeelte van hun soevereiniteit) hebben overgedragen en die de Lid-Staten en burgers rechtstreeks bindende beslissingen kunnen nemen, wordt ook geschetst. In vergelijking met de rol van de Raad van Europa is die van de Europese Gemeenschappen van minder belang in het licht van de tot nu gerealiseerde gemeenschapsrechtelijke grondslagen voor decentrale grensoverschrijdende samenwerking en zeker ten aanzien van het maken van publiekrechtelijke afspraken. Een algemene bevoegdheidsgrondslag in deze, in de zin van de genoemde European Outline Convention, b. w. in de vorm van een richtlijn of verordening is er (nog) niet. Met name op milieugebied bestaan er evenwel specifieke grensoverschrijdende samenwerkings verplichtingen betreffende informatieverschaffing en overleg. Die samenwerkingsbepalingen worden bekeken in het licht van een mogelijke rol voor decentrale overheden.

De rol van de Europese Gemeenschappen is vooral van belang voor de harmonisering. van het materiële recht, hetgeen voor grensoverschrijdende samenwerking uiteraard van groot belang kan zijn. Deze harmonisering vormt evenwel geen onderwerp van bespreking. Wel wordt ingegaan op de belangrijke rol van de Europese Gemeenschappen inzake de subsidiëring van samenwerkingsactiviteiten in grensgebieden.

In hoofdstuk 4 wordt het organieke recht inzake Belgische, Duitse en Nederlandse decentralle overheden beschreven. Het weergeven van de organisatie van deze decentrale besturen alsmede loun belangrijkste (autonome) bevoegdheden, is vooral een relevante inleiding op hetgeen in de hoofdstukken 5 en 6 behandeld wordt.

In de hoofdstukken 5 en 6 staat de nationalrechtelijke dimensie vam grensoverschrijdende publiekrechtelijke afspraken tussen decentrale overheden centraal. Deze nationaallrechtelijke dimensie ligt hier veel meer voor de hand dan de internationaalrechtelijke (vgl. hoofdstuk 2). Dit vloeit voort uit het decentrale overheidsniveau waarop wordt samengewerkt, de lokale/regionale onderwerpen van de samenwerking maar vooral het toepasselijke recht op die samenwerking. Tussen Nederland en België (hoofdstuk 5) geldt al ruim twee jaar de reeds genoemde Benelux-Overeenkomst inzake decentrale grensoverschrijdende samenwerking. Voor de decentrale grensoverschrijdende samenwerking tussen Nederland en Duitsland (Noordrijn-W estfalen en Nedersaksen) geldt sinds het begin van 1993 de reeds wermelde Duits-Nederlandse Overeenkomst inzake decentrale grensoverschrijdende samenwerking. Beide verdragen scheppen bevoegdheden voor decentrale overheden voor het aangaan van grensoverschrijdende publiekrechtelijke afspraken. Daarbij verwijzen zij voor een aantal zaken, zoals het toezicht, naar het 
nationale recht van de deelnemende overheden. In de hoofdstukken 5 en 6 stat voor de decentrale samenwerking tussen Nederland en België respectievelijk Nederland en Duitsland de beschrijving van de mogelijke vormen van samenwerking op basis van genoemde verdragen voorop. ${ }^{15}$

Hoofdstuk 7 bevat een korte samenvatting, enkele conclusies en aanbevelingen ten aanzien van de grondslagen voor en het juridisch kader van decentrale grensoverschrijdende samenwerking, in het bijzonder het aangaan van publiekrechtelijke afspraken door Nederlandse decentrale overheden met hun 'counterparts' in België en Duitsland.

15. Daarbij wordt niet ingegatn op de in de samenwerking in te brengen (materieje) bewoegdheden van decentrale overheden op de diwerwe beleidsterreinen. Fen inventarisatie wan de diverse sectorbewoguheden van decentrale overheden in Belgie, Duitsland en Nederland gat het kader wan dit proefschrift te buten. Zie voor de Belgisch-Nederlandse decenirale samerwerking b.V.: R.J,G.H. Seerden, M.W.J.A. Hertoghs, Belgisch-Nederlandse samemerking gedecentraliseerd. Een onderzoek naar het Beilgische organieke recht inzake decentralle overheden en hun bewoegdheden op thet gebied wan het milieu en de ruimtelijke ordening. 1993. 



\section{Internationaalrechtelijke aspecten van grensoverschrijdende samenwerking tussen decentrale overheden*}

\section{Inleiding}

Grensoverschrijdende afspraken tussen (decentrale) overheden in het kader van publiekrechtelijke taken en bevoegdheden worden door staten (regeringen) al snel binnen het stelsel van de internationale betrekkingen en daarmee bijna automatisch binnen het internationale recht geplaatst. Deze (vermeende) toepasselijkheid wan het internationale recht is vooral naar voren gekomen bij de totstandkoming van een aantal internationaalrechtelijke verdragen omtrent decentrale grensoverschrijdende samenwerking. ${ }^{1}$ In de literatuur wordt omtrent de (overall-)toepasselijkheid van het internationale recht in deze verschillend gedacht. Sommige auteurs ontkennen ten aanzien van lokale grensoverschrijdende samenwerking de overall-toepasselijkheid van het internationale recht. Zij onderbouwen dit door o.a. te wijzen op het lokale karakter van de samenwerking, de toepasselijkheid van het hoger bestuurlijk toezicht en door het handelen binnen de autonome dan wel medebewindsbevoegdheden te plaatsen en te wijzen op de vergelijkbare mogelijkheden van samenwerking binnen de grenzen. ${ }^{2}$ Als men uitgaat van een louter

* War in het vervolg van intermational recht wordt gesproken, is hiermee, tenzij uitdrukkelijk anders asingegeven, international publiekrecht/volkenrechtbedoeld.

1. Voor de beschrijving van de European Outhine Convention, de Benelux-Overeenkomsten de Duits-New derlandse Overeenkomst inzake decentralle grensowerschrijdende samenwerking wordt verwezen nadr hoofdsuk $3 ; 2$, hoofdstuk 5 \& respectievelijk hoofdstuk $6 \& 4$,

2. B.v.: J-M. Woehrling, Legal Problems of transfrontier co-operation at local or regional level, OECD, ENV/TFP/ 1977.10 ; P-M. Dupuy, La coopération régionalle transfrontalière at le droit international, AFDI, 1977, p. 844 e.v.; R. Lafore, L'action à l'Etranger des collectivités territoriales, RDP, 1988-3, p. 770 e. $;$; U. Beyerlin, Rech isprobleme der lokalen grenziberschreitendeZusammenarbeit, 1988. \$4lo 4.C. van dit hoofdstak wordt hierop nader ingegan. Andere auteurs vinden dat grensoverschrijdend handelen het primati wan de centrale owerheid is en accepteren (om die reden) op de enen of andere wijze de toepasselijkheid van het international publiekrecht, b.v.: E. W. Vierdag, De praktijk van de zogenoemde "internationale administratieveakkoorden" in: Spannigyen tussen recht en praktijk in het verdra- 
internationaalrechtelijke context voor decentrale grensoverschrijdende samenwerking, dan impliceert dat in ieder geval dat decentrale overheden in deze - zij zijn in tegenstelling tot staten geen subject van internationaal recht en beschikken daardoor niet over treaty-making capacity - in beginsel niet voor zichzelf over de grenzen publiekrechtelijke afspraken kunnen maken $\left(\$ 2 . A_{\text {. }}\right.$ ). Slechts bij een of andere vorm van toestemming van hun staten zouden door hen internationalrechtelijke rechtsgevolgen yoor de staat in het leven geroepen kunnen worden. In het nationale recht en meer in het bijzonder in het kader van de externe betrekkingen is voor bepaalde 'state organs' voorzien in bevoegdheden, treaty-making power, om namens de staat internationalrechtelijk te handelen. Decentrale overheden bezitten in dat kader (nog) geen algemene bevoegdheid tot grensoverschrij dend handelen (\$ 2.B.). Het is evenwel niet uitgesloten dat er specifieke hande lingsbevoegdheden voor decentrale owerheden bestaan om grensoverschrijdend te handelen.

In het licht wan het voorgaande wordt ingegaan op de vraag of en wanneer afspraken tussen decentralle overhedien in het kader wan hun publiekrechtelijke taken en bevoegdheden als internationaalrechtelijke owereenkomsten kunnen c.q. moeten worden aangemerkt. Als grensoverschrijdende publikerechtelijke afspraken tussen decentrale overheden op de een of andere wijze als internationaalrechtelijke overeenkomsten kunnen c.q. moeten worden beschouwd, dient allereerst het verschil tussen internationale verdragen (in de zin van Weens Verdrag inzake het verdragenrecht, WVV) en de mogelijkheid van andere soorten van internationale overeenkomsten, als instrumenten tot lokale grensoverschrijdende samenwerking, onderzocht te worden. Hiertoe zal het WVV besproken worden $(\$ 3)$. Meer speciale aandacht verdienen vervolgens de zogenaamde internationale administratieve akkoorden en in het bijzonder de juridische status ervan. Bepaalde schrijvers kennen aan de internationale administratieve akkoorden een aan verdragen gerelateerde juridische status toe, terwijl anderen menen dat dergelijke akkoorden geen internationaalrechtelijke verplichtingen met zich (kunnen) brengen. Er is in de literatuur nog nauwelijks systematisch ingegaan op vragen als: Door wie en op welke schaal. worden deze akkoorden gesloten? Hoe en op welke beleidsterreinen komen ze tot stand? Hetgeen hier geschreven zal worden is niet bedoeld als een integrale analyse van het fenomeen van de internationale administratieve akkoorden. Het is vooral de bedoeling om aan de hand van een globale notie omtrent de juridische status van deze akkoorden het mogelijk belang ervan woor het terrein van de lokale grensoverschrijdende samenwerking te schetsen. Hier wordt er woorshands vanuit gegaan dat grensoverschrijdende publiekrechtelijke afspraken tussen decentrale overheden in beginsel als een categorie van internationale administratieve akkoorden en deze laatste als een categorie van verdragen te beschouwen zijn. Deze these zal worden besproken (\$4.A.). Het aangeven van het onderscheid tussen internationale verdragen en internationale administratieve akkoorden geschiedt aan de hand wan de bevoegdheid (power) van overheden ("state organs") om ze te sluiten ( $\$ 4 . B$.) en de juridische bindende kracht ('binding legal force') ervan in het internationale recht $(\$ 4 . \mathrm{C}$.$) . Indien deze administratieve akkoorden, hoewel$

\section{2.(...vervolg)}

genrecht, Mededelingen wan de Nederlandse Vereniging voor Internationaal Recht, no. 99 oktober 1989 , p. 36 e.v.; H. Blix, Treaty making power, 1960, p. 17 e.v.; E. Zoller, La conclusion et la mise en ceuvre des traités dans les Etats fédérées et unitaires, RIDC 2-1990, p. 737 e.v. 
grensoverschrijdende effecten hebbend, niet noodzakelijk (bindende) internationaalrechtelijke overeenkomsten zijn, komt de mogelijke (bindende) nationaalrechtelijke aard ervan om de hoek kijken. Tot slot volgen een samenvatting en enkele conclusies $(\$ 5)$.

\section{Decentrale overheden en het internationale recht}

\section{A. DECENTRALE OVERHEDEN ALS (PARTIËLE) SUBJECTEN VAN INTERNATIONAAL RECHT}

In beginsel kurnen door het internationale recht beheerste betrekkingen slechts tussen subjecten wan internationaal recht plaatsvinden. ${ }^{3}$ In dat verband kan de vraag gesteld worden, wat die internationaalrechtelijke subjectiviteit inhoudt en of decentrale overheden c.q. grensoverschrijdende samenwerkingswerbanden daarover (kunnen) beschikken? ${ }^{4}$

Het Internationaal Gerechtshof heeft het zijn van subject van internationaal recht gedefinieerd als: "the capacity to be titular to international rights and obligations." ${ }^{5}$ Centraal in dat verband staan de treaty-making capacity, de bevoegdheid internationale claims in verband met de schending van internationaal recht naar voren te brengen alsmede het beschikken over immuniteiten. ${ }^{6}$ Staten voldoen aan deze criteria. ${ }^{7}$ Statenverbindingen

3. O.a.: I. Brownlie, a.w., p. 60 e.v.; Ch. Rousseau, Drout international public, Tome I, Sujets de Droit, 1974, p. 8 e.v.; H. Lauterpacht, Oppenheim's International Law, 1955, Vol. 1, 8th. edítion, p. 117.

4. Zie b.v. ook: U. Hambuchen, Potentielle Organisationsformen fiu grenzüberschreitendeinterkommunale Kooperation, dargestell am deutsch-niederländischen Grenzranm, 1980, p. 156: "Kann den grenzübergreifenden Zusammenschlissen zur Förderung interkommunaler Ge neinschaftsarbeit - auch bei luehlen einer verfestigten nationalstatlichen Insfututionalisierung - allein auf Grund ibrer neuzeitlich gewachsenen, besonderenStellung innerhalb der Völkergemeinschaf - partielle - Volkerrechtspersönlichkeit zu-

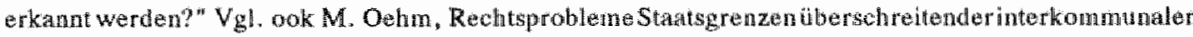
Zusammenarbeit, 1982,70 , 7 .

5. Uit: Reparations for Injuries Suffered in the Service of the United Nations, IC Reports (1949), p. 174. "All that can be said is that an entity of a type recognized by customary law as capable of possessing rights and kuties and of bringing international clams, and having these capacities conferred upon it, is

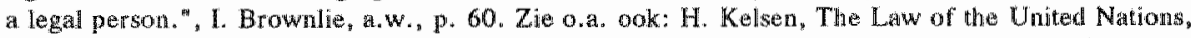
1950 , p. 329; O. Schwarze nberger, A Manual of Intternational Law, 4th. edition, 1960, p. 47.

6. I. Brownlie, a.w., p. 60: "States thave these capacities and inmunities, and inded the incidents of statehood as developed under the customary law have prow dex the indicia for, and instrunents of prersonality in other entities." Zie ook: Y. Lejeune, Le statut international des collectivités féderés, à la luniere de l'experiencesuisse, 1984, p. 46; Hij beschouwt het "jus tractati" (recht om verdragen te siltiten) en het "jus legationis" (recht op diplomatieke vertegenwoordiging)als "les atributs apparents de la personalite internationale"

7. "Comme brancine de l'ordre juridique gếnéral, le droit international public a pour objet de représenter" un ordre de justice entre les entites qui ne sont subordonnes a aucun pouwoir superienr organise. Ce sont, ancore atjourd "Iui, les Etats souverains." H. Mosler, Reflexions sur la personalite juridique en droit international public, in: Mélanges offerts a Henri Molin, 1964, p. 250; "International law is primarily concerned with collective growps of individuals, commonly known and legally recognised as sovereign states and constituting the normal subjects of inter anational law. ${ }^{\text {* }}$, N. Sirgth, Right to environment and sustainable development as a principle of international law, Studia Diplonatica, Vol. XLI, 1988, Num. 1. p. 45 . 
in de vorm van intergouvernementele organisaties kunnen als (partiële) subjecten van intemationaal recht aangemerkt worden.

Sub 3 van dit hoofdstuk wordt ten aanzien wan het sluiten van internationaalrechtelijke overeenkomsten aangegeven, dat in beginsel slechts staten hiertoe bevoegd zijn en daardoor rechtens gebonden kurnen worden. Daarbij is het onderscheid treaty-making capacity en treaty-making power van belang: "It is useful to speak of international capacity to make treaties and to reserve the expression treaty making power for the purpose of indicating the particular internal organ of a State that has the power to excercise the international capacity so as to bind the State." 9 In de literatuur is aan de mogelijke treaty-making capacity voor onderdelen van staten vooral aandacht besteed met betrekking tot de deelstaten van federale staten. ${ }^{10}$ Het is hier van belang na te gaan in hoeverre hetgeen met betrekking tot die deelstaten in deze geldt, ook van toepassing is c.q. kan zijn op andere "dlecentrale' overheden. Voorts is een nadlere uitwerking van de (internationaalrechtelijke) plaats van de deelstaten relevant vanwege de federale structuur van de buurlanden van Nederland en de rol van deze deelstaten als mogelijke verdragspariners van de Nederlandse staat alsmede 'counterparts' van vooral de Nederlandse provincies.

Hoewel Fitzmaurice treaty-making capacity voor deelstaten van federale staten ontkent " wordt toch vrij algemeen aangenomen, dat de constituties van (een aantal) federale staten een rechtsbron voor die treating-making capacity vormen en daarmee een zekere vorm van internationaalrechtelijke rechtspersoonlijkheid van die deelstaten met zich brengen. ${ }^{12}$ Lauterpacht acht treaty-making capacity in ieder geval aanwezig voor de deelstaten van de Bondsrepubliek Duitsland, Zwitserland en de Sovjet-Unie, omdat die deelstaten op basis van de federale constitutie rechtsgeldige internationaalrechtelijke

8. O.a.: 1. Seidl-Hohenveldern, Das Recht der hiternationalen Organisationeneinschliesslichder Supranatiomalen Gemeinschaften, 2. Auflage, 1971, p. 3.; A. Verdross, Volkerrecht, Se druk, 1964, p. 352 e.v; H. Mosler, Reflexions (..), a.w., p. 250.

Niet-goumernementele internationale organisaties beschiken in beginsel njet over internationale subjectiwiteit. In dit verband $a, a_{n}$ : A. Verdross, B. Simma, Universelles Volkerrecht, Theorie und Praxis, 1976 , p. 217; F. Berber, Lehrbuch des Vökerrechts, Band 1, 2. Auflge, 1975, p. 173.

9. Lord McNair, The Law of Treaties, 1961, p. 36 noot 1.

10. In dat wenbund acht Ago de bevogdheid (van deelstaten om partij te xinn bij internatonale verdragen ean essentiael element van de intermationale rechtspersoonlijkheid, R. Ago, Yearbook ILC, 1962, Vol. I. p. 36. Hier kan gewezen worden op het witeindelijk net in het WVV opgenomen ontwerp-artikel 5.2 ." "States members of a federal union may possess a capacicy to conclude treaties if such capacity is admit. led by the federa constituion and within the limits there laid down." Zie hierover ook: L. Di Marzo, Component Unis of Federal States and Internationa Agrements, 1980, p. 166.

11. G.G. Fitzmarice, Rapporteur on the Law of Treaties, Yearbook ILC, 1958. Wol. II, p. 24.

12. "Soweit hnen (de deelstaten, RS) dn Bundesstaatsver fassung die Wahrnelmung auswärthger Angelegenlue uten zubilligt, können sie Rechtsbeziehungen mit auswärigen Vökerrechusträgern unterhalten." $H$. Moslen, Die auswärige Gewalt in Verfassungssystem der Bundesrepubliek Dentschland, in: Völketrechtliche und Stabsrechtiche Athandlungen, Festschrift Carl Bilfnger, 1954, p. 261. Zie o.a. ook: R. Bernhadd, Der Abschluss vökerrechticher Verträge im Bundesstant, 1957, p. 18 e.v.; M. Huber, Le droit de conclure des traités internationaux, 1951, p. 76 .

"All we can say at this stage is that such entities cannot clam the status of an international person on the hasis of their sovereignty", 1. Bernier, International Legal Aspects of Federalism, 1973, p. 31. Bernier woegt aan de 'international competence' nog een tweede criteria voor het hebben van 'intermational personality" wan deelistaten toe, namelijk recognition". (p. 33 e.v./p. 74 e.v). 
verdragen kunnen sluiten. ${ }^{13}$ Voor de Duitse deelstaten wolgt dit uit artikel 32 Grundgesetz. Ook in België hebben de Gemeenschappen op basis van artikel 59 bis $\$ 2$ Grondwet juncto artikel 16 Bijzondere wet tot herworming der instellingen verdragsluitende bevoegdheden, echter uitsluitend inzake culturele en onderwijsaangelegenheden. De Belgische Gewesten beschikken sinds kort over verdragsluitende bevoegdheden. ${ }^{14}$ Indien, zoals in de visie van o.a. Wildhaber, de grondwettelijke bevoegdheidstoekenning om verdragen te sluiten kan worden beschouwd als een voorwaarde voor het zijn van subject van internationaal recht ${ }^{15}$, dan zullen andere onderdelen dan deelstaten op grond van het ontbreken van die voorwaarde in beginsel niet over internationale rechtspersoonlijkheid beschikken. Immers een geschreven dan wel ongeschreven grondwettelijke basis voor die andere (decentrale) overheden om in algemene zin internationale verdragen te sluiten is (nog) niet aanwezig. Aangezien deze overheden veelal niet eens geacht worden te beschikken over treaty-making power, zal van een statenpraktijk die een internationaal gewoonterechtelijke basis woor internationale rechtssubjectiviteit en daarmee treatymaking capacity zou kunnen impliceren, al helemaal geen sprake zijn. ${ }^{16}$ Daar waar de treaty-making capacity voor onderdelen van staten een grondwettelijke basis heeft, zijn hieraan bovendien veelal beperkingen gesteld. ${ }^{17}$ In dat opzicht is de treaty-making capacity van die onderdelen geen absolute. Het gaat daarbij in de regel zeker niet om een algemene en puur autonoom uit te oefenen treaty-making capacity analoog aan die van soevereine staten. De "international personality" van bepaalde onderdelen van de staat, blijkend uit de grondwet, is (en zal voorlopig ook nog wel blijven) daarmee toch een beperkte, afgeleid van die van de staat. ${ }^{18}$

13. H. Laterpacht, Rapporteur on the Law of Treaties, Yearbook ILC 1953, Vol II, p* 138-139.

Sinds enige tijd kent ook de Oostenrijkse Grondwet de mogelijkheid dat de Oostenrijkse Lander ondw bepaalde voorwatarden internationale verdragen sluiten. Zie b.v.: R. Rack, Österreichs Latnder wnd das Völkerrecht, AVR 1.989, 27. Band, 1. Heft, p. 32 44.

14. Voor en uitgebreidere uiteenzetting over Belgie en Duitsland in deze, zie: hoofdstuk 5 : 5. D.7 en hoofdstuk 6 , $4 . \mathrm{D} .6$.

15. L. Wildhaber, Treaty-Making Power and Constitution, An Internationat and Comparative Study, 1971 , p. 263.

In dat werband is mijns inziens weemd, dat het Secretariat van de Verengde Naties een bepalde internationatrechtelijk eovereenkomst tussen Nederland en de deelstadt Moordrijuland-West falen slecht kon registreren als "Agreement between the Kingdom of the Netherlands and the Federal Republio of Germany (Land of North Rhine-Westphalia)". Volgens bet secretariat is bel in dat soort overesenkomsten - het betrof de overeenkomst betreffende thet grenspark Mads-Swalm-Nette (Trb. 1976, nr. 76) de fede rale staat, fls intermationaal rechtssubject, die gebonden wordt en niet de dee sctatit; Zie hiorwoor H.H.M. Sondat, De Nederlandse Verdragspraktik $1,986, p .18-20$.

16. Zje in deze over de treaty-making power (woor decentraleoverheden): U. Beyerlin, Rechtsprobleme (..), a. W. p. 190. Zie ook 3 en 4 van dit hoofdstuk.

17. Di Marzo noemt er in dit verband een drital: "that the treaties stre subject to the approval of the federal governmeat; that they be limited to certaim subject matters" or to matters falling withio the legislative jurisdiction of the component units; and that no "political" treaties be concluded." "L. Dil Marzo, a.w., p. 49. In dit verband $k$ an ook opgemerkt worden dat deelstaten in de regel niet beschikken over het uan het "jus tractati" werbonden "jus legationis", Y. Lejeune, a.w., p. 52 .

18. As for member states, their cleim to international personality as sovereign entites fails entirely. But it does not follow that they vanot enjoy international personality. If the federall constitution grants them the right to deal separately whth foreign states and such states agree to deal with them, then they are subjects of international law," en "They are derived subjects of intermational law and their capacity as

(wordt verwolgd...) 
Op basis van het voorgaande zullen uit decentrale overheden samengesteldë grensoverschrijdende samenwerkings verbanden een mogelijke internationaalrechtelijke subjectiviteit niet kunnen ontlenen aan die van de decentrale overheden. Lang stelt in dit verband: "Zum Völkerrechtssubjekt könnte die Region (hiermee is een grensoverschrijdende (eu)regio bedoeld, RS) nach traditionellen Rechtsverständnis nur werden, wenn sie sich aus Staaten zusammensetzt und sich auf einen völkerrechtlichen Vertrag gründet, also eine internationale Organisation im klassischen Sinne verkörpert. Unter dieser Voraussetzung könnten dann die Beschlüsse, die in diesen Regionen von den zuständigen Organen gefasst werden, auch als Bestandteil des Völkerrechts angesehen werden." 19 Hambuchen toont aan, dat de (andere dan verdragen) positiefrechtelijke bronnen van het internationale recht - hij gaat zeer uitgebreid in op de plaats van het gewoonterecht - op dit moment onvoldoende bewijs leveren voor het kunnen aannemen van internationale rechtssubjectiviteit van Europese grensregio's analoog aan die van intergouvernementele organisaties. ${ }^{20}$

Wat ook zij van het bovenstaande, voor decentrale overheden c.q. grensregio's is op dit moment geen internationale competentie analoog aan die van deelstaten van bepaalde federale staten (indien al voor deze aanwezig) respectievelijk intergouvernementele organisaties aan de orde. Nog afgezien van mogelijke grondwettelijke belemmeringen voor het beschikken over internationaalrechtelijke rechtssubjectiviteit van onderdelen van staten ${ }^{21}$, is hiermee de afwezigheid op dit punt van de "international personality" van decentrale overheden, andere dan de deelstaten van bepaalde federale staten, een gegeven.

Naast de treaty-making capacity als voornaamste component van de voor het zijn van subject van internationaal recht relevante 'rights and obligations' speelt de internationaal-

18. (...verwolg) subjects deperds on the extent of their international competence" 1 . Bernier, a w., p. 82 respectieveljk 116. Zie: U. Beyerlin, Rechtsprobleme (..), a.w., p. 192; L. Di Marzo, a.w., p. 1.

19. W. Lang, Die normative Qualitat grenzitberschreitender Regiomen. Zum Begriff der "soft institution". AVR 1989, 27. Band, 3. Heft, p. 255. Zo ook: M.P. Orianne, Coppération européenne des régions ransfrontalière, les problèmes juridiques de la coopération des régions frontalières, A. D. MColl. Front, Strasbourg 1972, p.2, L. Frobler, P. Oberndorfer, F. Zehetner, Recintsproblemegremziberschreitender Raumplanung, 1977, 71 : A. Rest, Die Wahl des gänstigeren Rechts in grenziberschreitenden Umweltschutz, 1980, p. 42

20. U. Hambuchen, a.w*, p. 163-174: "Weder aut Grund eines sich almählich bildenden Volkergewohnheitorecht noch amhand allgemeine Rechtsgrundsaitze oder internationaler Ubereinkünfte lässt sich die eventuelle Zugehörigkeit dieser mehrere Staaten tangierenden Organisationen zum Krevise der Voukerrechtsubjekte begruinden. Derat ige interkommumale Vereinigungen werden vielmehr immer noch ais ein Bestandteil ihres jeweiligen nationaler Staatsgebietes angesehen. Trotz zahreicher Bemuliumgen sowohl aus den Reihen der betroffen Grenzraumpartner als auch durch europaische Institutionert thaben sich noch keme solch konkreten Arhaltspunkte herausgebidet, auf Grund derer man - vom Bodem des Art 38 T. IGH-Statut aus - eine Modifikation der derzeit herrschenden Anschauungen zur Vökerrechtssubjektivitär vornehmen konnte" (p. 174). Gezien de "soziologischen Verfestigung im transnationalen Rechtsverkehr' is hij overigens van mening dat euregio's een functionele internationaalrechtelijkesubjectiviteir toegekend dient ta worden (p. 196).

21. Zie b. w, U. Beyerlin, Rechtsprobleme (..), a.w., p. 193. 
rechtelijke aansprakelijkheld een grote rol, ${ }^{22}$ On het beeld in deze te completeren alsmede omdat het ook niet uitgesloten is, dat (in de toekomst) wellicht ook voou andere (verbanden van) decentrale overheden dan deelstaten van federale staten een juridische basis gecreëerd zal worden om internationaal te handelen, wordt hierop kort ingegaan. In het kader van de internationaalrechtelijke aansprakelijkheid wordt het handelen c.q. nalaten van onderdelen van de staat in beginsel aan de staat toegerekend. ${ }^{27}$ Als algemeen uitgangspunt geldt, dat slechts staten internationaalrechtelijk aansprakelijk kunnen zijn. ${ }^{24}$ Dit wordt met betrekking tot de aansprakelijkheid wan de federale staat voor handelen/nalaten van deelstaten door een aantal schrijwers op de volgende wijze genuanceerd. Het gaat hierbij dan niet om de aansprakelijkheid wan de federale staat voor handelingen/nalaten van deelstaten, die tot de internationale verplichtingen van de federale staten behoren, maar om de aansprakelijklheid van de federale staat voor handelingen/nalaten van de deelstaten, die tot de internationale verplichtingen van de deelstaten behoren. Ondat de verantwoordelijkheid veelal verbonden is met de uitoefening van de treaty-making capacity - de meeste internationale verplichtingen vloeien uit verdragen voort -, is het logisch dat als onderdelen van staten treaty-making capacity hebben en zij daarmee voor zichzelf internationale verplichtingen in het leven kunnen roepen, zij daarvoor in beginsel ook verantwoordelijk dienen te zijn. Op voorhand hoeft de federale staat in die situaties niet voor de internationale verplichtingen van zijn deelstaten in te staan. ${ }^{25}$ Het zal van de mate van onafhankelijkheid (van de positie in deze) van de deelstaten ten opzichte van de federale stat en van de controlemogelijkheden van deze laatste ten opzichte van de eerste afhangen in hoeverre de federale staat (mede)verantwoordelijk gehouden kan worden voor handelen/nalaten van de deelstaten. ${ }^{26}$ Treatymaking capacity en verantwoordelijkheid/aansprakelijkheid zijn mijns inziens aan elkaar gekoppeld. De aansprakelijkheid is een toetssteen (achteraf), die impliceert, dat de internationale verplichtingen ontstaan in de uitoefening van de treaty-making capacity inderdaad als internationale verplichtingen van de betreffende onderdelen van staten zijn aan te merken. De afwezigheid van een eigen internationaalrechtelijke aansprakelijkheid van deellstaten zal dan veelal hieruit voortvloeien, dat deze niet voor en door zichzelf internationale verplichtingen in het leven kunnen roepen. Hetgeen elders als treatymaking capacity is aangemerkt, kan in dat geval eigenlijk niet meer dan als treaty-making power beschouwd worden. De deelstaten shiten in dat gewal de verdragen blijkbaar niet voor zichzelf maar namens (en voor) de federale staat. Slechts deze wordt gebon-

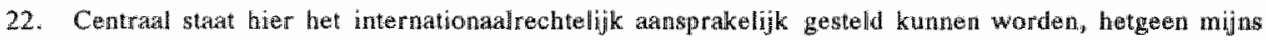
inziens gerangschikt kan worden onder het naar vore kunnen brengen wan inter ationale laims (zie noot 6 van dit hoofdstuk).

23. Op de problematiek met betrekking tot de immunteiten wordt hier niet ingegan. Zie b. $v$, I. Bernier, 和. D. 1.21 e.w. Zie ook hoofdstuk 5 5.D.6.b.

24. O.a.: G.G. Fitumatrice, a.w., p. 32.

25. P. Reuter, Droit international public, 1958, p. 153; H. Latuterpacht, Oppenheim "s Imternationd Law, 1955 , Vol. $\mathbb{I}, 8 \mathrm{dh}$ ed., $339-340$.

In het $\mathbb{E} G$-recht blift de federale overtheid verantwoordelijk woor het handelen van deelstaten.

26. I. Bernier, a.w., p. 115. Vgl. ook p. 120: "If the member states, in concluding gagreements with foreign states, exced their external competence, the federal government may denounce the agreement and in this case becomes null and void. If the federal gowernment regards the agreement as valid, and the other contracting party has no objection, then the treaty remains in force and the federal state as well as the menber states are responsible for its execution." ${ }^{*}$. Bernier, w. w., p. 120. 
den. Of dit in het licht van de geschetste doctrine ten aanzien van de treaty-making capacity en (eventueel) de statenpraktijk bij yoorbaat voor deelstaten van federale staten daadwerkelijk zo is, kan hier in het midden gelaten worden. ${ }^{27}$ Hier is van belang te constateren dat mijns inziens onderdelen wan staten pas als "echte' subjecten wan internationaal recht zijn te beschouwen, als zijzelf internationaalrechtelijk aansprakelijk zijn voor de door en woor henzelf aangegane internationale verplichtingen (b.v. middels verdragen). Als zij zelf niet internationaalrechtelijk aansprakelijk zijn, dan kan men zich afvragen of hun treaty-making capacity niet veeleer treaty-making power is. Dit betekent dat zij niet of nauwelijks als subjecten van internationaal recht zijn te beschouwen. Op bas is van het voorgaande zijn decentrale overheden c.q. grensoverschrijdende samenwerkingsverbanden niet als (partiële) subjecten van volkenrecht te beschouwen. Zij kunnen niet autonoom verdragen sluiten c.q. internationaalrechtelijk aansprakelijk gesteld worden.

\section{B. DECENTRALE OVERHEDEN EN HET GRONDWETTELIIK STELSEL VAN DE EXTERNE BETREKKINGEN 28}

Zoals aangegeven in de inleiding van dit hoofdstuk wordt grensoverschrijdend handelen van gedecentraliseerde overheden in het kader van hun publiekrechtelijke bevoegdheden (door staten) waak als onderdeel gezien van het internationaalrechtelijk handelen (van die staten zelf). Volgens Woehrling is het gezien het specifieke karakter van grensoverschrijdende samenwerking tussen decentrale overheden "not appropriate to try to apply the constitutional rules on inter-State agreements to questions of relations between neighbours." Prieur benadrukt het voorgaande door ten aanzien van de Franse situatie te stellen: "On pourrait même considérer que l'intervention de l'État dans le domaine de la coopération transfrontalière locale est un empiétement des autorités chargées des relations diplomatiques sur les compétences propres des collectivités locales". ${ }^{29}$ Ook in de Duitse literatuur wordt gesteld, dat het stelsel van de externe betrekkingen ex artikel 32 Grundgesetz decentrale grensoverschrijdende samenwerking niet in de weg staat. ${ }^{30}$

Een publiekrechtelijke afspraak gesloten tussen publiekrechtelijke rechtspersonen behorend tot verschillende rechtsstelsels wordt daarbij door staten in de regel beschouwd als afspraak van internationaal publiekrechtelijke aard: "Cette conception (la thèse du rattachement obligatoire des contrats transfrontaliers au droit international, RS) est défendue par plusieurs ministères des affaires êtrangères des pays. D'après elle, il convient de partir du principe de l'unité de l'Etat dans l'ordre des relations internationales. D'après

27. I. Bernier, a,w., p. 106 e.v.

28. Hier wordt vooral op de volkenrechtelijke geoorloofdheid van grensoverschrijdend handelen door decentrate owerheden ingegalt. Voor de staatsrechtelijke begrenzingen inzake buitenlandse betrekkingen door (Nederlandse) decentrale overheden wordt werwezen nas hoofdstuk 6 8.D.7.b. Vgl. ook noot 14 hoofdstuk 1 .

29. J.M. Woerhling, a. w., p. 15; M. Prieur, Les bases juridiques die la copperation frontalière locale et régionale, RFDA 1 (3), 1985 , p. 326

30. M. Oehm, a.w. p. 85; U. Hambuchen, a., w. p. 27; W. Hoppe, M. Beckmann, Juristische Aspekte ejner interkommunalem Zusanmenarbeit beiderseits der deutsch-niederländischen Grenze, DVBI; 1986, 1 , p. 5. 
ce principe, seul le Gouvernement possède compettence pour engager l'Etat par un accord conclu avec une autorité publique étrangère, car l'Etat possède le monopole de la personalité juridique internationale." "31 Zoals b.v. blijkt uit de in hoofdstuk 3 opgenomen beschrijving van de European Outline Convention heeft het monopolie van de staat op internationaal niveau, en met name het feit dat dit monopolie in beginsel op centraal overheidsniveau uitgeoefend dient te worden, een remmende rol gespeeld bij de totstandkoming en ook de implementatie van de European Outline Convention. Het beginsel van de eenheid van de staat is algemeen erkend. ${ }^{32}$ Het is gekoppeid aan de aan het internationale recht ten grondslag liggende soevereiniteit van staten: "Ce principe de l'Unitê de l'État est la conséquence directe du principe de souveraineté de l'État dans l'ordre international, et il postule que dans toute relation internationale, il y a toujouts une part de la souveraineté de l'État qui se trouve engagée". "33. Deze soevereniteit maw nifesteert zich enerzjjds in een grondwettelijk monopolie van de statat ten aanzien van de externe betrekkingen en anderzijds in de territorialiteit van het nationale publiekrecht. ${ }^{34}$ Bij de Duits-Nederlandse Overeenkomst inzake decentrale samenwerking is de (aantasting van de) soevereiniteit en daarmee samenhangend de vermeende territorialiteit van her publiekrecht aan de orde geweest. Met name voor de Bondsrepubliek Duitsland is deze problematiek de reden geweest om delegatie door decentrale overheden van regelgevende bevoegdheden aan grensoverschrijdende samenwerkingsverbanden c. $q$. buitenlandse overheden hierin uit te sluiten als mogelijke vorm van samenwerking evenals de deelstaten uit te sluiten van samenwerking op basis ervan. ${ }^{35}$

Welke organen van de staat binnen dit stelsel van externe betrekkingen over internationale handelingsbevoegdheden namens de staat beschikken (treaty-making power), is een

31. P.M. Dupuy, a.w., p. 844. Latore spreekt wan 'La thèse de l'exclusivite de l'Etat dans les relations exténeurs", R. Lafore, aw., p. 770. Zie over de rol wan de nationale overheid in deze ook P. Eckly, La coopéraüon transfrontaliere el l'admiristration française, Collection Etudes et Travaux 1. Conseil. de l'Europe, 1989, p. 14.

Hier zij er nogmaals op gewezen dat zuver privaltrechtelijke okereenkomsten buten met kador wan the internationale betrekkingen vallen. Zie b.w. U. Beyerlin, Rechtoprobleme (..), a, w. p. 175; M. Oelum, a.w. p. 77-79. Voor de afbakering tussen 'privaat" - en 'publiek" rechtelijke afspraken wordt ou a verwezer naar de algemene inleiding; hoofostuk.

32. "Il apparat en effet evident que pe principe est à l"heure actuelle effectivement reconnt par touss les Etats", P-M. Dupuy, a.w. p. 847. Zhe ook: M. Oelm, a.w, p. 83 e.v. die door te stellen dat grensoverschrijdend publiekrechtelik handelen van decentrale overheden niet persé wall binnen het stelsel der externe betrekkingen en onderworpen is aan het internationat pubiekrecht din beginsel in ieder gewal voor de Bondsrepubliek Duitsland nuanceert. Art. 32 Abs. I Grundgesetzheeft slechts betrekking op die internationale betrekkingen, waarbij aangelegenteden "des Gesamtstates centraal statn (p. 85).

33. R. Lafore, 2, w. p. 770-771. "Nach allgernener Auffassung bedeudet die Souveränitat des States, daws dieser einmal nach innen den höchsten Herrschaftsverband, den obersten Machttrager oder die oberste Rechtsordnung darstellt. Dazu kommt nach aussen die Unabhathgigkeit, d.h. die Freilheit von anderen Staten oder Statterverbindungen. Beides bedingt sich jedoch gegenseitig; das eine ist olme das anderte nicht möglich. "R.L. Bindschedler, Betrachtungen iber die Sowveranità, in: Recueil d"etudes de droit international, en hommage a Paul Guggenheim, 1968, p. 167. Zie over de soeveremiteit in dit verband 0.a. ook: A. Bleckmann, Das Souweränitätsprinzip im Völkerrecht, AVR 1985, 23. Band., 3. Heft, p. $450-477$

34. R. Latore, a.w. , p. 774 e. . Zie ook de vorige noot.

35. Voor een uitgebreidere beschrijving wan de artikelen 24 en 32 Grundgesetz word werwezen nat hoofdstuk 6 \& $\$ 4.7$. 
aangelegenheid, waarvan de regeling in principe aan het nationale recht is overgelaten. ${ }^{36}$ Hier wordt nagegaan of en in hoeverre decentrale overheden in het stelsel van de externe betrekkingen in het nationale recht internationale handelingsbe voegdheden zijn c.q. kunnen worden toegekend. Daarbij manifesteren de externe betrekkingen zich in beginsel in een tweetal vormen, namelijk de vertegenwoordiging en de verdragsiluitende bevoegdheid. In beginsel zijn dit twee gescheiden zaken. In eenheidsstaten behoren zij doorgaans tot de competentie van én en hetzelfde orgaan op centraal (regerings)niveau. In federale staten kumnen de deelstaten over expliciete (grond) wettelijke verdragsluitende bevoegdheden beschikken, zonder dat zij echter de bevoegdheid hebben de staat extern (lees: diplomatiek) te vertegenwoordigen. In vele federale constituties (b.v. die van Duitsland) is ten aanzien van het aspect van de vertegenwoordiging van federale staten door hun deelstaten in tegenstelling tot het aspect van de verdragsluitende bevoegdheden van de deelstaten ten opzichte wan de federale staat niets geregeld. ${ }^{33}$ In België hebben de Gemeenschappen en Gewesten verdragsluitende bevoegdheden en dient in een samenwerkingsakkoord tussen de federale overheid, de Gemeenschappen en de Gewesten de diplomatieke vertegenwoordiging geregeld te worden.

De meeste constituties centraliseren de buitenlandse betrekkingen met name in de persoon van het staatshoofd, de minister-president, en eventueel de minister van buitenlandse zaken: "Die weitaus überwiegende Zahl der geltenden Verfassungsurkunden erwähnt ausdrücklich nur das Vertragsschliessungsrecht des Staatsoberhauptes - sei es ein Monarch, sei es ein Präsident oder ein Kollegium. Die einschlägigen Bestimmungen sagen jedoch lediglich, dass das Staatsoberhaupt den Staat nach aussen vertritt und die Verträge schliesst; manchmal findet sich auch nur einer dieser Formulierungen. Diese Verfassungen lassen meist nicht klar erkennen, ob diese Kompetenz zwingenden und aussschliesslichen Charakters ist oder ob sie die Bildung eines Gewohnheitsrechts zugelassen hat oder zulassen würde, das etwa dem Ministerpräsidenten oder dem Aussenminister eine selbstständige Vertragskompetenz jedenfalls in bestimmten Fällen zuerkennt". ${ }^{38}$ Zo berust voor België de verdragsluitende bevoegdheid bij de Koning (artikel 68 Grondwet), in Duitsland bij de Bundespräsident (artikel 59 Grundgeset $Z$ ) en in Nederland bij cle regering (artikel 90 Grondwet). In de grondwettelijke stelsels betreffende de internationale betrekkingen van deze drie landen (en het merendeel der overige West-Europese staten) zijn voor de decentrale overheden - daar waar de deelstaten (Belgische Gemeenschappen en Gewesten/Duitse Länder) bevoegd zijn verdragen te sluiten, bepalen zij zelf wie namans hen de verdragen kan sluiten - geen (expliciete) bevoegdheden gecreeerd om (namens de staat) grensoverschrijdend te handelen. Hoewel de statenpraktijk laat zien, dat de kring van namens de staat verdragsluitende (en vertegenwoordigende

36. "Wenn das Vakerrecht hinsichthich der Rechtsoraussetzungen zur Erlangung der Volkerrechtssubjektivitât statlicher Untergliederungen regelmässig auf das betreffende nationale Verfassungsrecht zurückweist, so geschieht dies - wie gezeigt - ins besondere mut Rücksicht auf die Freiheit enes jeden Staates, señe Träger der auswartigen Gewalt selbst zu bestimmen " U. Beyerlin, Rechtsprobleme (..), a.W., p. 193. Zie ook: L. Di Marzo, a.ww, p. 1-4.

37. Vgl. A. Beirlaen, De internationale betrekkingen en de derde fase van de stagtsherziening Proeve van een oplossing. TBP, $1990 / 5$, p. 338 e.w.

38. W.K. Geck, Die völkerrechthichen Wirkungen verfassurngswidriger Verträge, 1963, p. 69. Zie woor Nederland, b.v: C. Flinterman, Parlement en butenlands beleid, p. 12-13, in: Staatsrecht, buitenlandse betrekkingen en de internationale rechtsorde, Staatsrechtconferentie, 1986. 
personen) groter wordt ${ }^{39}$, behoren de decentrale overheden hiertoe (nog) niet. Ten aanzien van de bevoegdheid om internationaalrechtelijk te handelen namens de staat, geldt het primaat van de centrale overheid. Daarbij is het bovendien de vraag of decenw. trale overheden uberhaupt wel over deze bevoegdheden kunnen beschikken? ${ }^{*}$ Het beginsell van de eenheid van de staat wordt zo nitgelegd dat bij extern publickrechtelijk handelen als het ware automatisch het internationale recht toepasselijk is. Als decentrale overheden extern willen handelen, dan dient dit dus binnen de regels van dit stelsel van externe betrekkingen te geschieden en daarmee automatisch binnen het kader van. het internationale recht. ${ }^{41}$ Willen decentrale overheden in juridische zin over de grenzen samenwerken en gaat men ervan uit dat dit inderdaad alleen maar binnen een internationaalrechtelijke context (binnen het stelsel der externe betrekkingen) kan, dan zijn zij aangewezen op degenen die wel bevoegdheden in dat verband hebben. ${ }^{42}$ In het navolgende worden de mogelijkheden van het internationale recht en de al dan niet 'overall'-toepasselijkheid ervan ten aanzien van decentrale grensoverschrijdende publiekrechtelijke afspraken uitgewerkt.

\section{\$3. Grensoverschrijdende overeenkomsten tussen decentrale overheden en het Weens verdrag inzake het verdragenrecht (WVV) ${ }^{4}$}

Als het over internationaalrechtelijke verdragen en met name de rechtsgeldigheid en verbindendheid ervan gaat, speelt "The Vienna Convention on the Law of Treaties" (het Weens Verdrag inzake het verdragenrecht) een zeer belangrijke rol. ${ }^{4}$ Omdat het in deze in het WVV geregelde voortvloeit wit de statenpraktijk en een zeer breed terrein van het verdragenrecht bestrijkt, kan hier met een behandeling van het WVV volstaan

39. W.K. Geck, a,w, p. 76. Zie ook noot 77 van dit hoofdstuk en de bijbehorende tekst bij de beschrijving van de administratieve akkoorden.

40. Zo woor frankrijk: "En d"autres ternes, la notion de souverainette nationale interdit que les attributs de

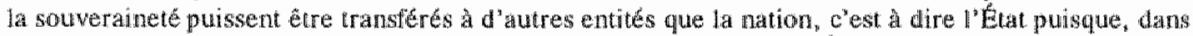
la conception française, la nathon est juridiquement personnifiée par l'Etat." , E. Zoller, a.w., p. 738 .

41. Het gaat hier on de actoren, die de bevoegdheid hebben on namens de stat extern te handelen. De nationaalrechtelikeprocedures tot goved keuring van verdrage ne.d., die eveneens in dit verband geregeld. worden, blijven hier buten bespreking; "A constitutional requirement may etter relate (a) to the scope and purpose of a treaty, or (b) to the organ and the procedure relevant to the conclusion of a treaty, or to both these matters." "McNair, a.W., p. 62.

42. "En effet, le principe d'Unite oblige, dravers les collectivites terricoriales, c"est bien I'Etat qui agit. et l'Etat est bien sujet du D.I.P. (Droit lnternational Public, RS) (ce que de plus les collectivitésterritoriales ne sont absolunent pas...) Les activites a l'ếtranger des collectivités territoriales sont donc redevables du seul Droil International Public, et n'entrent dans le cinamp de compétence que du seul Etat...", $\mathrm{R}$. Lafore, a.w. p. 771 .

43. The Vienna Convention on the Law of Treaties, 23 May 1969, Off. Rec. Documents. (A/Conf 39/27tCorr.1) 281 . Het is in werking getreden op 27 januan 1980.2 le ook: Trb. $1972 \mathrm{nr} .51$, Trb. 1977 nr. 169, Trb. 1985 nr. 79. Het verdrag wordt an de hathd van de Engelstalige verdragstekst besproken.

44. In dit werband is het niet van belang in te gan op de overige twee werdragen, wavin verdragenrecht gecodificeerd is, mamelijk. 'The Vienna Convention on Succession of States in respect of Treaties' en "The Wienna Convention on the Law of Treaties between States and International Organizations or berween International Organizations'. 
worden. "Hier zullen de in verband met lokale grensoverschrijdende samenwerking meest relevante artikelen van het WVV de revue passeren.

Artikel 2.1 (a) WVV definieert een verdrag als volgt: "Treaty means an international agreennent concluded between States in written form and governed by international law, whether embodied in a single instrument or in two or more related instruments and whatever its particular designation." 46 De internationaalrechtelijke effecten van een overeenkomst zijn niet afhankelijk van de benaming ervan. In deze maakt het niet uit of een overeenkomst als een 'verdrag', 'verklaring", 'overeenkomst", 'conventie", 'akkoord' of hoe dan ook betiteld wordt. ${ }^{47}$

Het WVV is van toepassing op internationale overeenkomsten 'in written form'. Hoewel het vereiste van schriftelijkheid als het enige vormwereiste is te beschouwen, wordt hiermee het toepassingsbereik van het WVV uiteraard beperkt. Dit is niet als een bezwaarlijke beperking van het toepassingsbereik wan het WVV te beschouwen, aangezien in de praktijk overeenkomsten in de regel op schrift zullen staan. Dit zal op het terrein van de lokale grensoverschrijdende samenwerking niet anders zijn. ${ }^{48}$

Het WVV is slechts van toepassing op verdragen tussen staten (artikel 1 WVV). In dat verband regelt artikel 6 WVV de "treaty making capacity". Het bepaalt: "Every State possesses capacity to conclude treaties "Een staat kan slechts middels zijn organen handelen. Artikel 7 (1) WVV regelt wie geacht kan worden namens de staat te handelen, met andere woorden wie over 'treaty making power' beschikt. ${ }^{49}$ Het gaat hier dan om: 'adopting or authenticating the text of a treaty or expressing the consent of the State to be bound by a treaty". Degenen die mamens de staat kunnen handelen, zullen over de zogenaamde "full powers" moeten beschikken. Dit impliceert, dat in beginsel een soort van machtiging van de staat vereist is, tenzij uit de praktijk van staten blijkt, dat het hun bedoeling is/was diegenen aan te merken als de staat vertegenwoordigend. ${ }^{50}$ Ingevolge artikel 7 (2) WVV worden een aantal personen geacht dit uit hoofde van hun functie te doen.

45. "In sum therefore, the Convention purports to corstitute a comprehensive set of principles and rules governing all the most significant aspects of the law of treaties." 1. Sinclair, The Vienna Convention on the Law of Treaties, 2 nd edition, 1984, p. 5.

Reuter stelt dat het WVV het meest homogene en belangrijkste dael van het verdragenrecht regelt. Paul Reuler, Introduction au Droit des Traites, 2 e ed., 1985, p. 23.

Met name de artikelen 3(b) en 38 van het WVV bepalen, dat het geregelde in het WVV ook voor staten, die niet partij zijn bij het werdrag, bindende werking heeft dan wel kan hebben in de toekomst. Het (arvwllend) gewoonterechtelijk verd ragentecht kan hier overigens buten beschouwing blijven. Over de verllouding tussen het verdragenrecht, zoals neergelegd in het WVV, en het international gewoonterechn, zie: I. Sinclair, a.k., p. 5 e.v. Zie ook de volgende noot!

46. Het is heel goed mogelijk dat, in het nationale recht wan een stat watrin het WVV in werking is getreden, de term "verdrag" een ruimere strekking heeft. Dit is bijwoorbeeld het geval in Nederland, zie: $\mathbb{E}$.W. Vierdag, De praktijk van de zogenoemde "internationale administratieve akkoorden", a.w., p. 37 e.v. Anderzijds kan het zijn dat in staten, waarin de WVV (nog) niet in werking is getreden, de verdragsdefinitie van het WVV gehanteerd wordt.

47. Zje o.a.: McNair, a.w., p. 22; A.M. Stuyt, Formeel Tractatenrecht, 1966, p. 27.

48. Zie in deze ook her gestelde in de algenene inleiding, hoofdstuk 1.

49. Zie ook noot 9 van dit hooflistuk en de bijbehorende tekst.

50. - Voor een uitgebreidere viteenzeting over de "full powers", zie: MoNair, a.w., p. 120 e.v.; I. Sinclair, a.w. p. 29 e.v. Zie ook noot 37 van dit hoofdstuk omtrent de (diplomatieke) wertegenwoordiging en de verdragsluitende bevoegdheid.

- Voor een uitgebreidere uiteenzetting ower de statenpraktijk in deze, zie: H. Blix, a.w., p. 23 e.w. Zie ook noten 70 en 71 van dit hoofdsiuk. 
Voor een overall-verdragsluitende bevoegdheid gaat het in beginsel om dezelfde personen als degenen die in de (grond-) w ettelijke stelsels omtrent de externe betrekkingen van staten aangewezen zijn namens de staat te handelen. Voor bepaalde bevoegdheden, zoals het aannemen van de tekst van een verdrag, worden hoofden van diplomatieke missies en vertegenwoordigers bij internationale organisaties als zodanig beschouwd. Voor de decentrale overheden zijn hier geen bevoegdheden gecreëerd. Van een statenpraktijk, die geacht kan worden decentrale overheden in zijn algemeenheid toe te staan namens de staat op te treden in het internationale verkeer, lijkt (nog) geen sprake. Decentrale overheden zullen derhalve over (expliciete) "full powers" dienen te beschikken, vooraleer zij de staat b. w. via een verdrag kunnen binden. Beschikken overheidsorganen niet over deze 'full powers' dan blijwen de verdragsluitende handelingen van degenen die niet geacht worden namens de staat te handelen (de staat te vertegenwoordigen) zonder rechtsgevolgen, tenzij, aldus artikel 8 WVV, 'afterwards confirmed by that State'. Voor de decentrale overheden impliceert dit, dat zij zonder witdrukkelijke voorafgaande machtiging of toestemming achteraf geen (door het internationaal recht beheerste) verdragen namens de staat in het leven kunnen roepen. ${ }^{\text {s1 }}$ Wil men de decentrale overheden tot het sluiten van verdragen in staat stellen, dan komt het er dus op aan hen van 'full powers' te voorzien. ${ }^{52}$ Zijn er 'full powers' (b. $\psi$. in de vorm van een interstatelijke verdragsrechtelijke grondslag) aanwezig, dan bestaan er geen internationaalrechtelijke belemmeringen voor door decentrale overheden binnen het kader van het WVV te sluiten internationaalrechtelijke verdragen. Hoewel het hier mijns inziens meer een theoretische dan praktische optie betreft, rechtvaardigt dit een voortzetting van de bespreking, voor zover hier van belang, van het WVV.

Artikel 11 WVV bepaalt: "The consent to be bound by a treaty may be expressed by signature, exchange of instruments constituting a treaty, ratification, acceptance, approval. or accession, or by ouler means if so agreed". In de artikelen $12 \mathrm{t} / \mathrm{m} 17$ WVV worden elk van deze instrumenten, betrekking hebbend op het vereiste van de wilsovereenstemming, nader uitgewerkt. Zaken als het beoogde doel van een verdrag alsmede de wederzijdse gehoudenheid eraan vinden niet expliciet regeling in het WVV. ${ }^{53}$ Dit mondt uit in het belangrijkste criterium om een overeenkomst als een intemationaalrechtelijk te kumnen aanmerken, namelijk, dat een dergelijke overeenkomst op basis en volgens de regels van het international recht gesloten dient te zijn: "The law governing validity, binding force, interpretation, application and termination of treaties between states cannot be the municipal law of any of them; it is well settled by the doctrine, practice and jurisprudence that this is international law." s4 Als decentrale overheden al internationaalrechtelijk zouden kunnen hande-

51. Zie b.v. P-M, a.w., p. 844; R. Lafore, a.w., p. 771. Zie voor cen nadere thitwerking van de woorafgatande machtiging of de toestemming achteraf het gestalde hieromtrent sub \& 4 van dit boofdstuk.

52. Het is duidelijk dat het hier met name zal gaan on "full powers" om te onderhandelen en wellicht om een verdrag te sluiten. Verder zullen de "full powers" niet reike Zi. Zo zal wooral daar waar decentrales overtreden optreden de will van de stat om gebonden te worden zich net name pas door ratificatie door regering/parlement manifesteren. Zie ook McNeilr, a. w., p. 120.

53. Een en ander staat (in de doctrine) in verband met zaken als o.a. "essential validity" MeNair, a.w., p. 214 e.w.), "severance of treaty provisions" MciNair, a.w., D. 474 e.w.) en de "interpretation of treaties' (I. Brownlie, a.w. p. 626 e.v. Sondacl lijkt een en ander in het kader valu de oordeelsvorming over de wenselijkheid van een verdrag te platatsen, H.H.M. Sondal, a.w., p. 77 e.w.

54. Harward Research in. International Law on Treatles, Supplememto 29 AIL, (1.935), p. 693. 
len in de zin van het sluiten van verdragen, dan zullen zij hierop in het kader van grensoverschrijdende samenwerking in de regel het internationaal recht niet als het toepasselijke recht (willen) zien. ${ }^{55}$

Deel $V$ van het WVV regelt $0 . a$. de ongeldigheid van verdragen. In dat verband komt met name de relatie van verdragen met het overige internationale recht en eventueel het nationale recht aan de orde. Artikel 43 WVV bepaalt, dat de ongeldigheid van een verdrag niet betekent dat men zich aan verplichtingen, die ook buiten dat verdrag reeds op basis van het internationale recht op een staat rusten, kan ontrrekken. Doet men dit toch, dan kan dat b.v. een onrechtmatige daad opleveren. De artikelen 53 en 64 WVV gaan nog verder door te bepalen dat verdragen nietig zijn, wanneer zij in conflict komen met ius cogens. ${ }^{56}$

De verhouding tot het nationale recht in dit verband is met name geregeld in artikel 46 WVV. Het bepaalt: (1) "A State may not invoke the fact that its consent to be bound by a treaty has been expressed in violation of a provision of its internall la.w. regarding competence to conclude treaties as invalifdating its consent unless that violation was manifest and concersed a rule of its internal la.w. of fundamental importance."; (2) "A violation is manifest if it would be objectively evident to any state conducting itself in the matter in accordance with normal practice and in good faith." Zoals reeds gesteld, kunnen decentrale overheden via verdragen in beginsel alleen maar de staat internationaalrechtelijk binden, als zij over 'full powers' beschikken. Artikel 46 WVV heeft hierbij betrekking op de situatie waarin overheden, in strijd met het nationale recht, internationaalrechtelijk handelen. Worden aan decentrale overheden al 'full powers' toegekend, dan ligt het zeer voor de hand dat de daarin neergelegde handelingsbevoegdheden in het kader van de verdragssluiting, vanwege de ongebruikelijkheid wan het optreden van decentrale overheden in het internationale rechtsverkeer, zeer precies omschreven zullen zijn. Het achteraf succesvol inroepen van een manifeste schending van fundamenteel nationaal recht inzake het sluiten van verdragen zal dan problematisch zijn. ${ }^{57}$ In het geval er een statenpraktijk bestaat, waarin niet op voorhand volmachten worden vereist, zal zich het probleem van de strijd van het internationale recht met het nationale recht manifesteren. $"$ s

De toepasselijkheid van een dergelijk, voor lokale grensoverschrijdende overeenkomsten, (rigide) stelsel ligt, mijns inziens, niet zo voor de hand. In het vervolg zal nog nader aangegeven worden, dat het in beginsel niet aannemelijk is dat de tot op heden tot stand gekomen publiekrechtelijke overeenkomsten tussen decentrale overheden in het kader van de grensoverschrijdende samenwerking (op voorhand) als internationaalrechtelijke verdragen in de zin van het WVV moeten worden gekwalificeerd. Zo verschaffen de eerst recentelijk gesloten interstatelijke overeenkomsten inzake lokale grensoverschrijdende samenwerking niet zonder meer 'full powers" voor internationaalrechtelijk handelen

55. Zie ook de noten 102 en 103 van dit hoofdstuk en de bijbehorende rekst.

56. Het is aannemelijk, dat ook strijd met algemene rechtsbeginselen tot die nietigheid van verdragen zal leiden. Te denken valt bijvoorbeeld aan het beginsel van pacta sunt servanda en de goede trouw (artikel 26 WVV).

57. Overigens zal het inroepen van een manifeste schending in zijj algemeenheid niet snel mogelijk zijn: P. Reuter, Droit (..), a.w., p. 136.

58. In zijn algemeenheid zal een handelen van personen, dat duidelijk kenbaar in strijd is met hun nationale bevoegdheden, zeer waarschijnlijk een beroep op artikel 46 WVV doen slagen. Vgl. in deze ook artikel 27 WVV. Zie ook noot 141, hoofdstuk 5 en bijbehorende tekst. 
van decentrale overheden. ${ }^{59}$ Dit het geval zijnde - er ontstaat dan een identieke situatie aan die waarbij een interstatelijke overeenkomst als juridische grondslag ontbreekt - zijin er binnen het kader van het WVV geen (verdere) mogelijkheden voor de decentrale overheden internationaalrechtelijk (verbindende) verdragen te sluiten. Wil men de overeenkomsten tussen de decentrale overheden in deze niet bij voorbaat (internationale) rechtskracht ontzeggen en wordt er voorshands vanuit gegaan, dat decentrale overheden niet (partieel) subject van internationaal recht zijn, dan zal de volgende vragag beantwoord dienen te worden. In hoeverre kunnen zij wellicht internationaalrechtelijke over eenkomsten vergelijkbaar met verdragen sluiten? Daarmee is men bij de behandeling van de internationale administratiewe akkoorden beland. Daarbij wordt ook bezien of op afspraken ussen decentrale overheden aan weerszijden van de grens wellich een ander rechtsregime dan het internationaal recht van toepassing kan zijn, bijvoorbeeld het nationale recht.

\section{\$4. Grensoverschrijdende publiekrechtelijke afspraken tussen decentrale overheden en internationale administratieve akkoorden}

\section{A. INTERNATIONALE ADMINISTRATIEVE AKKOORDEN VERSUS WERDRAGEN}

Een belangrijke aanzet tot beantwoording van de centrale vraag, zoals verwoord in de inleiding van dit hoofdstuk, is een citaat van Reuter betreffende de mogelijke internationaalrechtelijke aspecten van andere internationale overeenkomsten dan verdragen, b.v. grensoverschrijdende overeenkomsten tussen gedecentral iseerde overheden: "Il arrive que les parties à un accord soient, non pas directement les États, mais des services de l'État, plus ou mains décentralisées, ou même des personnes morales de droit publics (communes, établissements publics, agences, etc.). Dans ce cas-là, il faut rechercher si le service engage l'État; en cas de réponse negative, se posera alors la question de savoir s'ill s'agit d'un accord international de forme particulière, mais s"apparentant étroitement aux traités entre États." Dit citaat maakt duidelijk dat er naast verdragen een andere categorie van (aan verdragen gerelateerde) internationale overeenkomsten bestaat respectievelijk kan bestaan. Het betreft dan de zogenaamde in het Engels "administrative agreements", "agreements in simplified form', "executive agreements", of in het Frans 'accords administratives', "accords en forme simplifiée'. "Wl Hierna zullen zij als (inter-

59. Zie voof de bespreking van de Benelux-Owereenkomst en de Duits-Nederlandse Overeenkonst inzake decentrale grensoverschrijdende manerwerking, hoofustuk 55 respectievelijk hoofdsuk $6 \%$.

60. P. Reuter, Introduction (..)a.w. p. 36.

61. 'Administrat ve agreement'/ agreements in simplified forn': J. Basdevant, La conclusion et lat redaction aes traites et des instruments diplonatiques autres que les trates, Receuld des Cours, 1926, p. 601-641; Ch. Rousseau, Principes genęrax du droid nternational public, 1944, p. 306; MoNair, a.w., 1960, p. 20; H. Blix. Treaty making power, 1960, p. 17-25; Cll. Rousseau, Droit international public, fome I, Introduction sources, 1970, p. $70-73$; L. Wildhaber, Treaty-making (..), a.w. p. 106-146; L. Wild haber, Executive agreernents, Encyclopedia of Public International Law, 1984, Vol. 7, p. $81-86$. "Accords infra batiques". G. Burdeat: Les accords conclus entre autorités administratives ou organismes public de pays differents, dans: Mélanges offerts à Paul Reuter "Le droit international: Unite diversite" 1981, p. 1103-126; Y. Lejeune, $2 . w ., 1.4 ;$

"Contrats transfrontaliers": J-M. Woelurling, a.w. 
nale) administratieve akkoorden betiteld worden. Voor Reuter heeft het criterium voor het onderscheid tussen verdragen en (hieraan gerelateer de) andere internationale overeenkomsten blijkbaar te maken met het binden van de staat door de diverse overheden. Ook voor Wildhaber is de afwezigheid van de expliciete bevoegdheid om de staat te binden een criterium voor de definiering van administratieve akkoorden: "agreements concluded by an organ in which the municipal constitution did not, expressis verbis, vest treaty-making power." 62 Vierdag ziet het verschil tussen (sluiting van) verdragen en administratieve akkoorden met name in de afwezigheid bij de laatste van diplomatieke aspecten. ${ }^{63}$ In een preadvies voor de Nederlandse Veremiging van Internationaal Recht omschrijft hij de zogenaamde internationale administratieve akkoorden, als wolgt: "de zeer" heterogene groep overeenkomsten die met elkaar gemeen hebben dat ze buiten de diplow matieke kanalen om worden gesloten door vakministers, zelfstandige staatsinstellingen, departementen, of onderdelen daarvan, met gelijksoortige bewindslieden, diensten of instellingen van één of meer andere landen, die niet ter goedkeuring worden woorgelegd aan parlementaire organen en evenmin worden geratificeerd." Vierdags preadvies behandelt daarbij (expliciet) de grensoverschrijdende overeenkomsten tussen decentrale overheden: "In deze groep kunnen ook worden ondergebracht overeenkomsten gesloten door "local authorities", zoals bijvoorbeeld voorzien in het kader van de samenwerking waarvoor in de Raad van Europa is gesloten de European Outline Convention on Transfrontier Co-operation between Local Communities or Authorities...". 6.5

Het sluiten van deze administratieve akkoorden, door personen of organen die hiertoe niet constitutioneel bevoegd zijn, of buiten de gebruikelijke diplomatieke kanalen om, ${ }^{66}$ is mijns inziens een bruikbaar criterium om de administratieve akkoorden van verdragen (in de zin van het WVV) te onderscheiden. Het voorgaande is een negatief geformuleerde benadering. Daarmee is nog niet veel gezegd over de grondslag voor het sluiten van administratieve akkoorden en de bevoegdheid van degenen die dergelijke

62. L. Wildhaber, Treaty making (..), a.w., p. 141.

"The circumstance that so many modern treaties become binding merely by being sigmed by persons not. mentioned in the constitution accordingly may seem puzzling, and has caused doctrinaldebate.", $\mathrm{H} . \mathrm{Blix}$ a. W. 17. 17; Ook Rousseau noemt in dit werband de afwezigheid van grondwettelijke bepalingen inzake verdragsiluitende bevoegdheden (treaty-making power) als onderscheidend element tussem "les accords en forme simplifice" en "traitss" "Ch. Rousseau, Droit (..), a.w., p. 73.

63. Ook: Basdevant, die dergelijke overeenkomsten als instrumenten ziet dont le caractere diplomatique s'atcénue parce qu'ils ne sont plus élaborés par ceux dont la mission normale est de représenter l'Etat au dehors. Ce sont des instruments blaborés et signés par des fonctionnaires techniques. Pour l'éboration d'un tel acoord la negociation va tre conféte des agents techniques qui fixeront les termes de l'accord,

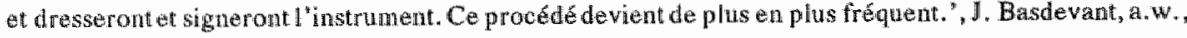
p. 624 .

64. E.W, Vierdag, a.w., p. 42

Nö, in een reactie op Viscrag, omschrijf administrative akkoorden als "internationale regelingen die Vakministers, statsinstellingen, departementen, overlweidsiastellingene.d. willen treffen met hun "counterparts" in het buitenland. "C.J. Noe, in: Vershg van de Algemene Ledenvergadering, Mededelingen Wan de Nederlandse Vereniging voor Internationaal Recht, no. 100, maart 1990, p. 11; Mc Nair spreekt wa "agreements expressed as made between departments, or ministers, or subordinate organs or agencies. of Governments", McNair, a.w., D. 20.

65. E.W. Vierdag, n.W., p. 42. Vanwege de referentie aan lolkale grensoverschrijdendesamenwerking staan Vierdags bevindingen in deze hier centraal.

66. Nar mijn mening is het verschil tussen de twee hier niet relewant. 
akkoorden sluiten. Daarmee is ook nog niets gezegd over de rechtsgeldigheid, de verschijnings vormen alsmede de inhoud van administratieve akkoorden. Toch kunnen grensoverschrijdende overeenkomsten tussen decentrale overheden voorshands op basis van het voorgaande naar mijn mening aangemerkt worden als administratieve akkoorden. ${ }^{67}$ Het is van belang na te gaan of dit criterium voor het onderscheid tussen verdragen en administratieve akkoorden, waaronder grensoverschrijdende publiekrechtelijke afspraken tussen decentrale overheden, ook verschillen impliceert in de internationaalrechtelijke status van beide. ${ }^{68}$ In dit verband worden de belangrijkste elementen in de toekenning van een internationaalrechtelijke status aan internationale overeenkomsten onderzocht, namelijk de bevoegdheid (power) om ze te sluiten - dit is vooral een zaak van nationaal grondwettelijk reclit - alsmede hun bindende rechtskracht in het internationale recht. Daarbij wordt in het licht van het citaat van Reuter van de voorlopige hypothese uitgegaan, dat administratieve akkoorden aan verdragen gerelateerde internationale overeenkomsten kunnen zijin.

\section{B. BEVOEGDHEID OM INTERNATIONALE OVEREENKOMSTEN TE SLUTTEN}

Als administratieve akkoorden een aan verdragen gerelateerde rechtskracht kunnen bezitten, ${ }^{69}$ dan is het duidelijk dat, evenals door verdragen, staten erdoor gebonden worden. Omdat staten de principale subjecten van internationaal recht zijn, kunnen in beginsel alleen staten gebonden worden door internationale overeenkomsten als bron van internationaal recht en dit alleen als zij willen dat zij gebonden worden (treaty-making capacity). Daarom kunnen (lokale) overheden (state organs) hun staat alleen maar binden middels een administratief akkoord als bron van internationaal (verdrags)recht, als zij op de een of andere wijze een van de staat afgeleide bevoegdheid hebben om dit te doen (treaty-making power). Als administratieve akkoorden verdragsrechtelijke rechtskracht kunnen hebben, dan is het evident dat op de een of andere wijze bevoegdheden noodzakelijk zijin voor overheden om dergelijke akkoorden te sluiten. ${ }^{70}$ Dan is derhalve enige

67. Zie ook: L. Wildhaber, Trealy-making (..), a.w., p. 14 I.

68. Men neemt aan dat administratieve akkoorden vakk gestoten worden, on de voor verdragengebruikeljke procedures, die te zwar en te omstachtig zijn voor de materie die zij willen regelen, te onzeilen. Mas Geesteranus spreekt in dit verband van 'gecamoufeende verdragen': $G$. W. Maas Geesteranus, m: Verstag wat de: Algenene Ledenwergadering, a.w., p. 5; Rousswau bakent de "traites proprenents dits" af legen de 'riccords techniques': Ch. Rousseau, Principes (..), a.w., p. 306.

69. Artikel 38.1 van het Statuat van het Jnernationaal Cerechtshof geef "the sources of internationatl law" ata. Als waststat dat internationale administratjeve akkoorden internationalrechtelijk bindend kunnen zijn, dan zullen zij in beginsel onder een van de in artikel 38 genoemde vier rechtsbronnen te platsath zijn. Ombat he bjj de internationalle administratieve akkoorden om overeenkomstengat, ligt ankmoping erwa bij de international rechtelikeovereenkomsten (verdragen) als rechtsbron wan inter nationat rech dan logisclierwijze woor de hand.

Op de mogelijkheid, dat de (staten)praktijk in verband met de internationale administratieve akkoorden ook kan leiden tot de vorming van internationaal gewoonterecht in deze, wordt hier, niet dan wel zijteJings ingegaran.

70. Zoals angegewen in 3 wan dit hoofustuk zijn voor de "treaty-making power" de artikelen 7 en 8 WVV van belang.

"Eine stillschweigende werfassungsrechtiche Konpe tenz lokaler Aufgabentrager zur grenzuachbarlichen Zusammerarbeit lässt. sich unter Umständen durch die Auslegung einer oder mehrerer geschriebenter

(word wervolgd...) 
vorm van machtiging (ex ante of post) van de staat aan gedecentraliseerde overheden om internationaal namens de staat te handelen een essentieel vereiste. ${ }^{71}$

De vraag is of deze bevoegdheden bestaan en of ze aangemerkt kunnen worden als machtiging van de staat aan decentrale overheden om internationaal te handelen met 'cross-border counterparts'. Een dergelijke machtiging zal mijns inziens veelal zijn basis vinden in een verdrag maar ook kunnen voortvloeien uit het nationaal recht b.v. uit regells met betrekking tot toezicht en controle: "La place et les fonctions assignées par les autorites publiques aux accords qu'on examine ici sont variables... L'absence de traité de couverture ne signifie d"ailleurs pas forcément l'absence de suivi de la part des autorités centrales de l'Etat. Par des procédés divers, tutelle, communication obligatoire des accords, assistance dans la négociation, etc..., celles-ci sont généralement informées des relations extérieures des organismes décentralisés." ${ }^{72}$ Er kan ook sprake zijn, vooral op centraal overheidsniveau, van (stilzwijgende) delegatie/vertegenwoordiging. ${ }^{73}$ Met betrekking tot (de bindende kracht van) 'accords en forme simplifiée' stelt Rousseau: "Le caractère obligatoire des accords en forme simplifiée, là ou il ne résulte pas de prescriptions constitutionelles expresses ... se justifie par la présomption de légalité qui s'attache aux actes accomplis par un organe étatique - ici l'organe exécutif - dans les limites de sa compétence fonctionelle." 74

Het is essentieel ten aanzien van de internationaalrechtelijke status van administratieve akkoorden verschil te maken tussen die welke op centraal overheidsniveau en die welke door decentrale overheden worden gesloten. Administratieve akkoorden met een juridisch bindend karakter, gesloten tussen organen van de centrale overheid zoals ministers, zullen eerder dan die totstandgekomen tussen lokale overheden als 'verdragen' aangemerkt kunnen worden en daardoor aan de staat als subject van internationaal recht toege-

70.(...vervolg)

Verfassungsnormen unter berileksichtigung ihrer systematiscben Stellung und des Gesamtzusammenhangs, in den sie eingebettet sind, gewinnen.", U. Beyerlin, Rechtsprobleme (..), a.w., p. 198. Zie ook noten 49 en 50 van dit hoofustuk.

71. "In the case of every State enjoying treaty-making capacity some provisions must exist, either as part of a written constitution or as rules of customary law and practice which indicate the organ or organs possessing power to conclude treaties and defining the mode of exercise of that power. ", McNair, a.w., p. 60. Zie ook de vorige noot.

72. G. Burdeau, g.t., p. $110,113$.

Zie ook Beyertim: "Rechtlich bemerkenswert erscheint, dass die lokalen grenznachlbarlichen Vereinbarungen offentlich-rechtichenTyps im deutsch-schweizerischenRaum allesant nicht auf der Basis eines hierzu ermächtigenden Vökerrechtsvertrages zwischen den betreffenden Nachbarstaaten zustande gekommen sind" U. Beyerlin, Dezentrale grenzüberschreitende Zusammenarbeitals transnationales. Rechtsphänomen, AVR 1989, 27. Band, 3. Heft, p. 297.

73. Zie b.v.: E.W. Vierdag, a.W., p. 59. Over delegatie in dit verband zie ook: H. Lauterpacht, Oppenheim"s linternational Law, 7 th edition, 1952, Vol. I, p. 885; Zie in dit verband ook het gestelde omtrent. artikel 7 en 8 WVV 3 van dit hoofdstuk.

74. Ch. Roussean, Droit (..), a.w., p. 73.

Rudolf heeft een andere visie. Hij stelt dat grensoverschrijdende samenwerking door organen, die niet door de grondwet hiertoe bevoegd zijm verklaard, in het algemeen, van een giet bindend karakter en derhalve van geen relevantie zijn in het internationale recht; W. Rudolf, Bundesstaat und Völkerrecht, AVR 1989, 27. Band, 1. Heft, p. 17. 
rekend worden. ${ }^{75}$ McNair spreekt over de eerste categorie als hij stelt: "that what is important is that this practice (praktijk van administratieve akkoorden, RS) must not be allowed to obscure the fact that the real contracting parties are States". "Ook al is er (wellicht) een statenpraktijk die ministers, binnen hun functionele competentie, een internationale bewoegdheid (treaty-making power) toekent, toch kan nawwelijks aangenomen worden dat een dergelijke statenpraktijk er ook is ten aanzien van (organen van) decentrale overheden. ${ }^{77}$ Een aanwijzing voor het feit dat ministers in beginsel hun staten (kunnen) representeren, wanneer zij internationaal in het kader van hun functionele competentie handelen, is te vinden in de Eastern Greenland Case. ${ }^{78}$ Hoewel het daarin een minister van Buitenlandse Zaken betrof, komt het herhaaldelijk voor dat vakministers internationaal optreden, b.v. in het kader van ontwikkelingssamenwerking, verkeer, milieu e.d. Het is niet aannemelijk dat representanten van decentrale overheden geacht worden de staat zonder meer op dezelfde wijze te kunnen wertegenwoordigen. ${ }^{79}$ (Ministeriële) administratieve akkoorden zijn veelal een uitwoering van en gebaseerd op bestaande verdragen. ${ }^{80}$ Deze verdragen kunnen in dit verband beschouwd worden als

75. Zie aok: G. Burdeau, a.w., p. $\Perp 7$.

McNair maakt ook een verschil tnssen overeenkomsten op centraal regeringsniveau en die gesloten op lokaal niweau. Met betrekking tot de eerste categorie stelt hij: "It is believed that it is true of an organ or agency of the central Government to say that its agreenents bind the State. "Hij voegt well nog toe: "but the precise relation of certain departments to the central Government varies greatly in different States, and every case requires separate consideration upon its facts.", McNair, a,w., p. 21 .

76. McNair, a.w., p. 20.

77. - Zie b.v. W.K. Geck, a,w., p. 76: "Verwendet man den Begriff der Ermächtigung in dem hier gebrauchten Sinne - ausdrücklich und stillschweigend, generell und speciell - und bejaht man atusserdem die Möglichkeit, dass sich in einer Anzah von Staaten ein Satz des Verfassungsgewohnheitsrechtesizber die originäre Vertragsschlusskompetenz won Ministern berausgebildet hat, so erscheint es durchaus möglich, dass alle Vertragserklärungenvon Ministern auf irgendeine Weisse verfassungsrechtlich legitimiert sind. Es wăre allerdings auch denkbar, dass sich ein Satz des Völkergewohnheitsrechtes herausgebildet hat, der die befugnis zur Aufgabe won Vertragserklärungen bestimnten oder allen Ministern unmittelbar und unabhängig won den Vorliegen einer verfassungssechthich einwandfreien Kompetenzzuweisung billigt."

- Zie b.v. BVerfG 22-3-1983 (2BvR 475/78) BVerfGE 63, 343, in: Deutsche Rechtsprechung in wökerrechlichen Fragen (1981-1985) (Fontes iuris gentium: SER.A:Sect.2;T.9), nr. 87 p. 27: "Das. Volkerrechi schützt insoweit auch we der ennen guten Gillauben an die Vertretungsmacht tntergeordneter Behör. den, noch keant es eine Vermutung zugunsten ihrer Vertretungsmacht:".

78. "The Court considers it beyond all dispute that a reply ... given by the Minister for Foreign affatrs on behalf of his Government ... in regard to a question falling within his province, is binding upon the Country to which the Minister belongs." ; The Eastern Greenland Case, 1933 P.C.IJ. Rep. (Ser. A/B, no. 53).

De bestissing in deze zaak sluit aam bij artikel 7 van het WVV: "Full powers", volgens artikel 7 , "are not Decessary ... it appears from the practice of the States concerned or from other circumstances that their intention was to consider that person as representing the State for such purposes and to dispence with full powers.'

79. Ean en ander heeft ook relatie met artikel 46 WVW, zie: L. Wildhaber, Executive Agreements, a.w.。 p. 85 .

80. Voor enige illustraties wan ministeriële ad ministratieve akkoorden ("arrangements") als implementavie van verdragen op thet gebied van de technische samenwerking tussen Nederland en enkele landen, zie b.x.: Trb. $1991 \mathrm{nrs} .21,22,23$ en 24.

Ten aanzien van de akkoorden in Trb. 1991 nrs. 21,23 en 24 is bepalald dat deze ingevolge het additiom neel artikel $\mathrm{XXI}$, eerste lid, onderdeel $\mathrm{b}$, wan de Grondwet, juncto artikel 62 , eerste lid, onderdeel $b$,

(wordt vervolgd...) 
machtiging van de staat om te handelen: "Il est fréquent que les accords infra-étatiques soient conclus en application d'un traité interétatique qui en prévoit expressément l'intervention". ${ }^{81}$ Zo de European Outline Convention al - de Benelux-Overeenkomst en de Duits-Nederlandse Overeenkomst inzake decentrale grensoverschrijdende samenwerking zijn dit zonder meer - gezien kan worden als een juridische basis voor decentrale overheden voor het realiseren van grensoverschrijdende overeenkomsten, lijkt deze evenwel niet bedoeld als een bevoegdheidsgrondslag voor het sluiten van internationaalrechtelijke overeenkomsten. ${ }^{82}$

Als een dergelijke juridische basis niet bestaat, dan zou een bevoegdheidsgrondslag voor (en daarmee de rechtskracht van) dergelijke overeenkomsten misschien kunnen voortvloeien uit "la rencontre de deux compétences définies dans le cadre national de chacune des parties en présence." ${ }^{83}$ Men zou er van kunnen uitgaan, dat het niet voor onmogelijk moet worden gehouden dat een aantal specifeke interne (nationaalrechtelijke) bevoegdheden, zonder een uitdrukkelijke verwijzing naar (externe) internationaalrechtelijke handelingsbe voegdheden toch als zodanig kunnen worden aangemerkt. ${ }^{84}$ Men zou kunnen denken aan grensoversclurijdend handelen in het kader van de autonone bevoegdheden van decentrale overheden. Ook kan gedacht worden aan het maken van afspraken over de uitoefening van publiekrechtelijke bevoegdheden, daar waar deze bevoegdheden van discretionaire aard zijn. Daarnaast bestaan er ook bepaalde sectorbevoegdheden, b.v. op milieugebied, waarin grensoverschrijdende afstemming van beleid wordt voorgeschreven. Dan gaat het dus niet om een overall-bevoegdheid voor decentrale overheden om internationaal te handelen b.v. aan verdragen gerelateerde overeenkomsten te sluiten maar om in specifieke gevallen grensoverschrijdend te handelen.

Een algemene regel ten aanzien van wat nu als een machtiging van de staat in deze kan worden beschouwd is niet te geven. Van geval tot geval zal het bestaan van (impliciete) bevoegdheden voor de diverse overheden om met gebruikmaking van het internationale recht over de grenzen te handelen onderzocht moeten worden.

\section{0.(...vervolg)}

de Grondwet naar ce tekst wan 1972 , niet de goedkeuring van de Staten-Generaal behoeven. Ten aanzien van de akkoorden in Trb. 22 is bepaald, dat deze - ze zijn afgedrukt in Trb. $1990 \mathrm{nr} .107$ - bij brieven medegedeeld zijn aan de Eerste en Tweede Kamer der Staten-Generaal. Het gat hierbij dus bijikbaar om (een vorm van) intemationaalrechtelijke overeenkomsten.

81. G. Burdeau, a.w., p. 115.

82. Zie hiervoor hoofdstuk $3 \& 2$.

In het kader van lhet voorstel tot verandering in de Grondwet wan bepalingen inzake buitenlandse botrekkingen wordt door de regering het wolgende gesteld: "Ter vermijding van miswerstand merken wij] op, dat deze overeenkomsten (gesloten op basis van de European Outline Convention en eventuele nadere verdragen, RS) van lagere overheden niet vallen onder her begrip 'verdragen' in de zin van de nietwe Grondwet.", MYA, Eerste Kamer, zitting 1980-1981, 15049 (R 1100), nr. 19. Zie ook H.H.M. Sondaal. a.w., p. 20.

83. G. Burdeau, a.w. p. 115. Vgll ook: Y. Lejeune, a.w., p. 412: "Des types wariés de liaisons de droïl public avec des personnes public étrangères attestent de l"autonomie croissante que les cantons, commi toutes les collectivités infra-étatiques, se sont reconnue dans les matières externes qui constinent lk prolongement de leurs compétences internes. "

84. In Frankrijk zijn ministers bevoegd om administratieve akkoorden te sluiten op dezelfde wijze als $z i$ bevoegd zijn de staat nationaalrechtelijk te binden. Deze akkoorden worden evenwel niet beschouwd al veruragen en hebben geen an verdragen gerelateerde rechtskracht: Zie $\mathrm{B}$. Zoller, a.w., p. 741 e.w. Zi ook P. Reuter, Introduction (..), a.w., p. 39 noot 71. 
De bevoegdheid om internationale overeenkomsten te sluiten is niet hel enige vereiste voor een mogelijk internationaalrechtelijk karakter ervan. Naast het feit dat partijen internationale overeenkomsten kunnen sluiten, is het van belang dat zij het oogmerk hebben dat deze beheerst worden door het internationaal recht. ${ }^{85}$ Op dit vereiste voor het bepalen van het internationaalrechtelijk karakter van internationale overeenkomsten wordt nu ingegaan.

\section{DE BINDENDE INTERNATIONAALRECHTELIKE STATUS VAN INTERNATIONALE ADMINISTRATIEVE AKKOORDEN}

Van den Brandhof meent dat administratieve akkoorden in het algemeen beleidsintenties zijn en niet internationaalrechtelijk bindend. ${ }^{86}$ Volgens Vierdag moet het bindende karakter ervan niet onderschat worden. ${ }^{87}$ Volgens mij kan alleen wan geval tot gevai aan de hand van het doel/de omstandigheden van sluiting e.d. het bindend karakter - voor wie worden er rechten en verplichtingen in het leven geroepen - ervan vastgesteld worden. Bindende formuleringen spelen hierbij natuurlijk ook een rol. Als er sprake is van juridische bindendheid van tussen decentrale overheden gesloten administratieve akkoorden dan betekent dit voor Vierdag bijna noodzakelijk internationaalrechtelijke rechtskracht: "Maar vanuit volkenrechtelijk oogpunt zal uiteindelijk de staat als gerechtigd of verplicht subject te beschouwen zijn." ${ }^{88} \mathrm{Hij}$ verwijst in dat verband naar de opvatting van Rapporteur Fitzmaurice in zijn derde rapport over 'the Law of Treaties' betreffende overeenkomsten gesloten door deelstaten van federale staten: "The component states of a federal union, not possessing any international personality apart from that of the union, do not possess treaty-making capacity. In so far as they are empowered or authorised under the constitution of the union to negotiate or enter into treaties with foreign countries, even if it is in their own name, they do so as agents for the union which, as alone possessing international personality, is necessarily the entity that becomes bound by the treaty and responsible for carrying it out..." ${ }^{89}$ Deze passage behelst met name overeenkomsten tussen deelstaten van een federale staat en andere sta-

85. Au fond les éfements essentiels des trattes internationatux sont comme pour las contracts entre particuliers un cons ntement réciproquie regulièrement exprimé, la capacité des contractants, un objet licite et possible au point de vue international." P. Fauchille, Traite de droit interndtional public "Tome ler, Troisisme Partie, 1921, p. 296. Zie ook: H.H.M. Sondad, a.w., p. 22 e.v.

86. M.C.E. wan den Brandhof, Administratieve overeenkonsten in het international publiekrecht; NJB $198640^{\prime}$ p. 1277 e.v.

Zie ook Rudolfs wergelijkbate visie, noot 74 wan dit hoofdstuk.

Noe is war mening dat aflankelijk van de beoogde verbindendleid ad ministratieveakkoorden of ventrag of beleidsafspratik zijm; C.J. Noé, a.w., p. 15 .

87. Dit is net echt nader beargumenteerd: "Het komt mij atanemelijk voor, dat administratieve akkoorden bindend zijn, althars indien er verplichtende formuleringen in zijn gebezigd." E. W. Wierdag; z.w., 19. 48 .

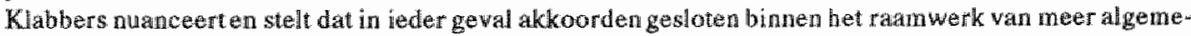
ne kade rovereenkomstenbindend zijn, J.A.M. Klabbers, Het volkenrechtelijkconvenant, NDA $1993 / 27$, p. 987.

88. E.W. Vierdag, a.w., p. 57. Zie ook Rudolfs opvatting, noot 74 van dit hoofdstuk.

89. G.G. Fitzmanrice, a.w. p. 24 . 
ten - het gat dan vooral om treaty-making capacity en niet treaty-making power ${ }^{90}$ - en niet overeenkomsten tussen deelstaten en andere "decentralised counterparts" in andere staten. Eigenlijk kan men dan ook niet echt spreken over administratieve akkoorden, zoals door Vierdag en anderen omschreven. ${ }^{\prime 1}$ Vierdags redenering heeft mijns inziens dan ook niet al te veel betekenis voor het vaststellen van de bindende internationale rechtskracht wan administratieve akkoorden. Op basis van deze redenering van Vierdag kan men aan administratieve akkoorden niet dezelfde (bindende) rechtskracht als verdragen toekennen. ${ }^{2}$

Ondat in het internationaal publiekrecht staten aansprakelijk zijn woor handelingen wan hun organen, wordt "state responsibility" als argument gebruikt woor het internationaalrechtelijk karakter van administratieve akkoorden. ${ }^{93}$ Natuurlijk kan er door het sluiten van administratieve akkoorden internationalrechtelijke "state responsibility' ontstaan. ${ }^{94}$ Maar het feit dat de staat aansprakelijk is voor handelen (of nalaten) van zijn organen kan op zichzelf geen (juridische) basis opleveren voor de veronderstelling dat administratieve akkoorden (dus ook die welke gesloten zijn tussen decentrale overheden) overeenkomsten met een internationaal bindende rechtskracht zijn. Het is immers zo, dat puur nationaatrechtelijk handelen (of nalaten) wan lokale overheden een schending wan internationaal publiekrecht kan opleveren en daarmee internationaalrechtelijke 'responsibility of the state'. ${ }^{95}$ Mogellike "state responsibility" is daarmee onvoldoende rechtvaardiging om een internationaalrechtelijke status toe te kennen aan grensoverschrijdende overeenkomsten, b.v. door ze te beschouwen als species van verdragen.

Vierdags opvatting (en ook die van andere schrijvers ${ }^{96}$ ) dat als er impliciete/expliciete bevoegdheden zijn om internationaal te handelen, de (bindende) rechtskracht van administratieve akkoorden bijna noodzakelijk internationaalrechtelijk is, is mijns inziens niet houdbaar of dient op zijn minst nuancering c.q. nadere beargumentering. Ik ben het met Vierdag eens, dat administratieve akkoorden internationaal bindende rechtskracht hebben in het geval ze daadwerkelijk als species van verdragen kunnen worden aangemerkt. $\mathrm{Zij}$ hebben naal: mijn mening alleen maar verdragsstatus als ze aan de vereisten voor de rechtskracht wan verdragen voldoen. Deze zijn, zoals eerder behandeld, de bevoegdheid

90. Zie met mame de noten 13,15 m 16 vam dit hoofdsuk en de bijbehorende tekst.

91. "Les rapports des Etals fédétes aved l'Gtranger sont en principe gouvemees par le droit international

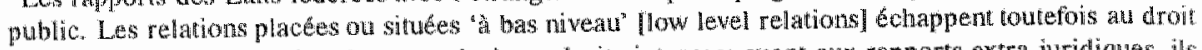
des gens pour être soumises a un ou plusieurs droits internes; quant aux rapports extra-juridiguges ils Echappent : tout droit." Y. Lejeune, w. W., p. 253.

92. Zie ook Y. Lejeune, a.w. , P. 44: "Mais les rapports des Etats fêerées awec letranger ne son pas axclusivenent régis par le droit international public. Des types de liaisons de plus divers surgissent entre personnes morales de droit public relevant d'Etats differrents. (Zie ook dezellite: p. 73 ).

93. O.a. E.W. Vierdag, a.w., p. 50-52; H. Blix, a.w. p. 20.

94. "Ces règles [des régles d'umputation des accords internationaux] abtablies doivent ici être combinées aver l'unite juridique de l'Eta pour conduite à assimiler en géneral les accords conclus entre ministres, même non expressement habilites, a des veritables trattés internationaux "G. Burdeau, a.w., p. 117.

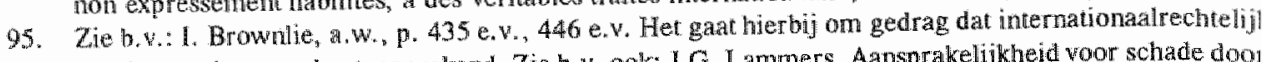
an de staat kan worden toegetekend. Zie b. w. ook: J.G. Lammers, Aansprakelijkheid voor schade doo grensoverschrijdende milieuverontreiniging, wolkenrechtelijke aspecten, p. $6 e^{2} v_{*}$ in: Mededelingen wa: de NVIR, no. 103, october 1991; M.A.J.M. Bronzwaer, Volkenrechtelike aansprakelijkheid wan states voor particulier milliewwervulend hendelen, TMA $1989 / 2, \mathrm{p}, 35$.

96. Vgl. noot I van dit hoofustuk. 
om internationaal namens de staat te handelen en de bedoelingen van partijen. De intenties van partijen voor het in het leven roepen van regels in een overeenkomst met een juridisch bindend karakter zijn beslissend voor het bindend karakter ervan. Het is van belang dat er overeenstemming bestaat tussen de partijen wat betreft het doel van de overeenkomst en de wederzijdse gehoudenheid eraan, met andere woorden de juridisch bindende kracht naar internationaal recht. Het is al gezegd dat de afwezigheid van expliciete constitutionele bevoegdheden voor (decentrale) overheden om over de grenzen te handelen niet zonder meer inhoudt, dat ze daartoe niet gerechtigd zouden kunnen zijn. ${ }^{97} \mathrm{Ik}$ ben het met Rosenne eens dat de bevoegdheid (voor staten) om internationale overeenkomsten te sluiten, niet zonder meer impliceert dat het internationaal recht op die overeenkomsten van toepassing is: "On the other hand, if the participants in that negotation, for whatever reason, do not intend the arrangement which comes out of the negotiation, however formal that arrangement might look, to be an agreement governed by international law, it will not be a "treaty" for the purposes of international law, whatever else it might be, and however much of a 'commitment' it might express. " 98 in de Serbian Loans Case heeft het Permanente Hof voor Internationale Justitie beslist dat op een overeenkomst tussen staten, die niet als subjecten van internationalal recht handelen, nationaal recht van toepassing is. ${ }^{99}$ Mann formuleert het aldus: "A problem of the choice of law is involved; it is the intention of the parties that determines the proper law of the contract in the sense of the branch of law applicable to it." ${ }^{100}$ Als staten internationaalrechtelijk kunnen handelen en zich buiten het internationale recht om over de grenzen kunnen binden, waarom zouden decentrale overheden dat dan niet kunnen? ${ }^{101}$ Lokale overheden zullen niet snel besluiten, als ze het at kunnen, tot de toepasselijkheid van internationaal recht als "the proper law" in hun grensoverschrijdende overeenkomsten. $\mathrm{Zij}$ hebben dat tot nu toe ook niet gedaan. ${ }^{102}$ Ook wanneer administratieve akkoorden gebaseerd zijn op verdragen hoeven de eerste nog niet een met de laatste wergelijkbare status te hebben. ${ }^{103}$ Vierdag veronderstelt dat de European Outline Convention (en de daarop gebaseerde Benelux-Overeenkomst inzake decentrale grensoverschrijdende samenwerking) internationaal publiekrechtelijke oplossingen zijn voor internationaal publiekrechtelijke problemen. Dit impliceert, dat op dergelijke verdragen geba-

97. "Ass "de bevoegde autorituten" de bedoeling hebben on en internationale regeling te treffen die wolkenrechtelijk veriondend moet zijn woor de staten, moet er, uiterard es verdrag worden gestoten. Dat

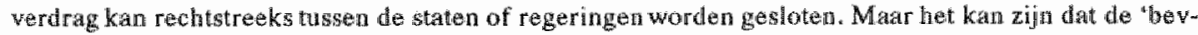

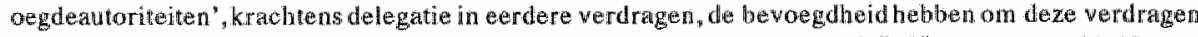
te sluten, of dat de regering de bevoegdheid datartoe ad hoc delegeert. " C. J. Nob, a, w., p. $11-12$.

98. 5. Rosenne, Developments in the Law of Treaties 1945\%1986, 1989, 9.87.

99. Serbian Laans Case, 1929 PCI (Ser. A, no. 20). Vgl. noot 78 van dit hoofdstuk.

100. F.A. Mann, The law governing state contracts, in: Sudies in International Law, 1973, p. 180. Met betrekking tot "the submission of treaties to municipal law" spreekt Mann van de "commercialisation" van verdragea. Hiji geeft aan dat dit fenomeen veel minder academische andacht heeft gekregen dan door het inernational publiekrecht beheerste contracten tussen staten en particulieren., W.A. Mann, A.W., D. $241-242$,

101. Zie b.w.: P. Dupuy, a.w: p. 849.

102. Beyerlin ontkent on die reden de toepasselijkheid vian international publiekrecht op gre fukoverschrij-

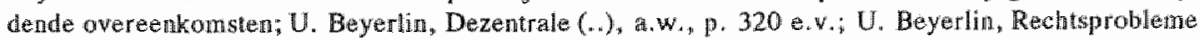
(..) a. a. P. 378 .

103. G. Burdeau, a.w., p. 115. 
seerde overeenkomsten tussen decentrale overheden cen internationaal publiekrechtelijk karakter hebben. Dit is, naar ik meen, geenszins het geval. ${ }^{104}$ Gesteld kan worden dat de EOC (en de daarop gebaseerde Benelux-Ov ereenkomst) internationaal publiekrechtelijke bases voor lokale grensoverschrijdende overeenkomsten zijn. Men kan zeker niet beweren dat de op die grondslag gebaseerde overeenkomsten automatisch ook internationaal publiekrechtelijke overeenkomsten zijn. Zoals elders vastgesteld, zijn er geen directe aanwijzingen dat in de $\mathrm{EOC}$ en de Benelux-Overeenkomst (en ook de nadien gesloten Duits-Nederlandse Overeenkomst inzake decentrale grensoverschrijdende samenwerking) relaties tussen decentrale overheden beheerst zouden worden door het internationale publiekrecht. ${ }^{105}$ In dit verband scheppen deze verdragen (ex ante of post) veeleer gemeenschappelijke juridische grondslagen (tussen buurlanden) voor nationaalrechtelijke overeenkomsten. ${ }^{106}$ Deze juridische grondslagen zijn noodzakelijk voor het kunnen aangaan van publiekrechtelijke afspraken tussen decentrale overheden, waarbij bevoegdheden van regeling en bestuur worden overgedragen. $\mathrm{Zij}$ zijn een gemeenschappelijk kader voor grensoverschrijdende samenwerking, die zich buiten het internationale recht afspeelt en zich dus bevindt binnen het kader van het nationale recht. ${ }^{107}$ Hieruit volgt dat administratieve akkoorden, ook die welke gesloten worden

104. E.W. Vierdag, Versiag wan de Algemene Ledenvergadering, a.w., p. 45.

105. Vgl. ook noot 82 van dit hoofdstuk.

106. Vanwege met name het stringent gehanteerde beginsel van de eenheid van de statat is het in Frankrijk wellicht wel zo dat grensoverschrijdende overeenkomstengebaseerd op verdragen als internationaalrechtelijke overeenkomsten (werdragen) kunnen worden aangemerkt, zie b.y.: E. Zoller, a.w., p. 738. Dupuy gaat er echter vanuit dat dit beginsel in deze niet van toepassing is, omdat het beperkt is tot het internationaal publiekrecht en de samerwerking wan decentrale overheden hierbuiten plaatsvindt, P-M. Dupuy, a.w., p. 849 .

107. Diverse schrijwers benadrukken het nationaalrechtelijke van decentrale grensoverschrijdende samenwerking. Zo stelt $\mathrm{J}-\mathrm{M}$. Woerling, a.w., p. 6 en 9: "From what follows ... that local and regional transfrontier co-operation should be seen as a natural extension, based on domestic law, of the normal legal responsability of local or regional boards and authorities." ; Zo ook M. Oethm, a. w., p. 87: "Dass. wedler ... Bedenken dagegen bestehen, dass die deutschen Gemeinden und Gemeindeverbände im Rahmen ihrer inverstatllichen Kompetenzenauch die Zuständigkeit zur Aufnahme offentlich-rechtlicher Auslandsbeziehungen zu ihren ausländischen Nachbarkommunen besitzen. "; Zo acht Autexier de bewoegdheid voor grensoverschrijdende samerwerking van Franse lagere overheden gelegen in de grondwettelijke gewaatrborgde regionale en lokale autonomie; $C$. Autexier, Le cadre juridique de l'action extérieure des régions; RFDA, 2 (4) 1986 , p. 574 ; Nalar aanleiding van een analyse van de doctrine constateert Godard: "Enfin tous les auteurs soulignent que la soumission aux règles de tutelles ou de controle prévues par les droits internes ... est un élément de sa légalité au même titre que le respect du principe de spécialité des competences propres à chacune des entités.", S. Godard, Contribution à l'étude des aspects juridiques de la coopération transfrontalière appliquée à la protection de l'environnement, le cas des tégions frontalières franco-espagnols, 1987 , p. 370.

Ook Witmer acht het wellicht niet uitgesloten dat de handelingsbevoegdheid wan o.a. Zwitserse gemeenten op het wezen 'der kommunalen Selbstverwaltung oder der Gemeindeautonomie' zou kunnen berusten: J. Witmer, Grenznachbarliche Zusammenarbeit, Das Beispiel der Grenzregionen von Basel und Genf, 1985 , p. 181.

Ook Jans is van mening, dat het in het kader van akkoorden gesloten door decentrale overheden binnen hun 'eigen' (zie hiervoor ook noot 83 van dit hoofdstuk) grensoverschrijilende bevoegdheden in beginsel om nationaalrechteljjke binding gaat: J.H. Jans, Verslag van de Algemene Ledenvergadering, a.w, p. 35 .

(wordt vervolgd...) 
Internationaalrechtelijke aspecten

door organen van de centrale overheid, niet noodzakelijk een aan verdragen gerelateerde status hebben maar overeenkomsten met een nationaalrechtelijk karakter kunnen zijn. In de literatuur wordt al gauw geconcludeerd dat het in dit werband on privaatrechtelijke overeenkomsten zal gaan. ${ }^{108}$ Ook waar het om overeenkomsten ussen overheden gaat, zal dat in een aantal gevallen zo kunnen zijn. Maar men dient mijns inziens niet te snel naar het privaatrecht te 'vluchten'. Zelfs aan op het eerste gezicht privaatrechtelijke overeenkomsten kunnen publiekrechtelijke aspecten zitten. Wat nu precies de onderscheidende criteria zijn om een overeenkomst een privaatrechtelijk dan wel publiekrechtelijk karakter toe te kennen, is per land verschillend en beslist niet overal even duidelijk. ${ }^{109}$ Ik wil hier volstaan, mede in verband met het gestelde hieromtrent in hoofdstuk 1 , met het volgende daarover op te merken. Als publiekrechtelijk kunnen zeker die atspraken gekwalificeerd worden, waarbij bestuurs- en regelingsbevoegdheden door het ene openbaar lichaam worden overgedragen aan een ander ( $a l$ dan niet nieuw) openbaar lichaam en (die) waardoor burgers gebonden kunnen worden. Voor dergelijke afspraken is in het nationale recht een wettelijke basis vereist. Daar waar het om grensoverschrijdende afspraken van deze aard gaat, zal, zoals aangegeven, een verdrag de gemeenschappelijke juridische basis vormen. Daarnaast zijn er afspraken tussen overheden, waarbij (slechts) overeengekomen wordt een bevoegdheid op een bepaalde manier te gebruiken (beleid). Deze kunnen veelal in het kader van discretionaire bevoegdheden e.d. gesloten worden en zijn ook als publiekrechtelijk aan te merken. Voor het sluiten hiervan is, zoals aangegeven, niet zonder meer een additionele wettelijke basis vereist. Het toepasselijke recht op beide soorten van afspraken kan het nationale (publiek)recht zijn. Wat hiervan ook zij, van gevall tot geval dient het toepasselijke recht vastgesteld te worden. ${ }^{110}$ Een probleem hierbij is dat over de uitkomst van mogelijke geschillen en het daarop toepasselijke recht vanwege de in de regel in dergelijke overeenkomsten voorkomende (informele) geschillenregelingen weinig naar buiten zal komen. Vanwege het speculatieve karakter

107.(...vervolg)

Schlögel likt in de afwezigheid wan expliciete grensoverschrijdende bewoegdheden woor decentrale overheden om publekrechelikg te hadielen de onmogelijkheid te zien van andere dan privatrechtelijke

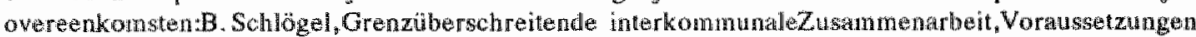
und Rechtsgrandlagen sowte Beispiele in der Abwasserbeseitigng Energio-und Wasserversorgung und im Nahverkehr, 1982, p. 118 ew.

108. Zo stelt Lissitzyn dat akkoorden tusgen niet soevereine entiteitem in het algemeen juridisch bindend zijn, man dat een antal ex privatrechtelikeaard hebben en dus eigenlijk to beschouwen $z$ ijn als contracten beherst door het interne redh: 0 . Lissitzyn, Territorial entities other than independant states in the law of treaties, RCADI, 1968 , wol. 125, p.83; MCNair stelt met betrekking tot de juridighe status van "administratieveagreements" in "the state practice" van het Verenigd Koninkrijk: "As regards interdepartmental agreements (i.e. agreements concluded directly between the Governinents Departments of different states) these agreements are, gemerally speaking, agreements which concern matters of private law (cursivering, RS) rather than matters of an international legal character." MoNair, a.w., p. 20; Zie ook: L. Di Marzo, a.w. . p. 153.

109. Zo kwalificeert Dupwy overeenkomisten geshoten tussen decentrale overheden axth wersijden van de grens in beginsel als publiekrechtelijke overeenkomsten. Deze rangschikt hij verwolgens onder de werking van linternational privatrectat, P.M. Dupuy, a.w., p. 852 .

110. 'Il serait certainement présomptueux de prétendre présenter de façon sygténatique le rêgime juridique des accords entre organismes publics de pays differents. Trop d"incertitudes regnent en effet sur le weritable nature de ces accords, qui ne pourra être determine qu "au cas par cas, et gécralement après un examen critique des elements de lewr contenu, *, G. Burdeau, a.w., p. 114. 
- er zou een gedegen wooral praktisch (algemeen inventariserend) onderzoek gedaan moeten worden naar alle gesloten overeenkomsten met een grensoverschrijdende dimensie - wordt daar hier niet dieper op ingegaan. Dit is ook niet nodig, omdat het er hier om gaat de al dan niet toepassellikheid van het internationale recht ten aanzien van decentralle grensoverschrijdende samenwerking te onderzoeken. In hoofdstuk 5 en 6 wordt hierop nog dieper ingegaan in het kader van de nationaalrechtelijke aspecten van decentrale grensoverschrijdende samenwerking.

\section{Samenvatting en conclusies}

Decentrale grensoverschrijdende publiekrechtelijke samenwerking wordt (door staten) snel in het internationale recht geplaatst. Staten zijn aan te merken als subjecten van internationaalrecht. Dit betekent dat zij bevoegd zijn internationaalrechtelijk te handelen. Zij kunnen voor zichzelf internationaalrechtelijke overeenkomsten (verdragen) sluiten en kunnen zelf internationaalrechtelijk aansprakelijk zijn.. Decentrale overheden - een uitzondering bestaat wellicht voor deelstaten van federale staten - kunnen, naar huidig recht, niet geacht worden voor zichzelf internationaalrechtelijk te handelen. Zij hebben in beginsel geen 'treaty-making capacity'. Indien men de toepasselijkheid van het internationale recht ten aanzien van decentrale grensoverschrijdende samenwerking aanneemt, in de zin dat deze slechts binnen het internationale recht kan plaatsvinden, dan is autonoom handelen van decentrale overheden in beginsel niet mogelijk. Ook kunnen deze decentrale overheden niet geacht worden de staat te binden, omdat hen binnen het (grondwettelijke) kader van de externe betrekkingen geen handelingsbe voegdheden zijn toebedacht.

Er is evenwel een statenpraktijk waarbij in toenemende mate overeenkomsten gesloten worden door staatsorganen uit verschillende landen, die hiertoe niet altijd expliciete (grondwettelijke) 'ureaty-making powers' hebben. Willen dergelijke internationale administratieve akkoorden, waartoe in beginsel grensoverschrijdende publiekrechtelijke afspraken tussen decentrale overheden gerekend kunnen worden, als internationaal rechtedijke overeenkomsten aangenerkt worden, dan zullen zij aan twee belangrijke vereisten moeten voldoen. Om een aan verdragen (in de zin van het WVV) gerelateerde status te hebben, vereisen deze akkoorden "case by case" onderzoek om vast te stellen of de partijen (gemandateerde c.q. gedelegeerde, al dan niet impliciete) bevoegdheden hebben om internationaalrachtelijk te handelen. Als dit her geval is, is aan de eerste belangrijke voorwaarde voldaan om deze overeenkomsten daadwerkelijk als aan verdragen (in de zin van het WVV) gerelateerde internationale overeenkomsten te kunnen beschouwen. Het sluiten van een internationale overeenkomst tussen staten of onderdelen van verschillende staten betekent niet noodzakelijkerwijs dat de overeenkomst beheerst wordt door het recht dat geldt tussen staten (handelend) als subjecten van internationaal recht. Voor het (bindend) intermationaalrechtelijk karakter van dergelijke overeenkomsten is de toepasselijkheid van het internationaal publiekrecht, gebaseerd op de intenties van de partijen, essentieel. Deze belangrijke voorwaarde is cumulatief aan die van de van de staat afgeleide bevoegdheid om internationaal te handelen. Als gedecentraliseerde overheden over de bevoegdheid tot internationaal handelen beschikken, dan kunnen de tussen hen gesloten overeenkomsten alleen maar van een bindend internationaalrechtelijk karakter zijn, als dat voortvloeit uit de intentie van de staten, waartoe die gedecentraliseerde 
overheden behoren. Of dit het geval is op het terrein van lokale samenwerking - voor administratieve akkoorden op centraal niveau is dit wellicht eerder zo - is nog maar de vraag. Het zal van geval tot geval onderzocht dienen te worden. Een expliciete juridische basis in de vorm van een verdrag tussen staten, zoals de European Outline Convention, de Benelux-Overeenkomst en de Duits-Nederlandse Overeenkomst inzake decentrale grensoverschrijdende samenwerking is er om een bevoegdheid te scheppen om grensoverschrijdende publiekrechtelijke afspraken te maken en niet om het internationaal publiekrecht (met het stelsel van de externe betrekkingen) hierop toepasselijk te verklaren. Daardoor komt ook de bevoegdheid om grensoverschrijdend te handelen, hoewel in een verdrag gelegen, toch eerder in een nationaal- dan internationaalrechtelijk perspectief te liggen. Voor afspraken waarbij geen publiekrechtelijke bevoegdheden worden overgedragen maar de uitoefening van deze bevoegdheden wordt afgestend, is wellicht niet eens een (additionele) wettelijke basis vereist. Het is niet uitgesloten dat (gedecentraliseerde) overheden binnen het kader van autonome of bepaalde sectorbevoegdheden (in het nationale recht) als competent kunnen worden gezien dergelijke grensoverschrijdende pubiekrechtelijke afspraken te maken.

(Decentrale) grensoverschrijdende afspraken zullen veeleer een (nationaalrechtelijke) binding met zich brengen, die niet op één lijn te stellen is met die van bindende verdragen. Het verschil tussen 'les relations publiques internationales' en 'les relations transfrontalières" wat betreft administratieve akkoorden lijkt in deze van toepassing. "11 Het feit dat in beginsel het nationale recht van toepassing zal zijn op dergelijke grensoverschrijdende overeenkomsten zal het afsluiten, door de overheden die het zelf aangaat, van deze 'bottum-up' bijdragen aan (Europese) integratie kunnen bevorderen. De relevante nationaalrechtelijke aspecten in deze worden in de hoofdstukken 5 en 6 nadler ingekaderd. In hoofdstuk 4 wordt hierop een inleiding gegeven. 


\section{Europese grondslagen voor decentrale grensoverschrijdende samenwerking}

\section{Inleiding}

In hoofdstuk 2 is aandacht besteed aan enkele met de (decentrale) grensoverschrijdende samenwerking verband houdende algemene aspecten van volkenrecht. In dit hoofdstuk staat, op Europees niveau, de specifieke aandacht van enkele internationale organisaties voor de decentrale grensoverschrijdende samenwerking centraal. De bedoeling van hoofdstuk 3 is de bemoeienis van de betreffende organisaties met de decentrale grensoverschrijdende samenwerking in kaart te brengen. Daarbij gat het vooral om het aangeven van mogelijke juridische grondslagen voor decentrale grensoverschrijdende samenwerking (het maken van publiekrechtelije afspraken).

Al vanaf het eind van de jaren zestig staat de decentrale grensoverschrijdende samenwerking op de agenda bij de Raad van Europa. Bimen de Raad van Europa is begin 1980 de European Outline Convention on Transfrontier Co-operation between Territorial Communities or Authorities (EOC) tot stand gekomen. Dit verdrag, dat hier uitgebreid besproken zal worden, beoogt naast een juridische grondslag een raamwerk te geven voor decentrale grensoverschrijdende samenwerking. Ook binnen de Raad van Europa is in 1985 het Europees Handvest voor de Lokale Autonomie opgesteld, dat een rechtsgrondslag voor decentrale grensoverschrijdende samenwerking bevat $(\$ 2)$.

Binnen de Europese Gemeenschappen is tot nu toe geen algemene juridische grondslag. voor decentrale grensoverschrijdende samenwerking (à la de EOC) gecreëerd. In een aantal milieurichtlijnen zijn informatie- en overlegverplichtingen tussen (decentrale) overheden opgenomen. Bijzonder voor de Europese Gemeenschappen is ook dat er financiële middelen beschikbaar gesteld worden inzake het regionale beleid woor het bevorderen van activiteiten in b.v. grensregio"s (\$ 3 ).

Naast de Raad van Europa en de Europese Gemeenschappen zijn er enkele andere organisaties, waarin de decentrale grensoverschrijdende samenwerking bevorderd wordt. Daarbij gaat het b.v. om de decentralle grensoverschrijdende samenwerking op milieuter- 
rein. ${ }^{1}$ Juist op dit terrein wordt de decentrale grensoverschrijdende samenwerking al langere tijd als een noodzaak gezien. De bespreking zal zich hier toespitsen op de grensoverschrijdende samenwerking op milieuterrein. In het kader wan de Economische Commissie voor Europa van de Verenigde Naties zijn met name de laatste jaren een aantal verdragen opgesteld, waarin grensoverschrijdende samenwerking op milieugebied tussen decentrale overheden een rol van betekenis kan spelen. Binnen de Organisatie voor Economische Samenwerking en Ontwikkeling zijn er sinds de jaren zeventig enkele aanbevelingen gedaan op dit punt. Waar het om decentrale grensoverschrijdende samenwerking gaat en in het bijzonder het scheppen van algemene bevoegdheidsgrondslagen hiervoor, zijn op dit moment de door de Raad van Europa ontplooide initiatieven de belangrijkste. De positie van de Europese Gemeenschappen is in dat perspectief al van minder belang. Dit laatste geldt (nog meer) ook voor de Economische Commissie voor Europa van de Verenigde Naties en de Organisatie van Economische Samenwerking en Ontwikkeling. Daarom wordt hierop minder uitgebreid ingegaan (\$4).

Tot slot volgen een samenvatting en enkele conclusies (\$5).

\section{§. De Raad van Europa}

\section{A. European OUtLINE CONVENTION ON TRANSFrontIER CO-Operation beTWEen TERRTTORIAL COMMUNTTIES OR AUTHORITIES (EOC) ${ }^{2}$}

\section{Inleiding}

In de landen waar de EOC in werking is getreden, heeft grensowerschrijdende samenwerking tussen decentrale overheden een expliciete (multilaterale) verdragsbasis gekregen. Hier wordt onderzocht of deze kaderovereenkomst een intentieverklaring tussem staten is om decentrale grensoverschrijdende samenwerking te bevorderen, dan wel een juridische grondslag inhoudt op basis waarvan, zonder dat nadere uitwerking door staten noodzakelijk is, decentrale overheden rechtstreeks met elkaar grensoverschrijdend kunnen samenwerken.

Vanwege het grote belang van de EOC voor het terrein van de grensoverschrijdende samenwerking tussen decentrale overheden passeert een aantal aspecten ervan uitgebreid de revue. Allereerst zal ingegaan worden op de ontstaansgeschiedenis ervan ( $\$ 2$.A.2). Daarna zullen aan de hand van een beschrijving van de belangrijkste verdragsbepalingen de doelstellingen, de instrumenten ter realisering van die doelstellingen e.d. van de EOC worden bezien ( $\$ 2 . A .3$ ). De juridische mogelijkheden van decentrale overheden in dit verband zullen worden geschetst. Kunnen zij aan de EOC (rechtstreeks) rechten tot het sluiten van grensoverschrijdende overeenkomsten ontlenen, waarbij bevoegdheden van

1. Voor een overzicht van internationala (ook niet Europese) organisaties, die zich met milieu bezighouden. zie: M. Kilian, Umweltsehulz durch Internationale Organisationen, 1987.

2. Madrid, 21-5-1980, European Treaty Series, mo. 106, Trb. 1980 nr. 129, inwerkingtreding 27-2-1.982, Trb. 1981, nr. 234. De beschrijving van deze Europese kaderovereenkonstinzake grensowerschrijdend samenwerking tussen territoriale samenwerkingswerbandenof mutoriteitengeschiedt and de hand van the Engelstalige (geldende) verdragstekst. Deze is als bijlage bijgevoegd. Overigens is dit verdrag in hel Nederlands vertald, Trb. 1981, ar. 74. 
regeling en bestuur worden overgedragen aan buitenlandse overheden c.q. publiekrechtelijke samenwerkingsverbanden worden opgericht, die, voor overheid en burger, juridisch bindende beslissingen kunnen nemen? Een en ander wordt bezien in het perspectief van de daadwerkelijke implementatie van de EOC tot nu toe door de verdragspartijen (\$2.A.4.). Hierna zullen de contouren wastgelegd worden van de positie van de EOC ten aanzien van de national- en/of internationaalrechtelijke dimensie van de decentrale grensoverschrijdende samenwerking. Anders gezegd: zijn de overeenkomsten tussen decentrale overheden als internationaal- dan wel als nationalrechtelijk aan te merken? Het beantwoorden van deze laatste vraag sluit aan bij en is met name van belang voor het gestelde in hoofdstuk 2 met betrekking tot de internationale administratieve akkoorden (\$2.A.5.). Sub $\$ 2$.A.6. wordt een en ander samengevat en worden uit het behandelde enkele conclusies getrokken.

\section{Ontstaan van de European Outline Convention}

De totstandkoming birnen de Raad van Europa van een overeenkomst inzake grensoverschrijdende samenwerking tussen decentrale overheden heeft geruime tijd in beslag genomen. ${ }^{3}$ Dit hield met name verband met het feit dat het toestaan van decentrale grensoverschrijdende samenwerking het primaat van de centrale overheden inzake buitenlandse betrekkingen kan doorkruisen. In 1966 legde de Parlementaire Assemblee in aanbeveling 470 aan het Comité van Ministers een door een parlementaire commissie voorbereide ontwerp-overeenkomst in deze voor: de Assemblee "recommends the Committee of Ministers to instruct a committee of governmental experts to prepare as early as possible a draft convention based on the text appended hereto." 4 Begin 1980 werd, na jaren van niet aflatende druk vanuit de Assemblée alsook de Permanente Conferentie van Lokale en Regionale Overheden in Europa, door het Comité van Ministers de laatste hand gelegd aan de onder zijn supervisie opgestelde EOC. ${ }^{5}$

Te Madrid werd op 21 mei 1980, tijdens de Vierde Conferentie van Ministers van Binnenlandse Zaken, de EOC voor ondertekening door de staten opengesteld.

3. Voor en witvoerigere beschrijung over de ontstanggesthiedenis: E. Decau, La Convention-cadre curopétene sur la coopénation transfrontaliere des collectivités locales, RODIP, 1984, p. 550 e.V. U. Beyerlin, GrenziberschreitendeunterstaaticheZusammenarbeit,Zum Entwhrfeines EuropaisohenRahmnubereinkommens uber die grenzubersohreitende Zusammenarbeit zwischen Gebietskönyerschaften, ZaÖRV, Bat, 40 (1980), p. 573 e.w, B. Schlogel, a.w., p. 27 e.v.; Explanatory report on the European Outline Convention on Transfrontier Co-operation between Territorial Communities or Authoritias, 1. $5+9$ !

4. Consultative Assembly of the Council of Europe, Recommendation 470 (1966) on a Draft Convention on Europeanco-operation between local authorities, Assembly Debate on 29th September 1966 (15th sitting); Text adopted by the Assembly on 29th September 1960 (15th sitting).

5. Voor een korte vergelijking van het ontwerp-verdrag van de Assembies en de onder supervisie van het Comite van Ministers opgestelde EOC, zie: B. Schlögel, a w " p. 64-67. Enkelle belangrijke verschillen zijn, dat het ontwarp-verdrag wan de Assemble zich in tegenstelling tot we EOC niet slechts beperkle tot grensoverschrijdendesamenwerking in grensgebieden en dat de terminologie van de EOC nogal varg is in vergeliking met die wan he parlementair onnwerpmerdirg. 
Per 1-1-1993 is de EOC in ten minste 16 landen van de Raad van Europa, waaronder Nederland, België en de Bondsrepubliek Duitsland, in werking getreden. ${ }^{\circ}$

\section{Inhoud van de European Outline Convention ${ }^{7}$}

De centrale doelstelling van de $\mathrm{EOC}$ is het bevorderen van grensoverschrijdende samenwerking tussen territoriale samenwerkingsverbanden en autoriteiten. In de preambule van de EOC wordt in dit verband gerefereerd aan artikel 1 van het Statuut van de Raad van Europa. Grensoverschrijdende samenwerking tussen decentrale overheden wor dt gezien als één van de middelen ter bereiking van de in dat artikel vermelde doelstelling, namelijk vergroting van de eenheid tussen de landen van de Raad van Europa. ${ }^{8}$ De preambule bevat een belangrijke geografische beperking van het toepassingsbereik van de EOC. Het verdrag heeft betrekking op grensoverschrijdende samenwerking tussen overheden in grensgebieden. Het Explanatory Report stelt in dit verband: "Neighbourhood relations include those situated on a territorial strip extending to a distance from the national frontier which each Contracting Party may determine freely in a declaration at the time of signature or ratification....the term 'neighbourhood' in international law implies a certain proximity, which should make it possible, even in cases where no territorial strip has been designated, to rule out unjustified requests from municipalities or regions not having any "neighbourhood" problems to settle with municipalities or regions on the other side of the frontier." " In de preambule wordt een aantal terreinen van samenwerking opgesomd. Deze betreffen o.a. ruimtelijke ordening, milieubescherming, grensoverschrijdende infrastructuur, ongevallenbestrijding e.d.

6. Zie 0. . Chart of signatures and ratifications, Transfront 1989 (2), CAHCT (89) 6. Vanwege hun ellandposittie hebben landen als Cyprus, Malta en Ijsland de EOC niet ondertekend. Zie ook. M. Mudrich. Grenzüberschreitende Zusammenarbeit im Europarat, p. 15, in: GrenzübergreifendeRamplanung, an. Voor Duitsland (BGB1. 1981 II, S. $965 / 985$ e.w) beeft er alleen en bekendmaking door de Bond (geem parlementaire goedkeuring door de Bond (of Länder) platatsgevonden (zie: U. Beyerlin, Rechtsprobleme

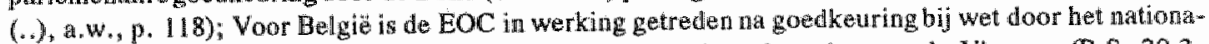
le parlement (B.S. 18-7-1987) en goedkeuring bij decreet door de raden van de Vlamse (B.S. 20-31987), Franse (B.S. 6-12-1986) en Duitstalige Gemeenschap (B.S. 23-1-1987); Voor Nederland wordt in deze verwezen natat noot 2 van dit hoofdstuk.

7. His wordt sllechts de EOC beschreven. Voor de wijzigingen van en asunvullingen op het ontwerp van dit verdrag van het Comite wn Ministers wordt verwezen nar: B. Schlogel, a.w., p. 46 e.v. Ik wil hier volstan met aan te geven, dat in de ontwerp - in tegenstelling tot de definiteve versie van het verdrag van het Comite van Ministers de bijtage een verdragsrechtelijke status had. Zie ook noot I1 van dit hoofidstuk an de bijbehorende tekst.

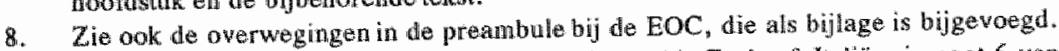

9. Explanatory report, A.w., p. 10 respectievelijk p. 11.2 o heef Itatie, zie noot 6 van dit hoofdlstuk, de grensizone bepasald op $25 \mathrm{~km}$.

- Hat met de EOC wergelijkbaar Verdrag bussen Denemarken, Finland, Noorwegen en Zweden inzake grensoverschrijdendesamenwarking tussen gemeenten. (Torshawn, 26 mei 1977), kent de beperking tout grensgebieden niet. Over de ontstaansgeschiedenis, de inhoud en de werking erwan in het interne recht van de staten, wolsta ik hier met te verwijen naar A. Bierg, Zum Ubereinkommen zwischen Dãnemark, Finnland, Norwagen und Schweden ïber grenziberschreitende Zusammenarbeit von Gemeinden der nordischen Staaten, ZaokV, Band 40, 1980, p. 600-624,

- De Benoluxovereenkomst en de Duits-Nederlandse Overeenkomst - zie voor de bepreking hiervam hoofdstuk 5 \& respecteweljjk hoofdstuk $6 \$ 4$, die als een uitwerking van de EOC zijn te beschowwen, kennen de beperking tot grensgebieden wiet. 
Het verdrag bestaat uit twaalf artikelen en een bijlage: ${ }^{10}$

- Artikel 1 geeft voortbouwend op de preambule de doelstelling van het verdrag aan, namelijk het bevorderen en vergemakkelijken door de verdragspartijen van grensoverschrijdende samenwerking tussen decentrale overheden.

- Artikel 2.1. definiëert het begrip grensoverschrijdende samenwerking. Het gaat hier min of meer om iedere vorm van onderling afgestemd optreden. Artikel 2.2. geeft aan wat onder 'territorial communities or authorities' moet worden verstaan. Er wordt verwezen naar hetgeen het nationale recht daarover bepaalt. Verder regelt dit artikel dat het verdragspartijen vrij staat (bij de ondertekening c.q. de akte van bekrachtiging) de werking van het verdrag te beperken tot bepaalde onderwerpen alsmede (bepaalde) overheden van de werking ervan uit te sluiten.

- Artikel 3 sub 1,2, en 3 gaat nader in op de instrumenten ter verwezenlijking van de doelstelling van het verdrag. Het gaat hier met name om het sluiten van aanvullende interstatelijke overeenkomsten alsmede overeenkomsten, contracten e.d. tussen de decentrale overheden zelf. Bij de overeenkomst is een bijlage gevoegd met voorbeelden van model- en kaderovereenkomsten, kaderstatuten en -contracten. In artikel 3.2. is aangegeven, dat deze slechts bedoeld zijn als richtsnoer en geen verdragsstatus hebben. "Artikel 3.4. begrenst het voorgaande door te bepalen dat "overeenkomsten en regelingen tot stand dienen te worden gebracht met inachtneming van de door het interne recht van elke verdragspartij vastgestelle bewoegdheid ten aanzien van internationale betrekkingen en algemeen beleid en met inachtneming van de voorschriften inzake controle en toezicht waaraan decentrale overheden onderworpen zijn'.

- Artikel 4 geeft aan, dat verdragspartijen er naar moeten streven alle juridische, administratieve en technische belemmeringen, die een soepele grensoverschrijdende samenwerking kunnen tegenwerken, op te lossen.

- Artikel 5 bepaalt, dat de verdragspartijen dienen te overwegen de decentrale overheden, die grensoverschrijdend samenwerken, dezelfde faciliteiten - te denken valt aan financiële - toe te kennen als handelden zij op nationaal niveau.

- De overige bepalingen betreften de informatieplicht van de verdragspartijen onderling (artikel 6), van verdragspartijen jegens decentrale overheden (artikel 7) en het Secretariaat van de Raad van Europa (artikel 8). ${ }^{12}$ De artikelen 9 tot en met 12 bevatten de gebruikelijke slotbepalingen betreffende ondertekening, inwerkingtreding, e.d. van her verdrag.

- In de bijlage bij de EOC worden een aantal voorbeelden gegeven van modelovereenkomsten, akkoorden e.d., ter uitwerking van de EOC, die een kaderovereenkomst

10. Slechts de voor mijn betoog relewante passages uit de tekst wan de EOC alsmede de bijbehorende bijlagge worden hier geciteerd. Voor het overige word verwezen naar de bijgevoegde bijlage.

11. Zie ook Explanatory Report, a.w., p. 14: "The reference to these models in the Convention does not give them treaty force but merely implies an undertaking by States to pay them all due attention. "Meth name Frankrijk heeft op deze constructie angedrongen, B. Schlögel, a.w., p. 47. Bij de behandeling van de EOC in het Franse parlement mak.ke de bijlage zels geen onderdeel uit wan he! goed te keuren verdiag, E. Decaux, a.w., p. 559 .

12. Volgens Decaux gaat het bij de hier genoemde artikelen om die, welke faciliter la cooperation'. De artikelen 1 tot en met 5 van de EOC plaatst hij in het kader van 'promouvoir la coopération", E. Decaux. a. W., p. 588 . 
is ${ }^{13} \mathrm{Er}$ wordt een onderscheid gemaakt tussen interstatelijke overeenkomsten (model 1.1-1.5 van de bijlage) en akkoorden, contracten en overeenkomsten tussen decentrale overheden (model 2.1-2.6 van de bijlage). Beide kunnen afzonderlijk of in combinatie met elkaar opgesteld worden. Er is een graduele opbouw wat betreft de reikwijdte van elk van de modellen. Ze betreffen consultatie, coördinatie e.d. en de oprichting van privaatrechtelijke (model 2.3) en publiekrechtelijke (modellen 1.5/2.6) samenwerkingsverbanden. ${ }^{14}$ De bijlage laat zien, dat er vele verschillende mogelijkheden zijn om grensoverschrijdende samenwerking tussen decentrale overheden, als uitwerking van de eigenlijke EOC, in een (aanvullend) jurid isch kader te plaatsen. Het is niet van belang al deze modellen - men zou er nog een aantal aan kumnen toevoegen - afzonderlijk te bespreken, temeer omdat ze slechts voorbeelden zijn en geen juridische (verdrags)status hebben. ${ }^{15}$ Vooralsnog gaat het er hier om aan te geven, dat er nogal wat vormvarianten woor handen zijn, waarin de samenwerking juridisch gegoten kan worden. ${ }^{16}$ In hoofdstuk 5 en 6 wordt op de belangrijkste in deze tot stand gekomen (interstatelijke) overeenkomsten uitgebreid ingegaan.

13. Voor andere documenten dan de EOC die woorzien in bepalde modelovereenkomsten voor grensoverschrijdende samemwerking: b.v CAHCT (89) 18 , addenda I en II betreffende "Preparation of modelagreementson transfrontier nature parks' en 'Preparation of model-agreementson interpegional economic comoperation and spatial planning".

14. Bij de contracten, dije 'privaatrechtelijke' samemwerking beogen gaat het om samenwerking in de economische en commerciëlesfeer, waar even zo goed particuliergn kunnen contracteren.. Hel is mogelijk, dat het nationale recht beperkingen stelt met name ten aanzien van de deelname van owerheden in (buitem* landse) privatrechtelijke rechtspersonen. In die gevallen voorzien de modellen 1.3 en 1.4 in combinatie met 2.3 en 2.4 in aanwullende grondslagen.

Er kan b. wedacht worden an het shiten van overeenkomsten c.q. de oprichting vata rechispersonen. die het beheer van een grensower schrijdend nwturgebied, een gemeenschappelijkewaterzuiveringsunstatlatie, e.t. op zich nemen. Zo bestat er b.v. Missen het Waterschap Zuveringschap Limburg en de ge. meente Sellhat (D) een overeenkomst met betrekking tot medegebruk wan de rioolzui we ringsinstallatie in Susteren (NL). Wellicht kumen hiortoe onk overeenkormaten op het gebied van de hulpverlening bij ongevallen (samenwerking brandweer e.d.) gerekend worden. Op dit punt is ar b.v. een overeenkomst gesloten tussen de gemeente Stramproy (NL) en Kinrooi (B), die overigens is gebaseerd op een BelgischNederlands verdrag in deze.

Voor meerdere voorbeelden in wit verband: o, a. Transfrontoftice $(83) 5,8,13$. Zie tevens de op basis van artike! 59 Granswerdiag gesloten, in hoofdstuk 6 \$. A. te behandelen, overeenkomsten.

Voor de "publiekrechtelijke" samemwerking word werwezen nat de bespreking van de Benelux-Overeenkomst (hoofdstuk 5 \& 5) en de Duits-Nederlandse Overeenkomst (hoofdstuk 6 4). Zie ook hoofdstuk 1 .

15. In we Toelichtende Nota inzake de parlementaire goedkeuring wan de EOC, Tweede Kamer, zittingsjaar

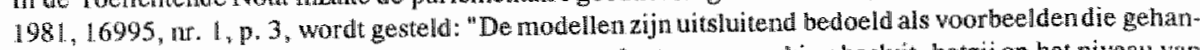
teerd kunen worden indien men in ev concreet gexal tot samemerking besluit, hetzij op het niveau van de centrale overheden, hetzij op het niveau van de lagere overheden. De modellem zullen daarbij dan wall geval tot gewal moeten worden bekeken en zo nodig aangepast."

Zie voor een nadere beschrijwing van de modellen, 0.a.: E. Decaux, a.w. p. 597 e. w.; B. Schlögel. a.w. $[$. 57 e.v.

16. Volgens Hambuchen zijn eigenlijk alleenmaur de modellen betreffendede privaatrechtelijkeverenigingen. en de publickrechtelijke lichamen als vernieuwend te betitelen, U. Hambuchen, a.W., p. 123. 


\section{Juridische status van de European Outline Convention, "soft or hard law"?}

Uit de voorbehouden/v erklaringen, die bepaalde staten gemaakt hebben bij de ondertekening/ratificatie van de EOC, blijkt dat publiekrechtelijke grensoverschrijdende samenwerking tussen decentrale overheden voorzichtig benaderd wordt. Zo is er door Frankrijk en Italië verklaard, dat de uitvoering van de EOC afhankelijk wordt gesteld wan nadere interstatelijke overeenkomsten. ${ }^{17}$ De voorzichtigheid ten aanzien van het geven van grensoverschrijdende handelingsbe voegdheden op basis van de EOC aan decentrale overheden blijkt ook uit de EOC zelf. De Assemblée verwoordde een en ander bij haar opinie over de ontwerp-EOC aldus: "Regretting the fact that the outline convention contains numerous extremely vague terms, and that the convention thus lacks precision and compelling force." ${ }^{18}$ De belangrijkste bepalingen zijn vaag geformuleerd. Zo wordt de doelstelling van de EOC in artikel 1 ruim omschreven: "Each contracting Party undertakes to facilitate and forster transfrontier co-operation between territorial communities .... It shall endeavour to promote the conclusion of any agreements and arrangements that may prove necessary for this purpose." Hetzelfde artikel 1 bepaalt ook dat een en ander dient te geschieden "with due regard to the different constitutional provisions of each Party.' "Voorts kunnen de overeenkomsten (artikel 3 sub 1, 2 en 3) ter realisering van de doelstelling slechts gesloten worden, aldus artikel 3.4. "with due regard to the jurisdiction provided for by the internal law of each Contracting Party in respect of international relations and general policy and to any rules of control or supervision to which territorial communities or authorities may be subject. " ${ }^{20}$ Decaux merkt met betrekking tot artikel 1 juncto artikel 3 respectievelijk artikel 1 juncto artikel 2.1., mijns inziens, terecht op: "que la convention-cadre se contente de renvoyer à la Constitution crée donc une sorte de cercle vicieux, là ou il faudrait une volonté d'adapter et de moderniser les dispositions constitutionelles! ". ." Mais en insistant ainsi sur le status quo juridique (de verwijzing naar het interne recht, RS) la conwention relègue ce caractère evolutif au deuxième plan ..." 21

De verwijzing naar het interne recht is te meer problematisch, ondat hierin, constitutioneel dan wel anderszins, in de meeste staten in beginsel geen expliciete bepalingen bestaan, waarin een algemene (publiekrechtelijke) bevoegdheid van grensoverschrijdend handelen door decentrale overheden is geregeld. In hoofdstuk 2 is reeds aangegeven dat veelal wel expliciet grondwettelijk is voorzien, dat de internationale betrekkingen, zoals

17. Hier kan ook gewezen worden op hatgeen namens de Bondsrepublek Duitsland verklarard is, namelijk dat de dewstaten - dit zijn geen decentrale overheden, RS - van de werthing war de EOC witgezonderd worden. Zhe de in noot 6 var dit hoofdstuk vernelde lijst van ratificaties

(Zie ook: hoofdstuk 6 \%.E.7.C.).

18. Parliamentary Assembly of the Council of Europe, Opinion no. 96 (1979) on the Draft European Outhe Convention on "Transfrontier Co-operation between Territorial Communities or Authorities, Assembly Debate on 1 Ith October 1979 (19th Sitting): Text adoptad by the Assembly on ll th October 1979 (19th Sitting).

19. In het Explanatory Report, a.w., p. 10, wordt dit beschoumd als stinciple of tundamental importance for the application of the whole Convention".

20. Zie ook: F. Zehetner, Das Europäsche Rahmenubereinkommen uber die grenzuberschreitende Zusammenarbeit zwischer Gebietskörperschafter, UPR 1983/7, p. $21 \%$.

21. E. Decrux, a.w. 1 . 594 respectiewelijk 595. 
het aangaan van internationaalrechtelijke overeenkomsten, tot de bevoegdheden van organen van de centrale overheid behoren en staten het grensoverschrijdend handelen van decentrale overheden min of meer automatisch in dat kader plaatsen. Overigens verzet zich het nationale recht er niet tegen dat decentrale overheden bij verdrag tot zodanig grensoverschrijdend handelen gemachtigd worden. De vraag hier is, hoe die verwijzing in de EOC naar het nationale recint geînterpreteerd dient te worden. Dient de EOC beschouwd te worden als een intentieverklaring van staten om te streven juridische mogelijkheden (inclusief een juridische grondslag) voor samenwerking tussen decentrale overheden in het interne recht te creëren? Of is de EOC reeds op zichzelf als een juridische grondslag voor grensoverschrijdende samenwerking door decentrale overheden te beschouwen? Met andere woorden: betreft de EOC een juridische grondslag, die tot aanvulling/wijziging van het interne recht zou moeten leiden?

Beyerlin is van mening, dat het sluiten van aanvullende interstatelijke overeenkomsten noodzakelijk is voor het voorzien in juridische grondslagen voor decentrale grensoverschrijdende samenwerking. Naar zijn mening zijn de door de staten gebruikte formuleringen in de EOC juridisch niet hard genoeg voor het aannemen van een bindende grondslag woor decentrale publiekrechtelijke samenwerking. ${ }^{22}$ Eerst in de Toelichtende Nota bij de goedkeuring door Nederland van de Beneluxovereenkomst inzake grensoverschrijdende samenwerking tussen samenwerkingsverbanden of autoriteiten, wordt door de regering expliciet en duidelijk gesteld: "Op internationaal terrein is allereerst de reeds hiervoor genoemde Europese kaderovereenkomst van Madrid van belang ... Deze Overeenkomst houdt overigens alleen een intentieverklaring (cursivering RS) in om grensoverschrijdende samenwerking mogelijk te maken en te bevorderen." Een formulering met misschien een iets verdergaande strekking is terug te vinden in de Toelichtende Notat bij Duits-Nederlandse Overeenkomst inzake grensoverschrijdende samenwerking: "Deze kaderovereenkomst legde de lidstaten die haar hebben bekrachtigd de inspanningsverplichting op grensoverschrijdende samenwerking tussen territoriale gemeenschappen mogelijk te maken en te bevorderen." ${ }^{23}$ In de General Remarks van het Explanatory Report, wordt gesteld: "The Convention seeks, in the first place, to fill a legal gap by offering forms of transfrontier co-operation particularly suited to the needs of territorial communities and capable of providing an additional legal basis (cursivering, RS) for any agreement which such authorities may conclude and secondly, to furnish States with various means of supervision and control for ensuring observance of the principle of

22. U. Beyerlin, Grenzüberschreitende (..), a.w. p. 590 .

23. Toelichtende Nota bij de goedkeuring (door Nederland) wan de Benelux-Overeenkomst inzakegrenkokerschrijdende sumenwerking tussen sumemerkingswerbanden of autoriteiten, Tweede Kamer, vergaderjaar 1986-1987, 1986, nr. 1, p. 1; Toelichtende Nota bij de goedkeuring (door Nederiand) wan de DuilsNedertandse Overenkomst inzake grensoverschrijtende samenterking tussen territoriale gemeenschap. pen of autoriteiten, Staten-Generaal, vergaderjatr 1991-1992, 22740, nrs, 375 en 1, p. 2.

In de Bondsrepubliek Duitsland is de EOC door de Bond niet aramemerkt als een normatiefipolitiek verdrag ( $v$ gl. noot 6 van dit hoofdstuk): Tijdens de parlementairegoedkeuring van de EOC in Belgue zijn, voor zover mij bekend, geen willatingen gedaan over we EOC, die een harde juridische status arwan bevestigen dan wel ontkennen. Wit het feit dat er in de nationale goedkeuringswet en ook het Vaame decreet inzake goedkeuring wan de EOC een arbitrageregeling voor publiekrechtelijke rech tspersonen is: opgenomen, moge enigszins neer dan een intentiekarakter van de EOC blijken. 
State sovereignty wherever necessary." ${ }^{24}$ Deze overweging, waarin de tweespaltigheid tussen de geest en de letter van de EOC duidelijk tot uitdrukking komt, vormt een goed uitgangspunt om nader op de juridische status van de EOC in te gaan. Het eerste deel van deze overweging impliceert, mijns inziens, dat de EOC een additionele grondslag kan vormen voor grensoverschrijdend handelen van decentrale overheden. Artikel 2.1 maakt immers duidelijk " that transfrontier co-operation must at all events be conducted in the framework of territorial communities' or authorities' powers as defined in each State's law....The extent of transfrontier co-operation is normally therefore, determined (barring intervention by the States themselves or by federate States) by the powers of authorities and communities performing local and regional functions." 25 In die optiek zou de EOC een 'formele' juridische grondslag kunnen zijn voor (publiekrechtelijk) grensoverschrijdend handelen, welk handelen zich binnen de in het nationale recht bestaande 'materiële' bevoegdheden zal dienen af te spelen. ${ }^{26} \mathrm{Er}$ zijn meer aanwijzingen aanwezig om de EOC in deze als een zelfstandige juridische grondslag aan te merken, waardoor in beginsel geen aanvullende interstatelijke overeenkomsten noodzakelijk zouden zijn om hierin te voorzien. Als de EOC niet meer zou zijn dan louter een intentieverklaring, dan is het bijzonder vreemd dat staten bepaalde overheden van de werking van de EOC kunnen uitsluiten, en dat ook doen, als de EOC op zich helemaal geen rechten c.q. verplichtingen voor die overheden in het leven kan roepen. Het feit dat de EOC meer is dan sec een intentieverklaring zou ook kunnen voortwloeien uit de overweging in het Explanatory Report dat "the Convention's entry into force does not per se have the effect of invalidating co-operation agreements already concluded between Contracting Parties." ${ }^{27}$ Voor het aannemen van een juridische grondslag zou, behalve de aard en de duur van de totstandkomingsprocedure, ook nog kunnen spreken, dat (slechts) enkele landen bij de ratificatie van de EOC grensoverschrijdend handelen van decentrale overheden uitdrukkelijk gekoppeld hebben aan het (voorafgaand) sluiten van interstatelijke verdragen. Hier staat tegenover dat landen, die bij ratificatie niet uitdrukkelijk de totstandkoming van interstatelijke overeenkomsten als eis hebben gesteld voor lokale grensoverschrijdende samenwerking, in de praktijk toch dergelijke overeenkomsten sluiten om het fenomeen duidelijker te regelen (de Beneluxlanden en de Bondsrepubliek Duitsland). Zou het voorgaande mijns inziens nog kunnen impliceren dat de EOC een juridische grondslag voor decentrale overheden oplevert om grensoverschrijdend te handelen, de nadere afbakening ervan zal toch vooral plaats dienen te vinden binnen "the various means of supervision and control.' Hiermee zijn wij bij het tweede gedeelte van de eerder vermelde overweging uit het Explanatory Report aangekomen, waarin wordt gezegd dat de EOC staten voldoende controle en toezichtsmogelijkheden biedt voor het bewaren van hun soevereiniteit. Staten wordt een grote vrijheid gelaten hoe zij het grensoverschrijdend handelen van decentrale overheden nader wensen in te kaderen. De

24. Explanatory Report, a.w., p. 10.

25. Explanatory Report, aw., p. 11 .

26. B.v. binnen de bevoegdheden inzake vergunningverlening en de vaststelling wan plannen op basis van sectorwetgeving. Vgl. a.a. hoofdstuk 5 \& 5.D.3.

27. "The forms of co-operation proposed in the Convention are not intented as a mandatory framework for transfiontier co-operation. It is therefore specified that States may resort to other lorms of transfrontier co-operation." Explanatory Report, a.w., p. 14. 
verwijzing naar het nationale recht zou vooral in het perspectief van het toezicht en de controle op grensoverschrijdend handelen van decentrale overheden te plaatsen zijn. Dat kan via het normale stelsel van toezicht en controle, zoals dat geldt bij louter nationaalrechtelijk handelen van decentrale overheden. ${ }^{2}$ Het kan ook internationaalrechtelijk geregeld worden. De artikelen 3.1 en 3.2. brengen tot uitdrukking "that States may con" clude inter-State agreements as they deem necessary for the conclusion of agreements or arrangements between territorial communities or authorities in order to stipulate more precisely (cursivering, RS) the framework, forms and limits within they would like territorial communities to act." 29 Zolang de randwoorwaarden van controle en toezicht. niet duidelijk aangegeven zijn, kunnen de decentrale overheden in feite geen gebruik maken van de potentiele juridische grondslag van de EOC. De 'formele' juridische grondslag, die de EOC zou kunnen zijn, is niet nader uitgewerkt. Deze uitwerking is owergelaten aan het nationale recht of aanvullend te sluiten internationale verdragen. Met het hebben van een juridische status wan de bijlage - quod non - zou een aantal randvoorwaarden gegeven zijn. ${ }^{30}$ Immers juist in die bijlage ligt voor een groot gedeelte de noodzakelijke uitwerking wan het verdrag. Thans kan zij echter niet veel meer dan een leidraad vormen woor een nadere (nationaalrechtelijke) uitwerking van de EOC dan wel (bij afwezigheid daarvan) een daadwerkelijk handelen van decentrale overheden: "C"est donc l"application de la convention-cadre qui constitue le véritable test". "11

Dat in ieder geval tot voor enkele jaren geleden de uitvoering door staten van de EOC te wensen overliet, blijkt eens te meer naar aanleiding van een enquête, die door de Ad hoc commissie voor grensoverschrijdende samenwerking van het secretariaat van de Raad van Europa naar de implementatie van de EOC is uitgevoerd. ${ }^{32}$ Hieruit komt naar voren dat in de tien jaar, nadat de EOC ter ondertekening werd opengesteld, in de wetgeving van die staten waar de EOC in werking is getreden, niet of nauwelijks is voorzien in nadere regeling van grensoverschrijdende samenwerking op decentraal

28. "Each State's rules of control and supervision to which territorial authonities or communities are subject rematin as prescribed by the State's domestic law. In the context of transfrontier co-operation, territorial authorities and communties are governed by the usual rules and supervision, unless the State to which they belong decides to modify the rules, in order, for example, to bring them closer into the line with the circumstances of transfirontier co-operation." "Explanatory Report, a.w., p. 15.

29. Explanatory Report, a.

30. In de literatuar word met betrekking tot de EOC de relatie fussen de 12 werdragsartikelenen de bil citge overigens als ongebrukelijkbeschouwd:" "Es (de EOC, RS) besteht einerseits aus einer 12 Artikel unfassenden Konwention, dem eigentlichen wölkerrechtlichen Vertrag, und anderseits aus iner relatiw tum fangreichen Anlage, der - und darin liegt das Ungewiohnliche-kein Vertragskarakter zukommt und die. nbwohl "Anlage" "nich Bestandteill des Ubereinkommens ist." F. Zehetwer, a.w., p. 2l1. Decatx sitelt dat in het internationale recht over het algemeen werdrag en bijlige dezelfoe juridische status hebben. E. Decanx, a.w. p. 592 end 593 .

31. E. Decaux, a.w., p. 597

Die besondere Kraft des Ubereinkommensliegt darn, dass es mit dem Instrumentarinm der Musterabkommen und Grundrissvereinbarungen die direkte Zusammenarbeit der örtichen und regionalen Gebietskörperschaften im Grensgebiet erleichtern und födern will." ${ }^{\text {, }}$. Ercmen, in: Rechusfragen grenzüberschreitender Unweltbelastungen, 1984, p. 256 .

32. Narar anleiding van de antwoorden op die enquete namens de diverse regeringen heett schrijwer dezes tijdens een stage bij de Raad wan Europa in december 1989 een rapport geschreven (CAHCT (89) 7 rev. Add. 1, II). De bevindingen van dit rapport komen met name aan de orde in een doct het Sectetariatat van de Raad wan Europa in 1991 gepubliceerde studie (LR-R-CT (91) 2), 
niveau. Slechts een tweetal verdragen (in Beneluxverband en tussen Nederland en de Bondsrepubliek Duitsland), die voorzien in structurele mogelijkheden voor decentrale samenwerking, zijn in deze tot stand gebracht. $\mathrm{Zij}$ worden uitgebreid behandeld in de hoofdstukken 5 en 6 . In het licht van deze toch wel geringe implementatie van de EOC wordt een additioneel protocol opgesteld, waarin het recht van decentrale overheden om grensoverschrijdend samen te werken uitdrukkelijk(er) erkend en gegarandeerd dient te worden door de staten en waarin met name de erkenning van de door publiekrechtelijke grensoverschrijdende samenwerkingsverbanden genomen besiuiten centraal staat. ${ }^{33}$

\section{Inter-en nationaalrechtelijke dimensies van de European Outline Convention}

Zoals uit het bovenstaande blijkt, lijkt het 'praktijk' te zijn dat het sluiten wan nadere interstatelijke overeenkomsten, als uitwerking van de EOC, min of meer conditio sine qua non is voor grensoverschrijdende samenwerking, in juridische zin, tussen decentrale overheden. Een voorafgaande interstatelijke overeenkomst zal zeker gesloten worden als het gaat om het aangaan van overeenkomsten, waarbij regelings- en bestuursbevoegdheden worden overgedragen aan buitenlandse overheden en die waarbij grensoverschrijdende samenwerkingsverbanden met publiekrechtelijke beslissingsbevoegdheden worden opgericht ( $\mathrm{vgl}$. hoofdstukken 5 en 6). Wordt hiermee de decentrale grensoverschrijdlende samenwerking in een overwegend internationaalrechtelijke context geplaatst? ${ }^{34}$

Het Explanatory Report is niet al te duidelijk als het gaat om het aangeven van de nationaal- en internationaalrechtelijke aspecten van de decentrale grensoverschrijdende samenwerking. ${ }^{35}$ Ten aanzien van het internationaalrechtelijke karakter wordt gesteld: "In no event are the central government's powers in general policy-making or the conduct of international relations affected by the Convention. The Convention does not have the effect of conferring an international (cursivering, RS) character on transfrontier co-

33. Het Ad Hoc Committee on Transfrontier Co-operation (CAHCT), zie b.v. noot 6, 13 en 32 van dit hoofdstuk, is inmiddels wervangen door het Select Committee of Experts on Transfrontier Co-operation. Naar ataleiding van instructes van her Select Comitee of Experts on Transfrontier Co-operation (LR-R. CT) is door het Secrettariaat van de Rad van Europa een Protocol vastgesteld: 'Draft Additional Protocol to the European Outine Convention on Transfrontier Cowoperation between Territorial Communities or Awthorities (zie: LR-R-CT (92) 9. Addendun en CDLR (93) 1). Dit Protocol is op 17.18 juni 1993 goedgekeurd door het Select Comnittee of Experts on Transfrontier Co-operation. Dit Select Committee is een ambtelijk adviesorgaan wan het Steering Committee on Local and Regional Authorities (CDLR). Het Steering Commitiee fungeert als een ambtelijk voorportaal van het Comite van Ministers. Nadat hei Protocol wor bredere besluitvorming aan het Steering Committee is worgelegd, dient het Protocol in het Comite van Ministers te worden aangenomen. Daarna kan het ter ondertekening door de staten worden opengesteld. Het Protocol is als bijlage bijgevoegd. $\mathrm{Vgl}$. ook noot 50 wan dit hoofdstuk.

34. B.w: W. Lang, a. W., p. 280: "Ist man auf der Suche nach der normativen Qualităt grenzüberschreitenden Regionen, so stellt sich die Frage, ob das Rahmenübereinkommen schon genügt, un Verträgen zwischen unterstattichen Gebietskörperschaften einen völkerrechtichen Charakter zu geben, oder ob noch ein zusätzlicher Vertrag zwischen den betreffenden Staten (Zentralregierungen) dazwischen treten muss."

35. "Il est regrettable que cette distinction fondamentale entre relations transfrontalières des entités territoriales ef relations internationales des Etats n"ait pas été clairement posée par la Convention elle-meme, alors que, de l'avis de la doctrine de la cooperation transficontalière locale, elle en sst le fondement." $\mathrm{s}$. Godard, a.w, p. 399; "Certes, il n'est pas douteux que les auteurs de la Convention-cadre européenne n'ont pas entendu conferer un caractère international aux relations transfrontalières mais au contraire les soumettre aux règles établies par le(s) droit(s) interne(s)." "Y. Lejeune, a. w. p. 78. 
operation". Daarnaast wordt de mogelijkheid van de decentrale overheden om grensoverschrijdend te handelen geplaatst in de staatsrechtelijke verhoudingen: "As regards any conclusion of agreements that are incompatible with the powers provided for in each Contracting Party's domestic law in the matter of international relations (cursivering. RS)....would naturally be null and woid." ${ }^{36}$ Hoe kan men lokale grensoverschrijdende samenwerking onder het stelsel van de externe betrekkingen ("international relations') plaatsen, als het er eigenlijk niets mee te maken heeft? Grensoverschrijdende samenwerking tussen decentrale overheden dient zich voornamelijk binnen het kader van de hun normaal toekomende (lokale) bevoegdheden af te spelen. Beyeriin ontkent o.a. om die reden het ontstaan van door het internationale recht beheerste rechtsbetrekkingen in de ze. ${ }^{37}$ Voor een uiteenzetting van de staatsrechtelijke aspecten inzake 'buitenlands beleid" door decentrale overheden wordt verwezen naar hoofdstuk $6 \S 4$.D.7.b. Ten aanzien van de internationaalrechtelijke aspecten verband houdend met het stelsel van externe betrekkingen kan, zoals reeds aangegeven in hoofdstuk 2 , het volgende opgemerkt worden. Toezicht en controle op handelen van decentrale overheden kunnen uiteraard via internationaalrechtelijke instrumenten geregeld worden. Een interstatelijke overeenkomst op het terrein van decentrale grensoverschrijdende samenwerking zal naast het mogelijk voorzien in een (nadere) juridische basis vooreerst ook als een middel voor het instellen c.q. het uitoefenen van toezicht en controle beschouwd moeten worden. Men verkiest hiertoe een interstatelijk verdrag, omdat dit er toe leidt dat het juridisch kader van de lokale grensoverschrijdende samenwerking aan de ene kant van de grems op dezelfde wijze wordt bezien als aan de andere kant van de grens. Het gaat derhalve om het scheppen van een gemeenschappelijk juridisch raamwerk. Een internationaalrechtelijke overeenkomst is hiervoor het geëigende instrument en is te preferen boven eenzijdige (mogelijk divergerende) nationaalrechtelijke regelgeving.

Resumerend dient gesteld te worden dat de grensoverschrijdende samenwerking tussen decentrale overheden niet binnen het stelsel van externe betrekkingen geplaatst dient te worden (vgl. de beschouwing over de internationale administratieve akkoorden in hoofdstuk $2 \& 2$.D. ) en (daarom) grensoverschrijdende samenwerking geen internationaalrechtelijk karakter heeft (vgl. hoofdstukken 5 en 6). ${ }^{38}$

\section{Samenvatting}

Met de $E O C$ is de problematiek van de grensoverschrijdende samenwerking tussen decentrale overheden in een verdrag vastgelegd. Naar de geest ervan zou de EOC mijns inziens een juridische grondslag kunnen zijn (geweest) voor decentrale overheden om grensoverschrijdend te handelen c.q. grensoverschrijdende publiekrechtelijke afspraken te maken. De praktijk wijst echter in een andere richting, namelijk dat de samenwerking in aanvullende verdragen - het nationale recht is nagenoeg in geen enkele staat aangepast aan de EOC - een juridische bas is moet krijgen: "Der bedeutsame Fortschritt liegt darin,

36. Explanatory Report, a.w., p. 14 respectievelijk p. 15.

"On peut les (relations frontalières, RS) interdire ou favoriser, mais on ne peut changer le sens des mots.", E. Decaux, a.w., p. 595 en 596.

37. U. Beyerlin, Dezentrale (..), a.w, p. 320 e.v.

38. Vgl. Y. Lejeune, a.w. p. 78. 
dass die Vertragsstaten die Phase blosser Duldung überwunden haben und sich zur Förderung der grenzüberschreitende Zusammenarbeit der Gebietskörperschaften verpflichtet haben." ${ }^{39}$ In het licht van deze praktijk kan het verdrag niet geacht worden rechten voor decentrale overheden in het leven te hebben geroepen. De oorzaak hiervan is dat de samenwerking geblokkeerd wordt door het (lang) uitblijven van aanvullende regelgeving. Het is voor decentrale overheden niet duidelijk (geweest) wat de EOC nu precies inhoudt, omdat het kader voor grensoverschrijdend handelen, in de vorm wan de precieze reikwijdte van de samenwerking, de controle erop, e.d. afwezig is (denk aarr: de riet-verdragsstatus van de bijlage). Te veel vragen zijn onbeantwoord gebleven en teveel onzekerbeden bleven bestaan (voor decentrale overheden). ${ }^{40}$ Voor de staten, die dat willen, behoeft de EOC praktisch niet veel meer te impliceren dan louter een bevestiging van het primaat van de centrale overheid in de externe betrekkingen. In dat verband wordt de decentrale grensoverschrijdende samenwerking, ten onrechte, al snel in een internationaalrechtelijke context geplaatst. Zolang er praktisch nog nauwelijks door decentrale overheden in de "spirit "van de EOC kan worden samengewerkt zal sec de EOC een te vage en zwakke juridische basis blijven voor met name die vormen van "publiekrechtelijke" grensoverschrijdende samenwerking, waarbij bestuursbevoegdheden worden overgedragen hetzij aan buitenlandse decentrale overheden hetzij aan op te richten grensoverschrijdende samenwerkingsverbanden.

\section{B. HET EUROPEes HANDVEST INZAKE LOKALE AUTONOMIE ${ }^{41}$}

Op 15 oktober 1985 is het Europees Handvest inzake lokale autonomie ter ondertekening door de staten opengesteld. Het geldt thans in ten minste 14 landen van de Raad van Europa, waaronder Nederland en de Bondsrepubliek Duitsland. ${ }^{42}$ Het Europees Handvest is een verdrag en geen niet-bindende beginselverklaring. ${ }^{43}$ Dit Europees Handvest maakt ratificatie mogelijk, zonder dat alle bepalingen moeten worden aangenomen. Zo

39. F. Zehetner, a.W., p. 214 .

40. Voor de algeznene inventartsatie van problemen en vagen, samenhangend met grensowerschrijdende sartuerwerking door decentrale owerheden, word 0. a. werwezen naar hoofdistuk 1.

41. Strastsurg, 15-10-1985, European Trealy Series, no 122, Trb. 1987 nt. 63, inwerkingtreding 1-7-199y. Trto. 1991, no 61 .

42. Duitsland heet in de akte van bekrachtiging het volgende gesteld, (zie: Trb. 1991 nr. 61, p. 4):

"Article 13, second sentence,

In the Federal Republic of Germany, the scope of the Charter is confined to Gemeinden, Verbandisge meinden and Kreise in Land Rhineland-Palatinate and to Gemeinden and Kreise in the othen Laender. Aricle 12 , paragraph 2 ,

The Federal Republic of Germany considers itself bound by all paragraphs of Part I of the Charter, with the following exceptions:

1. In Land Rhineland-Palathate, Article 9, Patragraph 3, does not apply to Verbandsgemeinden and Kreise

2. In the other Laender, Article 9, paragraph 3, does not apply to Kreise."

Artikel 13 betreft het uitzonderen wan lokale overheden van de werking van het Handvest.

Arikel 9.3 heefi betrekking op het recht tot lokale belastingheffirig.

Een mogelijke Belgische ratificatie van het Handwest is - woor zover mij bekend, nog niet gepubliceerd.

43. MwA betreffende de goedkeuring van her Europees Hand vest inzake lokale autonomie, Tweede Kumer, vergaderjaar 1988-1989, 20568, n. 9, p. 2 . 
is dit verdrag voor Nederland met uitzondering van het bepaalde in de artkelen 7 tid 2 , 8 lid 2,9 lid 5 en 11 per $\mathbb{1}$ juli 1991 in werking getreden. De genoemde artikelen zijn niet door Nederland onderschreven wanwege de discrepantie ervan met de actuele Nederlandse situatie. De voorbehouden hebben respectievelijk betrekking op de financièle vergoedingen voor de lokale vertegenwoordigers, op het karakter van het administratieve toezicht op lokale autoriteiten (beleidstoetsing van autonome besluiten) alsmede de positie van financieel zwakkere lokale autoriteiten. ${ }^{44}$ Daarmee heeft de bekrachtiging van dit verdrag geen verandering voor de Nederlandse situatie met zich gebracht. Het Handvest bevat een aantal aan de gedecentral iseerde eenheidsstaat ten grondslag liggende constitutionele beginselen, die, aldus de regering, reeds op zijn minst impliciet in de Nederlandse rechtsorde aanwezig zijn. ${ }^{45}$

Een integrale bespreking van dit Handvest is in dit kader niet noodzakelijk. Van belang hier is de algemene strekking van dit Handvest, namelijk het garanderen en beschermen wan de autonomie van het lokaal bestuur, alsmede het bepaalde in het kader van de grensoverschrijdende samenwerking. Artikel 3.1 definieert het begrip lokale autonomie als: "the right and the ability of local authorities, within the limits of law, to regulate and manage a substancial share of public affairs under their own responsibility and in the interests of the local population. ${ }^{.46}$ Het Handvest heeft voor Nederland betrekking op gemeenten en provincies. Artikel 1.3 geeft de mogelijkheid decentrale overheden uit te zonderen van de werking van het Handvest. Het geldt voor Nederland niet voor samenwerkingsverbanden, ingesteld krachtens de Wet gemeenschappelijke regelingen, gezien het feit dat hun organen, hetgeen door artikel 2 vereist wordt, niet bij wege van algemene verkiezingen worden samengesteld. ${ }^{47}$ Hoewel de waterschappen onder de formulering van het begrip lokale autonomie van artikel 3 lid 1 te rubriceren zijn en mitsdien onder de werking van dit Handvest kunnen vallen, is hiervan toch afgezien vanwege het vooral functionele (niet territoriale) karakter van deze bestuursvorm. ${ }^{48}$

44. Toelichtende Nota bij het Europees Handvest inzake lokale autonomie, Tweede Kamer, vergaderjaar 1987-1988, 20586, tr. 1, p. 5. Zie voor een korte beschrijving van de door Nederland gemaakte voorbehouden ten atanzien van de goedkeuring van dit Handvest: P.D.A. Claessen, Her Europees Handvest inzake Lokale Autonomie, TvO, 1988/20, p. 424 425; C.H. van Marle en A.J.H. Smallenbroek, Binnenlandse kroniek, Bestuurswetenschappen 1991/4, p. 331-332; NJB 1992, rubriek Nieuws, p. 657.

45. MvA betreffende de goedkeuring van het Europees Handvest inzake lokale autonomie, a.w., p. 4-5.

46. Voor het autonomie-aspect, zie b.v.: H-J. Blanke, Die kommunale Selbstverwaltung im Zuge fortschreitender Integration, Aspekte nationaler und supranationaler Verfassungsentwicklung DVBI. 1993/15, p. 819 .

47. In de goedkeuringsbehandeling van het Handvest is in dit werband o.a. ingegaan op de mogelijke strijd van de gedwongen oplegging van gemeenschappelijke regelingen met de reikwijdte van het begrip lokale antonomie (art. 3 Handvest), Eindverslag betreffende de goedkeuring van het Europees Hand vest inzake locale autononie Tweede Kamer, vergaderjaar 1989-1990, 20586, nr. 10, p. 4. In de nota naar aanleiding van het eindverslag betreffende cle goedkeuring van het Europees Handwest voor locale autonomie, a.w. n. 11, p. 5, is datomtrent door de regering gesteld dat deze oplegging alleen kan geschieden in het kader wan een zwarwegend openbaar belang en gezien deze uitzonderingssituatie derhalwe toelaatbatar moet worden geacht.

Vgl. hetgeen over de verplichte samemerking is geschreven in hoofdstuk $5 \$ 2 . D .4$.

48. Nota naar aanleiding van het eindwerslag betreffende de goedkeuring van het Europees Handvest inzake locale autonomie, a.w., p. 3, en MvA betreffende de goedkeuring van het Europees Handwest inzake locale autonomie, Eerste Kamer, wergaderjaar $1989-1990,20586$, nr. $189 \mathrm{~b}$, p. 1. 
Artikel 10 lid 3 is van belang voor de decentrale grensoverschrijdende samenwerking. Het bepaalt: "Local authorities shall be entitled, under such conditions as may be provided for by the law. to co-operate with their counterparts in other States. "Op basis van deze bepaling is de (formele) bevoegdheid van de decentrale overheden om grensoverschrijdend samen te werken (voor het eerst) algemeen en uitdrukkelijk erkend. Immers in de EOC lijkt (vooral) het bevorderen van de samenwerking door de staten nog voorop te staan. Overigens blijft gelden dat het formele recht tot samenwerking op zichzelf niet zo heel veel betekent, indien nadere uitwerking ervan in het nationale recht achterwege blijft. ${ }^{4}$

Het toeziem op de naleving en toepassing van dit Handvest is in beginsel in handen gelegd van de Permanente Conferentie van Lokale en Regionale Overheden, een adviesorgaan (van het Comité van Ministers) van de Raad van Europa. De werkzaamheden van deze Conferentie strekken zich ook uit op het terrein van de grensoverschrijdende samenwerking. ${ }^{50} \mathrm{Zo}$ is in 1991 een resolutie door deze Conferentie aangenomen houdende de aanbeveling aan het Comite van Ministers tot het opstellen van een additioneel Protocol bij de EOC alsmede tot het opstellen van een nieuw verdrag, dat interregionale samenwerking over de grenzen (niet beperkt tot grensgebieden) mogelijk moet maken. ${ }^{5 i}$

Het Europees Handvest inzake lokale autonomie is van belang voor de grensoverschrijdende samenwerking door lokale overheden. Veel meer dan de expliciete erkenning wan een bevoegdheid tot samenwerking levert dit Handvest evenwel niet op. Hoewel daardoor mijns inziens eigenlijk te weinig recht wordt gedaan aan het gewicht van de principiële bepaling van artikel 10 lid 3, komt het uiteindelijk, evenals bij de EOC, aan op de (nationale) invulling ervan,

\section{\$ 3. De Europese Gemeenschappen (EG)}

\section{A. DE EG EN DECENTRALE OVERHEDEN}

Als het gaat om de regeling van decentrale grensoverschrijdende samenwerking en in het bijzonder het voorzien in juridische grondslagen woor het maken van grensoverschrijdende publiekrechtellike afspraken, is tot op heden de positie van de Raad van Europa en zeker van bepaalde staten, zoals Nederland en de buurlanden, van groter belang dan die van de Europese Gemeenschappen. In het navolgende wordt op de rol van de EG ten aanzien van de decentrale grensoverschrijdende samenwerking ingegaan. Daarbij

49. Zie ook: U. Beyerlin, Rechtsprobleme (..), atw., p. 226.

50. Voor een korte beschrijving van deze Conference of Local and Regiomal Authorities in Europo (CLRAE) wordt verwezen maar de MvA betreffende de goedkeuring van het Europees Handvest inzake locale autonomie, a.w. . p. 14-15 alsmede La Conférence des pouwoirs locaux et régionaux de l'Europe, vingt années d'action en faveur des pouvoirs locaux et régionaux, Strasbourg 1977.

De CLRAE is als het ware de bestuurlijke pendant - hierin hebben vertegenwoordigers zitting van lokale en regionale overheden - van de in noot 33 van dit hoofdstuk beschreven ambtelijke commissies.

Zie ook: H.G. won Lennep, Kommunale Mitsprache in Europarat gefahrdet, Stadt und Gemeinde, 5/1993, p. 163-166.

51. Standing Conference of Local and Regional Authorities of Europe, 26th session (19-21 March 1991), Resolution 227. Zie ook: Report on the extermal relations of local and regional authorities, Rapportear: J.R. Guevara (Doc. CPL (26) 10, Part II Appendix). Vgl. noot 33 van dit hoofdstuk. 
wordt, in het licht van het supranationale karakter van de EG en de daaruit mogelijk voortvloeiende consequenties voor decentrale overheden, ook in meer algemene zin op de verhouding EG versus decentrale overheden ingegaan. Aangezien decentrale grensoverschrijdende samenwerking (publiekrechtelijke afspraken) hier het centrale onderwerp vormt, is de beschrijving van de algemene verhouding EG versus decentrale overheden niet als uitputtend bedoeld maar als een schets van de Europese dimensie ten aanzien van (grensoverschrijdende samenwerking tussen) decentrale overheden.

De EG vormen een supranationale rechtsorde. Gemeenschapsrecht kan rechtstreeks doorwerken in het nationale recht van de Lid-staten. Ook decentrale overheden kunnen verplicht zijn de nakoming van Gemeenschapsrecht (verdragsrecht en secundair recht) te garanderen. In deze kan b.v. gewezen worden op een rechtsoverweging van het Hof van Justitie in de zaak Von Colson en Kamann:

"Wel moet worden gepreciseerd, dat de uit een richtlign voortwoeiende verplichting der Lid-Staten on het daamee beoogde doel te verwezenlijkenalsook de verplichting der Lid-Staten krachtens artikel 5 EEG-Verdrag om alle algemene of bijzondere matregelen te treffen die geschiki zijn om de nakoming van die verplicining te verzekeren, voor alle met owerheidsgezag beklede instanties in de Lid-Staten gelden, en dus, binnen het kader van hun bevoegdheden, ook voor rechterlijke instanties." ${ }^{\text {sq }}$

De toenemende Europese dimensie van het binnenlands bestuur is voor decentrale overheden vooral aan de orde als het gaat om de consequenties van EG-beleid voor de dagel ijkse praktijk van deze decentrale overheden en waar het de participatie van deze betreft in het Europese besluitvormingsproces. Bij dat laatste staat de belangenbehartiging van de decentrale overherlen ten opzichte van de nationale overheid (de Lid-Staat). die formeel aanwezig is op EG-niveau, centraal. ${ }^{53}$ De Adviesraad van de Regionale en Plaatselijke Rechtsgemeenschappen is o.a. een adviesinstantie ten behoeve van de Europese Commissie, waarbinnen deze twee aspecten centraal staan. ${ }^{54}$ Intensivering van de decentrale grensoverschrijdende samenwerking kan in dit verband een rol spelen en de positie van decentrale overheden in het Europese integratieproces versterken. Hier is belangrijker of binnen de Europese Gemeenschappen de decentrale grensoverschrijdende samenwerking in meer of mindere mate is geregeld. Tot nu toe bestaat er nog geen integrale regeling (a la de EOC). ${ }^{55}$ Vooral in de Commissie voor regionaal beleid

52. H.V.J.F, G. Von Colson en Kamann, zaak 14/83, Jur. 1984, p. 1908, r.o 26. Zie ook noo 84 van dit hoofdstuk en de bijbehorende tekst.

53. Zie o.a: R. Sieben, J. Ziller, De gevolgen van EG-beleid voor decentrale owerheden in Nederland, 1989 ; C. Hauschild, "The impact of EC-law on the relation between central government and local and regional authorities, Regeimaat $1991-2$, p. 48 e.v; J.A. Winter, Gewolgen van het Gemeenschapsrechi voor de lagere overheden in Nederland, Regelmaat, $1991-2$, p. 52 e.v.; Europa vanuit de praktijk van de decenurale overheden, themanummer Bestuurswetenschappen, 1991/7; REGwijzer: Europese informatie ten dienste van decentrale overheden/Rad der Europese Gemeentenen Regio's, (verschijnt jarlijks); I. A.M. Hendrikx, J.M.E. Traag, Samenwerking thassen provincies op subnationaal niveau, Openbaar Bestuur $1992 / 1$, p. 7 e.v.; M. Zuleeg, Die Stellung der Luinder und Regionen im europäischen Integrationsprozess, DVBI. $1992 / 20$, p. 1229 e.v.

54. Zie o.a.: E.P. Woltjer, J.D. Wiersma, De territoriaal gedecentraliseerdeoverheden en de Europese integratie, in: N.F. Roest, K.J.M. Mortelmans, A.P. Oele, J.H. Boone (red.), Europa binnen hell bestuur, $199 \mathrm{l}$, p. 13 e.w. Organwaties als de Intemational Union of Local Authorities (IULA) en de Raad der Europese Gementen en Regio's (REGR) participeren hierin.

55. Voor de grensoverschrijdende samemwerking ten aanzien van econorwische activiteiten zou gewezen kunnen worden op de Verordening van de Raad van 25-7-1985 (2137/85/EEG, PB nr. L 199 wan (wordt vervolgd...) 
van het Europees Parlement het belang van grensoverschrijdende samenwerking (op regionaal niveau) benadrukt in verslagen en resoluties. De belangrijkste in dit verband zijn:

- Verslag namens de Commissie voor regionaal beleid, ruimtelijke ordening en vervoer over de ontwerp-resolutie inzake het regionaal beleid van de Gemeenschap ten aanzien van de regio 's aan de inteme grenzen van de Gemeenschap. ${ }^{56}$ Dit verslag bevat 0.a. een ontwerp-voorstel voor een verordening van de Raad betreffende de vorming van regionale verenigingen voor (vooral economisch-sociale) samenwerking over de grenzen heen (Euroverenigingen). Hier wordt volstaan met op te merken, dat deze Euroverenigingen, bestaande uit ten minste twee plaatselijke of regionale territoriale publiekrechtelijke lichamen dan well uit rechtspersonen naar publiekrecht, die met zelfstandige bestuurstaken zijn belast, en behorend tot tenminste twee Lid-Staten, rechtspersonen naar Gemeenschapsrecht zouden zijn.

- Resolutie inzake intensivering van de grensoverschrijdende samenwerking. ${ }^{57}$ Hierin wordt de Commissie o.a. verzocht om voorstellen te doen inzake de opstelling van een richtlijn betreffende administratiefrechtelijke coördinatie tussen plaatselijke en regionale publiekrechtelijke lichamen en overheden bij grensoverschrijdende problemen.

- Resolutie over de grensoverschrijdende samenwerking aan de binnengrenzen van de Europese Gemeenschap. ${ }^{58}$ Hierin wordt de Commissie (opnieuw) gevraagd voorstellen te formuleren voor een richtlijn, waarin de Lid-Staten worden verplicht de nodige voorzieningen te treffen voor uitwisseling van gegevens en zorg te dragen voor wederzijds overleg over bestuurlijke maatregelen in grensgebieden die direct of indirect van invloed zijn op de grensgebieden in buurlanden. Hierin wordt de Commissie tevens verzocht bij de Raad een voorstel voor een verordening in te dienen, waarin de LidStaten worden verplicht in hun grensregio's bij elk type emissies met grensoverschrijdend effect de normen van het buurland te eerbiedigen, indien deze strenger zijn dan die in eigen land.

- Verslag namens de Commissie regionaal beleid en ruimtelijke ordening over een ontwikkelingsprogramma voor de grensgebieden tussen Spanje en Portugal. ${ }^{59}$ Hierin wordt o.a. een uiteenzetting gegeven van het belang van de grensregio"s voor de Europese eenwording en de communautaire aanpak van dit thema.

55.(....verwolg)

31-7-1985, p. 1) tot instelling van Europese economische samenwerkingswerbanden (EESV). Dawarin kunnen ook publiekrechtelijke rechtspersonen participeren. Voor de (publiekrechtelijke) samenwerking, die hier aan de orde is, is deze vorm (van meer vennootschappelijke aardl) evenwel niet bedoeld. Zie over het EESV b.v.: M. yan Olffen, P.A.J. Beks, Het Europees Economisch Samenwerkingsverband, 1990. Vgl. art. 58 EEG-Verdrag.

56. Doc. 355/76, 25-10-1976, rapporteur H. Gerlach. Zie ook: A.W.H. Meij, C.W.A. Timmermans, Grensregio's en Europees recht, Bestuurswetenschappen, 1980/1, p. 6-8.

57. $\mathrm{PB}$ ar. $\mathrm{C} 127$ van $13-4-1984$, p. 214.

58. PB nr. C 99 van 13-4-1987, p. 153.

59. Doe. A2-142/88, 1-7-1988, rapporteur M. Chiabrando. 
De vermelde parlementaire voorstellen hebben tot nu toe niet geresulteerd - om die reden wordt hierop niet dieper ingegaan - in een algemene regeling, richtlijn respectievelijk verordening, betreffende de decentrale grensoverschrijdende samenwerking. Omdat een algemene regeling van de decentrale grensoverschrijdende samenwerking binnen de $\mathbb{E G}$ ontbreekt, wordt in \& 3.E. van dit hoofdstuk kort ingegaan op de al dan niet wenselijkheid in deze van een richtlijn c.q. verordening.

Er bestaan wel een aantal milieurichtlijnen, waarin specifieke bepalingen opgenomen zijn over b.v. de coördinatie tussen overheden aan weerszijden van de grens. De bepalingen uit de betreffende richtijnen worden hier besproken (\& 3.D.). Hieraan voorafgaand wordt kort op het EEG-Verdrag ingegaan, waarin een mogelijke basis voor decentrale grensoverschrijdende samenwerking gelegen kan zijn. Speciale aandacht gaat daarbij uit naar het EG-regionaal beleid, dat raakvlakken heeft met de decentrale grensoverschrijdende samenwerking ( $\$ 3$. B.). Tevens wordt bezien of de decentrale grensoverschrijdende samenwerking nadere aandacht heeft gekregen in het Verdrag betreffende de Europese Unie (\$ 3.C.).

\section{B. HET EEG-VERDRAG ${ }^{60}$}

De primaire doelstelling van de Europese Gemeenschap is, blijkens artikel 2 EEGVerdrag, een economische. Dit artikel luidt: "De Gemeenschap heeft tot taak, door het instellen vân een gemeenschappelijke markt en het geleidelijk nader tot elkaar brengen van het economische beleid van de Lid-Staten te bevorderen de harmonische ontwikkeling van de economische activiteit binnen de gethele Gemeenschap, een gestadige en evenwichtige expansie, een grotere stabiliteit, een toenemende ver betering van de levensstandaard en nauwere betrekkingen tussen de in de gemeenschap verenigde Staten." Decentrale grensoverschrijdende samenwerking zou een middel kunnen zijn voor het verwezenl ijken van het Europese integratiestreven. Artikel 3 EEG-Verdrag, dat de middelen aangeeft ter bereiking van deze doelstelling, noemt de decentrale grensoverschrijdende samenwerking evenwel niet. Hoewel het EEG-verdrag geen expliciete regeling bevat, kan een beginsel als Gemeenschapstrouw, neergelegd in artikel 5 EEG-Verdrag, wellicht enige betekenis in deze toekomen: "De Lid-Staten treffen alle algemene en bijzondere maatregelen weike geschikt zijn on de nakoming van de uit het EEG-Verdrag of uit handelingen van de instellingen van de Gemeetischap voortwloeiende verplichtingen te verzekeren. Zij vergemakkelijken de vervulling van haar taak. Zij onthouden zich van alle maatregelen welke de verwezenlijking van de doelstellingen van dit Verdrag in gevaar kunnen brengen." Hier is van groot belang, dat onder de term Lid-Staten in beginsel ook de gedecentraliseerde overheden vallen, indien deze een taak in de uitvoering van het Gemeenschapsrecht hebben. ${ }^{61}$ Dit zal, zoals aangegeven wordt sub \& 3.D. van dit hoofdstuk, met name het geval zijn waar het de uitvoering van het (rechtstreeks werkende) secundaire gemeenschapsrecht betreft. Vooral in dat perspectief zou het nietsamenwerken tussen (decentrale) overheden, daar waar er b.w. richtlijnen zijn die tot

60. Hier staat het Verdrag tot oprichting van de EEG centraal en wordt gezien de geringe relevantie wan het EGKS-en Euratom-Verdrag op deze latste twee niet ingegaan.

61. Vgl. noot 52 van di hoofdstuk en de bijbehorende tekst. Zie b.v. K.J.M. Mortelmans, Europees materieel recht: De hoofdlijnen geschetst woor het binnentunds bestaur, in: N.F. Roest, et al., a.w. p. 58 . 
samenwerking tussen Lid-staten verplichten, kunnen conflicteren met de strekking van artikel 5 EEG-Verdrag. ${ }^{62}$

Aangezien (grensoverschrijdende) samenwerking o.a. ten doel heeft dat de samenwerkende partijen zaken op een zelfde wijze aanpakken c.q. regelen, kan hiermee bijgedragen worden aan het opheffen van verschillen in behandeling. Het kan daarmee een instrument zijn in het kader van artikel 7 EEG-Verdrag, op basis waarvan iedere discriminatie (binnen het ruimtelijk geldingsbereik van een nationale regeling) op grond van nationaliteit (b.v. inzake het aanbestedingsbeleid) is verboden. ${ }^{63}$

Binnen de realisering van de doelstelling van de EG, speelt het regionaal beleid een belangrijke rol. Het regionaal EG-beleid heeft raakvlakken met de decentrale grensoverschrijdende samenwerking, daar waar de sociaal-economische ontwikkeling van en de samenhang tussen regio's (artikel 130 A EEG-Verdrag) - grensregio's wormen een belangrijke categorie in deze - in het geding zijn. ${ }^{64} \mathrm{De}$ EG-structuurfondsen (met name: het Europees Fonds voor Regionale Ontwikkeling (EFRO), gebaseerd op artikel 130C EEG-Verdrag) vormen belangrijke instrumenten in deze. ${ }^{65}$ Een recente vorm van financiële ondersteuning, overigens via de Lid-Staten, van activiteiten (in het kader van de voltooiing van de interne markt) van grensregio's (in bepaalde grensgebieden), geschiedt op basis van Interreg. ${ }^{66}$ Artikel 4 Interreg onderscheidt een drietal soorten van acties:

a) de gezamentijke opstelling en uitvoering van grensoverschrijdende progranma's;

b) de invoering van maatregeienter verbetering van informatie-uitwisseling tussen overheidsinstanties, particuliere organisaties en groeperingen aan weerszijden van grenzen en tussen grensgebieden onderling;

c) de oprichting van gezamenlijke institutiontele en administratieve structuren om samerwwerking te steunen en te bevorderen.

62. Zie over de reikwijdte van artikel 5 EEG-Verdrag: Dr. Ole Due, Artikel 5 van het EEG-Verdrag, Een bepaling met een federaal karakter, SEW 5 (1992), p. 355-366.

63. Artikel $7 \mathrm{EEG}$-Werdrag is met name van belang wat betreft de grensowerschrijdende inspraakmogelijkneden en rechtsbescherming In dit verband wordt volstaan met een werwijzing naar de bespreking door Jans van 0.A. artikel 7 EEG-Verdrag als mogelijke grondslag yoor een non-dscriminatoir milieubeleid, J.H. Jans, Grensoverschrijdend mileurecht, 1987 , p. 2345 .

64. Zie in deze b.v.: Resolutie van het Europees Parlement over een schema woor de ruimtelijke ordening. PB nr. C 10 van 16-1-1984, p. 115; Verstag namens de Commissie regionaal beleid en ruimtelijke ordening over het regionaal beleid wan de Gemeenschap en de rol van de regio's, Doc. A2-218/88/deel B, 21-10-1988 (meerdere rapporteurs). Hierin is o. a. het Communatair Hand west woor de regionalisering opgenomen.

Voor de relatie milieubeleid (art. 130R EEG-verdrag) en decentralegrensoverschrijdende samerwerking wordit verwezen naar thet gestelde \& $3 . D$ van dit hoofdstuk.

65. Zie ook Verordening 4254/88/EEG wan de Raad van 19412-1988 tot waststelling van toepassingsbepalingen voor Verordening 2052/88/EEG met betrekking tot het Europees Fonds voor Regionale Ontwikkeling, PB nr. L. 374, 31-12-1988, p. 15.

66. Mededeling C (90) $1.562 / 3$ aan de Lid-Staten tot vasistelling van richtsnoeren voor operationele programma's wan de Lid-Staten in het kader van een initiatief van de Gemeenschap betreffende grensgebieden, PB. nr. C 215 van 30-8-1990, p. 4. Voor de (nationale) werdeling van de Inierreg-gelden, zie: Besluit van 18-3-1993, houdende regels inzake de verstrekking van uitkeringen in het kader van de co-financiering waln Interreg-projecten in 1993 en 1994 (Besiuic uitkeringen Interreg 1993/1994), Stb. 1993, 173. Zie woor een bespreking van o.a. Interreg: P.L.J.M. wan Run, A.H. Verheij, Regio's in Europa/Europese Fondsen, in: N.F. Roest et al., a.w., p. 135; H.H.M. Jeurissen, Europese steunverlening, Bestuurswetenschatppen, 1991/7, p. 504 e.v.; K. Sevinga, Europese integratic, Kansen voor de decentrale overheid, Publiak domein, 1990, p. 335 e.v. 
O.a. programma's voor de preventie en de bestrijding van vervuiling, de verwerking van afval, milieubehoud en de controle van milieunormen van nieuwe industrievestigingen in grensgebieden komen voor financiering in aarmerking. Mede in dit verband zijn de grensoverschrijdende actieprogramma's, zoals die voor in ieder geval de Belgisch-Nederlandse en Duits-Nederlandse grensregio's zijn opgesteld, van belang.

Bij het EG-regionaal beleid gaat het om de financiering van activiteiten van (grensoverschrijdende) regio's en niet om inhoudelijke regelgeving betreffende (grensoverschrijdende puobliekrechtelijke samenwerking tussen) regio's. ${ }^{67}$

\section{HET VERDRAG BETREFFENDE DE EUROPESE UNIE ${ }^{68}$}

In het (nog niet in werking getreden) Verdrag betreffende de Europese Unie (hierna: Verdrag van Maastricht) wordt de decentrale publiekrechtelijke grensoverschrijdende samenwerking niet expliciet geregeld. De mogelijke grondslagen, zoals die in het EEGverdrag zijn opgenomen en \& 3.D. aangegeven worden, zijn niet aangevuld met nadere regels. Het accent blijft, behoudens het voorziene gemeenschappelijk buitenlandse- en defensiebeleid, in het Verdrag van Maastricht gericht op sociaal-economische samenwerking op het niveau van de Lid-Staten. Zo gaat het in artikel B (titel I) juncto titel VI Verdrag van Maastricht, dat voorziet in de samenwerking op het gebied van justitie en bimnenlandse zaken, niet on de decentrale grensoverschrijdende samenwerking. Het is in eerste instantie aan de Lid-Staten zelf daar nadere regels over te maken. Dit geldt in beginsel ook woor de politiële samenwerking, waarvoor ook de bij het Verdrag behorende Verklaring betreffende politiële samenwerking van belang is.

Met de geplande instelling op basis van artikel 198A t/m C EEG-Verdrag van het raadgevende Comité van de Regio's, bestaande uit vertegenwoordigers van regionale en lokale lichamen, kan hun positie in het kader van de Europese integratie versterkt worden en kan daarmee weilicht ook de grensoverschrijdende publiekrechtelijke samenwerking bevorderd worden. ${ }^{69}$ Overigens moet nog afgewacht worden of de lokale overheden even sterk vertegenwoordigd zijn in het Comité van de Regio's als de regio's. ${ }^{70}$

67. Voor een bespreking van het regionale beleid in samenhang met het millieubeleid, zie: $M$. Prieur (red.). Europe des Reggions et Enwironnement, 1988.

68. Mastrich, 7-2-1992, Trb. 1992, nr. 74. Waarschijnlijk zal dit verdrag in het najaar van 1993 in werking treden.

69. Zie woor de samenstelling van de Nederlandse delegatie, MvA, Goedkeuring van het op 7 februari 1992 te Masstricht tot stand gekomen verdrag betreffende de Europese Unie met protocollen, een overeenkomst betreffende de sociale politiek tussen de lidstaten wan de $\mathrm{EG}_{\mathrm{g}}$ met uitzondering van het Verenigd Koninkrijk, en verklaringen, Tweede Kamer, vergaderjaar 1992-1993, 22647 (R 1437), nr. 13, p. 57-58.

70. Zie b.v.: R. von Ameln, Auswirkungen des Europäischen Binnenmarktes auf Kommunalpolitik und Kommunalrecht der EG-Mitgliedstaten, Am Beispiel der Bundesrepublik Deutschland, DVBI. 1992/8, p. 478; H-J. Blanke, a.W., p. 828 e.v. 


\section{HET SECUNDAIRE EG-MILIEURECHT}

\section{Algemeen}

Verplichtingen inzake decentrale grensoverschrijdende samenwerking zullen veeleer uit verordeningen en richtlijnen voortvloeien dan wit EG-verdragsrecht. De belangrijkste algemene grondslagen voor het secundaire EG recht zijn de artikelen $100,100 \mathrm{~A}$ en 235 EEG-Verdrag. Voor het milieubeleid zijn in deze de artikelen 130 R-T EEG-verdrag van belang. ${ }^{71}$

Artikel 100 EEG-Verdrag bepaalt dat de Raad met eenparigheid van stemmen op voorstel van de Commissie richtlijnen vaststelt voor het nader tot elkaar brengen van de wettelijke en bestuursrechtelijke bepalingen der Lid-Staten welke rechtstreeks van invloed zijn op de instelling of de werking van de gemeenschappelijke markt. Artikel $100 \mathrm{~A}$ regelt hetzelfde, zij het dat het daar om een gekwalificeerde meerderheid gaat en het de interne markt betreft. Van een rumere strekking en daardoor wellicht eerder van toepassing op een mogelijke algemene regeling inzake decentrale grensoverschrijdende samenwerking is artikel 235 EEG-Verdrag. Het bepaalt:

"Indien een optreden van de Gemeenschap noodzakelijk blikt on, in het kader wan de gemeenschappelijke markt, een der doelsiellingen van de Gemeenschap te verwezenlijken zonder dat dit Verdrag in de daartoe vereiste bevoegdheden voorziet, neemt de Ratad met eenparigheid van stemmen op voorstel van de Commissie an na radpleging van de Vergadering de passende maatregelen. " 72

In het kader van het milleubeleid (artikel 130 R-T EEG-Verdrag) kan eveneens door de Gemeenschap opgetreden worden. Artikel $130 \mathrm{~S}$ bepaalt:

"Op woorstel wan de Commissie en na raadpleging van het Europese Parientent en lhet Economisch en Sociaal Comilie besluit de Raad met een eenparigheid van stemmen ontrent het optreden van de Gemeenschap. De. Raad bepaalt op de in de eerste alinea bepaalde wijze welke besluiten met gekwalificeerde meerderheid van stemmen. worden genomen."

EG-harmonisatieregelingen op basis van de woorgaande verdragsbepalingen - ik laat hierbij in het midden welke grondslag daadwerkelijk wordt gehanteerd, maar die van artikel 235 en 130 S EEG-Verdrag liggen wellicht het meest woor de hand - kunnen aspecten van decentrale grensoverschrijdende samenwerking bevatten. ${ }^{73}$ Op milieuterrein is er binnen de Europese Gemeenschappen een aantal richtijnen tot stand gekomen, waaruit samenwerkingsverplichtingen tussen aan de Lid-Staten ondergeschikte besturen (kumen) voortvloeien. ${ }^{74}$ In het navolgende wordit bezien of de desbetreffende.

71. Zie ook noot 83 van dit hoofdstuk, waar artikel 30 EEG-verdrag als grondslag voor informatieverschaffing door overheden aan de orde is.

72. In het in noot 56 van dit hoofdstuk genoemde versiag (p. 88) werd artikel 235 EEG-Verdrag als de grondslag voor de betreffende verordening gexien.

73. Het gaat hier derhalwe niet om richtlijnen warin (aan decentrale overheden) andere dan grensoversebrijdende samemwerkingsverplichtingen zijn toe bedeeld, b. v. in het kader valy de vergunning verlening. Zie hierover b.v.: HvJEG, 29-3-1990, $M$ en $\mathbb{R} 1992$ 7/8, p. 430 e.v.

74. IK beperk mij hier tot een bespreking van de belangrijkste milieurichtilinen. Overigens staan door de EG gesloten verdragen hiermee in beginsel op éfnllijn. Op basis van artikel 228 EEG-Verdrag zijn de door de EG gesloten internationale verdragen behalve voor de Gemeenschap ook verbindend voor de Lid-Staten (zie b.w. HwEG, zaak 8775, Brescani, Jur. 1976, p. 129). De besluiten van de Raad tot sluiting wan verdragen vallen onder het begrip 'handeling' in artikel 177 EEGi-Verdrag, zie: L. I. Brinkhorst, R. Barents, Grondlijnen van Europees recht, Se druk, 1990, p. 170.

(wordt verwolgd...) 
samenwerkingsbepalingen te plaatsen zijn in het kader van (grondslagen voor) publiekrechtelijke afspraken tussen decentrale overheden. Voordat hiertoe wordt overgegaan, dient nog een drietal zaken vermeld te worden. In de eerste plaats kan gesteld worden, dat het in de regel de Lid-Staten (de centrale owerheden) zijn die in nationale (al dan niei formele) wetgeving tot de implementatie van richtlijnen overgaan. Hoewel niet uitgesloten, zal er mijns inziens niet snel een praktijk ontstaan, waarbij het de decentrale overheden (voor de deelstaten in federalle staten geldt wellicht een uitzondering) zelf zijn, die b.v. via algemeen verbindende voorschriften de implementatie van richtlijnen kunnen bewerkstelligen. ${ }^{75}$ Ten tweede zij benadrukt dat het overgrote deel van de betreffende richtlijnen inmiddels al omgezet moet zijn in het nationale recht van de Lid-staten, omdat de termijn voor omzetting is verstreken. Hier is niet in extenso onderzocht of en hoe precies de genoemde samenwerkingsbepalingen in het nationale recht zijn omgezet. Dit heeft, daarmee al vooruitlopend op het karakter van de desbetreffende

\section{4.(...vervolg)}

Het voorgande impliceert, dater ganenwarkingswerplichtingen voor decentrale overheden kunnen woor" woeien uil door de EG gesloten werdragen. Met name op het tertein van de naturbescherming zijn de EG partij, evenals de meeste Lid-staten overigens, bij een aantal verdragen, zoals bet Verdirag van Ramsar, het Verdrag wan Bonn en het Verdrag wan Bern. Vooral het Verdrag van Bern voorziet in samenwerking, die met name ook voor decentrale overheden van belang kwn zijn. De verdragen van Bonn (art. I.3 sub c) en Ramsar (art. 5 ) kennen ook sanemwerkingsverplichtingen, maar veeleer op het niveau wan de staten dan op het niveau van decentrale owerheden.

* Het Verdrag wan Bern (zie verder noot 124 e.w. wan dit hoofdstuk):

artikel 4: "4. De Verdragsluitende Partijen werbinden zich ertoe hun inspanmingen ter bescherming var de in dit artikel bedoelde natuurlijke leefinilieus voor zower nodig te coórdineren wanneer deze zujn gelegen in gebieden die zich over de landsgrenzen witstrekken."

Artikel 11: "1. Bij de uitvoering van de bepalingen van dit Verdrag verbinden de Verdragslutitende Partijen zich ertioe:

a. samen te werken telkens wanneer dit wenselijk en noodzakelijk is en met name wanneer deze samenwerking de doeltreffendheid zou kumen werhogen van de matregelen, genomen krachtens de andert aritikelen van ditit Verdrag;"

In de belangrijkste natumbeschemingsichtlinenvan de EC is niet expliciet in dergelijke sumenwerking voorzten (Richtijn van de Rat van $2-4-1979$ inzake het behowd van de vogelstand, 79/409/EEG, PB. Nr. L. 103 van 25-4-1979, p. 1; Richtlijn wan de Rasd van 21-5-1992 inzake de instandhouding van de thatururlike habitats en de wilde flora en fatna, $92 / 43 / \mathrm{EEG}, \mathrm{PB}$. N. L 206 varn 22-7-1992, p. 7.

75. Implementatie dieat in beginsel door middel wan algemeen werbindende woorschriften (van dle rijksoverheid) te geschieden en b. W. niet door richtijnen, cireulaires e.d.

Zie b. v. het. Wetswoor stel tot wersneling wan de implementatie van EG-richtlinen, Tweede Kamer $1991 \mathrm{~m}$. 1992, 22690, nis. 1 e.v.; Zie hierover, I. Sewandono, Wetswoorstel tot versnelling van de implementatie wan EG-richthingen, NJB 1992/36, p. 1172-1175.

Vgl. b. $v$. de bepalingen 5.4 en 8.43 juncto 8.44 Wet milieubeheer. Hier wordt het primat bij de rijks. overhe: gelegd.

Vgl. het regeringsstandpunt natr anleiding van het advies van de Commissie voor de toe tsing van wetgevingsprojecten 'Inplementatie van EG-regelgeving in de nationale rechtsorde', Uitwoering wan DGrichtijnen, TK 1990-1991, 21109, nrs. 33 en 34, p. 6. Daarin wordt aangegeven, dat het kabinet waar nodig meer aandacht zal schenken aan implementatietaken en -mogelikheden van de decentrale overheden. In het nadere standpunt van het kabinet inzake voorneld advies wordt dit herhastd en word: ben aanzien wan de reeds bestaande EG regelgeving vooral gewezen op de naleving hiervan door decentrale overheden. In dit verband is in samemwerking met de Vereniging van Nederlandse Gemeenten en het Interprovincial Overleg een EG-informatiepunt opgericht. Overigens wijst de regering erop. dat de controle op de naleving het beste kan verlopen via het reguliere (repressieve) toezicht, Uitwoering van EG.richdijnen, a.w., nr. 43, p. 8 . 
samenwerkingsbepalingen, te maken met het gegeven dat deze in de regel niet het maken wan publiekrechtelijke afspraken betreffen. De samenwerking in de meeste wan de genoemde richtlijnen betreft informatieverschaffing en in bepaalde gevallen consultatie. Daar waar er al sprake is van een plich tot genoemde vormen van samenwerking, is het niet zo dat als gevolg van die samenwerking daadwerkelijk verplichtingen voor partijen in het leven geroepen worden. Voor zower nagegaan, zijn de hier te behandelen richtijnen in de regel omgezet, maar zijn juist de grensoverschrijdende samenwerkingsbepalingen uit de betreffende richtlijnen niet altijd expliciet terug te vinden in het nationale recht van Belgiè, Nederland en Duitsland. ${ }^{76}$ Daar waar deze omgezet zijn, is de samenwerking vaak niet nader uitgewerkt. Ten aanzien van de implementatie van één van de belangrijkste richtlijnen, namelijk die inzake de milieu-effectbeoordeling, die in \$ 3.D.2 uitgebreid wordt beschreven, wordt een en ander geillustreerd. Er is o.a. voor deze richtlijn gekozen, omdat juist inzake milieu-effectrapportage de grensoverschrijdende (decentralle) samenwerking zich steeds verder begint vit te kristalliseren. In de derde plaats zij nog het volgende opgemerkt. Daar waar de omzetting van de samenwerkingsbepalingen niet dan wel onjuist heeft plaatsgevonden, dient het nationale rechi geinterpreteerd te worden in overeenstemming met het gemeenschapsrecht (met name de richtlijnen) en desnoods buiten toepassing te blijven bij strijd hiermee. Om die reden wordt, in het in de bijlage vermelde overzicht van relevante samenwerkingsbepalingen uit milieurichtlijnen, de integrale (Nederlandstalige) tekst ervan en niet de eventuele omgezette wetgeving weergegeven.

Naar aanleiding van de in de bijlage opgenomen inventarisatie van samenwerkingsverplichtingen op basis van de belangrijkste EG-milieurichtijnen zijn de volgende twee algemene opmerkingen van belang:

- Over de aard van de samenwerking kan het volgende gesteld worden.

Vier van de twintig genoemde richtlijnbepalingen hebben betrekking op lozingen van bepaalde stoffen, die de wateren van meer dan éen Lid-Staat beïnvloeden. Zij schrijwen hamonisatie wan toezichtsprocedures voor. In de meeste overige richtijnen, inzake vooral water-en luchtverontreiniging, is overleg voorgeschreven. Vijf richtlijnbepalingen bevatten een informatieplicht. De richtlijn inzake milieu-effectbeoordeling is een voorbeeld wan een richtlijn, die zowel een informatie- als overlegplicht tussen overheden onderling creëert. Van de twintig genoemde richtlijnen heeft er éen, namelijk de drinkwaterrichtlijn, betrekking op de zogenaande reflexwerking. ${ }^{77}$ ledere Lid-Staat dient deze richtlijn toe te passen zonder onderscheid op nationale en grensoverschrijdende wateren.

In het merendeel gaat het in de genoemde richtlijnbepalingen om overleg - en informatieverplichtingen. ${ }^{78}$ Dit zijn geen vormen van samenwerking die als publiekrechtelij-

76. Met name tussen de Duitse Länder en de Belgische Gewesten, die belangrijke milleubevoegdheden hebben, zouden op dit punt werschillen kumen bestaan.

77. De erkenning door Lid-staten van kwersbare gebieden buiten hun nationale rechisgebied, zoals geregeld in de richtlinn inzake stedelijk afwalwater, kan wellicht ook in dit kader geplatatst worden. De reflexwerking is niet zozeer een vorm wan samemerking maar eerder een grondslag woor gamemwerking. Zie hierover hoofdstuk 1 .

78. Zie ook J.H. Jans, Europees miliekrech in Nederland, a.w., p. 197-211. 
ke afspraken zijn te kwalificeren. Bij het harmoniserem van toezichtsprocedures, waar een wederzijdse afstemming dient plaats te vinden, zou wel van publiekrechtelijke afspraken gesproken kunnen worden;

- In geen enkele van de vermelde richtlijnbepalingen worden de decentrale overheden - er wordt steeds gesproken van '(Lid)-Staten' - expliciet genoemd. ${ }^{79}$ Daarbij is inhoudelijk niets geregeld over door wie en hoe precies die samenwerking tussen LidStaten dient plaats te vinden.

De samenwerkingsvormen zoals die in de genoemde richtlijnbepalingen voorkomen, betreffen in de regel alleen iets tussen overheden. Hierom en omdat er eigenlijk steeds een nadere uitwerking in het nationale recht of wellicht in een regeling tussen meer LidStaten wan vooral het overleg en zeker ook de harmonisering van toezichtsprocedures kan/dient plaaks te vinden, kan een burger niet zonder meer genoemde samenwerkingsvormen bij de rechter afdwingen. Zouden genoemde samenwerkingsbepalingen rechtstreekse werking hebben, dan was dit anders. Over de rechtstreekse werking stelde het Hof in o.a de Marshall zaak: "Er zij aan herinnerd, dat volgens vaste rechtspraak van het Hof (met name het arrest van 19-1-1982, zaak 8/81, Becker, Jurispr. 1982, p. 53) in alle gevallen waarin de bepalingen van een richulijn inhoudelijk gezien onvoorwaardelijk en voldoende nauwkeurig zijn, particulieren gerechtigd zijn om hierop een beroep te doen tegenover de stat, wanneer deze hetzij verzuimt de richtijn binnen de gestelde termijnen in het nationale recht ten uitvoer te leggen, hetzij dit op onjuiste wijze doet." ${ }^{\infty}$

Daar waar er discretionaire bevoegdheden bestaan voor de overheden b.v. om samenwerking een bepaalde vorm te geven, kan een particulier zich waarschijnlijk niet snel op dergelijke bepalingen beroepen c.q. kan de rechter deze niet toepassen. ${ }^{81}$ In de uit-

79. Zo bevat ook het in mei 1992 door de Commissie bij de Raad ingediende voorstel betreffende een beleidsplan en actieprogramma van de Gemeenschap inzake het milieu en duurzame ontwilkeling, (COM (92 def deel I, II an III), weinig ten aanzien van lokaal en regionaal milieubeleid. Op p. 29 worde gesteld: "Lokale en regionale overheidsinstanties spelen een zeer belangrijke rol bij het streven natar duurzame ontwikkeling via de uitoefening van hun officiële functie als "bevoegde instantie" voor veel val de bestaande richtlijnen en verordeningen en in de context van de praktische toepassing wan het subsidiariteitsbeginsel."

Het woord 'grensoverschrijdend' kome magr zeer sporadisch woor in het wijfde milieu-actieprogrammat. Men zou dit op zijn minst mogen verwachten daar waar op p. 54 wordt gesteld: "individuele burgers en belangengroepen moeten een reële mogelijkheid hebben om in rechte op te treden om hun rechtmatige belangen it verdedigen en erwoor te zorgen dat de milieuwoorschriften worden nageleefd en aan illegale praktijken eeneinde wordt gemaakt". Het woord grensoverschrijdend wordt gebruikt op p. 92 tera aanzien van ondersteuning van regionale (in de zin van: submondiale) initiatieven van de Raat van Europa (werdrag inzake wettelijke aansprakelijkheid) en ECE (b.v. verdrag inzake milieu-effectrapportage in grensoverschrijdende context).

80. HvJEG, Marshalli, zaák 152/84, Jur. 1986, p. 747, r.0. 46.

81. Lauwaarsi en Timmermans gewen een duidelijke beschrijwing van het leerstuk van de directe werking wan gerneenschapsrecht. De discretionaire bevoegdheid achten wij het bestissende criterium in deze (p. 28 ) Zij leggen een relatie met de verhouding rechter - besturr: "In deze optiek werkt een bepaling wan gemeenschapsrecht rechtstreeks, indien de nationale rechter tot toepassing van deze bepaling in staat is zonder op de stoel van het communautaire of nationale bestuur te gaan zitten." (p. 30). Zij geven everneens een duidelijke beschrijving wan de met het leerstuk van de directe werking samenhangende voortang wan het gemeenschapsrecht (p. 33-38). Het voert te ver dit hier nader te bespreken, R.H. Lauwaars, C.W.A. Timmermans, Europees Gemeenschapsrecht in kort bestek, weede herziene druk, 1991.

Voor de positie van de nationale rechter, zie ook: T.M. Snoep, De nationale rechter, een vooruitgeschoven EG-post?, NJB 1992/8, p. 161-164. 
spraak van het Hof in de zaak Ryborg is bepaald, dat wanneer er een ruime beoordelingsmarge voor overheden bestaat voor het voeren van overleg, rechtstreekse werking afwezig is en particulieren zich derhalve hierop niet woor de nationale rechter kunnen beroepen. ${ }^{32}$

De redactie van de meeste van de hier genoemde samenwerkingsbepalingen laat evemwel geen beoordellingsmarge voor het voeren van overleg. De Lid-Staten zijn op basis van de desbetreffende bepalingen mijns inziens zonder meer verplicit in elk individueel geval het desbetreffende overleg aan te gaan. De overlegverplichtingen op basis van de genoemde milieurichtlijnen gaan derhalve werder dan die in de Ryborg zaak. Of deze (daar waar geen implementatie heeft plaatsgevonden) rechtstreekse werking voor burgers hebben, is thans niet met zekerheid te zeggen. Het lijkt mij niet uitgesloten dat daar waar geen overlleg (tussen overheden) heeft plaatsgevonden de rechter b. w. een eventuele vergunning zal vernietigen. Overleg kan immers wan invloed zijn op het al dan niet verlenen van de vergunning e.d. en dus van invloed zijn op b.v. de positie van de vergunninghouder of derde-belanghebbenden. ${ }^{83}$ Het procedurele karakter van de sa menwerking zal hier mijns inzlens niet per se hoeven te leiden tot het niet aannemen van rechtstreekse werking. Of de rechter hetzelfde zal doen, daar waar het om harmonisering van toezichtsprocedures gaat, laat zich niet zeggen. Hier geldt nog veel meer dan bij het verplicht voeren van overleg, dat wetgeving aangepast dient te worden e.d. Voor de informatieplicht zal waarschijnlijk ongeveer hetzelfde gelden als voor het overleg. Daar waar geen informatieverstrekking plaatsvind, zou een burger het verstrekken van die informatie mogelijk met succes kunnen inroepen bij de rechter.

Het is de vraag of daar waar de decentrale overheden b.w. uitvoeringstaken hebben, hetgeen op het terrein van het milieu zeker voor Nederland maar ook de andere Lidstaten het geval is, aan de Lid-Staat opgelegde verplichtingen, die niet zijn geïmplementeerd, door deze decentrale owerheden zelf gerealiseerd dienen te worden. Daar waar wel implementatie (van rechtstreeks werkende richtlijnen) heeft plaats gevonden is dit het geval. Daar impliceert, aldus de uitspraak van het Hof van Justitie in de zaak FratelliConstanzo, het supranationale EG-recht dat de decentrale overheden zelf (los van de Lid-Staat) de voorrang van het rechtstreeks werkende Gemeenschapsrecht dienen te verzekeren en daarmee strijdig nationaal recht buiten toepassing moeten laten. ${ }^{8: 4}$ In het licht wan de geest van de genoemde richtlijnbepalingen, dient er in bepaalde situaties samengewerkt te worden. Dit kan begunstigend werken voor burgers. ${ }^{85}$ Vooral de

82. HWEG, Ryborg, zaak C-297189, Jur. 1991, p. $1-1976$.

83. Wgl. College van Beroep voor het Bedrijfsleven, 13-11-1992, no, 91/2548/060/029. In deze uiltspratk werd wan de Nederlandse overhed, weliswar in het kader van artike $30 / 36$ EEG-verdrag, verlangd (in het kader van een af te geven besluit aan een burger) bepalde technische informatie in te winnen bij buitenlandse (in casu Franse) autoriteiten.

84. HvJEG, Fratelli Constanzo, zaak 103/88, Jur. 1989, p. 1870 en 1871. Zie ook: J.A. Winter, a, w, p. 56; K. Sevinga, WK Voetbal 1990, EG-recht en Jokkal bestuur, Publiek Domein, 1990, p. 198.

85. Hier word niet nader ingegaan op de problematiek, dat bij nietimplementatie van de richtlijnen deze in beginsel slechts in de relatie burger jegens de overheid (en niet andersom) ingeroepen kunten worden (Hv) Kolpinghuis, zaak 60/86, Jur. 1987, p. $3696 \mathrm{e}$. .) en in de relatie burger-burger in beginsel helemaal net gelden (HWEG, Marshall, zaak 152/84, Jur, 1986, p. 745 e.v.). Zie in deze: H.J. Papier, Direkte Wirkung won Richthiniender EG im Unwelt- Lnd Technikrecht, Verwaltangsverhahrensrechthiche Probleme des mationalen Vollzuges, DVBt. $1993 / 15$, p. 810 e.\%. 
owerleg-en informatieplicht kan zonder meer door deze decentrale overheden in bet kader van hun sectorbevoegdheden feitelijk uitgevoerd worden. Daar waar deze sectorbevoegdheden afwezig zijn en voor de harmonisatie van toezichtsprocedures, waarvoor wijziging van wetgeving aan de orde zal zijn, is dit anders. Er bestaan dan geen bevoegdheden voor de decentrale overheden. Het lijkt mij niet onmogelijk, dat als de rechtstreekse werking van de overleg- en informatieverplichtingen wordt aangenomen, de jurisprudentie in de zaak Frateli Constanzo doorgetrokken zou kunnen worden naar situaties waarin geen implementatie heeft plaats gevonden. Dit zou dan betekenen dat de decentrale overheden, hoewel niet expliciet genoemd in de richtlijnen, deze op het punt van overleg en informatie dienen toe te passen. Hieraan doen mijns inziens niet af de gevallen, waar wel geimplementeerd is en de centrale overheid in plaats van de decentrale overheden bevoegd is verklaard. Zoals aangegeven staat hier veel meer het EG-perspectief woorop en is niet, behalve voor de richtlijn inzake milieu-effectbeoordeling, in extenso nagegaan of en in hoeverre, daar waar de samenwerkingsbepalingen geimplementeerd zijn, centrale dan wel decentrale overheden tot samenwerking bevoegd zijn. 86

"Tot slot kan hier ten aanzien van eventuele gerechtelijke actiemogelijkheden van decentrale overheden om grensoverschrijdende samenwerking te bewerkstelligen, zoals in de desbetreffende richtlijnen voorzien, het volgende opgemerkt worden. De decentrale owerheden kumen in beginsel niet zelf in deze een procedure voor het Hof van Justitie starten (artikel 173 EEG-Verdrag), indien de (decentrale) overheden aan de andere kant van de grens niet in overleg willen treden c.q. geen informatie wensen te verschaffen. Indien zij actie wensen te ondernemen - dit kan pas nadat de termijn voor implementatie is verstreken -, dienen zij de samenwerking via de nationale rechter (van de andere staat) af te dwingen. Dit geldt ook voor burgers die in conflict raken met hun (buitenlandse) decentrale overheden. Het moet dan wel om rechtstreeks werkende normen gaan. De ene Lid-Staat kan een procedure aanhangig maken bij thet Hof van Justitie jegens de andere Lid-Stalat (ant. 170 EEG-verdrag). Maar dat gebeurt niet vaak. Dit zou bijvoorbeeld het geval kunnen zijn, indien de andere Lid-Staat weigert (een regeling inzake verplicht) overleg te voeren. Daarnaast blijft uiteraard de mogelijkheid bestaan, dat de Commissie (wegens niet nakoming van Gemeenschapsverplichtingen op basis van de richtlijn) een procedure aanhangig maakt bij het Hof tegen de betreffende Lid-Staat. Slechts de LidStaten en niet de decentrale overheden kunnen gemeenschapsrechtelijk gezien aansprakelijk gesteld worden door de Commissie (artikel 169 EEG-Verdrag).

Daar waar burgers (of clecentrale overheden zelf) bij de nationale rechter terecht komen, kan/dient de nationale rechter het Hof van Justitie bij zijn oordeel te betrekken (artikel $177 \mathrm{EEG}$-Verdrag). Overigens is het aan de nationale rechter om op basis van zijn beoordelings wrijheid het ter uitvoering van de richtlijn vastgestelde nationale recht in overeenstemming met de eisen van gemeenschapsrecht uit te leggen en toe te passen. Het

86. Zie b.v.: G. Bennet, J.H. Jans, De gevolgen van Europese eemording voor het milieubeleid wan lagers publiekrechelijke organisaties, in: N.F. Roest et al. a. w., p. 274 e.v.

Hier wordt ook niet nder ingegaan op de problematiek van mogelik verdergande regelingen op nationat niveau in het licht van artikel 100A lid 4 dan wel artikel $130 \mathrm{~T}$ EEG-Verdrag. 
gaat hier om de zogenaamde richtlijnconforme interpretatie. ${ }^{87}$ Daar waar het nationale recht geheel ontbreekt wordt dit uiteraard moeilijk.

\section{Decentrale grensoverschrijdende samenwerking inzake milieu-effectrapportage}

\section{a. De richtlijn inzake milieu-effectbeoordeling}

Met name de milieu-effectrapportage (in grensgebieden) vormt een goede illustratie van de positie van (decentrale) overheden als het gaat om samenwerking over de grenzen. Artikel 7 van de richtlijn betreffende de milieu-effectbeoordeling van bepaalde openbare en particuliere projecten (hierna: Mer-richtlijn ${ }^{88}$ ) bevat de volgende samenwerkingsbepaling:

"Wanneer een Lid-Staall constateert dat een project aanzienlijke effecten kan hebben op het milleu in een andere Lid-Siat, of wanneer een Lid-Stat die aanzierlijke effecten zou kunnen onderwinden hieron verzoekt, doet de Lid-Stat op welks grondgebied het project word woorgesteld, de krachtens artikel 5 verzamelde informatie aan de andere Lid-Staat toekonmen op helzelfle moment als hij deze informatie ter beschikking stelt an zijn eigen onderdanen. Deze informate dient als grondslag voor het in het kader wan de bilaterale betrekkingen wan beide Lid-Staten eventweel noodzakeljik overleg op basis van wederkerigheid en op voet van gelijkwaardig* 期e id.

Deze bepaling is vooral in de Duitse literatuur uitvoerig beschreven, b.v. ten aanzien van de precieze reikwijdte van de informatie en consultatie, waarop beide aspecten betrekking moeten c.q. kunnen hebben, e.d. ${ }^{89}$ Hier gaat het slechts om de mogelijke rol van decentrale overheden aan te geven.

Artikel 7 van de Mer-richtlijn noent decentrale overheden niet als zodanig. Hieruit zou geconcludeerd kumnen worden, dat de decentrale overheden niet gerechtigd zijn bedoelde samenwerking in de praktijk, daar waar zij bevoegd gezag zijn, toe te passen: "Wenn anders gewollt gewesen war, hätte dies die Richtlinie sicher geregelt, etwa dahingehend, dass - was denkbar und vielleicht sogar naheliegend gewesen wäre - die zuständige(n) Behörde(n) i.S.d. Art. 1 Abs. 3 der Richtlinie als auch für die Konsultationen zuständig erklärt werden, wie dies in Art. 7 S. 2 des Richtlinienvorschlages noch vorgesehen war." " 90 Hoewel in het licht van de redactie artikel 7 Mer-richtlijn verplichte samenwerking tussen staten beoogt, is aen rol van decentrale overheden ten aanzien van de hierin genoemde grensoverschrijdende samenwerking niet uitgesloten. Voor het geval artikel 7 Mer-richtlijn niet geümplementeerd is in het nationale recht (en als rechtstreekswerkend kan worden beschouwd), kan volstaan worden met een verwijzing naar het gestelde in dit verband \$ 3.D. 1 van dit hoofdstuk. Daar waar deze richtlijnbepaling wel geïmplementeerd is, is nader onderzoek noodzakelijk voor de vaststelling van de rol in deze voor decentrale overheden.

87. Zie b. . HvJEG, Von Colson en Kamann, zaak 14/83, Jur. 1984, p. 1909, r.o 28 alsmede HvJEG, Marleasing, zalak C-106/89, Jur. 1990, p. 4135 e.v., r.o. 13 .

88. Richtiin van de Raad van 27-6-1985, 85/337/EEG, PB nu. L 175 van 5-7-1985, p. 40.

89. Zle b.v: A. Randelzhofer, R. Harndt, Grenziberschreitende Zusammenarbeit bei der Umweltwerträglichkeitsprüfung, Berichte 2/89 Unwelt Bundes Amt, 1989; A. Weber, Die Unweltverträglichkeitsrichtlinie im deutschen Recht, Osnabrücker Rechtswissenschaftichen Abhandlung, Band 14, 1989, p. 233-251.

90. A. Randelzhofer, R. Harndt, a.w., p. 102. 


\section{b. Nationale uitwoeringswetgeving}

Artikel 7 Mer-richtlijn vereist, zeker wat de consultatie betreft een nadere uitwerking. Het zijn de Lid-stater, die de in artikel 7 Mer-richtlijn genoemde samenwerking dienen te regelen. Dit kan door (eenzijdige) wetgeving dan wel volkenrechtelijke afspraken. ${ }^{91}$ In dat verband kan aan decentrale overheden een rol toebedeeld worden. ${ }^{92}$ In het navolgende wordt bekeken in hoeverre artikel 7 Mer-richtlijn nader geregeld is in het Duitse, Belgische en Nederlandse recht, en zo ja, of decentrale overheden in deze een rol van betekenis spelen of niet.

In Duitsland is de Mer-richtlijn geïmplementeerd in het Umweltverträglichkeitsprüfungsgesetz (hierna: UVPG) en de verplichting tot grensoverschrijdende samenwerking ex artikel 7 Mer-richtlijn is opgenomen in $\$ 8$ van deze wet. ${ }^{93} \& 8 \mathrm{UVPG}$, voorzover van belang, luidt:"(1) Wenn ein Vorhaben erhebliche Auswirkungen auf die in $\$ 2$ Abs. 1 Satz 2 genannten Schutzüter in einem anderen Mitgliedstatat der Europaischen Gemeinschaften haben könnte, so werden die von dem Mitgliedstaat benannen Behöden zum gleichen Zeitpunkt und im gleichen Unfang uber das Vorthaben wie die nach 87 beteiligten Behörden unterrichtet. Wenn der andere Mitgliedstaat die zu beteiligenden Behörden nicht benannt hat, ist die oberste für Umweltangelegenheiten zuständige Behörde des anderen Mitgliedstads zu thrterrichen.

(2) $(=\ldots)$

(3) Konsultationen, die auf grund der Unterrichoung nach Absatz I mit den Behördendes anderen Mitgliedstatats oder nach A bsazz 2 mit den Behörden des Nachbarstaats er folgen, sind nach den Grundsätzen von Gegensejitgkeit und Gleichwertigkeit durchzufubren. Der Grundstaz der Gleichwertigkeit gill für die Verfaliren und Bewertungsmasstäbe, die in der Bundesrepublik Deutschland und dem anderen Mitgliedstaat oder in dem Nachbarstaat angewand werden..

(4) Völkerrechtliche Verpflichtungen von Bund und Ländern bleiben unberuhrt."

Ten aanzien van de informatieplicht is aangegeven dat bepaalde buitenlandse overheden geïnformeerd dienen te worden. Voor de omgekeerde situatie is niet aangegeven aan welke Duitse overheden de informatie verstrekt moet worden. ${ }^{94}$ De overlegregeling vereist mijns inziens nog additionele regeling, b.v. ten aanzien van de precieze uitwoe-

91. Vgl. A. Weltet, a.w., p. 237 e.4.; A. Randelzhofer, R. Harndt, a.w., 0.a. p. 133.

92. Voor een praktijkwoorbeeld van een vergaande Duits-Nederlandse (procedurele) afstemming van een Mer. procedure op decentraal niveau "zie het adviex: Tonnder, Hertoghs en Seerden, Grensoverschrijdend bedrijventerrein Heerlen en Aken, Een onderzoek naar de juridische afstemmingsmogelijkheden vam milieu-en ruimtelijke procedures, juni 1993. Ook in het kader wan de milieu-effectrapportage inzake de bruinkoolwinning wlak ower de Limburgse grens vindt coördinatie met Dutsland plats in het lich van artikel 7 Mer-richtijn (openbare bekendrnaking d.d. 23-3-1993 Regierungspräsident Köln, doss. nr. 64.2-2.3. (Garzweiler II)).

93. BGBI. 20-2-1990. Het betreft hier een Bondswet. Voor mer-plichtige activiteiten op basis van Landesrecht is deze Bondwet in teginsel van toepassing verklaard door de Lander. Voor b.v. Noordrign-West fatlen: Gesetz über die Unweltwerträglichkeitsprüfung in Lande Nordrhein-Westfalen.

94. In di verband kan verwezen worden maar de Runderlass wan het Noordrijn-Westfalse Ministeriurn fur Unwelt, Raumordnung und Landwirtschaft van 3-7-1991 (VI A 5-70.024, Ministerialblat für das Land Nord rhein West fallen, nr. 54 van 31-7-1991). In het kader van de "grenzüberschreitendeBehördenbeteiligung fur UVP-pflichtige Vorhaben' wordt 0.a. aangegeven dat voor Mer-plichtige activiteiten die bimen 5 kiloneter van de Belgische en Nederlandse grens gerealiseerd worden en aanzienlijke gewolgen woor het milieu kunnen hebben, de Nederlandse en Belgische overheden (Behörden) dezelfe informatie moet worden toegezonden als de Duitse overheden (Träger öffentlicher Belange). Hetzelde geldt wanneer Mer-plichtige activiteiten meer dan 5 kilometer vanaf de grens gerealiseerd worden en aanzientijke gevolgen kunnen hebben in Nederland en Belgiè. Als de Duitse en Nederlandse overheden er gemotiveerd om wragen dienen deze sowiezo op de hoogte te worden gesteld. 
ring e.d. In deze wordt tevens verwezen naar het gestelde met betrekking tot de Nederlandse implementatie van artikel 7 Mer-richtlijn.

In Belgie is zowel in Wallonie als in Vlaanderen de Mer-richtlijn nader uitgewerkt. ${ }^{9.5}$ In Vlaanderen is de samenwerkingsbepaling ex artikel 7 Mer-richtlin nog niet in de wetgeving geimplementeerd. Er wordt op dit moment een wijziging in Vlaanderen van de regeling inzake milieu-effectrapportage voorbereid. Hierin is de samenwerkingsbepaIing wel uitgewerkt. Een van de voorgenomen bepalingen omtrent mer-plichtige projecten, mamelijk artikel 23 , woor zover wan belang, luidt:" \$ 4 . Wanneer het project waarsehijnlijk betekeniswolle effecten kan hebben op het milieu in andere Lidstaten wan de Europese Gemeenschap en/of in Verdragspartijen bij bet Verdrag van Espoo van 25 februari $1991 \mathrm{en} / \mathrm{of}$ in andere Gewesten of wanneer de bewoggde zutoriteiten wan deze Lidstaten, Verdragspartijen en/of Gewesten daurom verzoeken, wordt de kennisgeving tevens owergemaakt aan de autoriteiten wan de betrokken Lidstaten, Verdragspartijen en/of Gewesten, en dit ten laatste op het tijdstip watrop de kennisgeving wordt overgemaakt gan de in $\$ 1$ bedoelde instanties. organisaties en personen.

In dit geval wordt bij de kennisgewing gevoegd:

1. een beschrijwing van de op het voorgenomen project van toepassing zijnde milieu-effectrapportageprocedure, met in het bijzonder een vermelding wan de termijn wam 60 dagen bedoeld in artikel 24,82 , alsmede andere relevante informatie terzake;

2. een aasduiding van de vergunningsplicht of de administratieve rechtshandeling waaraan het voorgenomen project is onderworpen en een beschrijving van het doel van deze vergumingsplicht of rechtshandeling en wan de van toepassing zijnde besluitwormingsprocedure."

Voor Wallonie is artikel 7 Mer-richtlijn al geimplementeerd in geldend recht. Artikel 39 van het besluit ter uitwoering van het Mer-decreet ${ }^{97}$ bepaalt: "Wanneer de bevoegde overlweid oordeelt dat het project anzienlijke effecten kan hebben op het leefmilieu van een naburige Lidstaat van

95. Voor Vlaanderen is de wettelijke grondslag inzake de milieu-effectrapportage gelegen in artikel 7 Vhams milieuvergunningendecreet. Inhoud, procedure e.d. zijn in diverse besluiten van de Vlaanase Executieve nader geregeld. Zie hierwoor: R.J.G.H. Seerden, M.W.J.A. Hertoghs, a.w., 5.2.3. Voor Wallonie is de wettelijke grondslag gelegen in het Decreet houdende organisatie van de milieu-effectbeoordeling in het Waalse Gewest (M.B. 24-1-1986). Dit decreet is unigewerkt in een besluit van de Waalse Gewestexecutjeve (M.B. 22-11-1991). Zie hiervoor: R.J.G.H. Seerden, M.W.J.A. Hertoghs, a.W., 5.3.3.

Als het gat om bevoegdheden inzake het milieu, is de federale overheid in Belgine eigenlijk alleen nog op het vlak van nucleaire angelegenheden bewoegd. Er is in België op dat punt nog geen federate wet, die de Mer-riclilijn titwerkt.

96. Zie: Voorontwerp van Kaderdecreet Milieuhygiëne, Volume 1993-1, Interuniversitaire Connmissive tot berziening wan het milieurecht, Colloquim 17-5-1993, H. Bocken, P. De Lembre, C. Lambert (Editors); p. 117 e.w. Het aangehaalde artikel 23 wordt 0.4 . uitgewerkt in de artikelen $23 \$ 4,27 \$ 2,31 \$ 3$ en $35 \% 1$.

Artikell 16 bevat een regeling, wamneer het gaat om beleidswoornemens, plannen of programma"s. Het luidt: "\$1. Wanneer een beleidsvoornemen, plan of programma warschijnlijk betekenisvolle milieueffecten kan hebben op bet milieu in andere Lidstaten van de Europese Gemeenschap, in andere Verdragspartijen bij het Verdrag van Espoo van 25-2-1991 en/of jin andere Gewesten of wamneer de bevoegde autoriteiten van deze Lidsaten, Verdragspartijemen/of Gewesten daarom verzoeken, wordt het millietueffectrapport owergemakt aath woormelde autoriteiten van zodrat het definitief is geworden. De Vlaanse Executieve stelt nadere regels vast betreffende de wijze waarop de autoriteiten wan deze Lidstaten, Verdragspartijen en/of Gewesten hun commentaar op het milieu-effectrapport en de actie kumen meedelen. en betreffende de wijze waarop hierover overleg wordt gepleegd.

\$2. In gevallen bedoeld in \& 1 wordt het vastgestelde beleidsvoornemen, plan of programma samen met de in artikel $3 \$ 3$ bedoelde motivering overgemaakt aan de bevoegde autoriteiten, Verdragspartijen enof Gewesten."

97. Zie noot 95 van dit boofdstuk. 
de Europese Gemeenschappen, wan een naburig gewest, provincie of gemeente, stuurt ze het dossier al naar gelang van het gevall nasr de owerheid die bevoegd is om de buitenlandse Stat daarvan op de hoogte te brengen, naar de woorzitter van de betrokken Executieve of naar woonoemde prowincies of gemeenten.Hetzelffe geldt wanneer étn van de overheden dit dossier viaagt."

Ik wil hier volstaan met het volgende. ${ }^{98}$ Zowel voor Vlaanderen als Wallonié is niet voorzien in het aangeven van de overheden, indien een dergelijke activiteit in het buitenland wordt ondernomen. Als de activiteit in Vlaanderen wordt ondernomen, is niet aangegeven welke overheid zich tot de buitenlandse overheid kan richten. Voor Wallonië lijkt in deze op basis wan de zinsnede 'de overheid die bevoegd is om de buitenlandse Staat daarvan op de hoogte te brengen' sprake van een centralisering. Voor de overlegverplichtingen geldt zowel in Wallonië als Vlaanderen, dat een nadere uitwerking op zijn plaats is. Over een mogelijke rol daarin voor de decentrale overheden is op dit moment niets bekend.

In Nederland is de regeling inzake milieu-effectrapportage opgenomen in de Wet milieubeheer. Daarbij is in eerste instantie niets geregeld woor informatie-uitwisseling en consultatie. Op dit moment wordt de Nederlandse Mer-wetgeving gewijzigd o.a. in het licht van artikel $7 \mathrm{Mer}-$ richtlijn. Speciaal voor activiteiten met mogelijke grensoverschrijdende millieugevolgen worden de artikelen $7.38 \mathrm{at} / \mathrm{m} 7.38 \mathrm{~g}$ in de Wet milieubeheer (hierna: Wm) opgenomen. ${ }^{99}$ Op de belangrijkste bepalingen wordt hier ingegaan. Artikel 7.38 a Wm luidt:" 1 . Indien een activiteit bij de voorbereiding waarvan een milieuneffectrapportage moet worden gemaakt, belangrijke madelige gevolgen kan hebben voor het milieu in een ander land wordt de in bei kader van dit hoofdstuk verzamelde informatie aln de regering of een door die regering aan te wijzen autoriteit in het andere land verstrekt op hetzelfide tijdstip als deze in Nederland bekend words gemaakt.

2. De informatie dient als grondslag woor het in het kader van de bitaterale betrekkingen eventueel noodzakelijke overleg.

3. Onze Minister is belast met de taken voortwloeiend uit de toepassing van het eerste en tweede lid."

Artikel $7.38 \mathrm{c}$ Wm verplicht het bevoegde gezag een exemplaar van de mededeling (ex artikel $7.12 \mathrm{Wm}$ ), een exemplaar van de richtlijnen (ex artikel $7.15 \mathrm{Wm}$ ) en een exemplaar van het milieu-effectrapport (ex artikel $7.20 \mathrm{Wm}$ ) naar de Minister te zenden met daarbij het verzoek toepassing te geven aan artikel $7.38 \mathrm{a} \mathrm{Wm}$. Artikel 7.38d Wm maak het mogelijk, dat artikel $7.38 \mathrm{a}$ Wm ook wordt toegepast als een ander land mogelijke belangrijke nadelige gevolgen verwacht van een in Nederland Mer-plichtige activiteit en om de toepassing verzoekt. Artikel $7.38 \mathrm{~g} \mathrm{Wm}$ voegt daar wat betreft het overleg het volgende aan toe:" 1 . Indieneen voorgenomen activiteit in een ander land mogelijke nadelige gevolgen voor het milieu in Nederland kan hebben, draagt Onze Minister zorg woor het onderhouden van de contacten met dat land." "

98. Ik wil woor een nadere bespreking verwijzen naw een over enige tijd nog te verschijnen artikel ower de milieu-effectrapportage in grensoverschrijdend en rechsivergelijkend perspectief door M. Hertoghs en R. Seerden.

99. Gewijzigd voorstel van wet, Wet tot wijziging van de regeling van de millieu-effectrapportage in de Wet milleubeheer, Tweede Kamer, vergaderjaar 1992-1993, 22608, mor. 8, p. 6-7.

100. Hier kan gewezen worden op her wolgende. In de bilaterale samenwerking cussen Nederland en Duitsland zijn een tweetal modellen ontworpen voor de uitvoering van Mer-plichtige activiteiten met gevolgen in het buitenland. Deze modellen dienen o.a. voor het aangeven van de verantwoordelijke autoriteiten voor het nemen wan procedurestappen. In het ene model ligt de verantwoordelijkheid geheel bij het bevoegde gezag in het land wat de activiteit platswindt. In het andere model verzorgt de autoriteit wan het (wordt vervolgd...) 
Het bovenstaande geeft aan dat de voorgenomen regeling in een centralisering van de informatieverstrekking en het overleg voorziet, namelijk bij 'Onze Minister' (Minister van volkshuis vesting, ruimtelijke ordening en milieubeheer). Mijns inziens is die centralisering niet per se noodzakelijk in het licht van de richtlijn. ${ }^{101}$ Hoewel artikel 7 Merrichtlijn de Lid-staten als zodanig noemt, is niet in te zien waarom, bij een nadere uitwerking door de Lid-staten van die bepaling in de nationale wetgeving, decentrale overheden niet bevoegd kunnen zijn in deze. Ik zie geen verschil met andere richtijnen die door decentrale overheden uitgevoerd (dienen te) worden. In dat perspectief acht ik de voorgenomen centralisering van informatieverstrekking en overleg, daar waar de decentrale overheden bevoegd gezag zijn (en dus wel de overige verplichtingen van de Mer-richtlijn dienen uit te voeren) ver gaand en helemaal niet passend binnen de decentralisering van overheidsbevoegdheden. Het bestuurlijk toezicht zou mijns inziens voldoende mogelijkheden kumnen bieden voor een richtlijn-conform handelen van decentrale overheden. In dat perspectief zou een meer ondersteunende rol van de centrale overheid voldoende zijn. Zijn de decentrale overheden niet de formele consultatie-instantie, in de praktijk zullen zij als het bevoegde gezag toch steeds inhoudelijk erbij betrokken dienen te zijn met name bij het overleg. Juist de decentrale samenwerkingsstructuren, zoals die zich beginnen te ontwikkelen ( $\mathrm{vgl}$. hoofdstukken 5 en 6 ) zouden in de praktijk een goede plaats kunnen bieden voor dergelijk overleg. ${ }^{102}$

In het kader van de grensoverschrijdende millieu-effectrapportage dient tevens gewezen te worden op het Verdrag inzake milieu-effectrapportage in grensoverschrijdend verband (hierna: Espoo-verdrag), hetgeen thans in diverse landen ter goedkeuring ligt. ${ }^{103} \mathrm{Het}$ Espoo-verdrag, dat ondertekend is door België, Nederland, Duitsland alsmede de EG,

\section{0. (...vervolg)}

butenland o.a. de inspraak e.d. Welk model gehanteerd zal worden is nog niet helemaal uitgekristalliseerd. Zie: MvA, Wet tol wijziging wan de regeling van de milieu-ffectrapportage in de Wet milieubeheer, a.w. nr. 6, p. 24; Nota naar aanleiding wan het eindwerslag, Wet tot wijziging van de regeling wan de milieu-ffectrapportage in de Wet milieubeheer, a.w., nr. 11, p. 18.

101. Wolgens de regering is dat wel het geval:" "Artikel 7 vall de richtijin creesert verplichtingen voor de lid. staten. Er dient derhalve (cursiwering RS) een instantie op rijksniveat te worden belast met taken woortvoenend uit toepassing var artikel 7 van de richtijn.", Mv"T, Wet wo wijzigirg van de regeling van do milewetectrapportage in de Wet agemene bepalingen milieuhygëne, Tweede Kamer, wergaderjaar $1991-1992,22608$, ar. 3, p. 12.

102. Het is de vadg of de regering deze decentrale sememwerkingsistruchuren voor ogen heeft dan wel de mer intergouvernementele overfegstructuren (vgl. voor deze latste hoofdstuk 5 sub 6 en hoofdstuk 6 sub 5), daar war zij stelt: "Dit laat echter onverlet dat de informatie-uitwisseling en consultatie zoveel mogelijk door midel van bestadade internationale overlegstruchuren in de grensregio's kunnen verlopen. In de praktigk zal dit betekenen dat alleen in gevallen warin dit niet op bevredigende wijze verloopt de mogelijkhid van een consul tatie op regeringsniveau gebruikt wordt gemak wan de regeling wan de milieu-ffectrapportage in de Wet algemene bepalingen milieuhygiène, a.w.; p. 23 .

Zle ook: MvA, Wet bo Wigziging wan de regeling wan de milieu-effectrapportage in de Wet milieubeheor, a. W. "p. 28; "Wel is de Minister wan Volkshuisvesting, Ruimtelijke Ordening en Milieubeheer belast met het onderthouden wan de formelle contacten met de regeringen wan de betrokken landen. De facto zal de grensoverschrijdende informatie-uitwisseling en het overleg weelal platatsinden op het niveau van regionale autoriteiten."

103. Espoo, 25-2-1991, Verdrag inzake miliev-effectrapportagein grensowerschrijdend verband, met Adinlangsels, Trb. 1991 nits. 104 en 174 
regelt meer dan de Mer-richtijn op het punt van de grensoverschrijdende samenwerking tussen overheden, b.v. ten aanzien van het tijdstip van informatie en overleg. Daarnaast is het Espoo-verdrag vooral van belang voor de participatie van burgers in grensoverschrijdende Mer-procedures. Bovendien wordt iets geregeld voor de evaluatie van de daadwerkelijk optredende gevolgen. ${ }^{104}$ Het Espoo-verdrag concentreert informatieverstrekking en overleg tussen overheden op het niveau van de verdragspartijen. Omdat de genoemde artikelen $7.38 \mathrm{at} / \mathrm{m} \mathrm{g} \mathrm{Wm}$ in feite ook ter implementatie strekken van het Espoo-verdrag, wordt hierop niet nader ingegaan. ${ }^{105}$

Hier past nog een slotopmerking. De Europese Commissie heeft o.a. Nederland in gebreke gesteld wegens het niet implementeren van artikel $7 \mathrm{Mer}$-richtlijn. Een aantal van de door mij genoemde richtlijnen inzake grensoverschrijdende samenwerking bevat vergelijkbare informatie- en owerlegbepalingen als artikel 7 Mer-richtlijn. Daar waar geen implementatie van deze bepalingen heeft plaatsgevonden, zal dat (in het licht van die ingebrekestelling) alsnog dienen te gebeuren.

\section{E. ALGEMENE EUROPESE REGELGEVING INZAKE DECENTRALE GRENSOVERSCHRUDENDE SAMENWERKING?}

Het is de vraag of er in EG-verband op een bepaald moment een EG-richtlijn of EGverordening zal komen, die de decentrale grensoverschrijdende samenwerking in meer algemene zin en verdergaand regelt dan de thans bestaande grensoverschrijdende samenwerking in diverse EG-(milieu)richtlijnen. Die algemene regeling zou in ieder geval de bevoegdheid voor decentrale overheden tot het maken van en de modaliteiten van publiekrechtelijke afspraken over de grens kunnen inhouden. ${ }^{106}$ Het voordeel van een verordening is, dat deze rechtstreeks toepasselijk is in de Lid-Staten (artikel 189 lid 2 EEG-Verdrag). Een richtlijn is verbindend ten aanzien van het resultaat, doch de vorm en middelen zijn ter keuze aan de Lid-Staat (artikel 189 lid 3 EEG-Verdrag). Door het geheel maar over te laten aan de Lid-Staten (geen regeling op EG-niveau) is het bijna vanzelfsprekend dat verschillen in deze optreden. In de hoofdstukken 5 en 6 is o.a. aangegeven dat de Nederlands-Belgische decentrale samenwerking afwijkt van de Nederlancls-Duitse. Omdat er tot op heden geen algemene regeling op EG-niveau tot stand is

104. Toelichtende Nota bij het Verdrag inzake milieu-effectrapportage in grensoverschrijdend verband, met Aanluangsels, Espoo, 25-2-1991, Staten-Generaal, vergaderjaar 1992-1993, 22883 (R 1453), nrs. 44 en 1 , p. 3. Zie voor de precieze werschillen tussen Mer-richtlijn en Espoo-verdrag tevens: MvA, Verdrag inzake nilleu-effectrapportage in grensoverschrijdend verband, met Aanhangels Espoo, 25-2-1991, Tweede Kamer, vergaderjaar 1992-1993 (R. 1453), nr. 8, p. 1-2.

105. MVA, Wet tot wigziging van de milieu-effectrapportage in de Wet milieubeheer, a.w., p. 22.

Hier is het interessant ie wijzen op de mogelijheid, die het Espoo-Verdrag (art. 3 lid 6, art. 4 lid 2 en art. 5 sub c) kent on informatieverstrekking, te laten verlopen wia tussenkomst wan een gezansenij $k$ lichaam.

106. Vgl. A.W.H. Meij en C.W.A. Timmermans, a.W., p. 9. Zij wijzen eveneens op de mogelijkheid en wenselijkheid wan een afzonderlijke richdijn, watrin woorzien wordt in een soort van permanente juridi. sche structuur voor grensoverschrijdende contacten tussen decentrale overbeden (in het licht van hun sectorbewaegdheden). Een dergeligke richthijn zot kunnen voorzien in de instelling van regionale commissies bestande uit overheden aan weerszijden van de grens. Zij, geven bovendien aan dat, als dergelijke commissies niet over operationale of regulerende bevogdheden beschikken, minder/geen bezwaren van constitutionele aard van de Lid-staten te duchten zijn. 
gekomen, is het de vraag of dit in de nabije toekomt anders zal zijn. Wellicht willen de Lid-Staten niet zover gaan om binnen de Raad een uniforme EG-regeling te bewerkstelligen, die vergaande vormen van decentrale samenwerking toestaat. Het gaat immers om een aangelegenheid die nauw verbonden is met de interne staatsstructuur en waaraan, bij de vergaande samenwerkingsvormen die hier in het geding zijn, soevereiniteitsaspecten verbonden kunnen zijn. Het subsidiariteitsbeginsel (artikel 3B, titel I van het Verdrag van Maastricht) pleit er - zeker nu een aantal Lid-Staten een aanvang maken met het regelen van de aangelegenheid - eveneens voor de aangelegenheid op het niveau van de Lid-staten te laten. 107

In het licht van het vorenstaande is het aannemelijk dat als er al een algemene EGregeling inzake decentrale samenwerking zou komen eerder het instrument van de richtlijn dan van de verordening gekozen zal worden. Zonder direct voor een EG-richtlijn in deze te willen pleiten, heeft een dergelijke regeling, vanuit het oogpunt van de samenwerking, voordelen ten opzichte van het belangrijkste alternatief, namelijk een regeling middels verdragen. Het regelen van de samenwerking wordt door de richtlijn verplicht, terwijl het sluiten van verdragen vrij is. Het voordeel van éen richtlijn is ook dat er een uniformering in alle Lid-staten van b.v. samenwerkingsvormen kan plaatsvinden. Bij het sluiten van verdragen kunnen belangrijke verschillen ontstaan. Hierop is al gewezen. ${ }^{108}$ Mijns inziens dient ook bij een algemene EG-richtlijn uitgangspunt te zijn dat de samenwerking niet verplicht is. Een zekere mate van vrijblijvendheid en stimulering verdient in beginsel de voorkeur boven verplichte samenwerking. Het is mijns inziens noodzakelijk, dat de decentrale overheden zelf (en liefst met voorafgaande instemming van de bevolking) uitmaken of zij tot (ver gaande) decentrale grensoverschrijdende samenwerking overgaan of niet. Een op te stellen Europese richtlijn dient dan ook niet het karakter te hebben van het van bovenaf opleggen van de samenwerking. Deze zou in de eerste plaats bevoegdheden dienen te scheppen tot en het juridisch kader moeten aangeven voor het vrijwillig maken van grensoverschrijdende publiekrechtelijke afspraken door decemtrale overheden.

107. Ten aanzien wan het milieu kan in dit verband gewezen worden op artikel $130 \mathrm{R}$ lid 4 EEG-Verdrag. Dit bepaalt, voor zover hier van belang: "Op milheugebied treedt de Gemeenschap op wanneer de in lid. 1 vermelde doelstellingen beter op het niveau van de Gemeenschap dan op dat van de Lid-Staten afzon-

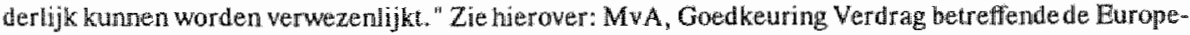
se Unie, a.w., p. 96.

108. Overigens zal, naarmate het proces van. Europese integratie en daarmee de harmonisering varn het materiële recht (eenmaking wan het recht) voortgaat, sowieso die (inhoudelijke) samerwerking wergemakkelijkt worden. 


\section{De Economische Commissie voor Europa van de Verenigde Naties (ECE) en de Organisatie voor Economische Samenwerking en Ontwikkeling (OESO) ${ }^{109}$}

Binnen de ECE is in met name de laatste tien jaar een aantal (ontwerp)-verdragen opgesteld op het terrein van de grensoverschrijdende milieuverontreiniging, die bepalingen omtrent grensoverschrijdende samenwerking bevatten. Van recente datum zijn de Draft Code of Conduct on Accidental Pollution of Transboundary Inland Waters, de Conventtion on the Protection and Use of Transboundary Watercourses and International Lakes en de Convention on the Transboundary Effects of Industrial Accidents. De twee laatstgenoemde verdragen liggen ter goedkeuring voor in diverse staten. Het eerst-genoemde verdrag bevindt zich in het eindstadium van voorbereiding. ${ }^{110}$ In 1991 is binnen de ECE de tekst van de Convention on Environmental Impact Assessment in a Transboundary Context aangenomen en ter ratificatie aan de staten voorgelegd. ${ }^{11}$

In OESO-verband heeft vanaf de jaren zeventig de grensoverschrijdende milieuverontreiniging bijzondere aandacht gekregen. Dit heeft o.a. geleid tot een aantal aanbevelingen in deze van de Raad, samengesteld uit vertegenwoordigers van de deelnemende. landen, waarin b.v. ook grensoverschrijdende informatie- en consultatie aan de orde komen. ${ }^{112}$ Ten aanzien van de (decentrale) grensoverschrijdende samenwerking (op milieugebied) kan hier de Recommendation of the Council for strengthening international

109. - De Economische Commmissie voor Europa is opgericht door de Economische en Sociale Raad (ECoSOC) van de Verenigde Naties op 28-3-1947, resolutie 36 (TV). De ECOSOC is gebaseerd op artikel 61 van het Hand vest van de Verenigde Naties, San Francisco, 26-6-1945, Stb. 1945, F 321, inwerkingtreaing 24-10-1945. Voor wijziging zie: Trb. 1979 nr. 137.

- Verdrag nopens de Organi satie voor Economische Samenwerking en Orwikkeling, met Aanvullende Protocollen en Memorandum, Parijs 14-12-1960, Trb. 1961. nr. 42, inwerkingtreding 13-11-1961, Trb. 1962 nr. 28.

Voor ern uitgebreidere bespreking van de ECE en OESO in deze, zie: M. Kilian, a.w., p. 212-215 respectivelijk p. 114-121.

110. Respectionelijk: ENVWANWP.3/R.1/Rev.1, 23-6-1989; ENVWA/R.54, 28-11.1991; ENVWAR. 54 19-12-1991. Beide latuste genoemde verdragen zijn op 17-3-1992 te Helinki door diverse staten onder tekend. Voor het Verdrag anzake de bescheming en het gebruk van grensowerschrijdende watemopen en internationale meren, net Bijlagen, zie; Trb. 1992 nr 199; Voor het Verdrag inzake de grensowerschrijdende gevolgen wan industriële ongevallem, met Bijlagen, zie: Trb. 1992 nr. 143 ,

111. Espoo, 25-2-1991, Trb. 1991 nr. 104 en m. 174 (nog niet in werking getreden). Voor een beschrigwing van dit Verdrag inzake milieu-ffectrapportage in grensoverschrijdend verband, mat Aanhangsals, wordt verwezen maar 3. D.2.b. wall dit hoofdstuk.

12. B. $\mathrm{V}_{\text {. }}$ Recommand tion du conseil concer rantes principes relatifs à la pollution transfrontière/ Quelques principes relatifis à la pollution transfrontiere, 14-11-1974, C (74) 224, 0. a. opganomen in: Aspect juridi. ques de la pollution transfromtiere, OCDE 1977, p. $11-18$.

- Ook op het punt van de milieu-effectrapportage bestadn er binnen de OESO a anbevelingen b. 6. Analy. sis of the environmertal consequences of significant public and private projects, $14-11-1974, \mathrm{C}(74) 216$. opgenomen in 0.2 OECD and the Enviroment, OECD 1986, p. 28-31.

- In het kader wan de grensoverschrijdende miletverontreiniging bestaan er met name ovk OESO-alanbevelingen betreffende de gelijke rechtstoegang en de non-discriminatie: Aspects juridiques de la pollation transfrontière, a.w., p. 19-33, OECD and the Environment, $O E C D$ 1986, p. 148-153.

- Over de staatsaansprakelijkheid in relatie tot grensoverschrijdende milieuverontreinging zijn in OESO. verband meerdere rapporten geschreven. Behalve naar het reeds genoende Aspects juridiques de la pollution tranfrontęre kan verwezen worden naar: Problems in transfronter pollution, OECD 1974. 
co-operation on environmental protection in frontier regions genoemd worden. ${ }^{113}$ Daarnaast bestaan er rapporten, waarin de (juridische aspecten wan) decentrale grensoverschrijdende samenwerking (op milieugebied) centraal staan, zoals het rapport van Woehrling. ${ }^{14}$

Voordat op de rechtstreekse werking en de doorwerking van internationale verdragen in het nationale recht wordt ingaan, zijn de volgende twee algemene opmerkingen van belang:

1. Als aan OESO-aanbe velingen al een juridische status kan worden toegekend, dan kan deze nog het beste gekwalificeerd worden als soft-law. Een (mogelijke directe) werking à la EG-richtlijnen hebben deze in het geheel niet.

2. In de genoemde ECE-verdragen worden de decentrale overheden meestal niet expliciet genoemd. Er wordt gesproken van werdragsluitende partijen, waarmee staten bedoeld worden. Toch zullen evenals bij de EG-regelgeving vaak de decentrale overheden een belangrijke rol spelen bij de daadwerkelijke uitvoering van de hierin geregeldie verplichtingen/rechten van verdragspartijen ((Lid)-Staten). ${ }^{115}$ Indien er in de verdragen rechtstreeks werkende bepalingen voor komen kan de burger deze in Nederland en België direct en in Duitsland na omzetting van het verdrag in het nationale recht inroepen tegen decentrale overheden. ${ }^{116}$ Ook de decentrale overheden kunnen dan ten opzichte van elkaar deze bepalingen inroepen. Evenals op basis van de in \& 3.D.1. van dit hoofdstuk aangegeven EG-richtijnen gaat de samenwerking veelal niet verder dan overleg-en informatieverplichtingen.

De doorwerking van internationale verdragen verschilt van de doorwerking van het Europese recht. ${ }^{11}$ Voor de Nederlandse situatie is het gestelde in artikel 93 en 94 van de Grondwet van belang. Bepalingen van verdragen en besiuiten van volkenrechtelijke organisaties, die eenieder kunnen verbinden, werken door in de nationale rechtsorde en gaan zelfs voor (strijdig) nationaal recht. In België is er sprake van eenzelfde stelsel. ${ }^{148}$ Duitsland hanteert in plaats van een in hoge mate monistisch een dualistisch stelsel. In Duitsland kunnen internationale verdragen pas gelden nadat deze omgezet

113. 21-9.1978, C (78) 77, o.a. opgenomen in: Enwironmental protection in frontier regions, OECD 1979 , p. 9. 16 .

114. Vgl. noot 2 van hoofustuk 2. Voor een alantal rapporten van deskundigen zie ook: Environmenta! protechion in frontien regions, OECD 1979; Transfontier pollution and the role of States, OECD, 1981.

115. B. in the kader van artikel 17 wan de Conwention on the Transboundary Effects of Industrial Accidents en artikel 9 van de Draft Code of Conduct on Accidental Pollution of Transboundary Inland Waters.

116. Wg nook 74 van dit hoofdsuk. Zods angegeven is dil anders lij die verdragen waxtbij de BO partij zijir.

117. Vgl. ook de woorrang van het Europese boven het nationale recht, zie o.a. de witspraken wan het Hof wan Justitie wan de EG: Costa-Enel, zaak 6/64, Jut. 1964, p. 1218, 1219; Simmental, zatak 106/77, Jur. $1978, \mathrm{p} .643$.

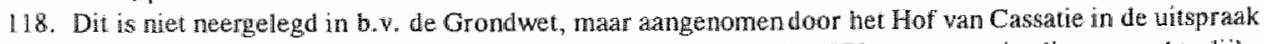
van 27-5-1971. Fromageries Franco Suisse Le Ski, RW 1971-1972 en daarta in diverse rechterlijke uikppaken, ook door b. v. de Ralad wan State bewestigd. Zie b. w. J. Velu, Toetsing van de grondwettigheid en toetsing van de verenigbaarheid met de verdragen, Rechtskundig Weekblad, 1992-1993, nr. 15, p. 481 e. $x$. 
(getransformeerd) zijn in het nationale recht, waarbij latere nationale normstelling het eerder omgezette internationale verdrag kan aantasten. 119

Over het algemeen betreft de rechistreekse werking van verdragen rechten en plichten van burgers. Van rechtstreekse werking van verdragsbepalingen kan mijns inziens ook sprake zijn als het verdrag (slechts) verplichtingen aan staten oplegt. Kooijmans stelt in deze: "Het is duidelijk dat een verdragsregel waarbij twee staten zich verplichien elkaar periodiek te zullen consulteren over het zuiver houden van het milieu, niet zodanig is geformuleerd dat burgers daaraan rechten kunnen ontlenen." "20 Dit standpunt verdieni mijns inziens toch enige nuancering. Men zal op zijn minst moeten letten op de bedoeling van het betreffende verdrag en de verdragspartijen. Immers als een verdrag, zoals dat van de ECE inzake milieu-effectrapportage, staat of valt met het elkaar over en weer informatie verschaffen, dan moet men zich afvragen of hieraan, tenzij blijkt dat verdragspartijen het tegendeel beoogd hebben, niet per definitie rechtstreekse werking toegekend moet worden (als dit nagelaten wordt). Met name ook de decentrale overheden, als de daadwerkelijke uitvoerende overheden, zullen de aan de staat opgelegde verplichtingen tot consultatie e.d. ter hand moeten nemen.

Het is in beginsel de nationale rechter die (van geval tot geval) bepaalt of er sprake is van directe werking van internationaal recht. ${ }^{121}$ Indien zoals de Winter het uitdrukt een bepaling onvoldoende 'handen en voeten' heeft, zal deze hieraan geen rechtstreekse ( $=$ directe) werking (voor de burger en decentrale overheden) toekennen. ${ }^{122}$ Anders gezegd: een bepaling werkt rechtsstreeks als die bepaling zonder meer als objectief recht kan functioneren. ${ }^{123}$

Het is interessant hier op een tweetal uitspraken, overigens niet verband houdend met ECE en OESO te wijzen, wat belang voor Nederlandse decentrale overheden, betreffende de rechtstreekse werking van enkele bepalingen van het Verdrag van Bern. ${ }^{124}$ In het ene geval werd de goedkeuring door Gedeputeerde Staten van Gelderland aan het bestemmingsplan van de Gemeente Arnhem door de Afdeling Geschillen van Bestuur van de Raad van State vernietigd, wegens strijd met artikel 4 (lid 1 en 2) van het Verdrag van Bern (bescherming van het leefmilieu van de kamsalamander). ${ }^{125}$ In het an-

119. Artikel 25 Grundgesetz en stikel 59 (2) Grundgesetz regelen de verhouding van het volkenrecht tot het nationalue recht Artikel 25 Crundgesetz regelt di woor het algemene en gewoonterechtelijke wolkenrecht. Artikel $59(2)$ Giundgesetz regelt dit woor het verdragsrecht. Op basis hiervan hebben verdragen in beginsel dezelfite status als wetten van de Bond. Verwalnungsabkommen, die geen werdragswet wereisen, hebben dezelthe rang als de regelgeving die de interne gelding bepalt. In hoofdstuk 6 sub 4.4 .7 word nder op een aantal bepalingen wan het Grundgesetz un deze ingegaam. Hiernaar wordt werwezen.

120. P.H. Kooijnualus, a.w., p. 84.

121. Zie b.v.: H.G. Schermers, International publiekrecht voor de rechtspraktijk, $1985, \mathrm{p} .155$.

122. R. de Winter. De overheid, 1991 , p. 141. Voor de doorwerking van internationaal recht in Nederliand, zie ook: Van der Pot, Doner, Mandboek van het Nederlandse statisrecht, bewerkt door L. Prakke, 120 druk, 1989 , Het bestuur van de butendandse betrekkingen, p. $536-545$.

123. MR $30.5-1986$, N. 1986, 688 .

124. Verdrag inzake het behoud van wilde dieren en planten en tun naturijik milieu in Europa (Trb. 1979 nf. 175, latstelik Tob. $1991 \mathrm{nr} .101$ )

125. AGRvS 22-4-1991, AB 1991, 592.

Artikel 4 lid 1 en 2 luid:

(wordt vervolgd...) 
dere geval oordeelde de Kroon, dat terecht goedkeuring was onthouden door Gedeputeerde Staten van Noord-Brabant aan het bestemmingsplan van de gemeente Beers wegens strijd met het Verdrag van Bern (bescherming van het leefmilieu van de das. ${ }^{126}$

Resumerend ten aanzien van de ECE en de OESO kan gesteld worden, dat met betrekking tot de decentrale grensoverschrijdende samenwerking en in het bijzonder grensoverschrijdende publiekrechtelijke afspraken tussen decentrale overheden, de betekenis van beide organisaties niet al te groot is.

\section{\$5. Samenvatting en conclusies}

Een algemene regel ing voor decentrale (publiekrechtelijke) grensoverschrijdende samenwerking is tot nu toe alleen bij de Raad van Europa tot stand gekomen, namelijk de European Outline Convention on Transfrontier Co-operation between Territorial Communities or Authorities (EOC). De juridische bindende kracht van de EOC lijkt gering. De BOC spoort de staten eerder aan de decentrale grensoverschrijdende samenwerking te bevorderen, dan dat dit verdrag bevoegdheden erkent in deze voor decentrale overheden. Dit wordt nog eens geillustreerd door het feit dat er een Protocol bij de EOC is opgesteld, waaruit een sterkere binding voor de staten dient voort te vloeien. Overigens erkent het Europees Handvest voor lokale autonomie het recht op decentrale grensoverschrijdende samenwerking, maar (ook) daar ontbreekt evenals bij de EOC een nader juridisch kader voor de invulling van de publiekrechtelijke samenwerking.

Het Verdrag van Maastricht brengt in de rol die het EG-recht speelt voor de decentrale grensoverschrijdende samenwerking geen verandering van betekenis. Met name de genoemde voorstellen van het Europees Parlement omtrent de decentrale publiekrechtelijke grensoverschrijdende samenwerking illustreren dat een meer integrale regeling hiervan binnen de Europese Gemeenschap zou kunnen plaatsvinden. De rol van de EG is in ieder geval van belang in verband met de financiering van de samenwerking. Deze financiering van (decentrale) grensoverschrijdende activiteiten in het kader van het EG. regionaal beleid is wellicht zelfs belangrijker dan het middels een Europese richtlijn c.q. verordening (van bovenaf) dwingend opleggen van decentrale grensoverschrijclende

125. (....wervolg)

"1. Iedere Verdragsi uitende Partij neemt passende en noodzakelijke maatregelen in de vorm van werten ely woorschriften om leefmilieus van in bet will voorkomende dier w en plantesoorken te beschermen, in thet bijzonder wan de soorten, genoemd in de bijlagen l en II, en om bedreigde natuurlijke leefmilieus in stand te houden.

2. De Verdragsilutende Bartijen houden bij hun beleid op het gebied van de ruimtelijke ordening en ontwikkeling, rekening met de behoeften van de instandhouding van de in het vorige lid bedoelde beschermde gebieden ten einde iedere achteruitgang wan deze gebieden zoveel mogelijk te vermigden of te verminderen."

126. KB 30-10-1991, Bouwrecht 1992/2, p. 136. Het is niet helemaal duidelijk op welke bepaling de Kroon zich met name gebaseerd heeft. Ook hier gaat het wellicht on artikel 4 lid I. (zie vorige noot) en mogelijk ook artikel 6.

Artikel 6 luidt (voor zower van belang): "Iedere Verdragsl uitende Partij neent passende en noodzakelijke maatregelen in de vorm van wetten en voorschriften om te zorgen woor bijzondere bescherning van de in het wild voorkomende diersoorten, genoemd in bijlage Il. Waar het deze soorten betreft, is met name: werboden:" Er volgt dan een opsomming. 
samenwerking. Tot op heden is in het bijzonder in een aantal EG-milieurichtlijnen, waarvan de meeste inmiddels omgezet (moeten) zijn in nationaal recht, sprake van grensoverschrijdende samenwerkings vormen. Overigens betreft het hier samenwerkingsvormen die, qua juridische reikwijdte, niet vergaand zijn, zoals het wederzijds overleggen en informatie verschaffen. Als voor deze vorm van samenwerking al een expliciete juridische basis noodzakelijk is, dan is het de vraag in hoeverre de samenwerkingsbepal ingen uit de genoemde richtlijnen, voorzover niet of onjuist omgezet in nationaal recht, rechtstreekse werking toegekend kan worden. Hetzelfde geldt voor een aantal regels die op basis van de intergouvernementele samenwerking in het kader van de Raad van Europa, ECE en OESO tot standkomen. $\mathrm{Na}$ (rechtstreekse) doorwerking van internationaal recht - dit verschilt, zoals aangegeven, voor het Europees recht en het volkenrecht en wat dit laatste betreft van land tot Iand -, kunnen decentrale overheden in ieder geval grensoverschrijdend handelen en kunnen burgers de decentrale overheden daarop aanspreken. Voor de hier behandelde EG-richtlijnen en verdragen wat betreft grensoverschrijdende consultatie/informatie zou mijns inziens sprake kunnen zijn van rechtstreeks werkende bepalingen, aangezien het om gebonden bevoegdheden gaat.

Zolang de EOC een beperkte juridische status heeft, zal de toekomst moeten uitwijzen of binnen de Raad van Europa, de EG, de ECE dan wel de OESO een meer integrale regeling het licht zal moeten zien, die voorziet in een juridische basis voor en het nadere juridische kader van decentrale publiekrechtelijke grensoverschrijdende samenwerking. De vraag is natuurlijk of dat noodzakelijk is, in het licht van het feit dat de decentrale grensoverschrijdende samenwerking en in het bijzonder grensoverschrijdende publiekrechtelijke afspraken tussen decentrale overheden nu juist op een kleinere schaal geregeld gaan worden, namelijk in verdragen tussen aan elkaar grenzende staten. Hierop wordt in de hoofdstukken 5 en 6 ingegaan. 
Hoofdstuk 4

\section{Het Belgische, Duitse en Nederlandse organieke recht inzake decentrale overheden}

\section{Inleĩding}

De Benelux-Overeenkomst inzake decentrale grensoverschrijdende samenwerking noemt een aantal Belgische en Nederlandse decentrale overheden die grensoverschrijdend kunnen samenwerken. De Duits-Nederlandse Overeenkomst inzake decentrale grensoverschrijdende samenwerking doet hetzelfde voor Duitse en Nederlandse decentrale overheden. De Benelux-Overeenkomst en de Duits-Nederlandse Overeenkomst verklaren het nationale organieke recht inzake deze decentrale overheden ook (grotendeels) van toepassing op de grensoverschrijdende samenwerking. Om een beeld te krijgen van de organisatie van deze overheden wordt hier een beschrijving (in hoofdlijnen) gegeven van het organieke recht van de op basis van de Benelux-Overeenkomst en Duits-Nederlandse Overeenkomst totgrensoverschrijdende samenwerking gerechtigde decentrale overheden. Daarbij staan de diverse bestuursorganen alsmede hun autonome bevoegdheden centraal en wordt ingegaan op het administratieve toezicht ten aanzien van de besluiten van de diwerse bestuursorganen. Hoewel er in de desbetreffende wetgevingen bepalingen zijn opgenomen inzake het financiële beheer van de diverse overheden, de manier waarop de verkiezing van de volksvertegenwoordigende bestuursorganen is geregeld, de rechten en plichten van de individuele leden van de (volksvertegenwoordigende) bestuursorganen e.d., wordt daarop in dit kader niet ingegaan. Tevens zij opgemerkt dat het hier eveneens te ver voert de bevoegdheden van c.q. Het administratieve toezicht op de diverse bestuursorganen op basis wan de sectorwetgeving (medebewindsbevoegdheden) te be schrijwen. "Hetgeen in hoofdstuk 4 beschreven wordt, is bedoeld alls een inleiding tot en aanvulling van het Belgische, Duitse en Nederlandse samenwerkingsrecht inzake decentrale overheden, dat in de hoofdstukken 5 en 6 beschreven wordt.

Achtereenvolgens worden in hoofdstuk 4 het Belgische $(\$ 2)$, het Duitse $(\$ 3)$ en het Nederlandse organieke recht $(\$ 4)$ inzake de tot grensoverschrijdende samenwerking ge-

1. In deze kan woor de bevoe gdheden wan de Belgische (decentralle) overlaeden inzake milieu en rumtelijke ordening b.v. verwezen worden natar: R.J.G.H. Seerden, M. W.J.A. Hertoghs, w., hoofdenk 5 en 6. 
rechtigde decentrale overheden beschreven. Overigens wordt voorafgand aan die beschrijving de plaats van deze decentrale overheden in de totale bestuursopbouw van het desbetreftende land kort geschetst. In verband met de federale bestuursopbouw wan Belgie en Duitsland valt die schets voor die landen wat ruimer uit dan voor de eenheidsstaat Nederland. 5 volgt een samenvattende vergelijking van het Belgische, Duitse en Nederlandse organieke recht inzake de diverse decentrale overheden in het licht van de decentrale grensoverschrijdende samenwerking.

\section{Het Belgische organieke recht inzake decentrale overheden}

\section{A. INLEIDING}

In de Benelux-Owereenkomst worden een aantal Belgische overheden genoend, die grensoverschrijdend kunnen samenwerken. Het betreft de Belgische gemeenten, verenigingen van gemeenten (intercommunales), provincies, polders, wateringen en de openbare centra voor maatschappelijk welzijn. In het navolgende wordt het organieke recht inzake deze Belgische overheden, met uitzondering van de intercommunales, besproken. ${ }^{2}$ Voor het recht inzake de intercommunales wordt verwezen naar hoofdstuk 53 . Voordat op de desbetreffende decentrale overheden wordt ingegaan ( $\$ 2 . C$. $-2 . F$.), wordt een korte schets gegeven van de plats van deze overheden in de federale bestuursopbouw van België (\$ 2.B.).

\section{B. BESTUURSOPBOUW VAN BELGIE}

In het navolgende wordt zoveel mogelijk in het licht van de decentrale grensoverschrijdende samenwerking ingegaan op de bestuursopbouw van België en met name de positie van de Gewesten en Gemeenschappen. Deze spelen een steeds belangrijkere rol ten aanzien van de decentrale overheden.

In België is het federaliseringsproces nog steeds gaande. Zo werd in mei 1993 de Belgische Grondwet nog aanzienlijk gewijzigd. Sindsdien bepaalt artikel 1 Belgische Cirondwet dat België een federale staat is, samengesteld uit Gewesten en Gemeenschappen. "

2. Bif de beschrijwing van de Belgische decentrale overheden is gebruikt genaakt van de volgende literaluni:

A. Mast, J. Dujardin, Overzicht wan het Belgiseh administatiefrecht, 120 druk, 1992; P. Lambert. (red.). Manuel de droit communal, 1992; J. Dujardin, W. Somers, L. Van Summeren, I. Debyser, Praktisch handboek voor gemeenterecht, derde volledig hermeuwde editie, 1991 ; A. Van Mensel, Administratief toezicht op de gemeenten, discretionaire bevoegdhedenen het beginsel van behoorlikk be stuur, TBP 1992/9, p. 607-613; J. Stewems, 1s een Executieve bevoegd tot het rechtstreeks wernietigen van een beslissing van een geneenteoverheid van Komen-Wasten of Voeren?, TGEM 90/2, $111-118$; A. Panwels, D. Deneyere, Polders en wateringen, Se druk, 1988; D. Vancraeynest. Polders en waterin. gen an hun rebatie tot de gemeentebesturen, De Gemeente 1992/11, p. 12-16; M. Vermarke, G-P. Libin, Maatschappelijk welzijn, De Geneente 1993/1, p. 60-68; M. Suykens, Ortwerpdecreat administratief toezicht, De Geneente $1993 / 3$, p. $131-134$.

3. Grondwetswijziging van 5-5-1993, B.S. 8-5-1993.

Zie: Wijziging van de Groudwet, Gedr.St. Senaat, 1992-1993, stuk 100-31/1\% e.v. Een groot anatat bepalingen van de grondwetswijziging heef betrekking op verande ringen van de Senaat, a.a. in relatie tot de (federale) Kamer van Volkswertegenwoondigers. Herop wond niet ingegaan. 
Aan het hoofd staat een Koning. Het centrale overheidsgezag wordt, in fasen, verdeeld tussen de federalle Staat, de Gewesten en de Gemeenschappen.

België is op basis van de Gecoördineerde wetten op het gebruik van de talen in bestuurszaken verdeeld in vier taalgebieden: het Nederlandse, het Franse, het Duitse en het tweetalig gebied Brussel. ${ }^{*}$ Er zijn drie Gemeenschappen: De Vlaamse voor het Nederlandse taalgebied, de Franse voor het Franse taalgebied en de Duitstalige voor het Duitse taalgebied. De Franse en Vlaamse Gemeenschap zijn ook bevoegd voor instellingen in het tweetalig gebied Brussel, waarvan de activiteiten uitsluitend gericht zijn op de betreffende Gemeenschap. Daarnaast zijn er drie Gewesten: Het Vlaamse, het Waalse en het Brusselse Hoofdstedelijk Gewest. Het Vlaamse Gewest omvat het Nederlandse taalgebied. Het Waalse Gewest omvat het Franse en Duitse taalgebied. Het Brussels Hoofdstedelijk Gewest omvat het tweetalig gebied Brussel. De Gemeenschappen en Gewesten in België hebben in beginsel grondwettelijk (art. 59bis respectievelijk art. 107 Grondwet) toegewezen bevoegdheden, die ze zelfstandig regelen en/of uitwoeren. ${ }^{5} \mathrm{De}$ grondwettelijke bepalingen inzake de Gemeenschappen en de Gewesten zijn uitgewerkt in de Wet van 8-8-1980 houdende Bijzondere Wet tot hervorming van de instellingen (hierna: Bijzondere wet). ${ }^{6}$ Tot vóór de genoemde grondwetswijziging van mei 1993 behoorden de residuaire bevoegdheden toe aan de Staat. Nadien zijn deze toebedeeld aan de Gemeenschappen en de Gewesten. ${ }^{7}$ Een en ander wordt overigens pas effectief, nadat een Bijzondere wet is vastgesteld, die de exclusieve bevoegdheden van de federale overheid bepaalt. Deze Bijzondere wet is er nog niet. Overigens is eind juli 1993 wel de parlementaire behandeling afgerond van een wijziging van de Bijzondere wet, die anderszins de Bijzondere wet (van 8-8-1980) aanzienlijk heeft veranderd. Het betreft de Bijzondere wet tot vervollediging van de federale staatsstructuur. ${ }^{8}$

Federale wetten hebben dezelfde rang als de wetgeving van de Gewesten en Gemeenschappen, de decreten. Voor het Brussels Hoofdstedelijk Gewest spreekt men overigens van ordonnantiën. Hier kan nog vermeld worden, dat bij bevoegdheidsgeschillen tussen

4. Gecoördineerd bij Koninklijk Beshüt van 18-7-1966, B.5. 2-8-1966.

5. Artikell 10 van de Bjzondere Wet (zie volgende moot) regelt de impliciete bevoeguheden: "De decreten kunnen rechtsbepalingen bevatten in angelegenthe den was woor de Raden niet bewoegd ziju, voor zover die bepalingen noodzakelijk zijn voor de untofening van hun bexoegdheid."

6. B.S. 15-8-1980. Deze wet is bij Wet van 8-8-1988, B.S. 13-8-1988, gewilzigd. Zite herover o, a : B. Habert, P. Vandernoot, La nouvelle loi de reformes ingtiutionelles du 8 aou 1988, Administration Publique T3/1988, p. $211-268$.

Wen Bijzondere wet is een wet, die moet worden aargenomen met de meerderheid van de stemmen in elke taalgroep van elke Kamer" (art. 1 Grondwet).

7. Wiziging van 5-5-1993, B.S. 8-5-1993. Artikel 25ter Grondwet luidt: "De federale overheid is stechts bevogd voor de angelegenhedendie de Grondwet en de wetten. krachtens de Grondwet zelf witgevardigd, har uiturukkelijk loekennen. De Gemeenschappen of de Gewesten zijn, ieder wat hen betreft, bevoegd voor de overige angelegenhedenonder de voorwarden en op de wije bepald doot de wet. Deze wet moet worden aangenomenmet de meerderheid bepaald in artikel 1 , latste lid." Zie: Wijziging varn de Grondwet, Voorstel Schiltz c.s., 1-12-1992, Gedr.St. Senwat, 1992-1993, 100-29/1"."

8. Wet van 16-7-1993, B.S. 20-7-1993. Zie tevens: Kamer van volksvertegemwoordigers, Prirlementaire stukken 1063/1, 1992-1993 (overgezonden door de Senáat, Gedr. St Senat, 558, 1992-1993, wrs. 1-50. Van dezelfe datum is ook de Gewone wet ter vervollediging van de federale Stantsstructuur. 
de centrale overheden het Arbitragehof als enig rechtscollege bevoegd is bij wijze van arrest uitspraak te doen. ${ }^{9}$

De navolgende beschrijving is toegespitst op de bevoegdheden van de Franse en Vlaamse Gemeenschap en het Waalse en Vlaamse Gewest. Voor het Brusselse Hoofdstedelijk Gewest alsmede de Duitse Gemeenschap gelden veelal andere wettelijke regimes dan voor de andere Gewesten/Gemeenschappen. Op de positie van het Hoofdstedelijk Gewest Brussel wordt niet nader ingegaan vanwege het feit, dat het territoir niet aan Nederland grenst. Voor de Duitstalige Gemeenschap, die weliswaar in de Euregio Maas-Rijn is vertegenwoordigd, wordt hier volstaan met het volgende. De Waalse wetgeving inzake gewestelijke aangelegenheden geldt in de regel voor het Duitstalig gebied. Daarbij kunnen bepaaide bevoegdheden gedelegeerd worden aan de Duitstalige Gemeenschap. Overigens kan ook de Duitse Gemeenschap bepaalde bevoegdheden delegeren aan de Waalse instellingen.

De Raad en de Executieve van de Vlaamse Gemeenschap oefenen naast de aangelegenheder van artikel $59 \mathrm{bis}$ Grondwet tevens de bevoegdheden voor/van de Gewestorganen ex artikel 107quater Grondwet uit (art. 1 \& I Bijzondere wet). Voor Wallonië is het nog steeds zo dat er, naast de Raad en de Executieve van de Franse Gemeenschap (Conseil/Exécutif de la Communauté française) voor de uitoefening van de aangelegenheden ex artikel $59 \mathrm{bis}$ Grondwet, een aparte Waalse Gewestraad en -executieve (Conseil/Exécutif régional wallon) bestaat voor de uitoefening van aangelegenheden ex artikel 107 quater Grondwet (art. $1 \$ 4$ Bijzondere wet).

In artikel 59bis Grondw et zijn de Gemeenschappen bevoegd verklaard op het terrein van de culturele en persoonsgebonden aangelegenheden. Deze zijn in artikel 4 respectievelijk artikel 5 Bijzondere wet nader uitgewerkt. ${ }^{10}$ De Gewesten worden in artikel 107 quater Grondwet bevoegd verklaard tot regeling en bestuur ten aanzien van bij wet te regelen gebiedsgebonden aangelegenheden. Deze zijn hoofcizakelijk in artikel 6 Bijzondere wet terug te vinden. Het betreft 0. a. de ruimtelijke ordening, diverse bevoegdheden inzake de bescherming van het leefmilieu, het algemene toezicht op decentrale overheden, e.d. De in de bijlage bij de Benelux-Overeenkomst opgesomde Belgische organieke wetgeving inzake decentrale overheden, die ook van belang is voor de decentrale grensoverschrijdende samenwerking, betreft veelal nationale wetten. Deze gelden in beginsel zonder onderscheid - voor een schematisch overzicht van de decentrale overheden in de bestuursopbouw van Belgiè wordt verwezen naar figuur 1 - voor het Vlaamse en Waalse gebied. Daarbij dient men zich wel te realiseren, dat deze wetten thans al veelal in combinatie met voor Wallonië en Vlaanderen van elkaar afwijkende decreten bezien

9. Artikel 107ter Grondwet vormi de grondwettelijke basis woor hel Arbitragehof. Het Arbitragehof wordt nader geregeld in de Bijzondere wet op het Arbitragehof, 6-1-1989, B.S. 7-1-1989.

Het Arbitragehof toetst de verenigbaarheid val wetcen (van de nationale overheid), decreten (vann de Gerneenschappenen Gewesten) en ordonnantiën (van het Brussels Hoofdstedelijk Gewest) aran bepataide door of krachtens de Grondwet vastigestelde regels. De gewone en administratieve rechter dienen bij gerschillen, watrbij sprake is van een mogelij $k$ bewegdheidsconflict tussen de centrale overheden, deze voor te leggen bij wijze van prejudiciële vraag an het Arbitragehof.

10. De overheveling (in 1988) van de bevoegdheden inzake monumenten en landschappen van de Gerneenschappen naar de Gewesten staat nog steeds ter discussie, zie: Advies Raad van State 24-11-1992, nar. L20.61 1/8, nata anleiding van het (voorontwerp) Decreet houdende bescherming van het archeologiscls parimonium, Stukken Vlatamse Rad, 1992-1993, $258 / 1$. 
moeten worden, zowel ten aanzien van normatieve-als uitwoeringsaangelegenheden. Ten aanzien wan de bevoegdheden van de federale staat dan wel de Gewesten/Gemeenschap. pen betreffende de organieke wetgeving inzake decentrale overheden dient het volgende opgemerkt te worden.

- Ten aanzien van gemeenten/provincies:

De gemeenten en provincies worden op basis van artikel 108 Grondwet bij de wet geregeld. Het toezicht op de gemeenten is evenwel een aangelegenheid, die op basis van artikel 7 Bijzondere wet bij de Gewesten berust. Vóór de grondwetswijziging van mei 1993 en de wijziging van de Bijzondere wet van juli 1993 behoorde de bevoegdheid tot regelgeving inzake verenigingen van gemeenten en provincies grotendeels tot de bevoegdheid van de nationale overheid. Voor de werkwijze, de controle en de vaststelling van het ambtsgebied van de verenigingen waren de Gewesten bevoegd op basis van artikel $6 \& 1$, VIII, $1^{\circ}$ Bijzondere wet. Na de grondwetswijziging van mei 1993 en de wijziging van de Bijzondere wet van juli 1993 is het zo, dat de samenwerking tussen gemeenten en provincies, onder de voorwaarden in artikel 108 Grondw et aangegeven, bij decreet geregeld kan worden. In dit verband is (het oude) artikel $6 \$ 1$, VIII, $1^{\circ}$ Bijzondere wet zodanig gewijzigd dat de verenigingen van provincies en van gemeenten bij decreet door de Gewesten geregell kunnen worden. ${ }^{11}$

- Ten aanzien van polders/wateringen:

Voor de polders en wateringen werd reeds voor de grondwetswijziging van mei 1993 (in combinatie met de wijziging van de Bijzondere wet van juli 1993) aangenomen, dat op basis van (het oude) artikel $6, \S 1, \mathrm{MI}, 10^{\circ}$ Bijzondere wet de Gewesten de normatieve en uitwoeringsbevoegdheden ten aanzien van de polders en wateringen hebben. ${ }^{12}$

- Ten aanzien van o.c.m.w.'s:

Voor de bevoegdheden van de Gemeenschappen inzake de openbare centra voor maatschappelijk welzijn is artikel $5 \$ 1, I I, 2^{\circ}$ Bijzondere wet van belang. Hierin was oorspronkelijk bepaald dat de Gemeenschappen bevoegd waren inzake maatschappelijk welzijn met uitzondering van o.a. de regelen tot inrichting van de openbare centra voor maatschappelijk welzijn. De Gemeenschappen waren slechts belast met de uitoefening van het toezicht op de openbare centra voor maatschappelijk welzijn. ${ }^{13} \mathrm{Na}$ de wijziging in juli 1993 van artikel $5 \$ 1,11,2^{\circ}$ Bijzondere wet hebben de Gemeenschappen ook bepaalde decreetgevende bevoegdheden gekregen ten aanzien van de organisatie van de openbare centra voor maatschappelijk welzijn. ${ }^{14}$

11. Een uitzondering geldt hier wat betreft het door de wet georganiseerde specifieke toezicht inzake brandbestrijding.

12. Zie L. Lavrysen, E. Orban de Xivry, M. Herbiet, J.P. Hannequar, De bevoegdheden inzake milieubeheer, Les compétences en matière de gestion đe l'environnement, 1990, p. 111.

Mijns inziens was vermelding van de polders en wateringen (beter) op zijn platats geweest bij de ondergeschikte besturen in artike $6 \& \mathrm{H}$, VIII, Bijzondere wet.

13. Zie inzake het onderscheid tussen uitoefening en organisatie van het toezicht in deze: het Advies van de Raad wan State van 2944-1991, Stukken Vlaamse Raad, 1990-1991, 429/2.

14. Zie: Gedr.St. Senaat, 1992-1993, 558/1. Vgl. noot 8 van dit hoofdstuk. 


\section{figuur 1}

Bestuursopbouw van België

\begin{tabular}{|c|c|c|c|}
\hline Niveau & Lichaam & $\begin{array}{l}\text { Wetgevend } \\
\text { orgaan/ } \\
\text { volksvertegen- } \\
\text { woordiging }\end{array}$ & Uitvoerend orgaan \\
\hline \multirow[t]{3}{*}{ Centraal } & Federalle staat & $\begin{array}{l}\text { Kamer van volks- } \\
\text { vertegenwoordi- } \\
\text { gers } \\
\text { Senaal }\end{array}$ & Regering \\
\hline & Gewesten & Raad & $\begin{array}{l}\text { Executieve } \\
\text { (Deelregering) }\end{array}$ \\
\hline & Gemeenschappen & Raad & $\begin{array}{l}\text { Executieve } \\
\text { (Deelregering) }\end{array}$ \\
\hline \multirow[t]{2}{*}{$\begin{array}{l}\text { Territoriale } \\
\text { decentralisatie }\end{array}$} & Provincies & Provincieraad & $\begin{array}{l}\text { Bestendige deputa- } \\
\text { tie } \\
\text { Gouverneur }\end{array}$ \\
\hline & Gemeenten & Gemeenteraad & $\begin{array}{l}\text { College van } \\
\text { burgemeester en } \\
\text { schepenen } \\
\text { Burgemeester }\end{array}$ \\
\hline \multirow[t]{3}{*}{$\begin{array}{l}\text { Functionele } \\
\text { decentralisatie }\end{array}$} & Polders & $\begin{array}{l}\text { Algemene } \\
\text { vergadering }\end{array}$ & $\begin{array}{l}\text { Dijkgraaf en } \\
\text { Gezworenen }\end{array}$ \\
\hline & Wateringen & $\begin{array}{l}\text { Algemene } \\
\text { vergadering }\end{array}$ & $\begin{array}{l}\text { Voorzitter en } \\
\text { beheerders }\end{array}$ \\
\hline & $\begin{array}{l}\text { Openbare centra } \\
\text { voor maatschappelijk } \\
\text { welzijn }\end{array}$ & $\begin{array}{l}\text { Raad voor } \\
\text { maatschappelijk } \\
\text { welzijn }\end{array}$ & $\begin{array}{l}\text { Voorzitter } \\
\text { Vast bureau }\end{array}$ \\
\hline
\end{tabular}

\section{Gemeenten}

\section{Algemeen}

Artikel 31 Belgische Grondwet bepaalt dat de uitsluitend gemeentelijke belangen door de gemeenteraden worden geregeld. Artikel 108 Grondwet voegt daaraan toe dat de gemeentelijke instellingen worden geregeld bij wet. Artikel 108 Grondwet noemt een aantal beginselen, die de wet dient te verzekeren. Het betreft o.a. de rechtstreekse verkiezing van de leden van de gemeenteraad, de bevoegdheid van de gemeenteraden 
voor alles wat van gemeentelijk belang is, behoudens goedkeuring in de gevallen en op de wijze bij wet bepaald, en het optreden van de toezichthoudende overheid indien de wet wordt overtreden of het algerneen belang wordt geschonden.

De autonome bevoegdheden van de gemeenten hebben in de loop van de tijd aan belang ingeboet. De gemeentelijke bevoegdheden in het kader van de sectorwetgeving (medebewindsbevoegdheden) zijn steeds belangrijker geworden. De taken/bevoegdheden wan de Belgische gemeenten - België telt circa 598 gemeenten - zijn gelegen op terreinen als de handhaving van de openbare orde en veiligheid, thet beheer van gemeentelijke eigendommen, het maken van ruimtelijke ordeningsplannen, het afgeven van bouw-en milieuvergunningen, het verzorgen van (openbaar) onderwijs, het cultuur- en welzijnsbeleid, het bijhouden van de burgerlijke stand, e.d.

Het organieke recht inzake de gemeenten is geregeld in de Nieuwe gemeentewet. ${ }^{15} \mathrm{De}$ Nieuwe gemeentewet geldt (nog) voor geheel Belgiè. De organisatie en de uitwoering van het algemene toezicht op de gemeenten is reeds geruime tijd een zaak van de Gewesten. Op termijn is een mogelijke verdere regionalisering middels decreten van deze thans nog federale wet wellicht niet uitgesloten.

De Nieuwe gemeentewet kent een drietal gemeentelijke bestuursorganen, namelijk de gemeenteraad, het college van burgemeester en schepenen en de burgemeester. Op deze bestuursorganen wordt thans nader ingegaan.

\section{Gemeenteraad}

De raad is het belangrijkste bestuursorgaan van de gemeente. Hij wordt rechtstreeks gekozen door de inwoners van de gemeente voor een periode van 6 jaar (art. 2 Nieuwe gemeentewet). Het aantal raadsleden is afhankelijk van het aantal inwoners. Het aantal varieert van 7 tot 55 leden (art. 8 Nieuwe Gemeentewet). De burgemeester is de voorzitter van de gemeenteraad. De gemeenteraad beslist over de openbaarheid van de vergaderingen. In artikel 93 Nieuwe gemeentewet zijn de aangelegenheden opgesomd, waarover in het openbaar vergaderd dient te worden. Het betreft o.a. de vergaderingen ter vaststelling van de begroting alsmede belastingen. De raadsvergaderingen, waarin het om personen gaat, zijn besloten (art. 94 Nieuwe gemeentewet). De overige vergaderingen kunnen openbaar zijn (art. 95 Nieuwe gemeentewet).

De belangrijkste bevoegdheden van de gemeenteraad betreffen de vaststelling van verordeningen, waarvan overtreding met straf bedreigd kan worden. Behalve de belastingverordeningen behoeven deze geen preventieve goedkeuring (art. 119 Nieuwe gemeentewet). Naast de belastingverordeningen noemt de Nieuwe gemeentewet de verordening met betrekking tot de organisatie van de gemeentelijke diensten (art. 119 Nieuwe gemeentewet) alsmede de gemeentelijke politieverordening (art. 119 juncto 135 Nieuwe gemeentewet).

Verdere bevoegdheden van de gemeenteraad betreffen de voorwaarden voor indienstneming, salariëring e.d. van het gemeentelijk personeel (art. 145 Nieuwe gemeentewet), het gemeentelijk aanbestedingsbeleid (art. 234 Nieuwe gemeentewet) en de vaststelling

15. Wet van 24-6-1988, B.S. 3-9-1988, bekrachtigd bij wet van 26-5-1989, B.S. 30-5-1989, Jaatstelijk gewijzigd 16-7-1993, B.S. 20-7-1993. 
van de begroting (artikel 241. Nieuwe gemeentewet). De gemeenteraad beslist tevens over de aankoop, verkoop e.d. van de gemeente-eigendommen (art. 117 Nieuwe gemeentewet). In het kader van de sectorwetgeving $\mathrm{kan}$ de raad aangewezen worden tor het maken van medebewindsverordeningen en plannen. Dit laatste is b.v. het geval ten aanzien van de ruimtelijke ordening.

\section{College wan burgemeester en schepenen}

De schepenen worden door en uit de raad gekozen (art. 15 Nieuwe gemeentewet). Het aantal schepenen varieert van 2 tot 10 . Hun zitlingstermijn is gelijk aan die van de raad. De schepenen kunnen tussentijds geschorst of afgezet worden door de gouverneur op advies van de bestendige deputatie (art. 83 Nieuwe gemeentewet). De burgemeester is van rechtswege voorzitter wan het college van burgemeester en schepenen (art. 103 Nieuwe gemeentewet). De belangrijkste bevoegdheden van het college, dat collegiaal besluiten neemt, betreffen de voorbereiding en uitvoering van de besluiten van de gemeenteraad, het beheer van de gemeentelijke diensten, het voeren van rechtsgedingen en het gunnen van overheidsopdrachten (art. 123 Nieuwe gemeentewet). Het college van burgemeester en schepenen is bij uitstek het bestuursorgaan dat tot uitvoering van medebewindsbevoegdheden is geroepen. Het college is b.v. bevoegd gezag inzake de afgifte van bouwvergunningen en bepaalde milieuvergunningen. Zijn vergaderingen zijn niet openbaar (art. 103 Nieuwe gemeentewet).

\section{Burgemeester}

De gemeenteraad speelt een belangrijke rol bij de benoeming van de burgemeester door de Koning. De hoofdregel is dat hij op voordracht van de gemeenteraadsleden uit hun midden wordt benoemd. In dat geval is hij stemgerechtigd lid van de gemeenteraad. Indien de burgemeester niet uit de raad wordt benoemd - dit is slechts mogelijk bij unaniem advies van de bestendige deputatie - heeft hij een adviserende stem in de gemeenteraad (art. 13 Nieuwe gemeentewet). Zijn zittingstermijn is gelijk aan die wan de raad, namelijk 6 jaar. Artikel 82 Nieuwe gemeentewet voorziet in de mogelijkheid dat hij door de Koning word geschorst of afgezet.

De burgemeester is wan rechtswege lid van het college wan burgemeester en wethouders (art. 103 Nieuwe gemeentewet). Daarin is hij stemgerechtigd. Belangrijke bevoegdheden van de burgemeester liggen op het terrein van de openbare orde en veiligheid. Zo berust bij hem de uicvoering van de politiewetgeving (art. 133 Nieuwe gemeentewet). Tevens kan hij in bijzondere onstandigheden zelf politieverordeningen uitvaardigen (art. 134 Nieuwe gemeentewet). Hij is hoofd van de gemeentepolitie en in dat verband o. a belast met de organisatie en leiding ervan (art. 172 Nieuwe gemeentewet). Daarnaast is hij vertegenwoordiger van het centrale gezag en in die hoedanigheid belast met het toezicht op de uitvoering van wetten, decreten, ordonnantiën en provinciale besluiten, tenzij dit expliciet is toegewezen aan het college van burgemeester en schepenen of de gemeenteraad (art. 133 Nieuwe gemeentewet). 


\section{Toezicht}

Zowel ten aanzien van de gemeenten en de provincies kan hiter het volgende opgemerkt worden. Krachtens artikel 108 Belgische Grondwet worden de provinciale en gemeentelijke instellingen beheerd door de (federale) wet. De nationale overheid is voor het grootste gedeelte tot wetgeving bevoegd gebleven ten opzichte van deze decentrale overheden. Artikel 7 van de Bijzondere wet bepaalt evenwel dat de organisatie alsook de uitoefening var het administratief toezicht op de provincies, de gemeenten en de agglomeraties en federaties van gemeenten tot de bewoegdheid van de Gewesten behoren. De nationale overheid blijft op basis van genoemd artikel 7 bevoegd voor de organisatie en de uitoefening van het gewoon administratief toezicht op de provincie Brabant en de gemeenten van het Duits taalgebied. ${ }^{16}$ De nationale overheid is ook bevoegd voor de organisatie van het gewoon administratief toezicht op de gemeenten genoemd in artikel 7 van de gecoördineerde wetten op het gebruik van de talen in bestuurszaken, en op de gemeenten Komen-Waasten en Voeren. Deze laatste gemeente grenst aan Nederlands Limburg (met name de gemeente Margraten). Het toezicht op o.a. de gemeente Voeren is geregeld in artikel 265 Nieuwe gemeentewet.

Het gewoon toezicht omvat elke worm van toezicht ingesteld door de Nieuwe gemeentewet, de Provinciewet of de Wet houdende organisatie van agglomeraties en federaties van gemeenten. Het specifieke toezicht omvat het toezicht voor de andere handelingen, b. w. ten aanzien van andere openbare besturen, zoals polders, wateringen en openbare centra voor maatschappelijk welzijn en op besluiten van gemeenten, provincies en agglomeraties en federaties van gemeenten op basis van sectorwetgeving. Evenals voor het gewone toezicht zijn de Gewesten in beginsel bevoegd inzake het specifieke toezicht op de gemeenten, de provincies en de agglomeraties en federaties van gemeenten. Er is geen bevoegdheid voor de Gewesten inzake het specifieke toezicht in aangelegenheden warvoor de nationale overheid of de Gemeenschapsoverheid bevoegd is en waarvoor bij wet of decreet een specifiek toezicht is georganiseerd. Ten aanzien van het gewone toezicht kan nog worden opgemerkt, dat dit onderverdeeld kan worden in drie vormem, namelijk het algemeen-, bijzonder- en dwangtoezicht. Veelal zijn de vormen van het specifieke toezicht hieraan ontleend. Hierna wordt ingegaan op het gewone toezicht. De regionalisering van het toezicht betekent dat het toezicht op gemeenten in Vlaanderen en Wallonie - het Hoofdstedelijk Gewest Brussel kan hier buiten beschouwing blijven van elkaar kunnen verschillen. Inrniddels is op het punt van het gewoon toezicht ten aanzien van decentrale overheden veelal regionale wetgeving tot stand gekomen, die de voorheen nationale wetgeving (ten dele) vervangt.

\section{a. Vlaanderen}

Inzake hel gewone toezicht op gemeenten geldt voor Vlaanderen het Decreet houdende vaststelling, voor het Vlaamse Gewest, van regelen betreffende de organisatie alsook de

16. Ingevolge de wijziging van de Bijzondere wet van juli 1993 (zie novt 8 van dit hoofdstuk) zijn uit artikel 7 de woorden 'de prowncie Brabant en' geschrapt. 
uitoefening van het administratief toezicht op de gemeenten. ${ }^{17}$ Dit decreet zal per 1-11-1993 vervangen worden door het Decreet houdende regel ing, voor het Vlaamse Géwest, van het administratief toezicht op de gemeenten. ${ }^{18}$ Overigens wijzigt het laatsi genoemde decreet het eerst genoemde decreet ntet ingrijpend. Hier wordt uitgegaan van het per 1-11-1993 in werking tredende decreet (hierna: Vlaams toezichtsdecreet).

Preventieve goedkeuring is b.v. nodig ten aanzien van de vaststelling van de begroting (art. 8 e.v. Vlaams toezichtsdecreet) en de rekening (art. 15 e.v. Vlaams toezichtsdecreet). In het eerste geval berust de goedkeuring bij de bestendige deputatie. In het tweede beslist de gouwerneur over de goedkeuring. Voor het repressieve toezicht zijn in de regel de gouverneur of de Executieve bevoegd. De gouverneur kan besluiten van het gemeentebestuur schorsen, indien deze in strijd zijn met de wet of het algemeen belang (art. 30 \& Vlaams toezichtsdecreet). De Executieve kan de (geschorste) besluiten van het gemeentebestuur op dezelfde gronden vernietigen (art. 30 \& en 4 Vlaams toezichtsdecreet).

De Nieuwe gemeentewet in combinatie met het Vlaams toezichtsdecreet bevat een taakverwaarlozingsregeling. Afhankelijk van de soort van taakwerwaarlozing berust hel dwangtoezicht bij de bestendige deputatie (art. 132 Nieuwe gemeentewet juncto art. 34 Vlaams toezichtsdecreet), de gouverneur (art. 266 Nieuwe gemeentwet juncto 34 Vlaams toezichtsdecreet) en de Executieve (art. 261 Nieuwe gemeentewet juncto art. 34 Vlaams toezichtsdecreet).

In het algemeen geldt, dat daar waar het toezicht bij de Executieve berust een directe beroepsgang mogelijk is bij de Raad van State. Daar waar de gouverneur c.q. de bestendige deputatie toezichthouder zijn, is allereerst een beroep bij de Executieve vereist vooraleer de beroepsgang naar de Raad van State mogelijk is.

\section{b. Wallonië}

Voor het Waalse Gewest geldt voor het toezicht op o.a. de gemeenten het Décret du Conseil régional wallon organisant la tutelle sur les communes, les provinces et les intercommunales de la Région wallonne (hierna: Waals toezichtsdecreet). ${ }^{19}$

In tegenstelling tot Vlaanderen is het toezicht in Wallonie meer geconcentreerd bij de bestendige deputatie.

Preventiof toezicht - goedkeuring kan slechts worden onthouden wegens strijd mei de wet of het algemeen belang - door de bestendige deputatie is o.a. vereist ten aanzien van de gemeentebegroting (art. 18 Waals toezichtsdecreet). In dit verband dient de gouwerneur in beroep te gaan bij de Executieve, indien de bestendige deputatie door (onthouding van) goedkeuring in strijd handelt met de wet (art. 16 Waals toezichtsdecreet). De

17. Decreet van 7-6-1989, B.S. 29-6-1989-Err. B.S. 28-7-1989. Zie voor een schematisch overzicht: Omzendbrief B.A.-G-89/12, B.S. 18-8-1989.

18. Decreet $\operatorname{van} 23-4-1993$, B.S. 3-8-1993. Zie voor een schematisch owerzicht: Omzendbrief BA-G-93/05, B.S. 3-8-1993.

19. Decreetvan 20-7-1989, M. B. 8-9-1989- Err. 10-5-1990. gewijzigd 25-7-1991, M.B. 15-10-1991 "Arrêté de l'Executifi régional wallon réglant les nesures d'exécution du décrer du Conseil régionall wallon đu 29-7-1989 organisant la tutelle sur les communes, les provinces et les intercommunales de la Région walonne, 14-11-1991, M. B. 17-1-1992. 
Executieve is bevoegd het besluit van de bestendige deputatie dan wel het gemeentelijke besluit te vernietigen (art. 17 Waals toezichtsdecreet). De bestendige deputatie is bevoegd besluiten van het gemeentebestuur te schorsen en te vernietigen, indien deze in strijd zijn met de wet of het algemeen belang (art. 13 en 15 Waals toezichtsdecreet). De Executieve kan gemeentelijke besluiten vernietigen (art. 13 Waals toezichtsdecreet). De bestendige deputatie heeft ook bevoegdheden inzake dwangtoezicht (art. 22 en 23 Waals toezichtsdecreet).

Ten aanzien van besluiten van de bestendige deputatie is een beroepsmogelijkheid voorzien bij de Executieve (art. 25 en 26 Waals toezichtsdecreet). Ten aanzien van besluiten van de Executieve staat beroep open op de Raad van State.

\section{PROVINCIES}

\section{Algemeen}

Artikel 31 Belgische Grondwet bepaalt dat de uitsluitend provinciale belangen door de provincieraden worden geregeld. Artikel 108 Grondwet voegt daaraan toe dat de provinciale instellingen worden geregeld bij de wet. Artikel 108 Grondwer noemt een aantal beginselen, die de wet dient te verzekeren. Het betreft o.a. de rechtstreekse verkiezing van de leden van de provincieraad, de bevoegdheid van de provincieraad voor alles wat van provinciaal belang is, behoudens goedkeuring in de gevallen en op de wijze bij wet bepaald, het optreden van de toezichthoudende overheid indien de wet wordt overtreden of het algemeen belang wordt geschonden. Een belangrijke taak van de provincies betreft het toezicht op de gemeenten binnen hun grondgebied. Mede in dat verband bestaan er een aantal provinciale diensten (ter ondersteuning van de gemeenten). Het aantal autonome taken van de provincie is gering in vergelijking met de medebewindsbevoegdheden op basis van sectorwetgeving. De provincies hebben bevoegdheden inzake het provinciale (water)wegennet, de gezondheidszor g, onderwijs, cultuur, jeugdzorg en monumenten. Ook in het kader van de milieuvergunningverlening spelen zij een belangrijke rol. Het organieke recht inzake de provincies is geregeld in de Provinciewet. ${ }^{20}$ Artikel 1 Belgische Grondwet noemt de 10 Belgische provincies. ${ }^{21}$ De Provinciewet kent drie bestuursorganen, namelijk de provincieraad, de bestendige deputatie en de gouverneur. Hierop wordt thans nader ingegaan.

\section{Provincieraad}

Na wijziging van de Provinciewet worden de leden van de provincieraad rechtstreeks gekozen door de inwoners van de provincie voor een periode van 6 jaar (was eerst 4

20. Wet van 30-4-1836. De Nederlandstalige tekst werd vastgesteld bij wet van 27-5-1975, B.S. 22-8-1975. in verband met de grondwetswijziging van mei 1993 en de wijziging van de Bijzondere wet van julli 1993 (vgl. noot 8 van dit hoofdstuk) is de Provinciewet op enkele punten (met name in verband mei verkiezingsaangelegenheden) gewijzigd. Daar waar deze wijzingen van belang zijn, worden deze aangegeven.

21. Overigens zijn er tot 31-1-1994 maar 9 provincies. Per genoemde datum wordt de splitsing van het huidige Brabant in een Vlaams en Waals Brabane pas effectief (overgangsbepaling ten aanzien wan artikel 1 Grondwet, B.S. 8-5-1993). 
jaar). De verkiezingen voor gemeenten en provincies zullen dan in beginsel gelijktijdig plaatsvinden. Het aantal leden van de provincieraad varieert van 56 tot 84 en is afhankelijk wan het aantal inwoners. De vergaderingen van de provincieraad zijn in beginsell openbaar (art. 51 Prowinciewet). De provincieraad kan raadscommissies instellen ter woorbereiding van de raadsbesluiten (art. 50 Provinciewet).

Het vaststellen van provinciale verordeningen, waarvan overtreding met straf bedreigd kan worden, is een bevoegdheid van de provincieraad. Artikel 85 Provinciewet noemt de politieverordening. Daarnaast kan bijwoorbeeld gedacht worden aan belastingverordeningen. Tevens wordt door de provincieraad de werking en organisatie van de provinciale diensten bij reglement geregeld. Voorts beslist de provincieraad o.a. over de vaststel. ling van de begroting (art. 69 Provinciewet), de oprichting van inrichtingen (art. 72 Provinciewet), het aangaan van leningen, het vervreemden en verkrijgen van goederen (art. 73 Provinciewet) en de machtiging voor het voeren van rechtsgedingen met betrekking tot goederen van de provincie (art. 74 Provinciewet).

\section{Bestendige deputatie}

De provincieraad kiest uit zijn midden de zes leden van de bestendige deputatie, het dagelijks bestuur van de provincie (art. 3 Provinciewet). Daarnaast maakt de gouverneur, als stemgerechtigd voorzitter, deel uit van dit college (art. 104 Provinciewet). De bestendige deputatie is in een aantal wetten bevoegd verklaard om administratieve geschillen te beslechten. Hiertoe bevat artikel 104bis Provinciewet een aantal regels. Naast deze kwaliteit van administratief rechtscollege is de bestendige deputatie vaak ook toezichthouder ten aanzien van de gemeenten. Meer dan de provincieraad beschikt de bestendige deputatie op basis van de sectorwetgeving over diverse bevoegdheden.

De bestendige deputatie, die collegiaal beslist, bereidt de besluiten van de provincieraad voor en is belast met de uitvoering ervan, beslist over alle zaken die tot het dagelijks bestuur behoren en speelt een belangrijke rol in gerechtelijke aangelegenheden (art. 106 Provinciewet). De bestendige deputatie is op basis van diverse wetten en decreten bevoegd taken uit te oefenen (zie ook art. 106 Provinciewet). Zo is de bestendige deputatie bevoegd gezag inzake de afgifte van bepaalde milieuvergunningen.

\section{Gouverneur}

De gouverneur wordt door de Koning (voor onbepaalde tijd) benoemd en ontslagen (art. 4 Provinciewet). Hij is bestuursorgaan van de provincie en in die hoedanigheid voorzitter en stemgerechtigd lid van de bestendige deputatie. Hij is niet die voorzitter van de provincieraad maar heeft wel het recht de vergaderingen van de provincieraad bij te wonen en daar het woord te voeren. De raad kan op zijn beurt de aanwezigheid van de gouverneur vorderen (art. 123 Provinciewet). De gouverneur is belast met de leiding van de provinciale griffie en de provinciale bureau's (art. 126 Provinciewet). Hij is belast met de handhaving van de openbare orde in de provincie. Daarbij kan hij over de politie beschikken (art. 128 en 129 Provinciewet). Naast bestuursorgaan van de provincie is hij vertegenwoordiger van het centrale gezag. Als vertegenwoordiger van het centrale gezag is hij belast met het toezicht op de naleving van de wetten en decreten in de provincie. Zo kan de provinciegouv erneur via een verklaring bepaalde provinciale verordeningen 
en reglementen ter goedkeuring aan de toezichthoudende instantie onderwerpen (art. 86 Provinciewet). Hij zit tevens een interministerielle commissie voor, die belast is met de bevordering van coördinatie en overleg tussen de in de provincie gevestigde diensten. inrichtingen en instellingen van de Staat (Gewest/Gemeenschap)(art. 124 Provinciewet). De gouwerneur heeft een belangrijke rol inzake het toezicht op de gemeenten alsmede de andere provinciale bestuursorganen (art. 124 Provinciewet). In zijn hoedanigheid als vertegenwoordiger van het centrale gezag is de gouverneur geen verantwoording schuldig aan de provincieraad. De gouverneur kan de uitoefening wan bepaalde bevoegdheden die hem bij wet of verordening zijn toegekend opdragen aan éen of meer arrondissementscommissarissen (art. 139bis Provinciewet).

\section{Toezicht}

Zoals aangegeven in $\$ 2 . C .5$. van dit hoofdstuk zijn de Gewesten bevoegd inzake het gewoon administratief toezicht op de provincies. Om die reden kan het toezicht op de provincies in Vlaanderen anders geregeld zijn dan in Wallonië.

\section{a. Vlaanderen}

Voor het gewoon toezicht op de provincies is voor Vlaanderen nog steeds de Provinciewet, met mame de artikelen 86 en 89 , van belang. Daar waar in de Provinciewet de Koning als toezichthoudende instantie is vermeld, dient steeds de Executieve gelezen te worden.

Ten aanzien van besluiten, zoals de vaststelling van de begroting , is de (voorafgaande) goedkeuring van de Executieve vereist. Daarnaast heeft de gouverneur de bevoegdheid bepaalde besluiten van de provincieraad aan de goedkeuring van de Executieve te onderwerpen (art. 86 Provinciewet).

Het repressieve toezicht omvat de bevoegdheid van de Executieve om besluiten van de provincieraad te vernietigen, die het algemeen belang schaden of buiten zijn bevoegdheid vallen. Besluiten die niet vernietigd zijn door de Executieve, kunnen door de decreetgevende macht worden vernietigd (art. 89 Provinciewet). Artikel 125 Provinciewet bepaalt, dat de gouverneur tegen besluiten van de provincieraad en de bestendige deputatie, die buiten hun bevoegdheid vallen of het algemeen belang schaden, in beroep dient te gaan bij de Executieve.

De Provinciewet voorziet niet in een taakverwaarlozingsregeling (dwangtoezicht).

\section{b. Wallonie}

Woor het Waalse Gewest geldt ten aanzien van het gewoon toezicht op de provincies het Décret du Conseil régional wallon organisant la tutelle sur les communes, les provinces et les interconmunales de la Région wallonne (hierna: Waals toezichtsdecreet). ${ }^{22}$ De Executieve is goedkeurende instantie ten aanzien van bijvoorbeeld de vaststelling van de begroting door de provincieraad (art. 32 Waals toezichtsdecreet). De Executieve kan 
besluiten van het provinciebestuur schorsen/vernietigen bij strijd met de wet of het algemeen belang (art. 28 e.v. Waals toezichtsdecreet). Artikel 30 Waals toezichtsdecreet bepaalt dat de gouverneur verplicht is in beroep te gaan bij de Executieve tegen besluiten van de andere provinciale organen, die in strijd zijn met de wet.

Er is een mogelijkheid van dwangtoezicht door de Executieve ten aanzien van de begroting (art. 34 en 35 Waals toezichtsdecreet). In dat verband kan na het verstrijken van de vernietigingstermijnen, behoudens beroep bij de Raad van State, de Gewesiraad deze besluiten nog vernietigen (art. 36 Waals toezichtsdecreet). Tegen besluiten van de Executieve is beroep mogelijk bij de Raad van State.

\section{E. Poldiers en WATERINGen}

\section{Algemeen}

Zoals aangegeven in \& 2.B. van dit hoofdstuk zijn de Gewesten, krachtens artikel $6 \&$ 1 , III, 10 van de Bijzondere wet, bevoegd tot normering en uitvoering inzake polders en wateringen. Overigens gelden wat betreft de polders en wateringen nog steeds de (vroeger nationale) Wet betreffende de polders respectievelijk de (vroeger nationale) Wet betreffende de wateringen. ${ }^{23}$

Op dit moment is er in Vlaanderen wetgeving in voorbereiding, waarbij de Wet betreffende de polders en de Wet betreffende de wateringen worden vervangen door een Vlaams decreet betreffende de kwantitatieve waterhuishouding. De (nog niet gepubliceerde) plannen voorzien in de oprichting van in totaal zo'n 50 polders/wateringen, die het gehele Vlaamse territoir zullen bestrijken en (met uitzondering van de gemeenten en provincies) bevoegd zullen worden inzake (de uitvoering van) het waterkwantiteitsbeheer. De polders/wateringen zullen meer bevoegdheden krijgen, waaronder planningsbevoegdheden.

Thans zijn er in Vlaanderen nog zo'n 100 polders/wateringen, die slechts zo'n 30 procent van Vlaanderen bestrijken. Wallonië kent (feitelijk) geen polders/wateringen. In Vlaanderen bevinden de meeste polders zich in het noordwestelijk deel. Enkele wateringen - het verschil met de polders is gelegen in de hoogteligging - bevinden zich bijwoorbeeld in Belgisch Limburg. Voor het niet door polders/wateringen bestreken gebied zijn thans in Vlaanderen gemeenten/provincies bevoegd inzake waterkwantiteitsbeheer. In Wallonië spelen samenwerkingsverbanden van gemeenten op dit terrein een belangrijke rol.

Gezien de op handen zijnde wijziging van de wetgeving inzake polders en wateringen, het geringe aantal polders/wateringen in het Nederlandse grensgebied alsmede het beperktere taakgebied (dan de Nederlandse waterschappen ${ }^{24}$ ) wordt op het geregelde in de Wet op de polders en de Wet betreffende de wateringen iets minder diep ingegeaan

23. Wet wan 3-6-1957, B.S. 21-6-1957, respectievelijk Wet van 5-7-1956, B.S. 5-8-1956.

24. Gezien het doel van respectievelijk polders en wateringen zou samerwerking met de Neder rlandse water. schappen/zuiverngschappen kunnen plats vinden. Hierbij dient wel opgemerkt, dat in Nederland we waterschappen/zuiveringschappen vaak bevoegdheden hebben inzake vergunwing verlening in het kaden van de Wet verontreinging oppervlakteweteren. Voor de vergunningsvereisten in deze in Vlaanderen en Wallonie, zie: R.J.G.H. Seerden, M.W.J.A. Hertoglhs, a.w., hoofdstuk 5. 
dan op de wetgeving inzake de Belgische gemeenten en provincies. Omdat de voorgestelde regeling voor een Vlaams decreet betreffende polders/wateringen waarschijnlijk zal overeenkomen met het geregelde in de Nederlandse Wet op de waterhuishouding alsmede de Waterschapswet wordt tevens verwezen naar het gestelde in $\$ 4 . \mathrm{E}$. van dit hoofdstuk.

\section{Polders}

Waar het gaat om de taken van polders is met name artikel 1 Wet betreffende de polders van belang, dat bepaalt dat polders openbare besturen zijn, "ingesteld met het oog op de instandhouding, drooglegging en bevloeiing van de ingedijkte gronden die op de zee en aan het getij onderhevige waterlopen zijn veroverd." Het belangrijkste bestuursorgaan is de algemene vergadering, die bestaat uit stemgerechtigde ingelanden (art. 12 Wet betreffende de polders). Naast de algemene vergadering is er het (dagelijks) bestuur. Dit laatste wordt in de regel (onder de ingelanden) gekozen door de algemene vergadering en bestaat uit een dijkgraaf, een adjunct-dijkgraaf en een aantal gezworenen (art. 28 juncto 31 Wet betreffende de polders).

De bevoegdheden van de algemene vergadering betreffen o.a. het vaststellen van het huishoudelijk reglement, de bijzondere politiereglementen, de begroting alsmede de invoering wan belastingen (art. 20 Wet betreffende de polders). De belangrijkste bewoegdheden van het dagelijks bestuur zijn het voorbereiden van de werkzaamheden en het uitvoeren van de beslissingen van de algemene vergadering, her dagelijks bestuur alsmede het beheer van de polder (art. 40 Wet betreffende de polders). De dijkgraaf is voorzitter van de algemene vergadering en voert de beslissingen van het bestuur uit. In spoedeisende gevallen kan hij beslissingen nemen, die tot de bevoegdheid van het bestuur behoren (art. 48 Wet betreffende de polders).

\section{Wateringen}

Artikel 1. Wet betreffende de wateringen bepaalt, dat wateringen openbare besturen zijn, "bulten de polderzones ingesteld met het oog op het tot stand brengen en handhaven, binnen de grenzen van hun territoriaal gebied, van een voor landbouw en hygiène gunstige bewatering, en met het oog op de beveiliging van de grond tegen watersnood, "Het belangrijkste bestuursorgaan is de algemene vergadering, die bestaat uit stemgerechtigde ingelanden (art. 12 Wet betreffende de wateringen). Naast de algemene vergadering is er het (dagelijks) bestuur. Dit laatste wordt in de regel gekozen onder de ingelanden door de algemene vergadering en bestaat uit een voorzitter, een ondervoorzitter en beheerders (art. 28 juncto 32 Wet betreffende de wateringen).

De bevoegdheden van de algemene vergadering betreffen 0 . a. het vaststellen van het huishoudelijk reglement, de bijzondere politiereglementen, de begroting alsmede de unworing wan belastingen (art. 21 Wet betreffende de wateringen). De belangrijkste bevoegdheden van het dagelijks bestuur zijn het voorbereiden van de werkzaamheden en het uitwoeren van de bes lissingen van de algemene vergadering, het dagelijks bestuur alsmede het beheer van de watering (art. 41 Wet betreffende de wateringen). De voorzitter van het dagelijks bestuur zit de algemene wergadering voor en voert de beslissingen 
van het bestuur uit. In spoedeisende gevallen kan hij beslissingen nemen, die tot de bevoegdheid wan het bestur behoren (art. 48 Wet betreffende de wateringen).

\section{Toezicht}

Zolang de Gewesten (in feite alleen het Vlaamse) middels decreten niet tot aanpassing van de Wet betreffende de polders/Wet betreffende de wateringen zijn overgegaan, geldt het specifieke toezicht zoals in die wetten thans is bepaald. Daar waar de Koning in de wet stat wermeld als toezichthoudende instantie dient evenwel de Executieve gelezen te worden. Wat betreft de polders is het toezicht o.a. geregeld in artikel 25 Wet betreffen de de polders. Op basis van dit artikel berust de goedkeuring van b.v. overeenkomsten tussen polders onderling, inzake geldleningen en inzake polderbelastingen bij de besierdige deputatie. De goedkeuring van o.a. de polderreglementen alsmede de overeenkomsten tussen polders omtrent samenwerking berust bij de Executieve (art. 26 Wet betreffende de polders). Besluiten van de algemene vergadering waarvoor geen goedkeuring is vereist, kunnen door de gouverneur c.q. de Executieve vernietigd worden wegens strijd met de wet (c.q. andere regels zoals het polderreglement) of het algemeen belang (art. 27 Wet betreffende de polders). Artikel 90 e.v. Wet betreffende de polders voorziet in een taakverwaarlozingsregeling (dwangtoezicht). In de Wet betreffende de wateringen is in een vergelijkbaar toezicht voorzien (artikelen 26, 27, 28 en 90 e.v. Wet betreffende de wateringen).

\section{F. OPENBARE CENTRA VOOR MAATSCHAPPELIJK WELZUN (O.C.M.W. 'S)}

\section{Algemeen}

Zoals aangegeven in $\S 2 . \mathrm{B}$. van dit hoofdstuk hebben de Gemeenschappen, krachtens artikel $5 \& 1$, II, $2^{\circ}$ Bijzondere wet belangrijke bevoegdheden inzake de o.c.m.w. 's. Zij zijn geregeld in de (nationale) Wet betreffende de openbare centra voor maatschappelik welzijn (hierna: Organisatiewet o.c.m.w.). ${ }^{2.5}$ Regionalisering van (delen van) de Wet betreffende de openbare centra voor matschappelijk welzijn in decreten is als gevolg vair de verdere uitbreiding (van juli 1993) van de Gemeenschapsbevoegdheden in deze niet uitgesloten.

Artikel 57 van de Organisatiewet 0. c.m.w. is van belang in het licht van de (functionele) taken van deze overheden. Hierin staat o.a. dat het openbaar centrum voor maatschappelijk welzijn tot taak heeft aan personen en gezinnen dienstverlening te verzekeren van sociale, geneeskundige, sociaal geneeskundige of psychologische aard. Daarnaast oefent de o.c.m.w. voogdij uit (art. 63 e.v. Organisatiewet o.c.m.w.). Tussen gemeenten en o.c.m.w's bestaat een geformaliseerd overleg (art. 26 Organisatiewet $0 . \mathrm{c.m} . \mathrm{w}_{.}$). ${ }^{26}$ In Nederland kennen wij niet een direct vergelijkbare instantie, maar de o.c.m.w.'s hebben kenmerken van de Nederlandse gemeentelijke sociale diensien, instellingen voor

25. Wet wan 8-7-1976, B.S. 5-8-1976/err. 26-11-1976. Deze wet is aanzienljik gewijzigd bij wet wan $5-8-1992$, B. $5.8-10-1992$.

26. Zie K. B. 21-1-1993, B.S. 9-2 1993, tot bepaling van de voorwaarden en modialiteiten van het overleg als bedoeld in artike $26 \$ 2$ Organisatiewet $0 . \mathrm{c.m} . w$. 
maatschappelijk werk, bejaardenzorg, ziekentondsen, e.d. De meeste hiervan behoren niet tot de "overheden", die op basis van de Benelux-Overeenkomst inzake decentrale grensoverschrijdende samenwerking kunmen samenwerken. Wellicht dat op bepaalde werkterreinen mogelijk toch taken overeenstemmen met $b . v$. die van gemeenschappelijke regelingen in Nederland (b.v. ten aanzien van ambulancevervoer). Bij de o.c.m.w.'s gaat het in beginsel om zaken, die sterk verbonden zijn met personen die op het territoir" wark een bepaalde Belgische gemeente wonen en van de betreffende diensten gebruik kunnen maken. Samenwerking op dit terrein - b.v gebruikmaking van diensten door burgers over de grens e.d. - kan zeer noodzakelijk zijn. Het voert in dit werband te ver daar diep op in te gaan. Om die reden wordt de organisatie van de o.c.m.w."s iets minder ver gaand beschreven dan die wan de Belgische gemeenten en provincies.

\section{Bestuursorganen}

O.c.m.w. 's zijn openbare instellingen, die rechtspersoonlijkheid bezitten (art. 2 Organisatiewet o.c.m.w.). In de regel zijn zij per gemeente opgericht. Er bestaat de mogelijkheid van intercommunale o.c.m.w. 's. Het belangrijkste bestuursorgaan van het openbaar" centrum voor maatschappelijk welzijn is de raad voor het maatschappelijk welzijn (art. 6 juncto 24 Organisatiewet $0 . c . m$. w.). Deze raad wordt gekozen door de gemeenteraad. Het aantal leden is afhankelijk van het aantal inwoners. Een beperkt aantal leden mag gemeenteraadslid zijn. De raad voor het maatschappelijk welzijn regelt alles wat tot de bevoegdheid van het openbaar centrum voor matschappelijk welzijn behoort, tenzij de wet anders bepaait (art. 24 Organisatiewet o.c.m.w.). De raad kiest onder zijn leden een voorzitter (art. 25 Organsiatiewet $0 . c . m . w$.). De raad dient uit zijn midden een vast bureau op te richten voor de afhandeling van het dagelijks bestuun respectievelijk waaraan deze welomschreven bevoegdheden kan overdragen (art. 27 Organisatiewet o.c.m.w.). De door de raad gekozen voorzitter is tevens voorzitter van het vast bureau. De voorzitter is belast met voorafgaand onderzoek van de zaken "die aan de beraadslagende organen worden voorgelegd, alsmede met de uitvoering van beslissingen van de raad en het wast bureau (art. 28 Organisatiewet o.c.m.w.).

\section{Toezicht}

De Gemeenschappen zijn na de wijziging in juli 1993 van de Bijzondere wet behalve voor de uitoefening van het toezicht tevens bevoegd inzake het regelen van het toezicht. ${ }^{27}$ Thans geldt nog de regeling op basis van de Organisatiewet o.c.m.w. Daar waar in die wet de Koning staat vermeld, dient de Executiewe van de Gemeenschap gelezen te worden. Ten aanzien van bepaalde de besluiten, zoals de vaststelling van de begroting, is de (voorafgaande) goedkeuring van de toezichthoudende overheic- dit kan de gemeenteraad c.q. de bestendige deputatie zijn - vereist. In de artikelen 108 e.v.

27. Vór de wijziging van artikel $5 \$ 1, \pi, 2^{\circ}$ Bijzondere wet (vgl. noot \& van dit hoofdstuk) waten de

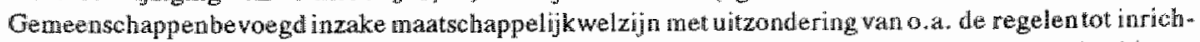
thig van de openbare centra voor matschappelijk wel zijn. De nationale overtheid was bevoegd grebleven on de regels vast te stellen betreffetde organisatie van b.v. het administratief toe $z$ icht op de o.c. m. w." $\$$. Darbij waren de Gemeenschappen belast met de uitoefening van dit toezicht. 
Organisatiewet o.c.m.w. is het specifieke administratieve (repressieve) toezicht geregeld. Zo bezit her college van burgemeester en schepenen een schorsingsbevoegdheid ten aanzien van beslissingen tot individuele dienstverlening. De gouverneur en (Gemeenschaps)Executieve bezitten een algemene vernietigingsbevoegdheid ten aanzien van besluiten van o.c.m.w.'s.

\section{Het Duitse organieke recht inzake decentrale overheden}

\section{A. INLEIDING}

In de Duits-Nederlandse Overeenkomst inzake decentrale grensoverschrijdende samenwerking wordt een aantal Noordrijn-Westfaalse en Nedersaksische decentrale overheden genoemd, die grensoverschrijdend kunnen samenwerken. Voor Noordrijn-Westfalen betreft het de Gemeinden, Kreise, Zweckverbände „Landschaftsverbände en de Kommunalverband Ruhrgebiet. Voor Nedersaksen betreft het de Gemeinden, Samtgemeinden, Kreise en Zweckverbände. In het navolgende wordt het organieke recht inzake deze overheden, met uitzondering van de Zweckverbände, besproken. ${ }^{28}$ Voor het recht inzake de Zweckverbände wordt verwezen naar hoofdstuk $6 \$ 2$.

Voordat op de desbetreffende decentrale overheden wordt ingegaan, wordt een korte schets gegeven van de plaats van deze overheden in de bestuursopbouw van Duitsland (Noordrijn-Westfalen en Nedersaksen).

\section{B. BESTUURSOPBOUW VAN DUITSLAND}

In het navolgende wordt zoveel mogelijk in het licht van de decentrale grensoverschrijdende samenwerking ingegaan op de Duitse bestuursopbouw en met de name de positie van de Länder Noordrijn-Westfalen en Nedersaksen. De Länder spelen een belangrijke rol ten aanzien van de decentrale overheden.

Duitsland is een federale staat, die is samengesteld uit de Bond (de federale overheid) alsmede de deelstaten (de Länder). Aan het hoofd staat een president. De bevoegdheidsafbakening inzake wetgeving tussen de Länder en de Bond is geregeld in de artikellen $70 \mathrm{l} / \mathrm{m} 75$ Grundgesetz. Artikel 73 Grundgesetz somt de aangelegenheden op, die tot de

28. Bij de beschrijving van het organieke recht wan de Duitse (Noordrijn-Westfablse en Nedersaksische) decentrale overheden is gebruik genaakt wan de volgende liferatuur:

Algemeen; E. Schmidt-Assmann, Kommunalrecht, in: 1. von Münch, E. Schmidt-Assmann (Hrsg.\%. Besonderes Verwaltungsrecht, 9. neubearbeitete Auflage, 1992; O. Seewalt, Kommunalrecht, in: U. Steiner (Hrsig.) Besonderes Verwaltungsrecht, 4. neubearbeitete und erweiterte Auflage, 1992.

Nedersaksen: H. Fàber, Kommunalrechu, in: H. Faber/H.P. Schneider, Niedersächisches Staats- und Verwaltungsrecht, 1985 ; B. Nedden, Verwaltungsorganisation, in: H. Faber/H.P Sichneider, aw. W. H. Korte, Verfassung und Verwaltung des Landes Niedersachsen, 2. wöllig neubearbeitete und erweiterte Aullage, 1986; K. Lüersen, Niedersächsiche Gemeindeordnung, Kommentar, 1991.

Noordrijn-West fater: H-U. Erichsen, Kommunalrecht des Landes Nordrhein-Westfalen, 1988; E.D. Bösche, Kommunal werfassungsrecht in Nordrhein-West thlen, 2. Auflage, 1989; G.D. Bühren, Allgenneines Kormmunalrecht Nordrhein-Westfalen, 4. überarbeitete Auflage, 1989; H. Körner, Gemeindeordnurig Nordirhein-West falen, Konmentar, 5. Auflage, 1990.

Ondat een aantal Duitse termen niet altijd een precieze Nederlandse vertaling hebben, worden deze in het navolgende niet vanuit het Duits in het Nederlands vertaald. 
uitsluitende wetgevende bevoegdheid van de Bond behoren. Middels delegatie door de Bond kunnen de Länder hier bevoegd worden (art. 71 Grundgesetz). Bij de concurrerende wetgevingsbevoegdheid (art. 72 Grundgesetz) zijn in beginsel de Länder bevoegd, zolang de Bond niet wan zijn bevoegdheden gebruik heeft gemaakt. De Bond is bevoegd, indien een aangelegenheid niet effectief kan worden geregeld door wetgeving op het niveau van de Länder. De aangelegenheden zijn opgesomd in artikel 74 Grundgesetz. Op basis van artikel 75 Grundgesetz is er de bevoegdheid, in de daar genoemde aangelegenheden, van de Bond tot het geven van kadervoorschriften. Die dienen door de Länder nader ingevuld te worden. Buiten de in de artikelen $71 \mathrm{t} / \mathrm{m} 75$ Grundgesetz aangegeven aangelegenheden zijn de Länder bevoegd. In artikel 70 (juncto art. 30) Grundgesetz is de uitsluitende wetgevende bevoegdheid van de Länder aangegeven. De Länder zijn tot wetgeving bevoegd, voorzover de het Grundgesetz de Bond hiertoe niet de bevoegdheid verleent. Zo zijn de Länder (exclusief) bevoegd inzake de wetgeving betreffende de organisatie van de zich onder het Landsniveau bevindende overheden. Er zijn in dit verband regels te vinden in de 'Landesverfassungen, Landesorganisationsgesetzen " en natuurlijk de organieke wetgeving inzake die overheden, zoals 'Gemeinde- en Kreisordnungen'.

De uitvoering van wetten is geregeld in de artikelen $83 \mathrm{t} / \mathrm{m} 85$ Grundgesetz. Het komt er op neer, dat behalve uiteraard de uitvoering van de eigen Landswetten ook de uitvoering van de meeste Bondswetten door de Länder, in de regel als eigen aangelegenheid, plaatsvindt. Tenzij de Bondswetten anders bepalen, wijzen de Länder bijvoorbeeld de tot uitvoering hiervan gerechtigde overheden aan. Tot slot kan hier opgemerkt worden, dat bij bevoegdheidsgeschillen tussen de Bond en de Länder het Bundesverfassungsgericht beslist. Het Bundesverfassungsgericht kan ook beslissen over grondwettigheidsbezwaren van gemeenten in verband met artikel 28 Grundgesetz, dat de gemeentelijke autonomie waarborgt. ${ }^{29}$

\section{Noordrijn-Wesifalen}

De bestuursopbouw van het Land Noordrijn-Westfalen is geregeld in de Verfassung des Landes Nordrhein-Westfalen (hierna: Verfassung Nordrhein-Westfalen) ${ }^{30}$ alsmede het Gesetz über die Organisation der Landesverwaltung (hierna: Landesorganisationsgesetz Nordrhein-Westfalen). ${ }^{31}$

Artikel 1 Verfassung Nordrhein-Westfalen bepaalt dat het Land is onderverdeeld in gemeenten en verbanden van gemeenten (Gemeinden und Gemeindenverbäncle). Daarbij garandeert artikel 78 Verfassung Nordrhein-Westfalen, in aansluiting op artikel 28 Grundgesetz, het recht op autonomie van gemeenten en verbanden van gemeenten. Daarbij wordt overigens bepaald dat het Land op basis van wettelijke voorschriften aan gemeenten en verbanden van gemeenten bepaalde taken verplicht kan opleggen en toezicht kan uitoefenen jegens deze overheden. Artikel 77 Verfassung Nordrhein-Westfalen bepaalt dat de bestuurlijke organisatie van het Land bij wet geregeld wordt. Dit is ge-

29. Zie 813 Gesetz ther das Bundesvertassungsgericht, in de tekst van 12-12-1985, BGB1. I \$. 2229.

30. Wet van 18-6-1950, GV NW S. 127, latatstelijk gewijzigd 24-11-1992, GV NW S. 448.

31. Wat van 10-7-1962, GV NW S. 421, hatstelijk gewijzigd 14-12-1989, GV NW S.678. 
beurd in het Landesorganisationsgesetz Nordrhein-Westfalen. Deze wet kent cen drietal soorten overheden, namelijk:

1. Landesbehorden;

2. Gemeinden/Gemeinde verbãnde;

3. Körperschaften, Anstalten und Stiftungen des öffentlichen Rechts.

ad 1. Op basis van 2 e.v. Landesorganisationsgesetz Nordrhein-Westfallen ziju de Landesbehörden onderverdeeld in:

- oberste Landesbehörden. Het betreft de regering van het land, de ministerpresident alsmede de vakministers.

- Landesoberbehơrden. Het betreft vooral gedeconcentreerde diensten (Landesämter), die direct ondergeschikt zijn aan de oberste Landesbehöden en voor het hele Land bevoegd zijn.

- Landesmittelbehörden. Dit zijn overheden, die direct ondergeschikt zijn aan de oberste Landesbehörden en bevoegd zijn voor een deel van het Land, bijwoorbeeld de Regierungsprässident. Deze laatste is de algemene vertegenwoordiger van de Landsregering in zijn Regierungsbezirk. Noordrijn-Westfalen telt 5 Regierungsbezirke, die een soort van gedeconcentreerde dienst van het Land zijn te beschouwen.

- untere Landesbehörden. Dit zijn overheden die ondergeschikt zijn aan de Landesoberbehörden/Landesmittelbehörden. Het gaat hier om de Oberkreisdirektoren alsmede een aantal gedeconcentreerde diensten.

Deze onderverdeling in Behörden is bijvoorbeeld van belang voor het onderlinge toezicht (Dienstauf sicht/Fachaufsicht)( $\$ 12$ Landesorganisationsgesetz Nordrhein-Westfalen).

Daarbij betreft het Dienstaufsicht zaken als de organisatie en personeelaangegelegenheden en het Fachaufsicht de (rechtmatige en doelmatige) taakuitoefening.

ad 2. Ten aanzien van de Gemeinden en Gemeindeverbände is bepaald, dat zij medewerking verlenen aan het Landsbestuur en dat zij bij de uitvoering van Bondsrecht gebonden zijn aan de aanwijzingen van de toezichthoudende overheden $(\$ 15$ e.v. Landesorganisationsgesetz Nordrhein-Westfalen). Welke de toezichthoudende overheden zijn, is bepaald in de wetgeving inzake Gemeinden en Gemeindeverbände alsmede de sectorwetgeving. Het verschil tussen Gemeinden en Kreise is, dat wat betteft de autonome taken de eerste voor de plaatselijke aangelegenheden alleen verantwoordelijk zijn, terwijl taken van bovenplaatselijk belang door de Kreise (Kreisfreie Städte) vervuld worden.

ad 3. Publiekrechtelijke rechtspersonen (Körperschaften des öffentlichen Rechts) kumen slechts bij of krachtens wet worden opgericht. Aan deze rechtspersonen kunnen bevoegdheden van het Land wonden overgedragen 18 en 19 Landesorganisationsgesetz Nord whein-Westalen).

\section{Nedersaksen}

De bestuurlijk opbouw van het Land Nedersaksen is geregeld in de Niedersächische Verfassung ${ }^{32}$ alsmede het Gesetz zur Verwaltungs- und Gebietsreform. ${ }^{33}$

32. Wet van 13-4-1951, Niederts. GVBl. Sb.I S. 5, naat de tekst van 28-3-1972, Nieders. GVBI, S, 171, lantstelijk gewijzigd, 19-5-1993, Nieders, GVBA. S. 107.

33. Wet van 28-6-1977, Nieders. GVBI. S. 233, laatstelik gewijzigd, 18-11-1984, Nieders. GVB!. S.267. 
De oberste Landesbehơrden zijn in de Niedersächsische Verfassung terug te vinden. Dit is de Landesregierung (de ministerpresident en de ministers) (alsmede de Landesrechnungshof als gedeconcentreerde dienst). De andere $\mathbb{L}$ andesbehörden zijn aangegeven in het Gesetz zur Verwaltungs- und Gebietsreform. Het gaat daarbij om de Bezirksregierungen, die onder leiding staan van de Regierungspräsident. Deze vertegenwoordigt de Landsregierung in het Regierungsbezirk.. Nedersaksen telt 4 Regierungsbezirke. Behalve de Bezirksregierungen functioneren op dit middenniveau o.a. het Niedersächsische Landesverwaltungsamt alsmede diverse andere diensten. Op het laagste niveau zijn er diverse diensten die onder toezicht staan van het middenniveau. Ook de Kreisdirektor behoort tot het laagste niveau. De oberste Landesbehörden, de Behörden der Mittelstufe en de Behörden der Ortsstufe zijn de zogenaamde unmittelbare Landesbehörden. Voor de niet tot de eigenlijke Landesbehörden behorende overheden wordt wel de term mittelbare Landesbehörden gebruikt. Zij zijn eigenlijk geen Landesbehörden, maar voeren wel taken/bevoegdheden in opdracht van het Land wit. De Gemeinden en de Gemeindeverbände zijn hiervan de belangrijkste. Maar ook andere rechtspersonen, zoals Kamers wan Koophandel e.d. kunnen als zodanig beschouwd worden.

Voor een schematisch overzicht van de plaats van de decentrale overheden in de bestuursopbouw van Duitsland, toegespitst op de deelstaten Noordrijn-Westfalen en Nedersaksen, wordt verwezen naar figuur 2.

\section{figuur 2}

Bestuursopbouw van Duitsland (Noordrijn-Westfalen/Nedersaksen)

\begin{tabular}{|l|l|l|l|}
\hline Niveau & Lichaam & $\begin{array}{l}\text { Wetgevend orgarn } \\
\text { Volksvertegen- } \\
\text { woordiging }\end{array}$ & Uitwoerend orgaan \\
\hline Centraal & Bund & $\begin{array}{l}\text { Bundestag } \\
\text { (Bundesrat) }\end{array}$ & Bundesregierung \\
\cline { 2 - 4 } & Länder & Landtag & Landesregierung \\
\hline Tecritoriale & Kreise & $\begin{array}{l}\text { Kreistag } \\
\text { Kreisausschuss }\end{array}$ & Oberkreisdirektor \\
\hline $\begin{array}{ll}\text { (kreisfreie } \\
\text { Städte) }\end{array}$ & $\begin{array}{l}\text { Gemeinderat } \\
\text { Verwaltungs- } \\
\text { ausschuss* }\end{array}$ & $\begin{array}{l}\text { Oberstadtdirektor } \\
\text { (Beigeordneten) }\end{array}$ \\
\hline $\begin{array}{l}\text { Gemeinden } \\
\text { Gemeinderat } \\
\text { Verwaltungs- } \\
\text { ausschuss* }\end{array}$ & Gemeindedirektor \\
\hline
\end{tabular}

\footnotetext{
* Alleen expliciet wettelijk geregeld in Nedersaksem. In Noordrija-West falen wordt op korte termijn woor-
} zien in exn vergelijkbare Gemeinde/(Stadt)aussehuss. 


\section{NOORDRIJN-WESTFALEN}

\section{Gemeinden}

\section{a. Algemeen}

Het organieke recht inzake de Gemeinden is voormamelijk te vinden in de Gemeindeordnung für das Land Nordrhein Westfalen (hierna: Gemeindeordnung). ${ }^{34} \mathrm{De}$ Gemeinden in Noordrijn-Westfalen kunnen onderverdeeld worden in kreisfreie Städte en kreisangehörige Gemeinden. Kreisfreie Städte bestaan uil Stadtbezirke, die over een eígen door de inwoners gekozen bestuur beschikken ( $\$ 13 \mathrm{t} / \mathrm{m} \& 13 \mathrm{c}$ Gemeindeordnung). Op basis wan het inwonertall zijn de kreisangehörige Gemeinden onder te verdelen in (kleine) gemeenten en middelgrote en grote steden ( $\$ 3$ a Gemeindeordnung). Kreisangehörige Gemeinden kunnen uit Ortschaften bestaan. Het bestuur van deze Ortschaften is opgedragen aan commissies (Ausschüsse) of individuele personen (Ortsvorsteher)( $\$ 13$ d Gemeindeordnung). In Noordrijn-Westfalen zijn 396 Gemeinden, waarvan er 23 kreisfreie Städte zijn.

De belangrijkste taken/bevoegdheden wan de gemeenten liggen op het terrein van het beheer van gemeentelijke eigendommen, ruimtelijke ordening, milieu, water-en energievoorziening, cultuur en welzijn, gemeentelijke voorzieningen inzake sport, scholen, brandweer, uitwoering van sociale wetgeving, wetgeving inzake de burgerlijke stand alsmede nationaliteitswetgeving.

Op de gemeentelijke bestuursorganen, namelijk de Rat en de Gemeindedirektor (en Beigeordeneten), wordt thans nader ingegaan.

\section{b. Rat}

Het belangrijkste bestuursorgaan is de Rat. Hij wordt rechtsreeks gekozen door de inwoners van de gemeente voor een periode van 5 jaar. Het aantal leden varieert al naar gelang het aantal inwoners van 21 tot 91 . Zijn vergaderingen zijn in beginsel openbaar ( $833 \mathrm{Abs} .2$ Gemeindeordnung). De gemeenteraad is voor alle gemeentelijke aangelegenheden bevoegd, tenzij de Gemeindeordnung anders bepaalt. Bepaalde bevoegdheden op basis van de Gemeindeordnung kunnen niet andere wel worden overgedragen aan andere gemeentelijke organen. $\$ 28$ Gemeindeordnung somt de niet overdraagbare bevoegdheden op. Het betreft o.a.: de verkiezing van de leden van commissies, de verkiezing van de Gemeindedirektor en de Beigeordneten, het aangaan van kredieten,

34. Wet val 13-8-1984, GV NW S. 475, latstelijk gewijzigd 3-4-1992, GV NW S. 124.

Overigens dient hier opgemerkt te worden, dat op dit moment een wijziging wan de gemeenteljke wetgeving, waaronder de Gemeindeordnung, aanhangug is bij de Landtag. De belangrijkste wijzigingen betreffen o.a. de unvoering van een referendum in Gemenden en Kreise, de oribouw van de gemeentelifke Haptausschuss to Gemeinde(/Stad)aussehuss, de instelling op gemeentelijk niveau van raden woor buitenlanders en het verwangen van de Innenminister door het Innenministerium (bijwoorbeeld inzake toezicht), Gesetz zur Änderung der Gemeindeordnung der Kreisordnung und anderer Kommunatverfassungsgesetze des Landes Nordrhein-Westalen, Drucksache LL/4983. Voorzover dat van belang is voor de onderhavige beschrijving, wordt op deze wijzigingen ingegan. Zie b.v.: R. Fingerhut, Zur Reform der Kommunalver fassung, Stadte- Lnd Gemeinderat 9/1993, p. 255-259, 
het vaststellen van de begroting en het aangaan van rechtsgedingen, tenzij het eenvoudige aangelegenheden van dagelijks bestuur betreft. $\$ 28$ Gemeindeordnung bepaalt eveneens dat de raad zich eenvoudige lopende zaken, die eigenlijk aan de Gemeindedirektor toekomen, kan voorbehouden. De gemeenteraad heeft de bevoegdheid inzake de gemeentelijke aangelegenheden verordeningen te maken, voor zover bij wet niet anders is bepaald. De verordeningen behoeven slechts de goedkeuring van de toezichthoudende instantie, als dit bij wet voorgeschreven is ( $\$ 4$ Gemeindeordnung). De gemeenteraad is verplicht een zogenaamde Hauptsatzung vast te stellen ( $\$ 4$ Abs. 3 Gemeindeordrung). In deze verordening dient o.a. geregeld te worden: een klachtenprocedure voor burgers ( $86 \mathrm{c}$ Gemeindeordnung) en zaken in verband met Stadtbezirke en Ortschaften $(\S 13, \S 13 \mathrm{~d}$ Gemeindeordnung). De raad kan commissies instellen ( $\$ 41 \mathrm{Gemeindeord-}$ nung). Bepaalde commissies, zoals de Hauptausschuss, zijn verplicht. Op korte termijn zal de de Gemeinde(/Stadt)ausschuss de Hauptausschuss gaan vervangen. Hiertoe worden enkele artikelen in de Gemeindeordnung gewijzigd dan wel ingevoegd. ${ }^{35}$

De voorzitter van de raad alsmede de representant naar buiten van de raad is de Bürgermeister. Hij wordt gekozen uit en door de raad en kan door deze ontslagen worden ( $\$$ 27 juncto $\$ 32$ Gemeindeordnung). De Bürgermeister heeft de bevoegdheid besluiten van de raad, die niet in het belang van de gemeente zijn, te weerspreken. Hierdoor worden de besluiten geschorst en dient er opnieuw door de raad besloten te worden ( $\$ 39 \mathrm{Abs}$. 1 Gemeindeordnung). De Bürgermeister stelt samen met de Gemeindedirektor de raadsagenda vast ( $\$ 33 \mathrm{Abs} .1 \mathrm{Gemeindeordnung).} \mathrm{Tevens} \mathrm{kan} \mathrm{de} \mathrm{Bürgermeister} \mathrm{inlichtingen}$ verlangen van de Gemeindedirektor inzake alle belangrijke bestuurlijke aangelegenheden van de gemeente ( $\$ 40$ Gemeindleordnung). Hij kan met raadgevende stem aan de zittingen van alle commissies deelnemen ( $\$ 42$ Abs. 1 Gemeindeordnung).

\section{c. Gemeindedirektor}

Het dagelijks bestuur wordt gevormd door de Gemeindedirektor en eventueel - deze kunnen worden gekozen - de Beigeordneten. De Gemeindedirektor en de Beigeordneten worden voor 8 jaar (hauptamtlich) of voor de duur van de raadsperiode (ehrenamtlich) gekozen door de raad en maken geen deell uit van de raad. Het aantal Beigeordneten wordt vastgesteld in de Hauptsatzung. De raad heeft de bevoegdheid de Gemeindedirektor en de Beigeordneten te ontslaan ( $\$ 49$ Gemeindeordnung). De Gemeindedirektor - in kreisangehörige en kreisfreie Städten wordt hij aangeduid als Stadtdirektor respectievelijk Oberstadtdirektor - is belast met de voorbereiding en uitvoering van de raads-

35. Het betreft 0 .a. wijziging van 41 Abs. 2 Gemeindeordnung dat in de werplichte instelling van de Gemeinde(/Stadt)ausschuss in plaats van de Hauptausschuss gaat voorzien. In het in te voegen $842 a$ Gemeindeordnung wordt de Gemeinde(Stadt)ausschuss nader geregeld. Hij bestatt uit bepaalde raadsleden, de Bürgermeister en de Gerneindedirektor (met raadgevende stem) en eventueel Beigeordneten(met raadgevende stem) ( $\$ 42 a$ (1) Gemeindeordnung). Ten aanzien wan de taken/bevoegdheden bepaalt $\$ 42 \mathrm{a}$ (2) Gemeindeordnung: "Der Gemeindeausschuss bereitet die Beschlüsse des Rates vor, soweit er nicht diese Aufgabe dem Gemeindedirektor überträgt; die Vorbereitung erfolgt in nichth-öftentlicher Sitzung. Er entlastet den Rat und überwacht die Ausfuhrung der Beschlüse." In dit werband kan deze Ausschuss onder bepalde woorwaarden over aangelegenheden beslissen, die door de Rat atan hem worden overgedragen., Gesetz zur Änderung der Gemeindeordnung, der Kreisordnung und anderer Kommunativerfassungsgesetze des Landes Nordrhein-Westfalen, a.w., (noot 34 van dit hoofdstuk). 
besluiten. Hij is verantwoordelijk voor de uitvoering van de aan de Beigeordneten opgedragen taken. De Gemeindedirektor is vaak uitvoerende instantie in het kader van diverse wettelijke voorschriften ( $\$ 47$ Gemeindeordnung). De Gemeindedirektor vertegemwoordigt de gemeente in gerechtelijke en bestuurlijke aangelegenheden ( $85 \mathrm{Ge}-$ meindeordnung). Voorts speelt de Gemeindedirektor een belangrijke rol inzake het toezicht. De Gemeindedirektor staat aan het hoofd van de ambtenaren.

\section{d. Toezicht}

\&106 e.พ. Gemeindeordnung regelt het toezicht. In $\$ 106$ Gemeindeordnung wordt een onderscheid gemaakt tussen het algemene en het specifieke toezicht. Het eerste heeft betrekking op de autonome bevoegdheden wan de gemeenten. Het laatste heeft betrekking op de uitoefening van bevoegdheden 'nach Weisung' en is geregeld in de diverse sectorwetten. Een belangrijk verschil tussen beide toezichtsvormen is, dat het algemene toezicht in de regel slechts een rechtmatigheidstoetsing omvat, terwijl het specifieke toezicht veeal ook betrekking heeft op de doelmatigheid. Op het specifieke toezicht wordt hier niet dieper ingegaan.

Wie algemeen toezichthoudende instantie is, is bepaald in $\$ 106$ a Gemeindeordnung. Voor de kreisangehörige Gemeinden is dit de Oberkreisdirektor, als untere stalliche Verwaltungsbehörde. Voor de kreisfreie Städte is de Regierungspräsident de algemene toezichthouder. Oberste Aufsichtsbehörde voor kreisangehörige Gemeinden is de Regierungspräsident en voor de kreisfreie Städte de Innenminister. Oberste Aufsichtsbehörde is de Innenminister. Bij aangelegenheden waarbij gemeenten uit meerdere Kreise of Regierungsbezirke zijn betrokken is de gemeenschappelijke (in rang één hogere) toezichthouder bevoegd.

De Gemeindeordmung vereist ten aanzien van een aantal besluiten, b.v. de oprichting van bedrijven, vennootschappen e.d. woorafgaande goedkeurimg. Het algemene (repressieve) toezicht op gemeenten is een rechtmatigheidstoezicht (strijd met het recht). De toezichthoudende instanties kunnen de besluiten van de gemeentelijke bestuursorganen vernietigen. Dit kan pas nadat de betreffende organen in de gelegenheid zijn gesteld hun besluit te herzien. Bij raadsbesluiten en besluiten van Ausschüsse is de Gemeindedirektor de instantie, die de zaak dient aan te kaarten bij de raad (\$39 Gemeindeordnung). Bij besluiten van de Gemeindedirektor is het de toezichthoudende instantie zelf die de zaak aankaart bij de raad ( $\$ 108$ Gemeindeordnung).

Indien de gemeente bepaalde verplichtingen niet ter hand neemt, kan de toezichthoudende instantie hiervoor in de plaats treden. Voordat zij hiertoe overgaat, dient ze evenwel eerst de gemeente de mogelijkheid te geven binnen een bepaalde termijn de wettelijke plichten alsnog na te komen ( $\$ 109$ Gemeindeordmung).

Behalve bovenstaande algemene toezichtsinstrumenten kan door de Innenminister een gevolmachtigde worden aangewezen, die alle of bepaalde gemeentelijke aangelegenheden overneemt ( $\$ 110$ Gemeindeordnung). Mogelijk kan de Innenminister op basis van een besluit van de Landsregierung gemachtigd worden de raad te ontbinden ( $\$ 111$ Gemeindeordnung).

Daar het bij besluiten in het kader van het algemeen toezicht in de regel om "Verwaltungsakte' gaat, kunnen de toezichtsbesluiten aangevochten worden bij het Verwaltungs- 
gericht, middels een 'Anfechtungsklage' in het 'Verwaltungsstreitverfahren' $(\$ 112$ Gemeindeordnung juncto $\$ 40$ Verwaltungsgerichtsordnung).

\section{Kreise}

\section{a. Algemeen}

Het organieke recht inzake de Kreise is voornamelijk geregeld in de Kreisordnung für das Land Nordrhein-Westfalen (hierna: Kreisordnung). ${ }^{36}$ Kreise zijn Gemeindeverbände ( 1 Kreisordnung). Het grondgebied van de Kreise beslaat meerdere gemeenten. Noordrijn-Westfaten heeft 31 Kreise. De Kreise zijn bevoegd inzake bovengemeentelijke aangelegenheden (autonomie) en die aangelegenheden welke door de wet aan de Kreise worden overgedragen. Belangrijke taken/bevoegdheden van de Kreise zijn er inzake afvalyerwijdering, ziekenhuizen, natuurbescherming, ongevallen- en rampenbestrijding en toezicht op de gemeenten.

Op de bestuursorganen van de Kreis ( $\$ 6$ Kreisordmung), namelijk de Kreistag, de Kreisausschuss en de Oberkreisdirektor, wordt thans nader ingegaan.

\section{b. Kreistag}

De Kreistag wordt rechtstreeks gekozen voor een periode van 5 jaar door de inwoners van de Kreis. Het aantall leden varieert al naar gelang het aantal inwoners van 49 tot 73 . Zijn vergaderingen zijn in beginsel openbaar (\$25 Abs. 2 Kreisordnung). De Kreistag bestuit over de Kreisaangelegenheden, die naar hun aard een besluit van de Kreistag behoeven en of door de Kreistag aan zichzelf voorbehouden worden, tenzij in de Kreisordnung anders bepaald ( $\$ 20$ Kreisordnung). De Kreistag is bij uitsluiting bevoegd inzake o.a. de verkiezing van de Kreisausschuss en andere Aussschüsse, de vasistelling wan verordeningen, het vaststellen van de begroting, de oprichting van bedrijven, het aangaan van rechtsgedingen (behalve bij eenvoudige dagelijkse aangelegenheden) en alle aangelegenheden waarin de wet de bevoegdheid van de Kreistag uitdrukkelijk voorschrifft ( $\$ 20 \mathrm{Kreisordnung).} \mathrm{Evenals} \mathrm{de} \mathrm{gemeenteraad} \mathrm{kan} \mathrm{de} \mathrm{Kreistag} \mathrm{verordeningen}$ vaststellen en is hij dit verplicht te doen voor de zogenaamde Hauptsatzung ( $\$ 3$ Kreisondnung). De woorzitter van de Kreistag is de Landrat. Deze wordt gekozen uit en door de Kreistag en kan ontslagen worden door de Kreistag ( $\$ 24$ Kreisordmung). Hij bezit o.a. de bewoegdheid besluiten van de Kreistag te weerspreken, waardoor deze geschorst worden en de Kreistag opnieuw dient te beslissen ( 831 Kreisordnung). De Landrat stelt samen met de Oberkreisdirektor de vergaderagenda van de Kreistag vast (\$25 Abs. 1 Kreisordnung), Besluiten van de Kreistag gaan via de Landrat naar de Oberkreisdirektor (\$ 30 Kreisordnung).

36. Wet van 13-8-1984, GV NW S. 497, laatstelik gewizigd 16-12-1992, GV NW S. 561. 


\section{c. Kreisausschuss}

De Kreisausschuss besluit over alle aangelegenheden, tenzij deze voorbehouden zijn aam de Kreistag of het zaken betreft die tot het dagelijks bestuur (laufende Verwaltung) behoren ( 834 Kreisordnung). Deze latste behoren tot de bevoegdheid van de Oberkreisdirektor. De Kreisausschuss wordt gekozen uit en door de Kreistag. De Landrat is voorzitter van de Kreisausschuss (8 25 Kreisordnung). De Landrat stelt samen met de Oberkreisdirektor de vergaderagenda van de Kreisausschuss vast ( $\$ 36$ Kreisordnung).

\section{d. Oberkreisdirektor}

De Oberkreisdirektor en zijn plaatsvervanger (de Kreisdirektor) worden door de Kreistag gekozen voor de duur van 8 jaren. Beide kunnen door de Kreistag ontslagen worden ( 8 38 Kreisordnung). De Oberkreisdirektor is bevoegd inzake het dagelijks bestuur. Hij is belast met de woorbereiding en uitvoering van besluiten van de Kreistag en de Kreisausschuss en vertegenwoordigt de gemeente in gerechtelijke en bestuurlijke aangelegenheden ( $\$ 37$ Kreisordnung). Hij speelt ook een rol in het kader van het toezicht ( $\$ 31$ Kreisordnung).

De Kreisordnung bevat tevens een aantal bepalingen over de "staatliche Verwaltung" in de Kreis. De Oberkreisdirektor is behalve orgaan van de Kreis tevens untere staatliche Verwaltungsbehörde (\$ 48 e.v. Kreisordnung). In deze hoedanigheid van vertegenwoordiger van het staatsbestuur is hij o.a. toezichthoudende instantie ten aanzien van de tot een Kreis behorende gemeenten, tenzij de wet anders bepaalt. In zijn hoedanigheid van staatsorgaan is hij alleen verantwoording schuldig aan hogere staatsorganen en niet aan de andere bestuursorganen van de Kreis ( $\$ 49$ Abs. 2 Kreisordnung).

\section{e. Toezicht}

Ten aanzien van het toezicht zijn de bepalingen van de Gemeindeordnung van overeenkomstige toepassing. In deze wordt verwezen naar het gestelde in \$ 3.C.1.d. van dik hoofdstuk. Toezichthoudende instantie voor de Kreis is de Regierungspräsident en (hogere) toezichthoudende instantie is de Innenminister ( $\$ 46$ Kreisordnung).

\section{Landschaftsverbände}

\section{a. Algemeen}

De belangrijkste organieke wet inzake de Landschaftsverbände is de Landschaftsverbandsordnung für das Land Nordrhein-Westfalen (hierna: Landschaftsverbandsordnung). ${ }^{37}$ Er zijn twee Landschaftsverbände in Noordrijn-Westfalen, namelijk de Landschaftsverband Rheinland en de Landschaftsverband Westfalen-Lippe. Zij bestaan uit de

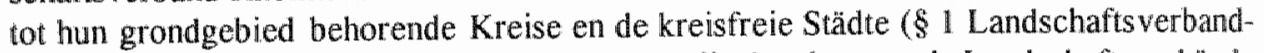
sordnung). In \$ 5 Landschafts verbandsordnung zijn de taken van de Landschafts verbände

37. Wert wan 27-8-1984, GV NW S. 544, laatstelijk gewijzigd 6-10-1987, GV NW S. 342. 
aangegeven. Het betreft aangelegenheden inzake sociale hulpverlening, jeugdzorg, gezondheids voorzieningen, wegen, cultuur en landschaps verzorging. De organen van de Landschaftsverbände zijn de Landschaftsversammlung, de Landschaftsausschuss en de Direktor des Landschaftsverbandes. Op deze bestuursorganen wordt thans ingegaan.

\section{b. Landschaftsversammlung}

De Landschaftswersammlung wordt samengesteld door de vertegenwoordigers van de deelnemende overheden, direct nadat deze zelf gekozen zijn. De leden van de Landschaftsversammlung kunnen behalve leden van de Kreise en Kreisfreie Städte ook werknemers van deze overheden alsmede vertegenwoordigers en werknemers van tot de Kreise behorende gemeenten zijn. Afhankelijk van het inwoneraantal van de deelnemende overheden hebben deze recht op één of meer vertegenwoordigers ( $\$ 7$ a Landschaftsverbandsordnung). De vergaderingen van de Landschaftswersammlung zijn openbaar ( $\$ 9$ Landschaftsverbandsordnung). De Landschaftsversammlung besluit over o. a. : de algemene grondbeginselen van het bestuur, de verkiezing van de Landschaftsausschuss en Fachausschüsse alsmede de Direktor, de vaststelling van verordeningen en de begroting. Het vaststellen van verordeningen geldt voor de in artikel 5 Landschaftsverbandsordnung aangegeven aangelegenheden ( $\$ 6$ Landschafts verbandsordnung).

De Landschafts versammlung kiest een voorzitter (Vorsitzende)( 8 8a Landschaftsverbandsordnung). Deze stelt samen met de Direktor de vergaderagenda van de Landschafts versammlung vast ( $\$ 9$ Landschafts werbandsordnung).

\section{c. Landschaftsausschuss}

De Landschaftsausschuss bestaat uit een aantal leden van de Landschaftsversammlung. De Landschaftsausschuss beslist over de niet aan de Landschaftsversammlung voorbehouden aangelegenheden, met uitzondering van de lopende zaken. Deze laatste behoren tot de bevoegdheid van de Direktor. De Landschaftsausschuss bereidt de besluiten van de Landschaftsversammlung voor en voert deze uit en controleert het bestuur van de Direktor (\& 11. Landschafts verbandsordnung). De vergaderingen van de Landschaftsausschuss zijn in de regel openbaar ( $\$ 14$ Landschaftsverbandsordnung).

\section{d. Direktor des Landschafts verbandes}

De belangrijkste bevoegdheden van de Direktor zijn de voorbereiding en uitvoering van besluiten van de Landschafts versammlung en -ausschuss en de Fachausschüsse, de door de Landschaftsausschuss overgedragen bevoegdheden, het voeren van het dagelijks bestuur en de vertegenwoordiging van de Landschafts verband in gerechtelijke en bestuurlijke zaken (\$17 Landschaftsverbandsordnung). De Direktor dient ook toe te zien op de rechtmatigheid van besluiten van de Landschaftsversammlung, de Landschaftsausschuss en de Fachausschüsse. Hij dient de mogelijke strijd bij de betreffende organen aan te kaarten, waarna deze hun besluit kunnen herzien. Doen zij dit niet, dan dient hij om een besluit van de toezichthouder te verzoeken ( $\$ 19$ Landschaftsverbandsordnung). De Direktor wordt bijgestaan door Landesräte. Zij worden evenals de Direktor voor 8 jaar 
gekozen door de Landschaftsversammiung, waarvan zij geen deel uitmaken. Zij kunnen door de Landschafts versammlung ontslagen worden ( $\$ 20$ Landschaftsverbandsordnung).

\section{e. Toezicht}

De Imnenminister is toezichthoudende instantie. In bepaalde gevallen voorziet de Landschaftsverbandsordnung (o.a. door een verwijzing naar de Gemeindeordnung) in voorafgaande goedkeuring van bepaalde besluiten. Het (repressieve) toezicht is geregeld in $\$ 26$ e.v. Landschafts verbandsordnung. Het algemene toezicht is een rechtmatigheidstoezicht. Het specifieke toezicht kan tevens de doelmatigheid omvatten. Op het specifieke toezicht, dat is geregeld in de sectorwetten, wordt hier niet ingegaan.

De toezichthoudende instantie kan de Direktor verzoeken besluiten van de Landschaftsversammlang, de Landschaftsausschuss en de Fachausschüsse, die in strijd zijn met het recht, bij deze organen voor te leggen ter herzjening. Overigens kan de toezichthoudende instantie dat ook zelf doen (\$28 Abs. 1 Landschaftsverbandsordnung). Ten aanzien van besluiten van de Direktor bezit de toezichthoudende instantie de bevoegdheid deze ter herziening voor te leggen aan de Direktor ( 828 Abs. 2 Landschaftsverbandsordnung). Bij het achterwege laten van de herziening voorziet de toezichthoudende instantie hierin.

Bij het niet voldoen aan wettelijke plichten bestaat de mogelijkheid dat de toezichthoudende instantie in plaats en op kosten van de Landschaftsverband handelt ( $\$ 29$ Landschaftsverbandsordnung). Tegen besluiten van de toezichthoudende instantie kan in beginsel beroep worden ingesteld op basis van $\$ 30$ Landschaftsverbandsordnung juncto $\$ 40$ Verwaltungsgerichtsordnung.

\section{Kommunalverband Ruhrgebiet}

\section{a. Algemeen}

De regeling inzake de Kommunalverband Ruhrgebiet berust op het Gesetz über den Kommunalverband Ruhrgebiet (hierna: Ruhrgebietgesetz). ${ }^{38}$ Deelnemers aan deze Gimeindeverband zijn een aantal in het Ruhrgebietgesetz genoemde kreisfreie Städte en Kreise van het Rulurgebiet ( $\$ 1$ Ruhrgebietgesetz). De belangrijkste wettelijke taken en bevoegdheden, zoals aangegeven in $\$ 4$ Ruhrgebietgesetz, van deze Kommunalverband zijn gelegen op het terrein van de bescherming van groen- en watergebieden (van regionale betekenis) en de deelname in de oprichting van recreatieve voorzieningen (van regionale betekenis). Daarnaast kunnen middels verordening en met toestemming van de deelnemende overheden andere gemeentelijke aangelegenheden met een regionale betekenis aan de Kommunalverband overgedragen worden. Bovendien kan de Kommunalverband op verzoek van een individuele deelnemer diens taken waarnemen op het gebied van de afvalverwijdering en ten aanzien van de opstelling van landschapsplannen en de bescherming van het landschap. Andere aangelegenheden van een individuele deelnemer kunnen op diens verzoek en met toestemming van een meerderheid van de 
andere deelnemers eveneens door de Kommunalverband worden waargenomen. De organen van de Kommunalverband Ruhrgebiet zijn de Verbandsversammlung, Verbandsausschuss en Verbandsdirektor ( $\$ 7$ Ruhrgebietgesetz).

\section{b. Verbands versammlung}

De Verbandsversammlung wordt samengesteld door de vertegenwoordigers van de deelnemende overheden, direct nadat deze zelf gekozen zijn. De leden van de Verbandsversammlung kunnen alleen maar vertegenwoordigers van de deelnemende overheden alsmede de tot de Kreise behorende gemeenten zijn. Afhankelijk van het inwoneraantal van de deelnemende overheden hebben deze recht op één of meer vertegenwoordigers ( 87 a Ruhrgebietgesetz). De vergaderingen van de Verbandsversammlung zijn openbaar ( 12 Abs. $\mathbb{R}$ Ruhrgebietgesetz). De Verbandsversammlung is o.a. bevoegd tem aanzien van de verkiezing van de Verbandsausschuss, de Fachausschüsse en de Verbandsdirektor, het vaststellen van verordeningen, het overnemen van taken en bevoegdheden van (individuele) deelnemers en de oprichting van inrichtingen. ${ }^{39}$ Bovendien kan de Verbandsversammlung zich de besluitvorming van aangelegenheden waarvoor de Verbandsausschuss bevoegd is voorbehouden ( $\$ 8$ Ruhrgebietgesetz). De Verbands versammlung kiest uit zijn midden een voorzitter (Vorsitzende) ( $\$ 8$ a Ruhrgebietgesetz). Deze stelt samen met de Verbandsdirektor de vergaderagenda van de Verbandsversammlung vast (\$12 Abs. 2 Ruhrgebietgesetz).

\section{c. Verbandsausschuss}

De Verbandsausschuss, bestaande uit de voorzitter en een bepaald aantal leden van de Verbands versammlung, is met name bevoegd inzake de voorbereiding en uitvoering van besluiten van de Verbandsversammlung, het afstemmen van de bezigheden van de Fiachausschüsse en de controle op het bestuur van de Verbandsdirektor ( $\$ 15$ Ruhrgebietgesetz). De vergaderingen van de Verbandsausschuss zijn in de regel openbaar $(\$ 18$ Ruhrgebietgesetz). De voorzitter van de Verbandsausschuss stelt samen met de Verbandsdirektor de vergaderagenda van de Verbandsausschuss vast (\$18 Abs. 1 Ruhrgebietgesetz).

\section{d. Verbandsdirektor}

De Verbandsdirektor wordt bijgestaan door Beigeordneten. Zij worden voor een periode van 8 jaar gekozen door de Verbandsversammlung. Zij zijn geen lid van de Verbands. versammlung. Zij kunnen door deze worden ontslagen. Het aantal Beigeordneten wordt vastgesteld in een verordening ( $\$ 24$ Ruhrgebietgesetz).

De Verbandsdirektor is bevoegd voor het voorbereiden en uitvoeren van besluiten van de Verbandsausschuss, de besluitvorming inzake de hem door de Verbandsausschuss overgedragen bevoegdheden, de lopende zaken en de vertegenwoordiging wan de Kom-

39. Owerigens zijn er natst de vertegerwoordigers van de deelnemende overheden ook een tiental vertegenwoordigers (me adviserende stem) uit de Kamers van kopphandel, werknemers en werkgerers. 
munalverband in gerechtelijke en bestuurlijke aangelegenheden. Hij heeft bovendien de bevoegdheid in spoedeisende gevallen bepaalde besluiten te nemen ( $\$ 21$ Ruhrgebietgesetz). De Verbandsdirektor dient toe te zien op de rechtsgeldigheid van besluiten van de Verbandsversammlung en -ausschuss en zonodig in deze om een besluit van de toezichthoudende instantie te verzoeken ( $\$ 23$ Ruhrgebietgesetz).

\section{e. Toezicht}

De Innenminister is toezichthoudende instantie. In bepaalde gevallen voorziet het Ruhrgebietgesetz (o.a. door een verwijzing naar de Gemeindeordnung) in voorafgaande goedkeuring van bepaalde besluiten. Het algemene (repressieve) toezicht is geregeld in $\$ 28$ Ruhrgebietgesetz. Het gaat daarbij om een rechtmatigheidstoezicht, tenzij het aangelegenheden (nach Weisung) betreft, waarvoor het specifieke toezicht uit de betreffende sectorwetten geldt. Op dit laatste wordt hier niet ingegaan. Voor het (algemene) toezicht wordt verwezen naar de van toepassing zijnde bepalingen in deze uit de Gemeindeordnung. Zie hiervoor \& 3.C.l.d. van dit hoofdstuk.

\section{NEDERSAKSEN}

\section{Gemeinden}

\section{a. Algemeen}

In $\$ 57$ Niedersächsische Verfassung wordt in aansluiting op artikel 28 Grundgesetz de gemeentelijke autonomie gegarandeerd. Het organieke recht inzake de Gemeinden is voornamellijk te vinden in de Niedersächsische Gemeindeordnung (hierna: Gemeindeordnung). ${ }^{40}$ De Gemeindeordnung maakt een onderverdeling in kreisfreie en kreisangehörige Gemeinden. Deze laatste bestaan uit (kleine) gemeenten en grote steden. De grote steden en de kreisfreie Städte hebben meer bevoegdheden dan de kleine gemeenten ( 811 Gemeindeordnung). In de kreisfreie Städte vallen gemeentebestuur en Kreisbestuur samen. Nedersaksen heeft 1028 Gemeinden, waarvan er 9 kreisfreie Städte zijn. Als het on de bevoegdheden van de Gemeinden gaat, definiëren de $\$ 4$ en 5 Gemeindeordnung de eigen aangelegenheden ("eigener Wirkungskreis') en de bij wet overgedragen aangelegenheden ('übertragener Wirkungskreis'). Ook al hebben de gemeenten wellicht minder dan de Kreise te maken met de uitvoering van 'staatliche Aufgaben', de Staatsverwaltung neemt een belangrijke plaats in naast de Selbstverwaltung.

De taken/bevoegdheden van gemeenten liggen op het terrein van de vaststelling van ruimtelijke plannen, water-en energievoorziening, het beheer van gemeentelijke eigendommen, het oprichten van gemeentelijke voorzieningen en inrichtingen b.v. inzake sport, onderwijs en welzijn (zie b.v. \& $8,22 \mathrm{~b}, 72$ Gemeindeordnung). ${ }^{41}$

40. Wet, in de tekst van 22 juni 1982, Nieders. GVBI. S. 229, 1aatstelijk gewijzigd 14-6-1993, Nieders. GVB1, S. 137 .

41. De uitwering van het Bondsrecht is voor Nedersaksen geregeld in de Algemeine Zuständigkeitsverordnung für die Gemeinden und Landkreise zur Ausführung von Bundesrecht van 19-1.2-1990, Nieders. 
$\$ 6$ Gemeindeordnung bepaalt dat de gemeenten (autonome) verordeningen kunnen vaststellen. Ten aanzien van de overige (medebewinds)verordeningen dienen de betreffende wetten hiertoe de bevoegdheid te geven. Overtreding van verordeningen is strafbaar op basis van het Gesetz über Ordnungs widrigkeiten. Evenals in Noordrijn-Westfalen is in Nedersaksen een 'Hauptsatzung' verplicht ( $\$ 7$ Gemeindeordnung).

De Gemeindeordnung van Nedersaksen kent bepalingen ten aanzien van (gemeenten, die deel uitmaken van de zogenaamde) Samtgemeinden ( 67 e.v. Gemeindeordnung). (Kleine) gemeenten kunnen samenwerken door Samtgemeinden te vormen. Van de genoemde 1028 Gemeinden zijn er 142 Samtgemeinden. Deze Samtgemeinden vervullen bepaalde bevoegdheden, zoals de opstelling van ruimtelijke plannen, het oprichten van gemeentelijke voorzieningen op het gebied van de sport en de gezondheid en bepaalde taken ten aanzien van de brandweer. $\mathrm{Zij}$ kunnen autonome taken, die worden overgedragen door de deelnemende gemeenten, uitoefenen. Tevens oefenen zij medebewindsbevoegdheden ('übertragen Wirkungskreis') uit. De Samtgemeinden dienen met toestemming van de deelnemende gemeenten een Hauptsatzung vast te stellen $(\$ 73$ Gemeindeordnung). Voorafgaande goedkeuring door de toezichthoudende instantie is vereist ( $\$ 74$ Gemeindeordnung). De organen van de Samtgemeinden zijn de Samtgemeinderat, de Samtgemeindeausschuss en de Samtgemeindledirektor. Hierop wordt thans niet nader ingegaan. In het navolgende wordt alleen op de bestuursorganen van de Gemeinden, namelijk de Rat, de Verwaltungsausschuss en de Gemeindedirektor nader ingegaan. Hetgeen voor deze bestuursorganen geldt, is grotendeels ook van toepassing ten aanzien van de bestuursorganen van de Samtgemeinden ( $\$ 71$ Abs. 2 Gemeindeordnung).

\section{b. Rat}

De raad is het belangrijkste gemeentelijke orgaan. Hij wordt voor 5 jaar rechtstreeks gekozen door de inwoners en is qua aantal 'Ratsmitglieder' (variërend van 7 tot 69) afhankelijk van het aantal inwoners. De zittingen zijn in beginsel openbaar $(\S 45 \mathrm{Ge}$ meindeordnung). De belangrijkste bevoegdheden van de raad zijn o.a. de vaststelling van verordeningen, de vaststelling van ruimtelijke plannen (Bauleitpläne), de vaststelling van de begroting, de oprichting van bedrijven en de deelname in samenwerkingsverbanden (\$4 Gemeindeordnung). De raad kan tevens raadscommissies in het leven roepen ( $\$ 51$ Gemeindeordnung). Voor grotere steden is er de verplichting Stadtbezirke in te stellen ( $855-55 \mathrm{~d}$ Gemeindeordnung). Kleinere gemeenten kunnen Ortschaften instellen ( $\$ 55 \mathrm{e}-$ 55 i Gemeindeordnung).

De Bürgermeister - in kreisfreie en grotere steden wordt hij aangeduid als Oberbürgermeister - is de voorzitter van de gemeenteraad. Hij wordt door de raad gekozen en kan door de raad ontslagen worden ( $\$ 43$ Gemeindeordnung). De belangrijkste taak van de (Ober)bürgemeister is de representatieve vertegenwoordiging van de gemeente $(\$ 31$ Gemeindeordnung).

41.(...verwolg)

GVBI. S. 521, laatstelijk gewijzigd 17-3-1993, Nieders. GVBI. S. 81. Het gaat hier voonamelijk om bevoegdheden in het kader van de sociale wetgeving, de nationaliteitswetgeving alsmede de wetgeving betreffende de burgerinke stand. 


\section{c. Verwaltungsausschuss}

Naast de Rat 4 er de Verwaltungsausschuss, die ingewolge $\$ 56$ Gemeindeordnung in de regel bestaat uit de voorzitter van de raad, de Beigeordneten, de Gemeindedirektor (met adviserende stem) en bepaalde raadsleden (met adviserende stem ingevolge $\$ 51$ Abs. 4 Gemeindeordnung). Het aantal Beigeordneten is afhankelijk van het aantal inwoners en varieert in beginsel van 2 tot 10. De Beigeordneten worden uit en door de raad gekozen (\$ 56 Gemeindeordnung). De vergaderingen van de Verwaltungsausschuss zijn niet openbaar ( $\$ 59$ Gemeindeordnung).

De Verwaltungsausschuss bereidt de besluiten wan de raad voor en is bevoegd in aangelegenheden waarvoor niet de raad (eventueel Stadtbezirksrat of Ortsrat) of de Gemeindedirektor bewoegd is. De Verwaltungsausschuss kan bepaalde bevoegdheden overdragen aan de Gemeindedirektor ( $\$ 57$ Gemeindeordnung).

\section{d. Gemeindedirektor}

De Gemeindedirektor wordt door de raad gekozen voor 12 jaar. Hij kan tussentijds ontslagen worden door de raad (\$61 Gemeindeordnung). De belangrijkste bevoegdheden van de Gemeindedirektor zijn de voorbereiding en witvoering van besluiten van de Verwaltungsausschuss, en eventueel de Stadtbezirksräte en Ortsräte, de uitvoering van besluiten van de raad, de uitvoering van aanwijzingen van toezichthoudende instanties, de uitvoering van lopende zaken en de vertegenwoordiging in rechtsgedingen ( $\$ 62$ en 63 Gemeindeordnung). In spoedeisende gevallen kan de Gemeindedirektor in overeenstemming met de raadsvoorzitter beslissingen nemen (\$ 66 Gemeindeordnung).

\section{e. Toezicht}

Vergelijkbaar met het toezicht op de gemeenten in Noordrijn Westfalen wordt bij het toezicht op de gemeenten in Nedersaksen een onderscheid gemaakt tussen het algemene (Kommunalaufsicht) en het specifieke toezicht (Fachaufsicht). Het eerste impliceert een rechtmatigheidstoetsing en geldt voor de bevoegdheden inzake de "eigenen Wirkungskreis'. Het Fachaufsicht kan naast een recht-tevens een doelmatigheidstoetsing omvatten en geldt ten aanzien van de bevoegdheden inzake de "übertragenen Wirkungskreis" (\$ 127 Gemeindeordnung). Overigens gelden voor het toezicht inzake de bevoegdheden 'nach Weisung' de betreffende sectorwetten. Inzake het Fachaufsicht is bepaald dat, tenzij bijzondere toezichthouders zijn ingesteld, de Landkreise bevoegd zijn ten aanzien van de kreisangehörigen Gemeinden (met uitzondering van de grotere zelfstandige steden). Voor de laatste is de Bezirksregierung toezichthouder ( $8128 \mathrm{Abs} .3$ Gemeindeordnung). Hier wordt slechts op het algemene toezicht ingegaan. Bij het Kommunalaufsicht is de toezichthoudende instantie voor de kreisfreie Städte en de grotere zelfstandige steden de Bezirksregierung met als hogere/hoogste instantie de Minister des Innern. Ten aanzien van de kreisangehörigen Gemeinden (met uitzondering van de grotere zelfstandige steden) zijn de Kreise de toezichthoudende instantie en zijn de Bezirksregierung en de Minister des Innern hogere respectievelijke hoogste toezichthouder $(\$ 128 \mathrm{Abs} .1 \mathrm{Ge}-$ meindeordnung). $\$ 133$ Abs. 1 en 3 Gemeindeordnung bevat een regeling ten aanzien van gemeentelijke besluiten die voorafgaande goedkeuring behoeven door de toezicht- 
houder. Het betreft hier b.v. de Hauptsatzung alsmede de besluiten omtrent het oprichten van vennootschappen e.d. ( $\$ 74$ en 116a Abs. 4 Gemeindeordnung). Hierbij is (bij het achterwege laten van de goedkeuring) expliciet in een beroepsmogelijkheid door middel van het instellen van een 'verwaltungsgerichtliche Klage' bij het Verwaltungsgericht voor de gemeenten voorzien ( $\$ 133$ Abs. 2 Gemeindeordnung). Preventief toezicht ten aanzien van autonome verordeningen is overigens alleen mogelijk, indien dit bij wet is voorgeschreven. De toezichthoudende instantie inzake het Kommunalaufsicht kan besluiten, die in strijd zijn met het recht, ter herziening aan de betreffende gemeentelijke organen voorleggen ( $\$ 130$ Gemeindeordnung). Naast dit repressieve toezicht is voorts woorzien in dwangtoezicht. Daar waar de gemeenten nalaten te handelen, kan de toezichthouder in de plaats en op kosten van de gemeenten optreden $(\$ 131$ Gemeindeordnung). Als de voorgaande toezichthoudende bevoegdheden niet afdoende zijn, kan de hogere toezichthouder een persoon aanstellen die alle of bepaalde zaken van de gemeenten waarneemt ( $\$ 132$ Gemeindeordnung).

Besluiten in het kader van het algemene toezicht zijn veelal "Verwaltungsakte', waartegen een rechtsgang open staat op basis van $\S 40$ Verwaltungsgerichtsordnung.

\section{Landkreise}

\section{a. Algemeen}

Evenals bij de Gemeinden wordt ten aanzien van de bevoegdheden van de Landkreise op basis van $\$ 3$ Niedersächsische Landkreisordnung (hierna: Landkreisordnung) ${ }^{42}$ een onderscheid gemaakt tussen de bevoegdheden inzake de "eigenen Wirkungskreis" en "übertragenen Wirkungskreis'. Tot de laatste bevoegdheden behoren de aan de Landkreise, als untere Verwaltungsbehörde, toegewezen statelijke aangelegenheden b.v, de toezichtsbevoegdheden ten aanzien van kreisangehörige Gemeinden. Tot de eerste behoren de andere (vrijwillige en verplichte autonome) bevoegdheden. Belangrijke taken/bevoegdheden van de Kreise zijn er inzake afvalverwijdering, ziekenhuizen, natuurbescherming en ongevallen- en rampenbestrijding. Nedersaksen telt 38 Kreise. De kreisfreie Städte vervullen de aangelegenheden van de Gemeinden alsmede de Landkreise ( $\$ 10$ en 11 Landkreisordnung).

De bestuursorganen van de Landkreise zijn de Kreistag, de Kreisausschuss en de Oberkreisdirektor ( $\$ 6$ Land kreisordnung). Hierop wordt thans nader ingegaan.

\section{b. Kreistag}

De Kreistag wordt voor 5 jaar rechtstreeks gekozen door de inwoners van de Landkreis Het aantal leden van de Kreistag varieert afhankelijk van het aantal inwoners van 43 tot 71. De vergaderingen van de Kreistag zijn in beginsel openbaar ( 841 Landkreisordnung). De Kreistag is o.a. bevoegd ten aanzien van: het vaststellen van verordeningen (\$ 7 Landkreisordnung). De Hauptsatzung is verplicht ( 88 Landkreisordnung). Daar-

42. Wet, naar de tekst van 22-6-1982, Nieders. GVB1. S. 256, laatstelijk gewijzigd 14-7-1993, Nieders. GWB1. S. 137. 
nast beslist de Kreistag over het invoeren van belastingen, de vaststelling van de begroting, het oprichten van bedrijven en de deelname in samenwerkings verbanden. Bovendien kan de Kreistag zich bevoegdheden van de Kreisausschuss en de Oberkreisdirektor voorbehouden ( $\$ 36$ Landkreisordnung). Ter voorbereiding van zijn besiuitvorming kan de Kreistag Ausschüsse instellen ( $\$ 47$ Landkreisordnung). De voorzitter van de Kreistag is de Landrat. Hij wordt door de Kreistag gekozen en kan door deze ontslagen worden ( 8 40 Landkreisordnung). Bij hem berust de representatieve vertegenwoordiging van de Landkreis (\$26 Landkreisordnung).

\section{c. Kreisausschuss}

Naast de Kreistag is er ingevolge $\& 49$ Landkreisordnung de Kreisausschuss, die in de regel bestaat uit de Landrat, een bepaald aantal stemgerechtigde Jeden van de Kreistag, enkele leden van de Kreistag met raadgevende stem ( 847 Abs. 4 Landkreisordmung) alsmede de Oberkreisdirektor (met raadgevende stem, \$58 Abs. 2 Landkreisordnung). De vergaderingen van de Kreisausschuss zijn niet openbaar ( 853 Landkreisondnung). De Kreisausschuss is belast met de voorbereiding van de besluiten van de Kreistag. Hij is bevoegd voor die zaken waarvoor niet de Kreistag, eventuele Werkausschüsse of de Oberkreisdirektor bevoegd zijn ( $\$ 51$ Landkreisordnung). De Kreisausschuss kam bevoegdheden overdragen aan de Oberkreisdirektor (\$ 57 Abs. 2 Landkreisordnung).

\section{d. Oberkreisdirektor}

De Oberkreisdirektor wordt gekozen woor 12 jaar door de Kreistag en kan door deze ontslagen worden ( $\$ 55$ Landkreisordnung). De Oberkreisdirektor is met name bevoegd inzake de woorbereiding van besluiten van de Kreisausschuss, de uitvoering van besluiten van de Kreisausschuss en de Kreistag, het doorvoeren van besluiten van de toezichthoudende instanties (tenzij beleidsvrijheid aanwezig is) alsmede de lopende zaken. Hij vervult de taken van de Landkreis als Kommunal- en Fachaufsichtsbehôrde. In een aantal gevallen is daarbij de toestemming van de Kreistag vereist ( $\$ 57$ Landkreisordnung). Hij vertegenwoordigt de Kreis naar buiten toe o.a. in gerechtelijke en bestuursaangelegenheden ( $\$ 58$ Landkreisordnung). In spoedeisende gevallen kan hij maatregelen nemen ( 859 Landkreisordnung).

\section{e. Toezicht}

Het toezicht ten arnzien wan de Landkreise is op dezelfde wijze geregeld als ten aanzien van gemeenten (\$69 e.v. Landkneisordnung). Hiervoor word verwezen naar het gestelde in \$ 3.D.1.e. van dit hoofdstuk. De toezichthoudende instanties ten aanzien van de Landkreise zijin de Bezirksregierung als Kommunalaufsichtsbehörde en de Innenminister alls hogere/hoogste Kommunalaufsichstbehörde ( $\$ 70$ Landkreisordnung). 


\section{\$ 4. Het Nederlandse organieke recht inzake decentrale overheden}

\section{A. INLEIDING}

In de Benelux-Overeenkomst inzake decentrale grensoverschrijdende samenwerking en de Duits-Nederlandse Overeenkomst inzake decentrale grensoverschrijdende samenwerking worden een aantal Nederlandse decentrale owerheden genoemd, die kumen samenwerken. Voor beide verdragen betreft het de Nederlandse gemeenten, provincies en samenwerkingsverbanden op basis van de Wet gemeenschappelijke regelingen. De Benelux-Overeenkomst noemt bovendien de Nederlandse waterschappen. In het navolgende wordt het organieke recht inzake deze overheden, met uitzondering van het samenwerkingsrecht tussen decentrale overheden op basis van de Wet gemeenschappelijke regelingen, beschreven. ${ }^{43}$ Voor dit samenwerkingsrecht wordt verwezen naar hoofdstuk 52 . Voordat op de desbetreffende decentrale overheden wordt ingegaan, wordt een korte schets gegeven van de plaats van deze overheden in de bestuursopbouw van Nederland.

\section{B. BESTUURSOPBOUW VAN NEDERLAND}

In tegenstelling tot Belgiè en Duitsland is Nederland geen federale staat maar een gedecentraliseerde eenheidsstaat. Evenals België is Nederland een monarchie, met aan het hoofd een Koning (thans Koningin).

De beschrijving omtrent de bestuursopbouw van Nederland kan hier (vanwege de toch complexere staatsstructuur van de buurlanden) een stuk korter zijn dan die van België en Duitsland. Bovenaan de bestuursopbouw van Nederland staat één centrale overheid, namelijk de nationale. Op het middenniveau zijn er de provincies en op lokaal niveau de gemeenten. De status van wetgevende en uitvoerende bevoegdheden van de gedecentraliseerde overheid is hiërarchisch ondergeschikt aan die van de hogere. Naast deze territoriaal gedecentraliseerde overheden zijn er functionele, waarvan de waterschappen de belangrijksite zijn. Voor een schematisch overzicht van de plaats van de decentrale overheden in de bestuursopbouw van Nederland wordt verwezen naar figuur 3.

43. Bij de beschrijuing van het organieke rech inzake Nederlandse decentrale overheden is gebruit gemák wan de volgende literatur:

Van der Pot, Donner, Hand boek van het Nederland se statsrecht, a. w., hoofdstukken 36-40, p. 613-685; W. G. Verkruisen, B.C. Vis, Gemeenten Gemeentewet, 7e herz. druk, 1990; B. Brederveld, Gemeente recht, 20 druk, 1989 en supplement $1992 ;$ E. Brederveld. H.C. Schroot, N. Wijne, Begrip van de Nederlandse gemeente, 2e geh. herz. druk, 1990; M.J.M. Schoonhoven, Provincierech, 1991; B.C. Knieriem, De Geneentewet van oud naar nieuw, Vereniging van Nederlandse Gemeenten, 1993; I.J.L. Verburg (red.), De Waterschapowet, een artikelsgewijs commentar, 1992. 
figutur 3

Bestuursophouw van Nederland

\begin{tabular}{|l|l|l|l|}
\hline Niveau & Lichaam & $\begin{array}{l}\text { Wetgevend orgaan/ } \\
\text { volksvertegen- } \\
\text { woordiging }\end{array}$ & Uitvoerend orgaan \\
\hline Centraal & Staat & Staten-Generaal & Regering \\
\hline $\begin{array}{l}\text { Territoriale } \\
\text { decentralisatie }\end{array}$ & Provincies & Provinciale staten & $\begin{array}{l}\text { Gedeputeerde staten } \\
\text { Commissaris van de } \\
\text { Koning(in) }\end{array}$ \\
\cline { 2 - 4 } & Gemeenten & Gemeenteraad & $\begin{array}{l}\text { College van burgemees- } \\
\text { ter en wethouders } \\
\text { Burgemeester }\end{array}$ \\
\hline $\begin{array}{l}\text { Functionele } \\
\text { decentralisatie* }\end{array}$ & $\begin{array}{l}\text { Water- } \\
\text { schappen }\end{array}$ & Algemeen bestuur & $\begin{array}{l}\text { Dagelijks besturr } \\
\text { Voorzitter }\end{array}$ \\
\hline
\end{tabular}

* = Natst de waterschappenzijn er nog ale eveneens functioneel gedecentraliseerdepubliekrechtelijke bedrijfslichamen. Huerop wordt niet ingegarn.

\section{Gemeenten}

\section{Algemeen}

Artikel 123 Nederlandse Grondwet bepaalt, dat bij wet gemeenten kunnen worden opgeheven en nieuwe ingesteld. In artikel 124 Grondwet is bepaald, dat de bevoegdheid tot regeling en bestuur inzake de gemeentelijke huishouding an hun besturen wordt overgelaten. Artikel 125 Grondwet wijst de gemeenteraad aan als het hoofd van de gemecnte en noemt de andere gemeentelijke bestuursorganen, namelijk het college van burgemeester en wethouders en de burgemeester. Het primaat van de gemeenteraad blijkt 0. a. uit de bevoegdheid tot het vaststellen van verordeningen (art. 127 Grondwe). Voorts legt de Grondwet de rechtstreekse verkiezingen van de gemeenteraad vast, de zittingsduur ervan alsmede de openbaarheid van zijn vergaderingen. Artikel 132 Grondwet bepalt, dat 0. a. de inrichting van de geneenten alsmede de samenstelling en bevoegdheid van thun besturen, de te heffen belastingen en het toezicht op het gemeentebestuur bij wet geregeld wordt. De organieke wet inzake de gemeenten is de gemeentewet. ${ }^{44}$ Naar verwachting zal deze per 1-1-1994 vervangen worden door een vernieuw-

44. Wet van 29-6-1851, Stb. 85, laatstelijk gewijzigd bij wet wan 6-6-1991, Stb. 379. 
de gemeentewet. ${ }^{45}$ In het navolgende wordt uitgegaan van de bepalingen nieuwde gemeentewet (hierna: Nieuwe gemeentewet). Het toevoegsel ' $N$ de inwerkingtreding kunnen vervallen.

Artikel 109 lid $\mathbb{1}$ Nieuwe gemeentewet bepaalt, dat de regeling en het be huishouding van de gemeente aan het gemeentebestuur wordt overgelate Artikel 109 lid 2 Nieuwe gemeentewet bepaalt dat regeling en bestuur $t$ een wet van het gemeentebestuur kunnen worden gevorderd (medebewind woegdheden van de Nederlandse gemeenten - Nederland telit ongeveer 6 komen overeen met die van de Belgische en Duitse gemeenten. De Neder! ten kennen een drietal bestuursorganen: de raad, het college van burger houders en de burgemeester. Op de gemeentelijke bestuursorganen wo ingegaan.

\section{Raad}

De raad is het hoogste orgaan van de gemeente. Hij wordt rechtstreek: een periode van 4 jaar. Het aantal leden is afhankelijk van het antal i rieert van 9 tot 45 . Zijn vergaderingen zijn in beginsel openbaar (art. meentewet).

De raad is bevoegd commissies in te stellen (art. 82 e. v. Nieuwe gemeen hier om functionele commissies en territoriale comm issies (deelgemeente raad is bevoegd verordeningen vast te stellen, tenzij bij de wet of door $\mathrm{dt}$ de wet de bevoegdheid aan het college van burgemeester en wethoude meester is toegekend (art. 148 lid 1 Nieuwe gemeentewet). De overigt (andere dan de vaststelling van verordeningen) berusten bij de raad, ten college van burgemeester en wethouders of de burgemeester zijn toegek 2 Nieuwe gemeentewet).

Op basis van de Nieuwe gemeentewet is de raad bevoegd verordeninge hij van belang acht voor de gemeente (art. 150 Nieuwe gemeentewet). " verordeningen kan strafbaar gesteld worden door de raad (art. $155 \mathrm{Ni}$ wet). O.a. een inspraakverordening, een verordening omtrent de ambte alsmede een verordening inzake het vermogensbeheer zijn verplicht. mogen niet in strijd zijn met hogere regelingen (wetten, algemene maa stuur, provinciale verordeningen). Bepalingen van gemeentelijke veror onderwerp door hogere regelingen wordt voorzien, zijn van rechtsweg 122 an 123 Nieuwe gemeentewet).

Andere bevoegdheden van de raad zijn het vaststellen van de begroting ( gemeentewet), het nemen van besluiten omtrent (de invoering e.d. van) 218 Nieuwe gemeentewet), warbij artikel 221 Nieuwe gemeentewet de

45. Wet van 14-2-1992, Stb. 96 (nog riet in werking getreden). Overigens hebben sim Staatsblac nog enkele vooral technische en redactionale wijzigingen van de tekst pl deze relevant zijn worden zij aangegeven. Zie: Wijziging van de Gemeentewet en wetten met het oog op de invoering van de Gemeenteswet en vaststelling van het tijds ding van de Gemeentowet (Invoeringswet Gemeentewet), Gewijzigd voorstel wat vergaderjaar 1992-1993, 22893 , nr. 347 . 
tingen aangeeft, alsmede het nemen van besluiten tot het oprichten van en deelnemen in stichtingen, verenigingen, vennootschappen e.d (art. 156 Nieuwe gemeentewet). Bepalde bevoegdheden van de raad kunnen aan het college van burgemeester en wethouders en aan commissies worden overgedragen. Artikel 157 Nieuwe gemeentewet noemt de niet over te dragen bevoegdheden, zoals o.a. het vaststellen van de begroting en het stellen van straf op overtreding van gemeentelijke verordeningen.

\section{College van burgemeester en wethouders}

De wethouders worden uit en door de raad benoemd (art. 35 Nieuwe gemeentewet). Het aantal wethouders is minimaal 2 en is maximaal $20 \%$ van de raadsleden (art. 36 Nieuwe gemeentewet).

Voorzover niet bij of krachtens de wet de burgemeester belast is met het dagelijks bestuur, berust dit bij het college van burgemeester en wethouders (art. 161 Nieuwe gemeentewet). Het college bereidt de vergaderingen van de raad voor en is belast met de uitvoering van de raadsbesluiten. In o. a. dat verband theeft het college handhavingsbevoegdheden, zoals het aanzeggen van bestuursdwang (art. $126 \mathrm{e} . \mathrm{v}$. Nieuwe gemeentewet) en het opleggen van een dwangsom (art. 137 e.w. Nieuwe gemeentewet). Overigens kunnen ook de andere gemeentelijke organen, in aangelegenheden waarin zij bevoegd zijn, beschikken over deze handhavingsbevoegdheden. Voorts heeft het college een aantal bevoegdheden met betrekking tot het voeren van rechtsgedingen (art. 165 Nieuwe gemeentewet). Op het terrein van de civiele verdediging draagt het college de zorg dat de voorbereiding ervan naar behoren geschiedt (art. 164 Nieuwe gemeentewet).

Bevoegdheden van het college kunnen door het college aan een van de leden gemandateerd (art. 170 Nieuwe gemeentewet) of door de raad aan commissies gedelegeerd (art. 167 Nieuwe gemeentewet) worden. Bovendien kan de uitvoering van bevoegdheden door het college gedlelegeerd worden aan amtenaren (art. 168 Nieuwe gemeentewet).

Tot slot kan nog opgemerkt worden dat het college van burgemeester en wethouders bij taakverwaarlozing door de raad c.q. commissie in plaats van deze besluiten kan nemen (art. 124 Nieuwe gemeentewet).

\section{Burgemeester}

De burgemeester wordt bij koninklijk besluit benoemd voor een periode van 6 jaar. Hij kan te allen tijde ontslagen worden (art. 61 Nieuwe gemeentewet). Ook kan hij geschorst worden (art. 62 Nieuwe gemeentewet). De burgemeester is de voorzitter van de raad (art. 6 Nieuwe gemeentewet) en de voorzitter van het college van burgemeester en wethouders (art. 34 Nieuwe gemeentewet). Hij is geen lid van de gemeenteraad en heeft hierin geen stem, hoewel hij aan de beraadslagingen mag deelnemen (art. 21 juncto art. 68 Nieuwe gemeentewet). Hij is wel stemgerechtigd in het college van burgemeester en wethouders.

De burgemeester is belast met de handhaving van de openbare orde (art. 174 Nieuwe gemeentewet). Hij kan daarbij beschikken over de politie. In noodgevallen beschikt hij over bijzondere bevoegdheden (art. 178 en 179 Nieuwe gemeentewet). Hij heeft het opperbevel bij brand (art. 175 Nieuwe gemeentewet). Hij is bevoegd met het toezicht op de openbare samenkomsten en vermakelijkheden (art. 176 Nieuwe gemeentewet). De 
burgemeester vertegenwoordigt de gemeente in en buiten rechte (art. 173 Nieuwe gemeentewet).

\section{Toezicht}

De goedkeuring van besluiten van het gemeentebestuur is geregeld in artikel 256 e.v. Nieuwe gemeentewet. Voorafgaand toezicht is alleen mogelijk indien dit bij wet is bepaald. De Nieuwe gemeentewet vereist bijvoorbeeld (voorafgaande) goedkeuring ten aanzien van besluiten tot oprichting of deelneming in stichtingen, vennootschappen e.d. en de vaststelling van de begroting. De gronden voor weigering van goedkeuring kunnen verschillen. Gedeputeerde staten zijn in beginsel de goedkeurende instantie, tenzij goedkeuring door de minister van binnenlandse zaken dan wel bij koninklijk besluit is vereist. In het laatste geval, bijvoorbeeld bij de invoering van belastingen, beslist de $\mathrm{K}$ roon. Het gemeentebestuur kan bij de Kroon in beroep gaan tegen besluiten (tot weigering van goedkeuring) van gedeputeerde staten of wan de minister van binnenlandse zaken.

De (repressieve) vernietiging van besluiten van het gemeentebestuur is geregeld in artikel 265 e.v. Nieuwe gemeentewet. Indien de burgemeester van oordeel is dat een besluit voor vernietiging in aanmerking komt, doet hij daarvan mededeling aan de minister van binnenlandse zaken. Besluiten van het gemeentebestuur kunnen vernietigd worden door de Kroon wegens strijd met de wet of het algemeen belang. Hangende de procedure van vernietiging kunnen de besluiten worden geschorst. Tegen schorsings- en vernietigingsbesluiten wordt op korte termijn (waarschijnlijk per 1-1-1994) een rechtsgang mogelijk bij de Afdeling Bestuursrechtspraak van de Raad van State, die in eerste en enige instantie beslist. ${ }^{46}$ Hier dient nog opgemerkt te worden dat tevens is voorzien in een taakverwaarlozingsregeling (dwangtoezicht), waarbij gedeputeerde staten besluiten kunnen nemen in plaats van het college van burgemeester en wethouders of de burgemeester (art. 125 Nieuwe gemeentewet). Op langere termijn wordt het toezicht op bestuursorganen algemeen geregeld in de Algemene wet bestuursrecht. De daarin voorziene regeling

46. Tweede nota van wijziging bij ther wetsvoorstel Wijziging van de Wet op de rechterlijke orga nisatie de Agenene wet besturrstecht, de Wet op de Ratd van Stedte, de Beroepswet, de Ambtenarenwet 1929 an andere wetten, alsmede intrekking wa de Wet administratieve rechtsprak overbeidsbeschikkingen (wolwooung erste fase herziening rechterlike organisatie) IWwede Kamer, vergaverjar 1992-1993, 22495, nr. 12, p. 15-17. Genoemd wetswoorstel (zie ook Nader gewijzigd wetswoorstel, Eerste Kamer, wergaderjaar 1992-1993, 22495, nr. 310, p. 62-64) woorziet in een artikel 278a Nieuwe gemeentewet, dat luidt: "1. Een belanghebbende kan tegen een beshit als bedoeld in artikel 265 , eerste ofl" tweede lid, berocp in stellen bij de Afdeling bestukrsrechispraak van de Raad van State. 2 . In a fwijking wan artikel 6.2 wan da. Algemene wet bestuurstecht kan geen beroep worden ingesteld tegen de schriftelijke weigering een besluit tot schorsing of vernietiging te nemen en tegen het niet tijdig nemen wan een beslugt tot schorsing of vernietiging."

Owerigens is het uitgangspunt dat het gehele Kroonberoep per 1-1-1994 zal verdwijnen en verwangen zat worden door de rechtsgang tegen besluiter op basis van de Awb. Een dergelijke rechtsgang zal ook ten aanien wan goedkeuringshesluiten van de Kroon regel worden.

Owerigens is onder het hudige rech een beroepsgang (door decentrate overheden) bij de gewone rechre tegen spontane verrietiging sbesluiten van de Kroon (als miet met voldoende waraborgen onklede rechts gang) niet uitgesloten. Zie: HA S-2-1993, AB 1993,239 (Welzijnsconenant Rotterdam). Een en ander zal miet anders zijn wat betreft goedkeuringsbesiluiten van de Kroon.

Zie tevens het gestelde in $\$ 5$. D.6.a. in hoofdsuk 5. 
wijkt niet dan wel nauwelijks af van die in de Nieuwe gemeentewet (alsmede de Nieuwe provinciewe: en de Waterschapswet). ${ }^{47}$

\section{PROVDNCIES}

\section{Algemeen}

Artikel 123 van de Nederlandse Grondwet bepaalt, dat bij wet provincies kunnen worden opgeheven en nieuwe ingesteld. In artikel 124 Grondwet is bepaald, dat de bevoegdheid tot regeling en bestuur inzake de provinciale huishouding aan hun besturen wordt overgelaten. Artikel 125 Grondwet wijst prownciale staten aan als het hoofd van de prowincie en noemt de andere provinciale bestuursorganen, namelijk gedeputeerde staten en de commissaris van de Koning(in). Het primaat van provinciale staten bijikt o.a. uit de bevoegdheid tot het vaststellen van verordeningen (art. 127 Grondwet). Voorts legt de Grondwet de rechtstreekse verkiezingen van provinciale staten wast, de zittingsduur ervan alsmede de openbaarheid van hun vergaderingen. Artikel 132 Grondwet bepaalt, dat de inrichting van de provincies alsmede de samenstelling en bevoegdheid van hun besturen, de te heffen belastingen en het toezicht op het provinciebestuur bij wet geregeld worden. Het organieke recht inzake de provincies is geregeld in de Provinciewet. ${ }^{48}$ Naar verwachting zal deze per 1-1-1994 vervangen worden door een nieuwe Provinciewet. ${ }^{49}$ In het navolgende wordt uitgegaan van de bepalingen van deze vernieuwde provinciewet (hierna: Nieuwe provinciewet). Het toevoegsel 'Nieuwe' zal met de inwerkingtreding kunnen vervallen.

Artikel 106 lid 1 Nieuwe provinciewet bepaalt dat de bevoegdheid tot regeling en bestuur inzake de huishouding van de provincie aan het provinciaal bestuur wordt overgelaten (autonomie). Artikel 106 lid 2 Nieuwe provinciewet bepaalt dat regeling en bestuur gevorderd kunnen worden bij of krachtens wet (medebewind). De taken/bevoegdheden van de 12 Nederlandse provincies manifesteren zich met name op het terrein van de ruimtelijke ordening, het milieu, cultuur en welzijn en economische ontwikkeling. Het provinciaal bestuur kent een drietal bestuursorganen, namelijk provinciale staten, gedleputeerde staten en de commissaris van de Koning(in). Op de desbetreffende bestuursorganen wordt hier nader ingegaan.

\section{Provinciale staten}

Provinciale staten zijn het hoogste bestuursorgaan van de provincie en worden voor 4 jaar rechtstreeks gekozen door de inwoners van de provincie. Het aantal leden is afhan-

47. MvT bij titel 1A.2 van het Voorontwerp van Welt tot anwulling wan de Algemene wet bestuurstecht (Derde tranche Algemene wet bestuurstecht), 1992, p. 195.

48. Wet Wan 25-1-1962, Stb. 17, laristelijk gewijzigd, 19-12 1991, Stb. 790

49. Wet van 10-9w1992, Stb. 550 . Overigens hebben sinds de plattsing in het Startsblad nog enkele vooral technische en redactionals wijzigingen van de tekst platsgevonden. Indien deze relevant zijn warden zij aangegeven. Zito: Wijziging van de Providievet en een aantal andere wetten met het oog op de invoering van de Prowinciewet en waststelling wan het tijdstip van inwerkingtreding van de Provinchewet lnwooringswet Provinciewel). Tweede Kamer, wergaderjakr 1992-1993, 23086, nrs. 1 e. $\%$. 
kelijk van de bevolking en varieert van 39-83 (art. 8 Nieuwe provinciewet). De vergaderingen van provinciale staten zijn in beginsel openbaar (art. 23 Nieuwe Provinciewel). Provinciale staten zijn bevoegd commissies in te stellen (art. $80 \mathrm{e} . \mathrm{v}$. Nieuwe provinciewet). Het kan hier om functionele commissies en territoriale commissies (deelprovincieraden) gaan. Provinciale staten zijn bevoegd verordeningen vast te stellen, tenzij bij de wet of door provinciale staten krachtens de wet de bevoegdheid aan het college van gedeputeerde staten of de commissaris van de Koningin is toegekend (art. 144 lid 1 Nieuwe provinciewet).

De overige bevoegdheden (andere dan de vaststelling van verordeningen) berusten bij provinciale staten, tenzij deze aan gedeputeerde staten of de commissaris van de Koningin zijn toegekend (art. 144 lid 2 Nieuwe provinciewet).

Op basis van de Nieuwe provinciewet zijn provinciale staten bevoegd de verordeningen te maken die zij van belang achten voor de provincie (art. 146 Nieuwe provinciewet). Provinciale staten kunnen straf stellen op de overtreding van verordeningen (art. 151 Nieuwe provinciewet). O.a. een inspraakverordening, een verordening omtrent de ambtelijke organisatie, een verordening inzake het vermogensbeheer alsmede waterschapsverordeningen zijn verplicht. Provinciale verordeningen mogen niet in strijd zijn met hogere regelingen (wetten, algemene maatregelen van bestuur). Bepalingen van provinciale verordeningen, in wier onderwerp door hogere regelingen wordt voorzien, houden van rechtswege op te gelden (art. 119 en 120 Nieuwe provinciewet).

Andere bevoegdheden van provinciale staten zijn het vaststellen van de begroting (art. 195 Nieuwe provinciewet), het nemen van besluiten omtrent (invoering e.d. van) belas tingen (art. 222 Nieuwe provinciewet), waarbij artikel 223 Nieuwe provinciewet de mogelijke belastingen aangeeft, alsmede het nemen van besluiten tot het oprichten van en deelnemen in stichtingen, verenigingen, vennootschappen e.d (art. 152 Nieuwe provinciewet). Bepaalde bevoegdheden van provinciale staten kunnen aan het college van gedeputeerde staten en aan een commissie worden overgedragen. Artikel 153 Nieuwe provinciewet noemt de niet over te dragen bevoegdheden, zoals b.v. het vaststellen van de begroting en het stellen van straf op overtreding van provinciale verordeningen.

\section{Gedeputeerde staten}

De gedeputeerden (minimaal 3 en ten hoogste 9) worden uit en door provinciale staten benoemd (art. 35 Nieuwe provinciewet). Behalve de voorzitter, zijnde de commissaris van de Koningin, maken de gedeputeerden tevens deel uit van provinciale staten. Voorzover niet bij of krachtens de wet de commissaris van de Koningin belast is met het dagelijks bestuur, berust dit bij gedeputeerde staten (art. 159 Nieuwe provinciewet). Gedeputeerde staten bereiden de vergaderingen van de provinciale staten voor en zijn belast met de uitvoering van de besluiten van provinciale staten. O.a. in dat verband heeft het college van gedeputeerde staten handha vingsbe voegdheden, zoals het aanzeggen van bestuursdwang (art. 123 e.v. Nieuwe provinciewet) en het opleggen van een dwangsom (art. 134 e.v. Nieuwe provinciewet). Overigens kunnen ook de andere provinciale organen, in aangelegenheden waarvoor deze bevoegd zijn, over deze handhavingsbevoegdheden beschikken. Voorts heeft het college een aantal bevoegdheden met betrekking tot het voeren van rechtsgedingen (art. 163 Nieuwe provinciewet). Op het terrein 
van de civiele verdediging berust bij gedeputeerde staten de zorg dat de voorbereiding ervan naar behoren geschiedt (art. 162 Nieuwe provinciewet).

Bewoegdheden van gedeputeerde staten kunnen door dit college aan een van de leden gemandateend (art. 168 Nieuwe provinciewer) of door provinciale staten aan commissies gedelegeerd (art. 165 Nieuwe provinciewet) worden. Bovendien kan de uitvoering van bevoegdheden door gedeputeerde staten gedelegeerd worden aan ambtenaren (art. 166 Nieuwe provinciewet).

Gedeputeerde staten delen besluiten van gemeenteraden c.q. colleges van burgemeester en wethouders, die voor vernietiging in aanmerking komen, mee aan de minister van binnenlandse zaken. Gedeputeerde staten vervullen een belangrijke rol met betrekking tot administratieve geschillenbeslechting (art. 170 Nieuwe provinciewet). Zo trachten zij geschillen tussen overheden in hun provincie in der minne te doen bijleggen en, indien zij daar niet in slagen, voor te dragen ter beslissing bij koninklijk besluit (art. 176 Nicuwe provinciewet).

Tot slot kan nog opgemerkt worden dat gedeputeerde staten bij taakverwaarlozing door provinciale staten $c_{.} q$. een commissie besluiten in hun plaats kunnen nemen (art. 121 Nieuwe provinciewet).

\section{Commissaris van de Koning(in)}

De commissar is van de Koningin wordt bij koninklijk besluit benoemd woor een periode van 6 jaar. Hij kan te allen tijde ontslagen worden (art. 61 Nieuwe provinciewer). Ook kan hij geschorst worden (art. 62 Nieuwe provinciewet).

De commissar us van de Koningin is de woorzitter van provinciale staten (art. 9 Nieuwe provinciewet) en de voorzitter van gedeputeerde staten (art. 34 Nieuwe provinciewet). Hij is geen lid van provinciale staten en heeft hierin geen stem, hoewel hij aan de beraadslagingen mag deelnemen (art. 21 juncto art. 67 Nieuwe provinciewet). Hij is wel stemgerechtigd in het college van gedeputeerde staten.

De commissaris van de Koningin vertegenwoordigt de provincie in en buiten rechte (art. 178 Nieuwe provinciewet). De commissaris van de Koningin deelt besluiten van burgemeesters, die voor vernietiging in aanmerking komen mee aan de minister van binnenlandse zaken. Hij is o.a. belast met het bevorderen van de samenwerking tussen de in de provincie werkzame rijksambtenaren onderling en met het provinciaal bestur, de gemeentebesturen en de waterschapsbesturen en de coördinatie van de voorbereiding van de civiele verdediging (art. 184 Nieuwe provinciewet).

\section{Toezicht}

De goedkeuring van besluiten van het provinciebestuur is geregeld in artikel 257 e. $v$. Nieuwe provinciewet. Voorafgaand toezicht is alleen mogelijk indien dit bij wet is bepaald. De Nieuwe provinciewet vereist b.w. (voorafgaande) goedkeuring ten aanzien wan besluiten tot oprichting of deelneming in stichtingen, vennootschappen e.d. en de vaststelling van de begroting. De gronden voor weigering van goedkeuring kunnen verschillen. De minister van binnenlandse zaken is in beginsel de goedkeurende instantie, tenzij goedkeuring bij koninklijk besluit is vereist. In dat geval beslist de Kroon. De 
Kroon is tevens beroepsinstantie. Tegen de beslissing van de minister van binnenlandse zaken kan het provinciebestuur beroep instellen bij de Kroon.

De (repressieve) vernietiging van besluiten van het provinciebestuur is geregeld in artikel 265 e.w. Nieuwe provinciewet. Indien de commissaris van de Koningin van oordeel is dat besluiten voor vernietiging in aanmerking komen, doet hij darvan mededeling aan de minister van binnenlandse zaken. Beslutten kunnen vernietigd worden door de Kroon wegens strijd met de wet of het algemeen belang. Hangende de procedure van vernietiging kumnen de besluiten door de Kroon worden geschorst. Tegen schorsings- en vernietigingsbesluiten wordt op korte termijn (waarschijnlijk per 1-1-1994) voor belanghebbenden een rechtsgang mogelijk bij de Afdeling bestuunsrechtspraak van de Raad wan State, die in eerste en enige instantie beslist. ${ }^{50}$

Hier dient nog opgemerkt te worden dat is voorzien in een taakverwaarlozingsregeling (dwangtoezicht), waarbij de minister van binnenlandse zaken besluiten kan nemen in plaats van gedeputeerde staten of de commissaris wan de Koningin (art. 122 Nieuwe provinciewet).

Op langere termijn wordt het toezicht op bestuursorganen algemeen geregeld in de Algemene wet bestuursrecht. De voorziene regeling wijkt niet dan wel nauwelijks af van die in de Nieuwe provinciewet (alsmede de Nieuwe gemeentewet en de Waterschapswet). 51

\section{E. WATERSCHAPPEN}

\section{Algemeen}

Gaat het bij de gemeenten en provincies om territoriaal gedecentraliseerde overheden, de waterschappen zijn functioneel gedecentraliseerde overheden. In tegenstelling tot gemeenten en provincies zijn de waterschappen geen lichamen van algemeen bestuur, maar oefenen zij slechts bepaalde taken uit. Artikel 133 Nederlandse Grondwet bepaalt "dat de opheffing en instelling van waterschappen, de regeling wan hun taken en inrichting, alsmede de samenstelling van hun besturen geschieden volgens de bij wet te stellen regels bij provinciale verordening, voorzover bij of krachtens de wet niet anders is bepaald. "Tevens bepaalt artikel 133 Grondwet dat de wet de verordenende en andere bevoegdheden van de waterschapsbesturen, de openbaarheid van hun vergaderingen alsmede het provinciale en overige toezicht op de waterschapsbesturen regelt. De meeste organieke bepalingen inzake de waterschappen zijn te vinden in de Waterschapswet. ${ }^{52}$ De taken/bewoegdheden wan de waterschapsbesturen op basis van de Waterschapswet

50. Het Wetswoorstel vollooing eerste fase herziening rechterlike organisetie, a.w., (zie noot 46 van dit hoofdstuk), woorziet in een artikel $278 \mathrm{a}$ Nieuwe provinciewet, dat luidt: " 1 . Fen belanghabbende kan begen een besluit als bedoeid in artikel 265 , eerste of twede lid, beroep in stellen bij de Afdeling bsstuursrechtspraak wan de Ralad van State. 2 . In afwijking wath artikel 6.2 wan de Algemene wet bestuursrech kan geen beroep worden ingesteld tegen de schriftelike weigering een besluit tot schorsing of vermetiging te nemen en tegen lhet niet thidig nemen van een besluit tot schorsing of vernietiging."

51. MvT bij titel 1A.2 wan het Voorontwerp van Wet tot aanulling van de Algemene wet bestuursrecht (Derde tranche Algemene wet bestuursrecht), $1992, \mathrm{p} .195$.

52. Wet van 6-6-1991, Sbb. 379, herplatst Stb. 444, laatstelijk gewijzigd bij Wet van 18-12-1991, \$tb. 1992, 13. 
betreffen de waterkering/waterhuishouding (waterkwantiteitsbeheer) (art. 2 Waterschapswet).

Veelal zijn waterschappen (zuiveringschappen) ook bevoegd inzake het waterkwaliteitsbeheer (op basis van de Wet verontreiniging oppervlakte wateren). De bevoegdheid tot het instellen en opheffen van waterschappen berust bij provinciale staten. Op dit moment wordt een aantal van de in totaal ca. 120 Nederlandse waterschappen samengevoegd. Ten aanzien van het besluit van provinciale staten in deze (reglement) is de goedkeuring vereist van de minister wan verkeer en waterstaat (art. 2 e.v. Waterschapswet). De Waterschapswet voorziet in de mogelijke instelling van interprovinciale waterschappen (art. 6 e.v. Waterschapswet). Het bestuur wan het waterschap bestaat uit een algemeen bestuur, een dagelijks bestuur en een voorzitter. Deze zullen in het navolgende beschreven worden. Mogelijk kunnen binnen een waterschap afdelingen worden ingesteld. De samenstelling van het bestuur van deze afdelingen wordt geregeld bij of krachtens het (instellings)reglement. Hierop wordt niet nader ingegaan.

\section{Algemeen bestuur}

Het algemeen bestuur van het waterschap wordt in tegenstelling tot de gemeenteraad en provinciale staten niet rechtstreeks gekozen. Het wordt voor 4 jaar samengesteld uit vertegenwoordigers van categorieën van belanghebbenden bij de uitoefening van de taken van het waterschap. Artikel 11 Waterschapswet somt de betreffende categoricën op. Het betreft o.a. eigenaren en pachters van onbebouw de onroerende zaken.

Het waterschapsbestuur is bevoegd tot regeling en bestuur ter behartiging van de taken die het waterschap in het reglement zijn opgedragen. Daarnaast kan regeling en bestuur worden gevorderd bij wet, algemene matregel van bestuur of provinciale verordening (art. 56 Waterschapswet). Artikel 77 Waterschapswet voegt daaraan toe dat de bevoegdheden van regeling en bestuur op basis van artikel 56 Waterschapswet berusten bij het algemeen bestuur, zover deze niet bij of krachtens reglement dan wel bij wet of algemene maatregel van bestuur zijn toegekend aan het dagelijks bestuur, aan de voorzitter of de afdeling. Het algemeen bestuur kan verordeningen (keuren) vaststellen, waarvan overtreding met straf bedreigd kan worden (art. 78 juncto 81 Waterschapswet). Een inspraakverordening is verplicht (art. 79 Waterschapswet), alsmede een verordening met betrekking tot de organisatie van de administratie en het beheer van vermogenswaarden (art. 108 Waterschapswet). De artikelen 110 e.v. Waterschapswet bevatten regels voor" het vaststellen (bij verordening) van waterschapsbelastingen. Het algemeen bestuur kan bevoegdheden overdragen aan het dagelijks bestuur, indien dit bij het reglement is bepaald. Ten aanzien van de overdracht van de bevoegdheid tot het maken van keuren gelden evenwel restricties (art. 83 Waterschapswet).

\section{Dagelijks bestuur}

Het dagelijks bestuur bestaat uit de voorzitter en een aantal bij reglement te bepalen andere leden (art. 40 Waterschapswet). De andere leden worden door en in beginsel uit het algemeen bestuur benoemd. Het dagelijks bestuur is belast met de dagelijkse aangelegenheden, tenzij deze aan de voorzitter bij het reglement zijn opgedragen. Het dagelijks bestuur is belast met de uitvoering van de besluiten van het algemeen bestuur (art. 84 
Waterschapswet). De leden van het dagelijks bestuur kunnen over opsporingsbe voegdheden beschikken (art. 85 Waterschapswet). Het dagelijks bestuur bezit enkele bevoegdheden inzake het voeren van rechtsgedingen (art. 86 Waterschapswet). Bevoegdheden van het dagelijks bestuur kunnen onder voorwaarden worden overgedragen door het algemeen bestuur aan afdelingen of cloor het dagelijks bestuur aan een of meer van zijn leden (art. 87 en 88 Waterschapswet). De artikelen $90 \mathrm{t} / \mathrm{m} 93$ bevatten bijzondere bewoegdheden voor het dagelijks bestuur, zoals de bevoegdheid bij dreigend gevaar maatregelen te nemen, desnoods met afwijking van andere dan bij de Grondwet gegeven voorschriften.

\section{Voorzitter}

De voorzitter wordt bij koninklijk besluit voor 6 jaar benoemd (art. 46 Waterschapswet). Hij heeft de leiding van de vergaderingen van het dagelijks en algemeen bestuur. In het eerste is hij stemgerechtigd, in het laatste heeft hij een raadgevende stem (art. 94 Waterschapswet). De voorziter vertegenwoordigt het waterschap in en buiten rechte (art. 95 Waterschapswet). In gevallen van dreigend/dringend gevaar kan hij de maatregelen nemen, waartoe het algemeen bestuur en het dagelijks bestuur bevoegd zijn (artikel 96 Waterschapswet).

\section{Toezicht}

Buiten de bij de wet aangewezen besluiten, behoeven, voorzover bij reglement bepaald, aan de goedkeuring van gedeputeerde staten slechts te worden onderworpen besluiten met betrekking tot regeling van waterbeheersing en aanleg en verbetering van waterstaatswerken (art. 148 Waterschapswet). Tegen de beslissing van gedeputeerde staten is Kroonberoep mogelijk door het waterschap en andere belanghebbenden. Overigens kunnen alle besluiten van het waterschapsbestuur door gedeputeerde staten worden vernietigd wegens strijd met het recht of het algemeen belang. Deze vernietigingsgronden vloeien voort uit artikel 133 Nederlandse Grondw et. De voorzitter heeft de bevoegdheid voor vernietiging vatbare besluiten mede te delen aan gedeputeerde staten (art. 158 Waterschapswet). Hangende het onderzoek tot vernietiging kunnen de besluiten geschorst worden (art. 156 Waterschapswet). Tegen vernietigingsbesluiten wordt op korte termijn (waarschijnlijk per 1-1-1994) het beroep op de Kroon vervangen door een rechtsgang bij de rechter. ${ }^{53}$

53. Vgl. noot 46 en 50 wan dit hoofdstuken het daar aangehalalde Nader gewijzigd voorstel van wet, a.w., p. 119-121. In de Waterschapswet worden enkele artikelen gewijzigd, waardoor bij goed keurings- en wernietigingsbesluiten in een rechtsgang word voorzien. Owerigens word niet in eenzelf de artikel voorzien als het nieuwe artikel 278 a (Nieuwe) gemeente-en provinciewet. De belangrijkste wijzigingen worden opgenomen in artikel 5 lid 3 (beroep bij de Afdeling bestuurse chtspraakinzake goedkeuring van een besluit van provinciale staten tot opheffing van een waterschap/wijzigentalak waterschap), artikel 151 (beroep bij de rechtbankt tegen een besluit van gedeputeerde staten inzake goedkeuring, met uitzondering van een werordening ex art. 110 lid 1 en 119 lid 1 ) juncto artikel 155 (beroep bij de rechtbank tegen bepaalde goedkearingsbesiuiten wan gedeputeerde staten), artikel 162 (beroep bi) de rechtbank tegen vernietigingsbesluiten van gedeputeerde staten). 
Voor het toezicht op de interprovinciale waterschappen dienen de hierop betrekking hebbende reglementen een regeling te bevatten (art. 164 Waterschapswet).

Op termijn wordt het toezicht op bestuursorganen algemeen geregeld in de Algemene wet bestuursrecht. De woorziene regeling wijkt niet dan wel nauwelijks af van die in de Waterschapswet (alsmede de Nieuwe prowinciewet en de Nieuwe gemeentewet). ${ }^{54}$

\section{Samenvattende vergelijking België, Duitsland en Nederland}

\section{A. IMLEIDNG}

In dit hoofdstuk stond de bestuursorganisatie alsmede de (autonome) bevoegdheids verdeling tussen de bestuursorganen van de op bas is van de Benelux-Overeenkomst en de Duits-Nederlandse Overeenkomst totpubliekrechtelijke grensoverschrijdende samenwerking gerechtigde decentrale overheden centraal. Door het beschrijven van het administratieve toezicht op de diverse decentrale overheden kwam de verhouding met hogere overheden aan de orde. Er kan mijns inziens gesteld worden, dat de organisatie van de Belgische gemeente- en provinciebesturen overeenkomt met die van hun Nederlandse counterparts en hierdoor geen barrière vormt voor grensoverschrijdende samenwerking. Voor Duitsland en Nederland kan hetzelfde gezegd worden voor de gemeentebesturen. Voor de Nederlandse provincies is niet een directe Duitse equivalent voor handen, waardoor de grensoverschrijdende samenwerking bemoeilijkt zou kunnen worden. Een probleem voor de Nederlandse waterschappen is, dat zij slechts kunnen samenwerken met Belgische counterparts, maar niet met die in Noordrijn-Westfalen en Nedersaksen. ${ }^{55}$

Grensoverschrijdende samenwerking wordt behalve door een vergelijkbare organisatie verder vergemakkelijkt als de sectorbevoegdheden van de diverse decentrale overheden overeenkomen. Het ruw geschetse taken/bevoegdhedenpakket van de gemeenten in de drie landen komt overeen. Voor de Belgische en Nederlandse provincies alsmede de Nederlandse provincies en de Duitse Kreise is dit al minder het geval. Het viteenlopen van sectorbevoegdheden, zowel qua inhoud als qua overheidsniveau, kan problematisch zijn voor de samenwerking. Voor het geven van een totaaloverzicht van de precieze inhoud van alle sectorbevoegdheden en welke overheden hierover beschikken is een zeer uitgebreid onderzoek noodzakelijk, hetgeen het kader van dit proefschrift te buiten gaat. In het navolgende wordt een korte samenwattende vergelijking gegeven van het organieke recht van de tot publiekrechtelijke grensoverschrijdende samenwerking gerechtigde decentrale overheden in de desbetreffende landen. Eerst worden enkele algemene opmerkingen gemaakt 5.B.). Vervolgens gebeurt de vergelijking vanuit de optiek van de grensoverschrijdende samenwerking in het Belgisch-Nederlands (\$ 5.C.) respectievelijk Duits-Nederlands (\$ 5.D.) grensgebied.

54. MvT bij titel L.2 van het Voorontwerp van Wet tot anvilling wan de Algemene wet bestuursrecht (Derde tranche Algemene wet bestuurstechly, 1992, p. 195.

55. Vel. hoofdstuk 6 5.An voor de samenwerking op basis wan het Grenswerdrag tuscen Nederlandse waterschappen en Duitse Wasserverbande. 


\section{B. AlGEMEEN}

Zowel in Belgie als in Duitsland en Nederland hebben in de loop van de tijd de algemene (vergelijkbare) bevoegdheden op basis van de organieke wetgeving plaats moeten maken voor bevoegdheden op basis van de sectorwetgeving. In Nederland en ook wel in Belgie wordt in deze het verschil tussen autonomie en medebewind gemaakt. In Duitsland wordt een vergelijkbaar onderscheid gemaakt, namelijk dat tussen 'Selbstverwaltung' versus 'Auftragsverwaltung' ('Auftragsangelegenheiten'). Bij de Selbstwerwaltung wordt een onderscheid gemaakt tussen de "freie" en "pflichtige" Selbstverwaltungsaufgaben". Bij de "freie' gaat het om bevoegheden op basis van de organieke wetgewing. Een voorbeeld van een belangrijke 'pflichtige' bevoegdheid is die inzake thet opstellen van ruimtelijke plannen op basis van het Baugesetzbuch. Overigens kunnen de 'pflichtige" weer onderverdeeld worden in die waarbij bepaalde aanwijzingen doorgevoerd dienen te worden of niet. Daar waar dit het geval is, komen zij overeen met de "Auftragsverwaltung". Daar gaat het niet meer om eigen aangelegenheden, maar om zaken, die staatsaangelegenheden zijn maar uitgeoefend worden door de decentrale overheden. Wat hiervan ook zij, van belang is dat in Duitsland ten aanzien van de 'freie' en "pflichtige Selbstverwaltung" in beginsel een (repressief) rechtsmatigheidstoezicht. geldt en ten aanzien van de 'pflichtige nach Weisung' en de 'Auftragsangelegenheiten' een recht- en doelmatigheidstoezicht. In Belgie en Nederland is er op dit punt ten aanzien van het toezicht eigenlijk geen verschil. Zowel bij autonomie als medebewind is in de regel sprake van een (repressief) recht- en doelmatigheidstoezicht (strijd met de wet c.q. het algemeen belang). Wat betreft het voorafgaand toezicht ten aanzien van autonome bevoegdheden (b.v. verordeningen) geldt in de drie llanden de regel dat dit niet mogelijk is, tenzij bij de wet aangegeven.

\section{NEDERLAND-BELGIË}

De overheden die op basis van de Benelux-Overeenkomst tot samenwerking overgaan, zullen in eerste instantie de gemeenten en provincies zijn. Zoals aangegeven lenen de taken/bevoegheden van de Belgische o.c.m.w.'s zich waarschijnlijk niet zo snel voor grensoverschrijdende samenwerking. Op het tertein van het waterkwantiteitsbeheer ligt samenwerking tussen de Belgische polders/wateringen en de Nederlandse waterschappen wel voor de hand. Op dit moment is het aantal polders/wateringen evenwel gering. Overigens zal de grensoverschrijdende samenwerking met de polders/wateringen kunnen toenemen als gevolg van de toekomstige verandering van het Belgische wettelijke regime inzake polders/wateringen.

Ten aanzien van de Belgische en Nederlandse gemeenten en provincies zijn de bestuursorganen equivalent. Voor Belgische en Nederlandse gemeenten zijn de gemeenteraden, het college van burgemeester en schepenen en het college van burgemeester en wethouders alsmede de burgemeesters elkaars equivalenten. Voor de Belgische en Nederlandse provincies zijn de provincieraad en provincialle staten, de bestendige deputatie en gedeputeerde staten alsmede de gouverneur en de commissaris van de Koningin elkaars equivalenten.

In vergelijkend perspectief bestaan er tussen de organieke wetgeving inzake de Belgische en Nederlandse gemeenten eigenlijk slechts enkele opvallende verschillen. Een eerste 
belangrijk verschil is de zittingsduur van het gemeentebestuur. In België is dat in de regel 6 jaar, terwijl dat in Nederland 4 jaar is. Een tweede belangrijk verschil is, dat in de gemeentewetgeving in Nederland voor alle organen vrij algemene handhavingsbevoegdheden geregeld zijn, terwijl dat in de desbetreffende wetgeving in België niet zo is. Een ander belangrijk verschil is dat in de Belgische Nieuwe gemeentewet veelal mogelijkheden tot delegatie van bevoegdheden tussen bestuursorganen onderling ontbreken, terwijl de equivalente Nederlandse wetgeving hierin voorziet. Voorts kan gewezen worden op het feit, dat de burgemeester in België benoemd wordt, nadlat deze uit de raad is gekozen. In Nederland wordt de burgemeester niet uit de raad benoemd. Zijn positie in deze is derhalve een andere dan die van zign Belgisch collega. Zijn bevoegdheden, die voornamelijk op het terrein van de openbare orde en veiligheid liggen, komen overeen met die van de Belgische burgemeester.

Als de organieke wetgeving inzake de Belgische en Nederlandse provincies vergeleken wordt, bestaan er eveneens niet al te veel significante verschillen. Het verschil in zittingsduur van het provinciaal bestuur gaat verschillen. In de gouverneur komt wellicht. meer dan de commissaris van de Koningin de representatie wan het centrale gezag naar voren.

De verschillen liggen veelal op het terrein van de sectorbevoegdheden. De Nederlandse provincies \ijken hierbij ruimer toebedeeld te zijn dan de Belgische. Kan gesteld worden dat de uitwoerende bevoegdheden, die veelal toekomen aan de bestendige deputatie c.q. gedeputeerde staten, (op bepaalde terreinen) nog overeenkomen, planningsbevoegdheden hebben de Belgische provincies veel minder dan de Nederlandse. In België zijn het veelal de bestuursorganen van de Gewesten die dergelijke plannende bevoegdheden hebben.

\section{NEDERLAND-DUTISLAND}

Ten aanzien van de Dütse en Nederlandse gemeenten zijn de bestuursorganen minder dan inzake de Belgische en Nederlandse gemeenten elkaars gelijken. Hoewel met name het dagelijks bestuur verschillend georganiseerd is, bestaan er daarnaast tussen de gemeentelijke wetgeving in Nederland en Duitsland eveneens slechts enkele significante verschillen.

De zittingsdum van de raad is in Duitsland 5 jaar en in Nederland 4 jaar. Een belangrijk ander verschil is er ten aanzien van de (positie van de) voorzitter van de gemeenteraad c. q. het dagelijks bestuur. In Noordrijn-Westfalen is, in tegenstelling tot de Nederlandse burgemeester, de woorzitter van de gemeenteraad niet tevens voorzitter van het dagelijks bestuur. In Nedersaksen is de voorzitter van de raad wel tevens voorzitter van de Verwaltungsausschuss. Deze Verwaltungsausschuss zit eigenlijk tussen het algemeen en dagelijks bestuur in. Ook in Noordrijn-Westfalen zal op niet al te lange termijn een vergelijkbare Gemeinde(/Stadt)ausschuss ontstaan, die als bindmiddel tussen Rat en Verwaltung moet fungeren. Hetgeen hierna voor de Nedersaksische Verwaltungsaus. schuss gesteld wordt, zal tenzij anders aangegeven ook voor de Noordrijn-Westfaalse Gemeinde(/Stadt)ausschuss gaan gelden.

Verschillen bestaan er tussen de Nederlandse wethouders en de 'equivalenten' in Duitsland. In Nederland maken de wethouders deel uit van de gemeenteraden. In Nedersaksen worden de hiermee overeenkomende 'Beigeordneten', die zitting hebben in de Verwal- 
tungsausschuss, eveneens uit de raad gekozen. In Noordrijn-W estfalen maken de "Beigeordneten' niet deel uit van het rechtstreeks vertegenwoordigend gemeentelijk bestuursorgaan. Daar dienen zij ter ondersteuning van de Gemeindedirektor. Zij zullen een adviserende stem gaan hebben in de Gemeinde(/Stadt)ausschüsse. Zowel in Nedersaksen als Noordrijn-Westfalen is de Gemeindedirektor belast met het dagelijks bestuur, waarmee in Nederland deels de burgemeester en deels het college van burgemeester en wethouders belast is. Vermeldenswaard is ook het feit dat de gemeentewetgeving in Duitsland verschillende typen gemeenten kent, namelijk de kreisangehörige en de kreisfreie. Nedersaksen kent bovendien Samtgemeinden. De Nieuwe gemeentewet voorziet eveneens in de mogelijkheid onderscheid te maken tussen gemeenten (art. 110 Nieuwe gemeentewet).

Een laatste belangrijk verschil dat hier vermeld kan worden, is dat in de gemeentewetgeving in Nederland algemene handhavingsbevoegdheden geregeld zijn, terwijl dat in de desbetreffende wetgeving in Duitsland niet zo is. Hoewel de taken/bevoegdheden inzake vooral het dagelijks bestuur in Duitse en Nederlandse gemeenten over andere bestuursorganen verdeeld zijn, kan toch gesteld worden dat de Duitse gemeentelijke bestuursorganen Nederlandse equivalenten kennen vice versa. De Noordrijn-Westfaalse, de Nederlandse en de Nedersaksische gemeenteraden (en eventueel de Nedersaksiche Verwaltungsausschuss en de Noordrijn-Westfaalse Gemeinde(/Stadt)ausschuss) zijn zonder meer elkaars gelijken. De Nederlandse burgemeester heeft bevoegdheden van zowell de Gemeindedirektor als de Bürgermeister. De Beigeordneten en de wethouders kunnen met elkaar vergeleken worden, met dit verschil dat de Beigeordneten in Noordrijn-Westfalen onder verantwoordelijkheid van de Gemeinde(Stadt)direktor en niet de gekozen organen handelen. De Verwaltungsausschuss/Gemeindedirektor/Beigeordneten en het college van burgemeester en wethouders kunnen gedeeltelijk ook elkaars equivalenten genoemd worden.

Daar waar de (Land)kreise bevoegdheden hebben, die de Nederlandse gemeenten ook uitoefenen, geldt het bovenstaande overeenkomstig wat betreft de bestuursorganen van de (Land)kreise en de Nederlandse gemeentelijke bestuursorganen.

In tegenstelling tot België en Nederland kent Duitsland geen provincies. De Duitse (Land)kreise zijn op basis van hun taken/bevoegdheden wellicht eerder de counterparts van de Nederlandse gemeenten c.q. de Nederlandse openbare lichamen op basis van de Wet gemeenschappelijke regelingen dan van de Nederlandse provincies. Op basis van bepaalde taken/bevoegdheden zijn de Duitse equivalenten van de Nederlandse provincies de Regierungsbezirke en de Länder. Evenals de Belgische Gewesten ten aanzien van de Benelux-Overeenkomst vallen de Länder en hun Regierungsbezirke buiten de werking van de Duits-Nederlandse Overeenkomst. Voor de Duits-Nederlandse grensoverschrijdende samenwerking van de Nederlandse provincies kan dit problematisch zijn. Overigens ligt wel de samenwerking tussen bepaalde Nederlandse provincies en de genoemde Kommunalverband Ruhrgebiet en de Landschafts verbände voor de hand. Die samenwerking is evenwel slechts mogelijk op beperkte beleidsterreinen. Voor de provincies zijn, zoals aangegeven, de equivalenten binnen de tot samenwerking gerechtigde overheden op basis van de Duits-Nederlandse Overeenkomst iets minder makkelijk aan te wijzen. Voor de Nederlandse waterschappen zijn er wel Duitse equivalenten, maar deze zijn niet tot samenwerking gerechtigd op basis van de Duits-Nederlandse Overeenkomst inzake decentrale grensoverschrijdende samenwerking. 



\section{Hoofdstuk 5}

\section{Nederland-België}

\section{\$1. Inleiding}

In hoofdstuk 5 staat de publiekrechtelijke samenwerking tussen decentrale overheden in België en Nederland en tussen de decentrale overheden van beide landen centraal. Er wordt een inventarisatie gegeven van de belangrijkste rechtsregels inzake interne (= nationale) en externe (= grensoverschrijdende) samenwerking).

Vanouds heeft de grensoverschrijdende samenwerking zich op centraal overheidsniveau (intergouvernementeel) afgespeeld. Er zijn een aantal intergouvernementele afspraken (vaak verdragen) gemaakt in het kader waarvan ook de decentrale overheden kunnen samenwerken ( 8 6).

Meer recentelijk is de samenwerking op gang gekomen, waarbij de decentrale overheden zelf, in meer algemene zin, grensoverschrijdende publiekrechtelijke afspraken kunnen maken. Als juridische grondslag hiervoor is vooral de Benelux-Overeenkomst inzake grensoverschrijdende samenwerking tussen territoriale samenwerkingsverbanden of autoriteiten van belang. Dit verdrag geeft een juridisch raamwerk, waarbinnen de grensoverschrijdende samenwerking tussen decentrale overheden in Nederland en België zich dient af te spelen (\$5). Deze Benelux-Overeenkomst verklaart o.a. het nationale recht, dat van belang is voor de nationale samenwerking tussen decentrale overheden, grotendeels van toepassing op de grensoverschrijdende samenwerking. Om die reden wordt een beschrijwing, in hoofdlijnen, gegeven van de wederzijdse nationale wetgeving inzake publiekrechtelijke afspraken tussen de op basis van de Benelux-Overeenkomst tot grensoverschrijdende samenwerking gerechtigde overheden. Het gaat dan om de beschrijving van de Nederlandse $(\$ 2)$ en Belgische (\$3) wetgeving, die in de bijlage bij de BeneluxOvereenkomst is genoemd en een algemeen (formeel) kader geeft inzake interne samenwerking tussen decentrale overheden. Hierbij staan de samenwerkingsvormen, de bevoegdheden van de eventuele bestuursorganen alsmede het toezicht op de samenwerking centraal. De meer organieke wetten, zoals de Belgische en Nederlandse Gemeente- en Provinciewet, worden ook genoemd in de bijlage bij de Benelux-Overeenkomst en zijn eveneens van belang voor de samenwerking. Deze organieke wetgeving is reeds beschreven in hoofdstuk 4 . In $\& 4$ wordt een korte vergelijking gemaakt van het interne samenwerkingsrecht tussen decentrale overheden in Nederland en België. Dit hoofdstuk wordt afgesloten met een samenvatting en enkele conclusies $(\$ 7)$. 


\section{\$2. Het Nederlandse recht inzake samenwerking tussen decentrale overheden}

\section{A. IMLEIDING}

Artikel 135 Nederlandse Grondwet bepaalt: "De wet geeft regels ter voorziening in zaken waarbij twee of meer openbare lichamen zijn betrokken. Daarbij kan de instelling van een nieuw openbatar lichaam worden voortien, in welk geval artikel 134 , tweede en derde lid (dit betreft het regelen van wettelijk toezicht, RS), van toepassing is." De organieke wetgeving in Nederland betreffende gemeenten (Gemeentewet) en provincies (Provinciewet) bevat geen enkele bepaling over deze publiekrechtelijke samenwerking. ${ }^{1}$ De organieke wetgeving betreffende de waterschappen (Waterschapswet) bevat ook geen samenwerkingsbepaling, die in deze echt relevant is. ${ }^{2}$ De in artikel 1.35 Grondwet bedoelde publiekrechtelijke samenwerking is voor zowel gemeenten, provincies en waterschappen geregeld in de Wet gemeenschappelijke regelingen."

Na een jarenlange discussie omtrent de reorganisatie van het binnenlands bestuur is (voorlopig) voor de aanpak van de regionale problematiek gekozen middels versterking van de intergemeentelijke samenwerking, resulterend in deze Wet gemeenschappelijke regelingen. ${ }^{4}$ Gemeenschappelijke regelingen (tussen gemeenten) worden gezien als een belangrijk middel voor de oplossing van regionale problemen. ${ }^{5}$ De Wet gemeenschappelijke regelingen is bedoeld als instrument ter verbetering van de bestuurlijke aanpak van gemeentelijke taken, die de lokale schaal overstijgen. ${ }^{6}$ De voornaamste doelstellin-

1. De in hoofdstuk 4 beschreven Nieuwe gemeentewel bewat ewenmin bepalingen inzake publiekrechtelijke samenwerking. Voor de in hoofdsuk 4 beschreven Nieuwe Provincivewet dient gewezen te worden op artikel 108. Artikel 108 Nieuwe Provinciewet, voor zover van belang, bepalt:

"1. Het provinciakl bestut kan bevoegdheden wan regeling en bestuur, gevorderd bij of krachtens een bijzondere wet, voor het gebied wan een of meer gemeenten of waterschappen overdragen an de besturen van die gemeenten of waterschappen voor zover die bevoegdheden zich nar hum aard en schaal dartoe lenen en die besturen daamee instemmen." Zie tevens noot 85 van dit hoofdstuk.

2. Overigens bevat artikel 6 Waterschapsweteen regeling ten aanzien van prowinciegrenzenoversch rijdende watersehapen. Deze bepaling, die voorziet in een samenwerking thssen provincies, luidt: "Het opheffen of instellen valu een waterschap dan wel het vaststellen of wijzigen wan hat reglement wan een waterwhan, warwan he gobad in twe of meer provincies is gelegen, geschiedt bij gemeenschappelijkesluit van provinciale staten van de betreffende provincies."

3. Wet wan 20-2-1984, 5tb. 667. Deze varving de Wet gemeenschappelikeregelingen van 1-4-1950, Stb. K 120. De befangrijkste bepalingen wan de Wet gemeenschappelijke regelingen zijn als bijlage bujgevoegd.

4. Zie b.v.: Handboek Bestuarlike Samenwerking (losbladig), Inleiding, P. 4 a*v; De WGR gewaardeerd, Eindrapport, Vereniging Nederlandse Gemeenten, 199 1, p. 2 e.v.

5. Mv' bij de Wet geneenschappelijkeregelingen, Tweede Kamer, 1980-1981, 16538, nr. 3, p. 6. Voor een historisch overzicht van het streksgewijs geordend openbaar bestur, zie o.a.: K.I. wan der Top, De Wet geneenschappelijkeregelingen: een oplossing voor de regionale problematiek?, 1986, p. 1. 1 e. H.

6. De WOR gewatrdeerd, a.w., j. 79 k. Men onderscheid regionale problematiek in enge zin (verlengd

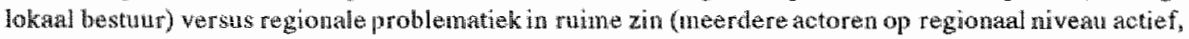

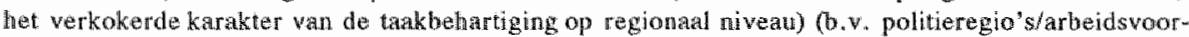
ziening s.d. (p. 102 e.v.). Volgens Van der Top kan de regionale problematiek besehreven worden wantit de schad wa het lokale, provinciale of regionale bestumrsnivea, warbij hij de dragvlakproblematiek (taken kumen niet meer uitsluitend op het wiveau wan de individuele gemeenten uitgeoefend worden) en het sturimgsaspect (specifiek op de regio gerichte voorbereidingen uitwoering) onderscheidt, K. J. van der Top, a.w, p. 31 e.v. 
gen van de Wet gemeenschappelijke regelingen betreffen de bundeling (het vereiste om zoveel mogelijk op de schaal van de vastgestelde samenwerkingsgebieden samen te werken) ${ }^{7}$ en de integratie (het streven naar éen gemeenschappelijke regeling per vastgesteld samenwerkingsgebied) van gemeenschappelijke regelingen, het realiseren van een natwere bestuurlijke (controle/openbaarheid) en financiële band tussen samenwerkingsverbanden en de deelnemers en het begrenzen van de vrijwilligheid van de samenwerking (het versterken van de rol van de provincie).

Bij de samenwerking op basis van de Wet gemeenschappelijke regelingen gaat het in de regel om ordenende dan wel verzorgende taken. Ten aanzien van de eerste is er veelal sprake van overleg (hel komen tot afstemming van beleid), terwijl het bij de verzorgende taken veelal gaat on de daadwerkelijke overdracht van bevoegdheden met de daaraan gekoppelde macht voor het bestuur van de gemeenschappelijke regeling on de besluitvorming feitelijk te realiseren.

Uit evaluatie van de Wet gemeenschappelijke regelingen is een aantal aanbevelingen ten aanzien van het gebruik en bruikbaarheid van deze wet gedestilleerd. "Een algemene conclusie is dat met name de basisregelingen hebben geleid tot een bestuurlijke infrastructuur en de samenwerkingsgebieden op basis van de Wet gemeenschappelijke regelingen een natuurlijk referentiekader zijn geworden woor de taakbehartiging op regionaal niveau. ${ }^{10}$

\section{B. SAMENWERKING TUSSEN GEMEENTEN, PROVINCIES EN WATERSCHAPPEN}

\section{Algemeen}

De samenwerking op basis van de Wet gemeenschappelijke regelingen is bij uitstek een samenwerking in het kader van (de overdracht/de uitoefening van) publiekrechtelijke bevoegdheden. il

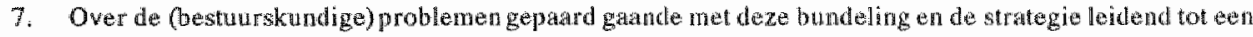

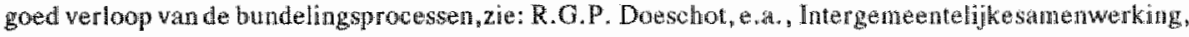
1987, p. 19 e.w.

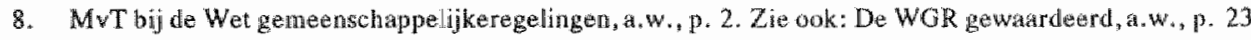
e.v.; K.I. van der Top, w., W. 27.

9. De WGR gewardeerd, a.w., p. 129 e.v.

10. De Wet gemeenschappelike regelingen is een algemene (procedurele) wet inzake pulviekrechtelike samenwerking tussen lagere overheden. Een anntal sectorwetten bevat bepalingen omtrent (verplichle) samenwerkthg. In een antal gewallen wordt angeknoopt bij de Wet gemenschappelijke regefingen, in een antal gevallen is de samenwerking a fwijkend (minder vergatand). De verhouding thssen deze wetten: en de Wet gemeenschappelijkeregelingen wordt wak middels circulairesangegeven. Zie voor een korte beschrijving van de relevante sam enwerkinghepalingenvaneen antal bijzonderewetten, zoals de Afvalstoffenwell, de Wet Ambulancevervoer, he Brandweerwet, de Rampenwet, do Wet sodial werkwoorziening, de Wet voorzieningen gezondheidszorg, de Woonwagenwet, de Distributiewet, de Politiewet, de Leerplichtwet, de Wat Personenwervoer: Handboek Bestunrijke Samenwerking, a.w. Bijzondere regelgeving, p. 1 e.v.; MvT bij de Wet gemeenschappelike regelingen, a.w., p. 49 e.v.

11. MWT bij de Wet gemenschappeljkeregelingen, a.w., P. 35. Voor de privatrechtelijke samenwerking, b.H. Het oprichtem van en deelnemen in vennootschappen, is het bepentde in artikel 228 lid 1 ander a juncto artikel 234 Gemeentewet respectieveljkartikel 93 van de Provinciewet van belang. Vergelikbare bepalingen zjin opgenomen in artikel 156 Nieuwe gendentewet en artikel 152 . Nienwe provinciewet. 
Artikel 1 lid 1 Wet gemeenschappelijke regelingen kent de mogelijkheid van gemeenschappelijke regelingen tussen de rader, de colleges van burgemeester en wethouders en de burgemeesters van twee of meer gemeenten ter behartiging van een of meer bepaalde belangen. ${ }^{12}$ Dergelijke regelingen zijn, op basis van diverse andere artikelen van de Wet gemeenschappelijke regelingen, ook mogelijk tussen de organen van provincies (art. 40 e.v.), waterschappen (art. 50 e.v.), gemeenten en provincies (art. 51 e.v.), gemeenten en waterschappen (art. 61 e.v.), gemeenten, provincies en waterschappen (art. 73 e.v.), provincies en waterschappen (art. 83 e.v.). Tevens kunnen nog (organen van) andere openbare lichamen (dan gemeenten, provincies en waterschappen) en een of meer andere rechtspersonen deelnemen aan gemeenschappelijke regelingen (art. 93 e.v.). Bovendien is er de mogelijkheid van regelingen tussen ến gemeente, provincie of waterschap en een of meer andere openbare lichamen en rechtspersonen (art. 96 e.v.). ${ }^{13}$ Omtrent samenwerking tussen uitsluitend (organen van) openbare lichamen of gemeenschappelijke organen, tot stand gekomen op basis van gemeenschappelijke regelingen, is in deze wet niets bepaald.

In de Nederlandse praktijk gaat het vooral om de samenwerking tussen gemeenten onderling. Omdat het op basis van de Benelux-Overeenkomst en de Duits-Nederlandse Overeenkomst inzake decentrale grensoverschrijdende samenwerking in eerste instantie gemeenten zullen zijn die grensoverschrijdend samenwerken, ligt hier de nadruk op de gemeentelijke samenwerking. Daarbij zij overigens opgemerkt dat hetgeen voor de gemeentelijke samenwerking is geregeld, te denken valt met name aan de aard van de over te dragen bevoegdheden, grotendeels ook voor de onderlinge samemwerking tussen andere openbare lichamen zoals provincies en waterschappen geldt. Slechts waar belangrijke afwijkingen bestaan, wordt hierop apart ingegaan. ${ }^{14}$ Overigens kunnen de waterschappen alleen grensoverschrijdend samenwerken op basis van de Benelux-Overeenkomst en niet de Duits-Nederlandse Overeenkomst.

Het vrijwillige karakter van de samenwerking staat in de Wet gemeenschappelijke regelingen (hierna: Wgr) in beginsel voorop. Indien een zwaarwegend openbaar belang dat vereist, kunnen provinciale staten gemeenten tot samenwerking verplichten (art. 99 Wgr). Artikel 100 Wet gemeenschappelijke regelingen voorziet zelfs in de mogelijkheid

12. De regeling wan artikel 1 lid 1 Wet gemeenschappelijke regelingen wordt in verhouding tot de mogelijk-

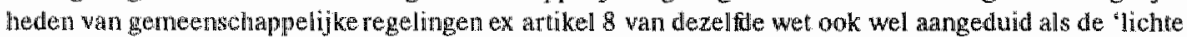
regehing".

13. Zo neom het Rijk deel asan de gemeenschappelijke regeling Natuur- en recreatiegebied De Grevelingen op basis van de Wet deelneming Grevelingen (Stb. 1985, 409).

14. Voor de samemwerking tussen Nederlandse provincies is en verwijizing nar hei Interp rovincial overleg (IPO) op zijn plats. Dit overleg is gebaseerd op een besluit, goedgekeund bij KB wan 10-5-1986, van de twallif provincies tot instelling van een openbaar lichasu. De voormamste taak is om te komen tot gemeenchappelijke standpuntbepaling en besluitworming over zaken van gemeenschappelijkprovinciaal belang (art. 3 wan het betreffende besluit), Daarbij gaat het mijns inziens meer om beraad dam de overdracht of de uitoefening van beslissingsbevoegdheden.

De tekst wan de regeling is opgenomen in het Handboek Bestuurlijke Samenwerking, a. W., IV B, p. 1 - 10. Het 1 PO houdt mijns inziens ongeveer het midden tussen de same wwerking tussen aangrenzende provincies op basis wan de Wet gemeenschappelijke regelingen en hetgeen de Veteniging van Nederlandse Geneenten voor de gemeenten betekent. Een vergelijkbare instantie voor de waterschappen is wellicht de Unie van Watterschappen.

Dergelijke vooral belangenorganisaties wan decentrale overheden zijn er ook in Belgie en Duitsland. 
dat provinciale staten worden uitgenodigd bij koninklijk besluit tot uitoefening van die bevoegdheid. Gemeenten dienen zoveel mogelijk binnen door provinciale staten aan te wijzen gebieden samen te werken. ${ }^{15}$ Op dit moment heeft die indeling in samenwerkingsgebieden in nagenoeg het hele land plaatsgevonden. Deze indeling is voornamelijk gebeurd op basis van maatschappelijke en bestuurlijke samenhang en het voorhanden zijn van een minimaal draagvlak. Naar oppervlakte, aantal inwoners en aantal gemeenten bestaan er grote verschillen. De provinciegrenzen zouden geen barrière mogen vormen voor de vorming van provinciegrenzen overschrijdende samenwerkingsgebieden. ${ }^{16}$ Op basis van artikel 36 Wet gemeenschappelijke regelingen dienen gedeputeerde staten de goedkeuring aan de gemeenschappelijke regelingen tussen (organen van) gemeenten te verlenen. ${ }^{17}$ Daarbij wordt naast de inhoud van de regeling vooral bezien of de regelingen beantwoorden aan de eis van bundeling alsmede het streven naar integratie, zoals verwoord in artikel 2 Wet gemeenschappelijke regelingen. ${ }^{18}$

\section{Samenwerkingswormen}

Voortbouwend op artikel 1 Wet gemeenschappelijke regelingen kunnen de desbetreffende gemeentelijke bestuursorganen een aantal gemeenschappelijke regelingen treffer ter behartiging van een of meer bepaalde belangen van die gemeenten. Artikel 8 Wet gemeenschappelijke regelingen noemt een drietal vormen, namelijk de instelling van een openbaar lichaam, de instelling van een gemeenschappelijk orgaan alsmede de instelling van een zogenaamde centrumgemeente. ${ }^{19}$

De desbetreffende gemeenschappelijke regeling vermeldt het belang of de belangen ter behartiging waarvan ze is getroffen (art. 10 lid $1 \mathrm{Wgr}$ ). Daarnaast is deze gemeenschappelijke regeling met name van belang voor de toekenning van bevoegdheden aan het openbaar lichaam of gemeenschappelijk orgaan (art. $10 \mathrm{lid} 2 \mathrm{Wgr}$ ). Voorts is de regeling

15. Zie: De WGR gewaarderd, a.w., p. 17 e.v. Zie tevens het gestelde in \$ 2.B.4. van dit hoofdstuk.

16. Mogelijk vanwege gewreesd bevoegdheids-c.q. gebiedswerlies op termijn van de provincies is hierwan slechts in een vijftal gewallen sprake, De WGR gewardeerd, a.w., p., 20. Daarbij komt dat gemeenten wellicht bevreesd zijn in hn eigen provincie en soort van tweederangsgenteenten te worden als hun prowinche hat bevoegdheden overdraagt, K.I. van der Top a.w., p. 43 .

17. Dit is de hoofaregel. Zo verleent de commissaris van de Koningin de (al dan niet) goedkeuring voor de samenwerking tussen burgemeesters (art. $38 \mathrm{Wgr}$ ).

18. Woor de burdelings-en integrati waspecten,zie: Handboek Besturlijke Samenwerking, a.w., p. 66: MyT bij de Wet gemeenschappelijkeregelingen, a., w., p. 15 e.v.

Geld speelt wak een rol voor het aangan varu samemwerkingsverbanden, De WGR gewarardeerd, a.w., p. 30. In dit verband kan b.w, worden gewezen op de samenwerking op miliehgebied. Zie b.w. L. Bomhof, Intergeneentelijkesamenwerking op miliengebied: rijksgelden en voor tschrijdend inzicht leiden tot vooruitgang, Gemeentestemn 1989, 6885, j. 391-395.

19. Op 1-1-1990 bestonden er ca. 750 gemeenschappelikeregelingen, waarvan meer dan tweederde de vorm wan het openbaar lichaam beeft en meer dan driekwart enkelwoudige regellingen betreft (eén belang of takk). Er bestaan een vijftigtal basisregelingen (overkowelende regeling meerdere taken/belangen alsmede algemene coordinatie) in de vorm van een openbabr licham (gewesten/ samenwerkingsverbanden). Zij beslaan bijna alle gemeenten in Nederland. Vooral bij enkelvoudige regelingen wordt er naast. net openbaar lichaam gebruikt gemak van het gemeenschappelijk orgarn en de centrumgemeente. Zie: De WGR gewaardeerd, a.w., p. 35 . 
van belang voor het eigenlijke functioneren van de samenwerkingsvorm, b.v. de mogelijkheid van het instellen van bestuurscommissies (art. $25 \mathrm{Wgr}$ ).

In de bevoegdheden, die het openbaar lichaam wan rechtswege bezit - het heeft rechtspersoonlijkheid - om aan het maatschappelijk verkeer deel te nemen (art. 31 Wgr), kunnen beperkingen worden aangebracht. Op basis van artikel 30 Wet gemeenschappelijke regelingen kan het (besturur van het) openbaar lichaam in beginsel beschikken over zodanige bevoegdheden van regeling en bestuur als aan de besturen van de aan de regeling deelnemende gemeenten toekomen. Het gaat daarbij om:

1. de autonome en medebewindsbevoegdheden die de gemeenten zelf bezitten op basis van de Gemeentewet en sectorwetten (b.v. de vaststelling van algemeen verbindende voorschriften en wergunningverlenende bevoegdheden);

2. de bevoegdheden welke een (rechtspersoonlijkheid bezittend) openbaar lichaam van rechtswege bezit (b.v. het aangaan van geldleningen en het benoemen van personeel, e.d.);

3. de afgeleide bevoegdheden (b.v. bestuursdwang, e.d. ${ }^{20}$

Slechts de bevoegdheid van het openbaar lichaam tot belastingheffing is beperkt (art. 30 lid 1 sub a Wgr). Artikel 13 en 14 Wet gemeenschappelijke regelingen voorzien in 3 bestuursorganen, namelijk het algemeen bestuur, het dagelijks bestuur en de voorzitter. De samenstelling van het algemeen bestuur varieert al naar gelang het een gemeenschap. pelijke regeling tussen gemeenteraden, colleges van burgemeester en wethouders dan wel alleen burgemeesters betreft. Het dagelijks bestuur bestaat uit de voorzitter en daarnaast minimaal 2 leden, die in beginsel gekozen worden uit en door het algemeen bestuur. Een of meer leden (nooit de meerderheid) van het dagelijks bestutur kunnen aangewezen worden buiten de kring van het algemeen bestuur. De leden wan het dagelijks bestuur mogen niet allen alkomstig zijn uit dezelfde gemeente. De voorzitter wordt uit en door het algemeen bestuur gekozen.

Het gemeenschappelijk orgaan kan helemaal geen belastingen heffen en kan ook niet de bevoegdheid hebben algemeen verbindende voorschriften te geven (art. 30 lid 1 sub b Wgr). Het gemeenschappelijk orgaan kan op basis van artikel 30 Wet gemeenschappelijke regelingen slechts over bestuursbevoegdheden beschikken. ${ }^{21}$ Het heeft geen rechtspersoonlijkheid en er is geen dagelijks bestuur vereist. Het gemeenschappelijk orgaan kent alleen een algemeen bestuur (art. 15 juncto $13 \mathrm{Wgr}$ ).

Bij de derde vorm van gemeenschappelijke regelingen op basis van artikel 8 Wet ge meenschappelijke regelingen wordt geen nieuw orgaan of lichaam in het leven geroepen. Het gaat daarbij om de overdracht van de uitoefening van bevoegdheden van bestuursorganen c.q. ambtenaren van deelnemende gemeenten aan bestuursorganen c.q. ambtena-

20. MvT bij do Wet geneenschappelijkeregelingen, a.w., p. 35 *

21. Zie: MvT bij de Wer gemeenschappelijke regelingen, a.w., p. 34: "... zal slechts ir didarvoor bijzonder in anmerking komende gevallen van de algemene ged ragsijin, dat ean openbaar lichaam wordt ingesteld, kwnen worden atgeweken en een gemeenschappelijk orgatan kunew worden ingeste H. Het gat hier om regelingen văn zeer eenvoudige atur, weelal nnet enkelvoudige, beperkt omschreven doelstellingen, die geen geleed bestuur noch rechtspersoonlijkheid - ononbeerljk woor deelneming anan het maatschappelijk

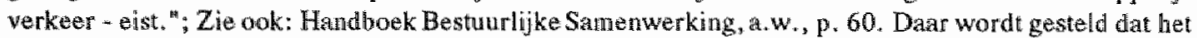
gemeenschappelijk organ "nauwelijks enige bestuurlijke importantie heeft". Dit is mijns inziens een understatement, angezien het geneenschappelijkorgan bestumsbevoegdhedenkan hebben en voor de witoofening erwan in beginsel zelf verantwoordelijk is. 
ren van een van de deelnemende gemeenten, ook wel aangeduid als cemrumgemeente. Ondat het slechts om de uitoefening van bevoegdheden gaat, blijft de overdragende partij verantwoordelijk (mandaat). In de overdracht van bevoegdheden, waarbij tevens de verantwoondelijkheid overgaat, is in deze niet voorzien (delegatie).

In \$ 5.D.2. van dit hoofdstuk wordt bij de bespreking van de samenwerkingsvormen op basis van de Benelux-Overeenkomst op de samenwerkingswormen ex Wet gemeenschappelijke regelingen nog dieper ingegaan.

\section{Toezicht en geschillenbeslechting}

Voor het aangaan van gemeenschappelijke regelingen (art. 8 Wgr) tussen gemeenten zijn gedeputeerde staten in beginsel de goedkeurende instantie (art. 36 lid $1 \mathrm{Wgr}$ ). Voor de goedkeuring wan gemeenschappelijke regelingen tussen waterschappen zijn eveneens gedeputeerde staten bevoegd (art. $50 \mathrm{~h} \mathrm{lid} 1 \mathrm{Wgr}$ ). Tegen de onthouding van goedkeuring is Kroonberoep mogelijk door de deelnemende gemeenten (art. 36 lid 4 Wgr) c.q. waterschappen (art. 50h lid $3 \mathrm{Wgr}$ ). Hetzelfde geldt voor gemeenschappelijke regelingen tussen gemeenten en waterschappen (art. 69 lid 1 juncto art. 69 lid 4 Wgr). ${ }^{22}$

Ten aanzien van de uitoefening van bevoegdheden alsmede het toezicht op besluiten van het bestuur van een openbaar lichaam (of gemeenschappelijk orgaan) bestaande uit gemeenten gelden in beginsel de regels betreffende de werdeling van de bevoegdheden van de gemeentebesturen over de gemeentelijke bestuursorganen alsmede het toezicht op besluiten wan die gemeentebesturen (art. $33 \mathrm{Wgr}$ ). Een vergelijkbare bepaling geldt bij een openbaar lichaam (of gemeenschappelijk orgaan) bestaande uit waterschappen (art. $50 \mathrm{~W}$ Wr) dan wel een openbaar lichaam (of gemeenschappelijk orgaan) bestaande uit provincies (art. $46 \mathrm{Wgr}$ ). Voor een openbaar lichaam (of gemeenschappelijk orgaan) bestaande uit gemeenten en provincies gelden de bepalingen voor provinciebesturen (art. $57 \mathrm{Wgr}$ ). In deze kan derhalve verwezen worden naar hoofdstuk 4.

De Wet gemeenschappelijke regelingen voorziet in een regeling voor geschillen tussen de samenwerkende overheden dan wel de samenwerkende overheden en het openbar licharm of gemeenschappelijk orgaan. Bij gemeenschappelijke regelingen tussen gemeenten beslist in beginsel gedeputeerde staten over geschillen. Dit is anders als het geschil is opgedragen aan een rechter. Gedeputeerde staten hebben de mogelijkheid het besluit dat onderwerp is wan geschil en bij hen voorligt te schorsen (art. $28 \mathrm{Wgr}$ ). Een zelfde geschillenregeling bestaat er voor de samenwerking tussen waterschappen (art. 50a juncto art. $28 \mathrm{Wgr}$ ) en gemeenten en waterschappen (art. 62 juncto art. $28 \mathrm{Wgr}$ ). Daar waar provincies onderling samenwerken dan wel met gemeenten dan wel met gemeenten

22. Deze bepalingen inzake het Kroonberoep vervallen bij de inwerkingtreding van de herziening van de rechterlige organisatie (voltooing exerste fase), a.w., noot 46, hoofdstuk 4. Het beroep dient dan volgens de bepalingen van de Algemene wet besturstecht platste vinder.

Woor de goedkeuring van gemeenschappelijkeregelingen assen provincies is de Kroon bevoegd. Dit is net in de Wet gemeenschappelijke regelingen zelf terug te vinden, maar is gebaseerd op artikel 16 en 17 juncto artikel 20 Wet houdende woorschriften met betrekking tot gemeenschappelijke regelingen (de voorloper wan de Wet gemeenschappelijkeregelingen, wet van 1-4-1950, Stb. K 120). Voor de goedkeuring van gemeenschappelijkeregelingen tussem prowincies en gemeenten en prowincies an waterschappen wordt de Kroon geacht bevoegd te zijn, hoewel dat ewereens nergens in de Wet gemeenschappelijke regelingen zelf is alangegeven. 
ch waterschappen geldt eweneens een dergelijke geschillentegeling, met dien verstande dat niet door gedeputeerde staten maar bij koninklijk besluit beslist wordt (art. 42, art.53 respectievelijk art. $75 \mathrm{Wgr}$ ). ${ }^{23}$ In $\$ 5 . \mathrm{D} .6$ van dit hoofdstuk wordt op de geschillenregeling nog dieper ingegaan.

\section{Wijziging van de Wet gemeenschappelijke regelingen}

De Wet gemeenschappelijke regelingen wordt in de nabije toekomst gewijzigd.

Een eerste aanscherping betreft het afdwingen (door de provincie) van de utvoering wan taken en besluiten. Gemeenten kunnen in de nabije toekomst sneller gedwongen worden tot samenwerking. Het opleggen van de samenwerking, welke thans al mogelijk is door provinciale staten, kan dan door gedeputeerde staten gebeuren. Hiertoe worden de artikelen 99 e.v. Wet gemeenschappelijke regelingen aangepast. Tevens wordt er in een soort van dwangtoezicht voorzien ten aanzien van gemeenten, die weigeren samen te werken. Het samenwerkingsverband kan er in dat gevall b.v. zelf voor zorgen, dat de uitvoering van afspraken op naam en kosten van de desbetreffende gemeenten plaatsvindt. Hiertoe wordt een additioneel artikel $10 \mathrm{a}$ in de Wet gemeenschappelijke regelingen opgenomen. ${ }^{24}$

Een tweede verandering ten opzichte van de Wet gemeenschappelijke regelingen zal plaatsvinden met de inwerkingtreding van de Kaderwet bestuur in verandering. Voor een zevental in deze kaderwet genoemde stedelijke gebieden dient het bestaande intergemeentelijk bestuur gefaseerd plaats te maken voor een volwaardig regionaal bestuur, namelijk een regionaal openbaar lichaam en op langere termijn een regionale gebiedsautoriteit. ${ }^{25}$ Beide hebben verdergaande bevoegdheden dan het openbaar lichaam op basis van artikel 8 Wet gemeenschappelijke regelingen, waarbij de bevoegdheden van de gebiedsautoriteit het verst gaan. De bewoegdheden hebben betrekking op de verhouding van het regionale orgaan respectievelijk de gebiedsautoriteit tot de deelnemende gemeenten, de in deze kaderwet geregelde bevoegdheden alsmede de medebewindsbevoegdheden van het regionale orgaan respectievelijk de gebiedsautoriteit. Met betrekking

23. Bij samenwerkingsverbandenfussem provincies en waterschapen geldt een vergelikbare regeling (art. $85 \mathrm{Wgr}$ ).

Met de inwerkingtreding van de her ziening van de rechterlijke organisatie (voltooing eerste fase), a, w., zie vorige noot, wervalt de geschillenregeling op basis van de artikelen $42,53,75$ en $85 \mathrm{Wgr}$. Omdat de expliciete bewogdheid wan de Kroon komt te werwallen, zal de burgerlike dan we administratieve rewhter, in het perspectief wan artikel 136. Grondwet, bevoegd zijn. Voor een nadere niteenzetting hilerover wordt verwezen netar het gestelde in \$ 5.D.6. a wan dit hoofdstuk.

24. Voorstel van wet tot wijziging van de Wet geneenschappelijke regelingen (in werband met anpassing en uitbreiding wan de bepalingen inzake verplichte samenwerking), Tweede Kamer, vergaderjactir 19921993,23139, ars. 1 o.k. Het wetsvoorstel voorziet o. a. vewens in een rechtsgang bij de rechthatak (op bosis van hoofdstuk 8 Awb) tegen de oplegging van de samenwerking, MWT, Voorstell van wet tot wijziging van de Wet gemeenschappelijke regelingen, a.w, nr. 3, p. 8 .

25. In dit werband zijn de pegeringsnota"s Bestuir in stedeljke gebie den (Bestuur op Niveau 1 en 2), Tweede Kamer, vergaderjaar 1990-1991,21062, nr. 3, 4 en 7 alsmede de regeringsnota Vernieuwing bestuurlijke

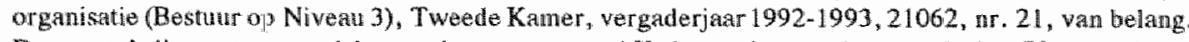
Deze nota's liggen ten grondslag an het wetwwoorstel Kaderwet bestuur in verandering (Voorzieningen ter bewordering van de totstandkoming van regional bestur in daartoe atagewezen gebieden). Tweedle Kamer, vergaderjaar 1992, 1993, 23048, nrs. 1 e.w. 
tot de laatste krijgt de gebiedsautoriteit b.v. belangrijke bevoegdheden op thet terrein van de ruimtelijke ordening (o.a. aanwijzingsbevoegdheden jegens gemeenten) en wordt de gebiedsautoriteit bevoegd een regionaal milieubeleidsplan vast te stellen. ${ }^{26}$

Voornoemde wijzigingen ten opzichte van de huidige Wet gemeenschappelijke regelingen en met name die betreffende de Kaderwet bestuur in verandering kunnen uiteraard van inwloed zijn op de grensoverschrijdende samenwerking. Het is de vraag of de Kaderwet bestuur in werandering op termijn voor het hele land gaat gelden en daarmee tot een volwaardig regionaal besturur naast of in plaats van provincies zal gaan leiden.

\section{Het Belgische recht inzake samenwerking tussen decentrale overheden}

\section{A. INLEIDING}

Artikel 108 Belgische Grondwet bepaalt o.a. "dat verscheidene provincies of verscheidenegemeenten zich met elkaar mogen verstaan of zich verenigen, onder de voorwarden en op de wijze door de wet te bepalen, om zaken van provinciaal belang of van gemeentelijk belang gemeenschappelijk te regeten en te beheren". In België regelt de organieke wetgewing betreffende gemeenten, de Nieuwe gemeentewet, nauwelijks lets omtrent samenwerking met andere gemeenten. De Nieuwe gemeentewet bevat slechts eén bepaling over de gemeentelijke samenwerking, namelijk op het gebied van de politie. Artikel 229 Nieuwe gemeentewet regelt de oprichting van een commissie tot overleg en coördinatie tussen de gemeentelijke politiediensten. ${ }^{27} \mathrm{De}$ samenwerking tussen gemeenten is geregeld in de aparte Wet betreffende de intercommunales. In België bevat de organieke wetgeving betreffende provincies, de Provinciewet, eveneens maar een enkele bepaling inzake samenwerking. Artikel 131 bis Provinciewet regelt het adviescollege van provinciegouverneurs. ${ }^{28}$ Voor de samenwerking tussen provincies bestaat geen aparte wettelijke regeling. Voor de onderlinge samenwerking tussen de polders, die tussen de wateringen en die tussen de openbare centra voor maatschappelijk welzijn bevatten de desbetreffende organieke wetten enkele bepalingen. In het navolgende wordt ingegaan op de (in de bijlage bij de Benelux-Overeenkomst aangegeven wetten inzake) samenwerking tussen de diverse decentrale overheden in Belgiè. Het samenwerkingsrecht ten aanzien van gemeenten, provincies, polders en wateringen alsmede openbare centra voor maatschappelijk welzijn wordt beschreven. Daarbij zal de nadruk liggen op de samenwerking tussen gemeenten (\$ 3.B.-3.E.). In

26. MWT, Kaderwet bestum in werandering, a.w., nr. 3, p. 65, 82, Zie tevens: H.Ph.J.A.M. Hennekens, De Kaderwet bestuur in werandering $(I+\mathbb{I})$, Een a-constitutionele wissellijs voor een perspectiefloze statsinrichting, Gemeentestem 6966 , p. 272 e.v. Wellicht is het nog interessant te wijzen op hot overzicht wan besluiten wartegen beroep openstat, op basis wan de Algeinene wet bestumracht on wel de Kaderwet bestuur in verandering, bü de rechtbatk dan wel de Afdeling bestuursrechtspraak, MvT. Kaderwet bestuur in verandering, a. w., nr. 3, p. 95 en 96.

27. Voor de intergemeentelijke samenwerking ussen Belgische politiediensten alsnede de grensoverschrij. dende samenwerking tussen Belgische en Nederlandse politiediensten, zie: C. Funaut (red.), De reguliere politiediensten in Belgie en Nederland, Hun reorganisatie en onderlinge samenwerking, 1992.

28. Dit adviescollege heeft slechts een beperkte tak ten anzien wan gemeenten met een afwijkend statuut (b. w. Vaeren).

Er kan eventueel ook nog op artikel 76 Provinciewet gewezen worden, dat bepatalt: "Over de ütvoering van werken van onderhoud of van herstelling wastbij verscheidene provincies betrokken $z_{1 j n}$, spreekt elke provincieraad zich wit; in geval wan onenigheid beslist de Koning." 
dat verband is het tevens interessant in te gaan op de samenwerkingsmogelijkheden tussen (de decentrale overheden en met name de gemeenten in) de Gewesten/Gemeenschappen onderling (\&3.F.). Er wordt afgesloten met enkele opmerkingen ten aanzien van wüjzigingen in het Belgisch samenwerkingsrecht (\$ 3.G.).

\section{B. SAMENWERKING TUSSEN GEMEENTEN (EN PROVINCIES)}

\section{Algemeen}

De gemeentelijke samenwerking is geregeld in de Wet betreffende de intercommunales. ${ }^{29}$ Van belang is, dat gemeenten niet buiten de wet om het beheer van een gedeelte wan hun taken onder kunnen brengen in een vereniging waarvan zij lid zijn, en die geen intercommunale vereniging is in de zin van de Wet betreffende de intercommunales. ${ }^{30}$ De Wet betreffende de intercommunales heeft bij gebreke van andere wetgeving een exclusief karakter. Hierbij kunnen in het kader van artikel 9 van de Bijzondere wet in plaats van bij wet ook bij decreet door de Gewesten en Gemeenschappen, in de aangelegenheden die tot hun bevoegdheid behoren, regels worden gesteld. ${ }^{31}$

Artikel 1 Wet betreffende de intercommunales (hierna: Wic) bepaalt, dat gemeenten verenigingen wan gemeenten (intercommunales) met welbepaalde oogmerken van gemeentelijk belang kunnen oprichten. Gemeenten zijn hierin vrij en kunnen hiertoe niet verplicht worden. ${ }^{32}$ Aan de intercommunales mogen alle andere publiek- of privaatrechtelijke personen deelnemen, uitgezonderd de publiekrechtelijke personen waarvan een orgaan het goedkeurings- en vernietigingsrecht uitoefent (art. $2 \mathrm{Wic}$ ). In de intercommunales

29. Wet van 22-12-1986, B.S. 26-6-1987. De tekst van van de Wet betreffende de intercommunales is als bijlage bijgevougd.

Met de Wet betreftende de intercommunales is de Belgische Wet op de vereniging van gemeenten tot

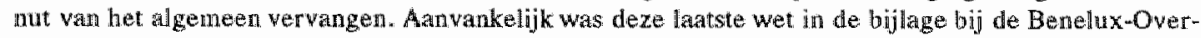
eenkomsit opgenomen. Eerst in november 1991 is de Wet betreffende de intercommunales expliciet in ale bijlage bij de Beneilux-Overaenkomst verneld. Zie: Trb. 1992, nr. 147.

Voor eell witenzenting van de intercommunales, zie: R. Maes, F. De Mot, J. De Power, L. De Sehepper, A Dessoy, M. Lint, C. Perpette (hierna: R. Maes et al.), De Intercommunales, 1992; A. Mast, J. Dujgrdin, a. W, p. 51 $1-523$; R. Maes, Een nieuwe wettelike regeling voor de intercommunalesamenwerking, Tijdschrift voot Gemeenterecht, $1988 / 3, p .144-176 ; A$. Coenen, L étendue du droit d"associattion des communes, Jurisprudence récente, Molvement Communal, 5/1993, p, 265-268.

30. Arrest van de Ratal van Stute wan 15-9-1992, nir. 40.314.

31. Zie b.v.: Het Whalse Decreet inzake bescherming wan oppervlaktewater tegen vervouling, dat voorziet in do erkenning van verenigingen van gemeenten als zuiveringsinstellingen, M. B. 10-1-1986, en het daarby bellorende Besluit wan de Waalse Exacutieve houdende erkenning van bepaalle verenigingen van gemeenten als zuiveringsinsting, M.B. 25-1-1989; Het Vlatuse Decreet tot toetreding var de Vlatuse Gemeenshatp tot een vereniging zonder winstoogmerk, genamd de Vlatamse Operastichting, B.S. 29-12-1992.

Enkele soctorwetten, all dan niet derogerend atn de Wet betreffende de intercommunales, bevatten expliciete grondshagen woor samenwerking (tussen gemeenten), zoals: Wet op de electriciteitsvorziening (intercommumal bedrij); Wet betreffende de civiele bescherming (intercommunale brandweerweren:ging: Wet houdende organisatie van de ruimtelike ordening en de Stedebouw (opstelling gemeenschappelijk plan van anlleg); Wet op de ziekenhuizen (exploitatie van het beheer van ziekenhuizen).

32. Zie ook: A. Alkn, Algemene beginselen en grondslagen van het Behgisch Publiekrecht, Boek 1: De Instellingen, 1988, p. 407; Arrest van het Arbitragehof wan 9-7-1992, nr. 56/92, B.S. 29-8-1992. 
kunnen derhalve eventueel provincies, polders, wateringen en openbare centra voor maatschappelijk welzijn participeren. Samenwerking tussen sec intercommunales is niet mogelijk. ${ }^{33}$ Daar waar alleen openbare besturen deel uit maken van intercommunales wordt ook wel gesproken van zuivere intercommunales. De intercommunales, waarin de particuliere sector een inbreng heeft, worden als gemengde aangeduid. Overigens dienen de gemeenten steeds over de meerderheid der stemmen te beschikken en over het voorzitterschap in de bestuurs- en controleorganen van de intercommunale (art. 11 Wic). Zoals aangegeven in $\S 3$.A. van dit hoofdstuk bestaat er geen wettelijke regeling voor onderlinge samenwerking tussen alleen provincies. Het komt wel eens voor dat provincies in een intercommunale participeren, hetzij door middel van het inbrengen van kapitaal, hetzij ondat de samenwerking tussen gemeenten het lokale belang overstijgt (art. $19 \mathrm{Wic}$ ). Het toezicht op een intercommunale, waarin een provincie participeert, zal dan in de regel bij de Gewestexecutieve berusten.

Hier is met name van belang, dat de Wet betreffende de intercommunales niet zozeer, in tegenstelling tot de Wet gemeenschappelijke regelingen, op een publiekrechtelijke samenwerking zoals de overdracht van bevoegdheden op het terrein van het milieu e.d. ziet, maar veeleer privaatrechtelijke samenwerking regelt in het kader van bepaalde verzorgende taken. Praktisch vertaald: de oprichting van/het beheer door intercommunales geschiedt hoofdzakelijk in het kader van de electriciteits-, gas- en of waterdistributie (nutsvoorzieningen), de waterzuivering, de aanleg van infrastructurele zaken, de economische expansie, de ruimtelijke ordening, de verwijdering van afvalstoffen, de medischsociale voorzieningen (b.v. ambulancevervoer), recreatieve voorzieningen, e.d. ${ }^{34}$ Sommige intercommunales voeren meerdere met elkaar verbandhoudende taken uit. Enkele taakvelden van de intercommunales, zoals de verwijdering van afvalstoffen en het ambulancevervoer komen overeen met die waarop in Nederland in het kader van de Wet gemeenschappelijke regelingen samengewerkt wordt. Er bestaan weinig intercommunales met een algemene doelstelling à la de basisregelingen voor openbare lichamen op basis van de Wet gemeenschappelijke regelingen. Er zijn evenmin vaste samenwerkingsgebieden. Overigens wordt de territoriale indeling van de intercommunales overwegend bepaald door de provincie- en arrondissementsgrenzen. Afhankelijk van het beleidsterrein waarop of de streek waar- in samengewerkt wordt, kan dit evenwel anders zijn.

\section{Samenwerkingswormen}

Hoewel de intercommunale een publiekrechtelijke rechtspersoon is, dient deze de privaatrechtelijke rechtsvorm van naamloze-, coöperatieve vennootschap of vereniging zonder winstoogmerk aan te nemen (art. 5 Wic). De belangrijkste bestuurs- en controle organen van de interconmunales zijn de algemene vergadering, de raad van beheer en het college van commissarissen. De algemene vergadering bestaat voor het grootste gedeelte uit vertegenwoordigers van de dee/nemende gemeenten, aangewezen door de raad uit de raad en het college van burgemeester en schepenen. De algemene vergadering benoemt de leden van het dagelijks bestuur, de raad van bestuur. Het college van

33. Zie ook J. Vanhaeverbeek, Les intercommunales, 1988, p. 58.

34. Zie b.v.: Verslag namens de commissie voor de binnenlandse aangelegenheden, Gedr. St., Senaat 1982$1983,529 / 2$, o.a. p. 86; R. Maes, in: R. Maes et al., a.w., p. 6. 
commissarissen, dat belast is met het interne toezicht op de intercommunale, wordt benoemd door de algemene vergadering. Behalve dat de statuten de bevoegdheden van de bestuurs-en controle organen dienen te vermelden, is niet direct uit de wet af te leiden - op basis van artikel 25 Wet betreffende de intercommunales is er overigens wel een geèxpiciteerde bevoegdheid tot onteigening - over welke bevoegdheden de intercommunale nu precies kan beschikken. Mast, Alen en Dujardin stelden met betrekking tot de Wet op de vereniging van gemeenten tot nut van het algemeen: "De betrokken gemeenten mogen derhalve, bij onderling akkoord, aan een intercommunale vereniging geen bevoegdheden opdragen welke de wet aan gemeentelijke organen, zoals de gemeenteraad, de burgemeester, de secretaris of de ontvanger toekent." 35 Deze strekking ligt eveneens ten grondslag aan zijn opvolger de Wet betreffende de intercommunales. Maes stelt hieromtrent: "Toch moet daarbij in acht worden genomen dat in het kader van de intercommunale samenwerking geen wijzigingen kunnen aangebracht worden aan de bewoegdheidsverdeling, zoals die in de gemeentewet of in andere wetten betreffende de gemeentelijke organisatie is vastgelegd." 36 In Belgie heerst de opvatting, dat de intercommunales niet als intercommunale macht kunnen optreden, tenzij de wet/decreetgever daarvoor in bijzondere gevallen een basis creeert. ${ }^{37}$ Overigens wordt in de model-statuten voor de instelling van een grensoverschrijdend openbaar lichaam ervan uitgegaan dat de Benelux-Overeenkomst een dergelijke grondslag levert en voorziet in een mogelijke overdracht van bevoegdheden. ${ }^{38}$

Naast het oprichten van intercommunales kunnen gemeenten onderling overeenkomsten sluiten met betrekking tot welbepaalde leveringen en diensten van gemeentelijk belang. Ook de intercommunales kunnen zulke overeenkomsten onder elkaar sluiten en met de gemeenten (art. 28 Wic). Het gaat hier om overeenkomsten waarop in de regel het privaatrecht van toepassing zal zijn. Deze bepaling, het feit dat het vrij gebruikelijk is dat naast openbare lichamen de particuliere sector in de intercommunales participeert ${ }^{39}$, alsmede de rechtsvorm van de intercommunales illustreren toch vooral het meer "privaatrechtelijke karakter" van de samenwerking op basis van de Wet betreffende de intercommunales. Dit moge ook nog eens blijken uit het feit, dat het stemrecht van de deelnemende gemeenten in de algemene vergadering dient overeen te stemmen met het aantal aandelen walrover deze beschikken (art. 12 Wic). De intercommunale is veel neer de (intergemeentelijke) pendant van de binnengemeentelijke regie (het gemeentelijk bedrijp.

35. A. Mast, A. Alen, J. Dujardin, Overzicht van het Belgisch administratief recht, 10e druk, 1986, p. $353-354$.

36. R. Maes, a.w., p. 159.

In dit vorband is ook artike 113 Grondwet illustratief dat, in tegenstelling tot alle overige publiekrechtelijke rechtspersonen, de intercommunale niet noemt als instantie, die belastingen van de burgers kan heffen. Voorts kan gewezen worden op artikel 14 Wet houdende organisatie van de ruimtelijke ordening en van do stedebouw. Hierin is welliswaar de mogelijkheid voorzien var de opstelling door intercommunales van een gemeenschappelijk algemeen plan van anleg - een algemeen plan van aanleg is te wergelijken met een Nederlands bestemmingsplan, de vaststelling ervan geschiedt evenwel door de desthetreffende gemeenteraden.

37. R. Maes, in: R. Maes at al., a.w., p. 315.

38. Sub 5.4.3 van dit hoofdstuk worden deze model-statuten nader beschreven.

39. Zie b.v.: Verslag namens de Commissie voor de binnenlandse aangelegentheden, a.w., p. 36-37. 
Het karakter van de samenwerking komt veel meer overeen met hetgeen in Nederland op basis van artikel 228 lid 1 juncto artikel 234 Gemeentewet en artikel 93 Provinciewet geregeld wordt. ${ }^{40}$ Daarbij zijn de intercommunales wel iets meer publiekrechtelijk ingebed. Zo heeft het personeel van de intercommunales de status van ambtenaar, is er toezicht van de hogere overheid op het handelen (en niet alleen het aangaan van privaatrechtelijke samenwerking) van de intercommunales en kunnen de intercommunales als administratiewe overheden beschouwd worden. Mochten de intercommunales al bevoegd zijn tot het nemen van eenzijdige besluiten, dan worden deze beheerst door de algemene beginselen van behoorlijk bestur en is hiertegen een rechtsgang bij de Raad van State niet uitgeslloten. Een rechtsgang bij de gewone rechter (verbintenissen uit contracten alsmede de aansprakelijkheid wegens onrechtmatige daad) of de handelsrechtbank (daden van koophandel) is evenwel eerder aan de orde. ${ }^{* 1}$

\section{Toezicht en geschillenbeslechting}

In hoofdstuk 4 is naar aanleiding van artikel 7 Bijzondere wet ingegaan op het administratieve toezicht op de gemeenten, provincies, polders en wateringen alsmede de openbare centra voor maatschappelijk welzijn. Hier wordt kort ingegaan op het administratieve toezicht op de intercommunales. ${ }^{42}$

Voor Vlaanderen en Wallonie is het specifieke toezicht op de intercommunales, op basis van artikel $6 \xi 1$, VIII, $1^{\circ}$ Bijzondere wet, in decreten geregeld. ${ }^{43} \mathrm{Op}$ basis van het Vlaamse decreet betreffende de werkwijze van de controle op en de vaststelling van het ambtsgebied van de intercommunales berust de vernietiging, schorsing en goedkeuring ten aanzien van (besluiten van) de intercommunales in de regel bij de Gewestexecutieve, die in dit kader het ambt van de Gewestcommissaris heeft ingesteld. Besluiten die de goedkeuring behoeven van de Gewestexecutieve zijn o.a. de oprichting van de intercommunale, de statutenwijziging, de overeenkomsten met betrekking tot welbepaalde leveringen en diensten, afgesloten tussen gemeenten, tussen intercommunales of tussen intercommunales en gemeenten (art. 8 van het desbetreffende Vlaamse decreet). De Gewestcommissaris heeft de bevoegdheid besluiten van de intercommunale te schorsen, die in strijd zijn met de wet, de statuten of het algemeen belang. De Executieve kan alle

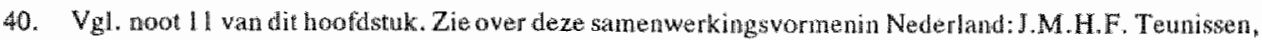
Samenwetking op basis van het privaatrecht, in: Handboek Bestuurlijke Sanenwerking, a.w., IV.C, p. 2 e.v.

41. Zie ook: R. Mats, in: R. Maes at al, p. 369.

4. Ower het toezichl op de intercommunales, zie o.a.: R. Maes, in: R. Maes et al, a. w., hoofdstuk XI.

43. - Dexreet van de Vlamse Raad betreffende de werkwijze van de controle op an de vaststelling vian het ambtsgebied van intercommunales, $1-7-1987$, B.S, 17-7-1987.

- Decrét du Consell régional wallon du 20-7-1989, M.B. 8-9-1989 (Err. 10-5-1990), organisant la tutelle sur les communes, les provinces et les intercommunates de la Region wallonne, gewijzigd door decreat van 25-7-199\%, M.B. 15-10-1991; Zie ook: Arrêté de l'Executif regional wallon réglatht les mesures d'execution du decret du Conseil régional wallon du 29-7-1989 organisant lat tutelle sur les communes, les provinces et les intercommunales de la Region wallonne, 14-11-1991, M.B. 17-1-1992.

De genoemde Waalse decreten heffen grotendeels op: het Decrét du Conseil rägional wallon du 5-11-1987 relatíf aux intercommuales dont le ressort ne dépásse pas les linnites de la Région wallonne, 5-11-1987, M.B. 8-1-1988. 
besluiten yan de intercommunale vernietigen op dezelfde gronden (art. $10 \& 3$ van het desbetreffende Vlaamse decreet).

Voor het specifieke toezicht op de intercommunales in Wallonië is in het Waals decreet betreffende het toezicht op gemeenten, provincies en intercommunales sprake van een algemeen vernietigingsrecht (la tutelle générale d'annulation) en een bijzonder goedkeuringsrecht (la tutelle spéciale d'approbation). Het vernietigingsrecht en het goedkeuringsrecht inzake de intercommunales berust bij de Waalse Gewestexecutieve. Evenals in Vlaanderen behoeft de oprichting yan de intercommunale alsmede de statutenwijziging voorafgaande goedkeuring. Voor de genoemde overeenkomsten met betrekking tot welbepaalde leveringen is in Wallonië geen goedkeuring vereist (art. $41 \S 2$ van het desbetreffende Waalse decreet).

In Wallonië is in tegenstelling tot Vlaanderen niet voorzien in een dwangtoezicht. In Vlaanderen is in deze voorzien in de mogelijke instelling van een Bijzondere Gewestcommissar is. De gronden voor goedkeuring dan well vernietiging zijn in beginsel dezelfde als in Nederland, namelijk strijd met de wet en het algemeen belang. Inzake de toezichtsbesluiten bestaat in België een beroepsmogelijkheid bij de Raad van State.

De Wet betreffende de intercommunales noch de beide toezichtsdecreten bevatten een regeling inzake geschillen tussen de deelnemende overheden dan wel de deelnemende overheden en de intercommunale. In de regel zal het om 'privaatrechtelijke' geschillen gaan en zal daatom de gewone rechter bevoegd zijn. In \& 5.D.6. van dit hoofdstuk wordt hierop nog dieper ingegaan.

\section{SAMENWERKING TUSSEN POLDERS EN WATERINGEN}

Is in Nederland de samenwerking tussen alle decentrale (territoriale danwel functionele) overheden in beginsel geregeld in één wet, namelijk de Wet gemeenschappelijke regelingen, in België is dat niet het geval. De wettelijke basis voor de samenwerking tussen polders onderling en die tussen wateringen onderling is gelegen in de Wet betreffende de polders respectievelijk de Wet betreffende de wateringen. Op basis van artikel 6 van de Wet betreffende de polders kunnen polders door de Koning (thans Executieve) bevolen worden een vereniging te vormen met het oog op hun gemeenschappelijke verdediging of voor de uitvoering van werken, waarbij zij gemeenschappelijk belang hebben. Deze vereniging bezit rechtspersoonlijkheid (art. 11 Wet betreffende de polders). Hetzelfde geldt voor de wateringen. Op basis van artikel 6 van de Wet betreffende de wateringen kunnen wateringen door de Koning (thans Executieve) bevolen worden een vereniging te vormen met het oog op hun gemeenschappelijke verdediging of voor de uitvoering van werken, waarbij zij gemeenschappelijk belang hebben. Deze vereniging bezit rechispersoonlijkheid (art. 11 Wet betreffende de wateringen).

Omdat er geen van dergelijke verenigingen van polders/wateringen zijn opgericht - in de praktijk wordt overigens wel feitelijk samengewerkt - wordt hierop niet verder ingegaan. 


\section{SAMENWERKING TUSSEN OPENBARE CENTRA WOOR MAATSCHAPPELIK WELZIN (O.C.M.W.'s)}

Is in Nederland de samenwerking tussen alle decentrale (territoriale danwel functionele) overheden in beginsel geregeld in één wet, namelijk de Wet gemeenschappelijke regelingen, in België is dat niet het geval. De samenwerking tussen openbare centra woor maatschappelijk welzijn is geregeld in de Organisatiewet betreffende de openbare centra voor maatschappelijk welzijn. In de regel zijn de o.c.m.w.'s per gemeente opgericht. $\mathbb{E r}$ bestaat de mogelijkheid van intercommunale o.c.m. W. "s (artikel 4 Organisatiewet o.c.m.w.). Hierop zijn dan in beginsel de regels betreffende de intercommunales vam toepassing. Hiervoor wordt verwezen naar het gestelde in 3.B. van dit hoofdstuk. Daarnaast is artikel 118 e.v. Organisatiewet o.c.m.w. rellevant in deze. In artikel 118 wordt bepaald: "een openbaar centrum voor maatschappelijk welzijn kan, om een van de opdrachten uit te voeren die door deze wet aan de centra zijn toevertrouwd, een vereniging tot stand brengen met een of meer andere openbare centra voor maatschappelijk welzijn, met andere openbare besturen en/of met rechtspersonen andere dan die winstoogmerken hebben. Deze verenigingen zijn onderworpen aan de regels en het toezicht, zoals die gelden voor de o.c.m.w.'s (artikel 126 Organisatiewet $0 . c . m . w$. .s). ${ }^{44}$ Hiervoor wordt verwezen naar hoofdstulk $4 \$ 2 . F$.

\section{E. AGGLOMERATIES EN FEDERATIES VAN GEMEENTEN}

Artikel 108bis Grondwet regelt de oprichting bij wet van agglomeraties en federaties van gemeenten. In $\$ 3$ van artikel 108bis Grondwet is bepaald dat verscheidene federaties van gemeenten zich met elkaar of met een of meer agglomeraties mogen werstaan of verenigen, onder de voorwaarden en op de wijze door de wet te bepalen, om zaken die tot hun bevoegdheid behoren gemeenschappelijk te regelen en te beheren. In de bijlage bij de Benelux-Overeenkomst is de uit artikel 108bis Grondwet voortvloeiende Wet houdende organisatie van agglomeraties en federaties van gemeenten niet opgenomen. ${ }^{45}$ Deze wet komt betreffende de gemeentelijke samenwerking inhoudelijk evenwel veel meer overeen met de Nederlandse Wet gemeenschappelijke regelingen. Om die reden wordt hierop kort ingegaan. Op basis wan artikel 4 van deze wet kan tot "publiekrechtelijke' samenwerking op terreinen als ruimtelijke ordening, bescherming van het leefmilieu e.d. gekomen worden. De mogelijke taken en bevoegdheden wan de organen van de agglomeraties en federaties van gemeenten, de raad en het witwoerend college, zijn veelal vergelijkbaar met (en zelfs veelall werdergaand dan) die van de organen van de openbare lichamen op basis van de Wet gemeenschappelijke regelingen in Neder-

44. Zie over de intercommunale O.c.m.w. "s respectievelijk verenigingen van o.c.m.w. "s. R. Maes, Van de intercommunale onderscheiden vormen wan samenwerking tussen openbare besturen en wan intergemeentelijke solidariteit, in: R. Maes al, a.w., p. 22 e.w.

45. Wet van $26-7-1971$, B.S. 24-8-1971.

Voor een uiteenzetting van de agglomerathes en federaties wan gemeenten, zie: A. Mast, I. Dujardin, a.w. $485-510$. 
land. ${ }^{4}$ In Belgie is op dit moment slechts voor de Brusselse agglomeratie daadwerkelijk (nog) iets geregeld mede op basis van artikel 108bis/ter Grondwet. ${ }^{47}$ Voor de overige vier agglomeraties, waarvan het gebied bij wet bepaald wordt is dit niet het geval. Artikel 2 van deze wet bepaalt dat elke gemeente die geen deel uitmaakt van een agglomeratie kan behoren tot een federatie. In het begin van de jaren zeventig zijn er wel enkelle (rand)federaties rond Brussel opgericht. Deze zijn opgeheven. De facto zijn er in Belgiẻ thans geen federaties van gemeenten. Dit heeft waarschijnlijk te maken met het dwingende karakter van de samenwerking en met het feit dat door de (voortvarende aanpak van de) herindeling van gemeenten de noodzaak hiertoe ging ontbreken. Het voert te ver daar thans dieper op in te gaan. ${ }^{48} \mathrm{Nu}$ deze wet niet in de Bijlage bij de Benelux-Overeenkomst is opgenomen en bovendien nauwelijks in de Belgische praktijk functioneert, zullen thans de instrumenten ervan ook niet toegepast kunnen worden ten aanzien van de decentrale grensoverschrijdende samenwerking. Hetgeen hier geschreven is, is veeleer een illustratie van het publiekrechtelijk karakter van de samenwerking op bas is van deze wet versus het meer privaatrechtelinke samenwerkingsrecht op basis van de Wet betreffende de intercommunales.

\section{F. GEWESTEN (GEMEENSCHAPPEN) EN INTERCOMMUNALES}

\section{Inleiding}

In het navolgende wordt zoveel mogelijk in het licht van de decentrale grensoverschrijdende samenwerking ingegaan op de positie van het Vlaamse en Waalse Gewest ten aanzien van de intercommunales. Het zijn deze Gewesten die belangrijke regelgevende bevoegdheden hebben ten aanzien van intercommunales. De Gemeenschappen spelen een beperktere rol (alleen in het kader van culturele en persoongebonden aangelegenheden) ten aanzien van de intercommunales. In het navolgende wordt dan ook hoofdzakelijk de positie van de Gewesten belicht. Hetgeen voor de Gewesten wordt geschreven, geldt overigens bimmen het bevoegdhedenpakket van de Gemeenschappen ook voor deze laatste. Aan het toezicht door de Gewesten op de intercommunales is, mede in het licht van de verwijzing door de Benelux-Overeenkomst naar het nationale recht, als het gat orn toezicht op decentrale grensoverschrijdende samenwerking, reeds aandacht besteed in 3. B.3 van dit hoofdstuk. Hier wordt de algemene positie van de Gewesten ten opzichte van de intercommunales (\$ 3.F.2) alsmede ten aanzien van de Gewestgrenzen overschrijdende intercommunales aan de orde gesteld (\$ 3.F.4). Aangezien deze laatste opgericht worden in het kader van de samenwerking tussen de Gewesten zelf, wordt op de samenwerking tussen Gewesten eveneens kort ingegaan (\& 3. F. 3).

46. Er is een duidelijke parallel tussen de Belgische agglomeraties (c. th. federaties) met de roekomstige regionale openbare liohamen en gebiedsatoriteiten in Nederland op basis van de Kaderwet besurur in verandering. Zie hionvoor 2.3 .4 van dit hoofdstuk.

47. Zie woor wen nadere beschriving ten anzien van de Brusselse agglomeratie en de opmame van de Brusselse agglomeratie in de structur van het Brusselse Hoofdstedelijk Gewest: A. Mast, J. Dujardin, a.w. p. 495 e.v,; A. Alen, a.w., p. 397 e.v.; R. Maes, in: R. Maes al., a.w. p. 223 e.v.

48. Zie b.w. F. Delpérée, Droit Constitutionnel, 1980, p. 324-325; G. Craenen, Het Koninkrijk Belgie, in: Her statsrecill wa de landen der Europese Geneenschappen, onder redactie van L. Prakke, C.A.J.M. Kortmann, 3e geheel herziene druk, 1988, p. 56. 


\section{Algemeen}

In het Vlaamse en Waalse Gewest zijn met betrekking tot de intercommunale aspecten, waarvoor de Gewesten bevoegd zijn, decreten tot stand gekomen. Hierop is bij de bespreking van het toezicht op de intercommunalles al ingegaan. ${ }^{49}$ De genoemde decreten zijn nog gebaseerd op het oude artikel $6 \& 1$, VIII, $1^{\circ}$ Bijzondere wet. Hierin was bepaald dat de werkwijze, de controle en de vaststelling van het ambtsgebied van de verenigingen van gemeenten tot nut wan het algemeen en de toepassing van de organieke wetten betreffende die verenigingen een aangelegenheid is, waarvoor de Gewesten be voegd zijn. De precieze bevoegdheidsafbakening in deze tussen de Staat en de Gewesten is onderwerp geweest van een aantal adviezen en rechterlijke uitspraken. Volgens het Arbitragehof behelsde dit artikel $6 \$ 1$ VIII, $1^{\circ}$ Bijzondere wet een onderscheid tussen tweeërlei bevoegdheden voor de Gewesten. Het gaat allereerst om een normatieve bevoegdheid. 50 Voor de Gewesten is er de normatieve bevoegdheid (en de uitoefeningsbevoegdheid, die eruit voortvloeit) die beperkt is tot de werkwijze, de controle en de vaststelling van het ambtsgebied van de verenigingen van gemeenten. De nationale overheid blijft derhalve bevoegd voor iedere andere aangelegenheid waar het gaat om de fundamentele kenmerken van de intercommunales. ${ }^{51}$ Te denken valt b.v. aan de voorwaarden tot het aangaan of de terugtrekking uit intercommunale verenigingen. Ten tweede, aldus het Arbitragehof, is er een bevoegdheid voor de Gewesten om de organieke wet toe te passen in materies waarvoor de Gewesten geen normatieve bevoegdheid bezitten. In dat verband kan b.v. gewezen worden op de uitoefening van het toezicht, waaraan in $\$ 3$. B.3 van dit hoofdstuk aandacht is besteed.

Na de recente wijziging van juli 1993 van de Bijzondere wet is het allemaal anders geworden. Het nieuwe artikel $6 \$ 1$ VIII, $1^{\circ}$ Bijzondere wet bepaalt, dat de Gewesten exclusief tot regelgeving (en dus uitvoering) bevoegd zijn inzake: 'de verenigingen van provincies en van gemeenten tot nut van het algemeen, met uitzondering van het door de wet georganiseerde specifiek toezicht inzake brandbestrijding. ' De bestaande nationale wetgeving blijft gelden, totdat deze via decreten gewijzigd/opgehe ven wordt.

\section{Samenwerking tussen Vlaanderen en Wallonië}

Samenwerking op het niveau van de decentrale overheden in het Waalse en Vlaamse Gewest is cerst aan de orde als de Gewesten zelf hiervoor iets geregeld hebben. De Gewestgrenzen zijn in dat perspectief te vergelijken met nationale grenzen. Evenwel voorziet de Belgische wetgeving in samenwerkingsmogelijkheden tussen de Gewesten. Zo dienen de betrokken Gewestexecutieven op basis van artikel $6 \$ 2$ Bijzondere wet onderling overleg te plegen ten aanzien wan bossen gelegen op het grondgebied van meer dan éen Gewest, het openen en sluiten wan de jacht, wogelvangst en visvangst en de waterlagen die zich over meer dan één Gewest uitstrekken. Terzijde zij opgemerkt dat

49. Zie noot 42 en 43 wan dit hoofdstuk.

50. Arrest valn het Arbitragehof van 28-6-1985, 1985/17, B.S. 6-7-1985.

51. Vgl. het advies van de Raad van State inzake het wetsontwerp betreffende de intercommunales, Gedr. St. Kanter, 1985-1986, 125/13, p. 4. Zie ook: A. Alen. J. Dujardin, Casebook Belgisch Grondwettelijk Rechi, 1986, p. 357. 
dit artikel overigens ook overlegverplichtingen bevat tussen de betrokken Executieven en de federale overheid, waronder die van 83 en 3 bis terzake (aspecten van) o.a. het nationaal energiebeleid, het luchtverkeer en de spoorwegen. Ten aanzien van de Gemeenschapsaangelegenheden bestaat er verplicht overleg tussen de Gemeenschapsexecutieven (en de nationale overheid) ter zake van b.v. het gezondheidsbeleid (art. 5 \& Bijzondare wet). Op basis van art. 31/31bis Wet van 9-8-1980 houdende gewone wet tot hervorming der Instellingen bestaat er een algemeen Overlegcomité tussen de Staat, de Gemeenschappen en de Gewesten. ${ }^{52}$

Daarnaast is er de mogelijkheid tot het sluiten van samenwerkingsakkoorden. ${ }^{53}$ Artikel $92 b i s \$ 1$ Bijzondere wet bepaalt dat de Staat, de Gemeenschappen en de Gewesten (facultatiewe) samenwerkingsakkoorden kumen sluiten die onder meer betrekking hebben op de gezamenlijke oprichting en het gezamenlijk beheer van gemeenschappelijke diensten en instellingen, op het gezamenlijk uitoefenen van eigen bevoegdheden of op de gemeenschappelijke ontwikkeling van initiatieven. Artikel $92 b$ is $\$ 2$ Bijzondere wet noemt enkele aangelegenheden, zoals Gewestgrenzen overschrijdende wegen en waterwegen, stads en streekvervoer, waarvoor Gewesten dergelijke akkoorden (verplicht) moeten sluiten. Sinds juli 1993 is hieraan de aangelegenheid "van de verenigingen van gemeenten en provincies die de grenzen van een Gewest overschrijden' toegewoegd. $\$ 3$ van ditzelfde artikel regelt de (verplichte) afs luiting wan akkoorden op enkele terreinen, zoals telecommunicatie, tussen de Gewesten en de Staat. \$4 van ditzelfde artikel regelt de afsluiting van éen (verplicht) akkoord tussen de Gemeenschappen. ${ }^{54}$ Artikel $92 \mathrm{~b}$ is \& $4 \mathrm{bis}$ en 4ter Bijzondere wet regelt het sluiten van (een) samenwerkingsakkoord(en) tussen de nationale overheid, de Gemeenschappen en de Gewesten ten aanzien van verdragssluiting en externe betrekkingen. Hiervoor wordt verwezen naar het gestelde in § 5.D.7.d. van dit hoofdstuk.

De juridische status van deze 'publiekrechtelijke overeenkomsten' is vaak gekoppeld aan het instrument van goedkeuring ervan. Zij kunnen de status van wet of decreet hebben. " ${ }^{55}$ Voor de rechtsbescherming van de partijen die dergelijke akkoorden sluiten,

52. B.S. 15-8-1980. Voor het Inwendig Reglement wanhet Overlegcomnte van 2 -6-1992, zie: B.S. $23-6-1992$. Het Over egcomite is o. at. verplicht een Interministeriele Conferentie voor het buitenlands beleid op to richtertis.

53. Zia over deze samenwerkingsakkoorden b.v.: A. Alen en P. Peeters, Samenwerkingswerbanden tussen de Stat, de Gemeenschappen en de Gewesten, in: Stat, Gemeenschappen en Gewester, R. Blanpaim et. al., 1989, p. 115-124; P. Coenraets Les accords de coopérationdaras la Belgique fédérale, Administration Publique, T $3 / 1992$, p. $1.58-200$.

54. Vgl. voot de samerwerking vande Duitstalige Gemeenschap artikel $55 / 550 \mathrm{~s}$ van de Wet tot hervorming der instellingen voor de Duitstatige Gemenschap, $21-12-1983$, B.S. 18-1-1984. Op basis van artikel 55 van de betreffende wet kan de Duistalige Gemeenschap samenwerkings- of verenigingsakkoorden sluiten met éç of meer Gemeenschappen. Daarbij word in commissies voor samenwerking voonzien. Artikel 55 bis wan de betreffende wet bepalli: "Artikel $92 \mathrm{bis}, 881$, 4 bis, 4 ter, 5 en 6 , alsook artikel 92 ter van de bijzondere wet zijon van overeenkomstige toepassing op de Duitstalige Gemeenschap."

55. F. Coenrates, a.w. p. 165-166.

In deze kan nog gewezen worden op de vergelijkbare "Staatsverträge" tussen de Duitse Lünder. Hierwoor wordt verwezen naar hoofdstuk $62 . \mathrm{C} .2$. 
is er het "Samenwerkingsgerecht" op basis van de Wet op het rechtscollege bedoeld buj artikel $92 \$ 5$ en 6 en artikel $94 \$ 3$ Bijzondere wet. ${ }^{56}$

\section{Gewestgrenzen overschrijdende intercommunales}

De genoemde Gewestelijke decreten inzake (het toezicht op) de intercommunales zijn alleen van toepassing op intercommunales, die qua werkgebied geheel binnen het Vlaamse dan wel Waalse Gewest gelegen zijn. In dit verband is lange tijd de vraag geweest of woor intercommunales, die de Gewestgrenzen overschrijden artikel 20 van de Wet betreffende de intercommunales onverkort gold en in hoeverre de regeling c. $\mathrm{q}$. witoefening van het toezicht op Gewestgrenzen overschrijdende intercommunales tot de bevoegdheid van de Gewesten (dan wel de Staat) behoorde.

Tot vó́r de wijziging van juli 1993 gold artikel $6 \$ 5$ Bijzondere wet ten aanzien van een intercommunale die op het grondgebied van de beide Gewesten was gelegen. Dit artikel bepaalde: "ledere beslissing betreffende verenigingen van gemeenten waarvan het ambtsgebied zich over meer dan érn Gewest uitstrekt, moet in onderlinge overeenstemming tussen de betrokken Executieven genomen worden." In dit verband stelde de Raad van State dat noch de Grondwet, noch de Bijzondere wet het aannemen van gemeenschappelijke normen door twee Gewestraden voorschreven. De Raad van State was van mening, dat bij gebreke aan een wettelijke regeling voor het bereiken van die onderlinge overeenstemming, dergelijke intercommunales ressorteren onder het toezicht van de nationale overheid. ${ }^{57}$ Het Overlegcomité sloot zich bij het standpunt van de Raad van State aan. ${ }^{58}$ Beide standpunten zijn achterhaald door een uitspraak van het Arbitragehof. Het Arbitragehof acht het niet vanzelfsprekend dat bij gebreke aan een uitdrukkelijke regeling omtrent de werkwijze, de controle op en de vaststelling van het ambtsgebied wan Gewestgrenzen overschrijdende intercommunales de nationale wetgever in die aangelegentheden bevoegd is gebleven. Er wordt door het Arbitragehof geen residuaire bevoegdheid van de Staat aangenomen ten aanzien van deze aangelegenheden in het licht van de expliciete bevoegdheid van de Gewesten op basis van artikel $6 \& 1$ VIII $1^{\circ}$ Bijzondere wet. ${ }^{59}$ Het feit dat de Gewesten alleen maar decreten hebben gemaakt woor intercommunales, waarvan het grondgebied binnen één Gewest is gelegen, brengt niet de consequentie met zich dat zij onbevoegd zijn een (zelfde) regeling te treffen met

56. Wet wan 23-1-1989, B.S. 24-1-1989.

Voor de verhouding inzake de rechtsbescherming tussen dit "Sameawerkingsgerecht, het Arbitragehof" de Raxd wa State en de gewone rechter, zle: $\mathbb{F}^{*}$. Coenrats. a.w. p. 168-177,

57. Adwies van de Rad van State inzake het wetsontwerp betreffende de intercommunates,a.w., p. 1-2. 27a over deze materie ook: R. Maes, a.w. p. 154.

58. Gemotiverd advies van het Overlegcomite over een wetsontwerp betreffende de intercommunales an anendementen, Stuk Kamer wan Volkswertegenwoordigers, 1985 1986, nr. 125/14, p. 2.: Het Overlegcomite sluit zich an bij het standpunt wan de Raad van State van 21 mei en 4 juni 1986 , en is derhalwe wan ardeel dat artikel $4,7^{\circ}$, artikel 6 , artikel $13, \$ 2$, th artikel 20 , wan het ontwerp val wet betref fende de intercommunalesuitsluitend betrekking kunen hebben op de intercommunaleverengingen wharHan het ambtsgebied de grenzen wan het Brusselse Gewest niet overschrijut, ewends op de verenigingen wan gemeenten waarvan het ambisgebied zich over meer dan én Gewent vitrokt, en dat, binnen deze grenzen, de voornoemde bepalingen de bevoegdheid wan de nationale wetgever niet overschrijden."

59. Arrest wan het Arbitragehof van 9-7-1992, nr. 56/92, 8.S. 29-8-1992. 
betrekking tot Gewestgrenzen overschrijdende intercommunales. Het voorgaande impliceert derhalve dat de normatieve en uitvoerende bevoegdheden van de Gewesten ten aanzien wan intercommunales ook golden ten aanzien van Gewestgrenzen overschrijdende intercommunales. De regeling van artikel 20 Wet betreffende de intercommunales was hierop niet van toepassing gebleven.

Sinds juli 1993 geldt in deze het aangepaste artikel 92 bis $\$ 2$ Bijzondere wet, waarin is bepaald dat Gewesten verplicht een samenwerkingsakkoord dienen te sluiten inzake "de verenigingen wan gemeenten en provincies die de grenzen van een Gewest overschrijden".

In de grensoverschrijdende samenwerking tussen België en Nederland speelt deze intergewestelijkefintergemeenschappelijke dimensie b.v. een rol daar waar samenwerking tussen Nederlandse én Vlaamse én Waalse overheden in het geding is. Een voorbeeld is de St. Pietersberg, een grensoverschrijdend 'natuur'gebied, dat zowel op Waals, Vlaams als Nederlands territoir is gelegen. ${ }^{61} \mathrm{Bij}$ de samenwerking binnen de Euregio Maas Rijn, hierbij valt ook te denken aan de samenwerking tussen de MHALH-steden, komt daar nog een Duitse dimensie bij. ${ }^{62}$ Het is op zijn minst bijzonder te noemen, dat de Benelux-Overeenkomst voor samenwerking tussen Nederlandse en Belgische (Vlaamse en/of Waalse) decentrale overheden regels bevat, terwijl het wettelijk regime in België voor de samenwerking tussen decentralle overheden in Vlaanderen en Wallonië nog nauwelijks is uitgekristalliseerd.

\section{G. WIZIGINGEN IN HET BELGISCHE DECENTRALE SAMENWERKINGSRECHT}

Zoals aangegeven in $\$ 3 . F .2$ van dit hoofdstuk is sinds kort het gewijzigde artikel $6 \$ 1$ VIII, $1^{\circ}$ Bijzondere wet in werking getreden, waardoor de Gewesten exclusief bevoegd zijn geworden inzake samenwerking tussen gemeenten en provincies. Als gevolg van deze wijziging is aanpassing van de op de samemwerking tussen gemeenten (en provincies) betrekking hebbende regelgeving op termijn niet uitgesloten. Een aantal "knelpunten' zoals het ontbreken van samenwerkingsmogelijkheden tussen provincies, de geringe publiekrechtelijke bevoegdheden van de intercommunales, het ontbreken van regels inzake Gewestgrenzen overschrijdende samenwerking alsmede de aanpassing van de Wet betreffende de intercommunales aan de Benelux-Overeenkomst kunnen hiervoor de

60. Hier wordt steeds gesproken van Gewestgrenzen owerschridende intercommunales. Bepaalde taken van dergelijke intercommunaleskunnen uitetaard ook tot de bevegdheden wan de Gemeensohappen behoren.

61. Zu hiorover: Rèné Seerden, Samenhang over de grenzen heen, Gremsoversiehrijdende samenwerking, wettelijke regelingen in het bijzonder de gemeentelik bevegdheden, TBP, 1989/8, p. 508 .

62. Het wordt dan extra gecompliceerd, omdat er tussen Delgiè en Duitsland (Noordrijn-Westfalen) een met de Benelux Overenkonst vergelikbaar verdrag inzake decentrale grensowersehrijdende samenwerking ontbrekt. Zolang een dergelik verdrag ontbreekt zijn voor deze 3 landen samenwerking twee oplossingen denkbara:

- Bern samenwerkingswarbandop basis van de Duits-Nederlandse Overeenkomst inzake decentrale samenwerking zou aangewezen kunnen worden als een overheid die kan samenwerken op basis wan de BeneluxOwereenkomst vice wersa. Dit is niet (goed) mogelijk, ondat de samenwerkingswormen (qua bevoegdheden) op basis van beide verdragen nogal uiteen kunnen lopen.

- Er kan natumrigk altijd feiteluk samengewerkt worden (door b.v. in dezelfde ruimte te vergaderen). 
directe aanleiding vormen. Op dit moment zijn er evenwel nog geen plannen openbaar gemaakt voor aanpassing van de bestaande regels in deze.

\section{\$. Samenvattende vergelijking decentrale samenwerking Nederland-België}

De nationale wetgeving in beide landen gaat mijns inziens uit van het principe, dat de interne samenwerking in eerste instantie zal plaatsvinden tussen overheden van hetzelfde niveau (horizontale samenwerking): gemeenten werken met gemeenten samen, polders werken met polders samen, wateringen werken met wateringen samen, waterschappen werken met waterschappen samen en o.c.m.w.'s werken met o.c.m.w.'s samen. Voor Nederland geldt dit in tegenstelling tot België, waar geen regeling is woor samenwerking tussen provincies onderling, ook voor de provincies. Mijns inziens ligt zowel in Nederland als in Belgie het zwartepunt op de samenwerking tussen gemeenten. Van samenwerking tussen overheden van verschillende niveau's (verticale samenwerking) is minder veelvuldig sprake. Dit heeft natuurlijk te maken met de identieke sectorbevoegdheden wan de desbetreffende overheden. De samenwerkingsverbanden, de Belgische intercommunales en de Nederlandse openbare lichamen/gemeenschappelijke organen, zijn overigens in beginsel niet bevoegd sec samen te werken met andere samenwerkingsverbanden. Zowel in Nederland als Belgie is participatie van privatrechtelijke personen in de samenwerking tussen overheden mogelijk. In de praktijk komt dit in België veel vaker voor dan in Nederland.

De belangrijkste verschillen tussen de beschreven Belgische en Nederlandse wetgeving inzake decentrale samenwerking worden hier samenvattend opgesond:

1. De meer privaatrechtelijke (bedrijfsmatige) samenwerking, vooral blijkend uit de rechtsvorm (en daarmee samenhangend het toepasselijke recht en de bevoegde rechter), op basis van de Wet betreffende de intercommunales is niet goed vergelijkbaar met de publiekrechtelijke (bevoegdheden)samenwerking op basis van de Wet gemeenschappelijke regelingen. ${ }^{63}$ Zie ook figuur 4.

De Wet houdende organisatie van agglomeraties en federaties van gemeenten is niet in de Bijlage bij de Benelux-Overeenkomst opgenomen. De publiekrechtelijke samenwerking op basis van die wet is beter te vergelijken met de (ontwikkelingen ten aanzien van) Wet gemeenschappelijke regelingen alsmede de Kaderwet bestuur in verandering. Overigens is in de praktijk samenwerking op basis van de Wet houdende organisatie van agglomeraties en federaties van gemeenten niet dan wel nauwelijks wan de grond gekomen.

2. De Wet gemeenschappelijke regelingen maakt samenwerking tussen de respectievelijke gemeentelijke bestuursorganen mogelijk (raden, colleges van burgemeester en wethouders en burgemeesters) mogelijk. De Wet betreffende de intercommunales voorziet in een samenwerking tussen (de rechtspersonen) gemeenten.

3. De samenwerking op basis van de Wet betreffende de intercommunales is vrijwillig. De samenwerking op basis van de Wet gemeenschappelijke regelingen kan dwingend worden voorgeschreven. Voor de openbare lichamen op basis van de Wet gemeen-

63. Kessen gaat aan deze divergentie tussen de Wet gemeenschappelijke regelingen en de Wet betreffende de Intercommunales geheel voorbij, A.A.L.G.M. Kessen, a.w., p. 98 e.v. 
schappelike regelingen gelden in dat verband in de regel bovendien afgebakende samenwerkingsgebieden.

4. Met het meer privaatrechtelijk karakter van de intercommunalles hangt samen, dat er minder garanties zijn ten aanzien van bijvoorbeeld de openbaarheid dan bij de Wet gemeenschappelijke regelingen.

5. Bij de samenwerking tussen provincies valt op, dat er voor de Belgische prowincies in tegenstelling tot de Nederlandse geen wettelijke regeling is ten aanzien van de onderlinge publiekrechtelije samenwerking. In het nationale recht van België bestaat er geen basis voor een algemene bevoegdheid om op eigen initiatief onderling dan wel met andere overheden, anders dan in een intercommunale, publiekrechtelijk samen te werken.

6. In België kunnen de polders en wateringen, bij gebreke aan bevoegdheden daartoe, niet los van de intercommunales met andere overheden publiekrechtelijk samenwerken. De Belgische polders en wateringen kunnen wel onderling samenwerken. Om die reden kunnen zij binnen hun bewoegdheden b.v. samenwerken met Nederlandse waterschappen. Daar staat weer tegenover dat er in het grensgebied tussen Nederland en Vlaanderen respecttievelijk Nederland en Wallonië nauwelijks polders en wateringen zijn en de bevoegdheden niet geheel parallel lopen.

7. De 0.c.m.w."s kunnen op basis van het nationale recht samenwerken met andere o.c.m.w.'s of andere openbare besturen. Ze hebben niet direct een vergelijkbare Nederlandse counterpart om mee samen te werken. Op enkele beleidsterreinen is samenwerking met Nederlandse gemeenten wel mogelijk.

\section{figuur 4}

Vergelijking Wet betreffende de intercommunales/Wet gemeenschappelijke regelingen

\begin{tabular}{|l|l|l|}
\hline Categorie & Nederland & België \\
\hline Wet & $\begin{array}{l}\text { Wet gemeenschappelijke } \\
\text { regelingen }\end{array}$ & $\begin{array}{l}\text { Wet betreffende de } \\
\text { intercommunales }\end{array}$ \\
\hline $\begin{array}{l}\text { Samenwerkings- } \\
\text { vormen }\end{array}$ & $\begin{array}{l}\text { Openbaar lichaam* } \\
\text { Gemeenschappelijk orgaan } \\
\text { Centrumgemeente }\end{array}$ & $\begin{array}{l}\text { Intercommunale* } \\
\text { Overeenkomst (levering en } \\
\text { diensten) }\end{array}$ \\
\hline $\begin{array}{l}\text { Olgemeen bestuur } \\
\text { Dagelijks besturur } \\
\text { Voorzitter }\end{array}$ & $\begin{array}{l}\text { Algemene vergadering } \\
\text { Raad van bestuur } \\
\text { College van commissarissen }\end{array}$ \\
\hline Bevoegdheden** & $\begin{array}{l}\text { Burgers en overheden } \\
\text { bindende bevoegdheden } \\
\text { (publiekrechtelijk) }\end{array}$ & $\begin{array}{l}\text { Overheden bindende } \\
\text { bevoegdheden } \\
\text { (privaatrechtelijk) }\end{array}$ \\
\hline
\end{tabular}

* Allem de organen en bevogdheden van de samenwerkingsvormendie met een * zijn amgegeven. 


\section{\$5. Benelux-Overeenkomst inzake grensoverschrijdende samenwerking tussen territoriale samenverwerkingsverbanden of autoriteiten (Benelux-Overeenkonst) ${ }^{64}$}

\section{A. INLEIDING}

Hoewel geen van de Beneluxlanden bij de ondertekening noch de ratificatie van de European Outline Convention uitdrukkelijk het vereiste van aanvullende interstatelijke overeenkomsten als (nadere) juridische grondslag woor grensoverschrijdende samenwerking door decentrale overheden heeft gesteld, is door deze drie landen in 1986, als concretisering van de EOC, een verdrag gesloten. ${ }^{65}$ In de gemeenschappelijke Memorie van Toelichting bij de Benelux-Overeenkomst wordt gesteld, dat de betreffende territoriale samenwerkingsverbanden/autoriteiten tot mu toe niet konden komen tot "bindende publiekrechtelijke afspraken' ook al sloten zij bijwoorbeeld wel privaatrechtelijke akkoorden. Het doel van de Benelux-Overeenkomst, aldus deze Memorie van Toelichting; is "voor hen een juridische basis te scheppen voor het organiseren van hun samenwerking op basis van het publiekrecht ... Deze basis ontbrak tot dusverre." "Is hiermee de juridische status van de Benelux-Overeenkomst als bevoegdheidsgrondslag voor publiekrechtelijke samenwerking en in het bijzonder het maken van publiekrechtelijke afspraken tussen decentrale overheden buiten elke twijfel? De beantwoording van deze vraag staat in het navolgende centraal.

$\mathrm{Na}$ een schets van de ontstaansgeschiedenis van de Benelux-Overeenkomst (§5.B.) wordt de inhoud ervan weergegeven $(\$ 5 . C$.). Daarna wordt dieper ingegaan op het karakter van de Benelux-Overeenkomst. De juridische reikwijdte van de in dit verdrag opgenomen samenwerkingsvormen tussen de tot samenwerking gerechtigde decentrale overheden wordt toegelicht, waarbij de rol van het interne recht ten aanzien van de nationaal- en/of internationaalrechtelijke dimensie van deze samenwerkingswormen aan de orde komt. Bij de rol van het interne recht staat 0 .a. de confrontatie van de rechtsstelsels van de samenwerkende overheden op de voorgrond. In dat verband en met betrekking tot de nationaal- en/of internationaalrechtelijke dimensie van de BeneluxOvereenkomst zijn vooral de opmerkingen van de Belgische Raad van State en de Belgische regering in het kader van de parlementaire goedkeuring van de Benelux-Overeenkomst het vermelden waard ( $\$ 5 . D$.). Aan het eind van dit hoofdstuk, na een korte beschouwing van de overige regels inzake (decentrale) grensoverschrijdende samenwerking (\$6), volgen een samenvatting en enkele conclusies (\$7).

64. Brussel 12-9-1986, Trb. 1986 nr. 160, in werking getreden Trb. 1991 nrs. 45, 88. Voor Belgie is de Benelux-Overenkomsigoedgekenrd bij wet van $23-3-1990$ (B.S. 30-3-1991). Overigens is de BeneluxOvereenkomst bij decreet wan de Vlaanse, Duitstalige en Franse Gemeenschapsratad wan 7-2-1990, 5-6-1990 respectievelijk 28-1-1991 goedgekeurd (19.5. 24-3-1990, 3-8-1990 respectievelijk 17-12-1991). De behandeling erwan geschiedt hier aan de hand van de geldende tekst, zoals opgenomina in Trb. 1991 nr. 45. Deze is als bijlage bij dit proefschrift opgenomen.

65. Chart of signatures and ratifications, Transfront 1989 (2), CAHCT (89) 6. De Benelux-Overeenkomst komt het meest overeen met model 1.5. van de bijlage bij de EOC.

66. Gemeemschappelijke MVT bij de Benelux-Owereenkomst op het gebiexll van de grensoverschrijdende samenwerking tussen ferritoriale samenwerkingsverbandenof autoriteiten, Benelux, Busisteksten 1987-3, p. 11 . 
Vooraf zij opgemerkt, dat hier de decentrale grensoverschrijdende samenwerking tussen België en Nederland beschreven wordt. De positie van Luxemburg komt vanwege het feit dat dit land niet aan Nederland grenst - om die reden zal niet snel tot samenwerking worden gekomen tussen decentrale overheden in Nederland en Luxemburg - niet nadrukkelijk aan de orde. ${ }^{67}$

\section{B. ONTSTAAN WAN DE BENELUX-OVEREENKOMST}

Ingegeven door de ontwikkelingen op het terrein van de lokale grensoverschrijdende samenwerking in het kader van de Raad van Europa, kwam dit onderwerp op de agenda van een aantal organen van de Benelux Economische Unie te staan. Voortvloeiend uit een aanbeveling van de Raadgevende Interparlementaire Beneluxraad werd in 1982 tijdens de vergadering van regeringshoofden en ministers van Buitenlandse Zaken besloten tot een onderzoek naar het opstellen van een kaderovereenkornst op het gebied van de decentrale grensoverschrijdende samenwerking. ${ }^{68}$ Dit resulteerde in september 1986 , na advies van de Raadgevende Interparlementaire Beneluxraad, in het sluiten van de Benelux-Overeenkomst. Nederland en Luxemburg zijn tot mededeling van de ratificatie overgaan op 25-8-1987 respectievelijk 22-9-1987. De oorzaak voor de veel latere inwerkingtreding hield verband met het feit dat de goedkeuring in Belgie plaatsvond zowel door het nationale parlement als de drie Gemeenschapsraden. Daarbij speelde bovendien een rol, dat de Belgische Raad van State de inhoud van de Benelux-Overeenkomst in strijd acht(te) met de Belgische Grondwet. ${ }^{69}$

De nationale goedkeuringswet van 23-3-1990 verscheen in maart 1991 in het Belgisch Staatsblad. Op 27-2-1991 vond mededeling van de ratificatie door België plaats, waardoor de Benelux-Overeenkomst ingevolge artikel 12 lid 1 per 1-4-1991 in werking is getreden. ${ }^{70}$

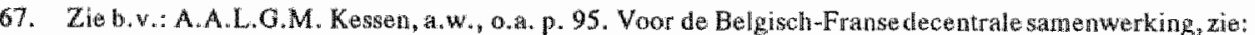
Grensoverschrijdende samenwerking tussen Noordfranse, Wadse en West-Wiamse intercommarales, De Gemeante, ar. 1/1991, p. 27, 28 .

68. Gemeenschappehjke MvT bij de Benelux-Overeenkomst, a.w.,p. 10 .

Over do voorgeselitedenis, zie ook: Toelichtende nota bij de Benelax-Overeenkomstinzake grensoverschrijdende sanenwerking tussen samenwerkingsverbandenof autoriteiten, wet bijlage, Tweede kamer, vergaderjat 1986-1987, 19986, nr. 1, p. 2; E.L H. de Wilde, Inleiding grensoverschrijdandesanenwerking, in: Handbotk Bestum lijke Samenwerking, a.w., MII-A, p. 5-7.

Over en erste uilvoerige beschrijwing wan de problematiek omtrent grensoversehrijdendesamenwerking in Nederland, zie: Samenwerking tussen lagere overheden an weerszijden van de grens met Duitsland en Belgic, (Rapport "de Menthon Batke"), Ministerie van Binnenlandse zaken, 1980 .

69. Zhe hiervoor uitgebreider het gestelde in \$ 5.D.7.c. van dit hoofustuk.

In verband net het bepalde in artikel 25 , lid 3, sub b van de Wet op de Raad van State is het advies van de Raad wan state in Nederland niet openbaar gemakt, Toelichtende Nota bij de Benelux-Overeenkomst, a. w., p. 2 .

70. In de tussantiju was er overigens nog een aanbeveling van het Com to wan Ministers inzake de grensoverschrijdende samenwerking uitgegan, warin wordt aanbevoler in het hicht wan de socian eoonomische ontwikeling van grensgebieden zoveel mogelijk met elkars belangen rekenirg te bouden, Aanbeveling van het Comites van Ministers van 27 nowember 1989 inzake de grensoverschrijdende samenwerking, M(89) 9. Benelux, Basistehsten/1990-1. 


\section{INHOUD VAN DE BENELUX-OVEREENKOMST}

Blijkens de inleidende overwegingen bij de Benelux-Overeenkomst is de voornaamste doelstelling erwan het scheppen van een mogelijkheid voor decentrale overheden aan beide zjjden van de intra-Beneluxgrenzen om op publiekrechtelijke basis samen te werken. Het verdrag bestaat uit een dertiental artikelen en een bijlage. Omdat in $\$ 5$. D. van dit hoofdstuk uitgebreid wordt ingegaan op de diverse artikelen en de bijlage, wordt hier volstaan met een korte uiteenzetting van de Benelux-Overeenkomst.

De Benelux-Overeenkomst geeft aan welke decentrale overheden onder de werking van het verdrag vallen. De reikwijdte van de vrijwillige samenwerking wordt in die zin afgebakend, dat samenwerking slechts mogelijk is binnen het kader van de bevoegdheden, die de betreffende overheden ingevolge het interme recht hebben. De Benelux Overeenkomst kent drie vormen vart samenwerking. Het betreft het instellen van openbare lichamen (organismes publics), het instellen van gemeenschappelijke organen (organes communs) en het maken van administratieve afspraken (accords administratifs). Het openbaar lichaam is de meest ver gaande vorm van samenwerking. Over het openbaar lichaam bevat de Benelux-Overeenkomst de meeste regels. Aan een openbaar lichaam, dat rechtspersoonlijkheid bezit, kunnen door de deelnemende overheden bevoegdheden van regeling en bestuur worden overgedragen. Hierbij wordt door de Benelux-Overeenkomst het toepasselijke recht geregeld inzake de rechtsbetrekkingen van het openbaar lichaam jegens derden en het personeel. Het oprichten en de besluiten van het openbaar lichaam zijn onderworpen aan toezicht en controle op basis van de betreffende bepalingen in het interne recht van de betrokken landen. Verder wordt in de Benelux-Overeenkomst geregeld dat de Overeenkomstsluitende Partijen bijzondere toezichthouders en ambtenaren grenscontacten kunnen aanstellen. Voorts is voorzien in de instelling van een Bijzondere Commissie. Deze laatste is als een soort van intermediair te beschouwen tussen de betreffende overheden, betrokken bij de grensoverschrijdende samenwerking, en het Comité van Ministers. ${ }^{71}$ Het Comité van Ministers heeft een tak in de beslechting van geschillen betreffende grensoverschrijdende samenwerking en kan nadere regels geven ontrent de uitwoering van de Benelux-Overeenkomst. Het Benelux-Gerechtshof wordt bevoegd verklaard bij de uitlegging van de Benelux-Overeenkomst. Verder regelt de Benelux-Overeenkomst zaken van procedurele aard, zoals het melden van samenwerkingsvormen bij de Secretaris-Generaal van de Benelux Economische Unie, de opzegging en inwerkingtreding van het verdrag, e.d.

De bijlage bij de Benelux-Overeenkomst bevat de verwijzing naar de relevante interne (organieke) wetgeving van elk der drie Beneluxlanden.

71. Het gaat hier on een Bijzondere Commissie ex artikel 31 Verdrag tot instelling van de Benelux Economische Unie. Deze Bijzondere Commissie voor de grensoverschrijdende samenwerking is bij beschikking van het Comité van Ministers ingesteld op 16-12-1991, M (91) 19, Trb. 1992 nr. 147. 


\section{JURUDISCHE REIKWUDTE WAN DE BENELUX-OVEREENKOMST}

\section{Tot samenwerking gerechrigde overheden}

Samenwerking op basis wan de Benelux-Overeenkomst is niet verplicht, maar vindt plaats op basis van vrijwilligheid. Zoals in de inleiding van dit hoofdstuk aangegewen, creèert de Benelux-Overeenkomst een juridische grondslag voor publiekrechtelijke grensoverschrijdende samenwerking tussen de in het verdrag zelf genoemde decentrale overheden (art. 1 lid 1 Benelux-Overeenkomst). De tekst van de Benelux-Overeenkomst spreakt van samenwerkingsverbanden of autoriteiten. Hier zal verder van overheden. gesproken worden.

Het gaat om de Nederlandse provincies, gemeenten, waterschappen en openbare lichamen op basis wan de Wet gemeenschappelijke regelingen, voor zover in de gemeenschappelijke regeling bevoegd verklaard, en de Belgische provincies, gemeenten, verenigingen van gemeenten, openbare centra voor maatschappelijk welzijn, polders en wateringen. Voor Nederland betreft het alle territoriale decentrale (en eén van de belangrijkste functionele) overheden. Voor Belgie is dit niet helemaal het geval, aangezien verenigingen van polders, wateringen en openbare centra voor maatschappelijk welzijn - in België bestaat geen regeling voor verenigingen van provincies - niet worden genoemd. Het is de vraag of al dan niet bewust de Benelux-Overeenkomst voor België slechts van toepassing is verklaard op verenigingen van gemeenten. $\mathrm{k}$ zie geen reden waarom de andere verenigingen van de werking van het verdrag zijn uitgesloten. Overigens kunnen deze, na overleg met de partnerlanden, aan de lijst van tot samenwerking gerechtigde overheden worden toegevoegd (art. 1 lid 2 Benelux-Overeenkomst).

In België zijn de Gewesten en Gemeenschappen in ieder geval wel bewust buiten de toepassing van de Benelux-Overeenkomst gelaten, omdat deze niet zijn aan te merken als decentrale overheden. Met name de uitzondering van de Gewesten - de Gewesten met de daaraan verbonden pararegionalen beschikken over belangrijke materiële bevoegdheden b.v. ten aanzien van het milieu, de ruimtelijke ordening en de natuurbescherming $^{72}$ - brengt met zich dat de samenwerking op die gebieden (met hun counterparts, veelal de Nederlandse provincies) problematisch kan worden.

Het gaat bij de decentrale grensoverschrijdende samenwerking niet noodzakelijk om die in grensgebieden. ${ }^{73}$ Hoewel het niet direct voor de hand zal liggen, dat Groningen op basis van de Benelux-Overeenkomst zal gaan samenwerken met Luik, heeft Groningen wel dezelfde juridische mogelijkheden hiertoe als b.v. Maastricht.

72. Pararegionglen zijn to vergelijken met gedeconcentreerde overhedusdiensten in Nederland. Woor een opsomming in deze, zie b. *. het Vlatms Decreet betreffende het bestuurlijk beleid, 12-10-1990, B.5. 21-12-1990. De pararegionalenzijn weelal de "verwangers" van de nationale parastatalen. Voor die laatste kan: verwezen worden nator het Koninklik Besluit houdende coördinatie van de wetten van 28-12-1984 en van 26 -6 1991 betreffende de afsthaffing en de hersuncturering van instellingen van openbaar mut en andere overheidsdiensten, 13-3-1991, B.S. 19-4-1991, erratum B.S. 20-11-1991.

Voorzover de Gewesten en de Gemenschappez niet hot wijiging erwan zjun overgegaan, geldt inzake het toezicht op de pararegionalende Wet betreffende de controle op sommige instellingen van openbar nut, $16-3-1954,6.5 .24-3-1956$

73. Genteenschappelijke MvT bij de Benelux-Overeenkomst, a.w. p. 12. 


\section{Samenwerkingsvormen}

De Benelux-overeenkomst kent een drietal vormen van samemwerking (art. 2 lid 2 Benelux-Overeenkomst). Het betreft het openbaar lichaam, het gemeenschappelijk orgaan en de administratieve afspraak. In het navolgende zal op elk van de drie worden ingegaan.

\section{- Openbaar lichaam}

Op basis van artikel 3 lid 1 Benelux-Overeenkomst kunnen door de deelnemende overheden aan het openbaar lichaam bevoegdheden van regeling en bestuur worden overgedragen. Hier is een duidelijke relatie met de Wet gemeenschappelijke regelingen (en niet met de Wet betreffende de intercommunales) aanwezig. Op basis van artikel 30 Wet gemeenschappelijke regelingen is het openbaar lichaam bevoegd de burgers bindende besluiten te nemen, waaronder de vaststelling van algemeen verbindende voorschriften en het heffen van bepaalde belastingen. Over deze mogelijkheid beschikt de intercommunale niet. Daarbij bepaalt artikel 30 lid 2 Wet gemeenschappelijke regelingen, dat de verhouding wan de toegekende bevoegdheden aan een openbaar lichaam (of gemeenschappelijk orgaan) tot die wan de besturen van de deelnemende gemeenten geregeld dient te worden. In de Wet betreffende de intercommunales en de Benelux-Overeenkomst ontbreekt een vergelijkbare bepaling, hetgeen niet betekent dat in de statuten van de intercommunale respectievelijk het openbaar lichaam op basis van de Benelux-Overeenkomst hierover niets bepaald zou kunnen worden. Het ligt voor de hand dat de deelnemende overheden hun bevoegdheden ten opzichte van die van het openbaar lichaam duidelijk in de statuten zullen afbakenen.

Het openbaar (publiekrechtelijk) lichaam op basis van de Benelux-Overeenkomst bezit privaatrechtelijke rechtspersoonlijkheid. De aan nationale rechtspersonen toegekende rechtsbevoegdheid komt op het grondgebied wan de Beneluxlanden aan het openbaar lichaam slechts toe, voorzover zulks noodzakelijk is voor de vervulling van zijn taak en voor de verwezenlijking van zijn doelstellingen (art. 3 lid 2 Benelux-Overeenkomst). In Nederland gaat het bij een openbar lichaam op basis van de Wet gemeenschappelijke regelingen om een privaatrechtelijke (en publiekrechtelijke) rechtspersoon. In Belgie wordt bij een intercommunale uitdrukkelijk over een publiekrechtelijke rechtspersoon (die evenwel als een privaatrechtelijke rechtspersoon opgericht dient te worclen) gesproken. Als er al verschil is, dan is dat hier niet relewant, omdat de rechtsstelsels van de deelnemende overheden van toepassing zijn. Een openbaar lichaam op basis van de Benelux-Overeenkomst, is in beginsel allebei. Handelt het in België dan zal het in beginsel Belgische rechtspersoonlijkheid bezitten en zal dat handelen tevens beheerst wordem door Belgisch recht. Handelt het in Nederland dan zal het in beginsel Nederlandse rechtspersoonlijkheid hebben en zal op dat handelen tevens Nederlands recht van toepassing zijn. Door de Bijzondere Commissie voor Grensoverschrijdende Samenwerking van de Benelux Economische Unie zijn model-statuten opgesteld voor een grensoverschrijdend openbaar lichaam. ${ }^{74}$ Dit model heeft geen bindende kracht, maar kan

74. Hnussel, 26-2-1993, GS (93) 3. Hierbij zijn ook modellen voor de begroting en rekening van het open baar licham opgesteld. De modelestatuten en modellin zijn als separate bijlage bijgevoegd bij de brochure: Benelux-Overeenkomst grensoverschrijdende samenwerking, Ministerie wan Bimnentandse zaken, december 1992 . 
als richtsfoer worden gehanteerd voor gemeenten, die onderling of met andere in de Benelux-Overeenkomst genoemde overheden willen samenwerken in de vorm wan een openbaar licharm. Volgens de opstellers voldoen de model-statuten aan de eisen van het interne recht wan alle bij de samenwerking betrokken landen. De samenwerkende overheden dienen het doel, de taken en de bevoegdheden zelf in te vullen. De model-statuten bevatten bepalingen over het ambtsgebied en de zetel van het openbaar lichaam. De model-statuten noemen een drietal organen: de algemene vergadering, de raad van bestuur en de voorzitter. Ten aanzien van elk van deze drie bestuursorganen zijn nadere bepalingen opgenomen. Zo is voor de algemene vergadering de samenstelling, de orde van vergaderen, de wijze van besluitvorming en de werhouding ten opzichte van de raden van de deelnemende overheden geregeld. Tevens is bepaald dat de algemene vergadering bestuurs- of adviescommissies kan instellen en dat de algemene vergadering alle bevoegdheden toekomen, die niet bij of krachtens de statuten aan andere organen zijn opgedragen. Ten aanzien van de raad van bestuur, zijnde het dagelijks bestuur, is de samenstelling, de orde van vergaderen, de wijze van besluitvorming en de verhouding tot de algemene vergadering geregeld. Ten aanzien van de voorzitter zijn er bepalingen opgenomen inzake zijn aanwijzing uit de algemene vergadering en de verhouding tot de algemene vergadering. Voorts bevatten de model-statuten regels inzake het verkrijgen van financiële middelen en de opstelling wan de begroting en rekening, de toetreding tot, de uittreding uit en de ontbinding e.d. van het openbaar lichaam. Een eerste openbaar lichaam, waarvan de oprichting in een afrondend stadium is, is Benego (Belgisch Nederlands Grensoverleg). Gezien de (ontwerp) statuten (hierna: Benego-regeling) van dit openbaar lichaam staat het bevorderen van de grensoverschrijdende samenwerking voorop. Hiertoe begeleidt en structureert Benego de grensoverschrijdende samenwerking tussen de deelnemende gemeenten en tracht zij fondsen e.d. te verwerven (art. $4(2)$ Benego-regeling). Vooralsnog heeft het Benego-samenwerkingsverband geen de overheden en burgers bindende bevoegdheden. Er is wel geregeld dat het openbaar lichaam namens de gemeenten en met de goedkeuring wan die gemeenten (gesubsidieerde) grensoverschrijdende projecten kan uitwoeren (art. 4(2) Benego-regeling). Voorts is geregeld dat het openbaar lichaam de deelnemende gemeenten kan verzoeken de uitoefening van bepaalde, welomschreven gemeentelijke bevoegdheden aan het openbaar lichaam toe te vertrouwen (art. 5(1) Benego-regeling). Voorts kunnen gemeenten op hun beurt het openbaar lichaam verzoken taken namens deze gemeenten war te nemen (art. 5(3) Benego-regeling). Het gat bij dit laatste om mandaat. De desbetreffende gemeenten blijven jegens derden aansprakelijk (att. 18 Benego-regeling). De organen van het openbaar lichaam zijn de algemene vergadering (art. 6 Benego-regeling) en het hieruit te kiezen dagelijks bestuur (art. 10 Benego-regeling). De algernene vergadering is belast met de besluitworming omtrent alle het samenwerkingsverband aambelangende zaken, voor zover deze niet aan het dagelijks bestuur zijn toevertrouwd (art. 8(3) Benego-regeling). Besluitvorming geschiedt bij gewone meerderheid van stemmen, waarbij een minimum aantal (Belgische en Nederlandse) vertegenwoordigers aanwezig dient te zijn (art. 8(5) en 8(6) Benego-regeling). Ook is er voorzien in mogelijke advisering door andere openbare instellingen in vergaderingen van het dagelijks bestuur alsmede werkgroepen (art. 13 Benego-regeling). Er is niet voorzien in een geschillenregeling tussen overheden. Voor het overige beval de Benego-regeling bepalingen over de vertegenwoordiging van de gemeenten in de algemene vergadering, het financiële beheer, e.d. 


\section{- Gemeenschappelijk orgaan}

Bij de instelling wan een gemeenschappelijk orgaan gaat het "naar het voorbeeld wan de situatie in Nederland" om 'een forum zonder eigen rechtspersoonlijkheid" "waarin overheidsinstanties elkaar vrijelijk kunnen ontmoeten om hun samenwerking te wersterken'. ${ }^{75}$ Wat is nu, bij gebreke van elke nadere witwerking in de Benelux-Overeenkomst c.q. de toelichting, het juridische karakter van zo'n gemeenschappelijk orgaan?

Omdat het hier, aldus de toelichting bij de Benelux-Overeenkomst, gaat om een gemeenschappelijk orgaan 'naar het voorbeeld van de situatie in Nedlerland' en het hier om een 'publiekrechtelijke' vorm van samenwerking gaat, kan er vanuit worden gegaan dat het in de Wet gemeenschappelijke regelingen geregelde daaromtrent - in België bestaat geen equivalent - van toepassing $\mathrm{kan} / \mathrm{zall}$ zijn. ${ }^{76}$ Met name artikel 8 juncto artikel 30 Wet gemeenschappelijke regelingen is relevant. Zoals aangegeven in $\$ 2 . B .2$ van dit hoofdstuk en hier voor de duidelijkheid herhaald, zijn hierin de drie, voor o.a. de samenwerking tussen gemeenten, vormen van gemeenschappelijke regelingen te vinden. Hieronder is die van het instellen van een gemeenschappelijk orgaan (art. 8 lid $2 \mathrm{Wgr}$ ). In artikel 30 Wet gemeenschappelijke regelingen is bepaald, dat aan het gemeenschappelijk orgaan zodanige bevoegdheden van regeling en bestuur kumnen worden toegekend als aan de besturen van de deelnemende gemeenten, met uitzondering van de bevoegdheid belastingen te heffen en de bevoegdheid algemeen verbindende voorschriften te geven. "Het gaat hierbij, mijns inziens, dus niet om een al te 'wrijelijke' vorm van 'ontmoeten". ${ }^{78}$ Een gemeenschappelijk orgaan is geen publiekrechtelijke rechtspersoon, zijnde de optelsom van alle tot een openbaar lichaam behorende bestuursorganen. Een gemeenschappelijk orgaan is ook geen privatrechtelijke rechtspersoon ex artikel 1:2 Burgerlijk Wetboek, waarbij het hebben van rechten en plichten op voet van gelijkheid van particulieren voorop staat. Als het gemeenschappelijk orgaan daartoe de bevoegdheid is toegekend, kan het wel tot concrete publiekrechtelijke rechtshandelingen overgaan, b.v. de afgifte van beschikkingen aan burgers. Om die reden is (in de Nederlandse context) het bestuur van zo'n gemeenschappelijk orgaan b.v. aan te merken als administratief orgaan in de zin wan de Wet administratieve rechtspraak overheidsbeschikkingen $^{79}$ en zal het ook zijn aan te merken als bestuursorgaan in de zin van de komende

75. Toelichting op de artikelen bij de Benelwxowerenkounst op het gebied wan de grensoverschrijdende samenwerking tussen samenwerkingsverbandenof atutoriteiten, Benelux, Basisteksten/1987 $3, \mathrm{p}$. 13 .

76. Zo ook: A.A.L.G.M. Kessen, a.w., p. 154. Vanhelleputte is van mening dat het gemeenschappelijk orgaxn op basis wan de Benelux-Owereenkomst, hoewel wontleend at de Wel gemeenschappelijkefegelingen, een ejgen bestaan leidt, L. Vanhelleputte, Benelux-Overeenkomsten grensoverschrijdende samenwerking, De Gemeente nr. 4/1992, p. 193.

77. Vergelikbare bevogdheden gelden voor gemeenschappelijke organen bestande uith andere overheden dan gemeenten. Zo geldr b. Whetzelfde op basis wan artikel 43 Wet gemensohappelijkeregelingen voor de sanenwerking tussen bestursorganen van provincies en op basis wan artikel 50 b Wet gemeensohappelijke regelingen voor de samenwerking tussen waterschappen.

78. De Belgische Ratd van State spreekt met betrekking tot gemeenschappelijke organen wan informele wormen van samenwerking", Ad wies van de Raad van State, Gedr. St., Senat, 1988-1989, 651/1, , 3. 13. Dit ward in een later advies genuanceerd., Adwies van de Rad van State, Stukken wan de Rad van de Franse Gemeensehap, 1989 1990,149/1, p.15. Voor de beschrijving wordt verwezen naar bet gestelde in 5.D.7.c. van dit hoofidstuk.

79. Zie in dit verband b.v.: P. Nieolä, De rechtspersoon in artikel 7 Wet Arob, naar een lostaten wan het civielrechtelijk rechtspersoonbegrip NJB 1988/6, p. 183-187. 
Algemene wet bestuursrecht. Het ligt ook voor de hand, dat het gemeenschappelijk orgaan bij de (administratieve) rechter ontvankelijk wordt geacht, wanneer het zelf een procedure begint. Een gemeenschappelijk orgaan - het is in een aantal zaken immers het enig bevoegd bestuursorgaan om lets te doen of na te laten - kan zeer wel als bestuursorgaan in civilibus aangesproken worden. ${ }^{80}$ In dat verband ligt het voor de hand dat deze gemeenschappelijke organen in het kader van hun bevoegdheden ook afspraken kunnen maken en deze in rechte (al dan niet in in civilibus) kunnen afdwingen. Mocht het voorgaande al niet het geval zijn, hetgeen zo'n gemeenschappelijk orgaan doet/nalaat zall uiteindelijk altijd nog als gedraging/nalaten van de samenwerkende overheden aangemerkt kunnen worden. Volgens Vanhelleputte is het gemeenschappelijk orgaan met. name een overlegorgaan, waarvan het denkbaar is dat dit orgaan de deelnemende overheden kan binden. ${ }^{82}$ Het is mogelijk dat er voor gekozen wordt een gemeenschappelijk orgaan op te richten dat slechts een forum voor overleg vormt, zonder dat het de deelnemende overtheden c.q. burgers kan binden. Hiervan is de afsprakenregeling tussen de provincies Zeeland, Oost-en West-Vlaanderen', in het kader van de Euregilo Scheldemond, een voorbeeld. ${ }^{83}$ Voor een dergelijke vorm van samenwerking is mijns inziens een juridische basis, zoals de Benelux-Overeenkomst, niet vereist. ${ }^{84}$

\section{- Administratieve afspraak}

De administratieve afspraak is in zijn geheel niet uitgewerkt in de Benelux-Overeenkomst. Gezien de doelstelling van het verdrag moet het gaan om 'een bepaald type van publiekrechtelijke samenwerking'. ${ }^{85}$ Daarbij is de administratieve afspraak in beginsel bedbeld als een lichtere vorm wan samenwerking dan het openbare lichaam en mijns inzilens ook het gemeenschappelijk orgaan. ${ }^{86}$ De Benelux-Overeenkomst dient ten aanzien van de administratieve afspraak aan te sluiten bij publiekrechtelijke vormen van

80. Vgl. het Rijbewijsarrest, HR 9-5-1958, NJ 1960,475.

81. Vgl. de arresten Kleuterschool Knabbel/Babbel (HR 6-4-1979, NJ 1980, 34) en Blaricum/Roozen (HR 30-1-1987, AB 1988, 42),

82. L. Vanhelleputte. a.W., p. 193. Hiermee komt het gemeenschappelijk organ op basis wan de BeneluxOveraetkomst op ongewer dezelfde lijn te staan als het openbar lichaam op basis wan de NederlandsDuitse Overewkomst inzake decentrale grensoverschrijdende samenwerking. Zie voor dit latutste hel gestelde in $\$ 4$. D. 2 in hoofdstuk 6.

83. De statuten wan dit intepromeiaal samenwerkingsvertand, genasmd de Furegio Scheldemond, zijn op 1-4-1993 goedgekeurd door de provincteramd van West-Vlanderen. Deze goedkeluring is gebaseend op artikel 65 (Belgische) Provinciewet. Dit artikel bepadt dat provinciale staten beslissen over hetgeen van prowincianal belang is.

84. Bieballwe de autonome provinciale bevoegdheid ( $\mathrm{wgl}$. de vorige noot) zou bijvoorbeeld artikel 65 (Nederlandse) Provinciewet als grondslag (zonder de additionelle grondslag wan do Benelux woverenkomst)kunmen fungeren. Dit artikel regelt de instelling door provinciale staten van vaste comissies van advies en bijstand (an gedeputeerde staten/de commissaris van de Koningin). Overigens is de instelling van commissies in do Nienwe Provinciewet geregeld in de artikelen 80 e.v.

85. Toelichtende nota bij de Benelux-Overeenkomst, a. w., p. 5. De Gemeenschappelijk Memorie van Toelichting vermeid uitdrukkelijk dat privatrechtelijke vormen wan samenwerking nist onder de werking var de Benelux-Overeenkonstwallen, GemeenschappelijkeMvT inzake de Benelux-Owereenkomst,a.w.,

86. Vgl. L. Vanhelleputte, a.w., p. 193. Deze stelt dat de administratieve afspraak gebruikt kan worden on afspraken in bet kader varu bet gemeenschappelijk orgaan wast te leggen of nader wit te werken. Hierme lijkt het gemeanschappelijk organ als een lichtere vorm wan samenwerking gezien te worden. 
samenwerking (op basis van het nationale recht). In dit verband zal derthalve worden nagegaan of het nationale recht, in het bijzonder de Wet gemeenschappelijke regelingen en/of de Wet betreffende de intercommunales een vergelijkbare vorm van samenwerking als de administratieve afspraak kennen. In het navolgende passeren een aantal mogelijkheden betreffende administratieve afspraken de revue.

Een eerste mogelijkheid van een administratieve afspraak is die van de overdracht (van de uitoefening) van bevoegdheden van overheden aan andere (buitenlandse) overheden via mandaat c.q. delegatie. De bevoegdheid wordt in beide gevallen dan niet overgedragen aan eem nieuw op te richten overheidsinstantie (al dan niet met rechtspersoonlijkheid. zoals het openbaar lichaam respectievelijk het gemeenschappelijk orgaan) maar aan een ander bestaand (buitenlands) overheidsorgaan, dat in geval van delegatie de verantwoordelijkheid voor de uitvoering gaat dragen. Bij mandaat blijft de verantwoordelijkheid bij het overdragende overheidsorgaan berusten. De mandaatvariant, waarbij de uitoefening van bevoegdheden wordt overgedragen, komt overeen met de instelling van de centrumgemeente op basis van artikel 8 lid 3 Wet gemeenschappelijke regelingen. De Wet gemeenschappelijke regelingen kent de delegatievariant, waarbij bevoegdheden worden overgedragen, niet. ${ }^{87}$ De Wet betreffende de intercommunales kent niet de mogelijkheid van mandaat noch die van delegatie. De 'öfentlich-rechtliche Vereinbarung" op basis van het Nedersaksische 'Zweckverbandgesetz' en het Noordrijn-Westfaalse 'Gesetz über kommunale Gemeinschaftsarbeit' is wel als een delegatievariant te zien. ${ }^{88}$ Burgers kunnen in dit geval dan rechtstreeks gebonden worden door een andere overheid dan die waartoe zij behoren. Overigens is de delegatie van bevoegdheden expliciet uitgesloten in de Duits-Nederlandse Overeenkomst inzake grensoverschrijdende decentrale samenwerking. Bij de "öffentlich-rechtliche Vereinbarung" op basis van de Duits-Nederlandse: Overeenkomst kan slechts sprake zijn van een overdracht van uitoefening via mandaat. ${ }^{89}$ Dit betekent dat de uitoefening van bevoegdheden weliswaar door een andere overheid plaatsvindt, maar namens de overheid die overdraagt.

Op basis van de Benelux-Overeenkomst is omtrent de overdracht van bevoegdheden via mandaat dan wel delegatie niets bepaald. In het licht van de overige vormen van samenwerking op basis van de Benelux-Overeenkomst, die verder gaan dan die op basis van de Duits-Nederlandse Overeenkomst moet mijns inziens de mandaatvariant zonder meer geoorloofd zijn. Het is de vraag of delegatie van bevoegdheden eveneens mogelijk is. Daarbij dient te worden opgemerkt, dat de overdracht van bevoegdheden via delegatie tot problemen kan leiden in de sfeer van het toezicht. Kan het delegatiebesluit wan de delegerende owerheid nog getoetst worden door zijn eigen toezichthoudende instantie,

87. Zie recentelijk nog: Voorzitter AGRS, 2-2-1993, nr. B05.92.1358 (Amsterdam). In deze witsprak oordeelt de Voorzitter van de Affeling woor de Geschillen van bestuur van de Raad wan State, dat een bij Koninklik goedgekeurde gemeenschappelijke regeling op basis van artikel 8 lid 3 Wet gemeenwo happelijke regellingen niet dh overdracht vat beschilkkingsbewegdheid inzake vergunningverleninge. q. handhaving op basis wan de Afvalstoffe nwet met zich kan brengen. Voor delegatie wan beschikkingsbewoegcheid is, aldus de Voorzitter, een wettelijk gromdstag vereist. Deze was er in casu niet, hetgeen aantoont dat artikel 8 lid 3 Weth gemeenschappelike tegelingen nief als zodanig kan worden gezien. Overigens voorziet artikel 108 Nieuwe Prowinciewet in een mogelije dehegatie van provinciale bevoegd theden aan gemeeten. Zie hierwoor noot 1 wan dit hoofdstuk.

88. Voor deze Duitse regelingen inzake gemeentelijke samenwerking wordt werwezen naar hoofustuk 62.

89. Zie hiervoor hoofdstuk 6 \$ 4 .D.2. 
dit zal niet het geval zijn ten aanzien van het handelen wan de buitenlandse overheid aan welke de desbetreffende bevoegdheid is overgedragen. Immers delegatie brengt met zich mee, dat die overheid verantwoordelijk wordt aan welke de uitvoering van de bevoegdheid is overgedragen, in casu de buitenlandse. De controle van de toezichthoudende instantie op de delegans strekt zich niet tevens uit tot de delegataris. Dit probleem betreffende het toezicht en het feit dat de delegatievorm niet geregeld is in het nationale recht van Belgiè en Nederland kunnen redenen zijn om zich ten aanzien van delegatile terughoudend op te stellen en deze zelfs uit te sluiten. Het Nederlands ministerie van binnenlandse zaken sluit zowel de mandaat- als delegatievariant ten aanzien van de Benelux-Overeenkomst uit. Dit ministerie is wan mening dat een administratieve afspraak niet kan voorzien in het overdragen van bevoegdheden, via mandaat, aan een orgaan of ambtenaar van éen van de deelnemers in de samenwerking, de zogenaamde centrumgemeente op basis van artikel 8 lid 3 Wet gemeenschappelijke regelingen, dan wel via delegatie. 90

Bij de administratiewe afspraak kan, behalve aan de genoemde vorm van mandaat en delegatie, ook nog gedacht worden aan afspraken in de zin van de (Nederlandse) bestuurs-, beleids- en bevoegdhedenovereenkomsten. Deze (laatste) worden veelal tussen overheden en burgers gesloten, maar het maken van dergelijke afspraken tussen overheden onderling is niet uitgesloten. ${ }^{91}$ Daar waar dit soort afspraken tussen overheden en burgers gemaakt wordt, worden zij vaak als privaatrechtelijk afgezet tegen de 'echte' publiekrechtelijke overeenkomsten tussen overheden onderling in het kader van de Wet gemeenschappelijke regelingen. ${ }^{92}$ Het gaat het kader van dit proefschrift te buiten een diepgaande en grondige analyse te maken van deze bestuursovereenkomsten e.d. Hier wordt, in het licht van de bevoegdheden tot grensoverschrijdende samenwerking van decentrale overheden, volstaan met het volgende. Met name daar waar overheden discretionaire bevoegdheden hebben, kunnen deze mijns inziens door middel van afspraken tussen overheden ingevuld worden. Er is een groeiende praktijk, waarbij overheden in het kader van discretionaire publiekrechtelijke bevoegdheden bepaalde afspraken met elkaar maken, b.w. bij de opstelling van plannen, maar ook in het kader van vergunningverlening en handhaving. Daar waar bepaalde overheden de bevoegdheid hebben iets af te spreken, b.v. in de vorm van een bepaald gemeenschappelijk beleid, kan dit wel zijn weerslag hebben op de burger. De algemene beginselen van behoorlijk bestuur kumnen zich hier dan doen galden. In Nederland is het in ieder geval niet uitgesloten dat de burger zich kan beroepen, b.v. inzake opgewekte werwachtingen van openbaar gemaakte afspraken, op hetgeen overheden zijn overeenkomen. ${ }^{93}$ Afwijkingen van deze afspra-

90. Zie de brochure: Benelux-Overeenkonstgrensowerschrijdende samenwerking, a.w., p. 15.

91. Over bevogdheidsowereenkomsten/bestumisovereenkomsten, e.d., zie b. .: Van Wijk/Konijnenbent, Hootdstukken van Adninistratief Recht, zevende druk, 1991, p. 295 e.\%.

92. In het arrest GCN/Nietwegein (HR 23-6-1989, AB 1989, 551) heeft de Hoge Raad een op basis van de Wet gemenschappelikeregelingen gesloten overeenkomstals 'publiekrechtelik' gekwalificeerd. Overigens betekent dit niet dat daarop het priwatrechut b. v. omtrent aansprakelijkheid ex artikel $6: 162$ Burger lijk Webovk niet in grote mate van toepassing is/kan zijn. Zie ook: HR 5-2-1993, Rechtspraak van de Weat 1993, 47 (Rotterdam/Sitant).

93. Zie o.a.: B. van der Maulen, e.a. , Besthursbewegdheid als bron van recht, NTB, 91/5 p. 133-141. Wellicht ligt hier ook een parallel met arresten als Landsmeer, HR 4w1-1963, NJ 1964, 202-204 en Amsterdam/kon, HR 3-3-1987, AB 1987, 273. 
ken door overheden zijn dan wellicht nog mogelijk, maar zullen gemotiveerd moeten gebeuren. In België is dit nauwelijks anders. ${ }^{94}$ Dergelijke afspraken in het kader van discretionaire bevoegdheden (bestuursovereenkomsten e.d.) zijn niet gelijk te stellen met de afspraken op basis van artikel 8 Wet gemeenschappelijke regelingen, waarbij immers bevoegdheden worden overgedragen. $\mathrm{Bij}$ afspraken in het kader van discretionaire bevoegdheden is een overdracht van bevoegdheden niet aanwezig. Omdat het bij deze afspraken gaat over de invulling van publiekrechtelijke bevoegdheden kunnen ze als publiekrechtelijke afspraken gekwalificeerd worden. Zij vallen mijns inziens dan ook onder de werking van de Benelux-Overeenkomst. Zo kan in de administratieve afspraak worden vastgelegd op welke wijze bij de uitoefening van eigen taken en bevoegdheden rekening zall worden gehouden met de belangen van de overheden aan de andere kant wan de grens. Hiertoe kan b.v. worden afgesproken, dat overheden elkaar over en weer ruimtelijke- en millieuplannen ter beoordeling woorleggen. ${ }^{95}$ Overigens worden bestuursakkoorden ook wel geplaatst in het kader van de zogenaamde "lichte regeling" van artikel 1 lid 1 Wet gemeenschappelijke regelingen. Volgens hel ministerie van binnenlandse zaken zijn dergelijke bestuursakkoorden in beginsel onder het begrip administratieve afspraak te brengen. Voorts zou, aldus het ministerie, door middel van dergelijke afspraken vastgellegd kumnen worden hoe concreet uitvoering wordt gegeven aan afspraken die in grensoverschrijdend overleg (b.v. in een gemeenschappelijk orgaan) zijn gemaakt. 96

Een derde categorie administratieve afspraken, die hier mijns inziens ook nog vermeld dient te worden, betreft de zogenaamde 'kadercontracten inzake leveranties of verlening van diensten tussen lokale autoriteiten in grensgebieden'. Deze worden in model 2.5 van de bijlage bij de European Outline Convention genoemd en als publiekrechtelijk aangemerkt. Het gaat hier b.v. om contracten woor openbare diensten, het verstrekken van financiële bijdragen e.d. Artikel 28 Wet betreffende de intercommunales kent eveneens deze vorm van overeenkomsten. Deze vorm van (administratieve) afspraken heeft wellicht meer een privaatrechtelijk karakter.

\section{Verwizing naar het inteme recht}

De mogelijkheden van samenwerking op basis van de Benelux-Overeenkomst zijn beperkt door de regel volgens welke de betreffende overheden kunnen samenwerken "binnen het kader van de bevoegdheden die zij ingevolge het interne recht van hun land hebben". Deze regel is in algemene zin geformuleerd in artikel 2 lid 1 Benelux-Overeenkomst en wordt geconcretiseerd in:

- artikel 2 lid 3 wat betreft de regels inzake het toezicht en de controle op het handelen van de overheden;

94. Zie b.v: L.P Suetens, Alge mene beginselen wan behoorlijk bestuur, begrip en platts in de hierarchie der normen , p. 1 e.v., in: 1. Opdebeek (ed.). Algemene beginelen van behoorlijk bestum, 1993; A. Wan Mensel, De fornele motiveringsplicht, De wet wan 29-7-1991, TBP $1992 / 6$, p. 384 a.v.

95. Vgl. L. Vanhelleputte, a.w., p. 193; Brochure: Beneluk-Overeenkomst grensoverschrijdende samenwerking, a., w. p. 18.

96. Brochure: Benelix-Overeenkomst grensoverschrijdende samenwerking, a, w., p. 18 en 19, Wgl. tevens mool 86 van dit hoofustuk. 
- artikel 3 lid 3 wat betreft de rechtsbetrekkingen tussen het openbaar lichaam en de daaraan onderhorige natuurlijke en rechispersonen;

- artikel 3 lid 5 inzake de statuten van het openbaar lichaam;

- artikel 4 lid 1 inzake het toezicht en de controle op de besluiten van het openbaar lichaam.

Artikel 2 lid 3 is de meest ruime bepaling. Deze is van toepassing bij het aangaan van de drie vormen van samenwerking. Bij de overige hier genoemde bepalingen valt op dat er geen expliciete regeling is ten aanzien van de rechtsbetrekkingen tussen het gemeenschappelijk orgaan en derden alsmede het toezicht en de controle op besluiten van het gemeenschappelijk orgaan. Voorshands wordt er vanuit gegaan, dat de verwijzing naar het interne recht, zoals hier aangeven tevens geldt voor het gemeenschappelijk orgaan. Deze verwijzing naar het nationale recht lijkt er op neer te komen, dat wat de betreffende overheden intern (binnen de landsgrenzen) niet kunnen op het gebied van publiekrechtelijke samenwerking extern (over de landsgrenzen heen) ook niet mogelijk is. ${ }^{97}$ Blijkbaar moet daar waar het om externe samenwerking gaat, steeds nagaan worden hoe en wat in het interne recht van de verschillende landen op het gebied van de samenwerking tussen overheden geregeld is. Met andere woorden: zonder interne samenwerkingsmogelijkheden geen externe samenwerkingsmogelijkheden. In de bijlage bij artikel 2 lid 1 Benelux-Overeenkomst worden de diverse wederzijds toepasselijke wetten inzake interne samenwerking opgesomd. Het lijkt er op dat de externe samenwerking binnen het stramien van met name de Wet gemeenschappelijke regelingen en de Wet betreffende de intercommunales dient plaats te vinden. Beide wetten geven juridische grondslagen voor interne samenwerking ( $\mathrm{vgl}$. in $\$ 2$ en $\$ 3$ van dit hoofdstuk). Zij scheppen vooral formele bevoegdheden (bevoegdheden om samen te werken) voor overheden, vooral gemeenten. De Benelux-Overeenkomst geeft een internationale dimensie aan deze samenwerkingswetten. Er wordt in de bijlage bij de Benelux-Overeenkomst niet verwezen naar meer bijzondere wetten op basis waarvan intern samenwerkingsverplichtingen, mogelijk afwijkend van deze beide wetten, kunnen bestaan. Hoewel de gemeenschappelijke Memorie van Toelichting lijkt uit te gaan van een limitatieve opsomming in de bijlage ${ }^{98}$, moet die andere wetgeving, zo die er al is, mijns inziens op voorhand niet uitgesloten worden geacht. In sectorwetten is soms in (verplichte) vormen van samenwerking voorzien. ${ }^{99}$

97. In de woorden wan de Belgische regering: "Bij de vormgeving van de overeenkonst is uitgangspunt geweest dat het recht van de drie betrokken landen onaangetast blift. Met andere woorden, de statuten van aen openbaar lichaan moeten zodanig worden ingerich dat deze niet un strijd komen met de wettelijke regells die terzake in de betrokken landen gelden. ", MvT bij het wetsontwerp tot goedkeuring van de Benelux Overeenkomst, Gedr. St., Senaat, 1988-1989, 651/1, p. 2.

Over de onaantastbaarheid wan het interne recht, zie ook: E.L.H. de Wilde, Benelux Overeenkomst grensoverschrijdende samenwerking, in: Handboek Bestuurlijke Samenwerking, a.w., MI-B.2, p. 3-5.

98. Gemeenschappelijke MvT bij de Benelux-Overeenkomst, a.w., p. 13.

99. Zo werd in het kader van de Grondwetsherziening van 1983 door de Nedenlandse regering gesteld, dat artikel 135 Grondwet niet persé een algemene wet (Wet gemeenschappelijke regelingen) vereist, jarar dat er ook sanenwerkingsbepalingen in bijzondere wetgeving opgenomen kumnen worden (Tweede Kamer, 1978-1979, 13995, nr. 9, p. 2). Vgl. tevens de noten $10 \mathrm{en} 31$ van dit hoofdstuk. 
Omdat niemand meer rechten kan overdragen dan hij/zij zelf heeft, zijn de bevoegdheden van de op te richten samenwerkingsverbanden een afgeleide van die van de aangesloten overheden. Deze materiële bevoegdheden (de in te brengen bevoegdheden: op welke terreinen hebben de overheden en daamee de samenwerkingsverbanden bevoegdheden) zijn vooral in de diverse sectorwetten (medebewindsbevoegdheden) te vinden. De bijlage bij de Benelux-Overeenkomst noemt slechts wetten als de Gemeentewet en de Provinciewet (autonome bevoegdheden). Hiertoe is het toepassingsgebied van de Beneux-Overeenkomst niet beperkt. Het gat naast autonome ook om medebewindsbevoegdheden. ${ }^{100}$

\section{Aanwullende werking}

Uit de beschrijuing van de relevante nationale wetten inzake decentrale samenwerking in Nederland en België (sub 2 en 3 van dit hoofdstuk) komt de beperkte relkwijdte van de Wet betreffende de intercommunales ten opzichte van de Wet gemeenschappelijke regelingen naar voren. Zou de Benelux-Overeenkomst wat betreft de formele bevoegdheden van de betreffende overheden om samen te werken aansluiten bij de bevoegdheden wan het nationale recht, dan is dat, b.v. gezien die beperkte reikwijdte van de Wet betreffende de intercommunales, zonder meer belemmerend woor de realisering van de in de Benelux-Overeenkomst aangegeven samenwerkingsvormen. Artikel 2 lid 1 Benelux-Overeenkomst - vgl. ook de vorige paragraaf - lijkt uit te gaan van een dergelijke beperkte reikwijdte. ${ }^{101}$ Zich baserend op de letter van artikel 2 lid 1 Benelux-Overeenkomst leek aanwankelijk de Nederlandse regering deze beperkte toepasselijkheid wan de Benelux-Overeenkomst aan te hangen. $\mathrm{Zij}$ stelde, naar aanleiding van vragen van de VNG omtrent de bevoegdheid van de Wgr-openbare lichamen om grensoverschrijdend samen te werken: "Voor de toepassing van de overeenkomst betekent dat intussen, dat openbare lichamen niet op basis van artikel 2 , eerste Jid, kunnen komen tot een uitsluitend onderlinge samenwerking over de landsgrenzen heen." 102 De reden hiervoor zocht de regering in het feit, dat in het nationale recht niet de mogelijkheid bestaat tot uitsluitend samenwerking tussen Wgr-openbare lichamen. Bij de goedkeuring van de Duits - Nederlandse Overeenkomst inzake decentrale grensoverschrijdende samenwerking is dit standpunt echter herzien en is, volgens de regering, deze samenwerking alsnog toegestaan: " De bevoegdheid tot dergelijke samenwerking berust op de Overeenkomsten (de Benelux-Overeenkomst en de Duits-Nederlandse Overeenkomst, RS) zelf, die als regelingen van hogere orde dan de Wet gemeenschappelijke regelingen deel uitmaken van

100. Zie ook: A.A.L.G.M. Kessen, a.w., p. 153, 160.

101. Zie ook de Toeliehting op de artikelen, a., p. 14, ten aanzien van artikel 2 lid 1: "Dit impliceert dat men niet meer bevogdheden kan overdragen dan men zelf bezih. Voorts his overdracht wan bevogdheden titgesloter indien het interne recht dat verbiedt. $Z$ ie ook ten aanzien wan artikel 2 lid 5 : "Daar waar het interne recht vergeljkbare regels bevat, zullen er geen problemen rijzen bij het vaststellen van de statuten. Daar war eisen worden gesteld die verschillen in zwaarte zullen, om tegemoet te komen aan beide rechtsstelsels, de zwaarste eisen moeten worden angehouden. Dar waar de eisen tegengesteld zijn zal geen regeling tot stand kunnen komen en zal aapassing wan de betrokken regels noodzakelijk zijn."

102. Toelichtende nota bij de Benelux-Overemkomst, a w., p. 5. Overigens geldt op basis varn artikel 2 Wet betreftende de intercommunales in beginsel hetzelfte voor de intercommunales in Belgió. 
het interne recht (...). Een andere interpretatic zou tot gevolg hebben dat de Overeenkomsten hun eigen werking blokkeren: op basis wan de Wet gemeenschappelijke regelingen alleen is immers geen enkele decentrale overheid bevoegd tot publiekrechtelijke grensoverschrijdende samenwerking. ${ }^{\text {103 }}$ Dit regeringsstandpunt bevat verscheidene interessante aspecten. Hier is van belang dat de regering op dit punt de Benelux-Overeenkomst (en de Duits-Nederlandse Overeenkomst) loskoppelt van de bevoegdheden op basis van het nationale recht. Het is de vraag in hoeverre deze loskoppeling doorgevoerd kan worden. Nog anders gezegd - ik beperk mij hier tot de Nederlands-Belgische situatie: in hoeverre vult de Benelux-Overeenkomst het interne recht (in België) aan? Als de werwijzing van de Benelux-Overeenkomst naar het nationale recht ook van toepassing is op met name de formele bevoegdheden om samen te werken, dan kan het doel van de Benelux-Overeenkomst, zoals eerder aangegeven, niet dan wel nauwelijks verwezenlijkt worden. Immers in dat geval, zoals blijkt uit de beschrijving van de nationale wetgeving in $\$ 3$ van dit hoofdstuk, hebben enkele van de in de Benelux-Overeenkomst opgenomen overheden helemaal geen bevoegdheid tot interne samenwerking (en daarmee dan ook nitet tot externe samenwerking!). In het licht van de doelstelling van de Benelux-Overeenkomst moet deze veeleer zelf de juridische grondslag zijn, die het mogelijk maakt dat in ieder geval alle in het verdrag genoemde overheden aan de ene kant van de grens extern kunnen samenwerken (binnen hun materiele bevoegdheden) met alle in het verdrag genoemde overheden aan de andere kant wan de grens, ongeacht of zij in het interne recht een formele bevoegdheid tot onderlinge dan wel samenwerking met andere overheden hebben. Hiervoor kan b.v. pleiten het feit dat de Benelux-Overeenkomst zaken regelt, die in het nationale recht van België in zijn geheel niet bekend zijn, zoals de instelling van een gemeenschappelijk orgaan, of onduidelijk zijn c.q. niet toegepast worden, zoals omtrent de (algemene) overdracht van bevoegdheden van regeling en bestuur aan openbare lichamen. Het is op zijn minst bijzonder dat bij afwezigheid van samenwerkingsvormen in het nationale recht hierin middels een verdrag beoogd wordt te voorzien, om daarna weer te verwijzen naar het nationale recht en de samemwerking slechts toe te staan, als dit in overeenstemming is met dat nationale recht (dat niets regelt/niet bestaat!). Wil samenwerking (in brede zin) van de grond kunnen komen, dan zal de verwijzing in de Benelux-Overeenkomst naar het nationale recht inderdaad slechts betrekking moeten hebben op de materiële bevoegdheden (wile is voor wat bevoegd op basis wan met name sectorwetgeving) en niet op de fomele bevoegdheid om samen te werken. Met andere woorden: De Benelux-Overeenkomst bevat het juridisch instrumentarium voor de overheden, die op vrijwillige basis op bepaalde zelf te kiezen beleidsterreinen, waarop zij materiële bevoegdheden hebben, willen samenwerken. Omdat de Benelux-Overeenkomst vooral aan de Wet gemeenschappelijke regelingen ontleende samenwerkingsvormen met de daarbij behorende bestuurs- en regelingsbevoegdheden kent, die in België niet geregeld zijn, betekent het woorgaande eigenlijk, dat de Wet gemeenschappelijke regelingen via de Benelux-Overeenkomst geëxporteerd is naar België. Het impliceert - de Benelux-Overeenkomst heeft alleen betrekking op grensoverschrijdende samenwerking - dat de samenwerking tussen louter Belgische overheden zal gaan afwijken van de samenwerking waarbij ook buitenlandse overheden betrokken zijn.

103. Toelichtende mota bij de Duits-Nederlandse Overeenkomst, (zie hoofdstuk 6 noot 28), p. 10. 
De consequentie (en niet de bedoeling?) is dat, bijwoorbeeld door een buitenlandse gemeente er bij te betrekken, Belgische (grens)gemeenten tot veel werdergaande wormen van samenwerking bevoegd worden dan die op basis van het nationale recht (Wet betreffende de intercommunales) voor de onderlinge samenwerking bestaan.

De verdragsluitende partijen hebben zich mijns deze problematiek onvoldoende gerealiseerd. Het is voor mij moeilijk stelling te kiezen in deze, omdat er zo weinig aanknopingspunten in het verdrag en de toelichting zijn te vinden. In het ene geval wordt de Benelux-Overeenkomst wel heel erg in haar werking beperkt en in hel andere geval is het heel erg ingrijpend voor de Belgische situatie. ${ }^{104} \mathrm{Bij}$ de opstelling van de ontwerpstatuten voor een grensoverschrijdend openbaar lichaam is mijns inziens uitgegaan van de laatste situatie. ${ }^{105}$

\section{Confrontatie van rechtsstelsels}

Slechts voor de rechtspositie van het personeel is op basis van artikel 3 lid 4 BeneluxOvereenkomst de mogelijkheid geopend van de toepasselijkheid van é̂n rechtsstelsel, namelijk dat van de plaats van vestiging van het openbaar lichaam. Voor het overige zijn de rechtsstelsels van de samenwerkende overheden van toepassing. Als de BeneluxOvereenkomst, zoals in de vorige paragraaf aangegeven, te zien is als een algemene formele juridische grondslag voor het aangaan door de desbetreffende overheden van de drie samenwerkingsvormen, dan zijn hiermee de verschillen in het nationale recht op het punt van de formele bevoegdheden (basis voor het aangaan van externe samenwerking) geëlimineerd. Dit is in ieder geval niet zo waar het betreft het - de materiële sectorbevoegdheden blijven hier even buiten beschouwing - toezicht en de controle op de overheden (bij het aangaan van de drie vormen van samenwerking), op het openbaar lichaam en het gemeenschappelijk orgaan. Dit is ook niet het geval als het gaat om de rechtsbetrekkingen van burgers jegens het openbaar lichaam en het gemeenschappelijk orgaan. Bij het laatste zit men al in de fase van de rechtsbescherming.

Toezicht en controle op het handelen wan owerheden (artikel 2 lid 1 Benelux-Overeenkomst) en op het handelen van het openbaar lichaam (art. 3 lid 5 en art. 4 lid 1 Benelux-Overeenkomst) (mins inziens ook op het handelen van het gemeenschappelijk orgaan) geschiedt via de rechtsstelsels - de rol van een eventueel aan te stellen bijzondere toezichthouder op basis van artikel 4 lid 2 Benelux-Overeenkomst is hieraan aanvullend ${ }^{106}$ - van de deelnemende overbeden. Daarbij ligt het voor de hand dat een geza-

104. In de Duitsonederlandse samenwerking speelt het voorgalande nitet dan wel in weel mindere mate, omdiat de Duits-Nederiandse Overeenkomst qua instrumentariun asusluit bij het grotendeels wergeljkbare Nederlandse samenwerkingsrectu op basis vam de Wet gemeenschappelijke regelingen en het Duitse samenwerkingsrecht op basis wan het Gesetz uber kommunalle Gemeinschaftsarbeit en het Zweckverbandgesetz. Zile hiervoor 0 . a. in 8 . B. in hoofdstuk 6.

105. Zie: hierwor in 5.D.2 van dit hoofdstuk. Ook het Nederlands ministerie wan binmenlandse zaken gavt van dit laatste standpunt uit, wanneer wordt geskeld dat de Benelux-Owereenkomst, als regeling van hogere orde, een aawwlling vormt op de in de betrokken landen toepasseligke regelingen "Brochure: Benelux-Overeenkomst grensoverschrijdende samenwerking, a.w., p. 13 .

106. Zie voor een beschrijwing van de relatie tussen deze bijzondere toezichthouder the reguliere toezichthonder(s), E.L.H. de Wilde, Benelwx-Overeenkomstgrensowerschrijdendesamenwerking, in: Handboek Bestuurlijke Samenwerking, a.w., MI-B.3, p. 10-1.2. 
menlijke afspraak of b.v. een besluit van een openbaar lichaam pas kan gaan gelden, als dit in beide landen is toegestaan. Anders gezegd: de samenwerking is niet mogelijk daar waar er geen sprake meer is wan een gemeenschappelijke toelaatbaarheid.

Zo wordt ten aanzien van de statuten van het openbaar lichaam uitgegaan van de grootste gemene deler: de statuten mogen niet in strijd komen met het recht van een van de betrokken landen. ${ }^{107}$ Het kan heel goed zijn, dat een gezamenlijke afspraak of het besluit van een openbaar lichaam (of gemeenschappelijk orgaan) in het ene land niet goedgekeurd of vernietigd wordt door een toezichthouder, terwijl in het andere land het omgekeerde het gewal is. Ook in de fase van de rechtsbescherming kan hieraan de rechtskracht in het ene land komen te ontvallen en in het andere land niet. In dit verband komen weer de verschillen tussen de Nederlandse Wet gemeenschappelijke regelingen en de samenwerking tussen overheden in Belgie, met name op basis van de Wet betreffende de intercommunales, naar voren. Daarnaast moet b.v. gedacht worden aan verschillen in het kader van de totstandkoming van overheidsbesluiten (zoals het ontbreken in België van een wet als de Algemene wet bestuursrecht, die op korte termijn voor Nederland van toepassing zal zijn op besluiten van bestuursorganen (van het openbaar lichaam). ${ }^{108}$ In het kader van de rechtsbescherming jegens bestuiten van het openbaar lichalam kunnen eveneens meerdere rechtsstelsels toepasselijk zijn. ${ }^{109}$ Dit is bijvoorbeeld het geval, wanneer een in Belgiè gelegen openbaar lichaam een besluit neemt, waartegen zowel in Nederلand als in België in rechte door burgers wordt opgekomen.

107. Toelirhting op de artikelen, a.w., p. 15.

108. In dit verband is het gestelde in de MvT bij het wetsworstel Awb, eerstetranche, wan belang ten aanzien van het ontbreken in artikel 1.1. Awb, anders dan in artikel 1 van de Wer Arob, van het element dat en persoon of college met enig openbaar gezag < binnen> Nederland moet zijn bekleed. De regering merkt in dit verband op dat de Awb zal gelden "voor alle personen of colleges die ingevolge Nederlamdse wetgewing met openbara gezag zijn bekleed, ongeacht of zij well of niet in Nederland werkzaam zijn." De Awb kam zich, aldus de regering, net witstrekken "tot colleges die bij of krachtens werdrag zijn ingesteld en zijn bekleed met opembaar gezag dat zij (mede) binnen Nederland ütoefenen (met mame de organen wan de Europese Gemeenschappen die krachten communatair recht beshitun aemen die direct thier te lande ge den. "Mierover stelt de regering." "De hierarchische verhouding tusse nupranationalen mational secht stat er immers and in de weg dat de Nederlandse wetgever voorschriften vaststelt voor We witoefening wan de bevoegdheden door organen die zijn ingesteld in internationale rege lingern "MvT, Algemene wet besturisnech, eersta tranche, Tweede Kamer, vergaderjat 1988-1989, 21221, ar. 3, p. 29.

Op basis van het vorenstatade is het de wraag of do Awb all dan niet wan loepassing is op b. $\gamma$. besiluten wan met name het openbaar hicham - dit geldt ook voor het gemeenschappelijk orgatan - op basis van de Benelnx-Overaenkomst, watar wo zetel in Belgie dan wel Nederland is gelegen. In de sfeer wan de rechtsbescherming kan er gezien de verwijzing wan de Benelux-Overeenkomst nasr het nationale recht, wrambiji de busluiten van het openbaar licham aangemerkt worden als beshüten van de deelnenende owerheden, mijns inziens vanuit gegnan worden, dat de Awb ook van toepassing zal zija op besiuiten varn het openbaar lichaam op basis van de Benelw -Overeenkomst. Daarbij kan dan in het midden blijven of het openbar licharan als een 'nationale' overheid gezien moet worden (én dus op Eén lifn te stellen is met de deelimende cverheden of niet. Het is de vraag of een en ander ook in de voorbereidende fase wan besluitworming onverkort zal gelden, angezien juist dar de Awb belangrijke eisen stelt. Een en ander geldt met name ook bij het openbaar lichaan op basis van de Duits-Nederlandse Owereenkomst (zie hoofdstuk 6), welk openbaar lichan de overheden bindende bevoegdheden heeft.

109. Ook in Belgie (zie voor Neclerland de vorige noot) is voor b.v. een beroepsgang bij de Raad van State witgangspunt, dat het woor beroep vatbare besluit afkonstig moet zijn van een Belgische administratieve overheid. Zie: W. Lambrechts, Gesehillen van bestur, 3e herwerkte uitgave, 1988, p. 37. 
Volgens artikel 3 lid 3 Benelux-Overeenkomst zal een derde, die met besluiten wan een openbaar lichaam geconfronteerd wordt, die hij/zij wil aanwechten, uiteindelijk bij zijn/haar nationale rechter terecht komen b.v. de Raad van State, al naar gelang in België of Nederland wonend, de Belgische dan wel de Nederlandse. Het feit dat de burger bij zijn/haar eigen rechter terecht kan is een goede zaak en voor hem/haar zeker de beste oplossing. Omdat op basis van artikel 3 lid 3 Benelux-Overeenkomst de rechter in België Belgisch recht en de rechter in Nederland Nederlands recht zal toepassen, kunnen er uiteenlopende interpretaties c.q. van elkaar afwijkende beslissingen in deze ontstaan. Zo lijkt het aannemelijk dat de Belgische Raad van State, als deze bevoegd is, als het er op aan komt zal oordelen, tenzij van het standpunt van de Afdeling Wetgeving zoals vermeld \$ 5.D.7.c. van dit hoofdstuk wordt afgeweken, dat derden niet door een beslissing van een openbaar lichaam gebonden kunnen worden. Naar de opvatting van de Nederlandse Raad van State in deze kan men slechts gissen. Het gevaar van divergentie als gevolg van de toepasselijkheid van twee rechtssystemen ligt voor de hand. Wanneer vanuit é́n van beide rechtssystemen bezwaren bestaan, zal dat dus kunnen betekenen dat samenwerking in zijn geheel niet mogelijk is of ten hoogste tot het niveau van het minst ver gaande rechtsstelsel (samenwerking op minimumniveau). In dat verband lijkt het op de allereerste plaats zaak om zoveel mogelijk te komen tot coördinatieregels om tegengestelde toezichtsbesluiten e.d. tegen te gaan. Het verder gaan door bijvoorbeeld het uitschakelen van eén rechtsstelsel ligt niet voor de hand in het licht van de complicaties hiervan voor de rechtsbescherming van de burger. Een gemeenschappelijk kader voor een grensoverschrijdend openbaar lichaam in de zin van een supradecentraal, naar analogie van een supranationaal, openbaar lichaam met dito toezicht en rechtsbescherming is eveneens nog ver weg. ${ }^{110}$ Overigens bestaan er (ten aanzien van de genoemde divergentie) uniformerende aspecten in deze richting, zoals de bevoegdheid van het Benelux-Gerechtshof inzake de uitleg van de Benelux-Overeenkomst. Hierop wordt ingegaan § 5.D.6.c. van dit hoofdstuk.

\section{Geschillenbeslechting en (uniforme) interpretatie}

\section{a. Geschillen tussen owerheden}

Ten aanzien van de geschillenoplossing zijn de artikelen 5,6 en 7 Benelux-Overeenkomst van belang. Artikel 5 Benelux-Overeenkomst regelt de (gezamenlijke) aanwijzing van een ambtenaar grenscontacten. Hoewel deze zelf geen geschillen kan beslechten, kan hij wel voorstellen tot oplossing ervan doen. Hij kan de geschillen voorleggen aan de ingestelde Bijzondere Commissie ex artikel 6 Benelux-Overeenkomst. Die heeft o.a. tot taak onderzoek in te stellen naar onenigheden en geschillen, die met betrekking tot op de Benelux-Overeenkomst gebaseerde grensoverschrijdende samenwerking zijn gerezen, teneinde deze via een verzoeningsprocedure op te lossen en als dat niet lukt aan het Comité van Ministers voor te leggen. Het Comité van Ministers heeft, behalve een taak bij de geschillenoplossing, tevens de bevoegdheid bij beschikking nadere regels te geven omtrent de wijze van uitvoering van de Benelux-Overeenkomst (art. 8 Benelux-Overeen-

110. Zie nader: actbeveling 9 in hoofdstuk 7 . 
komst), welke beschikkingen overigens geen verdergaande strekking kunnen hebben dan de in de Benelux-Overeenkomst vastgelegde regels. Blijkens de toelichting op artikel 6 Benelux-Overeenkomst gaat het om geschillen tussen de overheden onderling of tussen deze en de gemeenschappelijke openbare lichamen. " om belangen- dan wel rechtsgeschillen gaat. ${ }^{112}$ Daarbij is evenmin geregeld in hoeverre de beslissing van het Comite van Ministers ex artikel 7 Benellux-Overeenkomst, inzake de door de Bijzondere Commissie aan haar voorgelegde geschillen, in het kader van arbitrage geplaatst moet worden en als dat al het geval is of deze een definitief karakter kan of moet hebben. In het Benelux-Unieverdrag is ook niets bepaald omtrent een roll van het Comité van Ministers bij de oplossing van geschillen. In dit licht zal het Comité van Ministers slechts politieke oplossingen kunnen voorstellen. Naarmate de juridische binding groter wordt, is juist een goede geschillenregeling op zijn plaats. Enerzijds is met het ontbreken van een geschillenregeling in de Benelux-Overeenkomst natuurlijk niet zonder meer gezegd dat een geschillenregeling buiten de regeling van artikel 7 BeneluxOvereenkomst onmogelijk is. ${ }^{113}$ De desbetreffende overheden kunnen in hun samenwerkingsregeling afspreken dat geschillen aan arbitrage worden onderwerpen. Dit dient dan wel volgens de regels van het nationale recht te gebeuren. Daarbij heeft arbitrage in beginsel slechts betrekking op civielrechtelijke (en voornamelijk vermogensrechtelijke) zaken. ${ }^{114}$ Arbitrage tussen overheden in het kader van publiekrechtelijke bevoegdheden is niet altijd mogelijk. In Nederland is de mogelijkheid van arbitrage tussen overheden op basis van artikel 1020 Wetboek van Burgerlijke Rechtsvordering niet uitgesloten. De overeenkomst tot arbitrage mag evenwel niet leiden tot de vaststelling van rechtsgevolgen die niet ter vrije beschikking van de partijen staan. Dit zal het geval zijn bij geschillen inzake overheidsbesluiten die voor derden rechten/verplichtingen in het leven roepen. Voor België geldt artikel 1676 Gerechtelijk Wetboek. Met name lid 2 van dit artikel is van belang. Het luidt:" "Buiten de publiekrechtelijke rechtspersoon kan ieder die bekwaan of bevoegd is om een dading aan te gaan, een overeenkomst tot arbitrage sluiten. De Staat kan een dergelijke overeenkomst sluiten wanneer een verdrag hem toestaat in arbitrage toe te stemmen." "Een rechtsgang (al dan niet na arbitrage) is waarschijnlijk niet (altijd) uitgesloten. ${ }^{115}$ In het licht van een niet sluitende geschillenregeling op basis van de Benelux-Overeenkomst (juncto het BeneluxUnieverdrag) is de gang naar de nationale rechter niet uitgesloten. ${ }^{116} \mathrm{Het}$ is de vraag of en hoe overheden elkaar in rechte kunnen aanspreken: Is een Nederlandse of Belgi-

111. Toelichting op de artikelen, a.w., p. 17. Mijns inziens kan het ook gaan om gemeenschappelijke organer.

112. Zie woor de atbakening tussen beide in Nederland, P.W.C. Akkermans, A.K. Koekkoek (ted.), a.w., p. 1177. Vgl. C.A.I.M. Kortmann, Constitutionel recht, 1990, p. 417.

113. Vgl. het Decreet van de Vlamse Raad tot goedkeuring van de Europese Kaderovereenkomst inzake grensoverschrijdende samenwerking tussen territornale gemexuschappen of autoriteiten, en de Bijloge, 23-12-1986, B.S. 20-3-1987. In artikel 2 wan dit decreet is bepald dat publiekrechtelijkerechtspersonen voor de roepassing wan de in dit decreet bedoelde Owereenkonst een beroep kumen doen op arbitrage.

114. Vgl. A.J. wan den Berg, R. wan Delden, H.J. Snijders, Arbitragerecht, 2e druk, 1992, p. 3.

115. De Duits-Nederlandse Overeenkonst inzake decentrale grensoverschrjudende samenwerking bevat cen regeling waabij overheden vrijwillig overeen kunnen komen geschillen te onderwerpen aan arbitrage. Darriarast) is een eventuele rechtsgang evenwel nog mogelijk. Vgl hoofdstuk 6 sub $4.4,6.1$.

116. In de statuten voor het openbarar lichaam, zoals besproken in dit hoofdstuk \$ 5.D.2., is eveneens niet voorzien in een geschillenregeling. 
sche rechter bevoegd en welke $(1 / 2)$, en welk recht dient door de bevoegde rechter toegepast te worden (3)?

\section{- Beslist de gewone rechter over geschillen tussen overheden?}

De regels van het interne recht over de rechtsgang worden door de Benelux-Overeenkomst niet gewijzigd. In deze is van belang of de voor nationale bestuursgeschillen bewoegde rechter ook bevoegd is inzake bestuursgeschillen tussen Belgische en Nederlandse overheden. Voor geschillen tussen overheden zijn zowel in Nederland als België speciale procedures mogelijk. Het kan zijn dat niet de gewone burgerlijke rechter maar een administratieve rechter geroepen is te oordelen in bestuursgeschillen. De burgerlijke rechter in België beslist over geschillen over burgerlijke rechten (art. 92 Grondwet) en in Nederland over burgerlijke rechten en schuldvorderingen (art. 112 Grondwet). ${ }^{11}$ ? Daarnaast bestaan er in Nederland en België aanvullende procedures inzake bestuursgeschillen. Zo bepaalt artikel 1,36 Nederlandse Grondwet: "De geschillen tussen openbare lichamen worden bij koninklijk besluit beslist, tenzij deze behoren tor de kennisneming wan de rechterlijke macht of hun beslissing bij de wet aan anderen is opgedragen. "Het gaat hier om een soort van publiekrechtelijke arbitrage in bestuursgeschillen tussen overheden. ${ }^{11: 3}$ In Belgie is er ten aanzien van bevoegdheidsbetwistingen tussen overheden een equivalent op basis van artikel $12 \mathrm{Geco-}$ ördineerde wetten op de Raad van State. Dit artikel luidt voor zover van belang: "De afdeling beslecht bij wijze van arresten de moeilijkheden betreffende de respectieve bevoegdheid van de prowinciale en gemeentelijke owerheden of van de openbare instellingen (...) Deze moeilijkheden mogen bij haar aanhangig worden gemaakt door jeder betrokken administratieve overheid." In het licht van de samenwerking in Nederland is b.v. artikel 28 Wet gemeenschappelijke regelingen van belang. Dit bepaalt: "Geschillen ontrent de trepassing in ruimste zin, van een regeling tussen besturen van deelnemende gemeenten of tussen besturen van een of meer deelnemende gemeenten en het bestuur van het openbaar lichaam of het gemeenschappelijk orgaan worden door gedeputeerdestaten beslist, voor zover zij niet behoren tot die, wermeld in artikel 112, eerste lid van de Grondwet of tot die waarvan de beslissing krachtens artikel 112, tweede lid van de Grondwet is opgedragen hetzij aan de rechterlijke macht, hetzij aan gerechten die niet tot de rechterlijke macht behoren." 119 Voor andere dan gemeentelijke samenwerking bestaan er vergelijkbare bepalingen, namelijk de artikelen $42,53,75$ en 85 Wet gemeenschappelijke regelingen, met dien verstande dat deze geschillen bij koninklijk besluit worden beslist. ${ }^{120} \mathrm{Als}$ de aard van het geschil burgerrechtelijk is, zal de gewone rechter in

117. Zhe ook artikel 556 Gerechtelijk Wetboek en artikel 2 Wet op ke Rechterlike Organisatie.

118. Wetsonwerp eerste fase herziening rechterljke organisatie, Tweede Kamer, vergaderjaar $1991-1992$, 22495 , nr. 3. p. 52: "Dit betekent dat bestuursorganen in die gevallen (horizontallelzuive besturs beschillen, RS) kunnen kiezen tussen een gang naar de civiele rechter of een gang naar de Kroon." Vgl. tevens het gestelde \& 2.B.3 van dit hoofdstuk.

119. Over de functie van gedeputerde staten in de geschillenbeslewhing tussen de (organen van de) lagere owerheden, zie: M.J.M. Schoonhowen, a.w., p. 268-269.

120. Overigens worden deze bepalingen op korte termijn geschrapt, zie noot 22 en 23 wan dit hoofdstuk. Bjj de anhangige berziening van de rechterlijke organisatie in Nederland is beroep inzake beaturgbeslutten bij de (administratieve) rechter het uitgangspunt. Dit geldt in beginsel ook voor de zuivere bestuursgeschillen. Aft. III Overgangsbepalingem bepalt dat de rechtbank bevoegd wordt, indien in een wettelijk woorschrift beroep op de Kroon is opengesteld, Wijziging van de Wet op de rechterlijke organisallie (woltooling eerste fase herziening rechterlijke organisatie), a. w., Nader gewijzigd voorstell van wet, Eerste Kamer, vergaderjaar 1992-1993, 22495, nr. 310, p. 210. Evenwel lijkt in het licht van de Memorie wan Toelichting bij een aantal bepalingen het vermelde uitgangspunt toch miat zonder meer te gelden

(wordt vervolgd...) 
Nederland zich in deze geschillen in beginsel derhalve bewoegd èn ontwankelijk verklaren. ${ }^{121}$ Gezien de formulering van artikel 12 wan de Gecoördineerde wetten op de Raad van State zal dit mijns inziens in België niet anders zijn. Dit is zeker zo, gezien het feit dat de intercommunale samenwerking vooral privaatrechtelijk van karakter is. Behalve de rechtsgang in deze (zuivere) bestuursgeschillen, kunnen zowel de overheden in Belgie als Nederland gebruik maken van het beroepsrecht dat iedere (rechtstreeks) belanghebbende heeft.

- Is de Nederlandse of de Belgische rechter bevoegd te beslissen over geschillen tussen overheden?

Anders dan de Duits -Nederlandse Overeenkomst inzake decentrale grensoverschrijdende samenwerking bevat de Benelux-Overeenkomst geen regeling, waarbij inzake geschillen tussen overheden de rechtsgang bepaald wordt volgens de regels van de zetel van de gedaagde overheid. De verdragslluitende partijen bij de Duits-Nederlandse Overeenkomst hebben deze collisieregel opgenomen om te voorkomen dat buitenlandse gerechten overheden veroordelen tot een bepald doen of nalaten. Een dergelijke collisieregel is te plaatsen in het licht van de mogelijkheid wan een beroep door (een openbaar lichaam van) de staat woor een buitenlandse rechter op immuniteit. ${ }^{122}$ Als men deze regel consequent doorwoert, impliceert deze, dat als de gedaagde overheid het gelijk aan haar zijde heeft en het de eisende partij is, die iets moet doen of nalaten, de gedaagde overheid op haar beurt bij de rechter van de eisende overheid moet opkomen. Deze regeling is niet expliciet in de Benelux-Overeenkomst opgenomen, maar zal wel van toepassing

\section{0.(... verwolg)}

voor de zuivere bestuursgeschillen. Vgl. ook noot 118 van dit hoofdstuk.

In dit verband kan tevens nog gewezen worden op het feit dat in de Nieuwe gemeentewet geen regelimg omtrent bestursgeschillen is opgenomen a la het oude artikel 150 Gemeentewet. Dit laatste luidt:" $\mathrm{De}$ gemeentebesturengedragen zich nar hetgeen in geschillen wan bestuur, tussen geneente en gemeente. of tusschen geneente en provincie, waterschap, veenschap of veenpolder gerezen, door Ons ( $=\mathbb{K}$ roon, RS) wordt beslist."

In dit verband kw ook nog gewezen worden op de witsluiting van de zinwere bestuurigeschillen op basis wan artikel I Tijdelijke wet Kroongeschillen. Zie hierover: J.B.J.M ten Berge, M.C. Burkens, P.J.J. wan Bururu, De Tijdelike wet Kroongeschillen, 1987, p. 56-75.

121. VRI. HR 23-6-1989, AB 1989,551 (GCN/Nieuwegein) en HR 5-2-1993, qechtspraak wan de Week 1993, 47 (Rotterdam/Stath). Zie ook: Th. L. Bellekom et al., a.w., p. 242.

Overigens is tegen een beslissing van gedputeerdestaten op basis van artikel 28 Wet gemeenschappelijke: regelingen een rechtsgang mogelijk. Zo merkte de Afdeling Rechtsprakk een besluit van gedeputeerde staten op basis van artikel 28 Wet gemeenschappelhkerege lingen, inhoudende de gegrondverklaringwan een berosp wan en gemeentinzake en uittredingssom, ath als eer beschikking, ARRS, 12-8-1993, nr. $\mathbb{R} 03.89 .3622 . \mathrm{Vgl}$. ook noot 46 in hoofdsuk 4.

122. Het gant hier te wer dieper op de problematiek wan de immuniteiten in te gaan. Ik wil wolstas met een verwillzing naar artikel 27 bid 2 van de Europese Overeenkomst inzake de immuniteit wan Staten, Bazel 16-5-1972, Trb, 1973, nr. 3, 43 (Voor Nederland in werking getreden 22-5-1985, Trb. 1985, nr. 38), warin ten anzien van (de publiekrechteligke macht van) b.v. decentrale overheden in dit verband is bepard: "2. Proceedings may be instituted against any entity referred to in paragraph 1 (any legal entuty of a Contracting State which is distinct therefrom and is capable of suing or being sued, even if that entity has been entrusted with public functions, RS) before the courts of another Contracting State in the same wnanner as against a private person; however, the courts may not entertain proceedings in respeet. of acts performed by the entity in the exercise of sovereign aw thority (actat jure imperii). "Over immunjtheiten, zie b.v.: ILA, Report of the sixty-fourth Conference, 1991, p. 393 e.v. 
zijn. Het gaat hier immers om een in het algemeen gehanteerde volkenrechtelijke regel inzake publiekrechtelijke geschillen tussen overheden uit verschillende landen. Tenzij er door staten afwijkende afspraken zijn gemaakt, wordt de eigen rechter in dit soort geschillen alleen maar geacht iets te beslissen voor zijn eigen overheid. Daar waar sprake is van handelen door overheden, als waren zij particulieren, gaat deze regel niet op. ${ }^{123}$

- Welk recht zal de bewoegde rechter toepassen?

In privaatrechtelijke geschillen wordt het toepasselijk recht bepaald aan de hand van een aantal aanknopingsfactoren. Publiekrechtelijke geschillen tussen decentrale overheden in het kader van de publiekrechtelijke grensoverschrijdende samenwerking zijn tot nu toe niet dan wel nauwelijks voorgekomen. Indien de grensoverschrijdende samenwerking op basis van de Benelux-Overeenkomst van de grond komt, kunnen zich dergelijke geschillen vaker gaan woordoen. Het is de vraag in hoeverre hetgeen in het (Nederlands en Belgisch) internationaal privaatrecht gebruikelijk is ten aanzien van het bepalen van het toepasselijk privaatrecht toepasbaar is op publiekrechtelijke geschillen. ${ }^{124}$ Omdat op dit moment hierover alleen maar gespeculeerd kan worden, zal in voorkomende gevallen bekeken moeten worden welk publiekrecht toepasselijk is inzake publiekrechtelijke geschillen. ${ }^{125}$ In het licht van de samenwerking op basis wan de Benelux-Overeenkomst en de problematiek van de vorige paragraaf zal het mijns inziens vooral zo zijn, dat ten aanzien van een Belgische overheid de Belgische rechter Belgisch recht en ten aanzien van de Nederlandse overheid de Nederlandse rechter Nederlands recht zal toepassen. De rechter zal geen oordeel geven over het publiekrecht van de overheid over de grens. In \$ 5.D.6.c. van dit hoofdstuk wordt aangegeven in hoeverre, als het om de interpretatie van de Benelux-Overeenkomst gaat, het Benelux-Gerechtshof hier wellicht een verlossend woord kan spreken.

\section{b. Geschillen tussen overheden en burgers}

Hier kunnen dezelfde drie vragen als in de vorige paragraaf gesteld worden. Voor de antwoorden op de vragen betreffende de bevoegdheid van de Nederlandse dan wel Belgische rechter alsmede het toe te passen recht in het kader van het openbaar lichaam is artike] 3 lid 3 Benelux-Overeenkomst van belang. Dit artikel wijst het toepasselijke recht en daarmee mijns inziens ook de bevoegde rechter aan ten aanzien wan geschillen tussen het openbaar lichaam en burgers. De toelichting op dit artikel luidt: "Om te voorkomen dat de rechtsonderhorige natuurlijke of rechtspersoon bij een geschil tussen hem zelf en een aan gene zijde van de grens gelegen openbaar lichaam genoodzaakt zou zijn woor een rechter van het ander land te procederen, is bepaald dat de rechtsbetrekkingen in dat geval worden beheerst door het recht dat van toepassing zou zijn geweest indien het openbaar lichaam niet was ingesteld. In het merendeel der gewallen zal dit het recht

123. Zie over de immuniteit van de staat met betrekking tot de rechtsprak in aen andere staat: P. $H$. Koojmans, a.w. $w^{p}, 67-69$.

124. Hier is geen sprake van semipubliekrecht. Vgl. L. Strikwerda, Inleiding tot het Nederlandse internam tional privatrech, $3 \mathrm{e}$ druk, $1992, \mathrm{p}, 86 \mathrm{e} . \mathrm{v}$.

125. U. Beyerlin, Rechtsprobleme (..), a.w, H. $_{3} 387$ e.v. spreekt hier van transnational publiekredht. 
van de woonplatus of vestiging wan de rechtsonderhorigen zijn." 126 In \& 5.D.5. van dit hoofdstuk is reeds ingegaan op het feil dat de werwijzingsregel inzake het toepasselijke recht bij geschillen tussen burgers en het openbaar lichaam kan leiden tot gelijktijdige procedures wan burgers in België en burgers in Nederland. Hier is wan belang of van een absolute verwijzingsregel wordt uitgegaan. Zo is een dergelijke verwijzingsregel niet tevens opgenomen voor geschillen tussen burgers en het gemeenschappelijk orgaan of burgers en overheden inzake administratieve afspraken. Het ligt ook in die gevallen voor de hand dat de burger bij zijn eigen rechter terecht komt en de rechter aansluiting zoekt bij artikel 3 lid 3 Benelux-Overeenkomst. Het zal zo zijn, dat als een Belgische burger bij de Nederlandse rechter tegen een eenzijdig overheidsbesluit van in een Nederland gevestigd openbaar lichaam (of gemeenschappelijk orgaan) opkomt, de Nederlandse rechter zich oribevoegd zal verklaren en zal werwijzen naar de Belgische rechter (vice versa). Bij een privaatrechtelijke rechtshandeling tussen het in het buitenland gevestigd openbaar lichaam en de burger zal dit anders kunnen zijn. Een onbevoegdverklaring zal er ook zijn, als de burger (als eiser of gedaagde) bij zijn eigen rechter terecht komt en deze de buitenlandse overheid - zie ook de vorige paragraaf - tot iets publiekrechtelijks zou moeten verplichten. In dat geval zal de burger wel naar de buitenlandse rechter moeten gaan. Dit zal zich voor kunnen doen bij de al dan niet uitvoering van administratieve afspraken. Hier kan b.v. gewezen worden op het bij de afgifte van een millieuvergunning door de ene buitenlandse overheid naast zich neerleggen van een administratieve afspraak met een andere owerheid. De burger zal hiertegen in de buitenlandse milieuvergunningprocedture dienen op te komen. Bij het aangaan tussen overheden van de drie vormen van samemwerking kan er eventueel een rechtsgang zijn. In dat geval Jigt het voor de hand dat de burger bij de nationale rechter van zijn deelnemende overheid terecht komt.

In dit verband kan nog gewezen worden op de al dan niet toepasselijkheid van het EEGExecutieverdrag (hierna: EEX-Verdrag). ${ }^{127}$ Dit verdrag bevat regels inzake de rechterlijke bevoegdheid en de tenuitvoerlegging van beslissingen in burgelijke en handelszaken met een internationaal karakter. De toepasselijkheid van het EEX-Verdrag brengt de mogelijkheid wan een beroep op de buitenlandse rechter en effectuering van een buitenlandse uitsprak met zich mee. In geschillen tussen overheden en burgers is de toepasseljjkheid van het EEX-Verdrag evenwel niet snel aan de orde. Artikel 1 EEX-Verdrag verklaart het verdrag niet van toepassing op de staat en bepaalt dat het verdrag niet administratiefrechtelijke zaken omvat. Het Hof van Justitie van de EG heeft in deze beslist dat vorderingen van de staat bij handelen krachtens overheidsbevoegdheid niet onder de werking van het EEX-Verdrag vallen. ${ }^{128}$ Het is de vraag of de kwalificatie van een

126. Toelichting op de artikelen,

127. Verdrag betrefiende de rechterijke bevoegdheid en de rentitworlegging van beslissingen in burgerijke en tandelszakan, Brussi, 27-9-1968, Trb. $1969 \mathrm{nr}, 101$, watstelik gewijzigd 25iw10-1982, Trb. 1983 ne. 24. Herbij kan ook nog gewezen worden op het Nederlands-Belgisch Executieverdrag van 1925 (Nederlandse Wetgeving, VIB, Verdragen, nr. 5) en thet Nederlands-Duts Executieverdiag van 1962 (Nederlandse Wetgeving, WB. Verdragen, 1n. 15). Deze laatste twee verdragen bewatten in tegenstell ing tot het EEX.Verdrag, ook regels betreftende de henuitwoerlegging van arbitrale vonnissen. Dverigens is voor arbitrage ook het Verdrag wan New York van 1958 (Trb. 1958 nr. 145, Trb. 1959 nr. 58) wan belang. Zoals gezegd gaat het ook bij arbitrage orn burgerlijke en handelsgeschillen.

128. Rüfler, Hw EG 16-12-1980, zadk 814/79, NJ 1982, 97, Z he ook NJ 1982, 95, 96 en 98. 
geschil als burgerlijke-c.q. handelszaak eerder aangenomen zall worden bij een vordering van een burger jegens de owerheid. In het kader van de letterlijke bewoordingen van artikel 1 EEX-Verdrag alsmede de genoemde uitspraak van het Hof van Justitie zal hiervoor in ieder geval niet al te veel ruimte bestaan.

Ten aanzien van de wraag welke rechter, de gewone of de administratieve, bevoegd is, kan het volgende opgemerkt worden. In burgerrechtelijke zaken (denk aan: acties uit onrechtmatige daad) zal uiteraard de burgerlijke rechter veelal bevoegd zijn. In het kader wan publiekrechtelijke overheidsbeslüten, b.v. inzake milieuvergunningen en besluiten in het kader van de ruimtelijke ordening, zijn er zowel in België als in Nederland administratieve rechters bevoegd, in beide landen in beginsel de met rechtspraak belaste afdelingen van de Raad van State. ${ }^{129}$

Resumerend kan gesteld worden dat het toch vooral zo zal zijn, dat de burger bij zijn eigen (burgerlijke of administratieve) rechter terecht zal komen en deze rechter eigenlijk genoeg heeft aan het toepassen van het eigen privaat/publiekrecht van de burger om het conflict te beslechten. Dit zal wel, zoals aangegeven in $\$ 5 . D .5$ van dit hoofdstuk, tot divergentie kunnen leiden in rechterlijke uitspraken.

\section{c. Uniforme interpretatie van de Benelux-Overeenkomst}

Vanwege de toepasselijkheid van beide rechtsstelsels zal het kunnen voorkomen, dat de Belgische en Nederlandse rechter onafhankelijk van elkaar geschillen gaan beslechten. Daardoor ligt divergerende interpretatie van de Benelux-Overeenkomst voor de hand. De belangrijkste instantie bij de (uniforme) interpretatie van de Benelux-Overeenkomst en de daarop gebaseerde beschikkingen van het Comité van Ministers is het Benelux-Gerechtshof. In artikel 10 van de Benelux-Overeenkomst is bepaald dat de Benelux-Overeenkomst en de daarop gebaseerde beschikkingen aangewezen zijn als gemeenschappelijke rechtsregels voor de toepassing van de hoofdstukken III en IV van het Verdrag betreffende de instelling en het statuut van een Benelux-Gerechtshof (hierna: Statuut Benelux-Gerechtshof). ${ }^{130} \mathrm{Op}$ de relevante bepalingen van dit verdrag wordt thans ingegaan.

Artikel 1 lid 2 Statuut Benelux-Gerechtshof regelt het doel van het Benelux-Gerechtshof ${ }^{13 t . ~ " H e t ~ H o t ~ h e e f t ~ t o t ~ t a a k ~ d e ~ g e l i j k t h e i d ~ t e ~ b e w o r d e r e n ~ b i j ~ d e ~ t o e p a s s i n g ~ v a n ~ r e c h t s r e g e l s, ~ w e l k e ~ g e n u e e n ~}$ zijin:

a) arn de drie Bemelux - banden en welke zijn angewezen:

hetzin bij verdrag;

129. In verband met de op handen zijnde reorgatisatie wan de rechterlijke macht in Nederland verandert er ten aanzien wan de administrateve rechtsprak op korte temijo het een en ander. De Raad van State zal als (hogere) beroepsinstantie (A fieling bestuwrsechtspratk) in administratiefrechtelijkezaken bijwen bestam. Voor een aantal zaken, overigens niet milieu- en rumtelijke ordeningszakan, komen er administratieve kamers bij het gerecht in eerste atnleg. Een verdere bespreking van de bevoegde rechters in Nederiand en Belgiè, hua wijze van toetsing e.d., gat het kader van dit proefischrifte buiter. Zie o. al. ook: de noten 45 an 49 in hoofdstuk 4 alsmede noot 23,118 en 120 van dit hoofidgtuk.

130. Verdrag van 31 maart 1965, Trb. 1965. nr. 71, in werking gatreden op 1-1-1974, Trb. 1973. nr. 173.

131. Deze bepaling is gewijzigd bij Protocol wan 10-6-1981, Trb. 1981. nr. 159, in werking getreden op 1-11-1984, Trb. 1984. nr, 130 . 
hetzij bij beschikking wan het krachtens het Verdrag yan 3 febrari 1958 tot instelling van de Bewelux Economische Unie irugestelde Comile van Ministers. ${ }^{39:}$

b) aan wee der Bemel wwanden en welke zijn angewezer bij een tussen die twee landen jn werking getreden werdrag, ondertekend door de drie Beneluxlanden."

Hoofdstuk III heeft betrekking op de rechtspraak. Nationale rechtscolleges, alvorens uitspraak te doen, kunnen en in bepaalde gevallen moten de uitleg van het Hof vragen. Op basis van artikel 6 lid 1 Statuut Benelux-Gerechtshof neemt het Hof kennis van vragen betreffende de uitleg van rechtsregels, aangewezen krachtens artikel 1 Statuut Benelux-Gerechtshof, die zijn gerezen in zaken aanhangig bij een rechtscollege van én van de drie landen. Het bepaalde in artikel 6 lid 2 en 3 Statuut Benelux-Gerechtshof is hier vooral van belang . Lid 2 bepaalt: "Wanneer bijkt, dat een uitspraak in en woor een nationaal rechtscoll ege amhangige zatak med brengt de beantwoording van een vraag van uitleg wan eem krachtens artikel 1. angewezen rechtsregel, kan dat rechtscollege, indien het wan mening is dat een beslissing op dit punt nood zakeligk is on wonnis te kuthen wijzen, ook ambthalve zijn definitieve uispraak opschorten teneinde een beslissing van het Benehuxhof over de vriag van uitleg wit te lokken"; Lid 3 bepaalt: "Hodien aan de woorwatrden, onschreven in het voorgaande lid is voldaan, is en nationaal rechtseollege, tegen de uitspraken watr van krachtens het nationale recht geen beroep kan worden ingesteld, verplicht de vaag van uitleg aan het Beneluxhof woor te leggen." In artikel 2 lid 4 Statubt Benelux-Gerechtshof zijn de gevallen aangegeven warin niet gevraagd wordt om een prejudiciele beslissing: "indien thet rechtscollege wan oordeel is, dat er redelijkerwijze geen twijfel bestat ontrent de oplossing van de gerezen wragag van witlog, indien die zalk gen witstel gedoogt en indien de zaak overeenkom met witspraak respentievelijk advies wan het Benelux-Gerechtshofeerder gedtan.' De nationale rechters zijn gebonden aan de uitspraak van het Benelux-Gerechtshof, dat slechts een besissing geeft over de voorge legde vraag varu uitleg (art. 7 Statuut Benelux-Gerechtshof).

Hoofdstuk IV heeft betrekking op adviezen. In artikel 10 Statuut Benelux-Gerechtshof is bepaald, dat elk van de drie regeringen het Hof kan verzoeken bij wege van advies zijn oordeel te geven over de uitleg van een krachtens artikel 1 Statuut-Benelux-Gerechtshof aangewezen rechtsregel.

Van het stelsel van prejudiciële beslissingen zullen belangrijke impulsen kunnen uitgaan voor een uniforme uitleg van de Benelux-Overeenkomst. Daarbij dient opgemerkt te worden, dat dit stelsel vooral pas in beeld komt als aspecten van samenwerking in rechte (zo te zeggen: achteraf) ter beoordeling staan. Zo er al ten aanzien van het aangaan van de samenwerking door de overheden een rechtsgang voor de burger mogelijk is, zal die burger veelal pas in actie komen tegen besluitworming van b.v. het openbaar lichaam en het gemeenschappelijk orgaan. Toepassing ervan is ook aangewezen bij geschillen in rechte tussen samenwerkende overheden onderling en tussen overheden en het openbaar lichaam respectievelijk het gemeenschappelijk orgaan. In de fase van toezicht en controle door het (hogere) bestuur (zo te zeggen: vooraf) speelt het Benelux-Gerechtshof geen tol, tenzij de toezichtsbesluiten in rechte worden getoetst. Ten aanzien van arbitrage geldt hetzelfde.

132. Zo zijn bij Protocol van 29-4-1969, Trb. 1969. nr. 127, in werking getreden 1-1-1974 Trb. 1973. nr. 175 , een aumal reeds geldende Benelux-verdragenals gemeenschappelijkerechtsregels aangewezen.. Bij Protocol van 11 mei 1974, Trb. 1977. nr. 93, in werking getreden $1-8-1982$. Trb. 1982, nr. 124, zijn naakt onkele verdragen veneens een antal beschikkingen wan het Comite wan Ministers als gemeenschappelijke rechtsregels angewezen. 


\section{Benelux-Overeenkomst en de bepalingen in de Belgische Grondwet inzake exterme betrekkingen en werdragssluiting}

\section{a. Inleiding}

In het kader van de goedkeuring van de Benelux-Overeenkomst is in België de mogelijke strijd ervan met enkele Belgische grondwetsbepalingen inzake externe betrekkingen en in het bijzonder het sluiten van verdragen aan de orde geweest. De Raad van State acht(te) belangrijke bepalingen van de Benelux-Overeenkomst in strijd met de Belgische Grondwet. Vooraleer hierop in \$ 5.D.7.c. wordt ingegaan, wordt eerst het algemeen (grondwet)wettelijk kader in deze aangegeven. Bedacht moet worden, dat het daarbij om bepalingen van de Grondwet en de Bijzondere wet gaat, zoals die luidden ten tijde van de goedkeuring van de Benelux-Overeenkomst ( $\$$ 5.D.7.b.) Inmiddels is in mei 1993 de Belgische Grondwet en de Bijzondere wet gewijzigd wat betreft de internationale betrekkingen en verdragssluiting. Op die wijziging wordt kort ingegaan (\$5.D.7.d.).

\section{b. De bepalingen in de Belgische Grondwet inzake externe betrekkingen en verdragssluiting}

Voor de Staat golden ten tijde van de goedkeuring van de Benelux-Overeenkomst:

- Artikel 25 bis Grondwet: "De uitoefening van bepaalde machten kan door een verdrag of door een wet worden apgedragen aan volkenrechtelijke instellingen."

- Artikel 68 Grondwet: "De koning voert het bevel over land. en zeenacht, verklaart de oorlog, sluit de vredesverdragen, de verdragen wan bondgenootschapen de handelsverdragen. Hij geeft darvan kenmis aan de Kamers, zodra het belang en de veiligheid van de Staat het toelaten, onder toevoeging van de passende mededelingen.

De handelsverdragen en de verdragen die de Staat zouden kunnen bezwaren of Belgen persoonlijk zouden kunnen binden, hebben eerst gevolg nadat zij de instemming van de Kamers hebben verkregen.

Geen afstand, geen ruiling, geen toevoeging van grondgebied kan plaats hebben dan krachtens wet. In geen geval kunnen de geheime artikelen van een verdrag de openbare artikelen teniet doen." ${ }^{134}$

Voor de Franse en Vlaamse Gemeenschapsraad golden ten tijde van de goedkeuring van de Benelux-Overeenkomst:

- Artikel 59 bis $\$ 2$ Grondwet: "De Gemeenschapsraden regelen ieder wat hem betreft, bij decreet: 3 . de samenwerking tussen de Gemeenschappen, alsook de internationale samenwerking, met inbegrip wan het sluiten van verdragen, voor de aangelegenheden bedoeld in 1 en 2 wan deze paragrati" (dit is: culturele

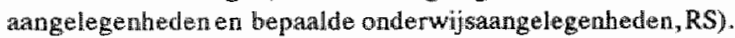

133. Vg1. artikel 92 Nederlandse Grondwet, dat bepaalt: "Met irachtneming, zo nodig, wan het bepaalde in artikel 91 , derde lid, kunnen bij of krachtens verdrag aan wolkenrechtelijke organisaties bevoegdbeden tot wetgeving, bestuur en rech tspraak worden opged ragen."

134. Vgl artikel 90 wan de Nederlandse Grondwet, dat bepaalt, "De regering bevordert de ontwikkeling van de internationale rechtsorde" 
- Artikiel 59 bis 2 bis Grondwet: De Gemeenschapsaden regelen teder wat bem betreft, bj decreet de parwoonsgebonden aangelegenheden, alsook voor deza augelegenheden, de samenwhrking tussen de Gemeenschappen en de internationale samenwerking met inbegrip wan bet sluten wan werdragen."

- Artikel 16 Bijzondere wet: "\$: 1:mstemming met verdragen of akkoorden betreffende de samenwerking in Whe angelegenheden bedoeld in artikel 59 bis, $21^{\circ}$ en $2^{\circ}$ en 20 is var de Grondwet en in de artikelen 4 wan deze wet, wordt verleend door de Vaamse Raad, de Franse Gemeenschapsraad of donr beide Raden indien $z i j$ er belde bij betrokken zijn

2: De in 1 bedowide verdragen worden bij de bewogde Raad ingediend door de Gemeenschapsexecutiever

- Arthel 81 Bijzondere wet: "In de aangelegenheden warvoor de Raad bevoegd is, wordt zijn Execulieve betrokken bij onderhandelingen ower de internatonale akkoorder, doch blijf de Koning de enige gespreks. partner op het internationale wlak met inachtneming wan artikel 68 wan de Grondwet." 13

In de praktijk kwam het er (ten tijde van de goedkeuring van de Benelux-Overeenkomst) op neer, dat het sluiten van de verdragen inzake communautaire aangelegenheden bij de Koning berustte, terwijl de instemming ermee een zaak van (naast het nationale parlement) de Gemeenschapsraad was en de Gemeenschapsexecutieve bij de onderhandelingen werd betrokken. ${ }^{137}$ Het laatste woord lag ten tijde van de goedkeuring van de Benelux-Overeenkomst uiteindelijk (nog) op nationaal niveau. ${ }^{138}$ De uitvoering van verdragen was, binnen het kader van de materièle bevoegdheidsverdeling, een zaak van de Gemeenschappen en zeker ook de Gewesten. ${ }^{139}$

\section{c. De Benelux-Overeenkomst en de bepalingen in de Belgische Grondwet inzake externe betrekkingen en verdragssluiting}

België heeft evenals Nederland de Benelux-Overeenkomst ondertekend onder het voorbehoud van goedkeuring. In Nederland heeft stilzwijgende goedkeuring van de Beneluxw Overeenkomst plaatsgevonden. Bij de bij de Benelux-Overeenkomst behorende Toelich-

135. Hoewel hier niet wordt ingegan op de Duitstalige Gemeenschap gold ten tijde van de goedkeuring van de Benelux-Overeenkomst voor deze en identieke mogeljkheid op basis van artikel 4 Wet van 31 12-1983 tot herworming der instellingern voor de Duitstalige Gemeenschap (B.S. 18-1 1984) juncto artikel 59 ter 24 Grondwet juncto artikel 4 en 5 Bijzondere wet.

136. Deze bepaling werd, in de praktijk, niet alleen toegepast ten asnzien van de Gemeenschappen, maar ook de Geweston.

137. Zie b.v: Nota wan de Regering over de bewegdheid wan de Gemeenschappen en de Gewesten inzake internationale betrekkingen, in: A. Alen, J. Dugardin, Casebook Grondwettelijk Recht, a.w., p. 449. Hierin wordt eveneens gesteld, dat en en ander woor het situiten van verdragengeldt ex dit de gemeenschappen niet belet "activiteiten te ontwikkelen "in hun hoedanigheid wan publiekrechtelijke rechtspersonen', op woorwakrde dat de prerogatieven wan de Koning worden gerespecteerd. " 2 te over de coördinatie der intertuationale betrekkingen: TBP 1991/1, p. 25-27.

138. In het kader wa de goedken ring wan de Bernelux-Owereenkomst is door de Rad wan State hieromtrent (nog eens) gesteld: "Un traité approuvé par un Conseil de Communauté ne peut donc entrer ou demeurer en vigueur que si le Gouvernement le souhate. Dans le cas d"une politique etrangere mene dans le cadre de trattss, les änstitutions communautaires flemeurent donc actwellement soumises à la wolonté politique des institutions nationales." ${ }^{\text {" }}$, Advies van de Rad wan State van 25-5-1988, p. 12 (zie noot 141 van dit hoofdstuk).

139. Zie b. v. Decret 14-12-1989 permettant à l'Executif régional wallon de prendre toutes les mesures que requiert l'application ou la mise en oeuvre des Traités el Conwention internationaux en matiere de Chasse, PEche, Protection des oiseaux et Conservation de la Nature (M.B. 14-2-1990). 
tende Nota is de bedoeling van de Benelux-Overeenkomst nog eens onder woorden gebracht. Deze bedoeling komt overeen met die van de verdragspartijen, zoals blijkend uit de tekst van de Benelux-Overeenkonst en de hierbij behorende gemeenschappelijke toelichting. In Belgie heeft de Benelux-Overeenkomst uitdrukkelijke instemming van de Senaat en de Kamer van Volksvertegenwoordigers gekregen. Daarnaast is de BeneluxOvereenkomst goedgekeurd door de Raad van de Vlaamse, Firanse en Duitstalige Gemeenschap. Aan de goedkeuring (door het Belgische partement c.q. de Gemeenschapsraden) zijn geen voorbehouden verbonden. In dat verband wordt voorop gesteld dat de Benelux-Overeenkomst, volkenrechtelijk, integraal zijn bedoelde uitwerking moet hebben. Dit volgt uit artikel $31 \mathrm{WVV}$, waarin de interpretatie van verdragen geregeld is. ${ }^{140}$ Men dient zich wel te realiseren dat in België de Benelux-Overeenkomst ter goedkeuring aan het nationale parlement is aangeboden met een qua strekking van de verdragstekst afwijkend advies wan de Raad van State. De Belgische regering heeft, naar aanleiding wan dit advies van de Raad van State, de reikwijdte van de samenwerkingsmogelijkheden, zoals aangegeven in de tekst van alsmede de gemeenschappelijke toelichting bij de Benelux-Overeenkomst, in twijfel getrokken. De Raad van State acht(te) enkele vormen van samenwerking op basis van de Benelux-Overeenkomst in strijd met de Belgische Grondwet. Ook de goedkeuring van de Benelux-Overeenkomst door de Vlaamse en Franse Gemeenschapsraad ging gepaard met een vergelijkbaar negatief advies van de Raad van State. Het nationale parlement en de Gemeenschapsraden hebben de respectievelijke adviezen van de Raad van State naast zich neergelegd. Hoewel deze adviezen niet afdoen aan de juridische (volkenrechtelijke) reikwijdte van de BeneluxOvereenkomst, ${ }^{141}$ kunnen deze vanwege de hierin aangegeven magelijke ongrondwettigheid van in ieder geval het in te stellen openbaar lichaam en de administratieve afspraken op zijn minst een hindernis vormen bij de praktische uitvoering van de BeneluxOvereenkomst in de nationale rechtsorde. Zo dienen in België besluiten van administratieve overheden te worden getoetst op hun overeenstemming met de (Grond) wet door de gewone en administratieve rechter. ${ }^{142} \mathrm{Bij}$ geschillen inzake besluiten van decentrale overheden in het kader van grensoverschrijdende samenwerking zal de Afdeling Administratie van de Raad van State (en ook de gewone rechter) het advies van de Afdeling Wetgeving van de Raad van State niet zonder meer terzijde leggen. ${ }^{143}$ Het niet terzijde leggen zal, conform het advies, betekenen dat een openbaar lichaam c.q. administratieve afspraak (waarbij overheden en burgers bindende bevoegdheden in het geding zijn) niet door de decentrale overheden in het leven kan worden geroepen, maar slechts middels een verdrag kan geschieden. Dit zall belemmerend werken voor de decentrale grensoverschrijdende samenwerking, omdat een verdrag een veel te zwaar en weinig flexibel instrument is voor de regeling van de grensoverschrijdende problemen van decentrale owerheden.

140. Vgl. hoofdstuk 2 3. Eventueel kan nog gewezen worden op artikel 10 WVV dat, voor zower hier van belang, bepanit dat na ondertekening de herdragstekst in beginsel vaststat.

141. In dit licht bezien zal er, mpjus inziens, geen sprake zijn wan een onmiskenbare strijdigheid zoals bedoeld in artikel $46 \mathrm{WVV}$. Vgl. hiervoor hoofdstuk 2 \& 3ie ook de vorige noot.

142. Hier kan gewezen worden op artikel 107 Grondwet, artikel 584 Gerechelijk Wetboek, artikel 1382 e.w. Burgerlijk Wetboek, artikel 14 en artikel 17 Gecoördineerde wetten op de Rath ven State.

143. Voor de mogelijke rol van het Arbitragehof in deze, zie: I. Velu, a.w. o.a. p. 482. 
In verband met het vorenstaande maar ook vanwege het belang voor het onderwerp van de decentrale grensoverschrijdende samenwerking in zijn algemeen, worden de belangrijkste passages uit de beide adviezen van de Raad van State hier weergegeven. ${ }^{144}$ Hierop zal van mijn kant een kort commentaar gegeven worden. Overigens is het advies van 25-5-1988 mijns inziens duidelijker en wult het dat van 16-6-1987 aan. Om die reden wordt met name op het eerst genoemde ingegaan. Dat gebeurt aan de hand van de betreffende samenwerkingswormen.

\section{- Openbaar lichaam}

Door de Raad van State is bezwaar gemaakt tegen de overdracht wan bevoegdheden van regeling en bestuur aan een openbaar lichaam:

"Conformement a l"article 25big de la Constitution, seuls des pouvairs détermines, cest a dire bien definis, peuvent etre attribues par un traité ou par une loi à des institutions de droit international public. Dans son avis: du 16-7-1987, le Consell d'Etat a, à cet égard, tstimé notamment ce qui suit: Le transfert de compétences s"éarte joi desprétisions de l'article 25 bis de la Constitution sur quatre points:

1. II "est réalise par un traté ou par une loi. Il resulte de la seule wolonte d une collectivité ou d"une autorité territoriale qui participe a la creation de l'organisation public de coopération transfrontalière.

$2^{\circ}$ Le transfert des compétences ne port pas sur l'exercice de pouvoirs déterminés mais sur lin'extrcice de n'import quelle attribution (et meme, a la limite, de toute les attributions) revenant â la collectivitê ou à l'autorité terifitoriale.

$3^{\circ}$ Le transfert de compétences ne se fait pas au profit d'institutions de droit international public que la Convention enumererait de maniere limitatiwe.

4. ... (sans intérêt ten l'espèce) ...." 1.4s

Blijkens de Memorie van Toelichting bij het wetsontwerp tot goedkeuring van de Benelux-Overeenkomst komt het standpunt van de Belgische regering overeen met dat wan de Raad van State:

"De Belgische publiekrechtelijke personen kunnen aan het openbaar lichaam geen bevoegdheden overdragen, wardoor dit openbaar licham in staat zou worden gesteld juridisch verbindende beslissingen te nemen ten opzichte van de geadministreerden die ressorteren onder deze publiekrechtelijke rechtspersonen." ${ }^{445}$

De bedoeling van de verdragspartijen is geweest grensoverschrijdende samenwerking in de vorm van een openbaar lichaam, met bevoegdheden tot regelgeving en bestuur, mogelijk te maken zonder het sluiten wan aanvullende verdragen. De interpretatie van de Raad van State en de Belgische regering komt daarmee in strijd met artikel 3 lid 1 en 3 Benelux-Overeenkomst en de gemeenschappelijke Toelichting hierop. In dit artikel is expliciet aangegeven dat het openbaar lichaam over bevoegdheden van regeling en bestuur kan beschikken. Deze interpretatie van de Raad van State brengt met zich mee, dat de Benelux-Overeenkomst uberhaupt geen juridische waarde heeft. Met een dergelijke witleg van de Benelux-Overeenkomst wordt niets meer toegevoegd aan hetgeen reeds op basis van de European Outline Convention mogelijk werd geacht. Als de oprichting van een openbaar lichaam al mogelijk blijft, kan het geen besluiten nemen, die de overheden (aldus de Raad van State) of derden (aldus de Raad van State en de

144. Het gat hier om: Adwies wan de Ragd van State d.d. 16-6-1987, Gedr. St., Senatt, 651/1, 1988-1989, p. 12-18; Advies wan de Ratd wan State d.d. 25-5-1988, Stukken wan de Franse Gemeenschapsraad, $149 / 1,1989$. 1990 , p. 11-15. Bij het lastste gaat het voornamelijk on een vertaling van bet adwes dat door de Vlaanse Rand was gevraagd. Hier wordt uitgegann van de Franstalige versie.

145. Advies van de Raad wan State wan 25-5-1988, a.w., p. 14.

146. MwT bij het wetsontwerp tot goedkeuring van de BeneluX-Overeenkounst, Gedr. St., Senaat, 1988-1989, $651 / 1.1 \%$. 
Belgische regering) binden. Een openbaar lichaam zal dan niet veel meer dan een forumfunctie, in het gunstigste geval privaatrechtelijke rechtspersoonlijkheid bezittend, kunnen vervullen. Die samenwerking is ook zonder de Benelux-Overeenkomst al mogelijk. De Raad van State is van mening, dat er een intermediair ontbreekt, namelijk een verdrag gesloten door de Koning en goedgekeurd door het parlement, dat een internationaalrechtelijke organisatie opricht met nauwkeurig omschreven bevoegdheden. Dat verdrag zou behalve het territoir van de instelling alle noodzakelijke regels betreffende de samenstelling, de organisatie, de funanciering, de uittreding en toetreding van overheden moeten regelen. De Raad van State gaat zelfs zo ver, dat aan internationale instellingen bestaande uit decentrale overheden 'sociétés internationales de droit public' privilleges en immuniteiten toegekend kunnen worden. ${ }^{147}$ Hetgeen de Raad van State opmerkt, gaat op wat betreft de overdracht van bevoegdheden aan internationale instellingen. Voorzover ik heb kunnen nagaan is er echter nergens enige aanwijzing te vinden voor het feit dat de oprichting van een openbaar lichaam voor grensoverschrijdende samenwerking tussen decentrale overheden gelijk gesteld moet (kan) worden met het oprichten van een volkenrechtelijke instelling voor internationale samenwerking tussen staten. ${ }^{148}$ Voor dat laatste is artikel 25 bis van de Belgische Grondwet geschreven. De op bijna alle fronten aanwezig zijnde verwijzing in de Benelux-Overeenkomst - in deze wordt verwezen naar de opsomming in \$ 5.D.3 van dit hoofdstuk - naar het interne recht, is juist een belangrijke indicatie dat de samenwerkingsverbanden niet als internationaal laat staan supranationaal zijn te beschouwen.

De Raad van State gaat voorbij aan het feit dat de Benelux-Overeenkomst, gesloten door de Koning en goedgekeurd door het parlement, rechtstreeks rechten en plichten voor decentrale overheden in het leven roept.

Ewenals in Nederland geldt in België, dat rechtstreeks werkende bepalingen van verdragen voorgaan op de (ermee strijdige) (Grond)wet. Weliswaar wordt hierbij de rechtstreekse werking van verdragen vooral ten opzichte van (bepaalde) burgers gehanteerd. Evenwel kan niet worden ingezien waarom dit niet eveneens voor decentrale overheden kan gelden. Waar het op aankomt is, dat de verdragsluitende staten niet slechts wederzijdse betrekkingen tussen de staten hebben willen regelen, maar directe rechtsgewolgen voor anderen in het leven hebben willen roepen. Voor de Benelux-Overeenkomst zijn dat de daarin genoemde decentrale overheden. Bowendien kunnen burgers rechtstreeks rechten en plichten ontlenen aan hetgeen geregeld is in de Benelux-Overeenkomst, op het moment dat de decentrale overheden overeenkomsten op basis van de BeneluxOvereenkomst zijn aangaan. De rechtstreekse werking impliceert dat, zelfs als er sprake zou zijn van strijd van de Benelux-Overeenkomst met de Belgische Grondwet, de Belgische Grondwet niet toegepast zou kunnen worden. ${ }^{149}$ Integendeel, de betreffende be

147. Advies van de Raad van State van $25-5$ 1988, a.w., p. 14 en 15 S.B.4 en $8 . B .5$.

148. Vgl. de opmerking vande Franse Gemeenschap sministerin het kader van de goedkeuring door de Franse. Gemeenschapsraud, Conseil de la Communauté Franģaise, 149/2, 1989-1990, p. 3: "le ministre considere qu'on peut objecter que les organismes transfrontaliers dont il s"agit ne sauraient par définition être considérés comme relevant du droit international public, des lors quils sont exclusiwement crés par des autorités lociales."

149. Vg: het gestelde in $\$ 3$ in hoofdstuk 3 met betrekking tot de rechtsitreekse werlking wan internationaal recht in Belgie. 
palingen van de Grondwet dienen, omdat het parlement bewust hieraan voorbij is gegaan, ten faveure van de rechtstreeks werkende Benelux-Overeenkomst buiten toepassing te worden gelaten.

\section{- Administratieve afspraak}

De Belgische Raad van State legt hier verband met de internationale administratieve akkoorden:

"Les accords administratifs visés dans la Convention Benelux ne répondent pas a la notion d'accords administratifs lelle que celle-ci est definie par la jurisprudence, la doctrine el la pratique judiciaire belges. Ces accords ne sont pas des conventions d"intêrêt mineur conclues entre autoritếs administratives sur des mesures rêglant les: détátlls de l'exécution d'un traite interétatique existant: n'étant pas précisếment circonscrits, ils constutuent eux-mêtnes des traitếz au sens veritable du terme."

Volgens de Raad van State zullen de administratieve afspraken betrekking kunnen hebben op aangelegenheden, die normaal gesproken in een verdrag worden geregeld en zo niet de vorm, dan toch de aard van een verdrag kunnen hebben, veeleer dan van een internationaal contract. ${ }^{151}$ Een zo'n ruime delegatie van bevoegdheden tot het afsluiten van verdragen aan ondergeschikte besturen is, aldus de Raad van State, in strijd met artikel 68 Grondwet:

"Pour que la Convention Benelux puisse produire des effects en ce qui concerne la conclusion d'accords administratifs de droit pubiic par des pouvoirs subordonées, il convient d'intercaler, entre la Convention et les accords administratifs visés, un élément juridique intermédiaire, qqui serait un traité interétatique définissant avec précision lies matières à traiter, la nature des compétences à exercer, la portée de l"accord et toutes les autres règles concernant la forme et contenu des compétences transférées." "isz

De Koning zal voor die additionele grondslag dienen te zorgen middels het afsluiten van een verdrag, dat de goedkeuring door de Kamers vereist, indien Belgen daardoor gebonden kunnen worden. Dit is niet nodig, aldus de Raad van State, als er geen sprake is van zich juridisch vastleggen, b.v. bij informatie-uitwisseling en consultatie c.q. de oprichting van werkgroepen. ${ }^{153}$ De Benelux-Overeenkomst biedt op zich, aldus de Raad van State, geen enkele mogelijkheid van internationale samenwerking met publiekrechtelijke effecten. ${ }^{154}$ Uit de Memorie van Toelichting blijkt dat de mening van de Belgische regering overeenkomt met die van de Raad van State:

"De administratieverafsprak kan derhalve slechts betrekking bebben op aangelegenheden waar voor bet sluiten wan een verdrag in te zin wan artikel 68 van de Grondwet niet vereist is."

Ten aanzien hiervan kan eigenlijk hetzelfde gesteld worden als betreffende het openbaar lichaam. Het is de vraag in hoeverre het de bedoeling is, dat de decentrale samenwerking op het niveau van het internationale recht terecht komt. Daar is nergens een aanwijzing voor te vinden. Dit was mijns inziens al niet de bedoeling bij de opstelling van de EOC. Het is jammer dat de Raad van State is blijven steken in het aangeven van het (vermeende) internationaalrechtelijke karakter van administratieve afspraken. Daardoor is totaal voorbijgegaan aan een benadering van de decentrale samenwerking vanuit het

150. Advies van de Rad wan State van $25-5-1988$, a.w. p. 13.

151. Advies van de Ratad wan Sitate van 25-5-1988, a.w., p. 15.

152. Advies van de Raad van State vam 25-5-1988, a.w, p. 13 en 14 sub 5.1.4.

153. Advies van de Raad van State wath 25-5-1988, a, wn, p. 13 sub 5.1 .5 .

154. Advies van de Raad wan State van 25-5-1988, a.w., p. 14 sub 5.1.6.; Zie ook: Advies van de Raad vam State van 16-6-1987, a.w., p. 15.

155. MvT bij het wetsontwerp tot goedkeuring van de Benelux-Overeenkomst, a.w., p. 4. 
nationale recht, waarvoor de Benelux-Overeenkomst, die rechtstreekse werking heeft, de noodzakelijke juridische grondslag vormt. Met name die benadering garandeert voor de decentrale overheden eigen, flexibele en zelfstandig uit te oefenen mogelijkheden inzake grensoverschrijdende samenwerking. Verdragen (tussen staten) lenen zich mijns inziens niet voor het wastleggen van afspraken tussen decentralle overheden in plaatselijke en regionale aangelegenheden, zoals over hoe rekening kan worden gehouden met elkaars belangen b.v. bij de verlening van milieuvergunningen, over de coördinatie van plannen, e.d.

\section{- Gemeenschappelijk orgaan}

In het licht van het vorenstaande spreekt dit citaat voor zich:

"La création d'organes communs conçus chacun comme un forum sans personalité juridique où des antoritês publiques peuvent se rencontrer librement en vue de renforcer leur cooperation ne suscite aucune objection, pour autant que le fonctionnement de ces organes ne puisse engendrer d "effets juridiques ni pour les autorités participants ni pour les administrés." "sto

In de parlementaire behandeling is nawwelijks (inhoudelijk) ingegaan op de beide adviezen van de Raad van State. Illustratief is de opmerking van de Vlaamse Gemeenschapsminister "dat de Raad van State met zijn advies bepaalde reserves heeft geformuleerd, maar dat de Senaat en Kamer blijkbaar geen moeite hadden om daarover heen te stappen." " 15 ?

Resumerend kan gesteld worden dat het feit, dat in de Grondwet niets is bepaald omtrent decentrale grensoverschrijdende samenwerking, niet betekent dat in strijd met diezelfde Grondwet wordt gehandeld, als die grensoverschrijdende samenwerking in de praktijk plaats vindt dan wel geregeld wordt in wetten of verdragen.

Zoals eerder aangegeven is in Nederland een mogelijke ongrondwettigheid van de Benelux-Overeenkomst niet aan de orde geweest. Toch bevat de Nederlandse Grondwet vergelijkbare artikelen als die waarop in België door de Raad van State de ongrondwettigheid van de Benelux-Overeenkomst is gebaseerd. Allereerst is artikel 90 Nederlandse Grondwet relevant. Dit situeert de verdragssluiting op het niveau van de centrale overheid. ${ }^{158}$ Belangrijker is hier artikel 92 Nederlandse Grondwet, dat bepaalt dat bevoegdheden tot wetgeving, bestuur en rechtspraak bij of krachtens verdrag aan wolkenrechtelijke organisaties kunnen worden opgedragen. ${ }^{159}$ Mochten samenwerkingsverbanden op basis van de Benelux-Overeenkomst al aangemerkt kunnen worden als volkenrechtelijke organisaties - dit is mijns inziens niet het geval en dus is artikel 92 Grondwet niet van toepassing -, dan zou de Benelux-Overeenkomst toch een voldoende juridische basis zijn

156. Advies van de Raad watn State van 25-5-1988, a.w., p. 15 .

157. Vlaanse Raad, Hendelingen Nr. 22, 25 januari 1990, p. 930.

158. In deze wordt tevens verwezen naar hoofdstuk 3 \$ 3 .

159. Overigens kent Belgie in tegenstelling tot Nederland geen regeling zoals voorzien in artikel 91 lid 3 Nederlandse Grondwet. Hierin wordt bepaald dat de Kamers de goedkeuring van een verdrag, dat bepalingen bevat die afwijken wan de Grondwet, slechts kunnen verlenen met twee derden van het aantal

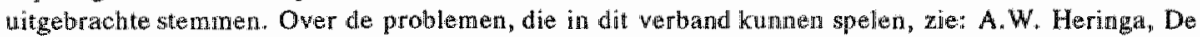
verdragen van Maastricht in strijd met de Grondwet, NJB 1992/24, p. 749-752. Op de visie van Heringa in deze zijn van een aantal schrijvers (afwijkende) reacties verschenen. Zie hierwoor 0.a.: NJB 1992/27, p. 861 e.v. 
voor het afsluiten door decentrale overheden van publiekrechtelijke overeenkomsten. Het woord krachtens in artikel 92 Nederlandse Grondwet sluit een interpretatie, zoals die van de Belgische Raad van State, voor de Nederlandse situatie uit.

\section{d. De gewijzigde bepalingen in de Belgische Grondwet inzake externe betrekkingen en verdragssluiting}

In mei 1993 is artikel 68 Grondwet gewijzigd en is inzake verdragssluiting en externe betrekkingen de Bijzondere wet hieraan aangepast. ${ }^{160}$ Hier worden kort de belangrijkste veranderingen ten opzichte van de situatie vóór de wijziging weergegeven. Het huidige stelsel inzake externe betrekkingen en verdragssluiting kont op het volgende neer.

Op basis van artikel 68 Grondwet heeft de Koning de leiding van de buitenlandse betrekkingen, onverminderd de bevoegdheid van de Gewesten en Gemeenschappen om de internationale samenwerking te regelen. Daaronder valt het sluiten van verdragen waarvoor zij door of krachtens de Grondwet bevoegd zijn. De Executieven van de Gemeenschappen en de Gewesten sluiten de verdragen, die betrekking hebben op de aangelegenheden waarvoor hun Raden door of krachtens de Grondwet bevoegd zijn. Deze verdragen hebben pas gevolg, nadat zij de instemming van de Raden hebben verkregen. Dergelijke verdragen die vór de inwerkingtreding van het nieuwe artikel 68 Grondwet zijn gesloten, dienen door de Koning te worden opgezegd in overeenstemming met de betrokken Executieven.

In de Bijzondere Wet zijn nadere regels opgenomen omtrent de verdragen van de Gewesten en Gemeenschappen, warvoor zij uitsluitend bevoegd zijn. Artikel 81 Bijzondere wet voorziet in een informatieplicht van de Executieven aan de Koning ten aanzien van het aangaan van onderhandelingen voor een verdrag. Hetzelfde artikel voorziet hierbij in een procedure, waarin de Koning bezwaar kan maken tegen dit voornemen. Voorts heeft de Koning de mogelijkheid, met inachtneming van de hiervoor aangegeven procedure, de uitvoering van verdragen op te schorten en voor te leggen aan de Interministeriële Conferentie voor het buitenlands beleid. Indien hierbinnen geen consensus bestaat, dan kunnen de verdragen op limitatieve gronden worden vernietigd. Bij het ontbreken van overeenstemming over de opzegging van een verdrag (wan vóor de inwerkingtreding van artikel 68 Grondwet) is voorzien in een procedure bij de Interministeriële Conferentie voor het buitenlands beleid. De Staat blijft bevoegd op verzoek van de betrokken Executieve(n) internationale rechtspersonen voor een inter- of supranationaal rechtscollege te dagvaarden. De Executieven kunnen de Belgisiche Staat binden in de Raad van de Europese Gemeenschappen, wanneer dit overeenkomstig een samenwerkingsakkoord is ex artikel 92 bis $\$ 4$ bis Bijzondere wet. Tevens bevat de Bijzondere wet regels die niet uitsluitend betrekking hebben op aangelegenheden, waarvoor de Gewesten en Gemeenschappen door of krachtens de Grondwet bevoegd zijn. Zo voorziet artikel 16

160. Grondwetswijziging van 5-5-1993, B.S, 8-5-1993, zie ook: Gedr.St, Senat, 1991-1992, 100-16/10; Wijziging van de Bijzondere wet betreffende de internationale betrekkingen van de Gemeenschappen en de Gewesten, 5-5-1993, B.S. 8-5-1993; Wet betreffende de interwationale betrekkingen wan de Gemeenschappen en de Gewesten van 5-5-1993, B.S. 8-5-1993, zie ook: Gedr.St. Senaat, 1991-1992, 457-1 en 458: 1 . 
$\$ 3$ Bijzondere wet in de mogelijkheid van de Staat, ter uitvoering van een uitspraak van een inter- of supranationaal college waarbij deze veroordeeld is, in de plaats te treden van de betrokken Gemeenschap respectievelijk het betrokken Gewest.

In het licht van het vorenstaande is het mijns inziens mogelijk, dat in het vervolg de Gewesten/(Gemeenschappen) in plaats van de Koning bevoegd zijn inzake het sluiten wan verdragen betreffende decentrale grensoverschrij-dende samenwerking. Hierdoor kunnen de Gewesten, die thans buiten de werking van de Benelux-Overeenkomst valien, zelf afspraken maken met b.v. de Nederlandse Staat. Voor het maken van publiekrechtelijke afspraken tussen de Gewesten/(Gemeenschappen) en b.v. de Nederlandse provincies zullen deze laatste nog expliciet bevoegd moeten worden verklaard (door de Nederlandse Staat).

\section{\$6. Overige tussen België en Nederland geldende regels inzake (decentrale) grensoverschrijdende samenwerking}

\section{A. INLEIDING}

In Benelux-verband c.q. tussen België en Nederland gelden naast de algemene BeneluxOvereenkomst nog andere meer specifieke regels inzake grensoverschrijdende samenwerking. Daarin speelt grensoverschrijdende (decentrale) samenwerking, vaak in juridisch veel minder ver reikende vormen dan publiekrechtelijke afspraken, zoals overleg- en afstemmingsverplichtingen, eveneens een rol van betekenis. Wellicht leidt de BeneluxOvereenkomst tot formalisering van deze consultatie- en overlegverplichtingen (administratieve afspraken/gemeenschappelijk orgaan/openbaar lichaam). Hier volgen de belangrijkste:

B. OVEREENKOMST TUSSEN HET KONINKRIK DER NEDERLANDEN, HET KONINKRIK BELGIË EN HET GROOTHERTOGDOM LUXEMBURG TOT INSTELLING VAN DE BENELUXECONOMISCHE UNIE (BENELUX-UNIEVERDRAG) ${ }^{161}$

Belangrijke fora voor samenwerking (coördinatie van beleid) in Benelux-verband zijn de Bijzondere Commissies ex. Hoofdstuk 4 van dit verdrag, b.v. de Bijzondere Commissie voor de Ruimtelijke Ordening en de Bijzondere Commissie voor het Leefmilieu. ${ }^{162}$ De Bijzondere Commissies hebben krachtens artikel 30 Benelux-Unieverdrag ieder op hun terrein tot taak o.a. het uitvoering geven aan de besluiten van het Comité van Ministers alsmede de uitvoering door de nationale administratie van de genomen beschikkingen na te gaan. Zo is in het kader van de Bijzondere Commissie voor de Ruimtelijke Ordening de Benelux Globale Structuurschets tot stand gekomen, waarin beleidscoördinatie tussen de drie Beneluxlanden op het gebied van de ruimtelijke planning (af-

161. Verdrag van 3-2-1958, Trb. $1958, \mathrm{nr} .18$, in werking getreden op 1-11-1960, Trb. 1960, wr. 124.

162. Ingesteld bij beschikking van het Comité van Ministers van 3-7-1969 M (69) 18 respectievelijk28-8-1980 $M(80) 7$. 
stemming van ruimtelijk relevante sectorontwikkelingen) centraal staat. ${ }^{163}$ Deze Bijzondere Commissie is in een aantal subcommissies onderverdeeld. Evenals de Bijzondere Commissie gaat het vooral om adviescommissies in bepaalde beleidsaangelegenheden. Voor de beide Limburgen en de provincie Lük functioneert de Subcommissie Oost. Hierin vindt op gezette tijden ruimtelijk overleg plaats. ${ }^{164}$ Het gaat hierbij in beginsel om overleg op regeringsniveau. Hoewel zij mogelijk feitelijk participeren - dit geldt vooral woor de Nederlandse provincies - in deze overlegsituaties en zij voor de uitvoering van hetgeen daarin afgesproken wordt zeker onmisbaar zijn, betreft de samenwerking de iure slechts de nationale overheden.

\section{OVEREENKOMST TUSSEN HET KONINKRIJK DER NEDERLANDEN, HET KONINKRIJK BELGIE EN HET GROOTHERTOGDOM LUXEMBURG OP HET GEBIED VAN NATUURBEHOUD EN LANDSCHAPSBESCHERMING ${ }^{165}$}

Het doel van dit verdrag is te komen tot overleg en samenwerking tussen de drie regeringen op het gebied van het behoud en bescherming van het natuurlijk milieu/landschap, hetgeen uiteindelijk zall dienen te leiden tot het instellen wan grensoverschrijdende natuurgebieden. Het betreft een kaderovereenkomst, waarvan de doelstellingen via beschikkingen van het Comite van Ministers gerealiseerd dienen te worden. Zo is b.v. de beschikking van het Comite van Ministers met betrekking tot een Belgisch-Nederlands grenspark 'Kalmthoutse Heide' tot stand gekomen. "166. Ten aanzien van een mogelijke rol voor decentrale overheden in dit verband is niets bepald. Het moge duidelijk zijn, dat als het gaat om de daadwerkelijke bescherming (de facto en de iure) decentrale overheden in deze een belangrijke rol kunnen en dienen te spelen. ${ }^{167}$

\section{OVEREENKOMST TUSSEN HET KONINKRIK DER NEDERLANDEN EN HET KONINKRIK BELGIE INZAKE WEDERZIJDSE BUSSTANDSVERLENING BIY HET BESTRIIDEN VAN RAMPEN EN ONGEVALLEN ${ }^{168}$}

Het doel wan ait verorag is een procedure te geven, die moet worden gevolgd voor het verzoeken en yertenen van bijstand bij rampen en ongevallen. De in artikel 3 eerste lid onder a bewoegde organen voor het werzoeken om bijstand alsmede voor het doen uitvoeren ervan zün de commissaris der Koningin en de provinciegouverneur, indien het be-

163. Benelux Globale Structurischets voor de Ruintelijke Ordening van 12-9-1986, M/RO (86) 1. Zie tevens Asnbeveling wan het Connts van Ministers van 25-11-1986 met betrekking tot de beleidsaanbevelingen. vati de Benelux Globale Structurschets voor de Ruimtelike Ondening, M (86) 14. Zle ook: Grensoverschrifond ruimtelijk owerlag, een notithe over twee Nederiandse grensgebieden, 1988, WROV werkgroep Europa.

164. Zi ook: Renc Seeruen, Samenhang over de grenzen heen, w. w., p. S01, noot 11.

167. Verdrag van 8-6-1982, Trb. 1982 nr. 97, in werking getreden op $1-10-1983$, Trb. 1983 nr. 147.

166. Beschikking van 24-11-1987, M (87) 10.

Zte ook: Beschikking van het Connte van Ministers van de Benelux EconomischeUnie tot instelling var een $B$ ijzondere Commssie van overleg a advies tot opstelling van een behers-en inrichtingsplan voor het toekomstig grensoverschrijdend park de Zoom-Kalm houtse Hejce, 15-6-1992, M (92) 3.

167. Zite: Rew Seerden, Samenhang over de grenzen heen, a.w., p. 500.

168. Verdrag wan 14-11-1984, Trb. 1984 nt. 155, in werking getreden op 1-11-1988, Trb. 1988 nr. 142 . 
treft het verlenen van bijstand door en aan provincies die aan elkaar grenzen, respectievelijk de Belgische en Nederlandse ministers van binnenlandse zaken, indien het betreft het verlenen van bijstand door en aan provincies die niet aan elkaar grenzen. De artikelen 4 tot en met 10 bevatten regels omtrent de uitvoering van de feitelijke bijstand, de grensformaliteiten voor personen en materieel, het gebruik van luchtwaartuigen en kosten en schadevergoeding.

Dit verdrag is ook voor gemeenten van belang. Het gaat met name om artikel 12, hetgeen bepaalt: " 1 . De artikelen 4 tot en met 10 van deze Overeenkonst zijn van overeenkomstige toepassing op het verlenen wan bijstand ingevolge afspraken die zijn genaakt door autoriteiten van aan elkaar grenzende gerneenten van elk der OvereenkomstsluitendePartijen, die verantwoordelijk zijn voor de hulpwerlening bij rampen en ongevallen, indien en voor zover deze afspraken betrekking hebben op aan elkaar te verlenen bijstand van personeel en materieel die met het oog op de dagelijkse taakuitwoering ter beschikking staan van die autoriteiten. 2. Afspraken, als bedoeld in het eerste lid, dienen, onverminderd hetgeen daaromtrent owerigens in het nationale recht van elk der Overeenkomstsluitende Partijen is bepaald " in leder geval te worden gemeld aan de bevoegde organen, bedoeld in artikel 3, eerste lid, onder a, van deze Overeenkomst." In de Memorie van Toelichting in het kader van de goedkeuring in Nederland wordt in het kader van artikel 12 gesproken van burenhulp, die in de praktijk vaak vastgesteld is in samenwerkingsverbanden tussen grensgemeenten. ${ }^{169}$ Wat precies onder dergelijke samenwerkingsverbanden verstaan moet worden, is niet nader aangegeven. Hierbij dient het volgende opgemerkt te worden. Op een parlementaire vraag daaromtrent is door de Belgische regering geantwoord, dat het niet is aangewezen, vanwege het wederkerigheidsprincipe dat ten grondslag ligt aan de Overeenkomst, dat een gemeente die niet over een eigen brandweer beschikt een bijstandsakkoord aangaat met een Nederlandse grensgemeente. ${ }^{170}$ Als deze interpretatie een juiste is, wordt hierdoor de mogelijkheid van het maken van afspraken uiteraard ingeperkt. ${ }^{171}$

169. MvT inzake de goedkeuring van de Overeenkomst tussen thet Koninkrijk der Nederlandenen thet Koni ikrijk Belgie inzake wederzijdse bijstandsverlening bij het bestrijden vin rampen en ongevillen, Tweede kamer, wergaderjaar 1984-1985, 18914, nrs. 1-3, p. 8. In het nader rapport, Tweede Kamer, vargaderjatar 1984 1985, 18914, A-C, p. 5 wordt overigens nog gesteld, dat artikel 12 er mede toe strekt 'om bestaande sanenwerkingswerbanden tussen grensgemeenten onder de werking van de overeenkomst ta brengen, zodat dwarop ook de faciliteiten, bedoeld in de artikelen 4 tot en met 10 van toepassung zijn." In deze kan gewezen worden op de circulaire van 8-1-1991, Eproj. 90/4/18 van de Minister van Binnenlandse Zaken, warbij een modelowereenkomst russe a grensgemeenten inzake wederzijkse bijstandsverleaing wordt aangeboden (opgenomen in Edite Schuurman en Jordens, Rampenwet (nt. 87), p. 214 e. v.

170. Cfr. Parl. vraag nr. 107 (Suykerbuyk) d.d. 21-8-1991, Bull. Vi a A. Senat, ar. 49, d.d. 24-9-1991, P. 2070.

171. Zie ook noot 106 en bijbehorende tekst in hoofdstuk 6 . 


\section{E. EERSTE AANVULLENDE OWEREENKOMST TER UITVOERING VAN DE OVEREENKOMST TUSSEN HET KONINKRIK DER NEDERLANDEN EN HET KONINKRUK BELGIË INZAKE WEDERZUDSE BIISTANDSVERLENING BD HET BESTRUDEN VAN RAMPEN EN ONGEVALLEN ${ }^{172}$}

Deze aanvullende Overeenkomst regelt een aantal zaken ter uitvoering van het in de worige paragraaf vermelde verdrag. Zo worden de eisen vermeld, waaraan een verzoek om bijstand dient te voldoen (art. 3), worden in de bijlagen bij deze Aanvullende Overeenkomst de eenheden aangegeven, die bijstand kunnen verlenen, bestaat er een inspanningsverplichting tot het houden van gemeenschappelijke oefeningen (art. 8), dient er jaarlijks overleg plaats te vinden tussen de bevoegde organen (art. 10), dient informatieuitwisseling plaats te vinden (art. 11), e.d. Voor de samenwerking tussen provincies is met name artikel 6 lid 3 en 4 van belang. Op basis daarvan kunnen door de bevoegde organen van aan elkaar grenzende provincies afspraken tot stand worden gebracht inzake de uitvoering van de bijstandsverlening. Deze afspraken mogen niet in strijd zijn met het in de vorige paragraaf beschreven verdrag, deze Aanvullende Overeenkomst en hetgeen in het nationale recht daartoe is bepaald.

\section{F. BESCHIKKINGEN/AANBEVELINGEN VAN HET COMITE VAN MINISTERS, WAARUTT INFORMATIE/OVERLEGVERPLICHTINGEN WOOR DECENTRALE OVERHEDEN VOORTVLOEEIEN ${ }^{173}$}

- Beschikking van 13-5-1974 inzake coördinatie van de streek- en gewestplannen in de Benelux-grensgebieden, M (74) 12.

- Beschikking van 17-10-1983 inzake wederzijdse bijstand ter vaststelling van schade veroorzaakt door grensoverschrijdende gevolgen van grondwateronttrekking, $M$ (83) 26.

- Beschikking van 12-12-1984 inzake overleg en samenwerking bij de voorbereiding van beslissingen omtrent vergunningen voor grondwateronttrekkingen, waarvan grensoverschrijdende gevolgen mogelijk zijn, M (84) 16.

- Beschikking van 25 mei 1988 inzake overleg en samenwerking bij de voorbereiding van beslissingen, die van belang zijn voor de bescherming van het grondwater in grensgebieden, $M(88) 8$.

- Aanbeveling van 17-10-1983 tot wijziging en aanvulling van de aanbeveling M 78 (16) van 14-11-1978 inzake samemwerking bij de bestrijding van de grensoverschrijdende luchtverontreiniging, $\mathrm{M}(83) 28$.

- Aanbeveling van 5-10-1982 inzake wederzijdse consultatie betreffende bepaalde werkzaamheden in het stroomvoerend deel van het winterbed van de Maas, $M(82) 11$.

172. Overeenkomst war. 5-2-1990, (op deze datum eveneens in werking getreden), Trb. 1990 nir. 42. Hierin is bepaald, dat deze Overeenkomst ingevolge art. XXI, eerste lid, onderdeel b, van de Grondwet junoto art. 62, eerste lid, onderdeel b, van de Grondwet nat de tekst van 1972, niet de goedkeuring behoeft van de Staten-Generaal.

173. De hierna te noemen beschikkingen/aabbevelingenzijn opgenomen in Benelux-Basisteksten. 
De rechtsgrondslag voor en de juridische status van beschikkingen en aanbevelingen volgt uit artikel 19 van het Benelux-Unieverdrag. Dit artikel bepaalt, voor zover hier relevant: "Ter uitwoering van de hem toevertrounde thak kan het Comite van Ministers:

a) beschikkingem nemen ter vaststelling van de wijze van uitwoering wan de bepalingen wan dit Verdrag onder de daarin vermelde voorwaarden. De beschikkingen van het Comité van Ministers verbindende Hoge Verdrag. sluitende partijen;

c) aanhevelingen doen ten behoeve wan de werking van de Unie. De aanbevelingen van het Comite verbinden de Hoge Verdragsluitende partijen niet;"

Beschikkingen en aanbevelingen treden veelal in werking op de dag van ondertekening. Zoals aangegeven in $\$ 6 . \mathrm{A}$. van dit hoofdstuk zullen vooral de in deze beschikkingen opgenomen consultatieverplichtingen zich bij uitstek lenen voor een formalisering door middel van de samenwerkingsvormen van de Benelux-Overeenkomst.

\section{G. ONTWERP MAASVERDRAG/SCHELDEVERDRAG ${ }^{174}$}

Al vele jaren wordt er tussen België en Nederland onderhandeld om te komen tot verdragen inzake her tegengaan van de vervuling van de Maas en de Schelde. Hoewel uit deze voorgestelde verdragen, als ze er ooit komen, met name verplichtingen voor staten zullen voortvloeien, is het wellicht wenselijk in de sfeer van overleg/samenwerking ook voor sommige niet nationale overheden, zoals de Gewesten in België en enkele provincies in Nederland, een plaats in te ruimen. Wellicht komen de betreffende verdragen er eerder als gevolg van de recente Belgische grondwetswijziging inzake externe betrekikingen en verdragssluiting en de daardoor geopende mogelijkheden voor Gewesten om verdragen te sluiten met de Nederlandse Strat.

\section{§. Samenvatting en conclusies}

In de loop van de tijd is naast de samenwerking tussen België en Nederland op het niveau van de staten de decentrale grensoverschrijdende samenwerking in belang toegenomen. Overigens berust die decentrale samenwerking in de regel op door de staten gemaakte afspraken. Daarbij zijn samenwerkingswormen, zoals consultatie- en informatieverplichtingen, op sommige specifieke terreinen, zoals de rampen- en ongevallenbestrijding, vervangen door verdergaande vormen van samenwerking, zoals het sluiten van overeenkomsten. Door de gelding van de Benelux-Overeenkomst bestaat er ook een meer algemene juridische grondslag voor, overigens vrijwillige, publiekrechtelijke samenwerking tussen decentrale overheden aan weerszijden van de Belgisch-Nederlandse grens.

De Benelux-Overeenkomst vorziet in een drietal, voornamelijk aan de Nederlandse Wet gemeenschappelijke regelingen ontleende, publiekrechtelijke vormen van samenwerking, variërend van zwaar (openbaar lichaam) tot minder zwaar (gemeenschappelijk orgaan en administratieve afspraak). In de Benelux-Overeenkomst wordt bepaald, dat de grensowerschrijdende samenwerking zich in beginsel volgens het nationale recht van de samenwerkende overheden dient af te spelen. De Benelux-Overeenkomst is onduidelijk wat betreft de precieze inhoud van de verwijzing naar het nationale recht. 
Geldt deze verwijzing voor thet aangaan van de verschillende vormen van samenwerking? Zo ja, dan zal de publiekrechtelijke samenwerking nauwelijks iets kunnen woorstellen, vanwege het feit dat er een groot verschil is tussen met name de Nederlandse Wet gemeenschappelijke regelingen en de Belgische Wet betreffende de intercommunales. Geldt deze verwijzing slechts voor de in te brengen materiële bevoegdheden? Zo ja, dan pas kan mijns inziens de Benelux-Overeenkomst iets gaan betekenen voor het terrein van de publiekrechtelijke samenwerking.

Zelfs als de samenwerkingsvormen in de Benelux-Overeenkomst te beschouwen zouden zijn als een soort van rechtsfiguren sui generis, dan nog zijn er vele problemen, in de fase van toezicht en rechtsbescherming, vanwege de toepasselijkheid van verscheidene rechtsstelsels c.q. het ontbreken van verwijzingsregels. Met name het ontbreken van een afdoende en duidelijke geschillenregeling tussen de samenwerkende overheden kan problematisch zijn.

De samenwerking op basis van de Benelux-Overeenkomst begint van de grond te komen. Deze beperkt zich tot nu toe vooral tot samenwerking in de vorm van (geformaliseerd) overleg. Zo deze afspraken al toezicht behoeven, zullen daarbij geen problemen ontstaan. Die zullen er wel zijn, als de samenwerking zich gaat uitkristalliseren in overheden en burgers bindende samenwerking. Het zal nog enige tijd duren, voordat er in dat verband beslissingen van toezichthoudende overheden en van (scheids)rechters voor handen zullen zijn. Om die reden heeft het beschrijven van een aantal (on)mogelijkheden van de Benelux-Overeenkomst een enigszins speculatief karakter. Eerst als het op daadwerkelijke uitvoering van de Benelux-Overeenkomst aankomt, zal vastgesteld kunnen worden hoe de Benelux-Overeenkomst precies geïnterpreteerd dient te worden en of dat, in verband met de verschillende reikwijdte van de interne samenwerking, b.v. in Nederland anders dan in België zal gebeuren. Daar waar de interpretatie van de Benelux-Overeenkomst in het geding is, zullen het Comité van Ministers respectievelijk de Bijzondere Commissie en in de gerechtelijke fase het Benelux-Gerechtshof hierbij in belangrijke mate uniformerend kunnen optreden.

Tot slot kan hier nog opgemerkt worden, dat er met de Benelux-Overeenkomst nog geen regeling is voor de harmonisatie van het materiële nationale recht. Als er grote verschillen zijn in materiële bevoegdheden op basis van sectorwetgeving van de diverse overheden aan weerskanten van de grens (qua niveau van uitoefening en inhoud), kunnen deze de nodige problemen voor de daadwerkelijke samenwerking opleveren. ${ }^{175}$ In de Benelux-Overeenkomst is daarover niets geregeld. Harmonisering van wetgeving, indien de verschillen inderdaad hiertoe noodzaken, en uiteraard de beschikbaarstelling van financiële middelen zijn zaken die erg belangrijk zijn, maar buiten het kader van de BeneluxOvereenkomst vallen.

175. Zie b.v.: Rene Seerden, Samenhang over de grenzen heen, a.w., p. 502 e.v.; R.J.G.H. Seerden, M.W.J.A. Hertoghs, A. W., hoofdstuk 7; C.P.J. Goorden, A.A. Freriks, Ontwikkeling wan landgrensowerschrijdende samenwerking tussen gemeenten, Gemeentestem 1991, 6927, p. 441-550. 


\section{Nederland-Duitsland}

\section{\$1. Inleiding}

In hoofdstuk 6 staat de samenwerking tussen decentrale overheden in Duitsland (Noordrijn-Westfalen en Nedersaksen) en tussen de decentrale overheden in Duitsland (Noordrijn-Westfalen en Nedersaksen) en Nederland centraal. Er wordt een inventarisatie gegeven van de belangrijkste rechtsregels inzake interne (= nationale) samenwerking in Noordrijn-Westfalen en Nedersaksen en excerne (= grensoverschrijdende) samenwerking.

Vanouds heeft de grensoverschrijdende samenwerking zich op centraal overheidsniveau (intergouvernementeel) afgespeeld. Er zijn een aantal inter-gouvernementele afspraken (vaak verdragen) gemaakt in het kader waarvan ook decentrale overheden kumen samenwerken (\$5).

Meer recentelijk is de samenwerking op gang gekomen, waarbij de decentrale overheden zelf, in meer algemene zin, grensoverschrijdendle publiekrechtelijke afspraken kunnen maken. Als juridische grondslag hiervoor is de Duits-Nederlandse Overeenkomst inzake decentrale grensoverschrijdende samenwerking van belang. Dit werdrag geeft een juridisch raamwerk, waarbinnen de grensoverschrijdende samenwerking tussen decentrale overheden in Nederland en Duitsland (Noordrijn-Westfalen en Nedersaksen) zich dient af te spelen $(\S 4)$. Evenals de Benelux-Overeenkomst verklaart de Duits-Nederlandse Overeenkomst grotendeels het nationale recht, dat geldt voor de interne samenwerking tussen decentrale overheden, van toepassing op de grensoverschrijdende samenwerking. Om die redlen wordt een beschrijving, in hoofdlijnen, gegeven van de wederzijdse nationale wetgeving inzake publiekrechtelijke afspraken tussen de op basis van de DuitsNederlandse Overeenkomst tot grensoverschrijdende samenwerking gerechtigde decentrale overheden. 'Het gaat hier dan on de beschrijving van de Duitse wetgeving, die een algemeen (formeel) kader geeft inzake interne samenwerking tussen decentrale overheden ( $\$ 2)$. De organieke wetgeving, zoals de Noordrijn-W estfaalse en de Nedersaksische Gemeindeordnung/Kreisordnung is reeds beschreven in hoofdstuk 4. De relevante Ne-

1. Omdat een santal Dutstalige termen niet altijd een precieze Nederlands werkaling hebben, worden deze in het nawolgende rier vanuit het Duits in het Nederlands vertaald. 
derlandse wetgeving is al beschreven in hoofdstuk 4 en 5 . In $\$ 3$ wordt een korte vergelijking gemaakt van het interne samenwerkingsrecht tussen decentrale overheden in Nederland en Duitsland (Noordrijn-Westfalen en Nedersaksen). Dit hoofdstuk wordt afgesloten met een samenvatting en enkele conclusies $(\$ 6)$.

\section{Het Duitse (Noordrijn-Westfaalse en Nedersaksische) recht inzake samenwerking tussen decentrale overheden}

\section{A. HET NOORDRUN-WESTFAALSE RECHT INZAKE SAMENWERKING TUSSEN DECENTRALE OVERHEDEN}

\section{Inleiding}

In de navolgende beschrijving wordt ingegaan op de samenwerking tussen Gemeinden en Kreise in Noordrijn-Westfalen. Daarbij staat de juridische status van de diverse samenwerkingsvormen tussen decentrale overheden centraal. ${ }^{2}$

\section{Samenwerking tussen Gemeinden en Kreise}

\section{a. Algemeen}

In Noordrijn-Westfalen is de samenwerking tussen Gemeinden en Kreise niet in de Gemeinde- c.q. Kreisordnung geregeld maar in het Gesetz über kommunale Gemeinschaftsarbeit (hierna: GkG). ${ }^{3}$ De samenwerking op basis van dit algemene Gesetz über kommunale Gemeinschaftsarbeit is bij uitstek een samenwerking in het kader van (de overdracht/de uitoefening van) publiekrechtelijke bevoegdheden. ${ }^{4}$

2. Zuken ats the inhoud van de statuten (Verbandssatzung) van de Zweckwerbände, de samenstelling van de be:stursorganen, het opheffen wan de Zweckverbände, e.d. "komen nuet dan wel nauwelijks aan de orde, wangezien deze aspecten niet direot relevant zijn wat betreft de mogelijkheid tot het aangan van de sarnenwerking.

Voor de onderhwige beschrijving van de decentrale samenwerking in Noordrijn- Westfalen en Nedersaksern is gebruk gemakt wan de literatuur, zoalls vermeld in hoofdstuk 4 noot 26 . Hier kunnen nog additioneel wermeld worderi: B. Zielke, Zwischengemeindliche Zusammenarbeit: Rechthiche, organisatortsche und finatinzelle Gestallungsmöglichkeiten, 1993; J. Oebbecke, Gemeindeverbandsrecht NordrheinWesthalen, 1985 .

3. In de tekst van 1-10-1979, GV NW S. 261, laatstelijk gewijzigd 26-6-1984, GV NW S. 362. De tekst varu het Geselz uber kormmuale Gemeinschaftsarbeit is als bijlage bijgevoegd.

4. Naast deze algemene (procedurele) wet bestaan er sectorwetten, die bepalingen bevatten omtrent (verplichte) samemwerking, zoals b. v. het Baugesetzbuch (Planumgsverbande) en het Wasserwerbandsgesetx (Abwasserverbunde). Daarmaast kan ook gewezen worden op de Land shaftsverbände en de Kommunalverband Ruhgebuet. Deze laatste wee zijn op basis vala de Duits-Nederlandse Ovareenkornst bevoegd tot grensoversehrijgende samerwerking. Voor een beschrijwing hiervan wordt verwezen nazar hoofdstuk 4 5. C.3 en 3.C.4. Lie overigens ook 3.1 (3) Gesefz uber kommunale Gemeinschaftsarbeit. Navrag bij de Nord thein-Westälische Stàdtatag heeft uitgewezen, dat er geen (precieze) overzichten bestaan wan het aantal (vrijwillige) Noordrijn-Westfalse Zweckverbände. 


\section{b. Samenwerkings vormen}

\$1 Gesetz über kommunale Gemeinschaftsarbeit bakent de reikwijdte van deze wet af en noemt de drie vormen van samenwerking. Er wordt bepaald dat gemeenten taken waartoe zij gerechtigd dan wel verplicht zijn gemeenschappelijk kunnen waarnemen, tenzij bij wet een bijzondere samenwerkingsvorm is voorgeschreven dan wel expliciet samenwerking uitgesloten is. Voor de gemeenschappelijke uitoefening van taken kunnen de gemeenten Arbeitsgemeinschaften instellen, Zweckverbände oprichten dan wel ôfentlich-rechtliche Vereinbarungen sluiten. Daarbij blijft de bevoegdheid gebruik te maken van het privaatrecht onaangetast. ${ }^{5}$

De drie vormen van samenwerking worden hier achtereenvolgens nader toegelicht.

\section{- Arbeitsgemeinschaft ( $\$ 2$ en $3 \mathrm{GkG}$ )}

De Arbeitsgemeinschaft betreft een worm van samenwerking, waarin naast gemeenten (Gemeinde) en verbanden van gemeenten (Gemeindeverbände) ook andere overheden (Körperschaften) en publiekrechtelijke rechtspersonen (Anstalten/Stiftungen) alsmede natuurlijke personen en privaatrechtelijke rechtspersonen kunnen samenwerken $(\$ 2(2)$ GkG). $\$ 2$ (1) Gesetz über kommunale Gemeinschaftsarbeit bepaalt dat op basis van de gesloten overeenkomsten de Arbeitsgemeinschaften overleg voeren over gemeenschappelijke aangelegenheden. De Arbeitsgemeinschaften (werkgemeenschappen) kunnen aanbevelingen (Anregungen) doen aan de deelnemers. De bevoegdheden van de deelnemers blijven onaangetast, hetgeen impliceert dat de Arbeitsgemeinschaft geen de overheden en burgers bindende beslissingen kan nemen $(\$ 3 \mathrm{GkG})$. Het doel van de Arbeitsgemeinschaft is derhalve als overlegforum voor overheden en de andere genoemde mogelijke participanten te fungeren.

\section{- Zweckverband ( $\$ 4 \mathrm{t} / \mathrm{m} 22 \mathrm{GkG}$ )}

In de Zweckwerband kunnen naast gemeenten en samenwerkingsverbanden van gemeenten ook andere overheden en publiekrechtelijke rechtspersonen alsmede natuurlijke personen en privaatrechtelijke rechtspersonen participeren ( $\$ 4 \mathrm{GKG})$. De deelname van een publiekrechtelijke rechtspersoon vam buiten Noordrijn W Westfalen aan een Zweckverband en van een Noordrijn-Westfaals publiekrechtelijke rechtspersoon aan een Zweckverband buiten deze deelstaat is mogelijk na goedkeuring van de Innenminister. In dit

5. Over de privatutechtelijke mogelijkheden tot samerwerking door gemeenten, stelt Oebbecke: "Als" Konkurtenz zum Zweckwerband stehen a $\mathrm{ls}$ rechtich verbindliche Formen atus dem Privatrecht vor allem die handelsrechelichenGesellschaftenGmbH und AO (Gesellschaft mït beschrinkter Haftung und Aktien-

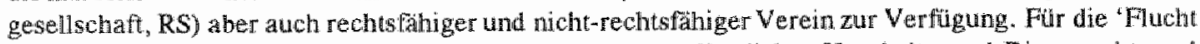
ins Privatrecit" mag dis Freiheit von den Bindungen des offertlichen Haushats- und Diensitrechts und von den stattlichen Aufsicht sprechen. Gronde fur tie Wahl der Zweckverbandsform sind die Dienstherrnqualität, die Satzungsgewaltund die Zulässugkeitder Verwaltungswollstreckung. "J. Oebbeche, a.w. , p. 100 .

6. Over de inhoud van het begrip Gemeindeverband, zie: J. Oebbecke, a.w., p. 1-3, 11 en 12. Hij concludeert op p. 12, dat Zweckverbände in verband met de specifieke (en niet algennene) taakuitoefening geen Gemeindeverbände zijn in de zin van artikel 28 If 2 Grundgesetzen datumee geen 'Eigenverantwortlichke it' toekomt. Landschaftswerbandezin dat weer wel. De mest bekende voorbeelden wan Gemeindeverbănde zilin de Kreise. 
verband zijn tussen Noordrijn-Westfalen en de onliggende deelstaten afspraken gemaakt. Hiervoor wordt verwezen naar het gestelde in 82. C. 3 van dit hoofdstuk.

De $\$ 5(1)$ en 6(1) Gesetz uber kommunale Gemeinschaftsarbeit geven voor het belangrijkste gedeelte de juridische status van de Zweckverband aan. Het gaat om een publiekrechtelijk lichaam "dat zijn taken/bevoegdheden wetmatig onder eigen verantwoordlijkheid uitwoert. Er is derhalwe sprake van een bevoegdheidso verdracht (delegatie) van de deelnemende overheden op de Zweckverband. Het Gesetz über die kommunale Gemeinschaftsarbeit in combinatie met de statuten (Verbandssatzung) is aan te merken als de voor deze delegatie (Zuständigkeitswechsel) vereiste wettelijke basis. ${ }^{7}$

Indien het Gesetz über kommunale Gemeinschaftsarbeit of de statuten niet anders bepalen, is, afhankelijk wan welke lokale overheden (kommunale Körperschaften) in de Zweckverband participeren, de Gemeindeordung, de Kreisordnung of de Landschaftsverbandsordnung van overeenkomstige toepassing. Het is mogelijk dat er Zweckverbände zign, waarin b.v. uitsluitend Kreise deelnemen. Binnen het takenpakket kan de Zweckverband met inachtneming van de voorschriften, zoals die gelden voor de deelnemende overheden in deze, verordeningen (Satzungen) vaststellen ( $\$ 8 \mathrm{GkG}$ ).

Binnen het kader yan de autonome taken van de deelnemende overheden is de oprichting van een Zweckwerband in beginsel wrij (Freiverband) en kan slechts bij wet een Zweckverband (gesetzlicher Zweckwerband) opgelegd worden ( $\$ 4$ juncto $22 \mathrm{GkG}$ ). In hec kader van de uitvoering door de deelnemende overheden van wettelijk medebewind is het verplicht opleggen van deze vorm van samenwerking (Pfichtverband) door de toezichthoudende overheid mogelijk, wanneer dit 'aus Gründen des öffentlichen Wohles dringend geboten' is ( $\$ 4$ juncto $13 \mathrm{GkG}) .{ }^{8}$

De bestuursorganen van de Zweckverband zijn de Verbandsversammlung en de Verbandsworsteher ( 14 GkG). De Verbandsversammlung bestaat uit vertegenwoordigers van de deelnemende overheden. Wanneer er andere deelnemers dan overheden zijn, kunnen die in beginsel niet meer dan de helft van het aantal stemmen hebben. De Verbandsversammlung kiest een voorzitter (Vorsitzende). De bevoegdheden van de Verbands versammlung worden in de statuten geregeld, voor zover ze niet al in de wet zijn aangege ven ( $\$ 15$ GkG). De Verbandsvorsteher wordt uit de (Hauptverwaltungsbeamten van de) deetnemende overheden gekozen. Hij mag geen lid zijn van de Verbandsversammlung. Bij hem berust het dagelijks bestuur alsmede het uitvoeren van (op basis van de wet, de statuten en de besluiten van de Verbands versammlung) andere bestuurstaken (\$ 16 GkG).

In het Gesetz über kommunale Gemeinschaftsarbeit is voorzien in bepalingen omtrent de precieze inhoud van de samenwerkingsovereenkomst ( $\$ 9$ e.v. GkG), het financiële beheer ( $\$ 18$ c.v. GkG) en de wijziging en opheffing van (de statuten van) de Zweckverband ( $\$ 20$ e.v. GkG). Hierop wordt niet verder ingegaan.

7. J. Oebbecke, a.w: p. 17.

8. "Dic Zwangskooperation stellt anerkantermasseneinen Eingrif in das Seltostverwaltungsrecht dar und

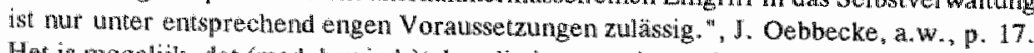
Het is nogelijk, dat (medebewinds) thken die in eerste instantie doö gemeentenuitgevoerd worden aan samenwerkingsverbanden (van gemeenten) overgedragendienen te worden. Zo zijn taken op het gebied van de waterzuivering, waarvan de uitvoering bij gemeenten lag, (bij wet) aan Abwasserverbände owergedragen (B. w.: VerfOH NW 2/90, Natur +Rech, 1992/1, p. 27-28). 
- Öfentlich-rechtliche Vereinbarung ( $\$ 23 \mathrm{t} / \mathrm{m} 26 \mathrm{GkG}$ )

Alleen gemeenten en verbanden van gemeenten kunnen schriftelijk overeenkomen, dat. een van de deelnemers taken wan de overige deelnemers "in seine Zustăndigkeit übernimmt oder sich verpflichtet solche Aufgaben für die übrigen Beteiligten durchzuführen' (\$23(1) GkG). Dit wordt uitgewerkt in \& 23(2) Gesetz über kommunale Gemeindschaftsarbeit, waar in is bepaald, dat als een deeinemer een aangelegenheid 'in seine Zuständigkeit' overneemt de rechten en plichten voor de uitoefening ervan mee overgaan, en, dat als een deeinemer zich verplicht een aangelegenheid 'durch zu führen', de rechten en plichten voor de overdrager onaangetast blijven. In het eerste geval gaan de rechten en plichten over naar de uitvoerder en is er sprake van delegatie. Het Gesetz über die kommunale Gemeinschaftsarbeit in combinatie met de overeenkomst is aan te merken als de voor deze delegatie (Zuständigkeitswechsel) vereiste wettelijke basis. In het tweede geval blijven de rechten en plichten van degene die overdraagt onaangetast en gaat het om mandaat. Mandaat van bestuursbevoegdheden is mogelijk, indien er geen wettelijke belemmering voor bestaat. ${ }^{9} \mathrm{Bij}$ beide vormen kan in de overeenkomst voor de overige deelnemers een medewerkingsrecht in het leven geroepen worden $(\$ 23(3)$ GkGi). Bij de öffentlich-rechtliche Vereinbarung is het ook mogelijk dat éen bepaalde overheid gemachtigd wordt het gebruik van een bepaalde inrichting middels een voor het hele gebied geldende verordening (Satzung) te regelen. In dat verband kan die overheid alle maatregelen treffen (met uitzondering van het heffen van belastingen), die zij op eigen gebied zou kunnen nemen ( $\$ 25 \mathrm{GkG})$. Evenals ten aanzien van het Zweckverband kan bij de öffentilich-rechtliche Vereinbarung ten aanzien van wettelijk medebewind een overeenkomst opgelegd worden door de toezichthoudende overheid, wanneer dit "aus Gründen des öffentlichen Wohles geboten' is $(\$ 26 \mathrm{GkG})$.

\section{c. Toezicht en geschillenbeslechting}

In $\$ 29$ Gesetz über kommunale Gemeinschaftsarbeit is het toezicht geregeld ten aanzien van de Zweckverbände en de öffentlich-rechtliche Vereinbarung. Voor het aangaan van de Zweckverbände en de öffentlich-rechtliche Vereinbarung is goedkeuring door de toezichthoudende instantie noodzakelijk. Dit geldt ook ten aanzien van bepaalde besluiten van de Zweckverbände, zoals de invoering van belastingen. Daarnaast zijn de bepalingen omtrent het toezicht uit de Gemeindeordnung, met uitzondering van $\$ 112$ Gemeindeordnung, van overeenkomstige toepassing. ${ }^{10}$ De goedkeurende/toezichthoudende overheid varieert al naar gelang de deelnemende overheden (hiërarchie/ligging) van de Oberkreisdirektor, de Regierungspräsident tot de Innenminister. Voor de Arbeitsgemeinschaft, die niet op rechtsgevolgen is gericht, is in het Gesetz über kommunale Gemeinschaftsarbeit niet in (extra) toezicht voorzien.

9. "Für die nicht-delegierende Kooperation bedarf es dagegen nur dann einer gesetzlichen Emächtigung, wenn dies wegen des rechtsstaatichen und/oder demokratischen Gesetzesvorbehaltes, etwa wegen der Grundrechtsrelevanz der getroffenen Regelung notwendig ist.", J. Oebbecke, a.w., p. 17. Owerigenss wordt wel aangenomen dat mandatering van regelgevende bevoegdheden niet mogelijk is, tenzij de wet hiertoe de mogelijkheid biedt.

10. 112 Gemeindeordnung regelt de mogelijkheid van een rechtsgang ten atnzien wan besluiten wan de toezichthouder. Hiervoor wordt verwezen naar het gestelde in 3.C.1.d. in hoofdsruk 4. 
De geschillenregeling op basis van $\$ 30$ Gesetz über kommunale Gemein-schaftsarbeit impliceert dat bij geschillen tussen deelnemers aan een öffentlich-rechtliche Vereinbarung of bij geschillen tussen het Zweckverband en de deelnemers of de deelnemers onderling de toezichthoudende overheid beslist, tenzij deze wet anders bepaalt of de offfentlich-rechtliche Vereinbarung of de Verbandssatzung voorziet in een scheidsgerecht. Voor de Arbeitsgemeinschaft is niet in een geschillenbeslechting voorzien, omdat deze vorm van samenwerking niet op rechtsgevolgen is gericht. Voor een nadere uiteenzetting over de geschillenregeling wordt verwezen naar het gestelde in $\S 4 . D .6$ van dit hoofdstuk.

\section{B. HET NEDERSAKSISCHE RECHT INZAKE SAMENWERKING TUSSEN DECENTRALE OVERHEDEN}

\section{Inleiding}

In de navolgende beschrijving wordt ingegaan op de samenwerking tussen Gemeinden en Kreise in Nedersaksen. Daarbij staat de juridische status van de diverse samenwerkingswormen tussen decentrale overheden centraal. "

\section{Samenwerking tussen Gemeinden en Kreise}

\section{a. Algemeen}

In Nedersaksen is de samenwerking tussen Gemeinden en Kreise niet in de Gemeindec.q. Landkreisordnung geregeld maar in het Zweckverbandgesetz (hierna: ZwVG). ${ }^{12}$ De samenwerking op basis van dit algemene Zweckver-bandgesetz is bij uitstek een samenwerking in het kader van (de overdacht/de uitoefening van) publiekrechtelijke bevoegdheden. ${ }^{13}$

\section{b. Samenwerkingswormen}

Het Nedersaksische Zweckverbandgesetz kent in tegenstelling tot Noordrijn-Westfalen slechts twee in plaats van drie vormen van publiekrechtelijke samenwerking, namelijk

11. Zaken als de inhoud wan dataten (Verbandssatzung) van de Zweckverbände, de samenstelling van de besturursorganem, het opheffen van de Zweck verbande e.d., komen niet dan wel nawwelijks aan de orde. angezien deze niet direct ralevant zijn wat betreft de mogelijkheid tot het aangan wan de samenwerking. Vgl. tevens noot 2 van dit hoofdstuk.

12. Wot wan 7-6-1939, Nieders. GVBI. Sb, II S. 109, lantstelijk gewijzigd door artikel 5 van de wet van 30-7-1985, Nieders. OVBI. S. 246. De tekst van het Zweckverbandgesetz is als bijlage bijgewoegd.

13. Nrast deze algemene (proeedurele) wet bestam er sectorwetten, die bepalingen bevatten omtrent (werplichte) satnenwerking, zoals b.v. het Batugesetzbuch (Planungsverbande) en het Wasserverbandsgesetz (Abwasserverbände). Door 'Sondergesetze" geregelde Zweckverbände zijn de 'Kommunalverband Gros5taum Mannover" (Wet van 20-5-1992, Nieders. GVBl. S. 153.) en de Zweck verband 'Grossram Braunschweig" (Wet wan 27-11 1991, Nieders. GVB1. S. 305).

Navratg bij de Niederstachsischer Städtetag heeft uitgewszen, dat er geen (precieze) overzichten bestaan van bet aantal (vrijwillige) Nedersaksische $Z$ weckverbände. 
de oprichting van een Zweckverband en het aangaan van een Vereinbarung. Elk van deze publiekrechtelijke afspraken wordt hier nader toegelicht.

\section{- Zweckverband ( $\$ 7 \mathrm{t} / \mathrm{m} 12 \mathrm{ZwVG}$ [Freiverbände], \& $15 \mathrm{t} / \mathrm{m} 20 \mathrm{Zweckverbandgesetz}$ [Pflichtwerbände])}

\$11) Zweckverbandgesetz bepaalt dat gemeenten en verbanden van gemeenten ter gemeenschappelijke uitvoering van aangelegenheden, waartoe zij tot uitvoering gerechtigd of verplicht zijn, Zweckverbände (Freiverbände) kunnen oprichten respectievelijk aan gemeenten en verbanden van gemeenten $Z$ weckverbände kumnen worden opgelegd (Pfichtverbände). Naast een gemeente (Gemeinde) of gemeenteverband (Gemeindeverband) kunnen ook andere publiekrechtelijke rechtspersonen (Körperschaften, Anstalten, Stiftungen) deel uit maken van het Zweckverband. De deelname van natuurlujke personen en/of privaatrechtelijke rechtspersonen behoeft dle goedkeuring van we Minister des Innern $(\$ 3 \mathrm{ZwVG})$.

Zweckverbändie zijn publiekrechtelijke lichamen ( $\$ 4 \mathrm{ZwVG}$ ). Het juridische karakter ervan blijkt b.v. uit $\$ 2(1)$ Zweckverbandgesetz, waarin is bepaald, dat rechten en plichten wan de deelnemende overheden overgaan op de Zweckverband. Indien het Zweckverbandgesetz of de Verbandssatzung (statuten) niet anders bepalen, zijn in beginsel de voor gemeenten geldende voorschriften van toepassing $(\$ 6$ (1) ZwVG). Op basis van \$ 6(3) Zweckverbandgesetz kumnen Zweckverbände, die niet uitsluitend uit gemeenten/verbanden van gemeenten bestaan, slechts wanneer zij door de wet daartoe gemachtigd zijn, Satzungen (verordeningen) uitwaardigen. Behalve het bepaalde in $\$ 6(3)$ Zweckverbandgesetz is een belangrijk verschil met de Zweckverbände in NoordrijnWestfalen, dat in Nedersaksen een Verbandsversammlung niet verplicht is voorgeschreven maar de mogelijkheid van 'alleinverantwortliche Verwaltung durch einen Leiter' (met Beiräte) bestaat ( $\$ 25(1)$ ZwVG). Ten aanzien van het Zweckverband zijn zoveel mogelijk de bepalingen inzake gemeenten (Gemeindeordnung) en mogelijk ook Landkreise (Landkreisordmung) van toepassing \& 6(1) en \& 25(1) ZwVG).

In het $Z$ weckverbandgesetz is tevens voorzien in bepalingen omtrent de wijziging/opheffing van de Zweckverband ( $\$ 21 \mathrm{t} / \mathrm{m} 23 \mathrm{ZwVG})$, de inhoud van de Verbandssatzung $(82 \mathrm{t} / \mathrm{m} 30 \mathrm{ZwVG})$, e.d. In dit verband is het van minder belang en wordt daarop niet nader ingegaan. Hier kan opgemerkt worden, dat $\$ 26$ Zweckverbandgesetz tevens een meer bedrijfsmatige (privaatrechtelijke) samenwerking regelt à la de Belgische intercommunales.

Voorts kan hier nog vermeld worden dat door de bekendmaking de oprichting van de Zweckverband gegeven is en niet ter toetsing door de rechter staat $(\$ 11$ (4) ZwVG).

\section{- Vereinbarung ( $\$ 13$ en 14 ZwVG)}

Behalve de Zweckverband is er ook de mogelijkheid tot het sluiten van schriftelijke overeenkomsten. $\$ 13(1)$ Zweckverbandgesetz is hier van belang. Gemeenten en verbanden van gemeenten kunnen overeenkomen dat één van de deelnemers tegen vergoeding een gemeenschappelijke aangelegenheid uitvoert of voorziet in het medegebruik wan een door die ene overheid gedreven inrichting. \$13(3) Zweckwerbandgesetz werkt dit uit door te bepalen dat, als een overheid een gemeenschappelijk aangelegenheid vervult, de andere overheden door de overeenkomst van de wettelijke plicht hiertoe bevrijd worden. Het gaat hierbij om delegatie, hetgeen niet per se hoeft te betekenen dat de mogelijkheid 
van mandaat is uitgesloten. Tevens kan de desbetreffende overheid gemachtigd worden het gebruik van een bepaalde inrichting middels een woor het hele gebied geldende verordening (Satzung) te regelen. In dat werband kan de desbetreffende averheid alle maatregelen nemen (met uitzondering van het heffen van belastingen), die zij op eigen gebied zou kumnen treffen ( $\$ 14 \mathrm{ZWVG}$ ).

Voor deze overeenkomsten geldt dat zij opgelegd kunnen worden door de toezichthoudende overheid. Anders dan ten aanzien van de Plichtverbände is niet expliciet bepaald, dat dit mogelijk is, wanneer dit 'aus Gründen des öffentlichen Wohles dringend geboten ist' ( 19 (1) juncto 15 (1) ZwVG).

\section{c. Toezicht en geschillenbeslechting}

In $\$ 7(2)$ juncto 31 Zweckverbandgesetz is het toezicht geregeld ten aanzien van de Zweckverbände en de Vereinbarung. Voor het aangaan van beide vormen van samenwerking is de goedkeuring noodzakelijk van de toezichthoudende instantie. Goedkeuring is b.v. ook vereist voor het door het Zweckverband instellen van belastingen. De toezichthoudende instantie varieert al naar gelang de deelnemende overheden (hiërarchie/ ligging) van de Landkreise (Landrat), Bezirk (Bezirksregierung) tot de Minister des Innern. Daarbij blijt het toezicht op basis van de sectorwetgeving onverkort gelden. De geschillenregeling op basis van de $\$ \$ 32$ en 33 Zweckverbandgesetz impliceert, dat bij geschillen tussen deelnemers aan een Vereinbarung of bij geschillen tussen het Zweckverband en de deelnemers of tussen de deelnemers aan een Zweckverband onderling de toezichthoudende overheid beslist, tenzij de wet in een andere procedure of de Verbandssatzung/Vereinbarung in een scheidsgerecht voorziet. Over een mogelijke rechtsbescherming tegen beslissingen van de toezichthouder is in het Zweckwerbandgesetz niets bepaald. ${ }^{14}$ Op de geschillenbeslechting wordt in § $4 . D .6$ van dit hoofdstuk nog dieper ingegaan.

\section{d. Vergeitiküng decentrale samenwerking Nedersaksen - Noordrijn-Westfalen}

Het samenwerkingsrecht tussen decentrale overheden is een aangelegenheid van de Länder. ${ }^{15}$ Als het samenwerkingsrecht inzake decentrale overheden op basis van het Nedersaksische Zweckverbandgesetz en het Noordrijn-Westfaalse Gesetz über kommunale Gemeinschaftsarbeit vergeleken wordt, bestaan er meer overeenkomsten dan verschillen. De vergelijking in deze kan dan ook kort zijn. Zowel in Nedersaksen als in Noordrijn-Westfalen is er de (bijna identieke) mogelijkheid van het oprichten van een Zweckverband en het aangaan van een (öffentlich-rechtliche) Vereinbarung. De voornaamste verschillen zijn: 14. Hetgeen voor de gemeenten geldt, zie hiervoor hoofdstuk 4 \& 3.D. L.e., zal hier in beginsel evenee ms van
toepassing zijn.

15. Zie thiervoor hoofdstuk 4 \& 3.B. 
1. In het Nedersaksische Zweckverbandgesetz ontbreekt een samenwerkingsvorm à la de Noordrijn-Westfaalse Arbeitsgemeinschaft. ${ }^{16}$

2. In het Nedersaksische Zweckverbandgesetz is in tegenstelling tot het Noordrijn-Westfaalse Gesetz über kommunale Gemeinschaftsarbeit bij de (öffentlich-rechtliche) Vereinbarung niet (expliciet) voorzien in een mandaatsvariant.

3. De bevoegdheid tot het nemen van algemene de burgers bindende voorschriften door een Zweckverband gaat op basis van $\S 8(4)$ van het Noordrijn-Westfaalse Gesetz über kommunale Gemeinschaftsarbeit iets verder dan op basis van \& 6(3) van het Nedersische Zweckverbandgezetz;

4. Nedersaksen kent in tegenstelling tot Noordrijn-Westfalen niet de verplichting van een Verbandsversammlung.

C. LÄNDER EN DECENTRALE SAMENWERKING

\section{Inleiding}

In hoofdstuk 5 \& 3.F. is 0.a. ingegaan op de Gewestgrenzen overschrijdende samenwerking tussen de Belgische Gewesten. Deze vormde in beginsel het kader voor de samenwerking tussen decentrale overheden in de betreffende Gewesten. Een en ander geldt ook voor de samenwerking tussen (decentrale overheden in) de Länder Noordrijn-Westfalen en Nedersaksen. Hierop wordt thans ingegaan.

\section{Samenwerking tussen Noordrijn-Westfalen en Nedersaksen}

In tegenstelling tot de samenwerking tussen Duitsland en vreende staten (art. 24(1), 25, 32 en 59 Grundgesetz) alsmede de samenwerking tussen Bund en Länder (art. $91 \mathrm{a} / \mathrm{b}$, art. 104 a(4) en 108(4) Grundgesetz) is in het Duitse Grundgesetz niets geregeld omtrent de samenwerking tussen de Duitse deelstaten onderling. De basis voor deze samenwerking is in beginsel gelegen in de diverse Landesverfassungen. Daarbij gaat het om algemeen geformuleerde bepalingen, die betrekking hebben op de buitenlandse betrekkingen. Zo bepaalt artikel 35 Niedersächsische Verfassung:

"(1) Die Mimisterpräsidentin oder der Ministerpräsident vertrit das Land nach aussen.

(2) Verträge des Landes, die sich auf Gegenstände der Gesetzgebung beziehen, bedürfen der Zustimmung des Landtages."

De meest relevante bepalingen voor Noordrijn-Westfalen in deze zijn de arikelen 57 en 66 Verfassung Jür das Land Nordrhein-Wesifalen:

Artikel 57 bepaalt: "Die Landesregierung vertritt das Land Nordrhein-Westfalten nach aussen. Sie kann diese Befugnis auf den Ministerpräsidenten, auf ein anderes Miglied der Landesregierung oder auf nachgeordnete Stellen übertragen." Artikel 66 bepaalt: "Die Gesetze werden vom Landtag beschlossen. Stiatswerträge bedurfen der Zustinmung des Landtags."

In de praktijk gaat het vooral om de samenwerking op bestuurlijk niveau. Samenwerking tussen organen van de wetgevende en rechtsprekende macht is van ondergeschikte

16. De Arbeitsgemeinschat als vorm van feitelike samemwerking is weer wel genegeld in de tussen NeWersaksen en Noordrin-Westallen gesloten overeenkomst inzake decentrale samemerking. Zue hiervor het gestelde in $\$ 2, C .3$. van dit hoofdstuk. 
betekenis. Op bestuursniveau is er sprake van ad-hoc samenwerking, geïnstitutional iseerde coördinatie (al dan niet krachtens Bondswetgeving), de oprichting van privaatrechtelijke inrichtingen en gemeenschappelijke (publiekrechtelijke) inrichtingen. Bij deze laatste vorm kan gedacht worden aan het oprichten van instanties, die bevoegdheden jegens burgers uitoefenen (b.v. ten aanzien van de toedeling van studieplaatsen, e.d). Tot deze laatste vorm behoren eveneens de 'Planungs- en Zweckverbände'. ${ }^{17}$ Bij de afspraken tussen de Länder wordt onderscheiden tussen "Verwaltungsabkommen " en 'Staatsverträge'. ${ }^{18}$ De Staatsvertrag vereist de goedkeuring van het parlement van het Land, terwijl het Verwaltungs-abkommen door een besluit van het bestuur gelding kan verkrijgen. ${ }^{19}$ Beide zijn juridisch bindend. ${ }^{20} \mathrm{Bij}$ de vaststelling van de precieze inhoud van het interdeelstatelijk recht wordt aangeknoopt bij de verdragen zelf, de belangen van de partijen alsmede het volkenrecht. ${ }^{21}$ Bij hetgeen de Länder met elkaar afspreken speelt uiteraard de bevoegdheidsafbakening tussen de Länder en de Bund een rol van betekenis. Deze competentieverdeling heeft in beginsel alleen betrekking op de overheidstaken, die in artikel 30 Grundgesetz uitdrukkelijk zijn opgenomen.

\section{Ländergrenzen overschrijdende decentrale samenwerking}

Op basis van de Staatsvertrag zwischen dem Land Niedersachsen und dem Land Nordrhein-Westfalen über Zweckverbände, öffentlich-rechtliche Vereinbarungen, kommunale Arbeitsgemeinschaften und Wasser- en Bodenverbände (hierna: Staatsvertrag ${ }^{22}$ ) is het mogelijk dat ter vervulting van publiekrechtelijke taken over de grenzen van de Länder samengewerkt wordt tussen decentrale overheden via Zweckverbände, öffentlich-rechtliche Vereinbarungen en Arbeitsgemeinschaften (art. 1 Staatsvertrag). Voor de Zweckverbände is daarbij het recht toepasselijk van de plaats van de zetel, voor de öffentlichrechtliche Vereinbarung geldt het recht van de plaats van de overheid waaraan de taken/bevoegdheden worden/zijn overgedragen (art. 2 Staatsvertrag). Het toezicht op het Zweckverband geschiedt door of namens de Innenminster van eveneens de plaats van de zetel van het $Z$ weckverband. Daarbij is met name voor de oprichting en wijziging (van

17. Zie: I. Pietzcker, in: Zusammenarbeit der Gliedstaaten im Bundesstaat, Landesberichte und Generabericht der Tagung fior Rechtsvergleichung 1987, 1e. Aufl. 1988, p. 20-34.

18. "Was die Exeloutive allein werwirkJichen karm, daruber kann sie sich auch im Wege des Verwalnugsabkommens mit anderen Lăndern verstăndigen; die Wahl dieser Form hat den Vorteil der leichteren Änderbarkeit. Die Eirichtung einer juristischen Person des öffentlichen Rechts, vielleicht anch die Ubertragung von Hoheitsgewalt, die ja regelmässig eine Verschiebung gesetzlicher Kompetenz-zuweisungen enthält, insbesondere aber die Verpflichoung zu Massnahmen dem Bürger gegenüber, die einer gesetzlichen Grundlige bedürfen, muss also die Form des Statsvertrages waihren.", J. Pietzcker, a.w, p. 47.

I19. J. Pietzcker, a.w., p. 50.

20. I. Pietzeker, a.w., p. 51

Het Verwallungsabkommen is wellicht te vergeijken met de bestuursovereenkomst in Nederland. Zie ook het gestelde in dit verband ten aanzien wan de administratieve afspraak op basis van de BeneluxOvereenkomst ( \$ 5.D.2. in hoofdstuk 5) en de öffentlich-rechtliche Vereinbarung op basis van de DuitsNederlandse Overeenkomst ( 4.D.2. van dit hoofdstuk).

Overigens doemt hier wat betreft de Verwaltungsabkommen een vergelijking met de internationale udninistratieve akkoorden op. Zie voor deze laatste hoofdstuk 2 .

21. BverwGE 60, 162.

22. Van 26-11-1969, GV NW 1969 S. 928. 
de Verbandssatzung) van de Zweckverband in een coördinatieregeling voor toezicht voorzien. Voor de öffentlich-rechtliche Vereinbarung geldt eenzelfde regeling (art. 3 Staatsvertrag). In veel gevallen wordt door de Innenminister bij Verordnung een overheid aangewezen als de bevoegde toezichthouder. ${ }^{23}$ Blijkens thet in noot 23 van dit hoofdstuk bedoelde overzicht, dat ook betrekking heeft op de vergelijkbare staatsverdragen tussen Noordrijn-Westfalen en Rijnland Palts en Noordrijn-Westfalen en Hessen, gaat het in ruim 20 gevallen om öffentlich-rechtliche Vereinbarungen ten aanzien van o.a: brandweer, rampen- en ongevallenbestrijding, toelating tot bepaalde scholen, verbetering van de infrastructuur, de instelling van een EG-adviesinstantie en waterzuiveringsinrichtingen. Deze laatste öffentlich-rechtliche overeenkomsten komen qua inhoud sterk overeen met de te beschrijven overeenkomsten, sub 5 van dit hoofdstuk, tussen Nederlandse en Duitse decentrale overheden op basis van het Grensverdrag. In twee gevallen is sprake van een grensoverschrijdend Zweckverband inzake waterbeheer. Voor de Ländergrens overschrijdende Wasser- und Bodenverbände gelden vergelijkbare regels als voor de Zweckverbände en öffentlich-rechtliche Vereinbarungen (art. 5 en 6 Staatsvertrag). Aangezien de Wasser- en Bodenverbände niet tot de kring van overheden behoren, die op basis van de Duits-Nederlandse Overeenkomst inzake decentrale grensoverschrijdende samenwerking kumen samenwerken, is het niet relevant hier nader op in te gaan. ${ }^{24}$

Van de oprichting van Arbeitsgemeinschaften dienen de wederzijdse toezichthoudende overheden in kennis gesteld te worden (art. 3 (5) Staatsvertrag).

Overigens kan hier het volgende nog opgemerkt worden. Vanwege het ontbreken van een juridische status van deze samenwerkings vorm bestaan er wellicht sinds langere tijd ook al tussen decentrale overheden in Nederland en Duitsland Arbeitsgemeinschaften b.v. de Arbeitsgemeinschaft Grenzland Kreis Heinsberg - Limburg. ${ }^{25}$ Vanwege het feit dat de deelnemende overheden hun eigen verantwoordelijkheden houden, is Oehm van mening dat de Arbeitsgemeinschaft zonder (nadere) wettelijke grondslag als vorm van grensoverschrijdende samenwerking gehanteerd kan worden. ${ }^{26}$

23. Voor een overzjcht van deze Verordnungen in Noordrijn-Westfalen, zie: Sammlung des bereinigten Gew setz- und Verordinungsblattes für das Land Nordrhein-Westfalen, nar. 202.

24. Volstaan wordt met het volgende. De voornaamste wettelijke grondslag voor deze Wasser-en Bodenverbände is het Wasserverbandsgesetz (Bondswet). De Wasserverbände kunnen b.v. een rol spelen in het kader van de vitwoering van het Wasserhaushaltgesetz. Het zijn evenwel de Länder, die ten aanzien van de uitwoering wan deze wet nadere regels dienen te geven (Landeswassergesetze) en b.w. de tot uitvoering bevoegde overheden aarwijzen. De betreffende Verbände kunnen ook nog een rol spelen met betrekking tot de landinrichting (Flurbereinigungsgesetz).

Voor de aspecten wan het waterrecht en waterschapsrecht van de Bondsrepubliek Duitsland/NoordrijnWestfalen, zie: W.F.A. Heemskerk, Waterrecht en waterschapsrecht, grenswerkenningen in ver band met de grensoverschrijdende rivier de Roer, 1985 , hoofdstukken 4 t/m 6.

25. Deze werkgemeenschap Grensland Kreis Heinsberg - Limburg heeft b.w. zijn eigen informatieblad getiteld 'Nachbarschaft im Grenzraum'.

Ook b.v. op het terrein van de grensoverschrijdende politiesamenwerking bestaat er een Arbeitsgemeinschaft, zie: Satzung der Arbeitsgemeinschaft der Leiter der belgischen, niederländischen und teutschen Polizeibehörden im Aachener Grenzgebiet.

26. M. Oehm, a.W., P. 100. 


\section{Samenvattende vergelijking decentrale samenwerking Duitsland-Nederland}

Qua (intergemeentelijke) samenwerkings vormen komen de Nederlandse Wet gemeenschappelijke regelingen (beschreven in hoofdstuk $5 \& 2$ ), het Nedersaksische Zweckverbandgesetz en het Noordrijn-Westfaalse Gesetz über kommunale Gemeinschaftsarbeit nagenoeg overeen (zie figuur 5 ).

Indien de juridsche reikwijdte van de samenwerkingsvormen op basis van de betreffende wetgeving vergeleken wordt, dan kan het wolgende geconcludeerd worden:

1. De Nedersaksische en Noordrijn-Westfaalse Zweckverbände, die uit gemeenten bestaan, kunnen dezelfde publiekrechtelijke bewoegdheden als het Nederlandse Wgropenbaar lichaam uitoefenen. Dit geldt, voor Nedersaksen met de restrictic van 8 6(3) Zweckwerbandgesetz, ook voor Zweckverbände waarin andere deelnemers dan overheden deelnemen;

2. De bevoegdheidso verdracht inzake de (offentlich-rechtliche) Vereinbarung kan een vergelijkbare strekking hebben als de centrumgemeente op basis van de Wet gemeenschappelijke regelingen (mandaat). Overigens kent de (öffen-tlich-rechtliche) Vereinbarung in tegenstelling tot de Wet gemeenschap pelijke regelingen ook de verder gaande mogelijkheid van delegatie;

3. De Arbeitsgemeinschaft op basis van het Gesetz über kommumale Gemeinschaftsarbeit is als een lichte(re) worm dan het gemeenschappelijk orgaan op basis van de Wet gemeenschappelijke regelingen te beschouwen. De laatste kan burgers en overheden bindende besluiten nemen. De eerste heeft slechts adviserende en geen de overheden en burgers bindende bevoegdheden. Om die reden ontbreekt waarschijnlijk toezicht op de Arbeitsgemeinschaft. In Nedersaksen ontbreekt deze vorm van samenwerking, die overigens weer wel mogelijk is tussen decentrale overheden in Noordrijn-Westfalen èn Nedersaksen;

4. De Wet gemeenschappelijke regelingen, het Gesetz über kommunale Gemeinschaftsarbeit en het Zweckverbandgesetz kemnen de mogelijkheid tot het dwingend opleggen (door de toezichthoudende instantie) van het openbaar lichaam/Zweckverband;

5. De genoemde Staatsvertrag inzake decentrale samenwerking tussen Nedersaksen en Noordrijn.W Westfalen maakt het mogelijk dat er samenwerking tussen Nederlandse, Noordrijn-Westfaalse én Nedersaksische overheden kan plaatsvinden;

6. Gezien de sub I t/m 5 genoemde overeenkomsten betreffende het formele juridische kader van publiekrechtelijke afspraken op basis van het interne recht, moet de grensoverschrijdende samenwerking, waarvoor bij dat interne recht wordt aangeknoopt, tussen Nederlandse decentrale overheden en hun Noordrijn-Westfaalse en Nedersaksische "counterparts' in ieder geval in dit opzicht minder problemen opleveren dan bij de Belgisch-Nederlandse samenwerking (vgl. hoofdstuk $5 \$ 4$ );

7. Zoals gesteld in hoofdstuk 4 \& 5 zullen met name de Nederlandse en Duitse gemeenten grensoverschrijdend kunnen samenwerken en kunnen profiteren van de overeenkomende (samenwerkings-en organieke) wetgeving. Voor de Nederlandse provincies wordt dit moeilijker, gezien het feit van de ontbrekende Duiltse counterparts. Voor de Nederlandse waterschappen en de Duitse equivalenten is dit onmogelijk, aangezien zij zijn uitgesloten van de werking van de Duits-Nederlandse Overeenkomst. 
Zie ook 4.D.1 van dit hoofdstuk, waar op de tot grensoverschrijdende samenwerking gerechtigde overheden op basis van de Duits-Nederlandse Overeenkomst wordt ingegaan.

\section{figuur 5}

Vergelijking Wetgemeenschappelijke regelingen/Zw eckverbandgesetz/Giesetz überkommunale Gemeinschaftsarbeit.

\begin{tabular}{|c|c|c|c|}
\hline Categorie & Nederland & $\begin{array}{l}\text { Nordrhein- } \\
\text { Westfalen }\end{array}$ & Niedersachsen \\
\hline Wet & $\begin{array}{l}\text { Wet } \\
\text { gemeenschappelijke } \\
\text { regelingen }\end{array}$ & $\begin{array}{l}\text { Gesetz uber } \\
\text { kommunale } \\
\text { Gemeinschaftsarbeit }\end{array}$ & $\begin{array}{l}\text { Zweckverband- } \\
\text { gesetz }\end{array}$ \\
\hline $\begin{array}{l}\text { Samenwer- } \\
\text { kingsvormen }\end{array}$ & $\begin{array}{l}\text { Openbaar lichaam** } \\
\text { Gemeenschappelijk } \\
\text { orgaan (delegatie) } \\
\text { Centrumgemeente } \\
\text { (mandaat) }\end{array}$ & $\begin{array}{l}\text { Zweckverband } * * \\
\text { Arbeitsgemeinschaft } \\
\text { offentliche- } \\
\text { rechtliche } \\
\text { Vereinbarung } \\
\text { (mandaat en } \\
\text { delegatie) }\end{array}$ & $\begin{array}{l}\text { Zweckverband** } \\
\text { Vereinbarung } \\
\text { (delegatie) }{ }^{* * * *}\end{array}$ \\
\hline Organen $*$ & $\begin{array}{l}\text { Algemeen bestuur } \\
\text { Dagelijks bestuur } \\
\text { Voorzitter }\end{array}$ & $\begin{array}{l}\text { Vertbands- } \\
\text { versammlung } \\
\text { Verbands vorsteher }\end{array}$ & $\begin{array}{l}\text { Verbands- } \\
\text { versammlung* } \\
\text { Leiter (Beiräte) }\end{array}$ \\
\hline $\begin{array}{l}\text { Bevoegd- } \\
\text { heden }\end{array}$ & $\begin{array}{l}\text { Burgers en } \\
\text { overheden bindende } \\
\text { bevoegdheden }\end{array}$ & $\begin{array}{l}\text { Burgers en } \\
\text { overheden bindende } \\
\text { bevoegheden }\end{array}$ & $\begin{array}{l}\text { Burgers en over- } \\
\text { heden bindende } \\
\text { bevoegdheden }\end{array}$ \\
\hline
\end{tabular}

* = facultatief

* = alleen de organen van de samemerkingsvommen die met * zijn arangegever

* mandat is wellicht niet uitgesloten 


\section{Overeenkomst tussen het Koninkrijk der Nederlanden, de Bondsrepubliek Duitsland, het Land Nedersaksen en het Land Noordrijn-Westfalen inzake grensoverschrijdende samenwerking tussen territoriale gemeenschappen of autoriteiten (Duits-Nederlandse Overeenkomst) ${ }^{27}$}

\section{A. INLEIDING}

Vijf jaren na de ondertekening van de Benelux-Overeenkomst is er ten behoeve van de publiekrechtelijke samenwerking tussen decentrale overheden over de Duits-Nederlandse grens een vergelijkbaar verdrag ondertekend. In het navolgende zal allereerst de totstandkoming van de Duits-Nederlandse Overeenkomst kort belicht worden ( $\$ 4$.B.). Na een behandeling van de inhoud $(\$ 4 . C$.), wordt de juridische reikwijdte ervan nader uitgewerkt (\$ 4.D.). De (beperkte) juridische reikwijdte van de samenwerkingswormen op basis van de Duits-Nederlandse Overeenkomst reflecteert de problemen, die in het algemeen met publiekrechtelijke vormen van grensoverschrijdende samenwerking verband houden. De Duits-Nederlandse Overeenkomst kent op hoofdlijnen dezelfde inhoud en structuur als de Benelux-Overeenkomst. Maar er zijn ook essentiële verschillen. In de bespreking van de belangrijkste zaken uit de Duits-Nederlandse Overeenkomst staat de vergelijking tussen beide verdragen centraal. Ten aanzien van een aantal (overeenkomende) zaken kan hier volstaan worden met een verwijzing naar hetgeen bij de beschrijving van de Benelux-Overeenkomst, in hoofdstuk $5 \S 5$, is gesteld. Tot slot volgen een samenvatting en enkele conclusies ( $\$ 5$ ).

\section{B. ONTSTAAN VAN DE DUITS-NEDERLANDSE OVEREENKOMST}

Voortbouw end op de European Outline Convention is op regeringsniveau tussen Nederland en de Bondsrepubliek Duitsland alsmede Noordrijn-Westfalen en Nedersaksen (gedurende vijf jaar) onderhandeld met het oog op de totstandkoming van een de European Outline Convention concretiserend verdrag. ${ }^{28}$ De Duits-Nederlandse Overeenkomst is per 1 1-1993 in werking getreden. ${ }^{29}$ Het feit dat naast de twee deelstaten ook

27. Isselburg-Anholl 23-5-1991, Trb. 1991 nar, 102, in werking getreden 1-1-1993, Trb. 1992 nr. 207. Voor Duitsland is de Duits-Nederlandse Overeenkornst goedgekeurd in Nedersaksen bij Wet van 16-3-1992, Nieders. GVB1. S. 69 em in Noordrijn-Westalen bij Wet van 20-11-1991, GV NW S. 530. De bekendmaking door de Bond d.d. 20-4-1993 van de inwerkingtreding heef plaatsgevonden in BGBI. 1993 S. $84 \%$.

De behandeling ervan geschid hier aan de hand wan de geldende tekst, zoals opgenomen in Trb. 199!1 nr, 102 . Deze is als bijlage bujgevoegd.

28. Toelichting bij de Duits-Nederlandse Overeenkomst, p. 1.

De parlementaite stukken in Nederland (Twelichtende Nota bij de Duits-Nederlandse Overeankomst. Staten-Generaal, vergaderjat 1991-1992, 22740, wrs. 375 en 1), in Noordrijn-Westalen (Landtag Drucksache 11/1970) en in Nedersaksen (Landtag Druchsache 2720) komen naganoeg overeen met de Toelichting bij de Duits-Nederlandse Overeenkomst. In het navolgende wordt alleen aan deze partementalre stukkengerefereerd, woorzover deze de Toelichting bij de Düts-Nederlandse Overeenkomst aamullen of herwan atwijken.

29. Er zijn nasa aanleiding van deze Duits-Nederlandse Overeenkomst enkele adviezen verschenen van onder andere de Vereniging wan Nederlandse gemeenten (VNG), het Interprovincial Overleg (PO) en de Ruad: 
de federale staat partij is bij de Duits-Nederlandse Overeenkomst houdt verband met het bepaalde in het Duitse Grundgesetz omtrent het al dan niet (zonder toestemming) kunnen shuiten van volkenrechtelijke verdragen door de deelstaten. Het feit dat de deelstaten uitgesloten zijn van de samenwerking op basis van de Duits-Nederlandse Overeenkomst houdt eveneens verband met de uitleg van enkele bepalingen van het Grundgesetz.

In 4.D.7 van dit hoofdstuk worden deze, in het licht van de daaruit voortvloeiende (beperkte) juridische reikwijdte van de samenwerkingsvormen op basis van de DuitsNederlandse Overeenkomst, beschreven.

\section{INHOUd VAN DE DUITS-NEDERLANDSE OVEREENKOMST}

De doelstelling van de Duits-Nederlandse Overeenkomst, zoalls aangegeven in de inleidende opmerkingen en artikel 2 ervan, is het binnen de bevoegdheden van het interne recht scheppen van de mogelijkheid voor decentrale overheden om op publiekrechtelijke basis samen te werken. De Duits-Nederlandse Overeenkomst moet als een aanvulling op het interne samenwerkings-recht tussen decentrale overheden in Nederland en Duitsland (Noordrijn-Westfalen en Nedersaksen) gezien worden. De Duits-Nederlandse Overeenkomst bestaat uit 14 artikelen en een protocol.

De overheden, genoemd in artikel 1 Duits-Nederlandse Overeenkomst, kunnen op een drietal manieren met elkaar samenwerken. Er kan tot samenwerking worden overgegaan door het treffen van een gemeenschap-pelijke regeling, waarbij een openbaar lichaam (Zweckverband) wordt opgericht, een gemeenschappelijk orgaan (Arbeitsgemeinschaft) wordt ingesteld of een andere overeenkomst wordt gesloten öfentlich-rechtliche Vereinbarung (art. 2 lid 2 Duits-Nederlandse Overeenkomst). Deze drie vormen van samenwerking worden respectievelijk in de artikelen $3 \mathrm{um} 5,7$ en 6 Duits-Nederlandse Overeenkomst nader uitgewerkt. Daarin staat de juridische reikwijdte van deze vormen centraal. In de artikelen $8 \mathrm{t} / \mathrm{m} 14$ Duits-Nederlandse Overeenkomst wordt een aantal zaken varn meer procedurele aard, zoals het toezicht op de aan samenwerking deelnemende overheden, het toezicht op de openbare lichamen/gemeenschappelijke organen, de rechtsgang en aanspraken van derden, een geschillenregeling voor o.a. de deelnemende overheden, de opzegging van de Duits-Nederlandse Overeenkomst door de verdragspartijen e.d., geregeld. Het protocol regelt de uniforme uitlegging van de Duits-Nederlandse Overeenkomst. Zo zullen in dit verband, indien een partij bij de Duits-Nederlandse Overeenkomst consultatie over de uitlegging of de toepassing ervan noodzakelijk acht, de verdragspartijen hiertoe op het niveau van de bevoegde ministeries bijeenkomen. De Duits-Nederlandise Overeenkomst kent in tegenstelling tot de Benelux-Overeenkomst geen bijlage, waarin het toepasselijke wederzijdse nationale recht is opgenomen.

29......vervolg)

voor het binnenlands bestuar (Rbb). Met name op het advies van deze laatste, Raad voor het binnenlands bestuur, Advies over de Nederlands-Duitse Overeenkonst inzake grensoverschrijdende samenwerking, september 1991, wordt in dit kader nader ingegaan. 


\section{JURIDISCHE REIKWIJTE VAN DE DUTTS-NEDERLANDSE OVEREENKOMST}

\section{Tot samenwerking gerechtigde overheden}

Samenwerking is niet verplicht. De Duits-Nederlandse Overeenkomst creëert een bevoegdheid voor bepaalde decentrale overheden om grensoverschrijdende publiekrechtelijke afspraken te maken. De tekst van de Duits-Nederlandse Overeenkomst spreekt van territoriale gemeenschappen of autoriteiten. Hier zall verder van 'overheden' gesproken worden.

In Nederland is de samenwerking over de Duits-Nederlandse grens mogelijk voor gemeenten en prowincies alsmede openbare lichamen op basis wan de Wet gemeenschappelijke regelingen, voorzover bevoegd op basis van hun interne (gemeenschappelijke) regelingen. In het Land Nedersaksen kunnen Gemeinden, Samtgemeinden en Landkreise grensoverschrijdend samenwerken. In het Land Noordrijn-Westfalen kunnen Gemeinden, Kreise, Landschafts verbände en de Kommunalverband Ruhrgebiet over de Duits-Nederlandse grens heen samenwerken. Voorts kunnen de Noordrijn-Westfaalse en Nedersaksische Zweckverbände, indien hun interne regeling dit toelaat, deelnemen aan de grensoverschrijdende samenwerking. Op basis van de Duits-Nederlandse Overeenkomst, in afwijking van de Wet gemeenschappelijke regelingen en het Nedersaksische Zweckverbandgesetz, kumnen openbare Wgr-lichamen of ZWVG-Zweckverbände aan vormen van grensoverschrijdende samenwerking deelnemen, zonder dat tenminste één gemeente of provincie respectievelijk "kommunale Körperschaft' aan de samenwerking deelneemt. Beide genoemde wetten - Noordrijn-Westfalen kent die mogelijkheid wel voor de GkGZweckverbände - laten dit niet toe bij de interne samenwerking. ${ }^{30}$ Men kan zich afvragen of voor grensoverschrijdende samenwerking op basis van de Duits-Nederlandse Overeenkomst de Wgr-openbare lichamen respectievelijk de Zweckverbände (op basis van het $\mathrm{GkG}$ en $\mathrm{ZWVG}$ ) een expliciete bevoegdheidsgrondslag nodig hebben in hun interne regelingen, dan wel dat de strekking ervan zich niet tegen grensoverschrijdende samenwerking moet verzetten. De Raad voor het binnenlands bestuur evenals de Nederlandse regering zün op dit punt voorstander van een expliciete grensoverschrijdende takstelling in de statuten. ${ }^{31}$ De Wgr-gemeenschappelijke organen of de GkG-Arbeitsgemeinschaften behoren niet tot de tot samenwerking gerechtigde overheden op basis van de Duits-Nederlandse Overeenkomst.

De Nederlandse waterschappen en de Duitse Wasser- en Bodenverbånde zijn buiten de werking van de Duits-Nederlandse Overeenkomst - de Benelux-Overeenkomst omvat de waterschappen respectievelijk polders/wateringen wel -gehouden. Dit houdt verband met de door de verdragspartijen voldoende geachte mogelijkheid voor waterschappen/Wasser-

30. Blijks de Toelichting bij de Duits-Nederlandse Overeenkonst, a.w., p. 11, derogeert de Duits-Nederlandse Overeenkomst op dit purt an genoemde wetgeving.

Zods vermeld in 4. D. 3 , in hoofdstuk 5 derogeerde de Benelux-Overeenkomst in eerste instantie op dit punt niat an de Wet gemeenschappelijke regelinger/Wet betreffende de Intercommunales. Vgl. ook: Raad voor het binnenlands bestuur, a.w., p. 6-7.

31. Radad voot het hineniands bestuur. a.W., p. 8; Toelichtende Nota bij de Duits-Nederlandse Overeenkomst. a. w. p. 10. 
en Bodenverbände tot het aangaan van grensoverschrijdende uitvoeringsovereenkomsten op basis van het Duits-Nederlands Grensverdrag, ${ }^{32}$

Aangezien de Nederlandse provincies vergelijkbare (sector)bevoegdheden hebben als de Duitse Länder en in her bijzonder de daarvan, als middenniveau, deel uitmakende Regierungsbezirke, en deze uitgezonderd zijn van de werking van de Duits-Nederlandse Owereenkomst, zal de samenwerking uiteindel ijk vooral tussen (samenwerkings verbanden van) gemeenten plaatsvinden.

Artikel 1 lid 3 Duits-Nederlandse Overeenkomst woorziet in de mogelijkheid dat de Overeenkomstsluitende partijen andere lokale of regionale overheden aanwijzen dan die genoemd in artikel 1 lid 1 van het verdrag. Op basis van artikel 1 lid 4 Duits-Nederlandse Overeenkomst geldt hetzelfde voor de participatie van andere publiekrechtelijke rechtspersonen dan (de tot samenwerking gerechtigde) decentrale overheden - die laatste moeten dan wel zelf participeren -, indien het interne recht dit toelaat. Via deze wegen zou het niet uitgesloten kunnen zijn, dat b.w. waterschappen/Wasser-en Bodenverbände en Länder toch (ooit) kunnen participeren in de samenwerking. " ${ }^{33}$ Deelname van privaatrechtelijke rechtspersonen aan de samenwerking, met uitzondering van deelname aan de overeenkomsten van artikel 6 Duits-Nederlandse Overeenkomst, is, indien hieraan ook decentrale overheden deelnemen, eveneens mogelijk. ${ }^{34}$ In dit verband kan b.v. gedacht worden aan Kamers van Koophandel e.d. ${ }^{35}$ Het ligt voor de hand dat de Duits-Nederlandse Overeenkonst derogeert aan de in $\$ 2 . C$. beschreven Staatsvertrag tussen Nedersaksen en Noordrijn-Westfalen inzake decentrale samenwerking, b.v. bij de oprichting van éen openbaar lichaam, waarin naast Nederlandse overheden zowel overheden uit Nedersaksen als Noordrijn-Westfalen participeren. ${ }^{36}$

Tot slot zij hier nog opgemerkt dat de samenwerking, die vrijwillig is, niet beperkt is tot die in het grensgebied.

32. Toelichende Nota bij de Duts Nederlandse Overeenkomst. 2. w., p. 6-7. Mins inziens is die veronderstelling niet helemal juist. Voor het gestelde met betrekking tot het Grenswerdrag wondt werwezen nat 5.1 van dit hoofdsituk.

33. Vgl. het overeenkomstige artikel 1 hid 2 Benelux-Overeenkomst.

34. In de Toelichting bij de Overeenkonst, a.w., p. 14, is vermeld dat het op basis wan de wetgeving in de beide Duitse deelstuten net mogelijk is dat (louter) priwatirechtehije personen offentich-rechtliche Vereinlaarungen treffen.

35. Art. 1 ld 4 Benelux-Overeenkomst beperkt de samenwerking tot territoriale samenwerkingsverbanden of autoriteiten Op basis van de Wet betreffende de intercompunales (art. 2) kunnen adan de intercommunale eveneens privatrechtelifke rechispersonen deelnemen. Op basis wan artikel 93 Wet gemeenschappe. lijke regelingen geldt hezelfde voor Nederlant. Via deelname an een intercommunale c.q. Wgr-openbaar lichaam kumen privatrechtelike personen derhalve toch participeren, hetzij indirect, in de samenwering op basis wan de Benelux-Overeenkonst.

36. Zoals gesteld in $\$ 3 . \mathrm{G}$. in hoofdstuk 5 is in Belgie de sinatije inzake samenwerking tussen decentrale overheden wan het Waamse en Waalse gewest nog niet helemalal uitgekristaliseerd. Zolang or geen regeling begtaat voor Vlaams-Walse decentrale samenwerking, is de samenwerking juridisch wel mogelijk maar is het de vrag of samenwerking tussen Nederlandse, Vlaamse en Waalse overheden in het kader van de Bendux-Overeenkomst, praktisch van de grond komt. Zle ook: noot 62 hoofistuk 5. 


\section{Samenwerkingsvormen}

De Duits-Nederlandse Overeenkomst kent een drietal vormen van samenwerking (art. 2 lid 2 Duits-Nederlandse Overeenkomst). Twee van de drie vormen van samenwerking, namelijk het oprichten wan een openbaar lichaam (Zweckwerband) en een gemeenschappelijk orgaan (kommunale Arbeitsgemeinschaft) zijn als zodanig ook in de Beneluxovereenkomst vermeld. Voorshands lijkt ook de derde vorm, namelijk een gemeenschappelijke regeling waarbijgeen openbaar lichaam of gemeenschappelijk orgaan wordt ingesteld (offentlich-rechtliche Vereinbarung), het equivalent van de administratieve afspraak ex Benelux-Overeenkomst. In het navolgende zal voor elk van de drie vormen bekeken worden of ze daadwerkelijk met die in de Benelux-Overeenkomst overeenkomen.

\section{- Openbaar lichaam}

Belangrijk is dat het openbaar lichaam niet bevoegd is algemeen verbindende voorschriften vast te stellen of bij beschikking verplichtingen op te leggen aan burgers (art. 5 lid 1 Duits-Nederlandse Overeenkomst). ${ }^{37}$ Zoals aangegeven in $\$ 2$. B. en $\$ 2 . C$. van dit hoofdstuk kunnen Zweckverbände (bestaande uit overheden) op basis van het Zweckverbandgesetz en Zweckverbände op bas is van het Gesetz über kommunale Gemeinschaftsarbeit zonder meer wel over deze bevoegdheden beschikken. Dit geldt, zoals aangegeven sub 2 in hoofdstuk 5, ook voor het openbaar lichaam op basis van de Wet gemeenschappelijke regelingen. Hiermee wijkt de Duits-Nederlandse Overeenkomst af van het betreffende interne recht in Nederland en de beide Länder. Deze vorm van samenwerking kent wel de mogelijkheid dat (publiekrechtelijke) rechten en plichten voor de deelnemende overheden ontstaan maar niet voor derden. Anders gezegd: In beginsel kunnen er in dit verband slechts 'publiekrechtelijke' geschillen tussen de deelnemende overheden onderling c.q. deze en het openbaar lichaam ontstaan maar niet tussen het openbaar lichaam en burgers. Vanwege de toegekende privaatrechtelijke rechtspersoonlijkheid kan het openbaar lichaam priwaatrechtelijk aansprakelijk gesteld worden en autonoom privaatrechtelijk handelen. Het hebben van de bevoegdheid privaatrechtelijke contracten e.d te sluiten kan essentieel zijn voor het functioneren wan zo'n openbaar lichaam, b.v. woor het aan-en verkopen wan grond mar ook in het kader van het privaatrechtelijk beheer/ exploitatie van een gemeenschappelijke stortplaats, een waterzuiveringsinstallatie, een grensoverschrijdend natuurgebied, e.d. De regeling van civielrechtelijke aanspraken van derden jegens dit openbaar lichaam vloeit met name voort uit artikel 10 Duits-Nederlandse Overeenkomst. Zie hiervoor uitgebreider het gestelde in \$ 4.D.6 van dit hoofdstuk.

Op basis van artikel 5 lid 2 Duits-Nederlandse Overeenkomst kan het openbaar lichaam de deelnemende overheden verplichten om maatregelen te nemen, indien dat voor de verwulling van zijn taken noodzakelijk is. Dit zou het witvaardigen van algemeen verbindende voorschriften kunnen zijm. De deelnemende overheden zijn bij hun besluitvorming (jegens derden) gebonden aan door het openbaar lichaam genomen besluiten. Omdat de beslissingsmacht ten aanzien van het gebruik van bevoegdheden in wezen bij het open-

37. Het openbaar lichaam op basis van artikel 3 lid 1 Benelux-Overeenkomst kan wel over deze bevoegdhend van regeling en bestum beschiken. 
baar lichaam kan gaan berusten, is mijns inziens sprake van een publiekrechtelijke afspraak. Net zoals bij het openbaar lichaam op basis van de Benelux-Overeenkomst (vgl. hoofdstuk $5 \$ 5 . D .2$.) zal afgewacht moeten worden, in hoeverre overheden bereid zijn uberhaupt bij voorbaat bepaalde (overheden bindende) bevoegdheden aan het openbaar lichaam te delegeren. ${ }^{38}$ Het is niet geheel duidelijk in dat werband in hoeverre de deelnemende overheden nog een bepaalde beleidswrijheid hebben bij het doorvoeren van besluiten wan het openbaar lichaam. De precieze reikwijdte van een dergelijke binding tussen overheden onderling is ook in het interne recht (in Nederland) nog niet echt uitgekristalliseerd. Het voert te ver hier dieper op in te gaan, maar met name in het milieurecht begint dit 'intern overheidsrecht' zich te onwikkelen, b.v. in het kader van aanwijzingsbevoegdheden.

Het treffen van een regeling is noodzakelijk voor het ontstaan van een openbaar lichaam (art. 4 lid 1 Duits-Nederlandse Overeenkomsi). Artikel 4 lid 2 Duits-Nederlandse Overeenkomst geeft regels omtrent de mogelijke bestuursstructuur. Het derde lid van dit artikel bevat een aantal verplicht in de regeling op te nemen zaken. De regeling kan slechts gewijzigd worden bij een meerderheid van ten minste twee derden (minimumvereiste) van het in de regeling bepaalde aantal vertegenwoordigers in het algemeen bestuur (art. 4 lid 4 Benelux-Overeenkomst). Daarbij richt de afvaardiging van vertegen woordigers zich in beginsel naar het nationale recht (art. 4 lid 5 Duits-Nederlandse Overeenkomst). Wat betreft de organen zijn een algemeen en dagelijks bestuur verplicht en kan met inachtneming van het interne recht in meer organen worden voorzien (art. 4 lid 2 Duits-Nederlandse Overeenkomst. Hiermee derogeert de Duits-Nederlandse Overeenkomst aan het Nedersaksische Zweckverbandgesetz, waarin een algemeen bestuur niet verplicht is. ${ }^{39}$

Bij de Benelux-Overeenkomst zijn er modelstatuten voor het openbaar lichaam opgesteld. Ten aanzien van de Duits-Nederlandse Overeenkomst is dat niet het geval. Een voor-beeld van een openbaar lichaam, dat thans op basis van de Duits-Nederlandse Overeenkomst wordt opgericht, is de Euregio Rijn-Waal. Gezien de (concept)statuten betreft het een openbaar lichaam, met zetel in Kleve (D), dat vooral een adviserende functie ten aanzien van de deelnemende overheden heeft. Het is niet zo, dat dit openbaar lichaam over overheden bindende bevoegdheden beschikt. Het kan wel personeel in dienst nemen en over financiële middelen beschikken. De organen van de Euregio Rijn-Waal zijn de Euregioraad en het dagelijks bestuur ( $\$ 6$ Gemeenschappelijke regeling Euregio RijnWaal). De Euregioraad is het hoogste orgaan en bestist over een aantal aangegeven aangelegenheden, zoals de begroting, de aanwijzing van de voorzitter, de wijziging van de regeling alsmede in zaken waarin de regeling niet voorziet $(\$ 7(7)$ Gemeenschappelijke regeling Euregio Rijn-Waal). Het dagelijks bestuur bereidt o.a besluiten van de Euregioraad voor en beslist over benoeming e.d. van personeel $(\$ 8$ (3) Gemeenschappelijke regeling Euregio Rijn-Waal). Verder beval de regeling bepalingen inzake de leiding.

38. Indien al bevoegdheden worden overgedragen aan het openbaar lichaam, zal in het kader van de voor beshut worming vereiste meerderhedenwarschijhijk in de praktijk gestreefd worden nar consensus. Vgl. Rad voor het binnenands bestuur, a.w. p. 9 .

39. De Benelux-Ohereenkomst noemt net expliciet be betreffende organen, maar stelt ten aanzien wan de imhoud wan de statuten dat de wijze van aznstelling van 'de beheers- en bestuursorganen' geregeld dievi. te worden (art. 3 lid 5 Benelux-Overenikomst). 
van het secretariaat, de samenstelling van de Euregioraad en het dagelijks bestuur, het financiele beheer, etc. 40

\section{- Gemeenschappelijk orgaan}

Dit orgaan kan in zijn geheel geen (de deelnemers of derden) bindende beslissingen nemen (art. 7 \|id 2 Duits-Nederlandse Overeenkomst). In deze is er overeenstemming met de Noordrijn-Westfaalse Arbeitsgemeinschaft. Deze regeling wijkt af van die van het Nederlandse gemeenschappelijk orgaan, dat wel de deelnemers bindende beslissingen kan nemen evenals beschikkingen aan derden kan afgeven. Deze regeling derogeert aan de situatie in Nedersaksen, dat geen Arbeitsgemeinschaft kent.

Het is de vraag of de oprichting van een gemeenschappelijk orgaan op basis van de Duits-Nederlandse Overeenkomst, gezien het feitelijk karakter, wel als een publiekrechtelijke afspraak gezien kan worden. De beoogde rechtsgevolgen, in het leven geroepen door overheden, zouden dan gelegen moeten zijn in het gecreèerde toezicht op het gemeenschappelijk orgaan. Daarbij dient dan wel opgemerkt te worden, dat in het Noordrijn-Westfaalse Gesetz über kommunale Gemeinschaftsarbeit er helemaal geen toezicht bestaat ten aanzien van de Arbeitsgemeinschaft (en de vorm van samenwerking in het Nedersaksische Zweckverbandgesetz geheel ontbreekt). Mijns inziens zal dit toezicht ten aanzien van het gemeenschappelijk orgaan derhalve alleen in Nederland plaats vinden. "Daarbij is dit toezicht ex Wet gemeenschappelijke regelingen 0. a. ingegeven door de mogelijkheid dat het Nederlandse gemeenschappelijk orgaan burgers en overheden bindende besluiten (geen algemeen verbindende voorschriften) kan vaststellen. Aangezien het gemeenschappelijk orgaan op basis van de Duits-Nederlandse Overeenkomst niet eens de deelnemende overheden bindende beslissingen kan nemen, laat staan de burgers, is de publiekrechtelijke status ervan mijns inziens zeer twijfelachtig. Er is bij deze vorm veeleer sprake van weliswaar geformaliseerde maar feitelijke samenwerking. Het gaat hierbij om een overlegform met adviserende bevoegdheden. Uitgaande van het uitgangspunt van de Duits-Nederlandse Overeenkomst, namelijk dat deze een aanvulling. vormt op het wederzijdse nationale recht en in de Duits-Nederlandse Overeenkomst geen bijzondere regeling daaromtrent is opgenomen, moet aangenomen worden dat het gemeenschappelijk orgaan op basis van de Duits-Nederlandse Overeenkomst geen privaatrechtelijke rechtspersoonlijkheid bezit en niet aan het privaatrechtelijk rechtsverkeer kan deelnemen c.q. aansprakelijk gesteld kan worden. "Hieruit blijkt eens te meer het feitelijk (overigens geformaliseerd) overleg/advieskarakter.

40. In fot bestat er hierdoon niet zo heel veel verschil met de samerwerking, dive reeds lange tija bestond voór de inwerkingtreding wan de Duits-Nederlandse Overeenkomst (en nog bestat) in de Euregio (Gronat Bnschede). Zie hierover J. Gabbe, Regionale grenzuberschreiteme Zusmmen-arbeit an der Busis, in: Grenzühergreitende Raumplanung, a. $W_{\text {, }}$ p. $187-208$.

41. Zie tevens het gestelde omtrent het toezicht op de overheden, die het gemeenschappelijkorgaan instellem, 5 4.D.5. van dit hoofdsuk.

42. In de Toelhothing bij de Benelux-Overeenkomst, a.w., p. 13, wordt in tegenstelling tot de Duts-Nederlandse Overeenkomst de niet-rechtspersoonljkkldeid van her geneenschappelijk organ uitrukkelijk arngegeren. 
- (Publiekrechtelijke) overeenkomsten

De rechtsgevolgen verbonden aan de derde categorie van samenwerking, die van de overeenkomsten ex artikel 6 Duits-Nederlandse Overeenkomst, sluiten aan bij die van het openbaar lichaam. Dergelijke schriftelijke overeenkomsten zullen rechtstreeks rechten en verplichtingen voor de deelnemende overheden met zich kunnen brengen maar niet voor derden.

Ten aanzien van de instelling van de centrumgemeente (art. 6 lid 2 Duits-Nederlandse Overeenkomst) kan de buitenlandse overheid de aan haar ter uitvoering overgedragen zaken niet in eigen naam (en slechts volgens de instructies van de overdragende overheid) behartigen. Bij deze vorm, die is geregeld in het Nederlandse en het NoordrijnWestfaalse decentrale samenwerkingsrecht, gaat het dus om een overdracht van bevoegdheden via mandaat. Gezien het feit dat het hier om de uitoefening in mandaat van publiekrechtelijke bevoegdheden door een buitenlandse overheid gaat en deze vorm in het interne recht een wettelijk grondslag heeft, kan men zeer wel spreken van een publiekrechtelijke afspraak. Delegatie aan buitenlandse overheden van bevoegdheden de burgers bindende beslissingen te nemen (overdracht van besl issingsbe voegdheid en verantwoordelijkheid) is op basis van de Duits-Nederlandse Overeenkomst niet mogelijk. ${ }^{43}$ Voor de Belgisch-Nederlandse administratieve afspraken op basis van de Benelux-Overeenkomst moet, zoals aangegeven in hoofdstuk $5 \$ 5 . D .2$., een dergelijke delegatie zeer waarschijnlijk eveneens uitgesloten geacht worden. Het aangaan van andere overeenkomsten ex artikel 6 Duits-Nederlandse Overeenkomst kan alleen geschieden, indien dit door het nationale recht is toegestaan. Het zal hier kunnen gaan om overeenkonsten omtrent het gebruik maken van elkaars voorzieningen (brandweer, waterzuiveringsinstallaties, etc.), over hoe bevoegdheden uitgeoefend kunnen/zullen worden (b.v. het afzien van de uitvoering van bepaalde plannen), e.d. Op deze afspraken in het kader van vooral discretionaire bevoegdheden is reeds bij de beschrijving van de administratieve afspraken op basis van de Benelux-Overeenkomst in hoofdstuk $5 \& 5 . D .2$. ingegaan. Hetgeen daar geschreven is, is in beginsel ook hier van toepassing. Het Duitse equivalent van de Nederlandse bevoegdheden/beleidso vereenkomsten zijn de Verwaltungs verträge. Ook in Duitsland bestaat voor dergelijke afspraken tussen decentrale overheden niet direkt een wettelijk regeling. ${ }^{44}$ Omdat artikel 6 lid 2 derogeert aan artikel 6 lid 1 Duits-Nederlandse Overeenkomst geldt ook voor die afspraken (zoals voor de instelling van een centrumgemeente), dat deze in beginsel geen rechtsitreekse derdenwerking kunnen hebben. Omdat de partijen overheden zijn en zij jegens elkaar rechtsgevolgen beogen in het kader wan de uitoefening (niet overdracht) van hun publiekrechtelijke (discretionaire) bevoegdheden, kan men deze afspraken als publiekrechtelijk kwalificeren. ${ }^{45}$

43. Vgl. Toelichting bij de Duits-Nederlandse Overeenkomst, a.w., p. 27.

Het $Z$ weckverbandgesetzen bet Gesetz über kommunale Gemeinschaftsarbeit kennen in tegenstelling tot de Wet gemeenschappelijke regelingen deze delegatiemogelijkheid overigens well.

44. Voor dergellike overeenkomsten tussen overheden en burgers inzake publiekrechnelijke aangelegenheden kan in deze gewezen worden op \$ 54 e.v. Verwallungswerfahrengesetz.

45. Dat daaruit mogelijk (in Nederland) een civielrechtelijke aansprakelijkheid voortvloeit, doet aan het publiekrechtelijke karakter niet zonder meer af. Zie b.v. ook: M. Scheltema, De burgerlijke rechter lost het probleem van de administratieve rechtsprak op, in: NJ 1913-1988, anotatoren kijken terug, 1988, p. 143; J. Van der Hoeven, De drie dimensies van het bestursrecht, 1989, p. 224. 


\section{Verwijzing naar het inteme recht}

Met betrekking tot de (totstandkoming van de) drie vormen van samenwerking dienen de bepalingen van het nationale recht in acht te worden genomen. De strekking van artikel 2 lid 1 Duits-Nederlandse Overeenkomst, die overeenkomt met artikel 2 lid 1 Benelux-Overeenkomst, is duidelijk. De samenwerking dient plaats te vinden binnen het bestaande kader van bevoegdheden in het interne recht. De algemene regel van artikel 2 lid 1 Duits-Nederlandse Overeenkomst wordt geconcretiseerd in:

- artikel 5 lid 2 wat betreft het treffen van maatregelen door overheden woor de vervulling wan de taken/bevoegdbeden van het openbaar lichaam;

- artikel 6 lid 1 inzake het aqngaan van een gemeenschappelike regeling waarbij geen openbaar lichaam of gemeenschappelijk organan wordt ingesteld;

- artikel 8 lid 1 ten aanzien van de geldigheidswereisten voor het aangaam en wijzigen van de drie vormen van saimenwerking;

- artikel 9 lid 2 inzake het roezicht op de vormen van samenwerking;

- artikel 10 lid 1 wat betreft de rechtsgang en anspraken van derden.

In dit verband is er overigens geen bijlage bij de Duits-Nederlandse Overeenkomst opgenomen, die de betreffende interne wetgeving aangeeft. Het zal hier analoog aan de Benelux-Overeenkomst in beginsel die wetten betreffen, die intern de publiekrechtelijke afspraken tussen de betreffende overheden en de organsatie en het toezicht op die overheden regelen. Het samenwerkingstecht voor Duitsland en Nederland is reeds in $\S 2$ van dit hoofdstuk respectievelijk $\$ 2$ van hoofdstuk 5 beschreven, terwijl het organieke Duitse en Nederlandse recht inzake de tot grensoverschrijdende samenwerking gerechtigde overheden in hoofdstuk 4 is geschetst.

\section{Aanvullende werking}

De discrepantie tussen de publiekrechtelijke samenwerking op basis van het interne recht in Duitsland en Nederland is, zoals aangegeven sub 3 van dit hoofdstuk, veel kleiner dan die tussen België en Nederland. Om die reden, maar ook omdat de vormen van samenwerking in de Duits-Nederlandse Overeenkomst qua juridische reikwijdte duidelijker zijn aangegeven, is de aanvullende werking van de Duits-Nederlandse Overeenkomst ten opzichte van het interne recht van de beide landen veel beter aan te geven. Het 'nemo plus iuris" beginsel - overheden moeten als zij grensoverschrijdend handelen, blijven binnen de bevoegdheden van het interne recht - leidt er immers niet toe dat de samenwerking op basis van de Duits-Nederlandse Overeenkomst (bijna) totaal gefrustreerd wordt. Met andere woorden: de vormen van samenwerking op basis van de Nederlands-Duitse Overeenkomst behoeven niet als sui-generis rechtsfiguren gekwalificeerd te worden om de samenwerking daadwerkelijk iets te laten voorstellen. ${ }^{46}$ Nog anders gezegd: De DuitsNederlandse Overeenkomst geeft zelf duidelijk aan in hoeverre het interne recht al dan niet gebruikt kan worden voor grensoverschrijdende publiekrechtelijke afspraken. De bedoeling van de verdragsluitende partijen blijkt uit de Duits-Nederlandse Overeenkomst zelf. Vooral uit het gestelde in $\$ 4 . \mathbb{D} .2$ van dit hoofdstuk, waarnaar wordt verwezen,

46. Zie ook hetgen hieromtrent is aangegeven ten aanzien wan de Benelux-Overeenkomst in hoofdstuk 5 \$.D. 3 . 
is duidelijk, waar de Duits-Nederlandse Overeenkomst aan het interne recht derogeert en waar dat niet het geval is.

\section{Confrontatie van rechtssielsels}

Zoals gesteld in $\$ 5 . D .5$ in hoofdstuk 5, knoopt de Benelux-Overeenkomst wat betreft o.a. het toezicht aan bij het interne recht van de diverse deelnemende overheden (art. 4 lid 1 Benelux-Overeenkomst). Ten aanzien van de (uitsluitende) toepasselijkheid van het recht van de plaats van vestiging van het openbaar lichaam op het doen en laten van dit openbaar lichaam is in de Benelux-Overeenkomst alleen iets bepaald in relatie met de rechtspositie van het personeel (art. 3 lid 4 Benelux-Overeenkomst), met dien verstande dat in de statuten ook nog anders kan worden bepaald. "

In de Duits-Nederlandse Overeenkomst is ten aanzien van het openbaar lichaam alsmede het gemeenschappelijk orgaan bepaald dat, voorzover de Duits-Nederlandse Overeenkomst hiervoor geen andere bepalingen bevat, het recht van de Overeenkomstsluitende staat waar de zetel is gevestigd van toepassing is (artikel 3 lid 3/artikel 7 lid 4 DuitsNederlandse Overeenkomst). Op de vormen van samenwerking op basis van de DuitsNederlandse Overeenkomst is vooral in de sfeer van het toezicht meer dan in de Benelux-Overeenkomst de toepasselijkheid van één rechtsstelsel voorzien. Zo zijn voor het toezicht op (de handelingen van) de eenmaal tot stand gekomen openbare lichamen en gemeenschappelijke organen de toezichthoudende autoriteiten van de Overeenkomstsluitende Staat, waar zij hun zetel hebben, bevoegd (art. 9 lid 3 Duits-Nederlandse Overeenkomst). De toezichtsbevoegdheden ten aanzien van de deelnemende overhedien, zowel betreffende het aangaan van de samenwerking als de implementatie van besluiten van het openbaar lichaam, vanuit de diverse rechtsstelsels blijven evenwel onverlet (art. 9 lid 2 Duits-Overeenkomst). In verband met het toezicht op het openbaar lichaam/gemeenschappelijk orgaan en het toezicht op de deelnemende overheden is in onderlinge procedurele afstemming van beide "toezichten' voorzien. Er geldt een informatieplicht en de Overeenkomstsluitende Staten dienen alvorens maatregelen te treffen in het kader van hun toezicht in beginsel onderling te overleggen (art. 9 lid 4 Duits-Nederlandse Overeenkomst).

Ten aanzien wan het voorgaande zijn enkele opmerkingen op zijn plaats.

Vooraf zij opgemerkt dat het toezicht ten aanzien van het gemeenschappelijk orgaan niet veel kan voorstellen. Immers het gaat hier om feitelijke samenwerking, waarover niets geregeld is in Nedersaksen, die wel voorkomt in Noordrijn-Westfalen, maar waromtrent daar geen toezicht plaatsvindt. Of in Nederland het toezicht op het (aangaan van het) gemeenschappelijk orgaan hetzelfde is als op het (aangaan van het) Wgr gemeenschappelijk orgaan is niet duidelijk. Omdat het Wgr-gemeenschappelijk orgaan overheden en burgers bindende besluiten kan nemen en het gemeenschappelijk orgaan op basis van de Duits-Nederlandse Overeenkomst niet, ligt enige vorm van Nederlands toezicht op het gemeenschappelijk orgaan niet zomaar voor de hand. Dit zal wellicht zelfs gelden voor het toezicht op de oprichting ervan door de deelnemende overheden.

47. De Toelichting bij de Duits-Nederlandse Overeenkomst, al.w, p. 19-21 gat vrij uitgebreid in op de rechtspositie van het personeel en de mogelijke belemmeringen in de nationale wetgewing van beide landen hieromtrent. On die reden zal detachering van (buitenlands) personeel platisvinden. 
Gezien het voorgaande zal het toezicht voornamelijk een rol spelen bij het openbaar lichaam. Het oprichten ervan volgt de toezichtsregels van de rechtsstelsels van de deelnemende overheden ten aanzien van de Zweckverband en het Wgr-openbaar lichaam (art. 9 lid 2 Duits-Nederlandse Overeenkomst). Hoewel artikel 9 lid 4 Duits-Nederlandse Overeenkomst aangeeft dat er maatregelen kunnen worden getroffen ten aanzien van opgerichte openbare lichamen (en gemeenschappelijke organen) door de toezichthouder van het recht van de plaats der zetel, is de precieze toepassing van het toezicht vanuit het rechtsstelsel van de zetell van het openbaar lichaam mij niet duidelijk. In het licht van de bevoegdheden van het openbaar lichaam kan hier het volgende gesteld worden. Het openbaar lichaam kan slechts de deelnemende overheden en niet burgers publiekrechtelijk binden. ${ }^{48}$ Wil het openbaar lichaam meer betekenen dan alleen maar een overlegorgaan voor de deelnemende overheden, dan zullen de besluiten ervan op een bepaald moment toch bindende werking moeten krijgen naar burgers toe. Dit kan pas aan de orde zijn, nadat de deelnemende overheden deze besluiten hebben doorgevoerd/ongezet en voor deze doorgevoerde/omgezette besluiten het eventuele toezicht in de diverse rechtsstelsels in het licht van artikel 9 lid 2 Duits-Nederlandse Overeenkomst is gevolgd. Het zal immers zo zijn, dat als er toezicht nodig is ten aanzien van de besluiten van het openbaar lichaam, dit ook wel zo zal zijn ten aanzien van de doorgevoerde/omgezette besluiten van de deelnemende overheden. Omdat de doorvoering/omzetting van besluiten bepaalde procedures doorlopen etc., is het niet zeker of de diverse toezichthouders ten aanzien van de besluiten van de deelnemende overheden hetzelfde kunnen, zullen of zelfs moeten besluiten als de toezichthouder ten aanzien van de besluiten van het openbaar lichaam. Het zal in die situatie van de coördinatie - b.v. welk toezicht er bij conflicten voor dient te gaan, is niet aangegeven tussen de toezichthouders - afhangen of het in eerste instantie geachte voordeel, namelijk toezicht op besluiten van het openbaar lichaam vanuit het rechtsstelsel van de zetel niet omslaat in een nadeel, namelijk bóvenop dat toezicht evengoed nog het toezicht op de implementatie van besluiten door de deelnemende overheden in de diverse rechtsstelsels.

Voor overheden bindende besluiten, die uiteindelijk derdenwerking dienen te verkrijgen, kan men zich in het licht van het vorenstaande derhalve afvragen waarom een additioneel toezicht vanuit één rechtsstelsel, namelijk dat van de zetel, überhaupt is opgenomen naast het toezicht op de deelnemende overheden. Enige verheldering in de Toelichting bij de Duits-Nederlandse Overeenkomst over het waarom van dit additionele toezicht, over waarop de maatregelen ex artikel 9 lid 4 Duits-Nederlandse Overeenkomst betrekking hebben en over dle aard van deze maatregelen, was op zijn plaats geweest. Mijns inziens was met een coördinatieregeling tussen de toezichthouders vanuit de diverse rechtsstelsels, zonder een additioneel toezicht op de besluiten van het openbaar lichaam vanuit de plaats van de zetel, hetzelfde resultaat bereikt. Een mogelijke andere variant zou ook nog kunnen zijn geweest, dat de coördinatie van het toezicht zich zou hebben

48. Het is, in het licht van de moge lijke aansprakelijkheid van het openbaar lichaam ex artikel 1.0 lid 2 DuitsNederlandse Overeenkomst wellicht niet onmogelijk dat burgers privaatrechtelijk gebonden kunnen worden door het openbaar lichaam. Hiervoor wordt verwezen naar het gestelde in \& 4.D.6.b. van dit hoofdstuk. Gezien de privaatrechtelijke rechtspersoonlijkheid van het openbaar lichaam kan hierdoor (en niet slechts door de deetnemende overheden) privaatrechtelijk gehandeld worden. Uiteraard kunnen de deelnemende overheden dit handelen beperken. 
toegespitst op de besluiten wan het openbaar lichaam. De zin hiervan is uiteraard nog groter, als de besluiten van het openbaar lichaam een publiekrechtelike binding jegens derden zouden hebben. Zoals aangegeven biedt de Duits-Nederlandse Overeenkomst die mogelijkheid nier.

Artikel 9 lid 5 Duits-Nederlandse Overeenkomst regelt een informatieplicllt/de onderlinge afstemming van de toezichthoudende overheden in beide landen in het kader van (het aangaan vanj de samenwerking bij een overeenkomst ex artikel 6 Duits-Nederlandse Overeenkomst. Ten aanzien van de centrumgemeente is bepaald dat, indien de DuitsNederlandse Overeenkomst geen andere bepalingen bevat, het recht van toepassing is van de Overeenkomstsluitende staat waar de verplichting voortvloeiend uit de gemeenschappelijke regeling moet. worden vervuld (art. 6 lid 5 Duits-Nederlandse Overeenkomst). Dit ziet vooral op de rechtsbescherming voor de burger. Heeft men getracht in de sfeer van het toezicht op het openbaar lichaam de toepasselijkheid van het recht van de zetel te introduceren, inzake de rechtsgang van derden is het uitgangspunt de toepasselijkheid van hun eigen rechtsstelsel. Hiervoor wordt verwezen naar het gestelde in \$ 4.D.6.b. wan dit hoofdstuk.

\section{Geschillenbeslechting}

Bij de beschrijving van de geschillenbeslechting op basis van de Benelux-Ov ereenkomst, in \$ 5.D.6 in hoofdstuk 5, is ingegaan op een aantal aspecten, die in beginsel op gelijke wijze van toepassing zijn ten aanzien van de geschillenbeslechting op basis van de DuitsNederlandse Overeenkomst. Hier wordt dan ook vooral ingegaan op die zaken, die in de Duits-Nederlandse Overeenkomst in dit opzicht anders geregeld zijn dan in de Benelux-Overeenkomst. Voor het overige wordt verwezen naar voornoemde paragraaf in hoofdstuk 5 .

\section{a. Geschillen tussen overheden}

Artikel 11 Duits-Nederlandse Overeenkomst bevat een regeling inzake publiekrechtelije geschillen tussen territoriale gemeenschappen of autoriteiten, openbare lichamen of gemeenschappelijke organen gerezen naar aanleiding van grensoverschrijdende samenwerking. In deze kan b.v. gedacht worden aan het feit dat de deelnemende overheden met overgaan tot uityoering van het door het openbaar lichaam bepaalde. De rechtsgang wordt bepaald volgens de regels van de Overeenkomstsluitende staat waar de zetel van de gedaagde is gevestigd. Hiermee wil men woorkomen dat b.v. een Duitse rechter (met toepassing van Duits recht) een Nederlandse overheid kan dwingen zich conform besluitvorming wan een openbaar lichaam te gedragen. In de Benelux-Overeenkomst is voor de oplossing van geschillen niet zonder meer aangeknoopt bij een dergelijke verwijzing naar het interne recht, maar is eerst woorzien in een verzoeningsprocedure bij de Commissie, al dan niet gevolgd door een beslissing van het Comité van Ministers (art. 6 lid 2 sub c Benelux-Overeenkomst). Daarna pas is mogelijk de nationale rechter, eventueel in combinatie met het Benelux-Gerechtshof, aan de beurt om over het geschil te oordelen. Met publiekrechtelijke geschillen zijn geschillen tussen overheden bedoeld van welke 
aard dan ook. ${ }^{49}$ Dat het nief alleen om rechtsgeschillen gaat moge blijken uit het feit dat het bij het gemeenschappelijk orgaan niet eens kan gaan om juridische geschillen. In tegenstelling tot de Benelux-Overeenkomst voorziet de Duits-Nederlandse Owereenkomst expliciet in de mogelijkheid geschillen voor te leggen aan een scheidsgerecht. Het betreft hier arbitrage, die de gerechtelijke weg naar de nationale rechter niet uits/uit. ${ }^{50}$ Juist omdat de samenwerkingsvormen van de Dưts-Nederlandse Overeenkomst geen de burgers bindende werking kumnen hebben (en in het uiterste geval slechts de overheden binden), had men mijns inziens de nationale gerechtelijke weg inzake geschillenbeslechting tussen de samenwerkende overheden onderling en die tussen het openbaar lichaam (en eventueel gemeenschappelijk orgaan) en de deelnemende overheden in beginsel kunnen uitsluiten.

Hetgeen in $\$ 5$. D.6.a. in hoofdstuk 5 is geschreven ten aanzien van de bevoegde rechter, de Nederlandse of de buitenlandse, de burgerlijke dan wel de administratieve en het toe te passen recht, geldt in beginsel ook hier. Voor Nedersaksen en Noordrijn-Westfalen kan wat betreft de instantie die beslist over de geschillen in het kader van interne samenwerking verwezen worden naar het gestelde in $\$ 2$.A.2.c. respectievelijk $\$ 2$.B.2.c. van dit hoofdstuk.

\section{b. Geschillen tussen owerheden en burgers}

In artikel 10 lid 1 Duits-Nederlandse Overeenkomst is geregeld, dat derden de rechtsvordering/rechtsgang behouden, die hen zou toekomen jegens hun overheden indien deze niet grensoverschrijdend gehandeld hadden: "De rechtsgang richt zich naar het recht van de Overeenkomstsluitende Staat van de territoriale gemeenschap of autoriteit wier taak is verwuld." Het betreft hier een identieke regeling als die van artikel 3 lid 3 Benelux-Overeenkomst. Hetgeen omtrent laatst genoemd artikel in hoofdstuk $5 \$ 5 . \mathrm{D} .6 . \mathrm{b}$. is geschreven, is evenwel gecompliceerder dan artikel 10 lid 1 Duits-Nederlandse Overeenkomst. Dit vloeit voort vit het feit dat de Duits-Nederlandse Overeenkomst, in tegenstelling tot de Benelux-Overeenkomst, geen rechtstreeks de burgers bindende samenwerkingsvormen kent. Enkele opmerkingen omtrent de regeling van artikel 10 Duits-Nederlandse Overeenkomst zijn nog op zijin plaats.

In artikel 10 lid 2 Duits-Nederlandse Overeenkonst is bepaald, dat derden ook aanspraken jegens het openbare lichaam c.q. de overheid die taken behartigt (de centrumgemeente ex artikel 6 Duits-Nederlandse Overeenkomst) geldend kunnen maken: "Rechtsvorderingen tegen hen richten zich naar het recht van de Overeenkomstsluitende Staat waar hun zetel is gevestigd." $5 \|$ Aangezien openbare lichamen op basis van de Duits-

49. In de Nota wall Toeliohting, a.w., p. 9, wordt gesproken wan bestursgeschillen.

50. Toelichting bij de Duits-Nederlandse Overeenkomst, a.w., p. 38 .

In Duitsland is het 'Sohiedsrichterliches Verfahren' geregeld in de \$ 1025-1048 Zivilpnozessordang. Overigens is het in Duitsland niet helemaal hitgesloten dat ma arbitrage tussen overheden bet bewandelen van de gerechtelijke weg onmogelijk is. Zie in dit verband b.w.: A. Rapsch, Konfliktbewältigung mit verfassungswidrigenMiteln? WasserverbandlichesSchiedswesen zwischen Wunsch und Realität, NVwZ $1993 \times 6, p, 534$.

51. Toelichting bij de Duits-Neder andse Overeenkomst, a.w., p. 34, 35.

(wordt vervolgd...) 
Nederlandse Overeenkomst slechts overheden bindende besluiten kunnen nemen en geen delegatie mogelijk is aan de centrumgemeente (maar de mandans verantwoordelijk is), kan het eigenlijk alleen om privaatrechtelijke aanspraken gaan. Dit blijkt (voor het openbaar lichaam) ook uit de vrijwaringsregeling van artikel 10 lid 3 Duits-Nederlandse Overeenkomst: Wordt een rechtsvordering ingesteld tegen een overheid namens welke een openbaar lichaam heeft gehandeld, dan dient dit deze overheid te vrijwaren van aansprakelijkheid jegens derden. Hoewel ik de zinsnede in artikel 10 lid 3 Duits-Nederlandse Overeenkomst 'namens welke een openbaar lichaam heeft gehandeld' niet goed kan plaatsen, zal de aansprakelijkheid in beginsel slechts betrekking kunnen hebben op feitelijk handelen van het openbaar lichaam en derhalve een actie uit onrechtmatige daad betreffen. Mogelijk is toch niet uitgesloten, dat aansprakelijkheid woortvloeit uit contracten die burgers rechtstreeks aangaan met een openbaar lichaam ('dat uit naam van de deelnemende overheden' handelt), dat privaatrechtelijke rechtspersoon-lijkheid heeft. Het zal vaker zo zijn, dat de burger te maken krijgt met zijn eigen overheid, die besluiten van het openbaar lichaam omzet/doorvoert. In het geval een deelnemende overheid besluitvorming wan het openbaar lichaam al dan niet (juist) doorvoert/omzet, kan een burger zich op die besluitvorming van het openbaar lichaam in een civiele c.q. administratiefrechtelijke procedure jegens die overheid beroepen. Hierbij sluit de genoemde vrijwaringsregeling aan.

Omdat bij de centrumgemeente de verantwoordelijkheid bij de mandans ligt, zal de burger zelfs indien duidelijk in strijd is gehandeld door de buitenlandse overheid met de verplichtingen voortvloeiend uit de mandaatsverhouding, bij zijn eigen overheid, die immers de verantwoordelijkheid draagt, en zijn eigen rechter verhaal dienen te halen (art. 10 lid 1 Duits-Nederlandse Overeenkomst). Zijn overheid zal dan eventueel op de buitenlandse overheid verhaal kunnen halen. Hierin voorziet artikel 6 lid 3 Duits-Nederlandse Overeenkomst door te bepalen, dat de betreffende overheden de vrijwaring ten opzichte van de aansprakelijkheid van derden dienen te regelen in de gemeenschappelijke regeling omtrent de centrumgemeente.

Omtrent de aansprakelijkheid van het gemeenschappelijk orgaan is niets geregeld. Zo het al mogelijk is dat dit niet rechtspersoonlijkheid bezittend orgaan iets doet wat juri-

\section{1. (...vervolg)}

De rest van de Toelichting in deze bij de Nederlands-Duitse Overeenkomst is nogal cryptisch: "Voor zover net in eigen natm is gehandeld (vgl. artikel 6 lid 2 Duits-Nader handse Overeenkomst, RS), is de regeling declaratoir, ondat woor de instantie namens welke is gehandeld, uit dat handelen in elk geval rechten en plichter voortwloefen. Voor zower in eigen nam, mar ten behoeve van een ander is gehandeld, is de regeling constitutief, maar slechts in die zin dat het aantal instanties tot welke men zijh axmspraken kan richten word uitgebreid, niet dat er een nieuwe rechtsgrond voor de aanspradk in hei leven word geroepen. Inhoudelijk richt de arnspratk zich natar her reeds geldende recht en is or siechs sprake wan verruming in die zin dat nu ook de instantie namens welke is gehandeld kan worden aangesproken (dit kon toch al, ondat het om mandaat gaat!, RS)... Nasst de araspraken ingevolge het serste Wid warborgt het tweede lid ook aansprakelikheid jegens het openbaar licham of de territoriate gemeenschap of autoriteit die feitelijk handelen. Voor zover taken niet in eigen naam worden behartigd, zou de feitelijk handelende instantie in de zin van een constitutieve regeling medeansprakelijk zijn. 00k op dit punt worden echter geen niewwe regelingen inzake de dansprakelikheid in het leven geroepen, maar reeds bestaande regelinger (tweede lid, tweede volxin) verruimd wat betreft de instantie tot wie men zijn aanspraken kan richten." 
disch relevant is, zullen derden bij (hun eigen) deelnemende overheden verhaal dienen te halen.

\section{De Duits-Nederlandse Overeenkomst en de bepalingen in het Grundgesetz inzake exteme betrekkingen en verdragssluiting}

\section{a. Inleiding}

In het kader van de goedkeuring van de Benelux-Overeenkomst is in België de mogelijke strijd ervan met enkele Belgische grondwetsbepalingen aan de orde geweest. De Toelichting bij de Duits-Nederlandse Overeenkomst verwijst naar enkele bepalingen inzake externe betrekkingen van het Grundgesetz en geeft aan dat deze bepalingen van invloed zijn (geweest) op de (beperkte) bevoegdheden van het openbaar lichaam alsmede een rol hebben gespeeld ten aanzien van de kring van overheden, die op basis van de DuitsNederlandse Overeenkomst grensoverschrijdend kunnen samenwerken. In Nederland is de Duits-Nederlandse Overeenkomst evenals de Benelux-Overeenkomst stilzwijgend goedgekeurd. In de Toelichtende nota bij de Duits-Nederlandse Overeenkomst is door de Nederlandse regering over de beperktere reikwijdte van de Duits-Nederlandse Overeenkomst in het perspectief van het Grundgesetz niet meer gesteld dan reeds in de Toelichting bij de Duits-Nederlandse Overeenkomst is gesteld. Ook in Nedersaksen en Noordrijn-Westfalen is tijdens de goedkeuring door de Landtag eigenlijk niets hieraan toegevoegd. Vooraleer in deze op de Toelichting wordt ingegaan (\$ 4.D.7.c.), zullen de relevante bepalingen van het Grundgesetz de revue passeren (\$ 4.D.7.b.). Bedacht moet worden dat het bij de bespreking van het Grund-gesetz gaat om de bepalingen, zoals die luidden ten tijde van het sluiten en de goedkeuring van de Duits-Nederlandse Overeenkomst. Inmiddels is het Grundgesetz enigszins gewijzigd wat betreft internationale betrekkingen en verdragssluiting.

Op die wijziging wordt kort ingegaan (\& 4.D.7.d.).

Wat betreft de publiekrechtelijke decentrale grensoverschrijdende samenwerking in het persectief van de Nederlandse Grondwet kan verwezen worden naar hetgeen in \$ 5.D.7 in hoofdstuk 5 gesteld is. Hetgeen daar is geschreven, is ook hier van toepassing.

\section{b. De bepalingen in het Grundgesetz inzake externe betrekkingen en verdragssluiting}

Inzake de internationale betrekkingen van Duitsland waren ten tijde van het sluiten en de goedkeuring van de Duits-Nederlandse Overeenkomst de artikelen 24,32 en 59 Grundgesetz, zoals hier aangegeven, het meest van belang. ${ }^{52}$

Artikel 24 Grundgesetz:

"(1) Der Buma kann durch Gesetz Hohe tsirechto aut zwischenstathche Einrichtungen übertragen.

(2) Der Bund kann sich zur Wahrung des Friedens einem System gegenseinger kollektiver Sicherheit einordnen; wird hierbei in die Beschrankungenseiner Hoheitsrechte einwilligen, die eine friedliche und dauerhafte Ordnung in Europa und zwischen den Volkern der Welt herbeifuhren und sicherm.

52. Artikel 25 Grundgesetz, in combinatie met artikel 59 (2) Grundgesetz, regelt de verhouding van het volkenrechit tot het nationale rech. Het is van minder belang daar hier op in te gan. Zie hiervoor hoofidstik 3 \&. 
(3) Zur Regelung zwischenstatlicher Sreitigkeiten wird der Bund Vereinbaringen uber eine allgemeine, unfossende, obligatorische intemationale Scheidsgerichtsbarkeit beitreten." ${ }^{3}$

Het eerste lid is hier van belang. Bij een 'zwischenstaatliche Einrichtung' gaat het om een supranationaal verband, opgericht bij verdrag en daarin bevoegd verklaard supranationale soevereiniteit op het territoir van de deelnemende staten uit te oefenen. ${ }^{54}$ Daarbij is geen nationale wetgeving noodzakelijk om deze uitoefening van Hoheitsrechte - "Hoheitsrechte verleihen die Befugnisse, Rechtsverhältnisse, die an sich der Staatlichen Rechtsordnung unterliegen, einseitig zu gestalten ${ }^{45}$ - te bewerkstelligen. Het is de Bond, die de bevoegdheid tot (Europese) integratie op basis van artikel 24 (1) Grundgesetz heeft. Een Land kan ook niet met toestemming van de Bund een verdrag sluiten dat tot een dergelijke overdracht van soevereiniteitsrechten leidt. ${ }^{56}$ Gezien het feit dat het vooral betrekking heeft op de Europese Gemeenschappen ${ }^{57}$, is het de vraag of artikel 24 Grundgesetz voor grensoverschrijdende samenwerking tussen decentrale overheden van toepassing is. Deze vraag wordt in \$4.D.7.c. behandeld.

In de Kehler Hafen-uitspraak van het Bundesverfassungsgericht is artikel 24 Grundgesetz (alsmede art. 32 Grundgesetz) aan de orde geweest in verband met een door het Land Baden-Württemberg (D) en de Port Autonome de Strasbourg $(F)$ gesloten overeenkomst tot het instellen van een publiekrechtelijke instantie, inzake de uitoefening van een gemeenschappelijk beheer van de Kehlerhafen/Port de Strasbourg. ${ }^{58}$ Enerzijds maakt deze uitspraak duidelijk, dat (decentrale) overheden niet in plaats van de Bond (zonder machtiging) volkenrechtelijke overeenkomsten kunnen sluiten. Dit volgt uit het feit dat zij als ondergeschikte overheden niet als subjecten van volkenrecht aangemerkt kunnen worden. ${ }^{59}$ "Damit fehlt es auch an jeder Anknüp fungsmöglichkeit für das Völkerrecht, soweit nicht die Träger auswärtiger Gewalt primär also der Bund (Art. 32 I Grundgesetz), partiell auch die Länder (Art. 32 III GG) - die Partizipation der kommunalen Gebietskörperschaften an ihren auswärtigen Kompetenzen begründen. Dazu bedarf es einer gesetzlichen Grundlage, wie sie weder vom Bund noch von den Bundesländern geschaffen worden ist." ${ }^{10}$ Anderzijds sluit deze uitspraak op voorhand niet uit "dat decentrale overheden, geen besluiten met een uitwerking naar het buitenland kunnen nemen: "Entscheidend für die rechtliche Zulässigkeit der konkreten Massnahme "kommunaler Aus" senpolitik" ist vielmehr, ob es sich dabei - erstens - (noch) um eine "Angelegenheit der

53. De leden 2 en 3 zijn in casu minder van belang en zwllen hier net werder behandeld worden.

54. M. Zueeg, in: Kommentar zum Grundgesetz fur die Bundesrepublik Deutschland, Reihe Alternativkonmentare, Band 1, 1984, Artikel 24 (1) Grundgesef, p. 169: "Damit ist die Ausschliensigkeit statudicher Herrschaf in Hoheitsbereich des States durchbrochen."

55. M. Zuleeg in: Kommentar zum Grundgesetz, a.w., Arikel 24 (1) Grundgesetz, p. 174; Voor deze 'Rechesske mit unmitelbaner inuerstatichen Wirkung", zie ook: Chr. Tomuschat, in: Kommentar zum Bonner Grundgesetz (losbladig). Artikel 24 Grundgesetz, p. 37.

56. M. Zuleeg, in: Kommentar zum Grundgesetz, a.w., Artikel 24 (1) Grundgesetz, p. 177; Chr. Tomu-

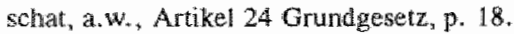

57. Chr. Tomuschat, w. w. Artikel 24 Grundgesetz, p. 22 juncto 77 \%.

58. BVerfGE 2,347 .

59. BVerfGE 2,347, p. 374. In casu hadden de partijen in eigen nam (en niet 'stellwertretend' voor de staat) de owereenkomst gesloten.

60. H. Heberlein, Die Rechtsprechung des BVerfG und des BVerwG zur "kommunalen Aussenpolitik", NVwZ $1992 / 6, p, 343$. 
örtlichen Gemeinschaft" handelt und - zweitens - ob dadurch die Träger auswärtiger Gewalt bei der Wahrnehmung der ihnen durch die Verfassung zugewiesenen Kompetenzen beeinträchtigt werden." " ${ }^{61}$ Het eerste aspect is in latere jurisprudentie van het Bundesverfassungsgericht aldus vitgewerkt dat "Angelegenheiten der örtlichen Gemeinschaft" zijn: "diejenigen Bedürfnisse und Interessen, die in der örtlichen Gemeinschaft wurzeln oder auf sie einen spezifischen Bezug haben, die also den Gemeindeeinwohnern als solchen gemeinsam sind, indem sie das Zusammenleben und -wohnen der Menschen in der (politischen) Gemeinde betreffen." ${ }^{62}$ Bij het tweede aspect zal het van de aard van de materie en de ernst van de inbreuk afhangen in hoeverre de politiek van de Bund in het gedrang komt. ${ }^{63}$ Indien dit het geval is, zal het Land in het kader van de Bundestreue de decentrale overheden tot de orde dienen te roepen. ${ }^{54} \mathrm{Bij}$ deze buitenlandse betrekkingen gaat het veeal om een (eenzijdig) handelen van decentrale overheden, dat mogelijk conflicteert met geformuleerd buitenlands beleid van de centrale overheid. Voor Nederland kan in dit verband gewezen worden op de (spontane) vernietigingsbesluiten van de Kroon b.v. inzake gemeentelijke ontwikkelingssamen werking en antiapartheidsbeleid. ${ }^{65}$ Een en ander kan natuurlijk ook van toepassing zijn ten aanzien wan de grensoverschrijdende samenwerking in het kader van publiekrechtelijke afspraken. ${ }^{66}$ Het gaat hierbij immers om een vorm van betrekkingen met het buitenland. Daarbij gaat het in tegenstelling tot het voorgaande om afspraken in het kader van de hun toegewezen bevoegdheden, weliswaar niet met hun eigen Nederlandse nabuuroverheden maar met die vlak over de grens b.v. inzake milieu en ruimtelijke ordening. Als hierover beleid op centraal niveau is geformuleerd, dienen de decentrale overheden uiteraard binnen dit beleid te opereren. Als het handelen van de decentrale overheden zich niet met dit beleid verdraagt, zal de centrale overheid in het kader van de staatsrechtelijke toezichtsverhoudingen er zorg voor dragen dat de rechtskracht hieraan komt te ontvallen. Daarbij maakt het niet eens uit of er privaatrechtelijk dan wel publiekrechtelijk gehandeld wordt. Als afspraken van Nederlandse decentrale overheden inzake grensoverschrijdende samenwerking met Belgische of Duitse counterparts in het kader van dit hoger toezicht vernietigd

61. H. Heberlein, a.w., p. 544 .

62. BVerfOE 79, 127, p. 151 . Dazu gehört auch ... das Gebat, die Leistungstähigkeit der Gebietskörperschaft für deren stetige Aufgabener fullung zu wahren und die Schranken Vermogerwirtschaftsrecht zu beachten." H. Heberlein, a.w., p. 544. Hij stelt dat de jurisprudentie van het BVerwG op dit pun hierrnee in overeenstemming is, H. Herbertein, a.w., p. 547 .

63. Voor enkele woorbeelden op het terrein wan vredespolitiek door gemeenten kan werwezen worden naar H. Heberlein, a.w. p. 544 e.v.

64. "Weil dem Bund keme Einwirkung auf die Gemeinden zustehe, erwachse den Ländern aus dem Grundsatz bundesfreundlichen Verhaltens die Rechtspflicht, won einer gegemäber den Gemeinden bestehenden Befugnis Gebrauch zu machen, "un eine Störung der grundgesetzlichen Ordnung zu beseitigen, zu deren Beseitigung der Bund mangels eigener Kompetenz nicht imstande" sei.", H. Heberlein, a.w., p. 544.

65. Zie b.v.: W. Wijzenbroek, Kunnen gemeenten zelstandig buitenlands beleid voeren, Bestuir rur.2/1988, p. 48-52; P.H. var der Tang-kan Loenen, Inventarisatie spontane vernietigings-besluitern wan de Kroon 1990-1991-1992, Gemeentesten 6966, p. 277-283.

Voor zover nagegaan, zijn mij voor Belgiè geen vernietigingsbesluten in verband met "buitenlandse" betrekkingen van decentrale overheden bekend an (daarom) ontbrekt ook literatun in deze.

66. De Jong rangschikt decentralle grensoverschrijdende samemerking onder 'buitenlands beteid", H.G. de Jong, De bevoegdheid tot het voeren van buttenlands beleid, Grensoverschrijding door parlement en gemeenten, in: Gegeven de Grondwet; 1988 , p. 152. 
worden, dan zal dat mijns inziens verband houden met het feit dat woor het aangaan ervan een rechtsgrondslag ontbreekt. On die reden zal de Kroon b. $v$. een besluit van de gemeente Heerlen kunnen vernietigen, waarbij Heerlen aan de stad Aken de vaststelling delegeert van een bestemmingsplan voor Heerlens grondgebied ten behoeve van een gezamenlijk grensoverschrijdend bedrijventerrein. ${ }^{67}$ In het licht van de grensoverschrijdende samenwerking ligt de reden voor vernietiging veel meer in de afwezige wettelijke grondslagen dan in mogelijke strijd met het algemeen belang vanwege een mogelijk conflict met centraal beleid (dat dergelijke afspraken verbiedt of $b, v$. voorbehoudt aan de centrale overheid) of dat het niet zou passen binnen het gemeentelijk belang. ${ }^{38}$ Overigens is het zo, dat al zeker wanaf het begin van de tachtiger jaren de decentrale grensoverschrijdende samenwerking gestimuleerd wordt door de centrale overheid. Op die grond zal decentraal grensoverschrijdend handelen sec (los van de inhoud) niet snel conflicteren met het algemeen belang. Als het niet zou passen binnen het gemeentelijk belang, dan zou het gehele nationale samenwerkingsrecht ter discussie kumnen komen te staan.

Met het bestaan van de Benelux-Overeenkomst en de Duits-Nederlandse Overeenkomst zijn er wettelijke grondslagen voor decentraal grensover-schrijdend handelen. Het bestuurlijk toezicht dient te waarborgen dat dit handelen over de grenzen binnen die kaders plaatswindt.

Grensoverschrijdende samenwerking door decentrale overheden in het kader van autonome en sectorbevoegdheden impliceert in de eerste plaats een mogelijke binding woor die decentrale overheden. Dat dit handelen daarmee niet per se als volkenrechtelijk aangemerkt dient te worden en dus de staat bindt, is aangegeven in hoofdstuk $2 \& 4$.

Artikel 32 Grundgesetz:

"(1) Die Pflege der Beziehungen zu auswärtigen Staaten ist Sache des Bundes.

(2) Vor dem Abschlusse eines Vertrages, der die besonderen Verhältnisse eines Landes berilhrt, ist das Land rechtzeitig zu hören.

(3) Sowteil die Länder für Gesetzgebung zuständig sind, können sie mit zustimmung der Bundesregierung mit auswärtigen Staten Verträge abschliessen."

Deze bepaling, die wordt benadrukt door de artikelen 73(1) en $87(1)$ Grundgesetz legt het primaat inzake externe betrekkingen met andere staten (en andere subjecten wan volkenrecht) en meer in het bijzonder het sluiten van verdragen bij de Bond. Privaatrechtelijke betrekkingen worden geacht - er is dan in beginsel geen sprake van de uitoefening van "hoheiticher Gewalt" - niet onder de werking van artikel 32 Grundgesetz te vallen. Overigens kan ook de decentrale grensoverschrijdende samenwerking als een niet-volkenrechtelijk maar eerder (trans)nationaalrechtelijk fenomeen gezien worden, waardoor dit buiten de werking van artikel 32 Grundgesetz valt. ${ }^{69}$ Het is in beginsel

67. Tenzijer een wettelike grondslag is, is de situatie niet anders als dit in platis van Aken een adngrenzende Nederlandse gemeente zou zija. De rechter zal in een eventuele rechtsgang (tegen de beslissing van de Kroon) eveneens de on whettigheid waststellen.

68. Zie woor de criteria 'algemeen belang" en 'gemeentelijke huishouding' ( $=$ gemeentelijk belang), $A$. W. Heringa, T. Knoop Pathuis, De gemeente en bet buitenlands beleid, NJCM 1989, p. 668-669.

69. "Bereits das Kehler Hafen-Urteil des BVerfG von 1953 hat aber shon auswartige Gewalt von den transmationalen Beziehungen innerstaatlicher offenthch-rechthicher Körperschaften abgegrenzt." $H$. Heberlein, a.w., p. 547. Vgl. Zuleeg, in: Kommentar zum Grundgesetz, an, , Artikel 32(3) Grundgesetz, p. 219-221; U. Beyerlin, Rechtsprobleme (. ), a.w., o.a. p. 387. 
mogelijk dat de Bond in het kader van zijn volkenrechtelijke competentie aan Landsorganen of organen van andere overheden bevoegdheden (b.v. het voeren van bepaalde onderhandel ingen e.d.) owerdraagt. Op basis van het tweede lid van artikel 32 Grundgesetz is bij het afsluiten van verdragen door de Bond in participatie van de Länder voorzien. ${ }^{70}$

Het derde lid geeft de Länder, voorzover zij (uitsluitend) bevoegd zijn voor de wetgeving - er is niet sprake van een koppeling aan de Verwaltungskompetenz ${ }^{71}$ - in deze, de competentie tot het afslutiten van verdragen. De toestemming van de Bond betekent overigens niet dat het een verdrag van de Bond wordt. Het onthouden van toestemming door de Bond maakt het onmogelijk "dat de Länder verplichtingen aangaan. Geldt het voorgaande voor het afsluiten van werdragen, het omzetten van verdrags verplichtingen in dit verband in het interne recht gebeurt aan de hand van de interne competentieverdeling, waarwoor wordt verwezen naar het gestelde sub artikel 59 Grundgesetz.

Vaak zal het zo zijn, dat de Länder niet uitsluitend tot wetgeving bevoegd zijn en daardoor niet alleen maar samen met de Bond verdragen sluiten. ${ }^{72}$ Dit zou bijvoorbeeld het geval kunnen zijn bij decentrale samenwerking, die niet tot bepaalde aangelegenheden (van de Länder) is afgebakend. De relatie tussen artikel 32 Grundgesetz met artikel 24 Grundgesetz ligt hierin, dat de Länder niet wia verdragen publiekrechtelijke bevoegdheden op tussenstatelijke organisaties kumnen overdragen. Hiervoor is op basis van artikel 24 Grundgesetz een wet vatn de Bond nodig.

Daar waar het niet om volkenrechtelijke verdragen gaat, wordt het aangaan van externe betrekkingen geplaatst binnen het kader van de Bundestreue (art. 31 en art. 87(1) Grundgesetz). Op basis van de Kehler Hafen-uitspraak is het mogelijk dat ook de Länder buiten het stelsel van artikel 32 Grundgesetz (niet-volkenrechtelijke) overeenkomsten sluiten met decentrale overheden in het buitenland. Naast privaatrechtel ijke overeenkomsten gaat het hier vooral om de zogenaamde Verwaltungsabkommen. De reikwijdte van de bevoegdheid tot het afsluiten erwan is niet geheel duidelijk en daarmee is de afbam kening met volkenrechtelijke verdragen eveneens niet zo makkelijk te maken. ${ }^{73}$ Voor het afsluiten ervan door de Länder dienen zij qua inhoud in ieder geval binnen de uitsluitende (bestuurs)bevoegdheid van de Länder te vallen. ${ }^{74}$ De standpunten in de Duitse literatuur over deze rechtsfiguur lopen uiteen. In de rechtspraak (met name door het Bundesverfassungsgericht) is hierover tot nog toe niet beslist. Gezien de toch wel onduidelijke status wordt hier slechts uitgegaan van de mogelijkheid tot het afsluiten ervan door de Länder, zonder daarbij dieper op de precieze afbakening met Verwal-tungsab-

70. Overigens word hier niet nader op het Lindauer Abkommen ingegaan dat in een bepaalde coördinatie tussen Bond en Lander voorziet. Hierover: U. Fastenrath, Kompetenzwerteilung im Bereich der auswärtgen Gewall, $1986, \mathrm{p} .163 ; \mathrm{R}$. Bleicher, Statsgrenzentibersche tende Raurnordnung und Landesplanumg, 1981 , p. 207 e.v.

71. Onder de Verwaltungskompetenz kan ook de uhtwoering van wetgewing wan de Bond vallen. De Bond bliff ten aanzien dakrvan bevoegd verdragen af te sluiten.

72. Zie in dit verband b. $b_{n}$. Grotefels, Gemeinsame grenziberschreitende Regionalplanung zwischen der Bundestepublik Deutschland und einem Grenzmachbarstaat, Am Beispiel Nordrhein-Westfalen und Niederlande, 1992, p. $43-50$.

73. Zie b.v. R. Bleicher, a.w., p. 202.

74. R. Bleicher, a.w., p. 203, knoopt met name ook aan bij de (uitshitende) wetgevingsbevoegdheid. Daarnaxst zou ook anngeknoopt kunnen worden bij de bestuursbevoegdheid. 
kommen van de Bond en de afbakening met volkenrechtelijke verdragen in te gaan. 75 Het verschil tussen verdragen in het kader van wetgevingsbevoegdheden en overeenkomsten in het kader van bestuurs-bevoegdheden is met name van belang voor het afsluiten en de goedkeuring ervan. Hiervoor is artikel 59 Grundgesetz van belang.

Artikel 59 Grundgesetz:

(1) Der Bundespräsident vertritt den Bund wolkerrechilich. Er schliesst im Namen des Bundes die Vertrage mit auswärigen Statem. Er beglaubigt und empfämgt die Gesandten.

(2) Vertriage, welche die politischen Beziehningendes Bundes regeln ader sich auf Gegenstände der Bundesgesetzgebung beziehen, bedïfen der Zustimmung oder der Mitwirkung der jeweils fü die Bundagesetzgebung zuständigen Körperschaften in der Form eines Bundesgesetzesin Für Verwalmugsabkommen gelten die Vor" schriften wber die Bundesverwaltung entsprechend."

Regelt artikel 32 Grundgesetz de Verbandskompetenz, in artikel 59 Grundgesetz staat de Organkompetenz centraal. De president sluit de verdragen, terwijl de goedkeuring van verdragen die de Gesetzgebung betreffen bij de Bundestag berust. ${ }^{76}$ Wat betreft het sluiten van de verdragen door de Länder regelt de Landesverfassung de 'Organkompetenz:. Voor het afsluiten van verdragen in het kader van de Gesetzgebung is dit in de regel de Ministerpräsident en voor de goedkeuring ervan de Landtag. Voor NoordrijnWestfallen en Nedersaksen is dit geregeld in de artikelen 57 en 66 van de Verfassung für das Land Nordrhein-Westfalen respectievelijk artikel 35 Niedersachsische Verfassung. Hierop is in \$2.C.2 van dit hoofdstuk al ingegaan.

c. De Duits-Nederlandse Overeenkomst en de bepalingen in het Grundgesetz inzake externe betrekkingen en verdragssluiting

De Duits-Nederlandse Overeenkomst kent een tweetal beperkingen, die samenhangen met het bepaalde in het Grundgesetz. Het betreft het ontbreken van burgers bindende bevoegdheden van het openbaar lichaam (1) alsmede het uitzonderen van de Länder van de werking van de Duits-Nederlandse Overeenkomst (2).

1. In de Toelichting bij de Duits-Nederlandse Overeenkomst wordt ten aanzien van de onmogelijkheid van het openbaar lichaam (artikel 5 Duits-Nederlandse Overeenkomst) burgers bindende besluiten te nemen, gesteld:

De bepalingen watborgen deat openbare lichamen in een andere Overeakomstshitende Stat geen de burger biadende beslissingen kunner nemen. Volgens Duits recht nag de owerdracht van bewogdheden van regeling en foestun door da Bond met inachtoeming wan artikel 24 , eerste lid, Dutse Grondwet (Grundgegelz), slechts

75. In deze kam owerigens nog verwezen worden nat het gestelde in hoofdstuk $2 \& 2$ met betrekking to do positio van deelstaten alsmede in hoofdstuk 2 \& inzake de infernationale administratieve akkoorden.

76. In somige gevallen is ook goedkeuring door de Bundesrat vereist, M. Zuleeg. in: Kommentar zum Grundgezetz, a.w., Artikel 59, Grundgesetz p. 237.

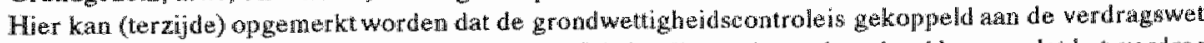
ter (ratificatie) van en niet an het verdrag zelf. Dit impliceert het wolgende. Als, woondat het verdrag gaat gelden, le ongrondwettigheid wan de verdragswet door het BVerfo wordt vastgesteld, kati de bindende kracht net in het leven worden geroepen. Wordt de ongrondwethigheid door het Bundesverfassungsgericht wastgesteld, madat het verdrag bindend is geworden, dan blijf het volkenrachelijk gelden. De consequentie hier wan zal zijn, dat in het licht van artikel 31 (1) GeBet BVarG het Grundgesetz amgepast dent te worden. Wgl. Zuleeg, in: Kommentar zan Grundgesetz, a.w., Arthel 59 Grund-gesetz, p. $235-236$. 
gescheden an internationale organisaties, zodat deze rechtstreeke warking hebben in het gebied van de Bondsrepubliek. Een dergeligke overuracht is de deelstaten niet toegestan, ook niet in het kader van artikel 32, derde lid, wan de Duitse Grondwei. Internationale organisaties zijn overigens organisaties die bij wolkenrethtijke overeenkomst tussen staten (subjecten van wolkenitecht) tot stand komen en zelf wolkenrechtelike rechisbevoeguheid hebben. Zij zijn vergelijkbaar met de volkenrechtelijke organisaties, waraan ingevolge artikel 92 van de Nederlandse Grondwet bij of krachtens verdrag bevoegdheden tot wetgewing, bestur en rechtsprak kunnen worden opgedragen. Het onderhavige openbaar lichaam is niet een dergelijke, buj wolkenrechtelike overeenkomst opgerichte, mutnationale organ satie" $"$

Als een verdrag overdracht van soevereiniteit aan een "zwischenstaathiche Einrichtung" dient te bewerkstelligen, dan is hiervoor wetgeving van de Bond krachtens artikel 24 Grundgeselz noodzakelik. Voor dit verdrag zal in beginsel op basis van artikel 59 Grundgesetz de goedkeuring van de Bundestag vereist zijn. De Toelichting bij de DuitsNederlandse Overeenkomst gaat ervan uit, dat het bij het openbaar lichaam op basis van de Duits-Nederlandse Overeenkomst niet gaat om een dergelijke 'zwischenstaatliche Einrichtung'. Gezien de eerder adigegewen strekking van artikel 24 Grundgesetz, dat vooral op volkenrechtelijke en supranationaalrechtelijke organisaties ziet, is dit juist. Daarbij wond artikel 24 Grundgesetz zo geinterpreteerd dat buiten dit artikel geen overdracht van soevereiniteit mogelijk is. ${ }^{79}$ Het is mijns inziens nog mar de vraag of buiten artikel 24 Grundgesetz geen overdracht van burgers bindende publiekrechtelijke bevoegdheden $b . y$. in de vorm van delegatic van bevoegdheden van decentrale overheden aan butenlandse decentrale overheden of aan een door deze overheden opgericht samenwerkingswerband kan plaatsvinden. Dit geldt te meer aangezien de rechtsbescherming voor de burger volgens zijn eigen interne recht blijf verlopen en ook het toezicht volgens het interne recht intact bliff. Hierdoor wordt het handelen van de buitenlandse overheid of een in het buitenland gelegen gemeenschappelijk openbaar lichaam op éen lijn gesteld met dat van binnenlandse overheden. Mits er voorzien is in een wettelijke grondslag, biedt met name het gestelde ten anzien wan de Kehler Hafen-uitspraak in deze toch zeker mogelijkheden. Die wettelijke grondslag kan uiteraard een verdrag zijn. Nu artikel 24 Grundgesetz hier niet van toepassing is, zou het gegeven, dat de Bond verdragspartij bij de Duits-Nederlandse Overeenkomst is, moeten voortvloeien uit artikel 32 Grundgesetz. Op basis hiervan kunnen de Länder een werdrag mer Nederland shuiten om in wettelijke grondslagen te voorzien voor (beperkte) publliekrechtelijke afspraken tussen Duitse en Nederlandse overheden. Immers het zijn in beginsel de Länder, die ten aanzien van de decenirale overheden en met name de gemeenten, over wetgevingsbevoegdheden beschikken en op het handellen van de decentrale owerheden toezien.

77. Toelichting bij de Duits-Nederlandse Overeenkomst, a.w., p. 24. Hetzeldile geldt woor de overeenkomsten ex artikel 6 . In de toelichüng op artikel 6 is bepald: "De op grond van de Overeenkomst in het leven geroepen speciale tregeling sluit delegatie van bevoegdheden de burger bindende beslissingen te nemen wit." (...) "Vampege de reeds in de toelichting bij artikel 5 uiteengezettegrondwettelike redenen en toelichting bij de artikelen 24 en 32 van de Duitse Grond wet kunnen naat Duits recht bevoegdheden tot het nemen wan ale burger bindende beslissingen niet worden gedelegeerd aan niet-Duitse instanties die geen wnternationale organisaties zijn." "Toellichting bij de Duits-Nederlundse Overeenkomst, a.w., p. 27.

78. Grotefels acht de toepasselijkheid van artikel 24 Grundgesetz wel van toepassing op b.v. een grensoverschrijdend orgaar/lichaam, dat een ruimtelijk plan vaststelt, dat bindend is in Nederland en NoordrijnWestfalen, S. Grotetels, a.w., p. 55 .

79. B.v. Chr. Tomuschat, a.w., nr. 44.

80. Zie ook: I. Bauer, Grenzüberschreitende Zusammenarbeit, Städte- und Gemeinderat, 8/1991, p. 232. 
woorzien in een wettelijke basis voor de grensoverschrijdende publiekrechtelijke samenwerking in de Landswetgeving, zonder de noodzakelijkheid van een verdrag, zou in dat perspectief voldoende kunnen zijn. Nederland zal dan natuurlijk eveneens een wettelijke regeling moeten treffen. Overigens zal, gezien het feit dat de decentrale grensoverschrijdende samenwerking niet beperkt is tot bepaalde aangelegenheden, wellicht naast Länder-ook in het kader van uitvoering van Bondsaangellegenheden samengewerkt worden. Dit verklaart waarschijnlijk het feit dat naast de Länder Nedersaksen en NoordrijnWestfalen ook de Bond partij is bij de Duits-Nederlandse Overeenkomst. In dit verband dient erop gewezen te worden, dat er slechts een bekendmaking van de inwerkingtreding van de Duits-Nederlandse Overeenkomst heeft plaats gevonden door de Bond. Op Bondsniv eau is in tegenstelling tot Nedersaksen en Noordrijn-Westfalen geen goedkeuringsprocedure gevolgd. ${ }^{81}$ Het feit dat er op Bondsniveau geen goedkeuring heeft plaats gevonden, kan eigenlijk al!een maar impliceren dat het voor de Bond om een verdrag gaat, dat niet tot de wetgevende aangelegenheden van de Bond behoort c.q. een politiek verdrag is (vgl. artikel 59(2) Grundgesetz). ${ }^{82}$ Het medesluiten door de Bond van de Duits-Nederlandse Overeenkomst is in dat perspectief weinig zinvol en gebeurt waarschijnlijk alleen maar omdat de Bond zijn primaat inzake de externe betrekkingen wenst te onderstrepen.

2. Het is aannemelijk dat de uitzondering van de Länder van de werking van de DuitsNederlandse Overeenkomst eveneens in het licht van het Grundgesetz geplaatst moet worden, daar waar in de Toelichting bij de Duits-Nederlandse Overeenkomst wordt gesteld:

"Op de door dit verdrag respectievelijk deze Overeenkomst geregelde terreinen is het aan Duitse zijde juridisch niet mogehijk en is er praktisch geen behoefte aan de reikwijdte wan deze Overeenkomst uit te breiden tot federale staatsinstellingen en staatsinstellingen op deelstaatni vean. Mutatis mutandis geldt dit ook voor instellingen en organen van de Nederlandse rijksoverheid. Een regeling van de samenwerking van staatsinstellingen in deze overeenkomst zou ook niet te werenigen zijn met het systeem en de structuur van de Overeenkomst. Het is bovendien niet denkbaar dat federale autoriteiten of autoriteiten op deelstaatnixeau of ook de Nederlandse rijksowerheid rechtstreeks gebruik kunnen maken van het in de Overeenkomst voorziene instrument " $Z$ weckverband" (gemeenschappelijke regeling waar bij een openbaar lichaam is ingesteld). De Kaderovereenkomst van Madrid betreft overigens ook alleen samenwerking tussen lokale of regionale territoriale gemeenschappen of aucoriteiten." "B?

Waarom de Länder uitgezonderd zijn van de werking van de Duits-Nederlandse Overeenkomst, is mij niet geheel duidelijk. De Länder zijn immers wel degelijk (vanuit volkenrechtelijk oogpunt) als regionale territoriale autoriteiten te beschouwen al was het maar vanwege de toch beperkte mogelijkheden tot autonoom volkenrechtelijk hande-

81. Het Bundesgesetzblatt bevar slechts een bekendmaking inzake de inwerkingtreding, BGBI. 1993, S. 843. Een parlementaire goedkeuringswet is er wel in Nedersaken en Noordrijn-Westalen (vgl. noot 27 van dit loofdstuk).

82. De Duits-Nederlandse Overeenkomst is hiermee en zelfo lot beschoren als de European Outline Convention: wel een bekendmaking van de inwerkingtreding mat geen goedkeuring in de zin varn artikel 59(2) Grundgesetz. Vg1. U. Beyerlin, Rechtsprobleme (..), a.w., p. 118, noot 196.

83. Toelichting bij de Duits-Nederlandse Overeenkomst, a.w., p. 6-7. Dit cital illustreert overigerns mijns inziens (nogmaals) de niet toepasselijkheid wan artikel 24 Grundgesetz op de decentrale grensoversehrijdende samemerking op basis van de Duits-Nederlandse Overeenkomst. 
len. ${ }^{84}$ Mijns inziens wordt daarom in de Toelichting bij de Duits-Nederlandse Overeenkomst de Nederlandse rijksoverheid c.q. de Duitse Bond ten onrechte op één lijn gesteld met autoriteiten op deelstaatniveau. Zouden de Nederlandse Staat en de Duitse Bond onder de werking van de Duits-Nederlandse Overeenkomst zijn gebracht, dan zou artikel 24 Grundgesetz van toepassing kunnen zijn geweest. Bij de toepasselijkheid van de Duits-Nederlandse Overeenkomst op de Länder is dat nog niet evident. De reden van de uitsluiting van de Länder is niet gegeven, maar zou verband kunnen houden met de vrees van de Bond dat door het onbeperkt kunnen sluiten door de Länder van (andere dan volkenrechtelijke) overeenkomsten met decentrale overheden, het grondwettelijk primaat inzake buitenlandse betrekkingen van de Bond te zeer in het gevaar kont (art. 32(1) Grundgesetz). Daarnaast willen de Länder waarschijnlijk niet op eén lijn gesteld worden met Gemeinden en Kreise en samenwerkingsverbanden van die overheden.

Met name in het licht van de mogelijkheden van samenwerking tussen de Länder onderling, die in $\$ 2$.C. van dit hoofdstuk zijn beschreven, valt niet goed te begrijpen waarom deze uitgezonderd zijn van de werking van de Duits-Nederlandse Overeenkomst. Dit geldt te meer omdat de Länder (in het bijzonder de Regierungsbezirke) met de Nederlandse provincies vergelijkbare sectorbevoegdheden hebben. Er moet maar afgewacht worden of zij, indien zij dat willen, toch niet buiten het grondwettelijk stelsel inzake volkenrechtelijk handelen - op basis van de Kehler Hafen-uitspraak is dit immers niet uitgesloten - grensoverschrijdend zullen gaan samenwerken.

d. De gewijzigde bepalingen in het Grundgesetz inzake externe betrekkingen en verdragssluiting

Eind 1992 is het Duitse Grundgesetz o.a. gewijzigd inzake verdragssluiting en externe betrekkingen. ${ }^{85}$ Hier wordt kort de belangrijkste wijziging weergegeven.

Vooral het nieuwe artikel 24(1a) Grundgesetz maakt de positie van de Länder inzake decentrale grensoverschrijdende samenwerking belangrijker. Het vroegere artikel 24 Grundgesetz is gedeeltelijk in het nieuwe artikel 23 Grundgesetz uitgewerkt. Het nieuwe artikel 23 regelt de realisering van de Europese Unie. Daarbij is de participatie van de Bond en de Länder geregeld. In het nieuwe artikel 24 Grundgesetz is lid 1(a) toegevoegd. Dit bepaalt:

"(1 howeit die Lunder fur die Ausibung der staatlichen Befugnisse und die Erfullung der stantlichen Ausgaben zuständ ig sind, könmensie mit Zustimmung der Bundesregierung Hoheitsrechte aul grenznachlarschaftiche Einriohtungen dibertragen."

De Länder kunnen (met toestemming van de Bond) 'grenznachbarschaftliche' - hier wordt niet de term ' $z$ wischenstaatliche' van artikel 24(1) Grundgesetz gebruikt - instanties in het leven roepen en hieraan publiekrechtelijke bevoegdheden toekennen.

84. Zie in dit verband het gestelde omtrent de werking van de European Outline Convention ten aanzien van de deelstaten win federale staten in hoofdstuk $3 \$ 2$.

85. Wet van $21-12-1992$, BGBI. I S. 2086 . 


\section{Overige tussen Duitsland en Nederland geldende regels inzake (decentrale) grensoverschrijdende samenwerking}

Tussen Duitsland en Nederland bestaan er naast de Duits-Nederlandse Overeenkomst regels, waarin grensoverschrijdende samenwerking in de vorm van wooral overleg-en afstemmingsverplichtingen een rol van betekenis speelt. Veelal gaat het hier om intergouvernementele samenwerking. Vanwege de mogelijke rol van decentrale overheden (denk aan: het zitting hebben in adviesorganen, het sluiten van de verdragen aanvullende uitvoeringso vereenkomsten en de praktische uitvoering van de verdragen) in deze alsmede het belang ervan yoor de grensoverschrijdende samenwerking in het algemeen wolgen hier de belangrijkste verdragen, waarwan de eerste twee genoemde zijn gebaseerd op het Algemeen Verdrag tussen het Koninkrijk der Nederlanden en de Bondsrepubliek Duitsland tot regeling van met de grens verband houdende vraagstukken en andere tussen beide landen bestaande problemen ${ }^{36}$. Waar mogelijk zal de Duits-Nederlandse Overeenkomst een aanwullende werking kunnen hebben ten aanzien van de te noemen samenwerkingsregels, b.v. inzake (verdere) formalisering van overleg.

A. VERDRAG TUSSEN HET KONINKRUK DER NEDERLANDEN EN DE BONDSREPUBLIEK DUTTSLAND NOPENS HET VERLOOP VAN DE GEMEENSCHAPPELUKE LANDSGRENS, DE GRENSWATEREN, HET GRONDBEZTT IN DE NABUHEID VAN DE GRENS, HET GRENSOVERSCHRIDEENDE VERKEER OVER LAND EN VIA BINNENWATEREN EN ANDERE MET DE GRENS VERBAND HOUDENDE VRAAGSTUKKEN, MET BILAGEN EN SLOTPROTOCOL. (GRENSVERDRAG) $^{87}$

Dit verdrag is met name van belang voor de samenwerking inzake de waterstaatkundige vraagstukken voor grenswateren, met uitzondering van de Rijn en de Dollard. ${ }^{88}$ Het hierin geregeld intergouvernementele overleg dient vooral plaats te vinden in de Permanente Nederlands-Duitse Grenswaterencommissie en haar subcommissies (art. 64). De Grenswaterencommissie heeft een adviserende taak en $k$ an $b . v$. aanbevelingen doen aan de regeringen en openbare lichamen. Zij dient ook in kennis te worden gesteld van maatregelen, welke de waterstaatkundige toestand op het grondgebied van de andere staat

86. Verdrag van 8-4-1960, Trb. 1960 nf. 67, he werking getreden $1.8-1963$, Trb. 1963 nr. 114 .

Op basis wan dit verdrag zijn andere werdragen gestoten, die betrekting hebben op grensowerschrijdende samemwerking, zoals de Overeenkomsi ussen het Koninkrijk der Nederlanden en de Bondsrepubliek Duitsland inzake het kleine grenswerkeer, 3-6-1960, Trb. 1960 mr. 162/TH. 1961 nr. 87. In thel kader van de grenswersahrijdende samemerking kan ook nog genoemd worden de overeenkomst tussen he: Kaninkigk der Nederlanden en de Bondsrepubliek Durisland nopens de samenwoeging van de grensconrole en de instelling wan gemeenschappelijke spoorwegstations of van grensaflosstations wan de Neder * lands-Duitse grens, 30-5-1958, Trb. 1958 nr. 81/Trb. 1961. nr. 95. Beide verdragen houden stechts zijdelings werband met grensoverschrijulende samemwerking cussen decentrale overheden en zijn in casu van minder belang. Zij worden hier niet verder behandeld.

87. Vendrag van 8-4-1960, Trb. $1960 \mathrm{Nr}$. 68, in werking getreden 1-8-1963, Trb. 1963, $114 \mathrm{l} 115$.

88. Op de samemerking in het Dollardgebied word in de volgende paragraaf kort ingegaan.

Bij de samemerking ten aanzien van de Rijn, gat het primair on interstatelike samemerkmg, waarbij decentrale overbeden geen rol val betekenis spelen. Hierop wordl dan ook net werder ingegaan. Zie herover, b.w. W. Brussaard e.a., Milieurecht, tweede druk, 1991, p. 527 e.v. 
kumen beinvloeden (art.60). Zij speelt tevens een rol in het kader van de in het verdrag geregelde geschillenbeslechting.

Voor de decentrale overheden is artikel 59 Grensverdrag van belang. Het bepaalt dat er voor afzonderlijke grenswateren overeenkomsten gesloten kunnen worden door de Verdragsluitende Partijen alsook tussen Nederland en de Länder Nedersaksen en Noordrijnland-Westfalen met toestemming van de Bondsregering. Met goedkeuring van de Regeringen van de Verdragsluitende Partijen kunnen de overeenkomsten ook gesloten worden door openbare lichamen. Enkele voorbeelden van door openbare lichamen gesloten overeenkomsten zijn: Overeenkomst tussen het Waterschap Roer en Overmaas en het Wasserverband Obere Wurm inzake het onderhoud van de Anselderbeek, Crombacherbeek en Blejjerheidebeek en van de daartoe behorende kunstwerken in het Nederlands-Duitse grensgebied; Overeenkomst tussen het Waterschap Roer en Overmaas en de Stadt Aachen inzake het onderhoud van de Selzerbeek en van de daartoe behorende kunstwerken in het Nederlands-Duitse grensgebied. ${ }^{8}$ Bij de publicatie van de beide overeenkomsten in het Tractatenblad is bepaald dat deze ingevolge additioneel artikel XXI, eerste lid, onderdeel $b$, van de Grondwet, juncto artikel 62 , eerste lid, onderdeel b, van de Grondwet naar de tekst wan 1972 niet de goedkeuring van de Staten-Generaal behoeven. ${ }^{90}$ Ook voor de overige in de bijlage bij dit proefschrift vermelde overeenkomsten op basis van artikel 59 Grensverdrag geldt, dat deze goedkeuring niet vereist is. In het licht van deze goedkeuringsprocedure zou aan deze overeenkomsten internationaal publiekrechtelijke status toebedacht kunnen worden. Anderzijds is op basis van de Wet houdende vaststelling van de Uitwoeringswet Nederlands-Duits Grensverdrag in deze veeleer sprake van een vorm wan toezicht van de Kroon, die niet afwijkt van het normale toezicht in het interne recht. In artikel 22 van deze Uitvoeringswet wordt bepaald: "Overeenkomsten, welke ingevolge het bepaalde in art. 59, lid 2 van het Grensverdrag door openbare lichamen worden gesloten, behoeven Onze goedkeuring, alvorens zij in werking treden." 91

Qua inhoud sluiten dergelijke overeenkomsten mijns inziens aan bij nationaalrechtelijke (privaatrechtelijke) overeenkomsten. Het gaat immers om onderhoudso vereenkomsten, waarbij in dat verband tussen de owerheden (waterbeheerders) over en weer (vermogensrechtelijke) rechten en verplichtingen - de ene partij neemt een onderhouds verplichting op zich voor een tegenprestatie van de andere partij o voortvloeien. Het gaat om zaken als het werbeteren van de afwatering (meestal op eigen territoir) door b.w. de bouw wan bepaalde werken en de verbreding van waterlopen, alsook om het zuiveren van de betteffencle waterstromen e.d. Hierbij is in enkele gevallen voorzien in de verplichting tot het opstellen wan verbeteringsplannen e.d. die de goedkeuring van toezichthoudende overheden behoeven (in Nederland in beginsel het dagelijks bestuur van de provincie en

89. Overkenkomsten van 25-941990, Trb. 1991 nt. 66.

Na de inwerkingtreding van het in de vorige noot vermelde werdrag zijn er diverse vergelijkbare overeenkomsten gesloten en in werking getreden. Een uitgebreid owerzicht van deze overeenkomsten is als bijlage bujgevoegd.

90. Op termin zal er ten anzien van de goedkeuring van werdragen een niewwe regeling komen, zie: Regeling betreffende de goedkeuring en bekendmaking van werdragen en de bekendmaking van bestujten var volkentechtelijhe organisaties (Rijkswet goedkeuring en bekendmalking werdragen), Tweede Kamer

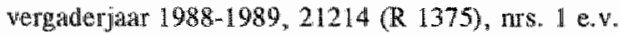

91. Wett wan 22-5-1963, Stbl. $1963,238$. 
in Duitsland in beginsel het Bezirk/Land). In enkele van deze overeenkomsten is expliciet bepaald, dat deze gelden binnen het raam van de vigerende wettelijke regelingen. Voor de overige blijkt dat uit de aard van de overeenkomsten zelf. Er wordt immers in beginsel geen wezenlijke verandering gebracht in de publiekrechtelijke bevoegdheidsuitoefening van de betreffende overheden, behalve misschien dat de leden van de op basis van de (meeste) overeenkomsten in te stellen gemeenschappelijke schouwcommissies ${ }^{92}$ tot bezichtiging van bepaalde beekvlakken over de grens kunnen overgaan. In de overeenkomsten is voor deze niets geregeld - het blijft bij kijken en niet aankomen - omtrent de daadwerkelijke uitoefening van bevoegdheden (jegens burgers) op het territoir van de buitenlandse waterbeheerder. Aangenomen kan worden dat daartoe de publiekrechtelijke bevoegdheid ontbreekt en deze in handen van de binnenlandse overheid is blijwen liggen. Er kan gesteld worden dat er op basis van deze overeenkomsten geen overdracht van publiekrechtelijke bevoegdheden plaatsvindt van een Nederlandse- aan een Duitste waterbeheerder vice versa. In het uiterste geval gaat het hier om overeenkomsten met afspraken over de uitoefening van bevoegdheden zoals b.v. het dulden van (denk aan: het betreden en berijden van bermen) en het uitvoeren van bepaalde werkzaamheden (denk aan: afvoeren specie/aanleg van bepaalde werken). In dat verband moet ook gezien worden het in een tweetal overeenkomsten bepaalde dat iedere partij de andere de gelegenheid geeft zich uit te spreken alvorens zij een publiekrechtelijke vergunning afgeeft, welke op de overeenkomst betrekking heeft. De overeenkomsten houden het midden tussen onderhoudso vereenkomsten en overeenkomsten in het kader van de invulling van discretionaire bevoegdheden, zoals aangegeven bij de administratieve afspraken op basis van de Benelux-Overeenkomst, in hoofdstuk $5 \& 5 . D .2 .^{93}$ Qua wijze van geschillenbeslechting is er sprake van volkenrechtelijke aspecten. Bij geschillen in het kader van de overeenkomsten (b.v. wanneer in de schouwcommissies niet tot overeenstemming wordt gekomen) zal namelijk in eerste instantie de subcommissie I van de Permanente Nederlands-Duitse Grenswaterencommissie beslissen. Daarna kan het Scheidsgerecht een uitspraak doen, als een van de Regeringen dit wenst (artikel 71). Conform artikel 72 beslist het Scheidsgerecht op basis van hoofdstuk 4 van het Grensverdrag, de overeenkomst(en) op basis van artikel 59 en de algemene regels van volkenrecht. Met name deze laatste toetsingsgrond illustreert het mogelijk volkenrechtelijk karakter van de op basis van het Grensverdrag gesloten overeenkomsten. Er is overigens veel voor te zeggen dat deze geschillenregeling vooral geschreven is voor geschillen tussen regeringen. Gezien de inhoud van de overeenkomsten moet een nationaalrechtelij-

92. Op de werkzaanheden van de schouwcommissies is het Reglement van Orde van de Permaneme Nederlands-Duitse Grenswaterencommissie, voor zover dit geldt woor de door deze Grenswatercommissie ingestelde subcommissies, wan loepassing.

93. Het priaatrechtelijk karakter van deze overeenkomsien, onk al gaat het hier on zaken betreffende het publiek domein, is, voor de Nederlandse situatie zeker, niet uigesloten. Het publiek domein roept als het ware een recht van beheer c.q. een plicht tot onderhoud in thet leven: HR 7-6-1918, NJ 1918, 717 (Hofwijuer). Zie ook: G. E. van Maanen, Publiek domein en het belang wan de overheid bij bodemunering. Een ongewasschen varken?, oratie, 1990, p. 15 . Indien geen onaanvard bare doorkrusing van publiekrechtelijke wegen plaatsvindt, kan de overheid deze privaatrechtelijke wegen inslaan, b.w. het afsluiten van priwatrechtelijke overeenkomsten: HR 26-1-1990, AB 1990, 143 (Stati/Windmill). Zie hicrover b.x.: A.Q.C. Tak, Publiek domein, overlueidscontract en rechterlike wetshandhaving, NTB, 90/2, p. 265. Zie ook HR 8-7-1991 Gemeentestem 6930, p. 546 e.*. (K an A/Lelystad). 
ke (civiele) rechtsgang door met name de openbare lichamen zelf mijns inziens niet uitgesloten worden geacht. In geen enkele van de (in de bijlage bij dit proefschrift) naar aanleiding van artikel 59 Grensverdrag genoemde overeenkomsten is omtrent een rechtsgang (of arbitrage) iets bepaald. Zelfs wanneer het om puur privaatrechtelijke overeenkomsten gaat, kunnen er toch problemen ontstaan wat betreft de bevoegde rechter en het toepasselijke recht. In deze kan verwezen worden naar het gestelde in hoofdstuk 5 \& 5.D.6.a. juncto hoofdstuk $6 \$ 4$.D.6.a.

Heemskerk neemt mijns inziens geen duidelijk standpunt in over de volkenrechtelijke dan wel nationaalrechtelijke status van de op basis van artikel 59 Grenswerdrag gesloten overeenkomsten door decentrale overheden. Enerzijds stelt hij, dat het vereiste van goedkeuring door de regeringen "van belang is met het oog op het volkenrechtelijk aspect (zijnde het scheppen van een gelijke rechtsband tussen de staten)...' Anderzijds stelt hij, refererend aan informatie wan de Bundesminister des Innern, dat de juridische reikwijdte van de artikel 59 overeenkomsten in Duitsland "wel zelden de drempel van de volkenrechtelijke verdragsbetrekkingen bereikt. ${ }^{94}$ De Nederlandse regering heeft zich slechts expliciet uitgesproken over de afspraken tussen decentrale overheden, die al bestonden vó́r de inwerkingtreding van het Grensverdrag, en daarbij volkenrechtelijke aspecten niet uitgesloten. ${ }^{95}$ Ten aanzien van de op basis van het Grensverdrag gesloten overeenkomsten sluit de regering nadrukkelijk aan bij de context van het verdrag. Zo wijst zij in deze op de mogelijke toepasselijkheid van het Scheidsgerecht, de positie van de Grenswaterencommissie (ook) ten aanzien van de decentrale openbare lichamen, de directe betrokkenheid van de decentrale openbare lichamen in de subcommissies alsmede de ook in dat verband gellende schadevergoedingsbepaling van artikel 63 Grensverdrag. Hieruit moge iets van een volkenrechtelijk karakter blijken. ${ }^{96}$

Resumerend zou ik willen stellen dat de afspraken op basis van artikel 59 Grensverdrag in ieder geval in de praktijk niet zo ver (lijken te) gaan, om deze zonder meer als publiekrechtelijk aan te merken. In het uiterste geval zijn deze te kwalificeren zoals die van artikel 6 lid $\mathbb{1}$ Duits-Nederlandse Overeenkomst. Van volkenrechtelijke overeenkomsten kan hier mijns inziens niet (snel) gesproken worden. Hiervoor wil ik tevens verwijzen naar het gestelde omtrent de administratieve akkoorden in hoofdstuk 2 sub 4 . Daar is gesteld dat grensoverschrijdend handelen van decentrale overheden weliswaar op een

94. W.F.A. Heemskerk, A.w., p. 182 respectievelijk 183.

95. In de Memorie wan Toelichting hield de Nederlandse regering een slag om de arm: "Enerzijds zijm de lokale antoriteiten op dit punt immers slechts in beperkte mate bewoegd. En anderzijds bestatan er geen algemene richtlijnen op het stuk wan de wederzijdse rechten en verplichtingen, met name wanneer aan de regeling belangrijke financiële lasten woor én der partijen zijn verbonden. Een andere moeilijkheid is het wraagstuk, welke wolkenrechtelijkebetekenis aan chergelijke tussen lagere publiekrechtelijkelichamen gesloten overeenkonsten moet worden toegekend, hetgeen zich in het bijzonder voordoet indien deze aanle iding geven tot geschillen." "MvT bij bet tussen het Koninkrijk der Nederlanden en de Bondsrepublick Duitsland gesloten Algemeen Verdrag, de verdragen, overeenkomsten en protocollen die daarvan deel uitmaken en wan enige te zelfdertijd gewisselde brieven, Tweede Kamer, zitting 1960-1961, $6250(\mathbb{R} 214)$, nr. 3, p. 7. Overigens is door de Nederlandse regering bepaald, "dat bevredigend werkende lokale overeenkomsten in beginsel onaangetast zullen worden gelaten en dat de commissie vooral haar aandacht zall richten op gevallen waarin nog geen regeling of samenwerking bestaat. ', MvA, ibid, Eerste Kamer, zitting 1962-1963, wr. 111 a, p. 4 .

96. MvT, abid, p. 11; MvA, ibid, Tweede Kamer, zitting 1962-1963, p. 9-10. 
verdrag gebaseerd kan zijn, maar dit handelen eerder als nationaal-dan volkenrechtelijk. aangemerkt dient te worden.

\section{B. EEMS-DOLLARDVERDRAG ${ }^{97}$}

Het Eems-Dollardgebied kent vanwege het feit dat de staatsgrens er niet duidelijk vastligt een bijzondere status. Het Eems-Dollardverdrag regelt vooral de samenwerking (tussen regeringen) ten aanzien van waterbouwkundige werkzaamheden. Er is hieryoor o.a. voorzien in een Eemscommissie, die een adviesfunctie heeft, inspecties houdt en beraadslaagt. Er zijn regels vastgelegd inzake gezamenlijk (politieel) toezicht. In dit ver band zal er veelal overleg met de plaatselijke en regionale overheden plaats vinden. Voorts is voorzien in een scheidsgerecht, dat op basis van artikel 53 beslist over geschillen op basis van het Eems-Dollardverdrag alsmede de algemene regels van volkenrecht. Hier kan nog worden vermeld, dat de goedkeuringsprocedure in Nederland van een hierop voortbouwend verdrag, namelijk het Verdrag tussen het Koninkrijk der Nederlanden en de Bondsrepubliek Duitsland inzake de samenwerking in het gebied van de Eems en de Dollard, alsmede in de aangrenzende gebieden (Samenwerkingsverdrag Eems-Dollard/Dollardha venverdrag) op het latste moment is stopgezet vanwege de nietreallisering van de aanleg van een haven aan Duitse zijde. "Dit verdrag voorzag nast de aanleg van een haven in vergaande vormen van samenwerking b.v. op milieugebied (het afstemmen van emissiewaarden, de sanering van lozingen, de aanwijzing van een grensowerschrijdend natuurgebied, een waarschuwingsplicht bij calamiteiten e.d.). Er was tevens voorzien in een Overlegcommissie Eems-Dollard alsmede een scheidsgerecht.

97. Verdrag wan 8-4-1960, Trb. 1960 nr. 69, in werking getreden 1-8-1963, Trb. 1963 nr. 114/116. Zie ook" Aarvullende Overeenkonst bij het Eems-Dollardwerdrag van 14-5-1962. Trb. 1962 nr. 54, in warking gedreden 1-8-1963, Trb. 1963 nr. 119.

98. Verdrag van 10-9-1984, Trb. 1984, nr 118. Het wetsvoorstel tot goedkeuring van dit verdrag is ingeprokken bij brief van de minister van buitenlandse zaken wan 19-7-1991. Eerste Kamer, vergaderjaar $1990-1991,19343$, nr. $^{2} 36$.

99. Over dit verdrag, zie b.v.: René Seerden, Het Dollardhavenverdrag en het internationali milieurech. ML $\mathrm{R} 1989 / 10, \mathrm{p} .400-409$.

Zie in dit verband ook het KB 19-2-1993, , ns. 93,001471, inzake een, in strijd met het Eems-Dollardwerdrag, vastgesteld bestemmingsplan door de gemeente Delfzijl wor het door Nederland en Duitsland berwiste gebied. 


\section{OVEREENKOMST TUSSEN HET KONINKRUK DER NEDERLANDEN EN DE BONDSREPUBLIEK DUTTSLAND INZAKE SAMENWERKING OP HET GEBIED VAN DE RUIMTELIJEE ORDENING ${ }^{100}$}

Het doel van dit verdrag is te komen tot samenwerking op het gebied van de ruimtelijke ordening binnen de Neclerlands-Duitse Commissie voor de ruimtelijke ordening. ${ }^{101} \mathrm{De}$ meeste bepalingen van het verdrag hebben betrekking op de inrichting en taken van deze commissie. Zij kan subcommissies en werkgroepen instellen (art. 5). Voor het noordelijk en zuidelijk gedeelte van het Nederlands-Duitse grensgebied functioneert de Subcommissie Noord respectievelijk Zuid, waarin naast vertegenwoordigers van de rijksoverheid ook die van decentrale overheden (kunnen) participeren. ${ }^{102} \mathrm{Al}$ deze commissies missen bevoegdheden om overheden c.q. burgers te binden. Zij hebben een overleg-, adviserende en coördinerende functie. ${ }^{103}$

Van belang is met name artikel 8 . Het regelt het opstellen van nadere overeenkomsten tussen de regering van Nederland en die van de deelstaat Nedersaksen of NoordrijnWestfalen met toestemming van de bondsregering, voorzover die deelstaten bevoegd zijn op het gebied van de desbetreffende wetgeving. De toestemming van de Bond is te plaatsen in het kader van artikel 32 Grundgesetz.

\section{OVEREENKOMST TUSSEN HET KONINKRIJK DER NEDERLANDEN EN DE DEELSTAAT NOORDRUN-WESTFALEN BETREFFENDE SAMENWERKING BUI DE STICHTING EN INRICHTING VAN EEN GRENSPARK MAAS-SWALM-NETTE ${ }^{104}$}

Dit verdrag is gebaseerd op artikel 8 van het in de vorige paragraaf vermelde verdrag. Het doel van deze overeenkomst is de ruimtelijke ontwikkeling in het betreffende gebied op elkaars behoeften af te stemmen. Deze overeenkomst kent een adviescommissie (art. 3), bestaande uit twaalf (door de regeringen benoende) leden. Deze moet o.a. gehoord worden, indien de overeenkomstsluitende partijen wijzigingen aanbrengen in de bestemming/bescherming van het binnen het grenspark gelegen grondgebied. In dit verband zullen de decentrale overheden in het desbetreffende gebied een belangrijke rol spelen.

100. Verdrag wan 30-3-1976, Trb. 1976 nu. 75, in werking getreden 1-2-1977, Trb. 1977 ar. 6. In dit verband kan b.v. gewezen worden op het Dutse Raumordnugsgesetz, dat bij plannen die grens. overschrijdende uitwerking hebben in afstemming voorziet ( 4 Abs. 6 Rammordnungs-gesetz). Die afstemming betreft in ieder gewal tijdige informatieverschafing en consulatie.

1.01. Voor een uilgebreidere beschrîying van de Duits-Nederlandse commussie voor de ruimtelijke ordening, zie". P. Simons, Grensoverschrijdendesamenwerking in de ruimtelijke ordening tussen de Bondstepubliek Duitsland en Nederland, Bestuurswetenschappen 1988/4, p. 244-248, 5. Grotefels, a.w., p. 24-30.

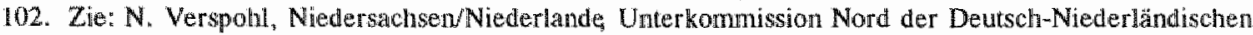
Raumord mugskommission respectievelijk E. Reis, Nordrhein-West falen/Niederlande, Unterkommission Std der Deutsch-Niederländischen Raumordnungskommission, in: Grenzübergreifende Raumplanung. a.w., p. $57-73$ respectickelijk $74-86$.

103. Simons kwalificeert de commissie als "een vrij lichte vorm van samerwerking, welke thet stadium wan wederzijdo intomatie en consultatie niet te boven gat", P. Sirnons, an. w. p. 248 .

104. Verdrag van 30-3-1976, Trt. 1976 ni. 76, in werking getreden 1-3-1977, trb. 1977. nr. 8, 2ke hierover: S. Grotefels, a.w. p. $30-31$. 


\section{E. OVEREENKOMST TUSSEN HET KONINKRUK DER NEDERLANDEN EN DE BONDS- REPUBLIEK DUITSLAND INZAKE WEDERZUDSE BUSTANDSVERLENING BU HET BESTRIJDEN VAN RAMPEN, ZWARE ONGEVALLEN DAAR ONDER BEGREPEN, METI PROTOCOL ${ }^{105}$}

Dit verdrag is vergelijkbaar met het tussen Nederland en België gesloten en in hoofdstuk 5 in $\$ 6 . E$. besproken verdrag in deze. Het verdrag regelt de te volgen procedure voor het verzoeken en verlenen van bijstand bij het bestrijden van rampen.

De in artikel 3 eerste lid onder a bevoegde organen voor het indienen van een verzoek. om bijstand alsmede voor het doen uitvoeren ervan zijn de Commissaris der Koningin en de Minister van Binnenlandse Zaken van de deelstaat, indien het betreft het verlenen van bijstand door en aan deelstaten en provincies die aan elkaar grenzen, respectievelijk de Ministers van Binnenllandse Zaken van de Bondsrepubliek Duitsland en Nederland. De artikelen 4 tot en met 10 bevatten regels omtrent de uitvoering van de feitelijke bijstand, de grensformaliteiten voor personen en materieel, het gebruik van luchtvaartuigen en kosten en schadevergoeding. Artikel 11 regelt het sluiten van aanwullende overeenkomsten. Artikel 12 is met name van belang voor gemeenten. Deze bepaling is bijna gelijkluidend aan die van artikel 12 uit de in hoofdstuk $5 \$ 6$. E vermelde BelgischeNederlandse Overeenkomst in deze. Voor gemeenten aan weerszijden van de grens wordt de mogelijkheid geopend afspraken te maken over hulp verlening bij rampen en zware ongevallen.

Hier dient nog gewezen te worden op de verhouding van deze Overeenkomst met de Duits-Nederlandse Overeenkomst. Er wordt vanuit gegaan dat, alleen daar waar de Overeenkomst qua inhoud de ruimte laat, het mogelijk is dat decentrale overheden met betrekking tot de rampen en ongevallenbestrijding samenwerkingsregelingen treffen op basis van de Duits-Nederlandse Overeenkomst. ${ }^{106}$ Het is afwachten hoe een en ander geïnterpreteerd moet worden en in hoeverre de verder gaande mogelijkheden van de Duits-Nederlandse Overeenkomst in deze al dan niet gehanteerd kumnen worden door de decentrale overheden.

\section{\$6. Samenvatting en conclusies}

Tot de inwerkingtreding van de Duits-Nederlandse Overeenkomst inzake decentrale grensoverschrijdende samenwerking speelde de grensoverschrijdende samenwerking wooral op intergouvernementeel niveau. Het gaat veelal om samenwerkingswormen, waarbij geen overdracht van publiekrechtelijke bevoegdheden plaatsvindt. Overleg. advisering en soms coördinatie staan centraal. Bij de Grenswaterencommissie, de Nederlands-Duitse Ruimtelijke Ordenings(sub)commissie(s) alsook de Adviescommissie inzake het grenspark Maas-Swalm-Nette gaat het om adviescommissies. Omtrent de wijze van

105. Verdrag van 7-6-1988, Trb. 1988 m. 95 (nog niet in werking getreden).

in deze kan b.v. ook verwezen worden op het (multilaterale) Verdrag imzake de verlening van bijstand in het geval van een nucleair ongevall of een calamiteit met radioactive stoffen, almede het verdrag inzake vroegtijdige kennisgeving van een nucleair ongeval, beide van 26-9-1986, Trb. 1986, nr. 165 respectievelijk 164. Beide zijn in werking getreden 24-10-1991, Trb. 1991, nrs. 140 en 141.

106. Zie nota wan Toelichting, opgenomen in Editie Schumrman en Jordens, Rampenwe!, nr. 87, p. 151. 
functioneren van deze commissies - het gaat in wezen om ambtelijk en mogelijk bestuurlijk overleg - komt weinig of niets in de openbaarheid. Om die reden is niet ingegaan op het functioneren van de betreffende owerleg en coördinatiestructuren. Een actievere rol van de decentrale overheden in deze intergouvernementeel getinte samenwerking lijkt alleen al hierom gewenst, omdat zij in de regel de bevoegde instanties zijn om het in dit kader totstand gekomene uit te voeren. Artikel 59 Grensverdrag kent een vrij zelfstandige rol voor de decentrale overheden, veelal waterschappien/W asserverbände, aan weerszijden van de Nederlands-Duitse grens. Zij kunnen overeenkomsten met elkaar sluiten. Het karakter van deze overeenkomsten is niet zonder meer als publiekrechtelijk aan te merken.

Met de inwerkingtreding van de Duits-Nederlandse Overeenkomst inzake decentrale grensoverschrijdende samenwerking zal er een meer algemene mogelijkheid bestaan voor decentrale overheden om publiekrechtelijke grensoverschrijdende afspraken te maken. Daarbij geldt evenwel een heel belangrijke restrictie: "Deze Overeenkomst sluit uit dat territoriale gemeenschappen of autoriteiten van een andere Overeenkomstsluitende Staat bevoegd worden verklaard de burger bindende beslissingen op vreemd staatsgebied te nemen." ${ }^{107}$ Het openbaar lichaam op basis van de Duits-Nederlandse Overeenkomst wijkt daarmee af van de vergelijkbare vorm van samenwerking in het Duitse (NoordrijnWestfaalse en Nedersaksische) en Nederlandse recht. De Noordrijn-Westfaalse en Nedersaksische Zweckverbände en het Nederlandse Wgr-openbaar lichaam kunnen in principe wel de burger bindende besluiten nemen. Een en ander geldt ten opzichte van de Duitse wetgeving ook voor de overeenkomsten op basis van artikel 6 Duits-Nederlandse Overeenkomst. De (offentlich-rechtliche) Vereinbarung op basis van de Duitse wetgeving kent in tegenstelling tot de overeenkomsten op basis van artikel 6 Duits-Nederlandse Overeenkomst wel delegatie - het Gesetz über kommunale Gemeinschaftsarbeit kent expliciet de mandaatvariant, terwijl deze wellicht niet onmogelijk is op basis van het Zweckverbandgesetz - van bevoegdheden aan een deelnemende overheid. Het voorgaande illustreert ook het verschil tussen het gemeenschappelijk orgaan op basis van de Duits-Nederlandse Overeenkomst en het Wgr-gemeenschappelijk orgaan. Dit laatste heeft in tegenstelling tot het eerste bestuursbevoegdheden. De Toelichting bij de DuitsNederlandse Overeenkomst gaat er vanuit, dat op bas is van de artikelen 24/32 Grundgesetz in beginsel de burger bindende besluiten slechts genomen kunnen worden door Duitse overheden c.q. internationale organisaties. Over mogelijke gelijkstelling met de eerste wordt, b. $w$ in de Toelichting bij de Duits-Nederlandse Overeenkomst, niet gesproken. Het openbaar lichaam zou, nu het geen internationale organisatie is, toch zeker kumnen aansluiten bij de nationale decentrale overheden, al naar gelang de plaats van de zetel bij de Duitse c.q. Nederlandse of allebei? Dit past in het licht van de in de DuitsNederlandse Overeenkomst in dit verband opgenomen toezichtsregeling en rechtsbescherming voor derden. Overigens is de precieze toepasselijkheid en het nut van het additionele toezicht vanuit het rechtsstelsel van de zetel van het openbaar lichaam (in combinatie met het toezicht ten aanzien van de deelnemende overheden vanuit de diverse rechtsstelsels) niet helemaal duidelijk. Ook is niet duidelijk hoever de binding van de deelnemende overheden door het openbaar lichaam kan gaan.

107. Toelichting bij de Duits-Nederlandse Overeenkonst, a.w., p. 9. 
Het is opmerkelijk, dat bepaalde overheden buiten de werking van de Duits-Nederlandse Owereenkomst wallen. Zo zullen de van de samenwerking uitgezonderde waterschappen in Nederland niet rechtstreeks met de eveneens uitgezonderde Wasser-en Bodenverbände in Duitsland (publiekrechtelijk) kunnen samenwerken. Als de overeenkomsten tussen laatste genoemde overheden op basis van het Grensverdrag dezelfde strekking kunnen hebben als de vormen van samenwerking op basis van de Duits-Nederlandse Overeenkomst is het witsluiten van deze overheden natuurlijk niet zo erg. Gezien het karakter van deze overeenkomsten op basis van het Grenswerdrag is dit nog maar de vraag. De uitsluiting van de desbetreffende decentrale overheden is dan mijns inziens niet terecht. Voor de Nederlandse provincies is er niet echt een Duitse tegenvoeter nu de Länder, en in het bijzonder de (gedeconcentreerde) Regierungsbezirke uitgezonderd zijn van de werking van de Duits-Nederlandse Overeenkomst. Zijn de Länder niet direct op hetzelfde niveau te stellen als de andere in de Duits-Nederlandse Overeenkomst genoemde overheden, de uitsluiting ervan zou op zijn minst nader onderbouwd kunnen zijn.

Het nieuwe van de Duits-Nederlandse Overeenkomst voor de decentrale grensoverschr ijdende publiekrechtelijke samenwerking is gelegen in de mogelijkheid dat er een openbaar lichaam opgericht kan worden, dat de deelnemende overheden bindende besluiten kan nemen en daarmee de deelnemende overheden kan verplichten deze jegens burgers uit te voeren. Het is de vraag wanneer daadwerkelijk bevoegdheden aan het openbaar lichaam op basis van de Duits-Nederlandse Overeenkomst worden overgedragen. Zoals aangegeven in hoofdstuk 5 blijkt, dat het oprichten van een openbaar lichaam op basis van de Benelux-Overeenkomst, dat rechtstreeks de burgers bindende besluiten kan nemen, in de praktijk nog niet aan de orde is. Het verschil tussen de (uitwoering van de) de Benelux-Overeenkomst en de Duits-Nederlandse Overeenkomst is op dit punt dan ook niet zo groot.

Hoewel in de Toelichting bij de Duits-Nederlandse Overeenkomst het publiekrechtelijke karakter van de samenwerking benadrukt wordt ${ }^{108}$, is de analogie met de publiekrechtelijk samenwerking tussen overheden in het interne recht naar mijn mening, wat genuanceerder. Het publiekrechtelijk karakter van het gemeenschappelijk orgaan is mijns inziens niet aanwezig. Voor de overeenkomst van artikel 6 lid 1 Duits-Nederlandse Overeenkomst is het publiekrechtelijk karakter ook niet zonder meer evident. Het sluiten van een verdrag, de Duits-Nederlandse Overeenkomst, moet met name geplaatst worden in het licht van de instelling van het openbaar lichaam en mogelijk ook de instelling wan de centrumgemeente (mandaat) en het feit dat op punten gederogeerd wordt aan de nationale wetgeving.

De samenwerking op basis van de Duits-Nederlandse Overeenkomst is evenals die op basis van de Benelux-Overeenkomst vrijwillig. Van deze Duits-Nederlandse Overeenkomst zal zeker een bepaalde de samenwerking bevorderende werking uitgaan, vooral ook omdat de Duitse en Nederlandse wetgeving inzake samenwerking alsmede de organieke wetgeving inzake de tot grensoverschrijdende samenwerking gerechtigde overheden met elkaar overeenkomt. Ten opzichte van de Benellux-Overeenkomst gaat de DuitsNederlandse Overeenkomst minder ver wat betreft de bedoelde (publiekrechtelijke) reikwijdte van de samenwerking. Ten aanzien van het toepasselijke recht op de samenwer- 
king lijkt deze Duits-Nederlandse Overeenkomst het in zoverre voor te hebben op de Benelux-Overeenkomst, dat met name in de sfeer van het toezicht de keuze voor én toepasselijk rechtsstelsel is gemaakt. Zoals aangegeven moet nog blijken of dit de problematiek van de confrontatie van rechtsstelsels wel vermindert. Net als met betrekking tot de Benelux-Overeenkomst geldt voor de Duits-Nederlandse Overeenkomst, dat de samenwerking in de praktijk uitgekristalliseerd dient te worden, woordat duidelijk is wat de precieze juridische reikwijdte erwan zal zijn. Op dat moment zal ook blijken in hoeverre de materięle bevoegdheden op de diverse beleidsterreinen tussen decentrale overheden in Nederland en Duitsland overeenstemmen. Zoals ook aangegeven ten aanzien van de Benelux-Overeenkomst is de sectorwetgeving in dit proefschrift geen onderwerp van bespreking. ${ }^{109}$ In figur 6 is een schematische vergelijking van de samenwerkingsvormen op basis wan de Duits-Nederlandse Overeenkomst en de Benelux-Overeenkomst aangegewen.

\section{figuur 6}

Vergelijking samenwerking Duits-Nederlandse Overeenkomst en Benelux-Overeenkomst

\begin{tabular}{|c|c|c|}
\hline Categorie & Benelux-Overeenkomst & $\begin{array}{l}\text { Duits-Nederlandse } \\
\text { Overeenkomst }\end{array}$ \\
\hline \multirow{3}{*}{$\begin{array}{l}\text { Samenwerkings- } \\
\text { vormen }\end{array}$} & Openbaar lichaam & Openbaar lichaam \\
\hline & $\begin{array}{l}\text { Burgers en owerheden } \\
\text { bindende bevoegdheden }\end{array}$ & $\begin{array}{l}\text { Overheden bindende } \\
\text { bevoegdheden }\end{array}$ \\
\hline & Gemeenschappelijk orgaan & Gemeenschappelijk orgaan \\
\hline \multirow[t]{3}{*}{ Bevoegdheden } & $\begin{array}{l}\text { Bestuursbevoegdheden } \\
\text { Geen regelgevingsbevoegdheid }\end{array}$ & $\begin{array}{l}\text { Geen bestuursbevoegdheden } \\
\text { Geen regelgevingsbevoegd- } \\
\text { heid }\end{array}$ \\
\hline & Administratieve afspraak & $\begin{array}{l}\text { Publiekrechtelijke } \\
\text { overeenkonst }\end{array}$ \\
\hline & $\begin{array}{l}\text { Overheden bindende besluiten } \\
\text { Geen delegatie van } \\
\text { bevoegdheden }\end{array}$ & $\begin{array}{l}\text { Overheden bindende besluiten } \\
\text { centrumgemeente/geen } \\
\text { delegatie van bevoegdheden }\end{array}$ \\
\hline Toezicht & $\begin{array}{l}\text { Volgens de nationale } \\
\text { rechtsstelsels }\end{array}$ & $\begin{array}{l}\text { Volgens de nationale } \\
\text { rechtsstelsels voor het } \\
\text { openbaar lichaam in } \\
\text { combinatie met plaats zetel }\end{array}$ \\
\hline
\end{tabular}

109. Zie voor een aanzet hiertoe inzake de (milheurechtelijke) samenwerking tussen noordelik Nederland en de Duitse deelstak Nedersaksen, B.W. Rawen, G.H.M. Tronp, Grensoversehrijdende samenwerking, 1993. 


\section{Hoofdstuk 7}

\section{Samenvatting, conclusies en aanbevelingen}

Aan het slot van de diverse hoofdstukken zijn reeds samenvattingen en conclusies opgenomen. Hiernaar wordt verwezen. In dit hoofdstuk volgen een summier samenvattend en concluderend antwoord op de in de algemene inleiding in hoofdstuk 1 geformuleerde probleemstelling en een aantal aanbevelingen.

\section{\$. Inleiding}

Tot voor kort kende het nationale recht van België, Nederland en Duitsland eigenlijk nauwelijks expliciete wettelijke grondslagen voor decentrale publiekrechtelijke grensoverschrijdende samenwerking. Als er al expliciete grondslagen bestonden, dan ging de samenwerking niet verder dan verplichtingen tot informatie/consultatie en vonden die hun basis, b.v. op milieurechtelijk terrein, in richtlijnen van de Europese Gemeenschappen alsmede in tussen Nederland en België respectievelijk Nederland en Duitsland geldende verdragen. Het Europees Handwest voor de Lokale Autonomie toont overigens

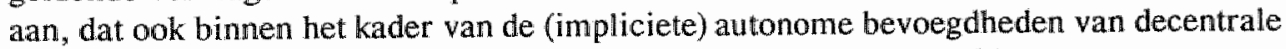
overheden, grensoverschrijdende samenwerking een plaats kan hebben.

Zeker voor publiekrechtelijke afspraken, waardoor rechten en plichten voor burgers kunnen ontstaan of waarbij inbreuken kunnen worden gemaakt op wettelijke bevoegd heidsverdelingen tussen overheden, zijn bovenstaande grondslagen onvoldoende. In dat werband werd in hoofdstuk 1 de volgende probleemstelling opgenomen:

Hebben Nederlandse decentrale overheden bevogdheden om met hun 'counterparts' in Belgie en Duitsland publiekrechtelijke afspraken re maken en, zo ja, binnen welk juridisch kader manifesteren zich die publiekrechelijke afspraken?

Voor verdergaande samenwerking tussen overheden is een aanvullende wettelijke basis, analoog aan die welke bestaat voor de vergelijkbare afspraken tussen decentrale overheden binnen éen staat, vereist. Het primaat om deze te verschaffen wordt geacht in beginsel bij de staten te liggen. Zij alleen kunnen de hun ondergeschikte besturen de bewoegdheid verlenen tot het maken van publiekrechtelijke afspraken met hun "counterparts" aan de andere kant van de grens. Een regeling tussen staten, een verdrag, is daarbij een voor de hand liggend middel. Middels een verdrag kunnen staten afspreken, dat (bepaalde van) de hen ondergeschikte besturen publiekrechtelijke afspraken kunnen maken. Als 
uitvoering van de European Outline Convention on Transfrontier Co-operation between Territorial Communities or Authorities, die door de staten kennelijk niet als een zodanige grondslag beschouwd wordr, zijn tot nu toe slechts enkele staten bereid geweest een algemene juridische basis in deze te creëren. Voor de Belgisch-Nederlandse decentrale samenwerking is dit gebeurd door een Benelux-Overeenkomst en voor de Duits-Nederlandse decentrale samenwerking in een Duits-Nederlandse Overeenkomst. Beide verdragen regelen behalve de bevoegdheid om samen te werken ook het juridische kader van die samenwerking, zoals de vormen van samenwerking , de juridische reikwijdte van de samenwerking, de beslechting van geschillen tussen overheden, het toezicht op de samenwerkende overheden, de rechtsbescherming voor burgers, e.d. Op basis wan deze verdragen beschikken de desbetreffende Nederlandse decentrale overheden over de bevoegdheid publiekrechtelijke afspraken te maken met hun 'counterparts' in België en Duitsland (Noordrijn-Westfalen en Nedersaksen). Deze bevoegdheid benadert die, welke op basis van het interne recht geldt voor het maken van publiekrechtelijke afspraken (vgl. hoofdstuk 1) tussen decentrale overheden binnen één staat, in aanzienlijke mate. Beide verdragen verklaren grotendeels het nationale recht van de samenwerkende overheden toepasselijk op de grensoverschrijdende samenwerking. Zoals aangegeven kennen de beide verdragen, die op enkele punten overigens verschillen, vooral door de wederzijdse toepasselijkheid van het nationale recht van de samenwerkende overheden, (belangrijke) knelpunten. De precieze reikwijdte ervan is niet overal even duidelijk, vooral omdat de interpretatie ervan - er zijn nog geen gerechtelijke uitspraken c.q. toezichtsbesluiten - nog op zich laat wachten. Overigens blijkt uit de tot nu toe gerealiseerde samenwerking, dat vooral aan de openbare lichamen nog geen overheden en burgers bindende bevoegdheden toegekend worden en dat daardoor de samenwerking over de grenzen in eerste instantie een niet bindend, doch geformaliseerd, overlegkarakter heeft.

\section{\$2. Samenvatting en conclusies}

Hier volgen hoofdstuksgewijs een samenvatting en conclusies ten aanzien van de in dit proefschrift behandelde aspecten van grensoverschrijdende publiekrechtelijke afspraken tussen decentrale overheden.

De toepasselijkheid van het volkenrecht op grensoverschrijdende publiekrechtelijke afspraken, waarbij overdracht wan (burgers en overheden bindende) bevoegdheden tussen decentrale overheden plaats vindt, is blijkens het gestelde in hoofdstuk 2 in beginsel beperkt tot het verschaffen van een juridische basis hiervoor door staten. Deze basis is vooral noodzakelijk voor die publiekrechtelijke afspraken waarbij bevoegdheden worden overgedragen aan nieuw te wormen samenwerkingsverbanden (die voor overheden en burgers bindende bevoegdheden hebben). Voor publiekrechtelijke afspraken over hoe door de respectievelijke overheden hun discretionaire bevoegdheden worden ingevuld en voor afspraken inzake het opzetten van overlegfora zonder beslissingsbevoegdheden is mijns inziens in de regel geen additionele verdragsrechtelijke grondslag vereist. Daar waar volkenrechtelijke verdragen de grondslag voor het aangaan van de samenwerking zijn, impliceert dit in de regel niet de toepasselijkheid van het volkenrecht op (de inhoud van) die afspraken. Een mogelijke toepasselijkheid van het volkenrecht op de decentrale grensoverschrijdende samenwerking is in hoofdstuk 2 vooral geplaatst in het licht van 
de internationale administratiewe akkoorden. Daarbij is ten aanzien van de juridische status van die akkoorden opgemerkt, dat hierwoor in beginsel moet worden aangeknoopt bij het internationale recht en de voor verdragen geldende eisen voor het sluiten ervan alsmede het daarop toepasselijke recht. In dit verband kan de conclusie getrokken worden dat op zijn minst vaker de (mogelijkheid van) toepasselijkheid van nationaal (publiek) recht op internationale administratieve akkoorden in het geding is. Anders gezegd: op het internationale niveau kunnen ook andere bindende afspraken dan verdragen bestaan.

In het verlengde wan het vorenstaande kan mijns inziens gesteld worden, dat de decentrale grensoverschrijdende samenwerking niet binnen het grondw ettelijke voorziene stelsel inzake externe/internationale betrekkingen is te plaatsen. Dit vloeit voort uit het (decentrale) overheidsniveau waarop wordt samengewerki, het feit dat er gehandeld wordt biimen lokale en regionale autonome en sectorbevoegdheden en uit het gegeven dat op de samenwerking het (wederzijds) nationale recht toepasselijk is. Anderzijds is in hoofdstuk 6 vastgesteld dat het natuurlijk niet uitgesloten is, dat de centrale overheid in het kader wan het algemene bestuurlijk/staatsrechtelijk toezicht tot vernietiging van besluiten van decentrale overheden in dit verband kan overgaan. De grondslag hiervoor zal dan eerder strijd met de wet (het ontbreken van wettelijke grondslagen) dan wel strijd met het algemeen c.q. gemeentelijk belang zijn en niet strijd met het grondw ettelijke primaat van de centrale overheid inzake externe/internationale betrekkingen.

In hoofdstuk 3 is aandacht besteed aan de rol van een aantal Europese organisaties ten aanzien van de decentrale grensoverschrijdende samenwerking en met name het voorzien in juridische grondslagen daarvoor. Daarbij is ingegaan op de zwakke juridische basis in deze van de in het kader van de Raad van Europa opgestelde European Outline Convention on Transfrontier Co-operation between Territorial Communities or Authorities. Thans is een aanvullend Protocol in voorbereiding dat in verdergaande mogelijkheden voor decentrale overheden in cleze voorziet en daardoor ook zal beantwoorden aan het in het Europese Handvest inzake Lokale Autonomie erkende recht in deze. Het supranationale karakter wan de Europese Gemeenschappen heeft er tot op heden niet toe geleid, dat in dat kader een algemene regeling voor grensoverschrijdende samenwerking tussen decentrale overheden is opgesteld. Het opstellen van een algemene regeling betreffende decentrale grensoverschrijdende samenwerking kan o.a. in het licht van het opbouwen van één Europa aan de basis (dicht bij de burger) en de uniformering van decentrale samenwerkingsvormen (in grensgebieden) in de diverse Lid-Staten gewenst zijn. Overigens manifesteert de rol van de Europese Gemeenschappen zich meer in de financiering van grensoverschrijdende samenwerking en ten aanzien van bepaalde lichtere vormen van samenwerking (overleg e.d.), zoals geregeld in milieu-richtlijnen. In dat perspectief valt de aan decentrale overheden toegedachte geringe rol op. In dit verband kan overigens opgemerkt worden dat decentrale overheden in het algemeen, hoewel zij belangrijke taken hebben op het gebied van het milieu, daar waar grensoverschrijdende samenwerking aan de orde is, langs het net vissen. Het zijn veelal de centrale overheden die (behalve in de richtlijnen van de Europese Gemeenschappen) ook in internationale milieuverdragen, b.v. die in het kader van de Economische Commissie voor Europa yan de Verenigde Naties, expliciet genoemd worden in deze en duidelijk moeten aangeven waar en hoe zij of de hen ondergeschikte besturen verplicht zijn aan de bepalingen van 
de betreffende verdragen te voldoen. Daarbij behouden de centrale overheden zich vaak, mijns inziens niet altijd terecht, het formele recht van grensoverschrijdende samenwerking voor. Het alles overlaten aan de 'verdragsluitende partijen' (in het perspectief van de Europese Gemeenschappen de 'Lid-Staten') is, daar waar de materiële uitvoering op decentraal niveau ligt, niet altijd effectief.

De rol van de Europese Gemeenschappen kan vooral van belang zijn voor de harmonisering van het materiële recht, hetgeen voor grensoverschrijdende samenwerking uiteraard van groot belang kan zijn. Deze harmonisering van nationale sectorwetgeving vormt evenwel geen onderwerp van bespreking.

In hoofdstuk 4 is de organisatie en zijn de bevoegdheden van de op basis van de Benelux-Overeenkomst en de Duits-Nederlandse Overeenkomst inzake decentrale grensoverschrijdende samenwerking (zie hoofdstukken 5 en 6) tot samenwerking gerechtigde overheden geschetst. Daarbij is vast komen te staan, dat zeker op gemeentelijk niveau de Belgisch-Nederlandse en de Duits-Nederlandse decentrale samenwerking niet als gevolg van werschillen in organieke wetgeving belemmerd zullen worden. Voor de $\mathrm{Ne}$ derlandse provincies geldt op dit punt hetzelfde in de Nederlands-Belgisch verhouding. Overigens kan als gevolg van de verschillen in bevoegdheden op basis van de sectorwetgeving die interprovinciale samenwerking over de Belgisch-Nederlandse grens problematisch worden. Problemen voor de samenwerking tussen Nederlandse provincies en Duitse overheden zijn er ook. In het kader van de decentrale grensoverschrijdende samenwerking zijn de Duitse equivalenten van de Nederlandse provincies niet direct voor handen.

Overigens kan hier gewezen worden op een verschil in nationale wetgeving, dat voor de continuitteit van de samenwerking in openbare lichamen van belang kan zijn. De zittingstermijnen van de gemeentelijke vertegenwoordigers voor dit openbaar lichaam is verschillend in de desbetreffende landen (in België 6 jaar/in Nederland $4 \mathrm{jaar} / \mathrm{in}$ Duitsland 5 jaar). Dit kan er toe leiden dat vaker (dan van de nationale besturen) de samenstelling van het openbaar lichaam zal wijzigen.

In de hoofdstukken 5 en 6 is de nationale dimensie van de publiekrechtelijke afspraken tussen decentrale overheden aan weerszijden van de grens aan de orde geweest. De in dit verband opgestelde verdragen, die voorzien in grondslagen voor samenwerking, verwijzen naar het hierop toepasselijke wederzijdse nationale recht. Bij het opstellen van de clesbetreffende Benelux-Overeenkomst is niet of nauwelijks rekening gehouden met het verschil tussen de samenwerking in Nederland op basis van de Wet gemeenschappelijke regelingen en de samenwerking in België op basis van de Wet betreffende de intercommunales. Omdat de samenwerking op basis van het nationale recht in hoge mate rïchtinggevend is voor de grensoverschrijdende samenwerking, moet de Benelux-Overeenkomst erg extensief geïnterpreteerd worden om aan haar doelstelling, namelijk de juridische basis voor publiekrechtelijke samenwerking, te kunnen beantwoorden.

Voor de desbetreffende Duits-Nederlandse Overeenkomst ontstaan door de verwijzing naar het Nederlandse en Duitse recht in deze minder problemen. Dit heeft te maken met het feit dat het interne recht van Duitsland (de deelstaten Noordrijn-Westfalen en Nedersaksen) en Nederiand inzake publiekrechtelijke samenwerking grotendeels overeenstemt. Hierdoor wordt de minder ver gaande reikwijdte van de samenwerking op basis 
van de Duits-Nederlandse Overeenkomst ten opzichte van de Benelux-Overeenkomst gecompenseerd.

Overigens bestaan er ten aanzien van de samenwerking op basis van deze beide verdragen nog diverse onduidelijkheden en problemen. Zo is in de Duits-Nederlandse Overeenkomst in tegenstelling tot de Benelux-Overeenkomst expliciet de collisieregel (bij geschillen tussen overheden) opgenomen, die bepaalt dat een overheid niet anders dan door zijn eigen rechter tot een doen of nalaten veroordeeld kan worden. Hierdoor ontstaat een over-en-weer verwijzing naar rechters. Dit probleem wordt in de Duits-Nederlandse Overeenkomst (gedeeltelijk) opgelost door de mogelijkheid van een arbitrale geschillenregeling tussen overheden. Hoewel deze collisieregel niet expliciet in de BeneluxOvereenkomst is opgenomen, is deze waarschijnlijk wel van toepassing, omdat het hier om een algemene volkenrechtelijke regel gaat. Het is afwachten of en in hoeverre het 'supranationale' Benelux-Gerechtshof deze collisieregel (gedeeltelijk) weet te doorbreken.

Andere problemen kunnen er bestaan naar aanleiding van de cumulatie van toezicht en de reikwijdte van de binding van de deeinemende overheden door het openbaar lichaam. In dat perspectief zal de samenwerking zich zeker in het begin wellicht concentreren op niet bindende besluitworming in overlegfora dan wel op de afspraken inzake discretionaire bevoegdheden.

Tot. slot kan hier gesteld worden, dat met name de formele kant van de samenwerking beschreven is, namelijk de bevoegdheid om samen te werken en het juridisch kader waar binnen dit dient te gebeuren. Uiteraard kunnen de in te brengen, materiële, sectorbewoegdheden zodanig verschillen, dat uiteindelijk het maken van publiekrechtelijke afspraken belemmerd wordt. In die gevallen zal harmonisatie van sectorwetgeving noodzakelijk zijn. Hierop is niet nader ingegaan.

\section{Aanbevelingen}

In het licht van het behandelde en de in de inleiding aangegeven maatschappelijke relevantie van de decentrale grensoverschrijdende samenwerking en in het bijzonder het maken van publiekrechtelijke afspraken worden tot slot de volgende aanbevelingen gedaan.

1. Ter benadrukking van de eigen positie en het belang van decentrale grensoverschrijdende samenwerking zou in Nederland (beter nog in Europees perspectief) een grondwettelijke verankering dienen plaats te vinden van de bevoegdheid voor decentrale overheden tot het maken van publiekrechtelijke afspraken met hun "counterparts' in het buitenland, waarbij aangegeven dient te worden dat de nadere uitwerking van het juridische kader in wetgeving dan wel verdragen moet plaatsvinden.

2. De positie van decentrale overheden betreffende grensoverschrijdende samenwerking dient ook buiten de toepassing van de samenwerking op basis van de Benelux-Overeenkomst en de Duits-Nederlandse Overeenkomst een meer fundamenteel karakter te krijgen. Daar waar deze overheden bepaalde materiële bevoegdheden uitvoeren, dienen zij (en niet per definitie de centrale overheid) in beginsel te beschikken over het daarbij behorende recht inzake grensoverschrijdende samenwerking. Met name 
bij de opstelling van verdragen en richtlijnen van de Europese Gemeenschappen dient de rol van de decentrale overheden meer benadrukt te worden.

3. Een uitbreiding van de werking van de Benelux-Overeenkomst en de Duits-Nederlandse Overeenkomst inzake decentrale grensoverschrijdende samenwerking ten aanzien van de Gewesten/Gemeenschappen respectievelijk de Länder dient, hoewel deze niet als decentrale overheden beschouwd kunnen worden, overwogen te worden. Zeker in het licht van de recente grondwetsherzieningen in België en Duitsland inzake verdragssluiting is dit mogelijk.

4. In verband met de verwijzing door de Benelux-Overeenkomst en de Duits-Nederlandse Overeenkomst inzake decentrale grensoverschrijdende samenwerking naar het wederzijds toepasselijke nationale recht en in het bijzonder het bestuurlijk toezicht, zijn nadere bepalingen in beide verdragen inzake coördinatie en zeker inzake toezichtsprocedures op zün plaats.

5. Gezien de problematiek wan de confrontatie van rechtsstelsels bij decentrale grensoverschrijdende samenwerking is, vooral met betrekking tot de geschillenbeslechting tussen overheden, een duidelijkere geschillenregeling gewenst. Daarbij is in geschillen die niet de rechten en plichten wan derden kunnen beïnvloeden een arbitrageregeling, die de rechtsgang naar de rechter uitsluit, te overwegen.

6. Het maken van publiekrechtelijke afspraken tussen overheden over de grenzen en met name die waarbij openbare lichamen in het leven worden geroepen moet gedragen worden door de bevolking. Het ontbreken wan betrokkenheid/invloed van de bevolking kan ertoe leiden dat op den duur deze afspraken schipbreuk leiden. Het feit dat b.v. bijgemeentelijke samenwerking de gemeenteraad moet instemmen met de instelling van b.v. een grensoverschrijdend openbaar lichaam is nog onvoldoende. Er dient een peilbare instemming van het wolk plaats te vinden b.v. via referenda. Daar waar minder zichtbare vormen van samenwerking zoals publiekrechtelijke afspraken inzake de invulling van discretionaire bevoegdheden gemaakt worden, is publikatie ervan een voorwarde voor opentheid en controle door burgers.

7. Aangezien de initiatieven ten aanzien van grensoverschrijdende samenwerking toenemen en daarmee de vormen en variaties ervan, is ten behoeve van de continuiteit structurering van de samenwerking - wie is met wat en hoe bezig - op den duur noodzakelijk. Wildgroei van grensoverschrijdende samenwerking dient voorkomen te worden.

8. Omdat er voor iedere vorm van grensoverschrijdende samenwerking een optimale schaalgrootte is, zal de te kiezen vorm van geval tot geval bepaald dienen te worden. Voor incidentele samenwerking tussen b.v. twee aan elkaar grenzende overheden is in de regel geen oprichting van een openbaar lichaam noodzakelijk, maar kan volstaan worden met b.v. een bevoegdheidsovereenkomst.

Voor meer structurele samenwerking tussen meerdere overheden zal tot de vorming van grensoverschrijdende openbare lichamen (omvorming van bestaande grens-/eure- 
gio's) kunnen worden overgegaan. Omdat deze grens-/euregio's nog niet erg bij de burger leven, dienen deze in beginsel aan de basis, dicht bij de burger op gemeentelijk niveau, tot stand te komen. Rechtstreekse verkiezingen van het vertegenwoordigend orgaan van deze grens-/euregio is in het licht van al vele bestaande verkiezingen misschien niet zonder meer wenselijk. De diverse gekozen gemeenteraadsleden of de vertegenwoordigers in de nationale gemeentelijke samenwerkingsverbanden kunnen de grens-/euregioraad vormen. De vertegenwoordiging kan b.v. aan de hand van inwoneraantallen bepaald worden. In deze gemeentelijke samenwerkingsverbanden kumnen hogere overheden, b.v, in Nederland de provincies, in Duitsland de Länder en in België de Gewesten/Gemeenschappen, als (coördinerende) adviesinstantie optreden. Een vergelijkbare participatie van andere (privaatrechtelijke) instanties kan worden voorzien.

9. Een regime voor een grens-/euregio, waarbij deze over burgers en/of overheden bindende bevoegdheden beschikt, impliceert een overdracht van bevoegdheden van de deelnemende gemeenten. Omdat deze vorm van samenwerking (op basis van de Benelux-Overeenkomst respectievelijk de Duits-Nederlandse Overeenkomst inzake decentrale grensoverschrijdende samenwerking) tot de toepasselijkheid van het interne recht van de deelnemers leidt, kunmen problemen ontstaan in verband met (uiteenlopend) toezicht en (uiteenlopende) rechtsbescherming.

Deze divergentie kan op drie manieren verkleind worden. In de eerste plaats kan tot een afstemming (coördinatie en harmonisatie) van toezichts- en rechtsbeschermingsprocedures overgegaan worden. Verder gaat de keuze voor de toepasselijkheid van één rechtsstelsel. De divergentie zou waarschijnlijk het meest vergaand opgeheven kunnen worden door een eigen rechtsregime voor de grens-/euregio in het leven te roepen, onafhankelijk van dat van de deelnemende overheden. Dit eigen regime impliceert het vervallen van de toepasselijkheid van de rechtsregimes van de deeinemende overheden en daardoor het vervallen van de (nationale) grens binnen de euregio. Omdat in dat geval het rechtsregime binnen de grens-/euregio afwijkt van de nationale regimes, ontstaat eenzelfde divergentieprobleem bij samenwerking tussen de grens-/euregio en aangrenzend nationaal gebied. Dit laatste geldt ook voor de samenwerking tussen grens-/euregio's onderling, indien hun rechtsregime niet hetzelffe is. Bij de toepasselijkheid van eén rechtsstelsel is dit ook thet geval voor de samenwerking tussen de grens-/euregio en het aangrenzend gebied van de staat van het niet toepasselijke rechtsstelsel alsmede tussen grens-/euregio's onderling, wanneer het toepasselijke rechtsstelsel verschilt. Anders gezegd: daar waar de staten soevereiniteit ten koste van de grens-/euregio's verliezen, worden de hwidige nationale grenzen alleen maar verlegd tot de buitengrenzen van de grens-/euregio's. Het kiezen van cen eigen rechtsregime c.q. de toepasselijkheid van én rechtsstelsel heeft in dat perspectief derhalve niet zoveel zin.

Indien (nog) niet tot de overdracht van bevoegdheden aan grens-/euregio's wordt overgegaan, die burgers en/of overheden binden, kan een samenwerking met een vergelijkbare jur idische reikwijdte bewerkstelligd worden, doordat binnen de grens-euregio's ad hoc afspraken over de uitoefening van bevoegdheden gemaakt worden, die daarna 'in eigen huis' door de deelnemende overheden aangepakt en uitgevoerd worden. 
10. Voor het maken van publiekrechtelijke afspraken tussen Belgische, Duitse en Nederlandse decentrale overheden in de Euregio Maas-Rijn is, behalve een afstemming van de Benelux-Overeenkomst en de Duits-Nederlandse Overeenkomst, tevens een vergelijkbaar verdrag tussen Belgiê en Duitsland noodzakelijk.

11. Financiering is zeker zo belangrijk woor het tot stand komen en uitwoeren wan publiekrechtelijke afspraken als het voorzien in wettelijke grondslagen hiervoor. In dat verband zal de subsidiëring in het kader van Interreg, die de politieke bereidheid tot samenwerking en een "euregiogeest" bevordert maar tevens een eigen bijdrage van de deelnemende overheden eist, nog zeker enkele jaren gecontinueerd moeten worden. 


\section{EUROPEAN OUTLINE CONVENTION ON TRANSFRONTIER CO-OPERATION RETWEEN TERRTTORIAL COMMUNTTIES OR AUTHORTIES*}

\section{Preamble}

The member States of the Council of Europe, signatories to this Conwention,

Considering that the aim of the Council of Europe is to achieve a greater unity between its members and to promote co-operation between them;

Considering that, as defined in Article $I$ of the Conncil of Europe Statute, this aim will bo pursued in particular by agreements in the adininistrative field;

Considering that the Council of Europe shall ensure the participation of the territorial communities or authorities of Europe in the achievement of its aim;

Considering the potential importance, for the pursuit of this objective, of co-operation between territorial communities or authorities at frontiers in such fields as regional, urban and rural development, environmental protection, the improvement of public facilities and services and mutual assistance in emergencies;

Having regard to past experience which shows that co-operation between local and regional authorities in Europe makes it easier for them to carry out their tasks effectively and contributes in particular to the improvement and development of frontier regions;

Being resolved to promote such co-operation as far as possible and to contribute in this way to the economic and social progress of frontier regions and to the spirit of fellowship which unites the peoples of Europe;

Have agreed as follows: 


\section{Article 1}

Each Contracting Party undertakes to facilitate and foster transfrontier co-operation between territorial communities or authorities within its jurisdiction and territorial communities or authorities within the jurisdiction of other Contracting Parties. It shall endeavour to promote the conclusion of any agreenents and arrangements that may prove necessary for this purpose with due regard to the different constitutionat provisions of each Party.

\section{Article 2}

1. For the purpose of this Convention, transfrontier co-operation shall mean any concerted action designed to reinforce and foster neighbourly relations between territorial communities or authorities: within the jurisdiction of two or more Contracting Parties and the conclusion of any agreement and arrangement necessary for this purpose. Transfrontier co-operation shall take place in the framework of territorial communities" or authorities" powers as defined in domestic law. The scope and nature of such powers shall not be altered by this Convention.

2. For the purpose of this Convention, the expression "territorial communities or authorities" shall mean communities, authorities or bodies exercising local and regional functions and regarded as such under the donestic law of each State. However, each Contracting Party may, at the time of signing this Convention or by subsequent notification to the Secretary General of the Council of Europe, name the conmunities, authorities or bodies, subjects and forms to which it intends to confine the scope of the Convention or which it intends to exclude from its scope.

\section{Article 3}

1. For the purpose of this Convention the Contracting Parties shall, subject to the provisions of Article 2 , paragraph 2, encourage any initiative by territorial. communities and authorities inspired by the outline arrangements between territorial communities and authorities drawn up in the Council of Europe. If they judge necessary they may take into consideration the bilateral or multilateral inter-state model agreements drawn up in the Council of Europe and designed to facilitate co-operation between territorial communities and authorities.

The arrangements and agreements concluded may be based on the model and outline agreements, statutes and contracts appended to this Convention, numbered 1.1 to 1.5 and 2.1 to 2.6 with whatever changes are required by the particular situation of each Contracting Party. These model and outline agreements, statutes and contracts are intended for guidance only and have no treaty value.

2. If the Contracting Parties deen it necessary to conclude inter-state agreements, these may inter alia establish the context, forms and limits within which territorial communities and authorities concemed with transfrontier co-operation may act. Each agreement may also stipulate the authorities or bodies to which it applies.

3. The above provisions shall not prevent the Contracting Parties from having recourse , by common consent, to other forms of transfrontier co-operation. Similarly, the provisions of this Convention should not be interpreted as invalidating existing agreements on co-operation.

4. Agreements and arrangements shall be concluded with due regard to the jurisdiction provided for by the internal law of each Contracting Party in respect of international relations and general policy and to any rules of control or supervision to which territorial communities or authorities may be subject.

5. To that end, any Contracting Party may, when signing the present Convention or in a later communication to the Secretary General of the Council of Europe, specify the authorities competent under its donestic law to exercise control or supervision with regard to the territorial communities and authorities concerned. 


\section{Article 4}

Eact Contracting Party shall endeavour to resolve any legal, administrative or technical difficultie liable to hamper the development and smooth running of transfrontier co-operation and shall consult with the other Contracting Party or Parties concerned to the extent required.

\section{Article 5}

The Contracting Parties shall consider the advisability of granting to territorial communities or authorities engaging in transfrontier co-operation in accondance with the provisions of this Convention the same facilities as if they were co-operating at national level.

\section{Article 6}

Each Contracting Party shall supply to the fullest possible extent any information requested by another Contracting Party in order to facilitate the performance by the latter of its obligations under this Convention.

\section{Article 7}

Each Contracting Party shall see to it that the territorial communities or authorities concerned are informed of the means of action open to thern under this Convention.

\section{Article 8}

1. The Contracting Parties shall forward to the Secretary General of the Council of Europe all relevant information concerning the agreements and arrangements provided for in Article 3.

2. Any proposal made by one or more Contracting Parties with a view to adding to or extending this Convention or the model agreements and arrangements shall be communicated to the Secretary General of the Council of Europe. The Secretary General shall then submit it to the Committee of Ministers of the Council of Europe which shall decide on the action to be taken.

\section{Article 9}

1. This Convention shall be open to signature by the member States of the Council of Europe. It shall be subject to ratification, acceptance or approval. Instruments of ratification, acceptance or approval shall be deposited with the Secretary General of the Council of Europe.

2. The Convention shall enter into force three months after the date of the deposit of the fourth instrument of ratification, acceptance or approval, provided that at least two of the States having carried out this formality possess a common frontier.

3. In respect of a signatory State ratifying, accepting or approving subsequently, the Convention shall come into force three months after the date of the deposit of its instrument of ratification, acceptance or approwal.

\section{Article 10}

1. After the entry into force of this Convention, the Committee of Ministers of the Council of Europe may decide unanimously to invite any Europeam non-member State to accede thereto. This invitation must receive the express agreement of each of the States which have ratified the Convention.

2. Such accession shall be effected by depositing with the Secretary General of the Council of Europe an instrument of accession which shall take effect three months after the date of its deposit. 


\section{Article 11}

1. Any Contracting Party may, in so far as it is concerned, denounce this Convention by means of a notification addressed to the Secretary General of the Council of Europe.

2. Such denunciation shall take effect six months after the date of receipt by the Secretary General of such notification.

\section{Article 12}

The Secretary General of the Council of Europe shall notify the member States of the Council of Europe, and any State that has acceded to this Conwention of:

a. any signature;

b. any deposit of an instrument of ratification, acceptance, approval or accession;

c. any date of entry into force of this Convention in accordance with Article 9 thereof;

d. any declaration received in pursuance of the provisions of paragraph 2 of Article 2 or of paragraph 5 of Article 3;

e. any notification received in pursuance of the provisions of Article 11 and the date on which denunciation takes effect.

In witness whereof the undersigned, being duly authorised thereto, have signed this Convention. Done at Madrid, the 21st day of May 1980, in English and French, both texts being equally authentic, in a single copy which shall be deposited in the archives of the Council of Europe. The Secretary General of the Council of Europe shall transmit certified copies to each member State of the Council of Europe and to any State inwited to accede to this Convention.

\section{APPENDIX}

Model and Oulline Agreements, Statutes and Contracts on Transfrontier Co-operation between Territorial Communities or Authorities (hier niet opgenomen, RS). 


\section{EUROPESE KADEROVEREENKOMST INZAKE GRENSOVERSCHRUDENDE SAMENWERKING TUSSEN TERRTTORIALE GEMEENSCHAPPEN OF AUTORTTEITEN *}

\section{Preambule}

De Lid-Staten van de Raad van Europa die dit Verdrag hebben ondertekend,

Ovenwegende dat bet doel van de Raad van Europa is het tot stand brengen van een grotere eenheid tussen zijn leden en het bevorderen wan samenwerking tussen hen;

Overwegende dat, zoals omschreven in artikel 1 van het Statuut van de Raad van Europa, dil doel in zonderheid zal worden nagestreefd door het slluiten van overeenkomsten op het bestuurlijk vllak;

Overwegende dat de Raad van Europa erop dient toe te zien dat de territoriale gemeenschappen of autoriteiten in Europa deelnemen aan de verwezenlijking van zijn doel;

In aanmerking nemende het bellang voor het nastreven van dit doel, wan samenwerking tussen territoriale gemeenschappen of autoriteiten in grensgebieden op terreinen zoals regionale ontwikkeling en stads-en plattelandsontwikkeling, milieubescherming, werbetering van openbare voorzieningen en diensten en wederzijdse bijstand bij rampen;

Gelet op de in het verleden opgedane ervaring, waaruit blijkt dat samenwerking tussen lokale en regionale autoriteiten in Europa het voor deze gernakkelijker maakt hun taken doeltreffend te verrichten en inzonderheid bijdraagt tot de ontsluiting en ontwikkeling van grensgebieden;

Vastbeslloten een zodanige samenwerking zoveel mogelijk te bevorderen en op deze wijze bij te dragen tot de economisch en sociale vooruitgang van grensgebieden en tot de solidariteit die de volken van Europa verenigt.

Zijn overeengekomen als volgt:

\section{Artikel 1}

Elke Overeenkomstsluitende Partij verbind zich ertoe grensoverschrijdende samenwerking tussen territoriale gemeenschappen of autoriteiten binnen haar rechtsmacht en territoriale gemeenschappen of autoriteiten binnen dle rechtsmacht van andere Overeenkomstsluitende Partijen te vergemakkelijken en te bevorderea. Zij tracht te bevorderen dat de overeenkomsten en regelingen, die hiertoe noodzakelijk blijken te zijn, tot stand worden gebracht, met inachtneming van de voor elke Partij geldende constitutionele bepalingen.

\section{Artikel 2}

1. Voor de toepassing van deze Overeenkomst wordt onder grensoverschrijdende samenwerking verstaan elk onderling afgestemd optreden met het oogmerk het nabuurschap tussen territoriale gemeenschappen of autoriteiten binnen de rechtsmacht wan twee of meer Overeenkomstsluitende Partijen te versterken en te bevorderen en de voor dit doel noodzakelijke overeenkomsten en regelingen tot stand te brengen. 
De grensowershrijdende samenwerking vindt plaats in he kader van de bevoegdheden van de temitoriale gemeenschappen of autoriteiten zoals omschreven in het interne recht De reikwijdte en axard van zodanige bewoegdheden worden niet door deze Overeenkomst gewijzigd.

2. Voor de topassing wan deze Owereenkomst wordt onder de uitdruklking, territoriale gemeenschappen of atoriluiten " verstan gemeenschappen, autoriteiten of lichamen, die lokale en regionale functies. vervullen en die als zodanig worden beschowwd in het interne recht van elke Staat. Elke Overeenkomstsuitende Partij kan evenwel, op het tjdstip van ondertekening van deze Overeenkomst of it an latere mededeling afun de Secretaris-Generaal van de Raad van Europa, de gemeenschappen, autoriteiten of lichamen, alsmede de onderwerpen en vormen aangeven waartoe zij de reikwijdte van deze Overeenkomat wenst te beperken of die $z j$ xan de reikwijdte van deze Overeenkomst wenst uil tei suiten.

\section{Artikel 3}

1. Voor de toepassing van deze Owereenkomst bevorderen de Overeenkomstshitende Partijen, behoudens het bepaalde in artikel 2 , tweede lid, elk initiatief van territoriale gemeenschappen en autoriteiten warbij rekening wordt gehouden met de kaderregelingen russen territoriale gemeenschappen en autoriteiten opgesteld binnen de Raad van Europa. Indien zij zulks noodzakeljk achten, kummen zij rekening houden met de bilaterale of multilatierale modelovereenkomsten tussen. Sitaten, opgesteld binnen de Raad van Europa met het oogmerk de samenwerking tussen territoriale gemeenschappen ven autoriteiten te vergemakkelijken.

De tot stand te brengen regelingen en overeenkomsten kumen worden gebuseerd op de model- en kaderovereenkomsten, kaderstatuten en kadercontracten die aan deze Overeenkomst zijn gehecht. onder de nummers 1.1 tot en met 1.5 en 2.1 tot en met 2.6 met de nodige wijzigingen in verband met de bijzondere situmite van elke Owereenkomstsluitende Partij. Deze model- en kaderovereenkomsten, kaderstatuten en kadercontracten zijn slechts als richtsnoer bedoeld en hebben niet de kracht van een overoenkomst.

2. Indien de Owereenkomstsiuitende Partijen het noodzakelijk achten, avereenkomsten tussen Staten te sluiten, kunnen daarin onder meer de context, wormen en grenzen worden vastgelegd voor het optreden van de territoriale gemeenschappen en autoriteiten die zijn betrokken bij grensoverschrijdende samenwerking. Elke overeenkonst kan tevens de autoriteiten of lichamen aangeven waarop zij wan toepassing is.

3. De bovenstaande bepalingen beletten de Overeenkornstsluitende Partijen niet, in onderlinge overeenstemming gebruik to maken wan andere wormen van grensoverschrijdende samenwerking. Evenmin dienen de bepalingen wan deze Overeenkomst zo te worden uitgelegd als zouden zij bestaande samenwerkingsowereakomsten ongeldig maken.

4. De overeenkomsten en regelingen diemen tot stand te worden gebracht met inachtneming van cle door het interne recht wan elke Overeenkomsts luitende Partij vastgestelde bevoegdheid ten aanzien van internationale betrekkingen en algemeen beleid en met inachtmeming van de voorschriften inzake controle of toezicht wararan territoriale gemeenschappen of autoriteiten onderworpen zijn.

5. Hiertoe kan liedere Overeenkomstsluitende Partij. op het tjidstip van ondertekening van deze Overeenkomst of in een latere mededeling an de Secretaris-Generaal wan de Raad van Europa, de antoriteitien angeven die ingevolge hat interne recht bevoegd zijn controle of toezicht uht te oefenen teth aanzien wan de betrokken territorialle gemeenschappen en autoriteiten.

\section{Artikel 4}

Elke Overeenkomstsluitende Partij tracht de juridische, bestuurlijke of technische moeilijkheden die de ontwikkeling en thet goede verloop, van grensoverschrijdende samenwerking kunnen belemmaren, op te lossen en pleegt voor zover nodig overleg met de andere betrokken Overeenkomstsluitende Partij of Partijer. 


\section{Artikel 5}

In geval wan grensoverschrijdende samenwerking overeenkomstig de bepalingen van deze Overeenkonnst, overwegen de Overeenkonustsluitende Partijen de wenselijkheid van toekenning aan de daaraan deelne. mende territoriale gemeenschappen of autoriteiten van dezelf fe faciliteiten als wanneer deze op nationaal niveau zouden samenwerken.

\section{Artikel 6}

Elke Overeenkomstsiuitende Partij verstrekt in zo ruim mogelijke mate alle informatie waarom een andere Overeenkomstsluitende Partij verzoekt ten einde het nakomen door deze laatsie Partij van haar werplichtingen ingevolge deze Overeenkomst te vergemakkelijken.

\section{Artikel 7}

Elke Overeenkomstsluitende Partij draagt er zorg voor dat de betrokken territoriale gemeenschappen of autoriteiten in kennis worden gesteld van middelen tot handelen waarvan zij ingevolge deze Overeenkomst gebruik kunnen maken.

\section{Artikel 8}

1. De Overeenkomstsluitende Partijen zenden de Secretaris-Generaal van de Raad van Europa alle ter zake dienende informatie toe betreffende de overeenkornsten en regelingen bedoeld in artikel 3 .

2. Elk voorstel van een of meer Overeenkomstsluitende Partijen woor inwulling of uitbreiding van deze Overeenkomst of van de modelovereenkormsten en -regelingen dient te worden nedegedeeld aan de Secretaris-Generaal van de Raad van Europa. De Secretaris-Generaal legt dit voor aan het Comité wan Ministers van de Raad van Europa, dat besluit welk gevolg eraan gegewen dient te worden.

\section{Artikel 9}

1. Deze Overeenkomst staat open voor ondertekening door de Lid-Staten van de Raad van Europa. Zij dient te worden bekrachtigd, aanvaard of goedgekeurd. De akten van bekrachtiging, aanvaarding of goedkeuring worden neergelegd bij de Secretaris-Generaal wan de Raad wan Europa.

2. De Overeenkomst treedt in werking drie maanden na de datum van nederlegging van de vierde akte van bekrachtiging, aanvaarding of goedkeuring, mits ten minste twee van de Staten die deze formaliteit hebben verricht ten gemeenschappelijke grens hebben.

3. Ten aanzien van iedere ondertekenende Staat die de Overeenkonst daarna bekrachtigt, aanvaardt of goedkeurt, treedt de Overeenkomst in werking drie maanden na de datum wan nederlegglng van zijn akte van bekrachtiging, aanvaarding of goedkeuring.

\section{Artikel 10}

1. Na de inwerkingtreding van deze Overeenkomst kan het Comite van Ministers van de Raad van Europa met eenparigheid van stemmen besiuiten iedere Europese Stat die geen lid is van de Raad, wit te nodigen tot deze Overeenkomst toe te treden. Deze uitnodiging dient de uitdrukkelijke instemming te verkrijgen van elke Staat die de Overeenkomst heeft bekrachtigd.

2. Toetreding geschiedt door nederlegging bij de Secretaris-Generaal van de Raad van Europa van een akte van toetreding, die drie maanden na de datum van nederlegging van kracht wordt. 


\section{Artikel 11}

1. Iedere Overeenkomstsluitende Partij kan, voor zover harzelf betreft, deze Owereenkomst opzeggen door een daartoe strekkende kennisgeving te richten aan de Secretaris-Generaal van de Raad van Europa.

2. De opzegging wordt van kracht zes maanden ma de datum van ontvangst van een zodanige kennisgeving door de Secretaris-Generaal.

\section{Artikel 12}

De Secretaris-Generaal van de Raad van Europa geft de Lid-Staten van de Raad van Europa en elke staat die tot deze Owereenkomst is toegetreden, kennis van:

a. elke ondertekening;

b. elke nederlegging van een akte van bekrachtiging, aanvaarding, goedkeuring of toetreding;

c. elke datum van unwerkingtreding van deze Overeenkomst overeenkomstig artikel 9;

d. elke werklaring ontvangen krachtens het bepaalde in artikel 2, tweede lid, of artikel 3, vijfde lid,

e. elke kennisgeving ontvangen krachtens het bepaalde in artikel 11, alsmede de datum waarop de opzegging van kracht wordt.

TEN BLIJKE WAARVAN de ondergetekenden, daartoe behoorlijk gemachtigd, deze Overeenkomst hebben ondertekend.

GEDAAN te Madrid, op 21 mei 1980, in de Engelse en de Franse taal, zijnde beide teksten gelijkelijk atuthentiek, in én enkel exemplaar, dat zal worden neergelegd in het archief van de Raad van Europa. De Secretaris-Generaal van de Raad wan Europa doet hiervan een voor eensluidend gewaarmerkt afschrift toekomen aan elke Lid-Staat van de Raad van Europa en aan alle Staten die zijn uitgenodigd tot deze Overeenkomst toe te treden.

(Voor de ondertekeningen zie blz. 12 van Trb. 1980, 129 en rubriek B van dit Tractatenblad)

\section{AANHANGSEL}

Model- en kaderovereenkomsten, kaderstatuten en kadercontracten inzake grensoverschrijdende samenwerking tussen territoriale gemeenschappen of autoriteiten (hier niet opgenomen, RS). 


\section{ADDTTIONAL PROTOCOL TO THE EUROPEAN OUTLINE CONVENTION ON TRANSFRONTIER COMOPERATION BETWEEN TERRITORLAL COMMUNTTIES OR AUTHORITES*}

The Council of Europe member States signatory to this Additional Protocol to the European Outline Convention on Transfrontier Cooperation between Territorial Communities or Authorities (hereinafter referred to as "the Outline Convention"),

Affirming the importance of transfrontier co-operation between territorial communities or authorities,

Being resolved to take new measures to guarantee transfrontier co-operation between territorial communities of authorities,

Wishing to facilitate and develop transfrontier co-operation between territorial conmunities or authorities,

Acknowledging the meed to adapt the Outline Convention to the actual situation in Europe,

Considering that it would be appropriate to amplify the Outline Convention with a view to reinforcing transfrontier co-operation between territorial communities or authorities,

Having regard to the European Charter of Local Self-Government,

Bearing in mind the Declaration made by the Committee of Ministers on transfrontier co-operation in Europe on the occasion of the 40 th anniversary of the Council of Europe which encouraged, anrong ather things, continued study of the work in order gradually to remove the barriers of every kind administrative, legal, political and psychological - which might curb the development of transfrontier projects,

Have agreed on the following additional provisions,

\section{Article 1}

All Contracting Purties shall recognize and guarantee the right of territorial communities or authorities under their jurisdiction and referred to in Articles 1 and 2 of the Outline Convention to conclude transfrontier co-operation agreements in the fields for which they are responsible, and in accordance. with the procedures laid down in their statutes and in national legislation, with the ferritorial communities or authorities of other States, in so far as such agreements are in keeping with the Parties international commitments.

\section{Article 2}

Acts accomplished by territorial communities or authorities under a transfrontier co-operation agreement shall have the same legal force and the same effects in their legal systems as they would have in a national legal system. 


\section{Article 3}

1. Territorial communities or authorities may, under a transfrontier co-operation agreement, set up a permanent co-operation body. The agreement shall indicate, in full respect of national legislation, whether such a body, taking into account the tasks which are entrusted to it, shall be a public law or a private law entity. Legal corporate capacity shall be granted to the body accordingly.

2. Decilions taken by the co-operation body shall be legally binding for the territorial communities or authorities which concluded the agreement. As to their implementation:

a. if the body is a public law entity, its acts shall have, in the legal system of each Contracting Party, the same legal force and the same effects as if they had been accomplished by the communities or authorities which concluded the agreement. However, the agreement may stipulate that it is for the communities or authorities which concluded the agreement to execute such acts, especially if these are likely to affect, the rights, freedoms and interests of individuals;

b. if the body is a private law entity it shall accomplish all the acts except those which, on account of their public law character, are to be accomplished by the communities or authorities which concluded the agreement.

3. The functioning of the co-operation body and the internal relations therein shall be governed by the rules contained in its Statutes or the law indicated by it.

\section{Article 4}

The territorial communities or authorities concluding a transfrontier co-operation agreement shall take, where appropriate, the necessary measures in their domestic legal system to implement the agreement as well as any act which derives from it.

\section{Article 5}

Acts accomplished by territorial communities or authorities under a transfrontier co-operation agreement, and those of a public law character, accomplished by any co-operation body set up under the agreement, shall be subject to the same controls as those provided for in the legal system of each Contracting Party for the acts of the territorial communities or authorities having concluded the agreement.

\section{Article 6}

No reservations to the provisions on this Additional Protocol shall be allowed.

\section{Article 7}

1. This Protocol shall be open for signature by the States which have signed the Outline Convention, which may express their consent to be bound by either:

a. signature without reservation as to ratification, acceptance or approwal, or

b. signature subject to ratification, acceptance or approval followed by ratification, acceptance or approval.

2. A menber State of the Council of Europe may not sign this Protocol without reservations as to ratification, acceptance or approval or deposit an instrument of ratification, acceptance or approval unless it has already deposited or simultaneously deposits an instrument of ratification, acceptance or approval of the Outline Convention.

3. The instruments of ratification, acceptance or approval shall be deposited with the Secretary General of the Council of Europe. 


\section{Article 8}

1. This Protocol shall come into force on the first day of the month following the expiry of a period of three months after the date on which four member States of the Council of Europe have expressed their consent to be bound by the Protocol in accordance with the provisions of Article 7.

2. In respect of any member State which subsequently expresses its consent to be bound by it, the Protocol shall come into force on the first day of the unonth following the expiry of a period of three months after the date of signature or deposit of the instrument of ratification, acceptance or approval.

\section{Article 9}

1. After the entry into force of this Protocol, any State which has acceded to the Outline Convention may also accede to the Protocol.

2. Accession shall be effected by the deposit with the Secretary General of the Council of Europe of an instrument of accession which shall take effect three months after the date of its deposit.

\section{Article 10}

1. Any Party may, at any lime, denounce this Protocol by means of notification addressed to the Secretary General of the Council of Europe.

2. Such denunciation shall become effective on the first day of the month following the expiry of a period of six months after the date of receipt of the notification by the Secretary General.

\section{Article 11}

The Secretary General of the Council of Europe shall notify the member States of the Council of Europe and any State which has acceded to this Protocol for:

a. any signature;

b. the deposit of any instrument of ratification, acceptance, approval or accession;

c. any date of entry into force of this Protocol, in accordance with Articles 8 and 9;

d. any other measure, notification or communication relating to this Protocol.

In witness whereof the undersigned, being duly authorized thereto, have signed the Protocol.

Done at .... this ... day of .... in English and French, both texts being equally authentic, in a single copy which shall be deposited in the archives of the Council of Europe. The Secretary General of the Council of Europe shall transmil certified copies to each member State of the Council of Europe and to any State invited to accede to this Protocol. 


\section{BENELUX-OVEREENKOMST INZAKE GRENSONERSCHRUDENDE SAMENWERKING TUSSEN TERRTTORLALE SAMENWERKINGSVERBANDEN OF AUTORITEITEN *}

De regering van het Koninkrijk Belgiè.

De regering vam het Groothertogdom Luxemburg.

De regering van het Koninkrijk der Nederlanden.

Zich bewust van de voordelen van grensoverschrijdende samenwerking zoals omschreven in de op 21 mei 1980 te Madrid gesloten Europese Kaderovereenkomst inzake grensowerschrijdende samenwerking tussen territoriale gemeenschappen of autoriteiten.

Met voldoening vaststellemde dat territoriale samenwerkingsverbanden of autoriteiten aan beide zijden van de intra-Beneluxgrenzen reeds veelvuldig met elkaar samenwerken op privaatrechtelijke basis.

Verlangende voor deze de mogelijkheid te scheppen om ook op publiekrechtelijke basis met elkaar te kumnen samenwerken.

Overwegende dat deze samenwerking beantwoordt aan de doelstelling van het op 3 februari 1958 te s-Gravenhage ondertekende Verdrag tot instelling van de Benelux Economische Unie.

Overwegende dat de regeringshoofden en ministers van Buitenlandse Zaken van de Beneluxlanden tijdens hun bijeenkomst te 's-Gravenhage op 10 november 1982 hebben besloten een onderzoek te doen instellen naar de mogelijkheid om op Benelux-niveau een kaderovereenkomst te sluiten inzake samenwerking tussen territoriale samenwerkingsverbanden of autoriteiten aan weerszijden van de landsgrenzen.

Gelet op thet advies van 7 juni 1986 van de Raadgevende Interparlementaire Beneluxraad. Hebben besloten te dien einde een Overeenkomst te sluiten en zijn het volgende overeengekomen.

\section{Artikel 1}

1. De onderhavige Overeenkomst is van toepassing op onderstaande territoriale sarmenwerkingsverbanden of autoriteiten:

- in België: provincies, gemeenten, verenigingen van gemeenten, openbare centra voor maatschappelijk welzijn, polders en wateringen; 
- in Luxemburg: gemeenten, gemeentelijke syndicaten en cuder gemeentelijk toezicht geplaatste openbare instellingen;

- in Nederland: provincies, gemeenten, waterschappen en openbare lichamen, bedoeld in de Wet gemeenschappelijke regelingen (Stb. 1984, 669), voor zover daartoe in de regeling ingevolge woornoende wet bevoegd werklaard.

2. Elk der Owereenkomstsluitende Partijen kan na overleg met de partnerlanden en wolgens de regels wan ziju interne recht, andere territoriale samenwerkingsverbanden of autoriteiten aanwijzen warop de onderhavige Overeenkomst van toepassing zal zijn.

\section{Artikel 2}

1. Onverminderd de mogelijkheden on op basis van het privaatrecht samen te werken kunnen de in arukell 1 genoemde territoriale samenwerkingsverbanden of autoriteiten, bimnen het kader van de bewegdheden die zij ingevolge het interne recht van hun land hebben, op basis van de onderhavige Overeenkomst met elkati samenwerken ten einde gemeenschappelijke belangen te belhartigen. Het op dit gebied in hoofdzalk geldende inferne recht van elke Overeenkomstsluitende Partij is weergegeven in de bijlage bij deze Overeenkomst.

2. De in artikel 1 bedoelde territoriale samen werkingswerbanden of autoriteiten kunnen voor de concretisering wan hun samemwerking administratieve afspraken maken en openbare lichamen of gemeenschappelijke organen instellem.

3. De controle- en toezichtsregelen waraan de territoriale samenwerkingsverbanden of autoriteiten uit hoofde van het interne recht der Overeerikomstsluitende Partijen zijn onderworpen, zijn van toepassing op besluiten wan de in artikel 1 bedoelde territoriale samenwerkingswerbanden of autoriteiten om op basis van de onderhavige Overeenkomst samen te werken alsmede op besluiten tot toetreding en uitreding.

\section{Artikel 3}

1. Indien de in artikel 1 genoemde territoriale samenwerkingsverbanden of autoriteiten besluiten een openbaar lichaam in te stellen kunnen deze aan dat lichaam bevoegdheden van regeling en bestuwr toekennen.

2. Het openbaar lichaam bezit rechtspersoonlijkheid. De aan nationale rechtspersonen toegekende rechtsbevoegdheid komt op het grondgebied van elk der Overeenkonstsluitende partijen aan bedoeld lichaam slechts toe voor zover zulks noodzakelijk is voor de vervulling van zijn taak en woor de verwezenlijking van zijn doelstellingen.

3. De rechtsbetrekkingen tussen het openbaar lichaam en de daaraan rechisonderhorige natuurlijke en rechtspersonen worden geregeld door het recht dat wan toepassing zou zijn als de in artikel $\mathbb{1}$ genoemde territoriale samenwerkingsverbanden of autoriteiten zelf de aan dit openbaar licladam toegekende bevogdheden inzake regeling en bestuur hadden uitgeoefend.

4. Behoudens uizonderingen die in de statuten wan het openbaar lichaam worden bepaald, is thet het recht van vestiging van de maatschappelijke zetel van dit lichaam van toepassing met betrekking tot de rechtspositie van llet personeel.

5. De statuten van het openbaat lichaam mogen niet in strijd zijn met het interne recht van de betrokken landen en regelen in ieder geval de volgende onderwerpen:

- de naam, de zetel en het maatschappelijk doel;

- de taken, de bewoegdheden en de werkwijze;

- de wijze van aanstelling van de leden van de beheers- en bestuursorganen;

- de draagwijdte van de verplichtingen jegens het openbaar lichaam;

- de wijze waarop vergaderingen worden georganiseerd en de besluitvorming;

- de openbaarheid van de beradslagingen;

- de toepasselijke regels inzake begroting en rekening;

- de wijze waarop de activiteiten worden gefinancierd; 
- de wijze waarop de regeling in werking treedt, gewijzigd of beeindigd wordt;

- de wijze van toetreding en uittreding der deelnemers.

\section{Artikel 4}

1. Op de besluiten vam het bestuur van het openbaar lichaam zijn met inachtneming van artikel 3 , wierde lid, de controle- en het toezichtsregelen woorzien in het interne recht van de Overeenkomsishuitende Partijen van overeenkomstige toepassing.

2. Elke Overeenkomstsluitende Partij kan, orverminderd het bepaalde in het eerste lid, voorzien in de functie van een of meer bijzondere toezichthouder(s) voor grensowerschrijdende samenwerking die tot taak heeft (hebben) de rechten wan zijn (hun) land te waarborgen en zich te verzetten tegen elke beslissing van de besturen van de in artikel 3 bedoelde openbare lichamen die deze rechten zou kunoen aantasten en maar zijn (hun) oordeel in strijd is met de wettelijke bestuurstechtelijke bepalingew. Zijn (hun) verzet zal tot gevolg hebben dat de tenuitvoerlegging valm de genomen beslissing wordt geschorst.

3. Een schorsing op basis van het eerste dan well het tweede lid wordt niet uitgesproken dan na overleg met of tenminste na melding aan de betrokken toezichthouder(s) van het andere lamd.

4. De geschorste beslissing wordt door de toezichthouder voorgelegd aan de bevoegde autoriteiten van zijn land die een oplossing voorstellen of het probleem aan de in artikell 6 bedoelde Bijzondere Commissie voorleggen.

\section{Artikel 5}

1. De Overeenkomstsluitende Pariijen en de provincies hebben het recht on elk voor zich dan wel gezanenlijk een ambtenaar grenscontacten aan te wijzen.

2. Aan hem kunnen vratgstukken worden voorgelegd die in het kader van de grensoverschrijdende samenwerking rijzen.

3. Deze ambtenaar is bevoegd woor deze vraagstukken oplossingen voor te stellen of deze voor te leggen aan de betrokken openbare lichamen, territoriale samenwerkingsverbanden of autoriteiten en toezichthouders, of aan de in artikel 6 bedoelde Commissie.

4. Deze ambtenaar is voorts bevoegd de inlichtingen in te wimen die voor de uitoefening van zijn taak nodig zijn.

\section{Artikel 6}

1. Met het oog op de uitwoering van de onderhavige Overeenkomst wordt overeenkomstig artikel $3 \sharp$ wan het Unieverdrage en Bijzondere Commissie ingesteld.

2. Deze Commissie heeft tot taak:

a. de activiteiten inzake grenssamenwerking te bevorderen en te coördineren en belanghebbenden inlichtingen over de wettelijke en andere aspecten van de samenwerkingsprojecten te verschaffen:

b. oplossingen te zoeken voor de vraagstukken die haar met betrekking tot op deze Overeenkomst betrekking hebbende grensoverschrijdende samenwerking tussen de territoriale samen werkingsverbanden of autoriteiten worden voorgelegd:

c. een onderzoek in te stellen naar onenigheden en geschillen die met betrekking tot op dexe Overeenkomst gebaseerde grensowerschrijdende samenwerking zijn gerezen, ten einde deze wia een verzoeningsprocedure op te lossen of aan het Comite van Ministers voor te leggen;

d. jaarlijks verslag aan het Comite van Ministers uit te brengen omtrent de stand van de op basis van onderhavige Overeenkomst gerealiseerde samenwerking;

e. elke andere taak te vervullen die haar door bet Comité van Ministers binnen het ram van de onderhavige Overeenkomst wordt opgedragen. 


\section{Artikel 7}

Het Comité vam Ministers beslist im aangelegenheden als bedoeld in antikel 6 , tweede lid, letter c) die hem door de Bijzondere Commissie worden voorgelegd.

\section{Artikel 8}

Het Camite van Ministers kan, bij beschikking genonen overeenkomstig artikel 19 , letter a) van het Unieverdrag, nadere regels geven omtrent de wijze van uittwoering van de onderhavige Owereenkomst.

\section{Artikel 9}

1. Elke Owereenkomstsluitende Partij stelt de Secretaris-Generaal van de Benelum-Economische Unie in kennis van wijzigingen in haar interne recht zoals aangegeven in de bijlage. De Secretaris-Generaal brengt de andere Overeenkomstsluitende Partijen onverwijld van dergelijke wijzigingen op de hoogte.

2. De in artikel 1 genoemde territoriale samenwerkingsverbanden of autoriteiten stellen de SecretarisGeneraal van de Benelux Economische Unie in kennis van alle op basis van deze Overeenkomst tot stand gebrachte wormen van samenwerking. Deze worden in het Benelux Publikatieblad vermeld.

\section{Artilkel 10}

Ter uitvoering wan artikel 1, tweede lid, van het Verdrag, betreffende de instelling en thet statuut van een Benelux-Gerechtshof, worden de bepalingen van de overhavige Overeenkomst, alsmede de beschikkingen van het Comite van Ministers tot vitvoering daarvan, aangewezen als gemeenschappelijke rechtsregels woor de toepassing van de hoofdstukken III en IV van bedoeld Verdrag.

\section{Artikel 11.}

Wat het Koninkrijk der Nederlanden betreft, geldt de onderhavige Overeenkomst alleen voor het land gelegen in Europa.

\section{Artikel 12}

1. De onderhavige Overeenkomst treedt in werking op de eerste dag van de tweede maand, volgende op de datum warop de drie Overeenkomstsluitende Partijen de Secretaris-Generaal van de Benelux Economische Unie hebben medegedeeld dat an hun grondwettelijke vereisten is voldaan.

2. Zij blijft woor dezelfde tijd wan kracht als het Verdrag tot instelling van de Benellux Economische Unie.

\section{Artikel 13}

1. Elke overeenkomstsluitende Partij kan deze Overeenkomst na overleg met de andere Overeenkomstsluitende Partijen opzeggen door een daartoe strekkende kennisgeving te richten tot de SecretarisGeneraal van de Benelux Economische Unie. De Secretaris-Generaal brengt de andere Overeenkomstsluitende Partijen onverwijld van een dergelijke kennisgeving op de hoogte.

2. De opzegging wordt van kracht zes maanden na de datum waarop de Secretaris Generaal de in het eerste lid bedoelde kennisgeving heeft ontvangen.

3. De opzegging laat de reeds op grond van de onderhavige Overeenkomst tot stand gekomen vormen van samenwerking en de werking van die bepalingen van de onderhavige Overeenkomst welke rechtstreeks op die vormen van samenwerking van toepassing zijn orverlet, tenzij de Overeenkomistsluitende Partijen anders overeenkomen. In dat geval regelen zij tevens de rechisgevolgen van beểindiging wan de samenwerking. 
TEN BLIJKE WAARVAN DE ONDERGETEKENDEN, daartoe behoorlijk gemachaigd, deze qvereenkonst hebben ondertekend.

Gredaan te Brussel, op 12-9-1986, in de Nederlandse en de Franse taal, zijnde beide teksten gelijkelijk authentiek.

Voor de regering wan het Koninkrijk Belgiè,

L. TINDEMANS

Voor de regeirng van het Groothertogdom Luxemburg,

R. GOEBBELS

Voor de regering van bet Koninkrijk der Nederllanden,

W.D. VAN DEN BERG

Bijlage betreffende de verwijzing naar het intern recht van de drie landen in artikel 2 van de overeenkomst (hier niet opgenomen, RS). 


\section{CONUENTION BENLLUX CONCERNANT IA COOPERATYON TRANSFRONTALIERE ENTRE COLLECTVES OU AUTORTTES THRRTIORLALES}

Le gouvemement du Royatume de Belgique.

Le gouvernement du Grand-Duché de Luxembourg.

Le gouvernement du Royaume des Pays-Bas.

Conscients des avantages attaches a la cooperation transfrontalière tels qu'ils sont definis la Convention cadre européene sur la coopération transfrontaliere des collectivités ou autorités territoriales a Madrid le 21 mai 1980.

Constatant avec satisfaction que les collectives ou autorites territoriales collaborent: dejà souvent entre elles de part ett d'autre des frontières intra-Benelus sur base du droit prive.

Souhaitant creer pour celles-ci la possibilité de coopérer également sur la base du droit public.

Considerant que celte cooperation rếpond aux objectifs du Traité instituant l'Union économique Benelux signe a La Haye le 3 fevrier 1958.

Considerant que les chefs de gouvernements et les Ministres des Affaires etrangères des pays du Benelux réunis à La Haye le 10 novenabre 1982 ont décidé d'examiner la possibilite d'élaborer au niveau Benelux une Convention-cadre relative a la cooperation entre les collectivités ou autorités territoriales, de part et d'autre des frontieres.

Vu l'amies émis le 7 juin 1986 par le Conseil Interparlementaire Consultatif de Benelux.

Ont décidé de conclure une Comvention et sont convenus de ce qui suit:

\section{Article 1}

1. La présente Convention s'applique aux collectivites ou autorités territoriales citées ci-dessous:

- en Belgique: provinces, conmues, associations de comnues, centres publics d'aide sociale, polders wateringues;

- au Luxembourg: conmunes et syndicats de commues et établissements publics placés sous la surveillance des communes;

- aux Pays-Bas: provinces, communes, wateringues et organisme publics vises dans La Loi concernant les réglementations communautaires (Stb. 1984 "669) pour autant que ladite rếglementation les đéclare conformément a la loi précitêe, compétentes en la matière.

2. Chaque Partie Contractante peut, après conformément aux règles du droit interne qui lui est propre, désigner de nouvelles collectivités ou autorités territoriales auxquelles s'applique la présente Convention.

\section{Article 2}

1. Sans préjudice des possibilités de coopération issues du droit privé, les collectivirés ou autorités territoriales des Parties Contractantes, mentionnées dans l"article ler, peuvent dans les limites des compétences que leur attribue le droit interne de leur pays, coopérèr sur base de la présente Convention en vu de défendre des intêrets conmuns. Les dispositions essentielles du droit interne de chaque Partie Contraciante vallable en la matière sont reprises a l'annexe a l'annexe à la présente Convention. 
2. Les collectivites ou autorites territoriales visees a larticle les peuvert, pur la concrétisation de la cooperation, conclure des accords administratifs, ainsi que créer des organes communs ou des organismes publics.

3. Les règles de controle et de tutelle sont soumises les collectivitês ou autorités territoriales en vertu du droit inteme des Parties Contractantes. s"appliquent aux décisions prises par la collectivites ou autorités territoriales visées a l"article les en vu de collaborer sur base de la présente Convention. ainsi qu'aux décisions d'adhésion ef de retrait.

\section{Article 3}

1. Si les collectivités ou autorites territoriales mentionnées a larticle ler décident de creer un organisme pubic, celles-ci peuvent lui attribuer des compétences de réglenentation et d"administration.

2. Lorganisme public a la personnalité juridique. La capacité juridique attribue aux personnes norales mationales ne lui est reconnue sur le territoire de chaque Partie Contractante, que dans la necessaire a l'accomplissement de sa mission et a la réalisation de ses buts.

3. Les rapports de droit entre l'organisme public et les personnes physiques et morales qui en relèwent, sont régis par le droit qui aurait eté applicable si les collectivités ou autorites territoriales nentionnées l'article ler awaient exercé elles-mêmes les competences de réglementation et $\mathrm{d}^{\mathrm{a}}$ administration à l'organisne public.

4. Sauf exception prevve dans les statuts de l"organisme public, le droit du lieu d"établissenuent du siege social de cet organisme est applicable en ce qui concerne le statut de son personnel.

5. Les statuts de l'organisme public ne peuvent pas etre en contradiction avec le droit interne des pays concernés et prévoient en tout cas une règlement pour les points suivants:

- le nom, le siège et l'objet social;

- les taches, les compétences et le mode de fonctionnenent;

- Le mode de désignation des membres des organes de gestion et de direction et du president de ceux-ci;

- la portee des obligations envers l'organisme public;

- les modalités d'organisation des reunions et de prise de décisions;

- le caractère public de ses délibérations;

- les règles applicables en matière de budget et comptes;

- les modalités de financement des activités;

- les modalités d'entrée en vigueur, de modification et d'expiration de l'accord;

- les modalités d'adlésion de nouveaux nembres et de retrait des membres.

\section{Anticle 4}

1. Les règles de contröle et de tutelle prévues dans le droit interne des Parties Contractantes $s^{8}$ appliquent par analogie aux décisions prises par les organismes publics en tenant compte de l'article 3 . paragraphe 4.

2. Chaque Partie Contractante peut, sans prejudice des dispositions du paragraphe ler, prevoir la fonction d'un ou de plusieurs commissaire(s) special (aux) en matière de cooperation transfrontalière dont la mission consiste à sauvegarder les droits du pays dont il(s) relève(nt) et de s'opposer a toute decision prise par la directions des organismes publics visés a l'article 3 qu'il(s) jugerai(enc) de nature a porter atteinte à ces droits ou quil, à son (leur) avis, est en contradiction avec lá dispositions légales ou réglementaires. Son (leur) opposition aura pour effet de suspendre l'exécution de la décision prise.

3. Une suspension sur base du premier ou du denxième paragraphe n'est décrétée qu"après concertation avec le(s) commissaire(s) concernés de l'autre pays ou au moins apres notification à celui (ceux)-ci.

4. La décision suspendue est soumise par le commissaire aux autorites competentes de son pays qui proposent une solution ou soumettent le probleme a la Commission spéciale viséte ta l'article 6. 


\section{Article 5}

1. Les Parties Contractantes et les provinces ont le droit de désigneer séparémeat ou en conmun un fonctionnaire pur les contact frontaliers.

2. Les problemes se posant dans le cadre de la cooperation transfrontalière peuvent etre soumis audit fonctionnaire.

3. Ce fonctionnaire est habilite a proposer des solutions a ces problemes ou a les soumettre aux organismes publics, collectivites ou autorites territoriales et commissaires concernes ou a la Commission visee al l'article 6.

4. Ce fonctionnaire est par ailleurs competent pour recueillir les informations nécessaire à l'accontplissement de sa tache.

\section{Article 6}

1. En vue de l'execution de la presente Conventions, il est institué une Commission spéciale conformément a l'article 31 du Traité d'Union.

2. Cette Conmission a pur mission:

a. de stimuler et de coordonner les activités concernant la coopération transfrontalière et d'informer les interressés sur les aspect legaux et autres des projets relatifs a la cooperation;

b. de rechercher des solutions aux problèmes qui lui sont soumis et portent sur la cooperation. transfrontalière entre collectivites ou autorités territoriales, objet de la présente Convention;

c. d'examiner les differents et les litiges qui surviennent dans le cadre de la cooperations transfrontaliêre basée sur la présente Convention en vue de les résoudre par vole de conciliation ou de les soumettre au Comite des Ministres;

d. de faire annuellement rapport au Comité des Ministres sur l'état de la coopération réalisếe sur base de la presente Convention;

e. d"accomplir tout autre tache qui lui sera confiée par le Comité de Ministres dans le cadre de la présente Convention.

\section{Article 7}

Le Comité des Ministres statue sur les affaires wises a l'article 6, paragraphe 2, point cy qui lui sont soumises par la Commission spéciale.

\section{Article 8}

Le Comité de Ministres peut, par décisions prise conformérment à l'article 19 point a) du Traité d'Union, formuler des règles complementizires pour les modalités d'exécution de la présente Convention.

\section{Article 9}

1. Chaque Partie Contractante notifie au Secretaire genéral de l'Union économique Benelux les modifications survenam dans les dispositions de droit interne indiquées a l'anmexe. Le Secrétaire general informe sans dêlai les autres Parties Contractantes de telles modifications.

2. Les collectivités ou autorités territoriales visées a l'article ler notifient au Secrétaire général de l'Union economique Benelux toutes les formes de coopération conclues sur base de la presente Convention. Celles-ci sont mentionmées dans the Bulletin Benelux. 


\section{Article 10}

En execution de l'article ler, paragraphe 2 du Traité relatif a l'Institution et au Statut d"une Cour de Justice Benelux, les dispasitions de la présente Convention, ainsi que les decisions du Comiré de Ministres prises en exécution, de celle-ci sont désignées conme règles juridiques comnunes pour l'application des chapitres III et IV du dit Traité.

\section{Article 11}

Et ce qui concerme le Royaume des Pays-Bas, la présente Convention ne s'applique qu'au territoire situes en Europe.

\section{Article 12}

1. La présente Convention entre en vigueur le premier jour du deuxième mois suivant la date a laquelle les trois Parties Contractantes auront notifié au Secrétaire gêneral de l'Union économique Benelux qu'il a été satisfait aux exigences constitutionnelles.

2. Elle reste en vigueur aussi longtemps que le Traite instituant l' Union économique Benelux.

\section{Article 13}

1. Chaque Partie Contractante peut denoncer la présente Convention, après consultation des autres parties Contractantes, par une notification envoyée a cet effet au Secrétaire général de l'Union économique Benelux. Le Secrétaire general informe sans đélai les autres Parties Contractantes de cette notification.

2. La dénonciation prend effet six mois après la date de la reception par le Secrétaire général de la notification visée au paragraphe 1 .

3. Cette dénonciation ne porte pas atteinte aux formes de coopération déjà réalisées sur la base de la présente Convention, ni à l'effet des dispositions de la présente Convention qui son directement applicables à ces formes de coopération, a moins que les Parties Contrantantes en conviennent autrement. Dans ce cas, elles déterminent les conséquences juridiques de la cessation de la coopération.

EN FOI DE QUOI les soussignés, dùment mandatés à cet effet, ont signé la présente Convention.

FArT a Bruxelles, le 12.9.1986 en triple exemplaire, en langues néerlandaise et française, les deux textes étanit authentiques.

Pour le gouvermement du Royaume de Belgique,

L. TINDEMANS

Pour le gouvernement du Grand-Duché de Luxembourg,

R. GOEBBELS

Pour lie gourvenement du Royaume des Pays-Bas, W.D. VAN DEN BERG

\section{ANNEXE}

Reférences du droit interne des 3 pays visé à l'article 2 de la Convention (hier niet opgenomen. RS). 


\section{Bijlage 3}

OVEREENKOMST TUSSEN HET KONINKRUK DER NEDERLANDEN, DE BONDSREPUBLIEK DUTTSLAND, HET LAND NEDERSAKSEN EN HET LAND NOORDRUN-WESTFALEN INZAKE GRENSOVERSCIRRUDENDE SAMENWERKING TUSSEN TERRTTORIALE OEMEENSCHAPPEN OF AUTORTTETEN*

Het Koninkrijk der Nederlanden, de Bondsrepubliek Duitsland, het Laud Nedersaksen en het Land Noordrijn-Westfalen.

zich bewust van de uit grensoverschrijdende samenwerking voortvloeiende voordelen, zoals omschreven in de op 21 mei 1980 te Madrid gesloten Europese kaderovereenkomst inzake grensoverschrijdende samenwerking tussen territoriale gemeenschappen of autoriteiten,

geleid door de wens voor deze gemeenschappen of autoriteiten de mogelijkheid te scheppen op publiekreclutelijke basis samen te werken,

zijn overeengekomen als volgt:

\section{Artikel 1 \\ Reikwijdte}

1. Deze Overeenkomst is van toepassing

1. in het Koninkrijk der Nederlanden op provincies en gemeenten,

2. in het Land Nedersaksen op "Gemeinden", "Samtgemeinden", en "Landkreise",

3. in het Land Noordrijn-Westfalen op "Geneinden", "Kreise" "Landschaftsverbände" en de "Kommunalverband Rulurgebiet".

2. Openbare lichamen in de zin van artikel 8 wan de Wet gemeenschappelijke regelingen wan 20 december 1984 , laatstelijk gewijzigd bij wet van 13 december 1990 , en "Zweckverbande" kumen deelnemen aan grensoverschrijdende samenwerking, indien dit op grond wan hun interne regelingen is toegestaan.

3. In overleg met de andere Overeenkomstsluitende Staten kan elk der Overeenkomstsluitende Staten andere lokale of regionale gemeensclsappen aanwijzen, waarop de bepalingen van deze Overeenkomst mede van toepassing zullen zijn.

4. Het derde lid is van overeenkomstige toepassing op andere publiekrechtelijke rechtspersonen, indien deelneming van hen volgens het interne recht wan hun Staat is toegestaan en indien ook lokale of regionale gemeenschappen van de desbetreffende Staat deelnemen aan de vormen varn grensover-

* Tractatenblad 1991, nr. 102, 1992, nr. 207. 
schrijdende samenwerking. Onder dexe voorwaarden is ook deelneming wan privatrechtelijke personen toegestatan, met uitzondering van samenwerking overeenkomstig artikel 6 .

5. Deze Overeenkomst is niet van toepassing op vormen van samenwerking waarin uitsiuitend Duitse of uitsluitend Nederlandse territoriale gemeenschappen of autoriteiten deeinemen.

6. Territoriale gemeenschappen of autoriteiten in de zin van deze Overeenkomst zijn de in het eerste, tweede en derde lid genoemde, alsmede de in het wierde hid bedoelde rechtspersonen.

\section{Artikel 2 \\ Doel en vormen van de samemwerking}

1. Territoriale gemeenschappen of autoriteiten kunnen in het kader van de bevoegdheden die zij volgens het interne recht van hun Staat hebben, op basis van deze Overeenkomst samenwerken, om een efficiente en doelmatige behartiging van hun taken door middel wan grensoverschrijdende samenwerking te bevorderen.

2. Onverminderd de mogelijkheden om op basis van het privatrecht samen te werken "kan de samenwerking geschieden door:

1. het treffen van een gemeenschappelijke regeling waarbij een openbaar lichaam wordt ingesteld,

2. het treffen van een gemeenschappelijke regelling waarbij geen openbaar lichaam of gemeenschapppelijk orgaan wordt in gesteld;

3. het treffen van een gemeenschappelijke regeling waarbij een gemeenschappelijk orgaan wordt ingesteld.

Artikel 3

Openbaar lichaam

1. Territoriale gemeenschappen of autoriteiten kunnen ter gemeenschappelijk verwulling van taken die volgens het voor elk van hen geldende interne recht door een publiekrechtelijk lichaam kunnen worden behartigd, een gemeenschappelijke regeling treffen waarbij een openbaar lichaam wordt ingesteld.

2. Het openbaar lichaam is een publiekrechtelijk lichaam. Het bezit rechtspersoonlijkheid.

3. Voor zover deze Overeenkomst geen andere bepalingen bevat, geldt woor het openbaar lichaam het recht van de Overeenkomstsluitende Staat waar de zetel van het openbaar lichaam is gevestigd.

\section{Artikel 4}

\section{Regeling en interne structuur van het openbaar lichaam}

1. De deelnemende territoriale gemeenschappen of autoriteiten stellen bet openbaar lichaam bij regeling in.

2. Organen van het openbaar lichaam zijn thet algemeen bestuur en het dagelijks bestuur. De regeling kan met inachtneming van het toe te passen interne recht in meer organen voorzien.

3. De regelling dient bepalingen te bevatten over:

1. de deelnemers aan de regeling;

2. de taken en bevoegdheden van bet openbaar lichaam;

3. de naam en zetel van het openbaar lichaam;

4. de bevoegdheden van de arganen van het openbaar lichaam en het aantal wertegenwoordigers van de territoriale gemeenschappen en autoriteiten in de organen;

5. de convocatieprocedure;

6. de voor besluitvorming vereiste meerderheden;

7. de openbaarheid van de vergaderingen;

8. de taal en de vorm van de notulen van de vergaderingen;

9. de wijze waarop de vertegenwoordigers van de territoriale gemeenschappen of autoriteiten in het algemeen bestuur inlichtingen verstrekken aan de organen van de territorialle gemeenschap of autoriteit die hen hebben afgevaardigd; 
10. de wijze waarop een vertegenwoordiger van de territoriale gemeenschap of autoriteit in het algemeen bestuur door de territoriale gemeenschap of autorivit die hem heeft afgevaardigd, ter verantwoording kan worden geroepen voor het door hen in dat bestuur gevoende beled;

11. de wijze waarop het algemeen bestuur inlichuingen verstrekt aan de territoriale gemeenschappen of autoriteiten die de regeling zijo aangegaan;

12. de wijze van boekhouding;

13. de vaststelling van de bijdragen van de deelnemers aan de regeling;

14. de toetreding en uittreding van de deelnemers aan de regeling;

15. de opheffing van de regeling waarbij het openbaar lichaam is ingesteld en

16. de afwikkeling van de regeling waarbij het openbaar lichaam is ingesteld nadat deze is opgeheven.

De regeling kam in verdere bepalen voorzien.

4. Voor wijzigingen van de regeling is een meerderheid van ten minste twee derde van het in de regeling bepaalde aantal vertegenwoordigers van de territoriale gemeenschappen of autoriteiten in het algemeen bestuur vereist. De regeling kan in aanvullende voorwaarden voorzien.

5. De afvaardiging van vertegenwoordigers van de deelnemende territoriale gemeenschappen of autoriteiten naar het algemeen bestuur richt zicht naar het interme recht wan de betrokken Staat. Hetzelfde geld $t$ voor de rechten en verplichtingen van deze vertegenwoordigers jegens de afvaardigende instellingen, voor zover deze Overeenkomst niet anders bepaalt.

\section{Artikel 5 \\ Bevoegdheden van het openbaar lichaam tegenover derden}

1. Het openbaar lichaam is niet bevoegd bij verordening algemeen verbindende voorschriften vast te stellen of bij beschilkking verplichtingen op te leggen.

2. De deelnemers aan de regeling waarbij het openbaar lichaam is ingesteld zijn jegens het openbaar lichaam verplicht, binnen de grenzen van de hum krachtens het interne recht van hun Staat toekomende bevoegdheden, de maatregelen te treffen die voot de vervulling van zijn taken noodzakelijk zijn.

\section{Artikel 6}

\section{Gemeenschappelijke regeling waarbij geen openbaar lichaam of gemeenschappelijk orgaan wordt ingesteld}

1. Territoriale gemeenschappen of autoriteiten kunnen een gemeenschappelijke regeling treffen, waarbij geen openbaar lichaam of gemeenschappelijk orgaan wordt ingesteld, voor zover dit wolgens het recht wan de Staat van de deelnemende territoriale gemeenschappen of autoriteiten is toegestatn. Do gemeenschappelijke regeling dient schriftelijk te worden vastgelegd.

2. In de in het eerste lid bedoelde gemeenschappelijke regeling kan in het bijzonder worden geregeld dat een territoriale gemeenschap of autoriteit taken behartigt van cen andere territoriale gemeenschap. of autoriteit in naam en volgens de instructies wan deze, met inachtrieming van het recht van de Staat van de tot het geven van instructies bevoegde gemeenschap of autoriteit. In de gemeenschappelijke regeling kan niet worden bepaald dat taken van een andere territoriale gemeenschap of autoriteit in eigen naam worden behartigd.

3. De gemeenschappelijke regeling diemt een bepaling te bevatten waariu is vastgelegd of, en zo ja, in welke mate, er sprake is van vrijwaring tussen de deelnemende territotiale gemeenschappen of autoriteiten ondexling van aansprakelijkheid jegens derden.

4. De gemeenschappelijke regeling dient een bepaling te bevatten over de voorwaarden voor de beëindiging van de samenwerking.

5. Yoor zover in deze Overeenkomst geen andere bepalingen zijn opgenomen, is het recht wan woepassing van de Overeenkomstsluitende Staat op het grondgebied waarvan de desbetreffende verplichting uit de gemeenschappelijke regeling moet worden vervald. 
Artikel 7

Gemeensehappelijk orgaan

1. Territoriale gemeenschappen of autoriteiten kunnen een gemeenschappelijke regeling treffen waarbij een gemeenschappelijk orgaan wordl ingesteld. Dit gemeenschappelijk orgaan beraadslaagt met inachtneming van het bepaalde in de gemeenschappelijke regeling over aangelegenheden die de deelnemers gezamenlijk aangaan.

2. Het gemeenschappelijk orgaan kan geen de deelnemers of derden bindende beslissingen nemen.

3. De gemeenschappelijke regeling dient bepalingen te bevatten over

1. de taakgebieden waarmee het gemeenschappelijk orgaan zich bezig zal houden,

2. de wijze waarop de samenwerking binnen het orgaan gestalte krijgt,

3. de zetel van het gemeenschappelijk orgaan.

4. Voor zover deze Overeenkomst geen andere bepalingen bevat, geldt voor het gemeenschappelijk orgaan het recht van de Overeenkomsisluitende Staat waar de zerel van het gemeenschappelijk orgaan is gevestigd.

\section{Artikeli 8 \\ Geldigheidsvereisten voor matregelen van grensoverschrijdende samenwerking}

1. De in artikel 2 , tweede lid, voorziene vomen van samenwerking kunnen slechts rechtsgeldig worden overeengekomen en gewijzigd, indien de bepalingen van het recht van de Staat van de deelnemende territoriale gemeenschappen of autoriteiten over

1. de bevoegdheid en de besluitvorming van de organen vam de territoriale gemeenschappen of autoriteiten,

2. vormuvoorschriften,

3. goedkeuring en

4. openbaarnaking in acht zijn genomen.

2. Territoriale gemeenschappen of autoriteiten als bedoeld in artikel 1 wijzen de territoriale gemeenschappen of autoriteiten die in andere Overeenkomstsluitende Staten zijn gevestigd op de vereisten die het eerste lid stelt.

\section{Artikel 9 \\ Toezicht:}

1. Indien het interne recht van hun Staat zulks vereist, geven de betrokken territoriale gemeenschappen of autoriteiten aan de autoriteiten aan bet toezicht waarvan zij onderworpen zijn, informatie over de oprichting, wijziging en opheffing van vormen van samenwerking ingevolge artikel 2 , tweede lid, waratan zij deelnemen.

2. De bevoegdheden valu de bevoegde autoriteiten van de Overeenkomstsluitende Staten inzake het toezicht op territoriale gemeenschappen of autoriteiten die aan hun toezicht onderworpen zijn, blijven onverlet.

3. Voor het toezicht op basis van deze Overeenkomst ingestelde openbare lichamen en gemeenschappelijke organen zijn met inachtneming van het interne recht wan hun Staat de toezichthoudende autoriteiten bevoegd van de Overeenkomstshitende Staat waar zij hun zetel hebben. De toezichthoudende autoriteit zongt voor de behartiging van de belangen van alle territoriale gemeenschappen of autoriteiten van de andere Overeenkomstsluitende Staten die deelnemen in het openbaar lichaam of gemeenschappelijk orgaan.

4. De ingevolge het derde lid bevoegde toezichthoudende autoriteit en de voor het toezicht op de deelnemende territoriale gemeenschappen of autoriteiten bevoegde toezichthoudende autoriteiten van de andere Overeenkomstsluitende Staten geven elkaar desgevragd alle informatie en stellen elkaar wederzijds op de hoogte van de essentiele maatregelen en resultaten van hun onderzoek, voor zover dit gevolgen kan hebben voor de samenwerking. Maatregelen inzake het toezicht die openbare licha- 
men of gemeenschappelijke organen betreffen mogen slechts na overlleg met de bevoegde toezichthoudende autoriteiten van de andere Overeenkonstsluitendle Staten worden getroffen, tenzij deze maatregelen geen uitstel dulden.

5. Voordat een toezichthoudende autoriteit van een Overeenkomstsluitende Staat maatregelen treft die betrekking hebben op de samenwerking ingevolge artikel 6 , informeert zij de bevoegde toezichthoudende instantie van de andere Overeenkomstsluitende Stat om tot onderlinge afstemming te komen, tenzij de matregel geen uitstel duldt.

\section{Artikel 10 \\ Rechtsgang en aanspraken wan derden}

1. Derden behouden jegens een territoriale gemeenschap of autoriteit ten behoeve waarvan of in naam waarvan een openbaar lichaam of een andere territoriale gemeenschap of autoriteit taken behartigen, alle rechtsvorderingen die hun zouden toekomen indien deze taken niet via grensoverschrijdende samenwerking zouden zij.jn vervuld. De rechtsgang richt zich naar het recht van de Overeenkomstslujtende Staat vam de territoriale gemeenschap of autoriteif wier taak is vervuld.

2. Naast de ingevolge het eerste lid aansprakelijke territoriale gemeenschap of autoriteit zijin ook het openbaar lichaam of de territoriale gemeenschap of autoriteit die taken behartigt aansprakelijk. Rechtsvorderingen tegen hen richten zich naar het recht van de Overeenkomstsiluitende Staat waar hun zetel is gevestigd.

3. Indien een rechtsvordering overeenkomstig het eerste lid wordi ingesteld tegen een territoriale gemenschap of autoriteit namens welke een openbaar lichaam heeft gehandeld, dan is het openbaar lichaam tegenover de territoriale gemeenschap of autoriteit verplicht dexe te vrijwaren van aansprakelijkheid jegens derden. Indien de rechtswordering gericht is tegen een territoriale gemeenschap of autoriteit die op basis van een gemeenschappelijke regeling ingevolge artikel 6 theeft gehandeld, geldt voor de onderlinge aansprakelijkheid tussen de twee betrokken territoriale gemeenschappen of autoriteiten het daaromtrent in de gemeenschappelijke regeling bepaalde ingevolge artikel 6 , dercle lid.

\section{Artikel 11}

\section{Rechtsgang bij geschillen tussen territoriale gemeenschappen of autoriteiten}

1. Bij publiekrechtelijke geschillen tussen territoriale gemeenschappen of autoriteiten, openbare lichamen of gemeenschappelijke organen die naar aanleiding van grensoverschrijdende samenwerking zijn gerezen, wordt de rechtsgang bepaald volgens de regels van de Overeenkonstsluitende Stat war de zetel van de gedaagde is gevestigd.

2. De betrokken territoriale gemeenschappen of autorifeiten kunnen overeenkomen geschillen voor te leggen aan een scheidsgerecht.

\section{Artikel 12}

Territoriale reikwijjte

Wat het Koninkrijk der Neder|anden betreft, geldt deze Overeenkomst slechts voor het Rijk in Europa.

\section{Artikel 13 \\ Inwerkingtreding}

De Overeenkomst treedt in werking op de eerste dag van de tweede maand volgend op de daturn waarop de laatste Owereenkomstsluitende Staat de andere Owereenkomstsluitende Staat mededeling doet dat aan de interne vereisten voor inwerkingtreding is voldaan. 


\section{Artikel 14 \\ Werkingsduur en opxegging}

1. Deze Overeenkomst wordt aangegaan voor onbepaalde tijd.

2. Ieder van de Overeenkomstsluitende Staten kan deze Overeenkomst tegenover de andere Overeenkomstsluitende Staten schriftelijk opzeggen; de opzegtermijn bedraggt twee jaar, te rekenen vanaf het einde van het kalenderjaar.

3. In geval van opzegging door thet Land Nedersaksen of het Land Noordrijn-Westfalen blijft de Overeenkomst tussen de overige Overeenkomstsluitende Staten van kracht. In geval van opzegging door Eén van deze Landen kan het andere Land binnen drie maanden na de ontvangst van de opzegging verklaren dat het zich daarbij aansluit.

4. Indien de Overeenkomst wordt opgezegd, blijwen de voor de buitenwerkingstelling van de Overeenkomst tot stand gekomen maatregelen als gevolg van samenwerking en de bepalingen van de Overeenkomst welke rechtstreeks op de vormen van samenwerking van toepassing zijn, onverlet.

TEN BLIJKE WAARVAN de daartoe behoorlijk bevoegd verklaarde gevolmachtigden deze Overeenkomst hebben ondertekend.

GEDAAN te Isselburg-Amholt, op 23 mei 1991 in wier oorspronkelijke exemplaren in de Nederlandse en de Duitse taal, zijnde beide teksten gelijkelijk authentiek.

Voor het Koninkrijk der Nederlanden

(w.g.) H. VAN DEN BROEK

(w.g.) I. DALES

Voor de Bondsrepubliek Duitsland

(w.g.) HANS-DIETRICH GENSCHER

Voor thet Land Nedersaksen

(w.g.) GERHARDT SCHRODER

Voor het Land Noordrijn-Westfalen

(W.g.) JOHANNES RAU

\section{PROTOCOL}

Bij de ondertekening van de Owereenkomst tussen het Koninkrijk der Nederlanden, de Bondsrepubliek Dvitsland, het Land Nedersaksen en het Land Noordrijn-Westfalen inzake grensoverschrijdende samenwerking tussen territoriale gemeenschappen of autoriteiter op 23 mei 1991 te Isselburg (BRD) hebben de Overeenkomstsluitende Partijen de volgende afspraken gemakt, die een integrerend deel van de Overeenkontst vormen:

De Overeenkomstsluitende Partijen zullen streven naar een uniforme uitlegging van deze Overeenkomst binnen de reikwijlte daarvan. Dit doel dient reeds de door de Overeenkomstsluitende Partijen gezamenlijk opgestelde Toelichting bij de Overeenkomst, die de Overeenkomstsluitende Partijen in het kader van de interne goedkeuringsprocedures steeds bij de Overeenkomst zullen voegen.

Indien een Overeenkomstsluitende Partij consultaties over de uitlegging of de toepassing van de Overeenkomst noodzakelijk acht, zullen de Overeenkomstsluitende Partijen op het niveau wan de bevoegde ministeries hiertoe bijeenkomen.

GEDAAN te Isselburg-Anholt op 23 mei 1991 in vier oorspronkelijke exemplaren in de Nederlandse en de Duitse taal, zijnde beide teksten gelijkelijk authentiek. 
Voor het Koninkrijk der Nederlanden (w.g.) H. VAN DEN BROEK

(w.g.) I. DALES

Voor de Bondsrepubliek Duitsland

(w.g.) HANS-DIETRICH GENSCHER

Voor het Land Nedersaksen

(w.g.) GERHARDT SCHRODER

Voor het Land Noordrijn-Westfalen

(w.g.) JOHANNES RAU 
ABKOMMEN ZWISCHEN DEM KONIGREICH DER NIEDERL ANDEK, DER BUNDESREPUBLIK DEUTSCHLAND, DEM LAND NIEDERSACHSEN UND DEM LAND NORDRHEIN-WESTFALEN UBER GRENSÜBERSCHRETTENDE ZUSAMMENARBEIT ZWISCHEN GEEHETSKÖRPERSCHAFTEN UND ANDERIN OFFENTLICHEN STELLEN

Das Königreich der Niederlande, die Bundesrepublik Deutschland, das Land Niedersachsen und das Land Nordrhein-Westfalen,

im Bewußtsein der aus grenzüberschreitenden Zusammenarbeit erwachsenden Vorteile, wie sie in dem am 21. Mai 1980 in Madrid geschlossenen Europảischen Rahmenübereinkommen über die grenzüberschreitenden Zusammenarbeit zwischen Gebietskörperschaften aufgezeigt sind, in den Wunsch, diesen Körperschaften und anderen öffentliche Stellen die Möglichkeit zu verschaffen, auf offentlich-rechtlicher Gundlage zusammenzuarbeiten,

haben folgemdes vereinbart:

Artikel 1

Anwendungsbereïch

1. Dieses Abkommen findet Anwendung:

1. im Königreich der Niederlande auf "provincies" und "gemeenten",

2. im Land Niedersachsen auf Gemeinden, Samtgemeinden und Landkreise,

3. im Land Nordrhein-Westfalen auf Gemeinden, Kreise, Landschaftsverbände und den Konmunalverband Ruhrgebiet.

2. "Openbare lichamen" Im Sinne von Artikel 8 des "Wet gemeenschappelijke regelingen" vom 20. Dezember 1984, zuletzt geändert durch das Gesetz vom 13. Dezember 1990, und Zweckverbände können sich an der grenzuberschreitenden Zusammenarbeit beteiligen, wenn ihre innerstaatlichen Organisationsstatute dies zulassen.

3. Im Einvernelmmen mit den anderen Vertragsstaten kann jeder Vertragsstaat andere kommunale Körperschaften benennen, auf die die Regelungen dieses Abkommens zusătzlich Anwendung finden sollen.

4. Absatz 3 findet auf sonstige juristische Personen des öfentlichen Rechts entsprechende Anwendung, wenn ilare Beteiligung nach innerstaatlichen Recht zulässig ist und an den Formen der grenzïberschreitenden Zusammenarbeit auch innerstaatliche kommunale Körperschaften beteiligt sind. Unter diesen Voraussetzungen ist auch die Beteiligung won Personen des Privatrechts mit Ausnahme einer Zusammenarbeit nach Artikel 6 zullässig.

5. Dieses Abkommen findet keine Anwendung auf Formen der Zusammenarbeit, an denen nur deutsche oder nilederlindische offentliche Stellen beteilligt sind.

6. Offentliche Stellen im Sinne dieses Abkommens sind die in den Absătzen 1,2 und 3 genannten sowie die in Absatz 4 einbezogenen Personen.

\section{Artikel 2 \\ Zilel und Formen der Zusammenarbeilt}

1. Öffentliche Stellen können im Rahmen der ihnen nach innerstaatlichen Recht zustehenden Befugnisse auf der Grundlage dieses Abkommens zusammenarbeiten, um eine wirtschaftliche und zweckmaßlige Erfullung ilhrer Aufgaben im Wege der grenzüberschreitenden Zusammenarbeit zu fördern.

2. Die Zusammenarbeit kann unbeschadet der zivilrechtliche gegeben Moglichkeiten erfolgen durch:

1. Bildung von Zweckverbänden,

2. AbschluB offentlich-rechtlicher Vereinbarungen,

3. Bildung kommunaler Arbeitsgemeinschaften. 


\section{Artikel 3}

\section{Zweckwerband}

1. Öffentliche Stellen können zur gemeinsamen Erfüllung von Aufgaben, die nach den für sie jeweils geltenden innerstaatlichen Recht von einem offentlich-rechtlichen Verband wahrgenommen werden dürfen, einen Zweckverband bilden.

2. Der Zweckverband ist eine offentlich-rechtliche Körperschaft. Er besizt Rechtsfahigkeit.

3. Soweit dieses Abkommen keine anderen Regelungen enthallt, gelten für den Zweckverband die Rechtsvorschriften des Vertragsstaats, in dem der Zweckverband seinen Sitz hat.

\section{Artikel 4 \\ Satzung und innere Struktur des Zweckverbandes}

1. Zur Bildung des Zweckverbandes vereinbaren die beteiligten offentlichen Stellen eime Verbandssatzung.

2. Organe des Zweckverbandes sind die Verbandsversammlung und der Verbandsvorstand. Die Verbandssatzung kamn unter Beachung des jeweils arzowwendenden innerstatlichen Rechts weitere Orgame vorsehen.

3. Die Verbandssakzung muß Bestinumungen enthalten über:

1. die Verbandsmitglieder,

2. die Aufgaben und Befugnisse des Zweckverbands,

3. die Namen und den Sitz des Zweckverbands,

4. die Zuständigkeiten der Organe des Zweckverbands und die Zahl der Vertreter der offentlichen Stellen in den Organen,

5. das Einladungsverfahren,

6. die zur Beschlußfassung erforderlichen Mehrheiten,

7. die Öffentliclakeit der Sitzungen,

8. Sprache und Form der Sitzungsniederschriften,

9. die Art, in der die Vertreter der offentlichen Stellen in der Verbandsversammlung den Organen der offentlichen Stelle, die sie entsandt haben, Informationen zu erteilen,

10. die Art, in der ein Vertreter der öffentlichen Stellen in der Verbandsversammlung von der offentlichen Stelle, die ahn entsandt hat, für seine "Tätigkeit im Rahmen dieser Versammlung zur Rechenschaft gezogen werden kann,

11. die Art, in der die Verbandsversammlung den offentlichen Stellen, die die Verbandssatzung verembart haben, Informationem erteilt,

12. die Art der Rechnungsführung,

13. die: Festsetzung der Beiträge der Verbandsmitglieder,

14. Beitritt und Austritt von Verbandsmitgliedern,

15. die Auflösung der Zweckverbands und

16. die Abwicklung des Zweckverbands nach seiner Auflosung.

Sie kann weitere Bestimmungen vorsehen.

4. Änderungen der Verbandssatzung bedürfen mindestens einer Zweidrittelmehrheit der satzungsgemdBen Zahl der Vertreter der offentlichen Stellen in der Verbandsversammlung. Die Verbandssatzung kann zusäizliche Voraussetzungen vorsehen.

5. Die Entsendung von Vertretern der offentlichen Stellen in die Verbandswersammlung richtet sich nach dem innerstaatlichen Recht des jeweiligen Staates. Gleiches gilt für die Rechte und Pflichien dieser Vertreter im Verháltnis zu ibren entsendenden Stellen, soweit dieses Abkommen nichts anderes regelt.

\section{Artikel 5}

\section{Befugnisse des $\mathbf{Z}$ weckverbands gegenüber Dritten}

1. Der Zweckverband ist nicht berechtigt, Dritten durch Rechtsnorm oder Verwaltungsakt Verpflichtungen aufzuerlegen. 
2. Die Mitglieder des Zweckverbandes simd ihm gegenuber verpflichtet, im Ralmen inrer innerstaat" lichen Befugnisse die Maßmahmen zu ergreifeu, die zur Erfüllung seimer Aufgaben erforderlich sind.

\section{Artikel 6 \\ Öfrentlich-rechuliche Vereinbarung}

1. Öffentliche Stellen konnen miteinander eine offentlich-rechtliche Vereinbarung abschließen, soweit der Abschlluf nach dem imerstaatlichen Recht der beteiligten offentichen Stellen zulässig ist. Die Vereinbarung bedarf der Schriftorm.

2. Durch offentliclu-rechtiche Vereinbarung kann insbesondere geregelt werden, daß eine offentliche Stelle Aufgaben einer anderen offentlichen Stelle in deren Namen und nach deren Weisung unter Beachtung des innerstaatichen Rechts der weisungsbefugten offentlichen Stellen wahrnimimt. Die Vereinbanung, Aufgaben einer anderen offentlichen Stelle im eigenen Namen wahrzunehmen, kann nicht getroffen werden.

3. Die offentlich-rechtiche Vereinbarung muf eine Regelung dariber enthalten, ob und in welchem Umfang im Verhältnis zwischen den beteiligten offentlichen Stellen eine Freistellung von der Haftung gegeniber Dritten erfolgt.

4. Die offentlich-rechtliche Vereinbarung mul eine Regelung über die Voraussetzungen fur eine Beendigung der Zusammenarbeit enthalten.

5. Soweit in diesem Abkommen keine anderweitige Regelung getroffen ist, ist das Recht des Verragsstats anwendbar, auf dessen Gebiet die jeweilige Verpflichtung aus der Vereinbanung erfullt werden soll.

\section{Artikell 7}

\section{Komnunale Arbeitsgemeinschaft}

1. Öffentliche Stellen können durch schriftliche Vereinbarung eine kommunale Arbeitsgemeinscliaft bilden. Eine kommunale Arbeitsgemeinschaft berät nach Mafigabe der getrofenen Vereinbarung Angelegenheiten, die ihre Mitglieder gemeinsam berühen.

2. Eime kommunale Arbeitsgemeinschaft kann keine die Mitglieder oder Dritte bindenden Beschlüsse fassen.

3. Die Vereinbarung mul Bestimmungen enthalten über:

1. die Aufgabengebiete, auf denen sich die kommunale Arbeitsgemeinschaft betätigen soll,

2. die Durchführung der Arbeitsgemeinschaft,

3. den Sitz der Arbeitsgemeinscluaft.

4. Soweil in diesem Abkommen keine anderewetige Regelung getroffen isit, ist auf die kommunale Arbeitsgemeinschaft das Recht des Vertragsstaats anwendbar, in dem die Arbeitsgemeinschaft ihren Sitz hat.

\section{Artikel 8 \\ Wirksamkeitsworaussetzungen für Maßnahmen der grenziiberschreitenden Zusammenarbeit}

1. Die in Artikel 2 Absatz 2 vorgesehenen Formen der Zusammenarbeit können ruer rechtsverbindlich vereinbart und geändert werden, wenn die Vorschriften des imerstatlichen Rechts der beteiligten offentlichen Stellen uber

1. Zuständigkeit und Beschludfassung der Organe der affentlichen Stellen,

2. Formerfordernisse,

3. Genelunigungen und

4. Bekanntmachungen eingehalten worden sind.

2. Öfentliche Stellen im Sinne won Artikel 1 haben die offentlichen Stellen, die in anderen Vertragsstaten gelegen sind, auff die Erfordernisse des Absatzes 1 hinzuweisen. 


\section{Artikel 9}

Aufsicht

1. Wenn das innerstaatliche Recht dies vorsieht, unerrichten die beteiligten offentlichen Stellen ihre Aufsichtsbehörden über Begründung, Anderungen und Beendigung von Fommen der Zusammenarbeit nach Artikel 2 Absatz 2, an denen sie beteiligt sind.

2. Die Aufsichtsbefugnisse der zustämdligen Behörden der Vertragsstaaten uber offentliche Stellen, die ihrer Aufsicht unterstehen, bleiben unberührt.

3. Für die Aufsicht über aufgnund dieses Abkonmens gebildete Zweckverbände und komnunale Arbeitsgemeinschaften sind nach Malggabe des innerstaatlichen Rechts die Aufsichtsbehorden des Vertragsstaats zuständig, in dem diese ihren Sitz habeu. Die Aufsichtsbehörde sorgt für die Wahrung der Interessen aller offentlichen Stellen der anderen Vertragsstaaten, die jeweils dem Zweckverband oder der kommunalen Arbeitsgemeinschaft angehören.

4. Die nach Absatz 3 zuständigen Aufsichtsbehörden und die für die Aufsicht über die beteiligten offentlicken Stellen zuständigen Aufsichtsbehörden der anderen Vertragsstaaten stellen sich auf Verlangen alle Informationen zur Verfugung und unterrichten sich gegenseitig über die wesentlichen Malßnahmen und Ergebnisse ihrer Aufsichtstätigkeit, sofern dies Auswirkungen auf die Zusanmenarbeit haben kann. AufsichtsmaßBnahmen, die Zweckverbände oder kommunale Arbeitsgemeinschaften betreffen, dürfen nur im Benehmen mit den zuständigen Aufsichtsbehörden der anderen Vertragsstaaten getroffen werden, es sei denn, diese Mallnahmen sind unaufschiebbar.

5. Bevor eine Aufsichtsbehörde eines Vertragsstaats Maßnnahmen ergreift, die sich auf die Zusammenarbeit nach Artikel 6 beziehen, unterrichtet sie die zuständige Aufsichtsbehörde des anderen Vertragsstaats mit dem Ziel, eine Abstimmung her-beizuführen, es seil denn, die MalBnahome ist unaufschiebbar.

\section{Artikell 10 \\ Rechtsweg und Ansprüche Dritter}

1. Driute behalten gegenüber einer offentlichen Stelle, zu deren Gunsten oder in deren Namen ein Zweckverband oder eine andere offentliche Sielle Aufgaben wahmehmen, alle Ansprüche, die ihnen zustehen würden, weun diese Aufgaben nicht im Wege der grenzüberschreitemden Zusammenarbeit erfüllt worden wären. Der Rechtsweg richtet sich nach dem Recht des Vertragsstaats der offentlichen Stelle, deren Aufgaben erfüllt worden ist.

2. Neben der nach Absatz 1 verpflichteten offentichen Stelle haften auch der Zweckverband odler die offentiche Stelle, die Aufgaben wahnelmen. Anspriche gegen sie richiten sich nach dem Recht des Vertragsstaats, in dem sie ihren Sitz haben.

3. Wird ein Anspruch nach Absatz 1 gegen eine offenuliche Stelle erhoben, für die ein Zweckverband geliandelt hat, so ist der Zweckverband gegenüber der offentlichen Stelle werpflichtet, diese won der Haftung gegenüber Dritten freizustellen.

Richtet sich der Anspruch gegen eine offentliche Stelle, die aufgnund einer Vereinbarung nach Artikel 6 gehandelt hat, so gilt fur die Haftung im Verhaltnis zwischen diesen beiden offentlichen Stellen die in der Vereinbanung nach Artikel 6 Absatz 3 enthaltene Regelung.

Artikel 11

\section{Rechtsweg bei Streitigkeit zwischen offentlichen Stellen}

1. Bei öfentich-rechulichen Streitigkeiten zwischen öfentlichen Stellen, Zweckverbănde oder kommunalen Arbeitsgemeinschaften aufgrund der grenzuberschreitenden Zusammenarbeit ist der Rechisweg mach den Vorschriften des Vertragsstaats gegeben, in dem der Beklagte seinen Sizz hat.

2. Die beteiligten offentlich-rechtlichen Stellen können eine Schieclsvereinbarung treffen. 


\section{Artikel 12 \\ Geltungsbereichsklausel}

In Bezug auf das Konngreich der Niederlande gilt dieses Abkommen nur für das in Europa gelegene Hoheitsgebiet.

\section{Artikel 13 \\ Inkraftretem}

Das Abkommen tritt an ersten Tag des zweiten Monats nach dem Tag in Kraft, an dem der letzte Unterzeichnerstaat den anderen Unterzeichnerstaten mitteilt, daß die erforderlichen innerstaatlichen Voraussetzungen fur das Inkrafttreten des Abkommens erfüllt sind.

\section{Artikel 14 \\ Geltungsdauer und Kündigung}

1. Dieses Abkommen wird auf unbestimmte Zeit geschlossen.

2. Jeder Vertragsstaat kann dieses Abkommen mit einer Frist von zwei Jallaren zum Ablauf eines Kalenderjahres, gegenüber den anderen Vertragsstaaten schriftlich kündigen.

3. Kündigt das Land Niedersachsen oder das Land Nordrhein-Westfalen, bleibt das Abkommen zwischen den übrigen Veriragsstaaten wirksam. Im Falle der Kündigung durch eines dieser Länder kann das jeweils andere Land innerhalb won drei Monaten nach Zugang der Kündigung erklären, dalf es sich dieser anschließt.

4. Wird das Abkommen gekündigt, so bleiben die vor dem Ausserkraftreten dieses Abkommens wirksam gewordenen Maßnahmen der Zusammenarbeit und die Bestimmungen des Abkommens, die sich unmittelbar auf die Formen der Zusammenarbeit beziehen, dawon unberührt.

ZU URKUND DESSEN haben die hierzu gehörig befugten Biewollmächtigten dieses Abkommen unterschrieben.

GESCHEHEN zu Isselburg-Anholt am 23. Mai 1991 in vier Urschriften, jede in niederländischer und deutscher Sprache, wobei jeder Wortlaut gleichermaBen verbindlich ist.

Für das Königreich der Niederlanden

(gez.) H. VAN DEN BROEK

(gez.) T. DALES

Für die Bundesrepublik Deutschlland

(gez.) HANS-DIETRICH GENSCHER

Für das Land Niedersachsen

(gez.) GERHARDT SCHRÖDER

Für das Land Nordrhein-Westfalen

(gez.) JOHANNES RAU

\section{PROTOKOLL}

Bei Unterzeichuung des Abkommens zwischen dem Königreich der Niederlande, der Bundesrepublik Deutschland, em Land Niedersachsen und dem Land Nordrhein-Westfalen über grenzüberschreitenden Zusammenarbeit zwischen Gebietskörperschaften und anderen offentlichen Stellen am 23. mai 1991 in Isselburg haben die Vertragsparteien folgende Vereinbarungen getroffen, die als Bestandteile des $\mathrm{Ab}$ komumens gelter: 
Die Vertragsparteien werden um eine einheitliche Auslegung dieses Abkommens in seinem Geltungsbereich bemüht sein. Diesem Ziell dient bereits die von den Ventragsparteien gemeinsan erarbeitete Bicgründung za dem Abkommen, die die Vertragsparteien dem Abkommen jeweils im Rahmen der ianerstaatlichen Zustimmungsverfahren beifugen werden. Hălt eine Vertragspartei Konsultationen uber die Auslegung für erforderlich, werden sich die Vertragsparteien zu diesem Zweck auf der Ebene der zuständigen Ministerien treffen.

GESCHEHEN zu Isselburg-Anholt am 23. mai 1991 in vier Urschriften, jede in niederlandischer und deutscher Sprache, wobei jeder Wortlaut gleichermaßen verbindlich ist.

Für das Königreich der Niederlande

(gez.) H. VAN DEN BROEK

(gez.) I. DALES

Für die Bundesrepublik Deutschland

(gez.) HANS-DIETRICH GENSCHER

Für das Land Niedersachsen

(gez.) GERHARDT SCHRÖDER

Für das Land Nordrhein-Westfalen

(gez.) JOHANNES RAU 
Bijlage 4

WET GEMEENSCHAPPELUKE REGELINGEN (BELANGRIJKSTE BEPALINGEN)*

\author{
HOOFDSTUK I \\ Regelingen tussen gemeenten \\ $\$ 1$ Bevoegdheid tot het treffer van een regeling
}

Art.1.

1. De raden, de colleges van burgemeester en wethouders en de burgeneesters van twee of meer gemeenten kumen afzonderlijk of te zamen, teder voor zover zij voor de eigen gemeente bevoegd zijn, een gemeenschappelijke regeling treffen ter behartiging van een of meer bepaalde belangen van die gemeenten.

2. De colleges van burgemeester en wethouders en de burgemeester gaan niet over tot het treffen van een regeling dan tha verkregen verklaring van geen bezwaar van de gemeenteraden.

3. Onder het treffen van een regeling wordt in dit artikel mede verstaan bet wijzigen wan, het toetreden tot en het uittreden uit een regeling.

\title{
$\$ 2$ Algemene bepalingen
}

Art.2.

1. Provinciale Staten delen hun provincie in samemwerkingsgebieden in. Zij bevorderen dat zoveel mogelijk regelingen binnen deze gebieden worden gebundeld of geïntegreerd.

2. (..)

Art.8.

1. Bij de regeling kan een openbaar lichaam worden ingesteld. Het openbaar lichaam is rechtspersoon.

2. In daarvoor in aammerking komende gevallen kan bij de regeling, in plaats van een openbaar licliaan, een gemeenschappelijk orgaan worden ingesteld.

3. In de regeling kan worden bepaald dat daarin omschreven bevoegdheden van bestuursorganen of van ambtenaren van aan de regeling deelnemende gemeenten worden uitgeoefend door bestuursorganen, onderscheidenlijk door ambtenaren van een der deelnemende gemeenten.

Art.10.

1. De regeling vermeldt het belang of de belangen ter behartiging warvan zij is getroffen of gewijzigd.

2. Een regeling, waarbij gebruik wordt gemaakt van de bevoegdheid, bedoeld in artikel 8 , eerste en tweede lid, geeft aan welke bevoegdheden de besturen van de deelnemende gemeenten aan het bestuur van het openbaar lichaam onderscheidenlijk aan het gemeenschappelijk orgaan bij het aan-

* Wet van 20-12-1984, Stb 667, laatstelijk gewijzigd 13-12-1990, Stb. 609 . 
gaan wan de regeling toekennen. Een regeling als hier bedoeld kan bepalingen inhouden omtrent de wijze waarop verandering kan worden gebracht in de toegekende bevoegdheden.

3. Een regeling als bedoeld in het tweede lid houdt bepalingen in omtrent de inrichting en samenstelling van het bestuur van het openbaar lichaam onderscheidenlujk van het gemeenschappelijk orgaan en wijst de plaats van vestiging aan.

Art.12.

1. Het bestuur van het openbaar lichaam bestaat uit een algemeen bestuur, een dagelijks bestuur en een woorzitter.

2. Het algemeen bestuur staat aan het hoofd van het openbaar lichaam.

3. De voorzitter is tewens voorzitter van thet algemeen bestuur en van het dagelijks bestuur.

Art.13...

1. Het algemeen bestuur van een openbaar lichaam, ingesteld bij een regeling die is getroffen of mede is getroffen door gemeenteraden, bestaat uit leden, die per deelnemende gemeente door de raad uit zijn midden, de voorzitier inbegrepen, worden aangewezen. Indien de regeling uitsluitend strekt tot behartiging van opleiding en worming van ambtenaren, kan in de regeling worden bepaald, dat ook de gemeentesecretaris als lid van het algemeen bestuur kan worden aangewezen.

2. Het lidmaatschap wan het algemeen bestuur eindigt van rechtswege, zodra men ophoudt lid of voorzitter te zijn van de raad uit wiens midden men is aangewezen dan wel secretaris van de desbetreffende deelnemende gemeente.

3. De regeling bepaalt het aantal leden van thet algemeen bestuur, dat door de raad van elke deelnemende wordt aangewezen.

4. (..)

\section{Art.14.}

1. Het dagelijks bestuur van het openbaar lichaam bestaat uit de voorzitter en twee of meer andere leden, door en uit het algemeen bestuur aan te wijzem, met inachtneming van het daaromtrent in de regeling bepaalde. De aldus aangewezen leden van het dagelijks bestuur mogen niet allen afkomstig zijn uit dezelfde gemeente.

2. Wanneer de aard van de regeling daartoe aanleiding geeft, kunnen eén of meer leden van het dagelijks bestuur, niet zijnde de woorzitter, worden aangewezen wan buiten de kring van het algemeen bestuur, met dien verstande dat op deze wijze aangewezen leden nimmer de meerderheid van het dagelijks bestuur mogen uitmaken.

\section{Ant.15.}

Op de samenstelling van het algemeen bestuur van het gemeenschappelijk orgaan, bedoeld in artikel 8 , tweede lid, is artikel 13 van overeenkomstige toepassing.

Art.28.

1. Geschillen omtrent de toepassing, in ruimste $z^{\| I} n_{\text {v }}$ van een regeling tussen besturen van deelnemende gemeenten of tussen besturen van een of meer gemeenten en het bestuur van het openbaar lichatam of litet gemeenschappelijk orgaan worden door gedeputeerde staten beslist, voorzover zij niet behoren tot die, wermeld in artikel 112 , eerste lid van de Grondwet, of tot die, walarvan de beslissing krachtens artikel 112, tweede lid wan de Grondwet is opgedragen hetzij aan de rechterlijke macht, hetzij aan gerechten die niet tot de rechterlijke macht behoren.

2. Gedeputeerde staten kunnen bij de beslissing van het geschil het desbetreffende bestuur opdragen een besluit te memen met inachtneming van het in hun beshissing bepaalde en binnen een daartoe te stellen termign. Indien binnen de gestelde termijn het besluit niet is genomen, geschiedt dit door gedeputeerde staten.

3. (..) 


\section{§3. Bevoegdheden bij regelingen tussen gemeenten}

Art.30.

1. Aan het bestuur van het openbaar lichaam of aan het gemeenschappelijk orgaan kunnen bij de regeling ten aanzien van de belangen ter behartiging waarvan zij wordt getroffen, en voor het gebied waarvoor zij geldt, zodanige bevoegdheden van regeling en bestuur worden toegekend als aan de besturen van aan de regeling deelnemende gemeenten toekomen, met dien verstande dat:

a. aan het bestuur van het openbaar lichaam niet de bevoegdheid kan worden opgedragen andere belastingen te heffen dan de rechten, bedoeld in artikel 272 onder i van de gemeentewet, de rechten waarvan de heffing krachtens bijzondere wetten geschiedt en de belasting, becioeld in artikel 6lal eerste lid, van de Wet algemene bepalingen milieuhygiêne (Stb. 1988, 133).

b. aan het gemeenschappelijk orgaan niet de bevoegdheid kan worden toegekend belastingen te beffen of anderszins algemeen verbindende voorschriften te geven.

2. Indien toepassing is gegeven aan het bepaalde in het eerste lid wordt daarbij tevens de verhouding van de toegekende besturen tot die van de besturen van de deelnemende gemeenten geregeld.

3. Voor zover een verordening van het openbaar lichaam voorziet in hetzelfde onderwerp als een werordening van een deelnemendé gemeente, regelt eerstbedoelde verordening de onderlinge verhouding. $\mathrm{Zij}$ kan bepalen, dat de verordening der gemeente voor het geluele gebied dan wel een gedeelte daarvan geheel of gedeeltelijk ophoudt te gelden.

Art.31.

Bij de regeling kunnen beperkingen worden aangebracht in de bevoegdheid die het operbaar lichaam van rechtswege bezit om aan het maatschappelijk verkeer deel te nemen.

Art.33.

1. Ten aanzien van de bevoegdheden van het bestuur van het openbaar lichaan of die van het gemeenschappelijk orgaan zijn van overeenkomstige toepassing de regels, in ruimste zin, welke bij of krachtens de wet zijn gesteld voor de verdeling van bewoegdheden van de gemeentebesturen over de gemeentelijke bestuursorganen, voor de uitoefening van die bevoegdheden, alsmede het toezicht daarop. Dit geldt niet voor zover daarvan bij of krachtens deze wet is afgeweken.

2. De besturen van de deelnemende gemeenten kunnen bij de regeling beperkingen aambrengen in de bevoegdheden die door het bestuur van het openbaar lichaam onderscheidenlijk het gemeenschappelijk orgaan zouden kumnen worden ontleend aan de regellen, bedoeld in het eerste lid.

3. Voor bij algemene maatregel van bestuur aan te geven categorieên van gevallen, waarin inachtneming van bepaalde regels, bedoeld in het eerste lid, onevenredig belastend zou zijn in verhouding tot het met die regels beoogde doel kunnen bij die maatregel datrvan afwijkende regels worden gestell.

\section{\$. Goedkeuring van regelingen}

Art 36 .

1. Een regeling waarbij gebruik is gemaakt van een bewoegdheid als bedoeld in artikel 8 , behoeft de goedkeuring van gedeputeerde staten.

2. Gedeputeerde staten nemen bij hum beslissing omtrent de goedkeuring met mame in overweging, in hoeverre behartiging van het belang of de belangen in het kader van de ter goedkeuring voorgelegde, afzonderlijke regeling de voorkeur verdient boven behartigiag daarvan in het kader van een regeling die zou ontstaan door integratie van de ter goedkeuring voorglegde regelling met een reeds goedgekeurde regeling.

3. Gedeputeerde staten verlenen aan een regeling die wat het gebied warvoor de regeling gejdt niet in overeenstemming is met een indeling als bedoeld in artikel 2 , slechis goedkeuring, indien in verband met de schaal waarop deze belangen behartigd moeten worden, afwijking wan de indeling bijzonder aangewezen is. 
4. Tegen onthouding wan goedkeuring kan elk van de besturen die aan de regeling deememen bij de Kroon beroep instellen binnen cen maand na de dag van verzending van de beslissing.

5. Onthouding van goedkeuring geschiedt bij met reden omkleed besluit. Tot onthouding wordt niet overgegaun dan nadat de gemeentebesturen gelegenheid tot owerleg is geboden.

Art.39.

1. Op wijziging van, uittreding uit en toetreding tot een regeling waarbij gebrulk is gemaakt van een bevoegdheid als bedoeld in artikel 8 , zijn de artikelen $36,37 \mathrm{en} 38$ van overeenkomstige toepassing.

2. Een besluit tot opheffing van een regeling die niet is opgelegd, wordt aan gedeputeerde staten gezonden.

3. Op een besluit tot opheffing van een regeling die is opgelegd, zijn de artikelen 36,37 en 38 van overeenkomstige toepassing.

Nota bene:

Vergelijkbare bepalingen zijn van toepassiug op de gemeenschappelijke regelingen tussen provincies (art. 40 e.v.), tussen waterschappen (art. 50), tussen gemeenten en provincies (art. 51 . e.v.), tussen gemeentem en waterschappen (art. 61 e.v.), tussen gemeenten, provincies en waterschappen (art. 73 e.w.) en tussen provincies en waterschappen (art. $83 \mathrm{e.w.)}$. Artikel 93 e.v. regelt de deelneming van andere openbare lichamen en rechtspersonen. Artikel $96 \mathrm{e.v}$. kent een regeling tussen ến gemeente, provincie of waterschap en een of meer andere openbare lichannen of rechtspersonen.

De hierop betrekking hebbende bepalingen worden hier niet weergegeven.

Art.99.

1. Indien een zwarwegend openbaar belang dat vereist, kunnen provinciale staten, al dan niet op verzoek van het bestwur van een of meer gemeenten, gemeenten aanwijzen waarvan de besturen een gemeenschappelijke regeling moeten treffen ter behartiging van een of meer bepaalde belangen, dan wel een bestaande regeling moeten wijzigen of opheffen. Een aanwijzing kan ook betreffem de verplichting tot het het toetreden tot of het wittreden uit een bestaande regeling. Een aanzwijzing wordt niet gegeven dan nadat met de betrokken gemeentebesturen overleg is gepleegd. Een aaanwijzing die niet in owereenstemming is met een indeling als bedoeld in artikel 2 , wordt slechits gegeven * indien in verband met de aard van het te behartigen belang of de te behartigen belangen of in verband met de schal warop deze belangen behartigd moeten worden, afwijking van de indeling bijzonder aangewezen is.

2. (..)

\section{Art.100.}

1. Bij koninklijk besluit kunnen provinciale staten worden uitgenodigd tot uitoefening van de bewoegdheid, bedoeld in artikel 99, eerste lid. De voordracht voor een uitnodiging wordt gedaan door Onze Minister, wie het aangaat, in overeenstemming met Onze Minister van Binnenlandse Zaken.

2. (..) 
WET EETREREENDE DE INTERCOMMUNALES*

\section{HOOFDSTUK I \\ Aard en oprichting van de intercommunales}

Art. 1. Verscheidene gemeenten kumen, onder de voorwaarden bepaald in deze wet, verenigingen wan gemeenten mei welbepaalde oogmerken van gemeentelijk belang oprichten.

Deze werenigingen worden biema intercommunales genoemd.

Art 2. Alle andere publiek- of privaatrechtelijke personen mogen eveneens deell uitmaken wan de intercommunales, uitgezonderd de publiekrechtelijke personen warvan een orgaan het goedkeurings- en wernietigingstoezicht bepaald bij artikell 20 , uitoefent.

Art.3. De intercommunales zijn publiekrechelijke rechtspersonen. Ongeacht hun worm en doel, hebben zij geen handelskarakter.

Ant. 4. De statuten van de intercommunales nemen de bijzondere vermeldingen over, opgelegd door deze wet en, al naar het geval, door de wetgeving betreffende de handelsvennootschappen of de verenigingen zonder winstoogmerk, en vermelden ten minste:

1. haar naam;

2. haar doel of haar doeleinden;

3. haar rechtsvorm;

4. haar maatschappelijke zetel;

5. haar duur;

6. de nauwkeurige aanwijzing van de vennoten, van hun inbrengen en van hun yerbintenissen;

7. de samenstelling en de bevoegdheden van de bestuurs- en controleorganen van de intercommunale, de wijze van aanstelling en afzeting van haar leden, evenals de mogelijkheid voor dexen on volmacht te geven aan een ander lid van hetzelfde orgaan dat zal worden angewezen binnen de categorie waartoe de volmachtgever behoort;

8. de wijze waarop an de vennoten mededeling gedaan wordi wan de jaarrekeningen, het verslag van het college van commissarissen en wan de commissie-revisor, een volledig verslag betreffende de activiteiten van de intercommunale, alsook van alle andere documenten die bestemd zijn voor de algemene ledenvergadering;

9. de besteding van de eventuele winsten;

10. de wijze van uittreden varn een vennoot;

11. de wijze van vereffening, de wijze waarop de vereffenaars worden angestelld en de onschijiving dezer bevoegdheden en, onvermindered artikel 23 , de bestemuning van de goederen en het lot wan het personeel in geval wan ontbinding.

Art.5. De intercommunales nemen de rechtsvom an ofwel van naamloze ventootschap, of wel wan coöperatieve vennootschap, ofwel van vereniging zonder winstoogmerk.

De wetten betreffende de handelsvennootschappen en de verenigingen zonder winstoogmerk zijn, waar gelang linet geval, op de intercommunales van toepassing voor zover de stauten er niet van afwijken wegens de bijzondere aard van de vereniging. In geen geval mogen de intercommunales die de vorm van een vereniging zonder winstoogmerk hebben aangenomen, nijverheids- of bandelszaken drijven of trachten een stoffelijk voordeel aan hun leden te verschaffen. 
Art.6. De maatschappelijke zetel van de intercommunale is gevestigd in een van de aangesloten gemeemten, in lokalen die aan de vereniging of aan een van de aangesloten publiekrechtelijke rechtspersonen toebehoren.

Art. 7. Onverminderd eventuele verlengingen bepaald bij artikel 21 , mag de duur van de intercommunale dertig jaar niet overschrijden.

Art.8. De statuten kunnen voorzien in de mogelijkheid voor een gemeente om uit de intercommunale te treden voor het verstrijken van de duur van de intercommumale. In alle geval mag iedere vennoot uit de intercommunale treden na vijftien jaar te rekenen, volgens het geval, vanaf de oprichting van de intercommunale of vanaf zijn axnsluiting met de instemming van twee derde van de stemmen wan de andere in de algemene vergadering anwezige of vertegenwoordigende leden, voor zover de positieve stemmen de meerderheid omvatten wan de stemmen uitgebracht door de vertgenwoordigers van de aangesloten gemeenten, en onder voorbehoud dat degene die uittreedt de schade vergoedt die zijn uittreding, naar schating van deskundigen, aan de intercommunale en aan de andere vennoten berokkent. Indien een zelfde activiteit van gemeentelijk belang in de zin van artikel 1, in een zelfde gemeente am verschillende intercommunales of regies toevertrouwd is, mag de gemeente beslissen die activiteit, voor haar gehele grondgebied, toe te vertrouwen aan éen enkele onder hen, mits alle belanghebbende partijen daarmee instemmen of, bij gebreke van die instemming, eenzijdig.

In de onderstellingen beschreven in het vorige lid, zijn de voorwaarden bepaald in het eerste lid, met uitzondering van die betreffende de vergoeding van een eventuele schade, niet van toepassing op de uittredingen die plaatshebben en die geschieden niettegenstaande iedere andersluidende statutaire bepaling.

Art.9. De publiekrechtelijke personen die bij de intercommunale zijn aangesloten, kunnen zich alleen affonderlijk en elk tot beloop van een bepaalde som verbinden.

Over iedere wijziging van de statuten die voor gemeenten bijkomende verplichtingen of een vermindering van hun rechten meebrengt, moet in de gemeenteraden worden beraadslaagd en beslist.

\section{HOOFDSTUK II}

\section{Organen van de intercommunalle}

Art. 10. ledere intercommunale heeft een algemene vergadering, een raad van bestuur en een college van commissarissen.

Art.11. Wellke ook de verhouding zij van de inbreng van de verschillende partijen in de samenstelling van het matschappelijk kapitaal, beschikken de gemeenten steeds ower de meerderheid van de stemmen en over het worzitterschap in de verschillende bestuurs- en controleorganen van de intercommunale.

Art.12. De vertegenwoordigers van de angesloten gemeenten in de algemene vergadering worden door de gemeenteraad van elke gemeente aangewezen onder de raadsleden, de burgemeester en schepenen van de gemeente.

ledere gemeente beschikt in de algemene vergadering over een stemrecht dat overeenstemt met het aantal aandelen waarover zij beschikt.

Art. 13. De allgemene vergadering benoemt de leden van de raad van bestur op de wijze bepaald in de statuten.

Tot de voor de aangesloten geneenten voorbehouden ambten van bestuurder kunnen alleen worden benoemd geneenteradsleden, burgemeesters of schepenen.

De raad van bestuur kan een of meer afgevaardigden wan het personeel omvatten. 
Art.14. Het college van commissarissen is belast met het toezicht op de intercommunale.

De conmissarissen, van wie ten minste een de hoedanigheid heeft van lid van heit lnstituut der Bedrijfsrevioren, worden door de algemene vergadering benoemd op de wijze bepald in de stanten.

Tot de voor de aangesloten gemeenten voorbehouden ambten van commissaris kunnen echter alleen worden benoend gemeenteraadsleden, burgemeesters of schepenen.

Art. 15. Niemand kan in de vereniging een van de angesloten administratieve overheden vertegenwoordigen, als hij lid is van een van de organen van de privêmaatschappij die het bestuur of de concessie heeft van de onderneming walvoor de vereniging opgericht is.

Art. 16. Elk lid van een gemeenteraad dat in deze hoedanigheid eem mandaat in een intercommunate witoefent, wordt verondersteld van rechtswege ontslag te nemen zodra het ophondt van deze gemeenteraad deel uit te maken.

Alle mandaten in de verschillende organen van de intercommunale worden geacht te vervallen onmiddelijk na de algemene vergadering die volgt op de vernieuwing varu de gemeenteraden.

Art. 17. De beslissingen van de algemene vergadering, van de raad van bestuur en van het college van commissarissen zijn slechts geldig indien zij, behalve de meerderheid van de uitgebrachte stemmen, ook de meerderheid van de stemmen van de in de organen aanwezige of vertegenwoordigendle gemeenteradsleden hebben verkregen.

De statuten kunnen voorzien in bepalingen die, met inachtneming van het voorgaande lid en van artike! 11 , de belangen van de minoritaire vennoten veilig stellen.

Te dien einde moeten de statuten in ieder geval de toepassing bekrachigen van de beginselen vermeld in de artikelen 70 en 73 , tweede lid, van de gecoobrdineerde wetteb op de handelsvennoot-schappen.

Art. 18. Het is elke bestuurder van een intercommunale verboden:

1. aanwezig te zijn bij een beraadslaging over zaken warbij hij een rechtstreeks belang heeft, of waarbij zijn bloed- of aanverwanten tot en met de vierde graad een persoonlijk en rechtstreeks belang hebben.

Dit verbod strekt niet verder dan de bloed- en aanverwanten tot de tweede graad, zo het gaat om voordrachten van kandidaten, benoemingen, afzettingen en schorsingen;

2. rechtstreeks of onrechistreeks deel te nemen aan overeenkomisten afgesloten met de intercommunale;

3. als advocaat, notaris of zaakwaarnemer op te treden in rechtsgedingen tegen de intercommunale. Het is hem verboden, in dezelfde hoedanigheid, ten behoeve van de intercommunale te pleiten, raad te geven of op te treden in enige betwisting, tenzij dit kosteloos gebeurt.

Art. 19. \$1. Wanneer de provincie een inbreng heft gedaan in de intercommunale die de helft wan het kapitaal overschrijdt of de goede afloop heeft gewaarborgd van meer dan de helft van de door de veremiging opgenomen leningen, kunnen de statuten in afwijking van artikel IIl bepalen dat:

a. de meerderheid van de stemmen in de bestuurs- en controlleorganen aan de provincie toekomt;

b. het voorzitterschap van de raad van bestuur en van thet college van commissarissen wordt toevertrouwd aan een lid van de provincieraad.

\$2. In geval van toepassing van 81 zijn de volgende bepalingen toepasselijk:

a. de vertegenwoordigers van de prowincie in de bestuurs-en controleorganen van de intercommunale noetea worden gekozen onder de leden van de provincieraad en op diens voorstel

b. elk lid van de provincieraad dat, in deze hoedanigheid, een mandaat in een intercommunale uitoefent, wordt geacht van rechtswege ontslag te nemen zodra het ophoudt van de prowincieraad deel uit te makeni

c. onverminderd de toepassing van artikel 17 zijn de beslissingen van de algexuene vergadering, van de raad van bestuur en van het college van commissarissen slechts geldig, indlen zij de meerderheid van de stemmen van de in die organen aamwezige of vertegenwoordigde leden atangewezen op voorstel wan de provincieraad, hebben verkregen; 
d. een uitwoerig verslag over de activiteiten wan de intercommunale moet ieder jaar aan de provincieratad worden toegezonden door de op voorstel van de provincie aangewezen bestuturders en commissarissen;

e. onverminderd hetgeen is bepaald in artikel 22 , mag de algemene vergadering de ontbinding van de intercommunale slechts uitspreken voor zover de provincie daarme instemt.

\$3.Overgangsbepaling: Wanneer, in de veronderstellingen bedoeld in 1 , tijdens de aanpassing van de statuten als gevolg van de inwerkingtreding van deze wet, door de algemene vergadering aan de provincie het woordeel van de bepalingen van dit artikel geweigerd wordt, zal de provincieraad voor het verstrijken van de ternijn ingesteld bij artikel $29 . \$ 1$, in afwijking van artikel \& en ongeach elke andersluidende statutaire bepalling, eenzijdig de terugtrekking van de provincie uit de intercomnumale vereniging kunnen beslissen. De wijze van terugtrekking van de provincie zal worden vastgesteld met algemene instemming van de betrokken partijen. Bij ontstentenis van instemming binnen zes maandem na de beslissing tot terugtrekking, moet het geschil aanhangig gemaakt worden bij de rechtbank van eerste aanleg van de plaats waar de zetel van de intercommunale gevestigd is. Deze rechtbank zal ütsprak doen op basis van een versilag van de door haar aangestelde deskundigen.

\section{HOOFDSTUK III \\ Voogdij}

Art.20. \$1. Aan de goedkeuring van de toezichthoudende overheid zijn onderworpen:

$1^{\circ}$ de oprichting wan de intercommunale, haar statuten en eventuele bijlagen;

$2^{\circ}$ iedere wijziging die nadertuand in de statuten van de intercommunale wordt aangebracht;

$\$ 2$ Elke handeling van de organen van de intercommunale die strijdig is met de wet of met de statuten of het algemeen belang schaadt, kam door de toezichthoudende overheid worden geschorst of nietig verklaard.

\section{HOOFDSTUK IV \\ Verlenging, ontbinding en vereffening van de intercommunale}

Art.21. Op verzoek van twee derde van de in de algemene vergadering aanwezige of vertegenwoordigde leden en voor zover de positleve stemmen de meerderheid omvatten van de stemmen, uitgebracht door de vertegenwoordigers van de gemeenten, mag de intercommunale worden vertengd voor een of meer termijnen warvan geen enkele dertig jaar mag overschrijden.

Geen enkele vennoot mag evenwel worden gebonden door een termijn die werder reikt dan hetgeen was besloten voor het ingaan wan de verlenging.

Art.22. De algenene vergadering mag de ontbinding van de intercommunalle, voor het verstrijken van de door de statuten bepalde termljn, slleclats uitspreken voor zover alle angesloten gemeenten daarmee instemmen.

Art 23. In geval van voortijige ontbinding of bij niet-verlenging van of bij uittreding uit de intercommunate is iedere gemeente of vereniging die de eerder aan de intercommunale tocvertrouwde activiteit zal blijven uitoefenen, gehouden, nar schatting van deskundigen, de installaties of inrichtingen over te nemen die op haar grondgebied zijn gelegen en die uitsluitend bestemd zijn woor de verwezenlijking van het matschappelijk doel wat haar betreft, evenals het personeel wan de intercommunale behorend tot de overgenomen activiteit, overeenkomstig tussen de parijen te bepalen nadere regelen. De bezittingen zullen evenwel kosteloos aan de gemeente toekomen in zoverre zij door haar of dank zij subsidhes van andere openbare besturen werden gefinancierc. Over de bestemming van de gemeenschappelijk gebruikte installaties en inrichtingen, evenals over de eraan verbonden lasten moeten tussen de partijen een overeenkomst worden gesloten.

De gemeente die uittreedt, is, niettegenstaande iedere andersluidende statuaire bepaling, gerechigd haar aandeel in de vereniging te ontvangen, zoals het blijkt uit de balans vain het maatschappelijk jaar waarin de wittreding zich werkelijk voordoet. 
De overname van de actiwiteit van de intercommunale door een gemeente of een andere vereniging gat slechts in vamaf het ogenblik dat alle aan de intercommunale verschuldigde bedragen effectief atan deze laatste zijn betaald. Ondertussen wordt de activiteit door haar verdergezel.

\section{HOOFDSTUK $V$ \\ Diverse bepalingen}

Ant.24. De boekhouding van de intercommunale wordt gevoerd volgens de wetgeving op de boekinouding van de ondernemingen.

De jaarrekeningen, het verslag van het college van commissarissen en dat wan de comnilssaris-revisor, alsmede een uitvoerig verslag omtrent de activiteiten van de intercommunale worden elk jaar, binnen de bij de statuten vastgestelde termijnen, aan alle leden van de gemeenteraden van de angesloten. gemeenten toegezonden.

Art.25. De intercommunale mag in eigen naan tot onteigeningen ten algemenen nutte overgaan, leningen aangaan, giften aanvaarden en toelagen van openbare overheden ontvangen.

Art. 26. Onverminderd de bestaande wetsbepalingen zijn de intercommunales vrijgestelld van alle belastingen ten gunste van de Staat, evenals van alle belastingen ingevoerd door de provincies, de gemeenten of enig andere publiekrechtelijke persoon.

Art.27. In geval van toepassing van artikel 8 , tweede en derde lid, worden de overdrachten wan de activa waarvan de intercommunalle vereniging of haar vennoten de eigendom hebben, met inbegrip van de overdrachten of terugtrekkingen van aandelen die eruit voortwloeien, verricht onder de volgende voorwaarden:

a. wat de belasting op de toegevoegde waarde betreft, worden de overdrachten geacht verricht te zijn onder het stelsel wan artikel 11 van het Wetboek op de belasting over de toegewoegde waarde;

b. wat de registratierechten betreft, zijn de onroerende overdrachten van het evenredige recht vrijgesteld;

c. wat de inkomstenbelasting betreft:

1. ingeval van overdracht van lichamelijke of onlichamelijke activa andere dan grondstoffen, produkten of goederen, worden de afschrijwingen, minderwaarden en meerwaarden die voor de overnemer ter zake van de overgedragen elementen zullen gelden, bepaald alsof deze elementen niet van eigenaar veranderd zijn;

2. in geval van overdracht van elementen bedoeld in 1 " of terugtrekkingen van aandelen, worden de eventueel gerealiseerde meerwarden vrijgesteld onder de voorwarden gesteld in artikel 35 van het Wetboek van de inkomstenbelasting.

\section{HOOFDSTUK VI}

\section{Overeenkomiten tussen gemeenten}

Art.28. De gemeenten kunnen onderling overeenkomsten voor bepaalde tijd sluiten met betrekking tot welbepaalde leveringen en diensten van gemeentelijk belang.

De intercommunales kunnen zulke overeenkomsten sluiten onder elkaar en met de gemeenten. Voor deze overeenkomsten is de goedkeuring van de toezichthoudende overheid verelst.

\section{HOOFDSTUK VII Slotbepalingen}

Art. 29. 1. De verenigingen van gemeenten opgericht krachtens de wetten van 6 augustus 1897 , 1 juli 1899,1 augustus 1907 en 1 maart 1922 moeten hun statuten in overeenstemming brenger met de bepalingen van deze wet binnen twalf maanden die volgen op de inwerkingtreding van de wet. 
82. Op wetzoek wan een vennoot of van een belanghebbende derde of van de administratieve overheid tot wier bevoegdheid de controle van de intercommunale behoort, kan de rechtbank van eerste aanleg. van de plaats waar de zetel van de intercommunale gevestigd is, de ontbinding uitspreken van iedere intercommunale dle haar gewijzigde stanten niet binnen een maand na die wijziging ter goedkeuring heeft voorgelegd an de toezichthoudende overheid.

Art. 30. Opheffingsbepalingen

Art. 31. Inwerkingtreding

Nota bene

Deze wet dient vooral wat betreft het toezicht in combinatie met de Gewestelijke decreten gehanteerd te worden (niet opgenomen $\mathbb{R S}$ ). Het betreft:

- Decreet van het Vlaamse Gewest, 1-7-1987 betreffende de werkwijze van de controle op en de vaststelling van het ambtsgebied van intercommunales (B.S. 17 juli 1987);

- Decreet van het Waalse Gewest, 20-7-1989 betreffende het toezicht op de gemeenten, de provincies en de intercommunales (M.B. 8-9-1989, M.B. 15-10-1991. 


\section{ZWECKVERBANDSGESETZ* \\ C. Teil. Grundlagen}

\section{$\$ 1$}

1. Gemeinden and Gemeindeverbände können sich zur gemeinsamen Erfüllung bestimmter Aufgaben, zu deren Durchfïhrung sie berechtigt oder verpflichtet sind, zu Zweckverbänden zusammen-schiliessen (Freiverbämde) oder zu solchen zusammengeschlossen werden (Pflichtwerbände).

2. Unzulässig ist die Bildung eines Zweckverbandes, wenn durch Gesetz eine besondere Verbandsform für die gemeinsame Erfüllung der Aufgabe worgeschrieben oder die gemeinsame oder verbandscnässige Erfüllung der Aufgabe ausgeschlossen ist.

3. Bedarf die Erfüllung der Aufgabe, die den Zweckverband gestellt wird, einer besonderen Genehmigung, so kann ein Zweckwerband nur gebildet werden, wem faststeht, dass die Genehmigung erteilit wird.

\section{$\$ 2$}

1. Das Recht und die Pflicht der an einem Zweckverband beteiligten Gemeinden und Geneindewer-bände zur Erfüllung der Aufgabe, die dem Zweekwerband gestellt wird, gehen auf den Zweckverband über.

2. Bestehende Beteiligungen der Gemeinden und Gemeindeverbände an Untemehmen und Verbänden, die der gleichen oder einer ähnlichen Aufgabe dienen wie der Zweckverband, bleiben unberihrt.

3. Hat nach der Verbandssatzung der Zweckverband anzustreben, solche Beteiligungen an Stelle seiner Verbandsmitglieder zu übernehmen, so sind die einzeinen Verbandsglieder zu den entsprechenden Rechtshlhandlungen verpflichtet.

\section{$\$ 3$}

1. Neben einer Gemeinde oder einem Gemeindeverband können auch andere öffentliche Körperscha ften,

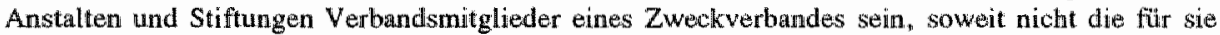
geltenden besonderen Vorschriften die Beteiligung aussschliessen oder beschränken.

2. Die Rechtsträger von Gutshezirken und sonstigen gemeindefreien Grundstücken werden für die Beteiligung an einem Zweckverband den Gemeinden gleichbehandelt.

3. Die Beteiligung von natürlichen Personen und von juristischen Personen des bürgerlichen oder Handelsrechts an einem Zweckverband bedarf der Zulassung des Ministers des Imnern. Dieses Erfordernis gilt niclat für juristischen Personen des bürgerlichen oder Handelsrechts, deren Kapital sich ausschliesslich in öffentlicher Hand befindet.

\section{4}

Die Zweckwerbände sind öffentliche Körperschaften. Sie verwalten sich selbst unter eigener Verantwordtung. Ihr wirken muss im Einklang mit den Gesetzen stehen.

\section{$\$ 5$}

Die RechtsverhäItnisse der Zweckverbände werden im Rahmen dieses Gesetzes durch eine Verbandssaltzang geordhet.

\section{\$ 6}

1. Soweit nicht das Gesetz und in Rahmen des Gesetzes die Verbandssatzung besondere Vorschriften treffen, finden auf die Zweckverbände die für Gemeinden geltenden Bestimmungen sinngemangs Anwendung.

* Van 7-6-1939 (Nieders. GWBI Sb. II S. 109) laatstelijk gewijzigd 30-7.1985 (Nieders. GWBI S. 246). 
2. Treffen diese Bestimmungen unterschiedliche Regelungen für Städte und sonstige Gemeinden, so sind auf den $Z$ wweckverband, dem Städte angehören, die für diese geltenden Vorschriften entsprechend an zu wenden. Beruht die unterschiedliche Regelung auf anderen Massstaben oder Unterschieden (wie Grösse, Einwohnerzah!, Stadtkreise und sonstige Gemeinden), so sind die Verhältnisse des Verbandsgliedes der höreren Ondnung massgebend.

3. Satzungen kơnnen Zweckverbände nur im Rahmen besonderer gesetzlicher Ermächtigung zulassen.

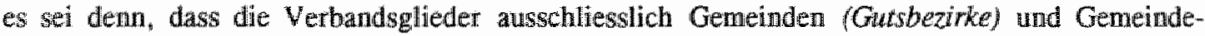
verbände sind. Im letzteren Fall steht dem Zweckverband für sein Aufgabengebiet das Satzungsrocht nach Massgabe der Deutschen Gemeindeordnung vom 30. Januar 1935 (Reichsgesetzbl. IS 49) zu; der ortliche Geltungsbereich der Satzung kann beschrinkt werden.

4. Ein Recht zur Erhebung von Steuern steht den Zweckwerbänden nicht zu.

\section{Teil. Bildung von Zweckwerbänden \\ 1. Abschnitt. Freiverbände}

\section{$\$ 7$}

1. Haben sich die Beteiligten, die Verbandsglieder des Zweckverbandes werden sollen, über die Verbandssatzung geeinigt, so haben sie unter Amerkemung der vereinbarten Verbandssatzung der zur Bildung des Zweckwerbandes zuständigen Behörde gegenüber zu erklären, dass sie auf dieser Grundlage dem Zweckverband beitreten.

2. Zustandig ist der Landrat, wenn sich der Kreis der Beteiligten auf einen Landkreis beschränkt, olne dass der Landkreis selbst beteiligt ist. Erstreckt sich der Kreis der Beteiligten darüber, jedoch nicht über den Verwaltungsbezirk einer oberen Aufsichtsbehörde hinaus, so sit die obere Aufsichtsbehörde zuständig. Gehören die Beteiligten zum Verwallungsbezirk verschiedener oberer Aufsichtsbehörden eines Landes, ... so bestimmt die zuständige oberste Landesbehörde ... die zuständige obere Aufsichtsbehörde; ...... ist ... ein Land ... selbst beteiligt, so bestimnat der Reichsminister des Innem! ... im Einvernehmen mit dem Reichsminister der Finanzen die zuständige Behörde.

3. Die Erklärungen der Beteiligten sind schriftlich abzugeben. Sonstige Vorschriften über die Rechtswirksamkeit von Verpflichtungserklärungen der einzelnen Beteiligten bleiben unberührt.

4. Die Erklärungen sind nur aus einem wichtigen Grunde widernuflich. Über das Vorliegen eines wichtigen Grundes entscheidet die nach Absatz 2 zuständige Behörde. Nach Bildung des Zweckverbandes sind die Erklärungen unwiderruflich.

\section{8}

1. Lehnt die zuständige Behörde die Bildung des Zweckverbandes $a b$, so ist dieser Beschluss den beteiligten ruzustellen.

\section{9}

1. Erachtet die nach $\$ 7$ Abs. 2 zuständige Behörde lediglich Änderungen der Verbandssatzung für erforderlich, so hat sie dies im einzelnen den Beteiligten schriftlich zu eröffnen. Neben der schrifillichen Eroffnung kann eine mündliche Verhandlung anberaunt werden.

2. Erheben die beteiligten binnen zwei Wochen nach der Zustellung oder in der mündlichen Verhandlung gegen die Ändenungen keinen Einspruch, so gilt ihre Zustimmung als erteilt.

3. Über den Einspruch der Beteiligten entscheidet die nach $\$ 7$ Abs. 2 zuständige Behörde.

4. Wird dem Einspruch nicht stattgegeben, so kömnen die Beteiligten bimen zwei Wochen nach der Zustellung der Entscheidung die Erklärung ihres Beitritts zum Zweckverband zurücknehmen.

\section{$\$ 10$}

1. Sind die Beteiligten über die Bildung, die Aufgabe und den Kreis der Verbandsglieder des Zweckverbandes, aber nicht über sonst notwendige Bestimmungen der Verbandssatzung einig, so kann mit der Beitrittserklärung der Antrag sämtlicher Beteiligten auf festsetzung solcher Bestimmungen durch die nach $\$ 7$ Abs. 2 zustăndige Behörde verbunden werden.

2. Für den Antrag gelten die Vorschriften des $\$ 7$ Abs. 3 und 4 . 
11

1. Ist die Verbandssatzung durch Vereinbarung der Beteiligten oder auf dem Wege der $\$ \$ 9$ oder 10 zustande gekommen, so beschliesst die nach $\$ 7$ Abs. 2 zustăndige Behorde uber die Bildung des Zweckverbandes unter Feststellung der Verbandssatzung.

2. Der Beschluss ist mit der Verbandssatzung in amtlichen Veroffentlichungsblatt der Behöde bekarntzumachen. Die Behorde kann bei der Bekanntmachung des Beschlusses eine vereinfachte Form für die Bekanntmachung der Satzung festlegen.

3. Der Beschluss und die Verbandssatzung werden am Tage nach der offentlichen Bekanntmachung rechtswirksam, falls nicht im Beschluss ein späterer Zeitpunkt hierfü bestimmt ist.

4. Nach ordnungsmässiger offentlicher Bekanntmachung ist die Bildung des Zweckverbandes der Nachprüfung der Gerichte and Verwaltungsgericinte entzogen.

\section{2}

1. Neben der Verbandssatzung können die Beteiligien schriftliche Vereinbarungen über den Ausgleich von Vorteilen und Nachteilen, die sich für sie aus der Bildung des Zweckverbandes ergeben, abschliessen. Vereinbarungen dieser Art sind nur rechtswirksam, wenn sie von der nach $\$ 7$ Abs. 2 zuständigen Behörde bestätigt werden.

2. Eine Vereinbarung nach Absatz 1 kann durch den Antrag sämtlicher Beteiligten an die nach $\$ 7$ Abs. 2 zustảndige Behörde ersetz werden, die aus der Bildung des Zweckverbandes unter den Beteiligten sich ergebenden Verhältnisse nach Recht und Billigkeit durch Beschluss zu regeln.

3. Der nicht mehr anfechtbare Beschluss begründet Rechte und Pflichten der Beteiligten und bewirkt den Übergang von Verbindlichkeiten.

\section{$\$ 13$}

1. Gemeinden und Gemeindeverbände können an Stelle der Bildung eines Zweckverbandes zur Erfüllung einer bestimmten Aufgabe vereinbaren, dass einer der Beteỉligten gegen angemessene Enischädigung seitens der tbrigen die gemeinsame Aufgabe erfullt oder den übrigen Beteiligten die Mitbenutzung einer von ihm betriebenen Einrichtung einräunt.

2. Die Vereinbarung ist schriftlich und unter Aufnahme des Hinweises, dass sie an Stelle der Bildung eines Zweckwerbandes erfolgt, abzuschliessen; sonstige Vorschriften über die Rechtswirksamkeit der Verpflichtungserklärung der einzeinen Beteiligten bleiben umberührt. Die Vereinbarung bedarf der Genelhmigung der nach $\$ 7$ Abs. 2 zuständigen Behörde.

3. Wird vereinbart, dass eine Körperschaft eine den beteiligten gesetzlich obliegende Aufgabe erfüllt. so werden die übrigen Körperschaften durch die Vereinbarung von der gesetzlichen Pflicht befreit.

\section{$\$ 14$}

1. Mit einer Vereinbarung nach $\$ 13$ kann die Bestimmung verbunden werden, dass die zar Erfullungg der gemeinsamen Aufgabe oder zur Gestattung der Mitbenutzung ihrer Einrichtung verpflichtete Körperschaft befugt sein soll, die offentliche Benutzung der Einrichtung durch eine fur das gesante Gebiet der Beteiligten geltende Satzung zu regeln.

2. Die Körperschaft kanm im Geltungsbereich der Stazung alle zur Durchführung erforderlichen Massnahmen wie im eigenen Gebiete treffen. Das Recht zur Erhebung von Stevern ist hierwon ausgenommen.

\section{Abschnitt. Pflichtverbande}

\section{5}

1. Ist die Bildung eines Zweckwerbandes zur Durchführung von Auftragsangelegenheiten oder von Pflichtaufgaben, deren Erfallung den offentlichen Körperschaften durch Gesetz ausdrücklich auferlegt worden ist, aus Gründen des offentlichen Wohles dringend geboten, so kann die nach $\$ 7 \mathrm{Abs}$. 2 zuständige Behörde den beteiligten Körperschaften eine allgemeine Frist für eine Einigung zur Bildung eines Freiverbandes sezen. Handelt es sich un die Erfullung anderer Aufigaben, so ist zu dem Vorgehen die Zustimming der nảchtshöheren Aufsichtsbehörde erforderlich. 
2. Nach fruchtlosem Ablauf der won der zuständigen Behorde gesetzien Frist kann diese Bebörde über die Erganzung der mangeInden Zustimmung von Gemeinden und Gemeimdeverbänden zur Bildung und Aufgabenstellung des Zweckverbandes sowie zum Kreis der Beteiligten Beschluss fassen. Der Beschlussfassung hat eine mundliche Verhandlung mit den Beteiligten vorauszugehen.

3.

4. Die mangelnde Zustimmung anderer beteiligter Körperschaften, Anstalten und Stiftungen kann nur durch die Erklärung ihrer obersten Aufsichusbehörde ersetz werden. Die Zustimmung des Reichs wird durch den Reichsminister der Finanzen, die Zustimmung eines Landes durch den Reichsminister des Innem im Einvernehmen mit dem Reichsminister der Finanzen erklärt.

\section{$\$ 16$}

Dïe Verbandssatzung kamn von den Beteiligten nach dem Beschluss gemåss $\$ 15$ binnen einer von der zuständigen Behörde gezetzten angemessenen Frist vereinbart werden. Hierfür gelten die Vorschriften der $\$ 7,9$ und 10 entsprechend. Die Zurücknahme der Beitrittserklärung nach $\$ 7$ Abs. 4 ist ausgeschlossen.

\section{$\$ 17$}

1. Kommt innerhalb der gesetzten Frist die Verbandssatzung weder durch eine Binigung der Beteiligten noch auf dem Wege der $\$ 9$ oder 10 zustande, so setz die nach $\$ 7$ Abs. 2 zustăndige Behörde die Verbandssatzung durch Beschluss fest.

2. Bei Beteiligung ... eines Landes ist vorher die Zustimmung des Reichsminister des Imnern und des Reichsministers der Finanzen einzuholen.

\section{$\$ 18$}

Für die Bildung des Zweckverbandes gilt $\$ 11$.

\section{$\$ 19$}

1. An Stelle der Bildung eines Zweckverbandes kann die nach \$ 7 Abs. 2 zustăndige Behörde den Gemeinden und Gemeindeverbänden den Abschluss einer Vereinbarung gemäss \$\$13 und 14 aufgeben

2. Eingen sich die Beteiligten innerhalb einer won der Behörde zu bestimmenden angennessenen Frist nicht, so kann die Behörde über die regelung Beschluss fassen. Im übrigen gelten die Vorschriften der $\$ \$ 13$ und 14 entsprechend.

\section{0}

Wird die Verbandssazung nach $\$ 17$ oder die Vereinbarung nach \$19 von der Behorde festgesetzt, so kann die Behörde auch die aus der Bildung des Zweckverbandes oder dem Abschluss der Vereinbarung unter den Beteiligten sich argebenden Verhaltnisse, falls sich die Beteiligten nich selbst hieriber bimnen einer von der Behöde gesetzten angennessenen Frist nach \& 12 einigen, durch Beschiuss nach Recht und Billigkeit naher ordnen.

\section{Teil. \\ Änderung und Auftösung von Zweckverbànden}

\section{$\$ 21$}

1. Die Verbandssatzung kann Vorschriften über die Voraussetzungen und das Verfahren für das Ausscheiden und den Abschluss von Verbandsgliedera, für freiwilligen Beitritt neuer Verbandsglieder, für die Auflosung des Zweckverbandes sowie für sonstige Änderungen der Verbandssatzungen worsehen.

Anderfalts finden die Vorschriften über die Bildung von Zweckverbänden sinngemäss Anwendung auf die Änderung und Auflösung von Zweckwerbänden.

2. Soweit die Verbandssatzung besondere Vorschriften nicht enthält, ist bei Freiverbänden die Zustimmung sämtlicher Verbandglieder Voraussetzung für jede Ändenung der Verbandssatzung. 
3. Hălt die nach $\$ 7$ Abs. 2 zustanndige Behörde die Auflösung eines Zweckverbandes aus Grinden des öfentlichen Wohles für dringend geboten, so konnen die Vorschriften des $\$ 15$ auf die Auflosung sowohl eines Freiverbandes wie eines Pflichtverbandes angewendet werden.

\section{$\$ 22$}

1. Änderungen des Kreises der Verbandsglieder, die als Folge einer Änderung in der Verwaltungsgliederung (wie Eingliederung eines Verbandsgliedes in eine andere Korperschaft, Zusammenschluss eines Verbandsgliedes mit einer anderem Korperschaft, Auflösung eines Verbandsgliedes) oder eines sonstigen Wegfalls eines Verbandsgliedes eintreten, sind der zur Bildung des Zweckverbandes zuständigen Behörde anzuzeigen.

2. Die Körperschaft, in die das Verbandsglied eingegliedert oder mit der es zusammengeschlossen wird, tritt in die Rechtsstellung des weggefallenen Verbandsgliedes ein. Beantragt der Zweckverband gegen den Willen dieser Körperschaft oder die Körperschaft gegen den Willen des Zweckwerbandes ihren Austritt oder die Auflosung des Zweckverbandes, so beschliesst liierüber die zur Bildung des Zweckverbandes zuständige Behörde.

3. Die Regelung der aus der Veranderung sich ergebenden Verhaltnisse des Zweckverbandes sowie. zwischen dem Zweckverband und seinen Verbandsgliedern einerseits und dem ausscheidenden Verbandsgleid anderseits steht der zur Bildung des Zweckverbandes zuständige Behörde zu. \$12 Abs. 3 gilt entsprechend.

4. Die Bebörde hat die Änderung der Verbandssatzung offentlich bekannizugeben.

\section{3}

Die Vorschriften der $\$ \$ 21$ und 22 gelten entsprechend für die Vereinbarung mach $\$ \$ 13,14$ und 19.

\section{Teil. Die Verbandssallzung}

\section{$\$ 24$}

1. Die Verbandssatzung muss bestinmen

a. die Verbandsglieder,

b. die Aufgaben.

c. den Namen und Sitz,

d. die Verfassung (Verwaltung und Vertretung),

e. die Deckung des Aufwands, insbesondere den Massstab, nach dem die Verbandsglieder zur Deckung des Bedarfs beizuragen haben,

f. die Art der offentichen Bekanntmachungen,

g. die Abwicklung im Falle der Auflösung des Zweckverbandes.

2. Im übrigen kann die Verbandssatzung die Rechtsverhältnisse des Zweckverbandes regeln, soweit das Gesetz keine Vorschriften enthalt ader die Regelung in der Verbandssatzung ausdricklich zulasst.

\section{5}

1. Die Verfassung (Verwaltung und Vertretung) von Zweckverbainden, die uberwiegend holutitlichen Aufgaben dienen, soll den Varschriften über die Verfassung und Verwaltung der Gemeinden angeglichen werden.

2. Wird die Verwalitung und Vertretung des Zweckverbandes einen Leiter in voller und ausschliesslicher Verantwordtung anvertraut, so sind dem Leiter aus dem Kreise der Verbandsglieder Beiratte in der Weise zur Seíte za stellen. dass jedes Verbandsglied dabei vertreten ist. Ist die Zahl der Verbandsglieder hoher als zehn, so kann die Vertretung auch Gruppenweise geordnet werden.

3. Die Berufung und Abrertigung der sarzungsmässigen Amtstrager des Zweckverbandes (des Leiters und seine Beiräte sowie deren Stellvertreter) ist in der Verbandssatzung zu regeln. Sie kani der Aufsichtsbehörde des Zweckverbändes, auch unter Einschränkungen, iibertragen werden.

4. Die Verbandssatzung kann der Aufsichtsbehörde des Zweckverbandes Mitwirkungs- und Entscheidungsbefugnisse zu Wahrung der Belange der einzelnen und von Gruppen der Verbandsglieder einraiumen. Wird die Verwaltung und Vertretung des $Z$ weckverbandes einem Leiter in voller oder 
ausschliesslicher Verantwortung ubertragen, so muss die Verbandssatzung solche Vorschriften vorsehen; zum mindestens muss Verbandsmitgliedern, die allein oder zusammen mindestens ein Drittel der Verbandsiasten zu tragen haben, das Recht eingerăunat werden, gegen Anordnungen und Massnahmen des Leiters des Zweckverbandes die Entscheiding der Aufsichtsbehörde mit der Wirkung anzurufen, dass diese die Anordnungen und Massnahmen des Leiters bis zur Entscheidung aussetzen kann.

\section{6}

1. Die Verbandssatzung won Zweckverbänden, die überwiegend wirtschaftlichen Aufgaben diemen, soll die Verfassung und Verwaltung grundsatzlich den handelstechtlichen Gesellschaftsrecht so anpassen, dass bei aller Wahrung der gemeinschaftlichen Bindungen sowobl die Beweglichkeit der Wirtschafsführung des Zweckverbandes als auch die berechtigten Belange der einzelnen Verbandsglieder sowie von Gruppen won Verbandsgliedern nach Massgabe ihrer wirtschaftlichen Beteiligung gesichert werden.

2. Betreibt der Zweckverband ein wirtschaftliches. Unternehmen, so kann die Verbandssatzung vorsehen, dass der Zweckwerband eine Betriebssatzung nach \$ 74 der Dewtschen Geneindeordnung erlasst.

\section{$\$ 27$}

1. Die satzungsmässigen Ambtsträger des Zweckverbandes sollen grundsătzlich ehrenamtlich tätig sein. Leiter des Zweckverbandes soll in der Regel der Leiter einer Gemeinde oder eines Gemeindeverbandes, seînen Stellwertreter und den Kassenverwalter kann die Verbandssatzung eine angemesende Aufwandissentschädigung festsetzen. Für den Ersatz der Auslagen und des entgangenen Arbeitswerdienstes der übrigen ehrenamtlich tätigen Ambtsträger kamn die Verbandssatzung Durchschnittssiätze bestimmen. Die Ansprïche auf dïese Bezuge sind nicht übertragbar.

2. Die Verbandssatzung kann vorsehen, dass Stellen der Verbandsverwaltung mit hauptamtlichen Beamten oder Angestellten besetz werden.

3. Enthalt die Verbandssatzung eine Vorschrift im Sinne des Absatzes 2, so muss sie auch Vorschriften über die Übernalhme der Beamten oder Angestellten durch Verbandsmitglieder oder über sonstige Abwicklung der Dienst- und Versorgungsverhaltnisse im Falle der Auflösung des Zweckverbandes oder der Änderung seiner Aufgaben treffen.

\section{$\$ 28$}

1. Die Verbandssatzung kann vorsehen, dass der Zweckverband über die Benutzung seiner öffentlichen Einrichtungen sowie uber die Erhebung van Gebuhren und Beitragen Satzungen erlassen kann.

2. Auf diese Satzungen finden die für die Gemeinden geltenden Vorschriften über Satzungen über dèn Anschluss- und Benutzungszwang, über das Recht der Einwohner, Grundbesitzer und Gewerbetrelbenden zur Benutzung offentlicher Einrichtungen der Gemeinde, über Erhebung von Gebuhren und Beitragen, uber das Verwaltungszwangverfahren sowie über die Entscheidung von Streitigkeiten entsprechende Anwendung.

\section{$\$ 29$}

1. Die Verbandssatzung hat die Deckung des Aufgabenbedarfs in der Weise zu regeln, dass die Verbandsglieder zu jarlalich festzusetzenden Umlagen therangezogen werden, soweit die sonstigen Einmahmen des Z weckverbandes zur Bestreitung der Verbandsausgaben (einschliesslich der vorgeschriebenen Rucklagen) nicht ausreichen. Der Fehlbedarf ist grundsatzlich auf die Verbandsglieder nach Massgabe des Nutzens, den die einzelnen Verbandsglieder aus der Erfüllung der Aufgabe des Zweckverbandes haben, umzulegen; hieriber hat die Verbandssatzung năhere Bestimmungen zu treffen. Aus besonderen Gründen kann an Stelle des anteilligen Nutzens ein anderer Massstab (Grösse, Steuerkraft und ähnliches) zugrunde gelegt werden. Die Verbandssatzung kann die Umlagenpflicht einzelner Verbandsglieder auf einem Hochstbetrag beschränken oder ganz ausschliessen. 
2. Die erstmalige Festsetzung des Umlagenbedarfs und seine Erhöhung bedarf der Genehmigung đer Aufsichtsbehorde des Zweckverbandes. Isc ein Land beteiligt, so ist die Zustimunung des Reichsministers der Finanzen oder der won ihm benannten Stelle erforderlich.

3. Die Verbandsglieder können gegen die Heranziehung zur Verbandsumlage Beschwerde zur Aufsichtsbehörde erheben. Die Beschwerde kann sich nicht gegen den in der Verbandssatzung fesigelegten Schlüssel richten.

\section{$\$ 30$}

1. Die Verbandssatzung von Zweckwerbänden, die überwigend wirtschaftlichen Aufgaben dienen, soll vorsehen, dass der Zweckverband hinreichend mit Eigenvermögen ausgestattet wird.

2. Solche Zweckverbände sind grundsätzlich so zu verwalten, dass unter Wahrung der gemeinwirischaftlichen Grundsätze bei Erfüllung der Aufgaben durch die Einnahmen mindestens die gesamuten durch die Unternehmung erwachsenden Auslagen einschliesslich der Verzinsung und Tilgung des Anlagekapitals und angemessene Rücklagen aufgebracht werden.

\section{Teill. Aufsicht}

\section{$\$ 31$}

1. Der Zweckverband stellit unter staatlicher Aufsicht.

2. Die Aufsicht hat den Zweckverband in seinen Rechten zu schützen und die Erfüllung seiner Pflichten zu sichern.

3. Die Aufsicht über den Zweckverband führt die nach $\$ 7$ Abs. 2 zuständige Behörde (Landrat, obere Aufsichtsbehörde, Reichsminister des Innern).

4. Die Zuständigkeit der Fachaufsichtsbehörden bleibt unberührt.

\section{Teill. Entscheidung von Streitigkeiten}

\section{2}

1. Streitigkeiten zwischen dem Zweckverband und seinen Verbandsgliedern sowie der Verbandsglieder untereinander über Rechte und Verbindlichkeiten aus dem Verbandsverhälltnis, insbesondere über das Recht zur. Benutzung der Verbandseinrichtungen und über die Pflicht zur Tragung der Verbandslasten, entscheidet die Aufsichtsbehörde des Zweckverbandes, soweit nicht in diesen Gesetz ein anderes 2. Verfahren oder in der Verbandssatzung ein Schiedsverfahren vorgesehen ist.

\section{3}

Die Vorschriften des $\$ 32$ gelten entsprechend für Sireitigkeiten über Rechte und Verbindlichkeiten der Beteiligten aus Vereinbarungen und Beschlussen gemalss den $\$ 12$ bis 14 sowie 19 und 20 .

\section{Teil. SchluBvorschriften}

\section{4}

1. Die Vorschriften von Reichs - und Landesgesetzen über sondergesetzliche Verbände der Gemeinden und Gemeindleverbände zur Erfüllung bestimmter Aufgaben bleiben unberührt.

2. Die obersten Landesbehörden kơnnen. für die Sonderverbände Munstersatzungen vorschreiben.

\section{5}

1. Auf bestehende Zweckverbände, die nach den allgemeinen Vorschriften uber die Bildung und Verwaltung von Zweckverbänden gegründet sind, findet dieses Gesetz erst nach Neufesttellung ihrer Verbandssatzung A mwantung. Die Verbandssatzangen dieser Zweckverbände bleiben in Geltung bis sie vorschriftsmassig geandert sind.

2. 
Bijlage 4

3. Über die neue Verbandssatzung beschliefht die Behörde, die nach den Vorschriften dieses Gezetzes des Zweckverbandes zustindig wäre. Dabei ist die neue Aufsichusbehörde zu bestimmen.

Der Beschluss ist mit der Verbandssatzung in dem amtlichen Veróffentlichtungsblatt der Bebörde offenilich bekanntzumachen.

\section{\$36 (aufer Kraft)}

\section{7}

Das Gesetz tritt am 1. Juli 1939 in Kraft. 


\title{
GESETZ ÜBER KOMMUNALE GEMEINSCHAFTSARBETT* \\ ERSTER TEIL \\ Formen kommunaler Gemeinschaftsarbeit \\ $\$ 1$
}

1. Gemeinden und Gemeindeverbände könsen Aufgaben zu deren Erfüllung sie berechtigt oder verpflichtet sind nach den Vorschriften dieses Gesetzes gemeinsam wahmehmen. Dies gilt nicht, wenn durch Gesetz eine besondere Rechtsform für die Zusammenarbeit worgeschrieben oder die gemeinsame Wahrnehmung einer Aufgabe ausgeschlossen ist.

2. Zur gemeinsamen Wahrnehmung von Aufgaben können Arbeitsgemeinschaften begnündet, ZWweckverbände gebildet und öfentlich-rechtliche Vereinbarnngen geschlossen werdien.

3. Die Befugnis, zur gemeinsamen Wahrnehmung von Aufgaben die Gestaltungsmöglichkeiten des Privatrechts zu benutzen, bleibt unberührt.

\section{ZWELTER TEIL}

\section{Die kommunale Arbeitsgemeinschaft}

$\$ 2$

\section{Zweck}

1. Gemeinden und Gemeindeverbände können sich zu kommunalen Arbeitsgemeinschaften zusammenschließen. In diese Arbeitsgemeinschaften können auch sonstige Körperschaften, Anstalten und Stiftungen des öffentlichen Rechts sowie natürliche Personen und juristische Personen des Privaitrechts aufgenommen werden.

2. Nach der getroffenen Vereinbarung beraten die Arbeitsgemeinschaften Angeltgenheiten, die ihre Mitglieder gemeinsam berühren; sie stimmen. Planungen der einzelnen Mitglieder für diese Angelegenheiten und die Tätigkeit von Einrichtungen ihrer Mitglieder aufeinander ab; sie leiten Gemeínschaftslösungen ein, um eine möglichst wirtschaftliche und zweckmäßige Erfüllung der Aufgaben in einem größeren nachbarlichen Gebiet sicherzustellen.

\section{$\$ 3$}

\section{Geschäftsfültrung}

1. Die Arbeitsgemeinschaften geben den Mitgliedern Anregungen; sie fassen keine die Mitglieder bindenden Beschlüsse. Die Zuständigkeit der Organe der einzelnen Mitglieder bleibt unberühirt.

2. Die Geschäftsführung der Arbei isgemeinschaften ist durch die Beteiligten zu regeln. In der Regelung sind die Aufgabengebiete näher zu bestimmen, auf denen eine Arbeitsgemeinschaft sich betäligen will; ferner sind in ihr die näheren Bestimmungen über die Durchführung der Arbeitsgemeinschaft zus treffen.

\author{
DRITTER TEIL \\ Der Zweckverband \\ Abschnitt I \\ Grundlagen \\ $\$ 4$. \\ Wesen, Arten, Mitglieder
}

1 Gemeinden und Gemeindeverbände können sich zu Zweckwerbanden zusammenschließen, um einzelne Aufgaben, zu deren Wahmehmung sie berechtigt oder verpflichtet sind, gemeinsam zu

* In de tekst van 1-10-1979, GVNW S. 261, laatstelijk gewijzigd 26-6-1984, GVNW S. 362. 
erfüllen (Freiverband): für Pflichtaufgaben können sie auch zusammengeschlossen werdlen (Pflichtverband).

2. Neben einer der in Absatz 1 genannten Körperschaften können auch der Bund, die Länder der Bundesrepublik und andere Körperschaften "Anstalten und Stiftungen des öffentlichen Rechts Mitglieder eines Zweckverbandes sein, soweit nicht die fü sie geltenden besonderen Vorschriften die Beteiligung ausschließen oder beschränken. Ebenso können natürliche Personen und juristische Personen des Privatrechts. Mitglieder eimes Zweckverbandes sein, wenn die Erfüllung der Verbandsaufgaben dadurch gefördert wird und Gründe des öffentlichen Wohles nicht entgegenstehen.

3. Die Mitgliedschaft einer Gemeinde oder eines Gemeindeverbandes außerhalb des Landes NordmeinWestfalen oder einer constigen nicht der Aufsicht des Landes unterstehenden Körperschaft, Anstalt oder Stiftung des öffentlichen Rechts in einern Zweckverband, der im Lande Nordrhein-Westfalen seinen Sitz hat, bedarf der Genehmigung des Innenministers. Das gleiche gilt für die Mitgliedschaft einer Gemeinde, eines Gemeindeverbandes oder einer sonstigen der Aufsicht des Landes NordrheinWestfalen unterstehenden Körperschaft, Anstalt oder Stiftung des offentlichen Rechts in einem Zweckverband außerhalb dies Landes.

\section{$\$ 5$}

\section{Rechtsform}

1. Der Zweckverband ist eine Körperschaft des öffentlichen Rechts. Er verwaltet seine Angelegenheiten im Rahmen der Gesetze unter eigener Verantwortung.

2. Der Zweckverband ist ein Gemeindeverband; Vorschriften, die bestimmen, daß sie für die Gemeindeverbände gelten, finden auf den Zweckverband Anwendung, soweit sich ans ihnen oder aus diesem Gesetz nichts anderes ergibt.

\section{$\$ 6$}

\section{Übergange der Aufgaben}

1. Das Recht und die Pflicht der an einem Zweckverband beteiligten Gemeinden und Gemeindeverbände zur Erfüllung der Aufgaben, die dem Zweckverband gestellt sind, gehen auf den Zweckverband über.

2. Bestehende Beteiligungen der Gemeinden und Gemeindeverbände an Unternehmen und Verbände, die der gleichen oder einer ähnlichen Aufgabe dienen wie der Zweckwerband, bleiben unbenührt. Hat der Zweckverband nach der Verbandssatzung anzustreben, solche Beteiligungen an Stelle seiner Verbandsmitglieder zu übernehmen, so sind die einzelnen Verbandsmitglieder zu den entsprechenden Rechtsgeschäften und Verwaltungsmabnahmen werpflichtet.

\section{$\$ 7$}

\section{Verbandssatzung}

Die Rechtsverhältnisse des Zweckverbandes werden im Rahmen dieses Gesetzes durch eine Verbandssatzung geregelt.

\section{$\$ 8$}

Amwendung der für Gemeinden Kreise oder Landschaftsverbände geltenden Bestimmungen

1. Soweit nicht das Gesetz oder die Verbandssatzung besondere Vorschriften treffen, finden auf den Zweckwerband die Vorschriften der Gemeindeordnung sinngemäß Anwendung.

2. Treffen diese Vorschriften unterschiedliche Regelungen für einzelne Gruppen von Gemeinden, so bestimmt die Verbandssatzung, welche dieser Regelungen Anwendung finden soll. Gehören dem Zweckverband als kommunale Körperschaften neben Gemeinden auch Kreise an, so kann die Verbandssatzung bestimmen, daf anstelle der Gemeindeordnung die Kreisordnung Anwendung finden soll. 
3. Gehören einem Zweckwerband als kommunale Körperschaften nur Kreise oder nur Kreise und Landschaftsverbände an, so finden die Vorschriften der Kreisordnung, gehören ihm als kommunale Körperschaften nur Landschaftsverbände an, so finden die Vorschriften der Landschaftsverbandesordnungsinngemäli Anwendung.

4. Das Recht Satzangen zu erlassen, steht dem Zweckverband nach Maßgabe der für Gemeinden geltenden Vorschriften, im Falle der Absätze 2 und 3 nach Maßgabe der dort genannten Vorschriften für sein Aufgabengebiet zu.

\section{Abschnitt II \\ Bildung des Zweckverbandes \\ $\$ 9$ \\ Inhalt der Verbandssatzung}

1. Zur Bildung des Zweckverbandes (Freiverband) wereinbaren die Beteiligten die Verbandssatzung. Führen kreisangehörige Gemeinden die Verhandlungen mit Körperschaften des öffentlichen Rechts außerhalb des Kreises, um mit ihnen einen Zweckverband zu bilden, so haben sie den Kreis rechtzeitig $2 \mathrm{u}$ unterrichten.

2. Die Verbandssatzung muß die Verbandsmitglieder, die Aufgaben, den Namen und Sitz des Verbandes, die Form der öffentlichen Bekanntmachungen sowie den Maßstab bestimmen, nach den die Verbandsmitglieder zur Deckung des Finanzbedarfs beizutragen haben; sie muß ferner die Angelegenheiten regeln, deren Regelung durch die Verbandssatzing das Gezetz ausdrücklich worschreibt. Darüber hinaus kann die Verbandssatzung Bestimmungen enthalten ilber

1. die Verfassung und Verwaltung,

2. die Abwicklung im Falle der Auflösung des Zweckverbandes,

3. sonstige Rechtswerhältnisse des Zweckverbandes,

soweit das Gesetz keine Vorschriften enthält oder die Regelung in der Verbandssatzung ausdrücklich zuläßt.

\section{Genehmigung}

1. Die Verbandssatzung bedarf der Genehmigung der in $\$ 29$ Abs. 1 bestianmten Aufsichtsbehörcle. Will die Aufsichtsbehörde die Genehmigung versagen oder nur nach Änderung der Verbands- satzung erteilen, so hat sie dies vorher mit den Beteiligten in einer mündlichen Verhandlung zu erörtern. Ist der Oberkreisdirektor für die Entscheidung zuständig, so bedarf er der Zustimmung des Kreisausschußes, wenn er die Genehmigung versagen oder nur nach Änderung der Verbandssatzung erteilen will; $\S 48$ Abs. 1 Satz 3 und Abs. 2 der Kreisordnung gilt entsprechend.

2. Ist für die Übernahme der Aufgaben, für die der Zweckverband gebildet werden soll, eine besondere Genehmigung erforderlich, so kann die Verbandssatzung nicht genehmigt werden, wenn zu erwarten ist , dal die besondere Genehmigung versagt wird.

\section{$\$ 11$}

\section{Entstehung des Zweckverbandes}

1. Die Aufsichtsbehörde hat die Verbandssatzung und ihre Genehmigung in ihrem amtlichen Veröffenlichungsblatt bekanntzumachen. Die Gemeinden und Kreise haben in der für ithre Bekanntmachungen vorgeschriebenen Form auf die Veröffentlichung hinzuweisen.

2. Der Zweckverband entsteht am Tage nach der öfentlichen Bekannmachung der Verbandssaizung und der Genehmigung im Veröffentlichungsblatt der Aufsichtsbehörde, soweit nicht hierfür in dler Verbandssatzung ein späterer Zeitpunkt bestimmt ist. 
Neber der Vertbandssatzung können die Beteiligten schriftiche Vereinbanungen über den Ausgieich von Vorteilen und Nachteilen abschliefen, die sich für sie ans der Bildung des $Z$ weckverbandes ergeben. Auf Antrag saimtlicher Beteiligten karn die Aufsichtsbehörde diesen Ausgleich regeln.

$\S 13$

Pflichtwerband

1. Ist die Billung eines Zweckverbandes zur Durchführung won Pflichtsaufgaben, die den Gemeinden oder Gemeindeverbände durch gesetzliche Vorschrift auferlegt sind, aus Gründen des biffentlichen Wohles dringend geboten, so kann die Aufsichtsbehörde den Beteiligten eine angemessene Frist zur Bildung des Zweckwerbandes als Freiverband setzen.

2. Konmt imnerhalb der Frist ein Freiverband nicht zustande, so kann die Aufsichisbehörde die Verbandssatzung erlassen und die Bildung des Zweckwerbandes als Pflichtverband verfügen. Sollen kreisangehörige Gemeinden oder Gemeindeverbände auß̉erualb des Kreises zu einem Zweckwerband zasammengeschlossen werden, un gemeinsame Bauleitpläne aufzustellen oder durchzuführen, sogilt $\$ 4$ des Bundesbaugesetzes. Vor der Entscheidung nuB den Beteiligten Gelegenheit gegeben werden, ihre Auffassung in mündlicher Verhandlung darzulegen.

3. Ist der Oberkreisdirektor für die Entscheidung zuständig, so bedarf diese der Zustimnung des Kreisausschußles; $48 \mathrm{Abs}$. 1 Satz 3 und Abs. 2 der Kreisordnung ist entsprechend anzuwenden. Ist der Regierungspräsident oder der Innenminister zuständig, so ist in den Falllen, in denen eine kreisangehorige Gemeinde beteiligt ist, der Kreisausschuß vor der Entscheidung zu hören; dasselbe gilt, wenn die Landesregierung für die Entscheidung zustảndig ist. Im übrigem gilt \$ 11 entsprechend.

4. Hält die Aufsichtsbelhörde einen Ausgleich aus Billigkeitsgründen für erforderlich, so kann sie diesen selbsi treffen, falls die Beteilligten dies beantragen oder sich nicht innerhalb einer von der Aufsichtsbehörde gesetzten angemessenen Frist einigen.

Abschnitt III
Verfassung und Verwaltumg des Zweckwerbandes
Organe

Organe des $Z$ weckverbandes sind die Verbandsversanmolung und der Verbandsvorsteher.

\section{Verbandswersammlung}

1. Die Verbandsversammlung besteht aus den Vertretern der Verbandsmitglieder. Jedes Verbandsmitglied entsendet wenigsteus einen Vertreter in die Verbandsversammlung. Sind natürliche Personen oder juristische Personen (\$ 4 Abs. 2) Verbandsmitglieder, so dïfen ihre Stimmen insgesamt die Halfte der in der Verbandssatzung festgelegten Stimmenzahl nicht erreichen. Die Aufsichtsbehörde kann Ausnahmen zulassen.

2. Soweit Gemeinden oder Gemeindeverbände Verbandsmitglieder sind, werden die Vertreter durch die Vertretungskörperschaft für deren Wahlzeit aus ihrer Mitte oder aus den Dienstkriafte des Verbandsmitgliedes gewällt; sind mehrete Vertreter zu wailnen, so gelten dafür die Grundsätze der Verballiniswahl. Die Vertreter anderer Verbandsmitglieder werden für dieselbe Zeit in die Verbandswersammlung entsandt. Die Vertreter üben ihr Amt nach Ablauf der Zeit, für die sie bestellt sind, bis zum Amtsantritt der neubestellten Vertreter weiter aus. Dite Mitgliedschaft in der Verbandswersanmlung erlischt, wenn die Voraussetzungen der Wahl oder Entsendung des Mitgliedes wegfallen.

3. Für jedes Mitglied der Verbandsversammlung ist ein Stellventreter für den Fall der Verhinderung zu bestellen. Scheidet ein im Wege der Verhältniswahl gewähltes Miglied oder stellventetendes 
Mitglied wor Ablauf der Wahlzeit aus, so bestimmt die Gruppe, die den Ausscheidenden zur Wahl vorgeschlagen hatte, den Nachfolger.

4. Die Verbandsversammlung wählt aus ihrer Mitte den Vertreter einer Gemeinde oder eines Gemeindeverbandes zum Vorsitzenden; in gleicher Weise whit sie einen Stellvertreter des Vorsitzenden.

5. Die Verbandswersammlung tritt wenigstens zweimal im Jahr, und zwar zur Beschlußfassung über die Haushaltssatzung sowie über die Rechnungslegung und die Enilastung des Verbandsvorstehers, in. übrigem nach Bedarf zusammen. Zu ihrer erster Sitzung nach der Bildung des Zweckwerbandes wird sie durch die Aufsichtsbehörde eimberufen, soweir nicht die Verbandssatzung etwas anderes vorschreibt. Die Verbandsversammlung ist nur beschlubfälig, wem die anwesenden Vertreter von Geneinden und Gemeindeverbände wenigstens die Hailfe der Stimmenzahl erreichen; im Falle des Absatzes 1 letzter Satz kann die Aufsichtsbehörde Ausnahmen zulassen. Die Verbandssatzung kann weitere Vorraussetzungen der Beschluffahigkeit bestimmen.

6. Die Zuständigkeiten der Verbandsversammlung regelt die Verbandssatzung, soweit sie sich nicht aus dem Gesetz crgeben.

\section{$\$ 16$}

Verbandsvorsteher

1. Der Verbandsvorsteher wird von der Verbandsversanmlung aus den Kreise der Hauptwerwaltungsbeamten der zum Zweckverband gehörenden Gemeinden und Gemeindeverbände gewalht; er darf der Verbandsversammlung nicht angehören. Er wird von seinem Vertreter im Hauptamt vertreten; die Verbandssatzung kann die Vertretung durch einen anderen Beamten eines Verbandsgliedes worsehen. Hat die Aufsichtsbehörde eine Ausnalume nach $\$ 15$ Abs. 1 letzter Salu zugelassen, so kann die Verbandssatzung bestummen, daß auch naturliche Personen, die Verbandsmitglieder sind, oder Vertreter von verbandsangehörigen juristischen Personen (\$ 4 Abs. 2) als Verbandsworsteher oder Stellvertreter gewählt werden können.

2. Der Verbandsworsteher führt die laufenden Geschafte sowie nach Maßgabe der Gesetze, der Verbandssatzung und der Beschlüsse der Verbandswersammlung die übrige Verwaltung des Zweckverbandes und vertritt den $Z$ weckverband gerichtich and aufergerichtlich. Eirt ist Dienstvorgesetzter der Dienstkräfte des Zweckwerbandes. Die Verbandsversammlung ist Dienstvorgesetzten des Verbandsworstehers.

3. Erklärungen, durch die der Zweckwerband verpflichtet werden soll, bedïrfen der Schriftform. Sie sind von dem Verbandsvorsteher und von seinem Vertreter oder einem von der Verbandsversammiung zu bestimmenden Beamten, Angestellten oder Mitglied der Verbandswersammlung zu unterzeichnew. Die Verbandssatzung kann allgemein oder für einen bestimmen Kreis won Geschäftea bestimmen, daß die Unterschrift der Verbandsworstehers oder seines Vertreters genugt. Im übrigen gilt $\$ 56$ Albs. 2 bis 4 der Gemeindeordnung entsprechend.

\section{$\$ 17$}

\section{Ehrenamtliche und hauptamtliche Tätigkeit}

1. Die Mitglieder der Verbandsversammlung und der Verbandsvorsteher sind ehrenamilich tätig. Sie haben nur Anspruch auf Ersatz ihrer Auslagen und des Verdienstausfalls. Der Verdienstausfall kann nach $\$ 30 \mathrm{Abs}$. 4 Gemeindeordnung berechet werden.

2. Der Zweckverband hat das Recht, Beamte zu emennen. Beamte oder Angestellte düfen hauptamtlich nur eingestellt werden, wenn das in der Verbandssatzung vorgesehen ist. Die Verbandssatzung mußh in diesem Falle auch Vorschriften ülber die Übernahme der Beamten und Angestellten durch Verbandsmitglieder oder über die sonstige Abwicklung der Dienst- und Versorgungsverhattnisse im Falle der Auflösung des Zweckverbandes oder der Änderung seiner Aufgaben treffen. 
1. Auf die Wirtschaftsfuhrung des Zweckverbandes finden die Vorschriften über die Gemeindewirtschaft sinngemäls Arwendung mit Ausnahme der Vorschriften uber die Auslegung des Entwurfs der Haushaltssatzung, uber die Auslegung des Haushaltsplanes und der Jahresrechnung sowie über das Rechnungsprüfungsamt.

2. Die uberorrtiche Prifung ist Aufgabe des Gemeindleprifungsamtes der Behörde, der nach $\S 29$ Abs. $1 \mathrm{Nrn} .2$ und 3 die Aufsicht obliegt. Im Falle des $\$ 29$ Abs. 1 Nr. 1 bestimmt der Innenminister durch Rechtsverordnung das Gemeindeprüfungsamt, das die überortliche Prüfung wahrzunehmen bat.

3. Ist der Hauptzweck eines Zweckverbandes der Betrieb eines wirtschaftlichen Unternehmens oder einer Einrichtung, die entsprechend den Vorschriften über die Eigenbetriebe geführt werden kann, so kann die Verbandssatzung bestimmen, daß auch auf die Wirtschaftsfithrung und das Rechnungswesen des Zweckverbandes selbst die Vorschriften über Wirtschaftsführung und Rechnungswesen der Eigenbetriebe simgemaß Anwendung finden. An die Stelle der Haushaltssatzung tritt in diesem Falle der Wirschaftsplan an die Stelle der Rechnung der Jahresabschluh. Sofern dem Werksausschuf nicht nach $\$ 93$ Abs. 3 der Gemeindeordnung Beschaftigte des Eigenbetriebs angehören müssen, kann die Verbandssatzung bestimmen, dafl die Aufgaben des Werksausschußes von der Verbandsversammlung wahrgenommen werden.

\section{Deckung des Finanzbedaris}

1. Der Zweckverband erliebt von den Verbandsmitgliedern eine Umlage, soweit seine sonstigen Einnahmen nicht ausreichen, um seinen Finanzbedarf zu decken. Die Umlagepflicht einzelner Verbandsmitglieder kann durch die Verbandssatzung auf einen Hdchstbetrag beschränkt oder ausgeschlossen werden; dies gilt nicht bei Sparkassenzweckverbänden. Die Umlage soll in der Regel nach dem Verhalltnis des Nutzens bemessen werden, den die einzelnen Verbandsmitglieder aus der Erfüllung der Aufgaben des Zweckverbandes haben. Ein anderer Maßstab kann zugrunde gelegt werden, wenn dies angemessen ist. Soweit die Umlage nach der Steuerkraft bemessen wird, geiten die Vorschriften über die Kreisumlage, bei Zweckwerbänden, denen als kommunale Körperschaften nur Landschaftsverbände angehören, die Vorschriften über die Landschaftsver- bandsumlage entsprechend.

2. Die Umlage ist in der. Haushaltssatzung, im Falle des $\$ 18$ Abs. 3 im Wirtschaftsplan für jedes Haushaltsjahr neu festzusetzen. Düe Festsetzung der Umlage bedarf der Genehmigung der Aufsichtsbehörude.

3. Der Zweckwerband kann Gebithren und Beiträge in entsprechender Anwendung der Vorscluriften des Kommunalabgabenrechts erleben. Das Recht zur Erhebung von Steuern steht ihm nicht zu.

\section{Abschnitt IV \\ Änderung der Verbandssatzung und Auflösung des Z weckverbandes $\$ 20$ \\ Verfahren}

1. Änderungen der Verbandssatzung, insbesondere der Beitritt und das Ausscheiden von Verbandsmitgliedern, sowie die Auflösung des Zweckverbandes bedürfen, falls die Verbandssatzung nichts anderes bestimmt, einer Mehrheit von zwei Drittein der satzungsmäßigen Stimmenzahl der Verbandsversammlung; die Verbandssatzung kann bestimnen, daß aulerdem die Zustimmung einzelner oder aller Verbandsnitglieder erforderlich ist. Beschlüsse zur Änderung der Aufgaben des Zweckwerbartdes müssen einstimmig gefallst werden. Ist eine Auseinandersetzung notwendig, so entscheidet darüber, falls sich die Beteiligten nicht einigen, die Aufsichtsbehörde.

2. Bei Freiverbänden bedüfen die Ändenung der Verbandsaufgabe, die Aufnahme von Bestimmungen uber die hauptberufliche Einstellung von Beamten oder Angestellten und die Auflösung des Zweckverbandes der Genehmigung der Aufsichtsbehörde; sonstige Änderungen der Verbandlssatzung sinnd 
der Aufsichtsbehörde anzuzeigen. Bei Ptlichtverbänden bedarf jede Ändenng der Verbandssatzung der Genelhmigung der Aufsichtshehörde.

3. Die Aufsichtsbehörde kann einem Pflichtverband gegenuber erklären. dall die Gründe für seine zwangsweise Bildung weggefallen sind. Der Zweckwerband besteht in diesem Falle als Freiverband weiter. Innerhalb won sechs Monaten kann jedes Verbandsmitglied seinen Austritt aus dem Zweckverband erklären.

4. Für die Anderung der Verbandssatzung und die Auflosung des Zweckverbandes sind $\$ 10$ Abs 1 Satz 2 und 3. Abs. 2 und \$ 11 entsprechend anzuwenden. Beim Beitrift oder Ausscheiden eines Verbandsmitgliedes wird die Änderung der Verbandssatzung mit dem Zeitpunkt wirksam, zu dem der Beitritt oder das Ausscheiden erfolgt.

5. Der Zweckverband gilt nach seiner Auflösung als fortbestehende, soweit der Zweck der Abwicklung es erfordert.

\section{1}

Wegfall won Verbandsmitgliedern

1. Fallen Gemeinden oder Gemeindeverbände, die Verbandsmitglieder sind, durch Eingliederung in eine andere Körperschaft, durch Zusammenschluß mit einer anderen Körperschaft oder aus einem sonstigen Grunde weg, so tritt die Körperschaft des offentlichen Rechts, in die das Verbandsmitglied eingegliedert oder zu der es zusammengeschlossen wird, an die Stelle des weggefallenen Verbandsmitgliedes. Entsprechendes gilt, wenn eine Gemeinde oder ein Gemeindeverband auf mehrere andere Korperschaften aufgeteilt wird oder wenu bei der Auflosung eines Gemeindeverbandes seine Aufgaben auf mehrere andere Körperschaften übergehen.

2. Wenn Gründe des öffentlichen Wohles nicht entgegenstehen, kann der Zweckverband binmen drei Monaten "vom Wirksamwerden der Änderung ab das neue Mitglied ausschliellen; in gleicher Weise kann dieses sein Ausscheiden aus dem Zweckverband verlangen. Falls das neue Mitglied dem Ausschlub widerspricht oder der Zweckverband seinem Verlangen auf Ausscheiden nicht entspricht, entscheidet auf Antrag eines der Beteiligten die Aufsichtsbehörde. Diese hat auch die aus der Veränderung sich ergebenden Verhält tnisse zwischen dem Zweckverband und dem ausscheidenden Mitglied zu regelln.

3. Die Absätze 1 und 2 gelten sinngemäß für andere Verbandsmitglieder.

4. Die durch den Mitgliederwechsel sich ergende Änderung der Verbandssatzung ist nach den Vorm schriften des $\$ 11$ Abs. 1 öffentlich bekanntzumachen.

\section{Abschnitt $V$ \\ Gesetzlicher Zweckwerband \\ 22 \\ Voraussetzungen}

1. Einigen sich die Beteiligten über die Bildung eines Freiverbandes nicht, so bedarf es eines Gesetzes, wenn Gemeinden oder Kreise zu einem $Z$ weckverband zusammengeschlossen werden sollem, um einzelne Aufgaben, zu deren Wahrnehmung sie berechtigt, aber nicht verpflichtet sind, gemeinsam zu erfüllen.

2. Die gemeinsame Aufsichtsbehörde lat die Gründe der beabsichtigten Maffnahme mit den Beteiligten, soweit kreisangehörige Gemeinden beteiligt sind, auch mit dem Kreis in einer mündlicher Verhandlung, zu der wenigstens einen Monat vorher eingeladen werden muß, zu erörtern. Sie hat den beteiligten eine angentessene Frist zur Bildung eines Freiverbandes zu setzen. 


\section{VIERTER TELL \\ Die offentlich-rechtliche Vereinbarung \\ 823 \\ Inhalt der Vereinbarung}

1. Gemeinden und Gemeindeverbände können vereinbaren, dafs einer der Beteiligten einzelne Aufgaben der ubrigen Beteiligten in seine Zustandigkeit übernimmt oder sich verpflichtet solche Aufgaben für die ubrigen Beteiligten durchzufuhren.

2. Übernimm ein Beteilligter eine Aufgabe der übrigen in seine Zuständigkeit, so gehen das Recht und die Pflicht zur Erfullung der Aufgabe auf ihn über. Verpflichtet sich einer der Beteiligten eine Aufgabe fur die ubrigen durchzufuhren, so bleiben deren Rechte und Pflichten als Trager der Aufgabe unberuhrt.

3. In der Vereinbarung kann den übrigen Beteiligten ein Mitwirkungsrecht bei der Erfullung oder Durchführung der Aufgaben eingeräumt werden; das gilt auch fur die Bestellung von Dienstkrafte.

4. In der Vereinbarung soll eine angemessene Entschadigung vorgesehen werden, die in der regell so zu benessen ist, daß die durch die Übernahme oder Durchfuhrung entstehenden Kosten gedecki werden.

5. Ist die Geltungsdauer der Vereimbanung nicht befristet oder betragt die Frist melhr als 20 Jahre, so muß die Vereinbarung bestimmen, unter welchen Vorraussetzungen und in welcher Form sie von einem beteiligten gekündigt wercen kam.

\section{$\$ 24$}

\section{Verfahren}

1. Die Vereinbarung ist schriftich abzuschliefen. Kreisangehörige Gemeinden baben den Kreis rechizeitig zu unterrichten, wenn sie mit Gemeinden oder Gemeindeverbände auberlualb des Kreises Verhandlungen fuhren, um mit ihnen eine offentlich-rechthiche Vereinbarung za treffen.

2. Die Vereinbanung bedarif der Genehmigung der in $\$ 29 \mathrm{Abs} .4$ bestimmten Aufsichtsbehörde. $\$ 10$ Abs. 1 Satz 2 und 3 findet entsprechende Anwendung.

3. Die Aufsichtsbehörde hat die Vereinbarung und ihre Genehnigung in ihrem amtlichen Veröffentlichungsblatt bekanntzumachen. Die Beteiligten haben in der für ilure Bekanntmachung vorgeschriebenen Form auf die Veröffentlichung hinzuweisen.

4. Die Vereinbarung wird am Tage nach der Bekanntrnachung im Veröfentlichungsblatt der Aufsichtsbehörde wirksam, soweit nicht in ihr ein späterer Zeitpunkt bestimmt ist.

\section{$\$ 25$}

\section{Satxung zur Erfüllung der gemeinsamen Aufgaben}

1. Durch die Vereinbanng kann clie zur Erfüllung gemeinsamer Aufgaben verpflichtete Körperschatt ermabchtigt werden, die Bentzung einer Einrichtung durch eine für das gesamte Gebiet geltende Satzung zu regeln.

2. Die Körperschaft kann um Geltungsbereich der Satzung alle zur Erfüllung erforderlichen Maßnahmen wie in eigenen Gebiet reffen. Das recht zur Erhebung von Steuern ist hiervon ausgenommen.

\section{$\$ 26$}

Pflichtregelung

1. Ist der AbschhiB einer Vereinbarung zur Erfüllung oder Durchfihthung einzelner Pflichtansgaben, die den Gemeinden oder Gemeindenverbainden durch gesetzliche Vorschrift auferlegt sind, aus Gründen des offentlichen Wohles dringend geboten, so kann die Aufsichtsbehörde den beteiligten eine angemessene Frist zur Abschluß der Vereinbarung setzen. 
2. Nach fruchilosen Ablauf der Frist kann die Aufsichtsbehörde die erforderliche Regelung treffen. Der Entscheidung der Aufsichtshehörcle muff eine muindliche Verhandiung mit den Beteiligten vorausgehen.

3. $\$ 13$ Abs. 3 Satz 1 bis 3 und die $\$ 23$ bis 25 gelten für die Pflichtregelung entsprechend. Zar Kündigung ist die Genehmigung der Aufsichisbehörde erforderlich. Die Aufsichtsbehörde katnn den Beteiligten gegenüber erllären, daß die Gründe für die zwangsweise Regelung weggefallen sind. Die Pflichtregelung gilt in diesen Falle als Vereinbarung weiter; sie kann von jeden Beteiligten mit einer Frist von sechs Monaten gekiundigt werden.

4. Für die Ausstellung oder. Durchfohrung von Bauleitplänen kawn eine Pflichtregelung nicht geüroffen werden.

\section{FÜNFTER TEIL \\ Aufsilcht und Entscheidung ubber Streitigkeiten \\ Allgemeine Aufsicht}

1. Auffich htsbehörde für die Zweckwerbände ist

a. der Innenminister oder der von ihm bestimmte Behörce, wenn ein anderes Land, eine Gemeinde oder ein Gemeindeverband eines anderes Landes oder der Bund beteiligt ist,

b. der Regierungspräsident, in dessen Bezirk der Zweckverband seinen Sitz hat, wenn Kreise, kreisfreie Städte, das Land oder Gemeindeverbände, zu deren Mitgliedern Kreise, kreisfreie Städte oder das Land gehören, beteiligt sind,

c. in allen übrigen Fällen der Oberkreisdirektor als untere staatliche Verwaltungsbehörde, indessen Bezirk der Zweckverband seinen Sitz hat.

2. Obere Aufsichtsbehörde ist der Regierungspräsident, wenn der Oberkreisdirektor Aufsichtsbehörde ist, sonst der Inmenminister. Oberste Aufsichutsbehörde ist der Innenninister.

3. Im übrigen gelten fïr die Aufsicht über die Zweckverbände die Vorschriften des VIl. Teiles der Gemeindeordnung mit Ausnahme des 112 entsprechend.

4. Durch offentlich-rechtliche Vereinbanngen und Pflichtregelungen wird die Zustandigkeit der Aufsichtshehörde der beteiligten Gemeinden und Gemeindeverbände, die ordnungsmälige Durchführung der Aufgaben innerhalb ihres Verwaltungsbezirks zu überwachen, nichi berührt. Für die zum Abschlub und zur Kundigung einer Vereinbarung erforderliche Genehmigung, die Anordnung einer Pflichtregellung und die Gienehnigung ihrer Kunndigung ist zustandige Aufsichtsbebörde

1. der Innenminister oder die von ihm bestimmte Behörde, wemn eine Gemeinde oder ein Gemeindeverband eines anderen Landes beteiligt ist,

2. der Regierungspräsident,

a. wean Kreise oder Kreisfreie Stadte beteiligt sind,

b. wenn ein Gemeindeverband beteiligt ist, zu dessen Mitgliedern Kreise ader kreilsfreie Stidte, der Bund oder das Land gehören;

zuständig ist der Regienungspräsident, zu dessen Bezirk die Körperschaft gehör oder in đessen Bezirk die Körperschaft ihren Sitz hat, die die Aufgabe für die anderen Beteiligten ubernimmat oder durch führt.

3. in allen übrigen Fällen der Oberkreisdirektor als untere staalliche Verwaltungsbehorde; zustündig ist. der Oberkseisdirektor, zu dessen Bezirk die Körperschaft gehört oder in dessen Bezirk die Körperschaft ihren Sitz hat, die die Aufgabe für die anderen Beteiligten übernimmi oder durchführt. 


\section{0}

\section{Schlichtwng ron Streitigkeiten}

Bei Streitigkeiten uber Rechte und Verbindlichkeiten der Beteiligten aus ôffentlich-rechtlichen Vereinbarungen sowie bei Streitigkeiten zwischen dem Zweckverband und seinen Verbandsmitgliedern oder der Verbandsmitglieder untereinander uber Rechte und Verbindlichkeiten aus dem Verbandsverhalltnis ist die Aufsichtsbehorde zur Schlichtung anzurufen, soweit nicht dieses Gesetz etwas anderes bestimmt ader in der Vereinbarung oder der Verbandssatzung ein besonderes Schiedsverfahren vorgesehem ist.

\section{SECHSTER TELL \\ Übergangs- und Schlussvorschriften \\ $\$ 31$ \\ Anwendung auf bestehende $\mathbf{Z}$ weckverbände}

1. Auf bestehende Zweckverbazde ist dieses Gesetz erst anzuwenden, wenn ihre Verbandssatzung den Vorschriften dieses Gesetzes angepaf3t ist. Solange bleiben die Verbandssatzungen dieser Zweckverbändle und die ihnen zugrunde liegenden gesetzlichen Worschriften in Kraft. Für das Verfaluren der Satzungsänderung gelten jedoch die Vorschriften dieses Gesetzes.

2. Jeder Zweckverband hat seine Verbandssatzung innerhalb eines Jahres nach dem Inkrafttreten dieses Gesetzes mit dessen Vorschriften in Einklang zu bringen.

3. Dieses Gesetz gilt auch für Gemeindeforstverbände, soweit nicht Bundesrecht entgegensteht. Für Schulverbände bleiben die $\$ \$ 11$ und 33 des Schulverwaltungsgesetzes unberihrt.

Planungsverbände

Auf Planumgsverbände nach $\$ 4$ des Bundesbaugesetzes sind die Vorschriften dieses Gesetzes entsprechend anzuwenden, soweit sich aus dem Bundesbaugesetz nichts anderes ergibt.

\section{Durchführungsbestimmungen}

Der Innenminister erlaßt die zur Durch führung dieses Gesetzes erforderlichen Verwaltungs- vorschriften.

\section{Inkraftureten}

Dieses Gesetz tritt am 1. Jull 1961 in Kraft. 


\section{Bijlage 5}

\section{SAMENWERKINGSBEPALINGEN EUROPESE MILIEU-RICHTLUNEN}

1. Richtlijn van de Raad van 16-6-1975 betreffende de vereiste kwaliteit van het oppervlaktewater dat is bestemd voor produktie van drinkwater in de Lid-Staten.'

Artikel 4.1: "De Lidstaten nemen de nodige maatregelen om te bewerkstelligen dat het oppervlaktewater in overeenstemming is met de ingevolge artikel 3 vastgestelde waarden. Daarbij past elke Lid-staat deze richtlijn zonder onderscheid toe op nationale en grensoverschrijdende wateren."

2. Richtlijn van de Raad van 8-12-1975 betreffende de kwaliteit van het zwemwater. ${ }^{2}$

Artikel 4.4: "Voor wat betreft zeewater in de nabijheid van grenzen en grensoverschrijdende wateren die van invloed zijn op de kwaliteit van het zwemwater in een andere Lid-Staat, zullen de consequenties die de gemeenschappelijke kwaliteitsdoelstellingen hebben voor de badzones in onderling overleg door de oeverstaten worden bepaald."

3. Richtlijn van de Raad van 20-2-1978 betreffende de afvalstoffen afkomstig van de titaandioxydeindustrie. $^{3}$

Artikel 8.2" "Indien hierbij meer dan een. Lid-Staat betrokken is, worden de maatregelen in gemeenschappelijk overleg genomen."

4. Richtlijn van de Raad van 18-7-1978 betreffende de kwaliteit van zoet water dat bescherming of verbetering behoeft ten einde geschikt te zijn voor het leven van vissen."

Artikel 10: "Ingeval zoet water de grens tusen Lid-Staten vormt of overschrijdt en een van de betrokken Staten dit water overweegt aan te wijzen, dienen deze Staten overleg te plegen over de vaststelling van de wateren waarop de richtlijn van toepassing kan zijn, alsmede over de gevolgea die uit de gemeenschappelijke kwaliteitsdoelstellingen woortvloeien en die na onderling overleg door elke betrokken Stat: worden vastgesteld. De Commissie kan aan deze beraadslagingen deelnemen."

1. 75/440/EEG, PB nr. L. 194 van 25-7-1975, p. 34. Gewijzigd bij Richtlijn wan de kand van 9-10-1979, 79/869/EEG, PB nr. L. 271 wan 29-10-1979, p. 44; K.J.M. Mortelmans, EG-milieu wetgeving, 1992, p. 65-67.

2. 76/160/EEG, PB nr. L. 31 van 5-2-1976, p. 1. Gewizigd bij het Toetredingswerdrag Griekenland (PB nr. L 291 wan 19-11-1979, p. 111) en het Toetredingsverdrag Spanje/Portugal (PB ar. L 302 van 15-11-1985, p. 218); EG-milieu wetgeving, w. w. 79-82.

3. 78/176/EEG, PB nr. L 54 van 25-2-1978, p, 19. Gewijzigd bij Richtlin wan de Rand van 3-12-1982, 82/883/EEG, PB nr. L 378 wan 31-12-1982, p. 1, gewijzigd bij Richtlin van de Raad van 24-1-1983, 83/29/ EEG, PB nr. L 32 wan 3-2-1983, p. 28; EG-milieu wetgeving, aw, p. 131-142.

4. 78/659/EEG, PB nr. L 122 wan 14-8-1978, p. L. Gewijzigd bij Toetredingswerdrag wan Griekenland, w. w noot 1, p. 112 en Toetredingsverdrag van Spanje/Portuggil, a,w. noot 1, p. 219; EG-milieu wetgeving, \&.w.", p. 149-158. 
5. Richtlijn wan de Raad van 30-10-1979 inzake de vereiste kwaliteit wan schelpdierwater." Artikel 10." Wanneer een Lid-Staat ovenweegt schelpdienwater aan te wijzen in de onmiddelijke omgeving wan de grens met een andere Lid-Staat, plegen deze Staten overleg over de vaststelling van de wateren waarop deze richtlijn van toepassing kan zijn, alsmede van de gevolgen die uit dfe gemeen. schappelijke kwaliteitsdoelstellingen voortvloeien en die na onderling overleg door elke betrokken Staat worden vastgesteld. De Commissie kan aan deze beraadslagingen deelnemen."

6. Richtlijn van de Raad van 17-12-1979 betreffende de bescherming van het grondwater tegen verontreiniging veroorzaakt door de lozing van bepaalde gevaarlijke stoffen. ${ }^{\text {" }}$

Artikel 17: "In geval wan lozing in grensoverschrijdend grondwater brengt de bevoegde instantie van de Lid-Staat die overweegt een dergelijke lozing toe te staan, vóón de afgifte van een vergunning de andere betrokken Lid-Staten op de hoogte. Op verzoek van die Lid-Staten vindt vớr de afgifte van een vergunning overleg plaats; de Commissie kan hieraan deelnemen."

7. Richtlijn van de Raad wan 15-7-1980 betreffende grenswaarden en richtwaarden van de luchtkwaliteit voor zwavaldioxyde en zwevende deeltjes.

Artikel 11: "1. Wanneer de Lid-Staten in grensgebieden waarden vaststellen voor de concentraties van zwaveldioxide en zwevende deeltjes in de lucht overeenkomstig artikel 4, leden 1 en 2, plegen zij vooraf overleg met ellkaar. De Commissie kan bij dit overleg aanwezig zijn.

2. Wanneer de in bijlage I opgenomen grenswaarden of de in artikel 4 , leden 1 en 2, bedoelde waarden, voor zover over latst genoemde waarden overleg is gepleegd overeenkomstig lid 1 , worden overschreden of dreigen te worden overschreden ten gevolge wan een merkbare verontreiniging die een andere Lid-Staat als oorsprong heeft of kan hebben, plegen de betrokken Lid-Staten overleg met elkaar ten einde de situatie te verhelpen. De Commissie kan bij dit overleg aanwezig zijn."

8. Richtlijn van de Raad van 22-3-1982 betreffende grenswaarden en kwalliteitsdoelstellingen voor kwiklozingen afkonstig van de sector elektrolyse van alkalichloriden. ${ }^{B}$

Artikel 4: "De betrokken Lid-Staten houden toezicht op het aquatisch milieu dat door lozingen van industriële bedrijven is beïnvloed. Ingeval van lozingen die de wateren van meer dan ến Lid-Staat beïnloeden, werken de betrokken Lid-Staten samen om de toezichtsprocedures te harmoniseren."

9. Richtlijn wan de Raad wan 3-12-1982 betreffende de voorschriften voor het toezicht op en de controle van de milieuss die betrokken zijn bij lozingen van de titaandioxyde-industrie."

Artikel 13: "Wanneer overeenkomstig artikel 4 lid 1 van Richtlijn 78/176/EEG voor de verwijidering van afvalstoffen de bevoegde instanties vam meer dan eén Lid-Staat voorafgaande vergunningen dienen te verlenem, plegen de betrokken Lid-Staten onderling overleg over de inhoud en de uitvoering wan het controleproguanma."

5. 79/923/EEG, PB nr. L 281 van 10n11-1979, p. 47; EG-milieuwetgevimg, a.w, p. 185-191.

6. B0/68/EEG, PB nr. L 20 wan 26-1-1980, p. 43; EG-miliew wetgeving, a.w. p. 191-195.

7. 80/779/EEG, PB int. L 229 van 30-8-1980. Gewijzigd bij Richtlijn van de Rad van 19-10m-1981, 81/857/EEG, PB nr. L. 319 wan 7-11-1981, p. 18, alsmede bij het Toetredingsverdrag Spanje/Portugal, a.w. noot 1, p. 219. Gawijzigd bij Richtlijn wan de Raad van 21-6-1989, 89/427/EEG, PB ar. L 201 van 14-7m1989, p. 53; EGmiliet wetgeving, a. p. 207-221.

De EG zijn ook partij bij het Verdrag betreffende grensoverschrjodence luchtverontreining over lange afstand (Besluit van de Rard wan 11-6-1981. PB nr. L 171 van 27-6-1981, P. 11). De samenwerking lijkt zich hier mel name af te spelen op regeringsmiveau.

8. 82/176/EEG, PB nr. L 81 van 27-3m-1982, p. 29, EG-milieu wetgeving, a.w., p. 235-239.

9. 82/883/EEG, PB nr. L. 378 van 31-12-1982, p. 1. Gewijzigd bij Toetredingswerdirag Spanje/Portugal, a. w., noot 1, p. 219; EG-milien wetgeving, a.w., p. 247-256. 
10. Ficlitlijin van de Raad van 24 juni 1982 inzake de risico"s van zware ongevallen bij bepaalde industriele activiteiten. ${ }^{10}$

Artikel 8: "1. De Lid-Staten zien erop toe dat informatie over weiligheidsnaatregelen en de bij en ongeval te volgen gedragslijn op passende wijze wordt verstrekt aan personen die kunnen worden getroffen door een zwaar ongeval ten gevolge van een industrielle activiteit waarvan overeenkomstig artikel 5 kennis is gegeven, zonder dat deze daarom behoeven te verzoeken. De informatie wordit met passende tussenpozen herhaald en bijgewerkit, en ook ter beschikking van het publiek gesteld.

2. De betrokken Lid-Staten verstrekken de andere betrokken Lid-Staten gellijktijdig dezelfde inlichtingen als die welke zij aan hun eigen onderdanen verstrekken, zulks als uitgangspunt voor ieder noodzakelijk overleg in het kader van bun bilaterale betrekkingen."

11. Richtlijn van de Raad van $26-9 \times 1983$ betreffende grenswarden en kwaliteitsdoelstellingen voor lozingen van cadmium."

Artikel 4: "De betrokken Lid-Staten houden toezicht op het aquatisch milieu dat door lozingen van industriële bedrijven wordt beïnloed. In geval van lozingen die de wateren van meer dan sén Lid-Staat beïnloeden, werken de betrokken Lid-Staten samen om de toezichtprocedures te harmoniseren."

12. Richtlijn van de Raad van 8-3-1984 betreffende grenswaarden en kwaliteistdoelstellingen voor kwiklozingen afkomstig van andere sectoren dan de elektrolyse van alkalichloriden."

Artikel 5: "De betrokken Lid-Staten houden toezicht op thet aquatisch milieu dat door lozingen wan industriële bedrijwen wordt beïnvloed. In geval van lozingen die de wateren van meer dan én Lid-Stat beïnloeden, werken de betrokken Lid-Staten samen om de toezichtprocedures te harmoniseren."

13. Richtlijn van de Raad wan 28-6-1984 betreffende de bestrijding van door industriële inrichtingen veroorzaakte luchtverontreiniging. ${ }^{\text {"3 }}$

Artikel 7: "Onder voorbehoud van de bepalingen inzake het handelsgeheim wisselen de Lid-Staten onderling en met de Commissie inlichtingen uit over hun ervaring en kennis met matregelen ter voorkoming en beperking van luchtverontreiniging, technische apparatuur en methoden, alsnede. grenswaarden van luchtkwaliteit en emissie."

Artikel 10: "De Lid-Staten stellen dezelfde gegevens als die zij ten behoeve van hun eigen onderdanen verspreiden ter beschikking van de overige belanghebbende Lid-Staten als grondslag voor overleg in het kader van hun bilaterale betrekkingen."

14. Richtlijn van de Raad van 9-10-1984 betreffende de grenswaardlen en kwaliteitsdoelstellingen voor de lozing wan hexachloorcyclohexaan. ${ }^{14}$

Artikel 4: "De betrokken Lid-Staten bouden toezicht op het acquatisch millieu dat door lozingen van industriêle bedrijven wordt beänvloed. In geval van lozingen, die de wateren van meer dan eén Lid-Staat beimvloeden, werken de betrokken Lid-Staten samen om de toezichtsprocedures te harmoniseren."

10. 82/501/EEG, PB nit. L 230 wan 5-8-1982, p. 1 (rectificatietie PB nr. L 289 van 13-10-1982, p. 35. Gewijzigd bij Richtljin van de Radd van 19-3-1987, 87/216/EEG, PB nr. L 85 van 28-3-1987, p. 36. Gewijzigd bij Fichtijn wan de Raad van 24m11-1988, 88/610/EEG, PB nr. L 336 van 7-12-1988, p. 14.

In deze kan bok nog werwezen wonden naar de richtlijn van de Raad wan 27-11.-1989 betreffende de in fomatio van de bevolking over de bij strallingsgevaar toepassalijke matregelen ter bescherming wan de gezondhoid on over de allsdan te wolgen gedragslijn, 89/618/Euratom, PB nr. L 357 wan $7-1241989$, p. 31 .

11. 83/513/EEG, PB nor. L 291 kan 24-10-1983, p. 1; EGmilien wetgeving, a.w. p. 263-268.

12. 84/156/EEG, PB m. L 74, van 17-3-1984, p. 49; EG-milieu wetgeving, a w., p. 269-273.

13. 84/360/EEG, PB nr. L 188 van 16-7-1984, p. 20; EG-milleu wetgewing, a.w. p. $281-285$.

14. 84/491/EEG, PB mi. L 274 van 17-10-1984, p. 11; EG-nullieu wetgeving, a.w., p. 289.294. 
15. Richtlijn wan de Raad van 7-3-1985 inzake luchtkwaliteitsnormen woor stikstofdioxyde. ${ }^{15}$ Artikel 11: "1. Wanneer een Lid-Staat voornemens is voor gebieden die in de nabijheid van een grens met of meer andere Lid-Staten zijn gelegen waarden voor de stikstofdioxyde-concentraties in de lucht vast te stellen overeenkomstig artikel 4 , leden 1 en 2 , zorgt hij voor voorafgaand overleg met de betrokken Lid-Staten. De Commissie wordt hiervan op de hoogte gesteld en kan aan dit overleg deelnemen.

2. Wanneer de in bijlage I vermelde grenswavarde of de in artikel 4 , leden 1 en 2 , bedoelde waarden, voor zover over laatst genoemde waarden overeenkomstig lid I overleg is gepleegd, worden overschreden of dreigen te worden overschreden tengevolge van een merkbare verontreiniging die een andere LidStaat als oorsprong heeft of kan hebben, plegen de betrokken Lid-Staten overleg ten einde verbetering te brengem in de situatie. De Commissie wordt hiervan op de hoogte gesteld en kan aan dit overleg deelnemen."

16. Richtlijn van de Raad wan 27-6-1985 betreffende de milieu-effectbeoordeling van bepaalde openbare en particuliere projecten. ${ }^{16}$

Artikel 7: "Wanneer een Lid-Staat constateert dat een project aanzienlijke effecten kan hebben op het milieu in een andere Lid-Staat, of wanneer een Lid-Staat die aanzienlijke effecten

zou kunnen ondervinden bierom verzoekt, doet de Lid-Staat op welks grondgebied het project wordt voorgesteld, de krachtens artikel 5 verzamelde informatie aan de andere Lid-Staat toekomen op hetzelfde moment als hij deze informatie ter beschikking stelt aan zijn eigen onderdanen. Deze informatie dient als grondslag woor het in het kader van de bilaterale betrekkingen wan beide Lid-Staten eventueel noodzakelijk overleg op basis van wederkerigheid en op voet van gelijkwaardigheid."

17. Richtlijn wan de Raad van 12-6-1986 betreffende grenswaarden en kwaliteitsdoelstellingen woor lozingen van bepaalde onder lijst I van de bujlage wan Richtlijn 76/464/EEG vallende gevaarlijke stoffen." "7"

Artikel 4: "De betrokken Lidstaten houden toezicht op het aquatisch milieu dat wordt beïnvloed door lozingen van industriële bedrijven en andere bronnen wan significante lozingea. In geval van lozingen die de wateren van meer dan één Lid-Staat beïnvloeden, werken de betrokken Lid-Staten samen om de toezichtprocedures te harmoniseren."

18. Richtlijn van de Raad van 24-11-1988 inzake beperking van de emissies van bepaalde verontreinigende stoffen in de lucht door grote stookinstallaties. ${ }^{\text {is }}$

Artikel 12: "Bij de bouw van stookinstallaties die aanzienlijke gevolgen hebben op het millieu in eem andere Lid-Staat, zorgen de Lid-Staten ervoor dat alle passende informatie wordt uitgewisseld en overleg word gepleegd overeenkomstig artikel 7 van Richtlijn 85/337/EEG van de Raad van 27-6-1985 inzake de milieu-effectbeoordeling van bepaalde openbare en particuliere projecten."

15. $85 / 203 / E E G, P B$ ar. L 87 van 27-3-1985, p. 1. Gewijzigd bij Richtijin van de Raad van 20-12-1985, 85/580/ EEG, PB nr. L 372 van 31-12-1985, p. 36; EG-milieuwetgeving, a.w., p. 303-307

16. 85/337/EEG, PB nr. L175 van 5-7-1985, p. 40; EG-milien wetgeving, p. 315-321. Zie ook: sub III.3 het verdrag van Espoo, warbij de EG als partij is toegetreden. Vgl noot 69.

17. 86/280/EEG, PB nr. L 81 van 4-7-1986, p. 16 (rectificatie PB nr. L 210 wan 1-8-1986, p. 108/PB nr. L221 wan 7-8-1986). Gewjizigd bij Richtlijn van de Rasd van 16-8-1988, 88/347/EEG, PB nr. L 158 van 25-6-1988, p. 35. Gewijzigd bij Richtlijn wan de Raad van 27-7-1990, 90/415/EEG, PB nr. L 219 van 14-8-1990, p. 49; EG-milieu wetgeving, a.w. p. 349-352.

18. 88/609/EEG, PB nr. L336 van 7-12-1988, p. 1. Gewijzigd bij Richtlijn van de Raad van 4-12-1990, 90/656 EEG, PB mr. L353 van 17-12 1990 , p. 59; EG-milien wetgewing. p. $475-481$. 
19. Richtliju van 7 juni 1990 inzake vrije toegang tot milieu-informatie."

Artikel 3: "Behoudens het bepaalde in dit artikel waarborgen de Lid-Staten dat overheidsinstanties gehouden zijn op verzoek milieu-informatie beschikbaar te stellen aan iedene natuurlijke of rechtspersoon, zonder dat deze een belang hoeft aan te tonen."

20. Richtlijn van de Raad van 21-5-1991 inzake de behandeling van stedelijk afvalwater. ${ }^{\text {20 }}$

Artikel 9: "Indien wateren die onder de jurisdictie van een Lid-Staat vallen nadelig worden beinvloed door lozingen van stedelijk afvalwater uit een andere Lid-Staat, kan de eerstgenoemde Lid-Stat de andere Lid-Staat en de Comissie van de betrokken feiten in kennis stellen.

De betrokken Lid-Staten organiseren, eventueel samen met de Commissie, het nodigo overleg om na te gaan om welke lozingen het gaat en welke mattregelen aan de bron moeten worden genomen om de getroffen wateren te beschermen ten einde de inachtneming wan deze richilijn te waarborgen."

Bijlage II, minder kwetsbare gebieden

Een mariene watermassa of marien gebied kan als een minder kwetsbaar gebied worden aangewezen wanneer de lozing van afvalwater geen nadelige invloed heeft op het milien yanwege de morfologische, hydrologische of specifieke hydraulische omstandigheden in dat gebied.

Bij het aamwijzen van minder kwetsbare gebieden moeten de Lid-Staten rekening houden met het risico dat de geloosde belasting ook terecht kan komen in aangrenzende gebieden, waar zij schadelijk kan zijn woor het millieu. De Lid-Staten moeten de aanwezigheid van kwetsbare gebieden buiten hun nationale rechtsgebied erkennen.

Bij het aanwijzen van minder kwetsbare gebieden moeten de wolgende elementen in aanmerking worden genomen:

Open baaien, estuaria en andlere kustwaterem met een goede wateruitwisseling, die niet gevoelig zijn voor eutrofiëring of zuurstofgebrek of die geen gevaar lopen door de lozing van stedelijk afvalwater eutroof te worden of zuurstofgebrek te vertonen.

19. 90/313/EEG, PB ar. L 158 van 23-6-1990, p. 56; EG-milieu wetgeving, a.w , p. 577-579. Op basss wan artikel 12 doen de Lid-5taten de nodige wettelijke en bestumstechtelijke bepalirgen in werking tredisa om uilierlijk 31-12-1992 aan deze richtlijn te voldoen.

20. 91/271/EEG, PB mr. L 135 van 30-5-1991, p. 40, EG-milieu wetgeving, a. . p. 617-625. Conform artikel 19 doen de Lid-Staten de nodige wettelijke en bestwursrechtelijke bepalingen in werking treden om witerlijk op 30-6-1993 aan deze richtlijn te voldoen. 


\section{Bijlage 6}

\section{OVEREENKOMSTEN OP BASIS VAN ARTTKEL 59 GRENSVERDRAG}

- Overeenkomst tussen het Wasserverband Netterdenscher Kanal en het polderdistrict Oude Rijn inzake het gemaal Kandia, 3-12-1971, Trb. 1973 nr. 12.

- Overeenkomst tussen het Deichverband Kleve-Landesgrenze en het polderdistrict Maas en Waal oyer de waterafvoer uit het gemeenschappelijk stroomgebied naar het gemaal te Nijmegen, 20-9-1972, "Trb. $1973 \mathrm{nr} .12$.

- Overeenkomst tussen het Isselverband en het Waterschap Oude Ussel over de verbetering en het onderhoud van een gedeelte van de Issel (Oude IIIssel) in het grensgebied, 6-4-1973, Trb. 1973 mr. 160.

- Overeenkomst tussen de Kreis Ahaus en het Waterschap van de Berkel over de verbetering en het onderhoud van de Ramsbeek en de Veengoot, 8-6-1973, Trb. 1974 ur. 33.

- Overeenkomst tussen het Waterschap van de Geleen- en Molenbeek met zijtakken en het Rodebachverband inzake het onderhoud van de Rode Beek, de Grensgraaf, de wroegere Rigolbach en de Ruischerbeek, 12-9-1975, Trb. 1976 nr. 27.

- Overeenkomst tussen het Wasser- und Bodenverband Itterbecker Moor en het Waterschap De Bovenvecht inzake het onderhoud wan de Dooze, 2-6-1976, Trb. 1977 nr. 2.

- Overeenkomst tussen bet Waterschap Regge en Dinkel, het Unterhaltungsverband 114 Vechte en het Wasser- und Bodenverband Rammelbecke over het onderhoud van zowel de Rammelbeek als de Oude Ranmelbeek, 16-10-1975, Trb. 1978 nr. 56.

- Overeenkomst tussen het Waterschap van de Oude IJsel en het Land Nordrhein-Westfalen over het onderhoud wan de Aastrang (Bocholter Aa) in het grensgebied , 14-2-1978, Trb. $1978 \mathrm{nr}$ : 112.

- Owereenkomst tussen het Waterschap van de Berkel en de Kreis Borken over het onderhond en het materiaaltransport van de Berkel in het grensgebied, 19-10-1978, Trb. $1979 \mathrm{nr} .110$.

- Overeenkomst tussen het Waterschap van de Berkel, de Teilnehmergemeinschaft der Flurbereinigung Vreden en het Wasser- und Bodenverband Grosse Mast-Gaxel over de verbetering en het onderhoud van de Beurzerbeek met enkele zijleidingen in het grensgebied, 19-10-1978. Trb. $1979 \mathrm{ur} .110$.

- Overeenkomst tussen het Waterschap van de Berkel en het Wasser- und Bodenverband Kalkbachgebiet betreffende het onderhoud van de Ratumsebeek en van een zijleiding in het grensgebied, 19-10-1978, Trb. $1979 \mathrm{nr} .110$

- Overeenkonst tussen het Waterschap van de Berkel en het Wasser- und Bodenverband Wellingbachgebiet betreffende het onderhoud van de Willinkbeek in het grensgebied, 19-10-1978. Trb. $1979 \mathrm{nr}$. 110.

- Overeenkomst tussen het Wasser- und Bodenwerband Spanische Ley, Wasser- und Bodlenwerband Haimer Heidle, Wasser- und Bodenwerband Wolfsgraben, Wasser- und Bodenverband Schwarz-, Laarund Baaler Bnch en het Waterschap Het Maasterras inzake het onderhoud van de Oude Spanische Ley (Grensgraaf), de Nieuwe Spanische Ley, de Hülmer Leitgraben, de Wolfsgraben, de Horsterbeek en de Eckeltsebeek, alsmede het beherem van de kunstwerken in en aan deze waterlossingen, 16-11-1979, Trb. 1980 nr. 94. 
- Overenkomst tussen het Waterschap Het Maasterras en Wasser- und Bodemverband Straelener Veen inzake het onderhoud van de Straelener Leitgraben en de Lingsforterbeek alsmede het beheren van de kunstwerken in en aan dexe waterlossingen, 21-3-1980, Trb. $1980 \mathrm{nr} .137$.

- Overeenkonst tussen het Waterschap Regge en Dinkell en het Wasser- und Bodlenverband Unteres Dinkelgebiet ower het onderhoud wan de Dinkel in thet grensgebied Gronau, 7-9-1981, Trb. $1981 \mathrm{mr}$. 257.

- Overeenikomst tussen heit Wasser- und Bodenverband Unterhaltungsverband 114-Vechte, Neuenhaus, en het Waterschap Bargerbeek, Klazienaveen, inzake het onderhoud van hei Schoonebeekerdiep/ Grenzaa en de Nieuwe Sloot/Grenzschloot, alsmede het onderhoud en het beheer van werken in en langs deze wateren, 8-3-1983, Trb. 1983 nr. 137.

- Overeenkomst tussen het Waterschap Regge en Dinkel, het Unterhaltungsverband 114 Vechte en het Wasser- und Bodenverband Puntbecke over het onderhoud van de Puntbecke, de Haarmanngraben, de Ravenshorster Bach, de Stollwerkgraben, de Aarninkgraben en de Ohmanngraben, 12-3-1986, Trb. 1987 nr. 43.

- Overeenkonst tussen het polderdistrict Rijn en ISssel en het Wasserverband Netterdenscher Kanal over de verbetering en het onderhoud van het Grenskanaal (Netterdenscher Kanal) en de Wild alsmede het onderhoud en de bediening van kunstwerken in en aan deze wateren, 21-9-1988, Trb. $1989 \mathrm{nr}$. 72 .

- Overeenkomst tussen de Stadt Wassenberg, de Stadt Wegberg en het Waterschap Roer en Overmaas inzake het onderhoud van de Rode Beek en het onderhoud en de instandhouding van de afvoerregulerende kunstwerken bij de Dalheimer Molenvijver, 21-1.1988, Trb. 1989 nr. 72.

- Overeenkomst tussen het polderdistrict Groot Maas en Waal en het Deichverband Kleve-Landesgrenze inzake het onderhoud van de in thet grensgebied liggende watergang achtereenvolgens genaand Bimmensche Wetering, Zeeländische Wässerung en Hauptwässerung alsmede het onderhoud van de kunstwerken in en aan deze watergang, 5-6-1989, Trb. $1990 \mathrm{nr} .66$. 


\section{Literatuur}

\section{Literatuurlijst}

- Achterberg N., G. Püttner (Hrsg.), Besonderes Verwaltungsrecht, Band II, 1992.

- Ago R., Yearbook ILC, 1962, Vol. I, p. 36 e.v.

- Akkermans P.W.C., A.K. Koekkoek (red.), De Grondwet, tweede druk, 1992.

- Alen A., Algemene beginselen en grondslagen van het Belgisch Publiekrecht, Boek 1: De Instellingen, 1988.

- Alen A., P. Peeters, Samenwerkingsverbanden tussen de Staat, de Gemeenschappen en de Gewesten, in: Staat, Gemeenschappen en Gewesten, R. Blanpain e.a., 1989, p. $115-124$.

- Alen A., J. Dujardin, Casebook Belgisch Grondwettelijk Recht, 1986.

- Ameln von R., Auswirkungen des Europäischen Binnenmarktes auf Kommunalpolitik und Kommunalrecht der EG-Mitgliedstaten, Am Beispiel der Bundesrepublik Deutschland, DVB1. 1992/8, p. 477-484.

- Autexier C., Le cadre juridique de l'action extérieure des régions, RFDA 2 (4) 1986, p. 568-579.

- Basdevant J., La conclusion et la redaction des traités et des instruments diplomatiques autres que les traités, Receuil des Cours, 1926, p. 601-641.

- Bauer J., Grenzüberschreitende Zusammenarbeit, Städte- und Gemeinderat 8/1991, p. 231-233.

- Beirlaen A., De intermationale betrekkingen en de derde fase van de staatsherziening, Proeve van een oplossing, TBP, 1990/5, p. 338-342.

- Bellekom van Th.L., A.W. Heringa, T. Koopmans, R. de Winter, Koopmans' Compendium van het staatsrecht, 6e druk, 1992.

- Bennett G., J.H. Jans, De gevolgen van de Europese eenwording voor het milieubeleid van lagere publiekrechtelijke organisaties, p. 265-294, in: N.F. Roest et al., a.w.

- Benz A., Regionen als Machtfaktor in Europa, Verwaltungs-Archiv, 84. Band, Heft 3, 1993, p. 328-348.

- Berber F., Lehrbuch des Völkerrechts, Band I, 2. Auflage, 1975.

- Berg A., Zum Übereinkommen zwischen Dänemark, Finnland, Norwegen und Schweden über grenzüberschreitende Zusammenarbeit von Gemeinden der nordischen Staaten, ZaöRV, Band 40, 3. Heft, 1980, p. 600-624.

- Berg Van den A.J., R. van Delden, H.J. Snijders, Arbitragerecht, 2e druk, 1992.

- Bernhardt R., Der Abschluss völkerrechtlicher Verträge im Bundesstaat, 1957. 
- Bernier I., International Legal Aspects of Federalism, 1973.

- Besselink L.F.M. Staatsrecht en buitenlands beleid, 1991.

- Besturen in Limburg, provincies en gemeenten in de beide Limburgen, 1989.

- Beyerlin U., Grenzüberschreitende unterstaatliche Zusammenarbeit, Zum Entwurf eines Europäischen Rahmenübereinkommens über die grenzüberschreitende Zusammenarbeit zwischen Gebietskörperschaften, ZaöRV, Bd. 40 (1980), p. 573-599. Citeerwijze: U. Beyerlin, Grenzüberschreitende (..).

- Beyerlin U., Rechtsprobleme der lokalen grenzüberschreitende Zusammenarbeit, 1988. Citeerwijze: U. Beyerlin, Rechtsprobleme (..).

- Beyerlin U., Dezentrale grenzüberschreitende Zusammenarbeit als transnationales Rechtsphănomen, AVR, 1989, 27. Band, 3. Heft, p. 286-327. Citeerwijze: U. Beyerlin, Dezentrale (..).

- Bindschedler R.L., Betrachtungen über die Souveränität, in: Recueil d'études de droit international, en hommage à Paul Guggenheim, 1968, p. 167-183.

- Blanke H.J., Die kommunale Selbstverwaltung im Zuge fortschreitender Integration, Aspekte nationaler und supranationaler Verfassungsentwicklung, DVBI. 1993/14, p. 819-831.

- Bleckmann A., Das Souverănitätsprinzip im Völkerrecht, AVR, 1985, 23. Band., 3. Heft, p. 450-477.

- Bleicher R., Staatsgrenzen überschreitende Raumordnung und Landesplanung, 1981. Blix H., Treaty making power, 1960.

- Bomhof L.. Intergemeentelijke samenwerking op milieugebied: rijksgelden en voortschrijdlend inzicht leiden tot vooruitgang, Gemeentestem 1989, 6885, p. 391-395.

- Boot D.J., D.W.P. Ruiter, Van periferie tot centrum, Intergemeentelijke samenwerking in de stedendriehoek Enschede/Hengelo-Münster-Osnabrück, 1992.

- Bösche E., Kommunalverfassungsrecht in Nordrhein-Westfalen, 2. völlig neugefasste Auflage, 1989.

- Bothe M., Rechtsprobleme grenzüberschreitender Planung, AöR, Band 102/1, p. 75 e.v.

- Brandhof wan den J.C.E., Administratieve overeenkomsten in het internationaal publiekrecht, NSB $1986 / 40$, p. 1277-1282.

* Brederveld E.; Gemeenterecht, 2e druk, 1989, en supplement 1992.

- Brederveld E., Schroot J.C., Wijna N., Begrip van de Nederlandse gemeente, $2 \mathrm{e}$ geh. herz. druk, 1990.

- Bronzwaer M.A.J.M., Volkenrechtelijke aansprakelijkheid van staten voor particulier milieuvervuilend handelen, TMA $1989 / 2$, p. 33-46.

- Brownlie I. Principles of Public International Law, 4th. edition, 1990.

- Burdeau G. Les accords conclus entre autorites administratives ou organismes public de pays differents, in: Mélanges offerts à Paul Reuter 'Le droit international: Unité et diversité, 1981 , p. 103-126.

- Bülnren G.D., Algemeines Kommunalrecht Nordrhein-Westfalen, 4. überarbeitete Auflage, 1989.

- Claessen P.D.A., Het Europees Handvest inzake Lokale Autonomie, TvO, 1988/20, p. $424-425$.

- Coenen A., L'étendue du droil d"association des communes, jurisprudence récente, Mouvement Communal 5/1993, p. 265-268. 
- Coenraets P., Les accords de coopèration dans la Belgique fédérale, Administration Publique T3/1992, p. 158-200.

- Commissie van de Europese Gemeenschappen, Europa 2000, perspectieven voor de ruimtelijke ontwikkeling van de gemeenschap, 1992.

- Conférence des pouvoirs locaux et régionaux de l'Europe, vingt années d'action en faveur des pouvoirs locaux et régionaux, Strasbourg, 1977.

- Decaux E., La Convention-cadre européenne sur la coopération transfrontalière des collectivités locales, RGDIP, 1984, p. 557-620.

- Delpérée F., Droit Constitutionnel, 1980.

- Dijk van J.R., Hoefsloot I.B.M., Het waterschap en zijn voortbestaan, Openbaar bestuur 1993/2, p. 13-16.

- Doeschot R.G.P., et al., Intergemeentelijke samenwerking, 1987.

- Due O., Artikel 5 van het EEG-Verdrag, Een bepaling met een federaal karakter, SEW 5 (1992), p. 355-366.

- Dujardin J., W. Somers, L. Van Summeren, J. Debyser, Praktisch handboek voor gemeenterecht, 3e volledig hernieuwde editie, 1991.

- Dupuy P-M., La coopération régionale transfrontalière et le droit international, AFDI, 1977,p. 837-860.

- Eckly P., La coopération transfrontalière et l'administration française, Collection Etudes et travaux 1, Conseil de l'Europe, 1989.

- Engel R., Rechtsprobleme der Abfallentsorgung im deutch-schweizerischen Grenzgebiet, Verwaltungsblätter für Baden-Württemberg, 1/1990, p. 5 e.v, 3/1990 p. 81-88.

- Ercman S., Das Europäische Rahmenübereinkommen über die grenzüberschreitende Zusammenarbeit zwischen Gebietskörperschaften, p. 249-261, in: Bothe, Prieur, Ress, Rechtsfragen grenzüberschreitender Umweltbelastungen, 1984.

- Erichsen H-U., Kommunalrecht des Landes Nordrhein-Westfalen, 1988.

- Europa vanuit de praktijk van de decentrale overheden, themanummer Bestuurswetenschappen, 1991/7.

- Faber H., Kommunalreclat, p. 225-277, in: H. Faber, H-P. Schneidier, Bearb. von K. Berg u.a., Niedersächsisches Staats- und Verwaltungsrecht, 1985.

- Fastenrath U., Kompetenzverteilung im Bereich der auswärtigen Gewalt, 1986.

- Fauchille P., Traité de droit international public, Tome Jer, Troisième Partie, 1921. p. 296 e.v.

- Fingerhut R., Zur Reform der Kommunalverfassung, Städte- und Gemeinderat 9/ 1993, p. 255-259.

- Fitzmaurice G.G., Rapporteur on the Law of Treaties, Yearbook ILC, 1958, Vol. II, p. 24-32.

- Flinterman C., Parlement en buitenlands beleid, p. 7-23, in: Staatsrecht, buitenlandse betrekkingen en de internationale rechtsorde, staatsrechtconferentie, 1986.

- Fröhler L., P. Oberndorfer, F. Zehetner, Rechtsprobleme grenzüberschreitender Raumplanung, 1977.

- Fijnaut C.(red.), De reguliere politiediensten in België en Nederland, Hun reorganisatie en Onderlinge Samenwerking, 1992.

- Gabbe J., Institutionelle Aspekte der grenzüberschreitenen Zusammenarbeit, p. 174186, in: Grenzübergreifende Raumplanung, Erfahrungen und Perspektiven der Zu- 
sammenarbeit mit den Nachbarstaaten Deutschlands, Akademie für Raumforschung und Landesplanung, 1992.

- Gabbe J., Euregio-Regionale grensüberschreitende zusammenarbeit an der Basis, p. 187-208, in: Grenzübergreifende Raumplanung, a.w.

- Geck W.K., Die völkerrechtlichen Wirkungen verfassungswidriger Verträge, 1963.

- Gerlach H., rapporteur, Verslag namens de Commissie voor regionaal beleid, ruimtelijke ordening en vervoer over de ontwerp-resolutie inzake het regionaal beleid van de Gemeenschap ten aanzien van de regio's aan de interne grenzen van de Gemeenschap, Doc. 355/76, 25-10-1976.

- Godard S., Contribution à l'étude des aspects juridiques de la coopération transfrontalière appliquée à la protection de l'environnement, le cas des régions frontalières franco-espagnols, 1987.

- Goorden C.P.J., A.A. Freriks, Ontwikkeling van landgrensoverschrijdende samenwerking tussen gemeenten, Gemeentestem 1991/no. 6927, p. 441-550.

- Grotefels S., Gemeinsame grenzüberschreitende Regionalplanung zwischen den Niederlanden und Nordrhein-Westfalen, 1992.

- Hagelstein G.H., H.J. de Ru, J.L. Boxum/L.J.A. Damen, Functioneel bestuur, 1993.

- Hambuchen U., Potentielle Organisationsformen für grenzüberschreitende interkommunale Kooperation, dargestellt am deutsch-niederländischen Grenzraum, 1980.

- Harvard Research in International Law on Treaties, Supplement to 29 AJIL, 1935.

- Hatzfeld U., B. Temmen, Interkommunale Zusammenarbeit, eine Zwischenbilanz, Stadt und Gemeinde 1/1991, p. 21-25.

- Haubert B., P. Vandernoot, La nouvelle loi de reformes institutionelles du 8 aout 1988, Administration Publique T3/1988, p. 211-268.

- Hauschild C., The impact of EC-law on the relation between central government and local and regional authorities, Regelmaat 1991-2, p. 48-51.

- Haeverbeek J., Les Intercommunales, 1988.

- Heberlein H., Die Rechtsprechung des BVerfG und des BVerwG zur "kommunalen Aussenpolitik", NVwZ 1992/6, p. 543-547.

- Heberlein H., Aktuelle Rechtsprobleme "Kommunaler Aussenpolitik", Die Verwaltung, 1993/2, p. 213-234.

- Heemskerk W.F.A., Waterrecht en waterschapsrecht, grensverkenningen in verband met de grensoverschrijdende rivier de Roer, 1985.

- Hendrikx J.A.M., J.M.E. Traag, Samenwerking tussen provincies op subnationaal niveau, Openbaar Bestuur 1992/1, p. 7-11.

- Hennekens H.Ph.J.A.M., De Kaderwet bestuur in verandering, Een a-constitutionele wissellijst voor een perspectiefloze staatsinrichting, Gemeentestem 1993/no. 6966, p. 269-277, Gemeentestem 1993/no. 6967, p. 301-309.

- Heringa A.W., T. Knoop Pathuis, De gemeente en het het buitenlands beleid, NJCM 1989 , p. $667-674$.

- Hinssen J.P.P., H. van Hoorn, J. Maessen-van Aalst, Grensoverschrijdende bestuurlijke samenwerking en milieuproblematiek, Bestuurswetenschappen 1993/1, p. 32-43.

- Hoeven Van der J., De drie dimensies van het bestuursrecht, 1989.

- Hoppe W., M. Beckmann, Juristische Aspekte einer interkommunalen Zusammenarbeit beiderseits der deutsch-niederländischen Grenze, DVBI. 1986/1, p. 1-9.

- Huber M., Le droit de conclure des traités internationaux, 1951. 
- Jans J.H., Grensoverschrijdend millieurecht, 1987.

- Jans J.H., Europees milieurecht in Nederland, 1991.

- Jeurissen H.H.M., Europese steunverlening, Bestuurswetenschappen, 1991/7, p. 502507.

- Jong H.G., De bevoegdheid tot het voeren van buitenlands beleid, Grensoverschrijding door parlement en gemeenten?, p. 145-160, in: Gegeven de Grondwet, 1988.

- Jordans H., Grenzüberschreitende Rechtsprobleme zwischen den niederländischen, belgischen und deutschen Gemeinden im Aachener Grenzraum und ihre Lösungen, 1974.

- Kelsen H., The Law of the United Nations, 1950.

- Kessen A.A.L.G.M., Bestuurlijke vernieuwing in grensgebieden, Intergemeentelijke grensoverschrijdende samenwerking, 1992.

- Kilian M., Umweltschutz durch Internationale Organisationen, 1987.

- Knieriem B.C., De gemeentewet van oud naar nieuw, 1993.

- Kooijmans P.H., Internationaal publiekrecht in vogelvlucht, 4e druk, 1993.

- Kopp F.O., Verwaltungsgerichtsordnung, 1992.

- Körner H., Gemeindeordnung Nordrhein-Westfalen, Kommentar, 5. Auflage, 1990.

- Korte H. begr, von, Fortgef. von B. Rebe. Unter Mitarb. von M. Berenskötter u.a., Verfassung und Verwaltung des Landes Niedersachsen, 2e völlig neubearbeitete und erweiterte Auflage, 1986.

- Kortmann C.A.J.M., Constitutioneel recht, 1990.

- Lafore R., L'action a l'étranger des collectivités territoriales, RDP, 1988-3, p. 764811.

- Lambert P.(red.), Manuel de droit communal, 1992.

- Lambrechts W., Geschillen van bestuur, 3e herwerkte uitgave, 1988.

- Lammers J.G., J.M. van Dunné, Aansprakelijkheid voor schade door grensoverschrijdende millieuverontreiniging, volkenrechtelijke en civielrechtelijke aspecten, Mededelingen van de NVIR, no. 103, october 1991.

- Lang W., Die normative Qualität grenzüberschreitender Regionen. Zum Begriff der "soft institution", AVR, 1989, 27. Band, 3. Heft, p. 253-285.

- Lauterpacht H., Oppenheim's International Law, Vol. I, 8th. edition, 1955.

- Lauterpacht H., Rapporteur on the Law of Treaties, Yearbook ILC 1953, Vol II, p. $138-139$.

- Lauwaars R.H., C.W.A. Timmermans, Europees Gemeenschapsrecht in kort bestek, 2e herziene druk, 1991.

- Lejeune Y., Le statut international des collectivités fédêrées (à la lumière de l'expérience suisse), 1984.

- Lennep von G., Kommunale Mitsprache im Europarat gefährdet, Stadt und Gemeinde 5/1993, p. 163-166.

Linazasoro J.L., La coopération transfrontalière dans les communautés européennes: bilan et perspectives, RMC, no. 315, 1988, p. 140-151.

- Lissitzyn $\mathrm{O}$., Territorial entities other than independant states in the law of treaties, RCADI, 1968, Vol. 125, p. 83 e.v.

Lïersen K., Niedersächsische Gemeindeordnung, Kommentar, (Iosbladig), 1991.

- Maanen van G.E., Publiek domein en het belang van de overheid bij bodemsanering, Een ongewasschen varken?, 1990. 
- Maes $\mathbb{R}_{*}$ Een nieuwe wettelijke regeling voor de intercommunale samenwerking, TGEM 1988/3, p. 144-176.

- Maes R., F. De Mot, J. De Pover, L. De Schepper, A. Dessoy, M. Lint, C. Perpette, De Intercommunales, 1992. Citeerwijze: R. Maes et al.

- Malchus von V. Frhr., Partnerschaft an Europäischen Grenzen, Integration durch grenzüberschreitende Zusammenarbeit, 1975.

- Malchus von V. Firhr., Empfehlungen für die künftige grenzübergreifende Zusammenarbeit auf dem Gebiet der Raumplanung an den Deutschen Staatsgrenzen, p. 209. 225, in: Grenzübergreifende Raumplanung, a.w.

- Mann F.A., Sudies in International Law, 1973.

Marzo Di L., Component Lnits of federal States and International Agreements, 1980.

- Mast A., A. Alen, J. Dujardin, Overzicht van het Belgisch Administratief Recht, $10 \mathrm{e}$ druk, 1986.

- Mast A., J. Dujardin, Overzicht van het Belgisch Administratief Recht, $12 \mathrm{e}$ druk, 1992.

- McNair Lord, The law of Treaties, 1960.

- Meij A.W.H., Timmermans C.W.A., Grensregio's en Europees recht, Bestuurswetenschappen, $1980 / 1$, p. 1-13.

- Mensel van A., De formele motiveringsplicht, De wet van 29-7-1991, TBP 1992/6, p. 384-393.

- Mensel van A., Administratief toezicht op de gemeenten, discretionaire bevoegdheden en het beginsel van behoorlijk bestuur, TBP 1992/9, p. 607-613.

- Meulen van der B., e.a., Bestuursbevoegdheid als bron van recht, NTB 91/5, p. 133141.

- Mortelmans K.J.M., Europees materieel recht: De hoofdlijnen geschetst voor het binnenlands bestuur, p. 55 70, in: N.F. Roest, et al., a.w.

- Mosler H., Die auswärtige Gewalt im Verfassungssystem der Bundesrepubliek Deutschland, in: Völkerrechtliche und Staatsrechtliche Abhandlungen, Festschrift Carl Bilfinger, 1954, p. 261 e.v.

- Mosler H., Reflexions sur la personalité juridique en droit internationall public, in: Mélanges offerts à Henri Molin, 1964, p. 228-251. Citeerwijze: H. Mosler, Réflexions (..).

- Mudrich G., Grenzüberschreitende Zusammenarbeït im Europarat, p. 9-30, in: Grenzübergreifende Raumplanung, a.w.

- Nedden B., Verwaltungsorganisation, p. 105-143, in: H. Faber, H.P. Schneider (Hrsg.), Bearb. von K. Berg u.a., 1985.

- Nelissen N.J.M., R.W.J.M. Uijen (red), Grensoverschrijdende samenwerking in een Europa zonder binnengremzen, 1993.

- Nicolai P. „De rechtspersoon in artikel 7 Wet Arob, naar een loslaten van het civiel. rechtelijk rechtspersoonbegrip. NIB 1988/6, p. 183-187.

- Nicolail P., B.K. Olivier, L.J.A. Damen, H. Troostwijk, Bestuurstecht, 4e herziene druk, 1993.

- Obermayer K., Kommentar zum Verwaltungsverfahrensgesetz, 2. erg. Auflage, herausgegeben von D. Ehlers, C. Link, 1990.

- OCDE, Aspects juridiques de la pollution transfrontière; 1977.

- Oebbecke J., Gemeindeverbandsrecht Nordrhein-Westfalen, 1985. 
- OECD, Environmental protection in frontier regions, 1979.

OECD, Transfrontier pollution and the role of States, 1981.

OECD, OECD and the Environment, 1986.

Dehm M., Rechtsprobleme Staatsgrenzen überschreitender interkommunaler Zusammenarbeit, 1982.

Olffen van M., P.A.J. Beks, Het Europees Economisch Samenwerkingsverband, 1990.

- Orianne M.P., Coopération européenne des régions transfrontalière, les problèmes juridiques de la coopération des régions frontalières, A.D./Coll. Front, Strasbourg 1972 , p. 2-8.

- Papier H-J., Direkte Wirkung von Richtlinien der EG im Umwelt und Technikrecht, Verwaltungsverfahrensrechtiche Probleme des nationalen Volzuges, DVB1., 1993/15, p. 809-814.

- Pauwels A., D. Demeyere, Polders en wateringen, 5e druk, 1988.

- Pietzcker J., Zusammenarbeit der Gliedstaaten im Bundesstaat, Landesbericht Bundesrepublik Deutschland, p. 19-76, in: Zusammenarbeit der Gliedstaaten im Bundesstaat, Landesberichte und Generalbericht der Tagung für Rechtsvergleichung 1987, 1. Auflage, 1988.

- Prakke L., Van der Pot, Donner, Handboek van het Nederlandse staatsrecht, 12e druk, 1989.

- Prakke L., Kortmann C.A.J.M. (red.), Het bestuursrecht van de landen der Europese Gemeenschappen, 3e geheel herziene druk, 1988.

- Prakke L., Kortmann C.A.J.M. (red.), Het staatsrecht van de landen der Europese Gemeenschappen, 3e geheel herziene druk, 1988 en 4e geheel herziene druk, 1993.

- Prieur M., Les bases juridiques de la coopération frontalière locale et régionale, RFDA 1 (3) 1985, p. 322-331.

- Prieur M. (red.), Europe des Régions et Environnement, 1988.

- Raad voor het Binnenlands Bestuur, Advies over de Duits-Nederlandse Overeenkomst inzake grensoverschrijdende samenwerking, sept. 1991.

- Rack R., Österreichs Länder und das Völkerrecht, AVR, 1989, 27. Band, 1. Heft, p. 32-44.

- Randelzhofer A, R. Harndt, Grenzüberschreitende Zusammenarbeit bei der Umweltverträglichkeitsprüfung, Umwelt Bundesamt, Berichte 2/1989, 1989.

- Rapsch A., Wasser- und Bodenverbände als grundrechtliche nichtkommunale Verbandspersonen öffentlichen Rechts, Die öffentliche Verwaltung, 1992/15, p. 657-664.

- Rapsch A., Konfliktbewältigung mit verfassungswidrigen Mitteln? Wasserverbandliches Schiedswesen zwischen Wunsch und Realität, NVwZ, 1993/6, p. 534-539.

- Raven B.W., G.H.M. Tromp, Grensoverschrijdende samenwerking, Een onderzoek naar bestuurlijke en juridische mogelijkheden bij grensoverschrijdende samenwerking tussen noordelijk Nederland en de Duitse deelstaat Nedersaksen, Samenwerkingsverband Bestuurswetenschappen Noorden des Lands, nr. 17, 1993.

- REGwijzer: Europese informatie ten dienste van decentrale overheden/Raad der Europese Gemeenten en Regio's, 1991 (verschijnt jaarlijks).

- Reis E., Nordrhein-Westfalen/Niederlande, Unterkommission Süd der Deutch-Niederländischen Raumordnungskommission, p. 74-86, in: Grenzübergreifende Raumplanung, a.w. 


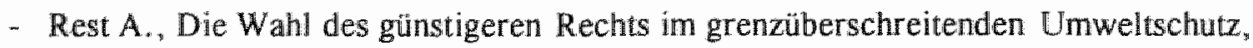
Beiträge zur Umweltgestaltung, Band A 68, 1980.

- Reuter P., Droit international public, 1958.

- Reuter P., Introduction au droit des traités, 2 e ed., 1985.

- Roest N.F. K.J.M. Mortelmans. A.P. Oele "J.H. Boone (red), Europa bimen het bestuur, Essaybundel, 1991. Citeerwijze: N.F. Roest et al.

- Rosenne S., Developments in the Law of Treaties 1945-1986, 1989.

- Rousseau Ch., Droit international public, Tome I, Introduction et sources, 1971. Citeerwijze: Ch. Rousseau, Droit (..).

- Rousseau Ch., Droit international public, Tome II, 1974, Sujets de Droit. Citeerwijze: Ch. Rousseau, Droit (..). "Tame II.

- Rousseau Ch., Principes généraux du droit international public, 1944. Citeerwijze: Ch. Rousseau, Principes (..).

- Rudolf W., Bundesstaat und Völkerrecht, AVR, 1989, 27. Band, 1. Heft, p. 1-30.

- Run van P.L.J.M. A.H. Verheij, Regio's in Europa/Europese Fondsen, p. 123-144, in: N.F. Roest et al., a.w.

- Scheltema M., De burgerlijke rechter lost het probleem van de administratieve rechtspraak op, in: NJ 1913-1988, annotatoren kijken terug, 1988, p. 141-149.

- Schermers H.G., Internationaal publiekrecht voor de rechtspraktijk, 1985.

- Schlögel B., Grenzüberschreitende interkommunale Zusammenarbeit, Voraussetzungen und Rechtsgrundlagen sowie Beispiele in der Abwasserbeseitigung Energie- und Wasserversorgung und im Nahverkehr, 1982.

- Schmidt-Assmamn E., Kommunalrecht, in: Besonderes Verwaltungsrecht, I. Von Münch, E. Schmidt-Assmann (Hrsg.), 9. neubearbeitete Auflage, 1992, p. 1-97.

- Schoonhoven M.J.M., Provincierecht, 1991.

- Schwarzenberger G., A Manual of International Law, 4th. edition, 1960.

- Seerden R., Samenhang over de grenzen heen: Grensoverschrijdende samenwerking, wettelijke regelingen in het bijzonder de gemeentelijke bevoegdheden, TBP 1989/8, p. 489-508.

- Seerden R., Het Dollardhavenverdrag en het internationaal milieurecht, M enl R 1989/10, p. 400-409.

- Seerden R., The Public International Law Character of Transfrontier Agreements between Decentralized Authorities, LJIL, Vol.5, No.2, Oct. 1992, p. 187-213.

- Seerden R.J.G.H, M.W.J.A. Hertoghs, Belgisch-Nederlandse samenwerking gedecentraliseerd, Een onderzoek nalar het Belgische organieke recht inzake decentrale overheden en hun bevoegdheden op het gebied van het milieu en de ruimtelijke ordening, 1993.

- Seewald O., Kommunalrecht, in: U. Steiner (Hrsg.), Besonderes Verwaltungsrecht, 4. neubearbeitete und erweiterte Auflage, 1992, p. 1-161.

- Seidl-Hohenveldern I., Das Recht der Internationalen Organisationen einschliesslich der Supranationalen Gemeinschaften, 2. Auflage, 1971.

Sevinga K., WK-voetbal 1990, EG-recht en lokaal bestuur, Publiek Domein, 1990, p. $198-202$.

- Sewandono I., Wetsvoorstel tot versnelling van de implementatie van EG-richtlijnen, NJB 1992/36, p. 1172-1175 (naschrift NJB 1993/4, p. 198-202. 
- Sieben R., J. Ziller, De gevolgen van EG=beleid woor decentrale overheden in Nederland, 1989.

- Simons P., Grensoverschrijdende samenwerking in de ruimtelijke ordening tussen de Bondsrepubliek Duitsland en Nederland, Besturrswetenschappen 1988/4, p. 242-255.

- Sinclair 1., The Vienna Convention on the Law of "Treaties, 2 nd edition, 1984.

- Singh $\mathbf{N}$., Right to environment and sustainable development as a principle of international law, Studia Diplomatica, Vol. XLI, 1988 , Num. 1, p. 45 e.v.

- Snijders H.J. (red.), Toegang tot buitenlands burgerlijk procesrecht, 1992.

- Snoep T.M., De nationale rechter, een vooruitgeschoven EG-post, NIB 1992/8, p. $260-263$.

- Sociaal-geografisch en Bestuurskundig Onderzoek, De WGR gewaardeerd, 1991.

- Somers W., Bestuurlijk toezicht op gemeentelijk optreden: rechtsmiddelen van de gemeente, TGEM 90/1, p. 18-26.

- Sondaal H.H.M., De Nederlandse Verdragspraktijk, 1986.

- Stevens J., Is een Executieve bevoegd tot het rechtstreeks vernietigen van een beslissing van een gemeenteoverheid van Komen-Waasten en Voeren?, TGEM 90/2, p. $113-118$.

- Strikwerda L., Inleiding tot het Nederlandse internationaal privaatrecht, derde druk, 1992.

- Stuyt A.M., Formeel Tractatenrecht, 1966.

Suikens M., Omtwerpdecreet administratief toezicht, De Gemeente 3/1993, p. 131134.

- Tak A.Q.C., Publiek domein, overheidscontract en rechterlijke wetshandhaving, NTB $90 / 2$, p. 265-270.

- Tang-van Loenen van der P.H., Inventarisatie spontane vernietigingsbesluiten van de Kroon 1990-1991-1992, Gemeentestem 1993/no. 6966, p. 277-283.

- Teunissen J.M.H.F., Samenwerking op basis van het privaatrecht, in: Handboek Bestuurlijke Samenwerking (losbladig).

- Tomuschat C., in: Kommentar zum Bonner Grundgesetz (losbladig).

- Top van der K.I. De Wet gemeenschappelijke regelingen; een oplossing voor de regionale problematiek?, 1986.

- Vancraeynest D., Polders en wateringen en hun relatie tot de gemeentebesturen, De Gemeente 1/1992, p. 12-16.

- Vanhelleputte L., Benelux-Overeenkomst grensoverschrijdende samenwerking, De Gemeente 4/1992, p. 192-195.

- Velu J., Toetsing van de grondwettigheid en toetsing van de vernigbaarheid met de verdragen, Rechtskundig Weekblad 1992-1993, nr. 15, p. 48 \-516.

- Verburg J.J.L. (red.), De Waterschapswet, een artikelsgewijs commentaar, 1992.

- Verdross A., Völkerrecht, 5e Auflage, 1964.

- Verdross A., B. Simma, Universelles Völkerrecht, Theorie und Praxis, 1976. Verkruisen W.G. Vis B.C., Gemeente en gemeentewet, 7e herziene druk, 1990. Vermaerke M., G-P. Libin, Maatschappelijk welzijn, De Gemeente 1/1993, p. 60-68. Verslag van de Algemene Ledenvergadering, Mededelingen van de NVIR, no. 100 , maart 1990. 
- Verspohl N., Niedersachen/Niederlandse - Unterkommission Nord der Deutsch-Niederlăndischen Raumordnungskomission, p. 57-73, in: Grenzübergreifende Raumplanung, a.w.

- Versteden C.J.N., Grondwettelijke haken en ogen van de Kaderwet bestuur in verandering, NTB 93/6, p. 212-222.

- Vierdag E.W., De praktijk van de zogenoemde 'internationalle administratieve akkoorden', p. 36-73, in: Spanningen tussen recht en praktijk in het verdragenrecht, Mededelingen wan NVIR, no. 99, oktober 1989.

- Weber A., Die Umweltwerträglichkeitsrichtlinie im deutschen Recht, 1989, p. 233251.

- Wijk Van, Konijnenbelt, Hoofdstukken wan Administratief Recht, zevende druk, 1991 .

- Wijzenbroek W.J., Kunnen gemeenten zelfstandig buitenlands beleid voeren?, Bestuur $1988 / 2, \mathrm{p}, 48-52$.

- Wilde de E.L.H., Inleiding grensoverschrijdende samenwerking, in: Handboek Bestuurlijke Samenwerking (losbladig).

- Wilde de E.L.H, Benelux-Overeenkomst grensoverschrijdende samenwerking, in: Handboek Bestuurlijke Samenwerking, a.w.

- Wildhaber L., Treaty-making Power and Constitution, An International and Comparative Study, 1971. Citeerwijze: L. Wildhaber, Treaty-making (..).

- Wildhaber L., Executive Agreements, 7 Encyclopedia of Public International Law, 1984, p. 81-86. Citeerwijze: L. Wildhaber, Executive agreements.

- Winter de R., De overheid, 1991.

- Winter J.A., Gevolgen van het Gemeenschapsrecht voor de lagere overheden in Nederland, Regelmaat, 1991-2, p. 52-56.

- Witmer J., Grenznachbarliche Zusammenarbeit, Das Beispiel der Grenzregionen von Basel und Genf, 1985.

- Wittkåmper, Reform der verwaltungsstruktur in Nordrhein-Westfalen?, Städte- und Gemeinderat, 6/1993, p. 163-167.

- Woehrling J-M., Legal Problems of transfrontier co-operation at local or regional level, OECD, ENV/TFP/1977.10.

- Woltjer E.P., J.D. Wiersma, De territoriaal gedecentraliseerde overheden en de Europese integratie, p. 11-36, in: N.F. Roest et al., a.w.

- Zehetner F., Das Europäische Rahmenübereinkommen über die grenzüberschreitende Zusammenarbeit zwischen Gebietskörperschaften, UPR 1983/7, p. 209-215.

- Zielke B., Zwischengemeindliche Zusammenarbeit, Rechtliche, organisator ische unf finanzielle Gestalltungsmöglichikeiten, 1993.

- Zoller E., La conclusion et la mise en oeuvre des traités dans les Etats fédérées et unitaires, 2 RIDC 1990, p. 737-750.

- Zuleeg M., in: Kommentar zum Grundgesetz für die Bundesrepublik Deutschland, Reihe Alternativkommentare, Band I, 1984.

- Zuleeg M., Die Stellung der Länder und Regionen im europäischen Integrationsprozess, DVBl. $1992 / 20$, p. 1329-1337. 
Zusammenfassung

\begin{abstract}
Öffentlich-rechtliche grenzüberschreitende Zusammenarbeit zwischen untergeordneten Behörden

Juristische Aspekte von öffentlich-rechtlichen Absprachen zwischen niederländischen untergeordneten Behörden und ihren "Counterparts" in Belgien und Deutschland
\end{abstract}

\title{
ENNFUHRUNG
}

Viele niederländische untergeordnete Belörden grenzen mit ihrem Gebiet unmittelbar an Belgien und Deutschland. Es handelt sich hierbei um mehr als die Hälfte aller niederländischen Provinzen, ungefähr ein Achtel der niederländischen Gemeinden, circa ein Fünftel der niederländischen Wasserbehörden (waterschappen) und gut ein Drittel der Kooperationsgebiete auf der Grundlage des Gesetzes über öffentlich-rechtliche kommunale Zusammenarbeit (Wet gemeenschappelijke regelingen). Bislang wurden zwischen den Provinz-, Kommunal- und Regionalbehörden und ihren "Counterparts" auf der anderen Seite der Grenze kaum öffentlich-rechtliche Vereinbarungen getroffen. Die nationale Grenze stellt hierbei offenbar eine Barriere dar, da innerhalb der betreffenden Ländern selbst eine Zusammenarbeit öffentlich-rechtlicher Art häufiger vorkommt. Noch immer erfolgt die grenzüberschreitende Zusammenarbeit zwischen untergeordneten Behörden größtenteils auf amtlicher und administrativer Ebene und ist sozusagen faktischer Art. Dabei manifestiert sich die grenzüberschreitende Zusammenarbeit auf verschiedenen Behördenebenen: zwischen einzelnen Gemeinden, zwischen einer großen Anzahl von Gemeinden bzw. einigen Provinzen (Grenz-/Euregios) und auf höherer interregionaler Ebene zwischen niederländischen Provinzen und den (Ämtern von) belgischen Regionen/Gemeinschaften (Gewesten/Gemeenschappen) sowie deutschen Bundesländern. In der Praxis wird in den letzten Jahren eine immer größere Anzahl grenzüberschreitender Initiativen im Rahmen öffentlich-rechtl icher Aufgaben und Zuständigkeiten ergriffen.

In dieser wachsenden Verwirklichung dezentraler grenzüberschreitender Zusammenarbeit und dem zunehmenden Bedürfnis nach juristisch weiterreichenden Vereinbarungen liegt bereits ein Grund für die Bedeutung näherer Untersuchungen über die diesbezüglichen rechtlichen Grundlagen und Rahmenbedingungen. Die Beschreibung von Zuständigkeitsgrundlagen und die Darstellung möglicher Formen der Zusammenarbeit ist aber auch aus verschiedenen anderen Gründen von (gesellschaftlicher) Bedeutung. 
Zunächst ist die dezentrale grenzüberschreitende Zusammenarbeit unter dem Gesichtspunkt der Internationalisierung als Folge der Auflösung der europäischen Binnengrenzen zu sehen. Gerade die Zusammenarbeit bei öfentlich-rechtlichen Befugnissen auf der Ebene jener Behörden, die dem Bürger am nächsten stehen, kann einen Beitrag auf dem Weg zu einem geeinten Europa leisten. Daneben nimmt im Zusammenhang mit dem Wegfallen der Landesgrenzen die wechselseitige Abhängigkeit zwischen den Behörden in den Grenzgebieten zu. Bei der Lösung von Problemen könnte sich für eine optimale politische Lenkung die Zusammenarbeit mit "ausländischen" Behörden anbieten. Zu denken ist an eine gemeinsame Erstellung von Plänen und ein gemeinsames Erteilen von Genehmigungen, aber auch an die Möglichkeit, die Ausübung derartiger Befugnisse neu zu gründenden öffentlich-rechtlichen Kooperations verbänden zu übertragen. Möglicherweise wird eine International isierung in den grenzüberschreitenden Regionen stattfinden. Gerade die Möglichkeit, gemeinsam in (bestimmten) politischen Bereichen weitgehend zusammenzuarbeiten, wird die Gründung derartiger grenzüberschreitender Regionen beschleunigen können und deren interne und externe Position verstärken. An dieser Stelle ist darauf hinzuweisen, daß die rechtliche Reichweite der grenzüberschreitenden Zusammenarbeit bislang noch nicht so ausgeprägt ist, wie die offentlich-rechtliche Zusammenarbeit zwischen untergeordneten Behörden innerhalb der betreffenden Staaten. So verfügen die Niederlande und Deutschland und auch in geringerem Maße Belgien über gesetzlíche Regelungen im Bereich der dezentralen Zusammenarbeit, die besagen, daß die untergeordneten Behörden öffentlich-rechtliche Befugnisse neu zu gründenden Zweckverbänden übertragen können, eine Nachbargemeinde mit der Ausübung öffentlich-rechtlicher Befugnisse beauftragen können oder in anderer Weise Vereinbarungen im Rahmen ihres Ermessensspielraums bei der Auslegung öffentlich-rechtlicher Befugnisse treffen können. Da diese Untersuchung einen Vergleich des belgischen, deutschen und niederländischen Rechts in Sachen untergeordnete Behörden und dezentrale Zusammenarbeit beinhaltet, können in diesen Punkten mögliche rechtliche Gemeinsamkeiten festgestellt werden und es könnte angezeigt werden, ob diese rechtlichen Gemeinsamkeiten die (europä ische) Integration fördern können. Liegen rechtliche Übereinstimmungen vor, wird eine Zusammenarbeit leichter möglich sein als bei divergierenden Rechtssystemen. Im übrigen dürfen meines Erachtens rechtliche Bestimmungen (oder Gemeinsamkeiten) als möglicher Katalysator für die Integration nicht überbewertet werden. Übereinstimmungen bzw. Unterschiede bei der Sprache und der Verwaltungskultur sowie Interessengegensätze und dergleichen werden die Zusammenarbeit vielleicht stärker beeinflussen können als Übereinstimmungen oder Unterschiede in der Gesetzgebung. Andererseits wird eine Institutionalisierung und Formalisierung grenzüberschreitender Zusammenarbeit und damit auch das Erstellen diesbezüglicher Regelungen dazu beitragen können, zu einer Abstimmung von staatlicher Politik und Zuständigkeit im Hinblick auf Probleme und Chancen in Grenzgebieten zu gelangen.

Eine andere Bedeutung für die Aufnahme einer grenzüberschreitenden Zusammenarbeit liegt in der Vermeidung haftungsrechtlicher Konsequenzen, wie sie im Falle einer fehlenden Zusammenarbeit auftreten können. Hierbei ist auf die sogenannte ReflexWirkung von Vorschriften hinzuweisen. In der niederländischen Rechtsprechung wurde z.B. angenommen, daß bei behördlichen Entscheidungen (vor allem bei Umwelt-Genelmigungen und Planungs verfahren) ausländische Auswirkungen bzw. Gegebenheiten mitberücksichtigt werden müssen. Im Zusammenhang mit dieser Pflicht zum Schutz 
ausländischer Rechte und Interessen liegt eine Zusammenarbeit in Form einer vorab vorgenommenen gegenseitigen Abstimmung - etwa durch Absprachen zwischen den Behörden - auf der Hand. Dies ist in jedem Fall besser als eine mögliche Haftung im nachhinein oder eine nachträgliche Aufhebung von Beschllüssen aufgrund einer mangelnden Abstimmung. Gerade die Möglichkeit zur Vornahme weitreichender öfentlichrechtlicher Vereinbarungen kann dafür sorgen, daß z. B. für ausländische Behörden/Bürger nicht nur Rechte, sondern auch Pflichten entstehen. Neben dem Beispiel aus der Rechtsprechung gibt es in den Niederlanden übrigens einige gesetzliche Bestimmungen, in denen eine Abstimmung mit ausländischen Behörden ausdrücklich geregelt ist.

AuBerdem ist es irmmer wirkungs voller zusammenzuarbeiten, als wern jeder für sich bestimmte Dinge anders tut oder der eine etwas tut und der andere nicht.

\section{DIE PROBLEMATIK}

Im Moment bildet sich eine rechtliche Ordnung in bezug auf die Möglichkeiten grenzüberschreitender öfentlich-rechtl icher Vereinbarungen zwischen untergeordneten Behörden heraus. Ziel dieser Dissertation ist eine Analyse der juristischen Möglichkeiten (die Befugnis für eine Zusammenarbeit sowie der juristische Rahmen einer Zusammenarbeit) füt grenzüberschreitende öffentlich-rechtliche Zusammenarbeit zwischen niederländischen untergeordneten Behörden und ihren "Counterparts" in Belgien und Deutschland. Bei der dezentralen grenzüberschreitenden Zusammenarbeit steht die folgende Frage im Mittelpunkt:

Haben niederländische untergeordnete Behörden die Befugnis, mit ihren "Counterparts" in Belgien and Deutschland offentlich-rechtiche Vereinbarungen zu treffen und, wenn dies so ist, in welchem rechilichen Rahmen manifestieren sich diese offentlich-rechtichen Vereinbarungen?

Für die Zusammenarbeit in Form von Vereinbarungen in bezug auf Verwaltungs- und Regelungsbefugnisse und deren Übertragung sind zwischen Behörden im eigenen Land gesetzliche Grundlagen vorhanden. So gilt z.B. für diese Art der Zusammenarbeit zwischen untergeordneten Behörden in den Niederlanden das "Wet gemeenschappelike regelingen", in Belgien das "Wet betreffende de intercommunales" sowie das "Wer hou dende organisatie wan agglomeraties en federaties van gemeenten" und gelten in Nord rhein-Westfalen und Niedersachsen das Gesetz über kommunale Gemeinschaftsarbeit bzw. das Zweckverbandsgesetz.

Die wichtigsten Formen öffentlich-rechticher Vereinbarungen zwischen Behörden sind entsprechend der jeweiligen nationalen Gesetzgebung:

- die Errichtung eines neuen gemeinschaftlichen Zweckverbandes mit Regelungs- bzw. Vervaltungsbefugnissen;

- die Ubertragung offentlich-rechtlicher Befugnisse von der einen Behörde auf eire andere Behörde (Delegation);

- die Übertragung der Ausübung öfentlich-rechticher Befugnisse von der einen Behörde auf eine andere Behörde (Mandat).

Auch kann bei öffentlich-rechtlichen Vereinbarungen z.B. an Absprachen gedacht werden, für die im nationalen Recht nicht ohne weiteres eine (zusätzliche) gesetzliche Grundlage (neben der privatrechtlichen Vertragsfreiheit) für erforderlich angesehen wird. 
Es geht hierbei z.B. um Vereinbarungen zwischen Behörden über die Art der Ausübung bestimmter öfentlich-rechnlicher Befugnisse oder über die Koordination von Beschlüssen. Oft finden derantige Vereinbarungen ihre Grundlage in offentlich-rechtlichen Befugnissen mit Ermessensspielraum. Aus diesem Grunde wüde ich vorläufig diese letzte Kategorie von Vereinbarungen vor allem hinsichtlich einer Abgrenzung zu privatrechtlichen Vereinbarungen ebenfalls als öfentlich-rechtliche Vereinbarungen bezeichnen. Das diesbezügliche (aus der Verfassung abgeleitete) Recht und of auch das sonstige (fachgesetzliche) Recht regelt im Grunde nur die interne Zusammenarbeit und sagt nichts über vergleichbare grenzüberschreitende Kooperationsmöglichkeiten zwischen untergeordneten Behörden aus. Die obengenannten gesetzlichen Kooperationsmöglichkeiten sind territorial gebunden. Dort, wo derartige offentlich-rechtliche Vereinbarungen das Grundgebiet des Staates überschreiten, ist das Bedürfnis nach einer gesetzlichen Grundlage noch deutlicher vorhanden. Gelegentlich gibt es auf der Grundlage der Richtlinien der Europäischen Gemeinschaften und internationaler Abkommen grenzüberschreitende Kooperationsbefugnisse für untergeordnete Behörden. Diese enthalten bis auf wenige Ausnahmen in der Regel nur Beratungsverpfichtungen. Weitergehende Formen der öfentlich-rechtlichen Zusammenarbeit analog zu der in der nationalen Gesetzgebung genannten Zusammenarbeit sind dabei nicht vorgesehen. Kürzlich wurden zwischen den Niederlanden und Belgien und zwischen den Niederlanden und Deutschland Abkommen über eine dezentrale Zusammenarbeit geschlossen, die das im Rahmen des Europarats geschlossene Europâische Rahmenübereinkommen über die grenzüberschreitende Zusammenarbeit zwischen Gebietskörperschaften (Madrid 1980) weiter ausarbeiten. Ziel dieser Abkommen ist es, öffentlich-rechthiche grenzüberschreitende Vereinbarungen zwischen untergeordneten Behörden zu ermöglichen. Bei der belgisch-niederländischen dezentralen Zusammenarbeit handelt es sich um das Benelux-Abkommen über die grenzüberschreitende Zusammenarbeit zwischen Gebietskörperschaften oder anderen öfentlichen Stellen (Benelux-Overeenkomst inzake grensoverschrijdende samenwerking tussen territoriale samenwerkingswerbanden of autoriteiten/Brïssel 1986). Für die deutsch-niederländische dezentrale Zusammenarbeit geht es um das Abkommen zwischen dem Königreich der Niederlande, der Bundesrepublik Deutschland, dem Land Niedersachsen und dem Land Nordrhein-Westfalen über grenzüberschreitende Zusammenarbeit zwischen Gebietskörperschaften und anderen offentlichen Stellen (Isselburg-Anholt 1991). Beide Abkommen sind von großer Bedeutung für die Befugnis dezentraler Behörden in bezug auf eine grenzüberschreitende Zusammenarbeit und den diesbezüglichen rechtlichen Rahmen.

\section{DIE EINZELNEN KAPITEL IM ÜBERBLICK}

In Kapitel 2 steht die Frage im Mittelpunkt, ob die Souveränitäts-/Territorialitätsproblematik bewirkt, daß öffentlich-rechtliche Vereinbarungen bezüglich der Übertragung und Ausübung eigener Befugnisse zwischen untergeordneten staatlichen Organen beidseitig der Grenze dem Völkerrecht unterliegen.

Die Anwendung des Völkerrechts auf grenzüberschreitende öffentlich-rechtliche Vereinbarungen, bei denen eine Übertragung von (Bürger und Behörden bindenden) Befugnissen zwischen untergeordneten Behörden stattfindet, ist nach den Feststellungen in Kapitel 2 im Prinzip auf die von den Staaten ausgehende Schaffung einer diesbezüglichen 
rechtlichen Grundlage beschränkt. Diese Grundlage ist vor allem für die öffentlichrechtlichen Vereinbarungen notwendig, wobei Zuständigkeiten auf ausländische Behörden oder auf neu zu bildende grenzüberschreitende Kooperationsverbănde (mit fü: Behörden und Bürgern verbindlichen Kompetenzen) übertragen werden. Für öffentlichrechtliche Vereinbarungen etwa im Rahmen von Befugnissen mit Ermessensspielraum und für die Bildung von Beratungsgremien ohne Entscheidungsbefugnisse ist meines Erachtens in der Regel keine zusätzliche vertragsrechtliche Grundlage erforderlich. Dort, wo völkerrechtliche Verträge die Grundlage für eine öffentlich-rechtliche grenzüberschreitende Zusammenarbeit zwischen untergeordneten Behörden bilden, impliziert dies in der Regel nicht die Anwendung des Völkerrechts auf diese Vereinbarungen oder auf deren Inhalt. Eine mögliche Anwendung des Völkerrechts auf die dezentrale grenzüberschreitende Zusammenarbeit wurde in Kapitel 2 vor allem von der Seite der internationalen Verwaltungsabkommen beleuchtet. Dabei wurde im Hinblick auf den rechtlichen Status dieser Abkommen angemerkt, daß hierfür im Prinzip an internationales Recht und die für den Abschluß von internationalen Abkommen geltenden Voraussetzungen und das diesbezüglich gellende Recht angeknüpft werden muß. In diesem Zusammenhang kann die Schlußfolgerung gezogen werden, daß zumindest häufiger die (Möglichkeit einer) Anwendung von nationalem (öffentlichem) Recht bei internationalen Verwaltungsvereinbarungen zur Diskussion steht. Anders ausgedrückt: Auf internationaler Ebene können auch andere bindende Absprachen als Abkommen bestehen.

Aufgrund dieser Ausführungen kann meines Erachtens festgestellt werden, daß die dezentrale öffentlich-rechtliche grenzüberschreitende Zusammenarbeit nicht in den Bereich des grundgesetzlich vorgesehenen Systems der auswärtigen Beziehungen fällt. Dies ergibt sich aus der (dezentralen) Verwaitungsebene, auf der zusammengearbeitet wird, aus der Tatsache, daß im Rahmen kommunaler und regionaler autonomer Kompetenzen und Fachkompetenzen gehandelt wird, sowie aus der Situation, daß auf die Zusammenarbeit das (wechselseitige) nationale Recht anwendbar ist. Andererseits wurde in Kapitel 6 festgestellt, daß es natürlich nicht ausgeschlossen ist, daß der Staat im Rahmen der alıgemeinen verwaltungs- und staatsrechtlichen Aufsicht Beschlüsse der untergeordneten Behörden in diesem Zusammenhang aufheben kann. Die Grundlage hierfür wird dann eher gegen das Recht (Fehlen einer gesetzlichen Grundlage) oder gegen das allgemeine bzw. kommunale Interesse verstoßen und nicht im Widerspruch zum grundgesetzlichen Primat des Staates in bezug auf auswärtige (internationale) Beziehungen stehen.

Kapitel 3 befaßt sich mit der Rolle einer Reihe europäischer Organisationen in bezug auf die dezentrale grenzüberschreitende Zusammenarbeit sowie vor allem mit der Schaffung der diesbezilglichen gesetzlichen Grundlagen. Eingegangen wurde dabei auf die schwache rechtliche Grundlage des im Rahmen des Europarates aufgestellten Europäischen Rahmenübereinkommens über die grenzüberschreitende Zusammenarbeit zwischen Gebietskörperschaften. Im Moment wird ein Ergänzungsprotokoll vorbereitet, das weitergehende Möglichkeiten für untergeordnete Behörden im Bereich der grenzüberschreitenden Zusammenarbeit vorsieht und dadurch auch dem in der Europäischen Charta zur kommunalen Autonomie anerkannten Recht entsprechen wird. Der supranationale Charakter der Europäischen Gemeinschaften hat bislang nicht dazu geführt, daß in diesem Rahmen eine allgemeine Regelung für eine dezentrale grenzüberschreitende 
Zusammenarbeit zwischen untergeordneten Behörden getroffen wurde. Die Schaffung einer allgemeinen Regelung bezüglich einer dezentralen grenzüberschreitenden offentlich-rechtlichen Zusammenarbeit kann u.a. im Lichte der Bildung eines geeinten Europas an der Basis (also nahe beim Bürger) und der Vereinheitlichung dezentraler Kooperationsformen (in Grenzgebieten) in den einzelnen Ländern gewünscht werden. Im übrigen manifestiert sich die Rolle der Europäischen Gemeinschaften mehr in der Finanzierung einer grenzüberschreitenden Zusammenarbeit und im Hinblick auf bestimmie weniger intensive Formen einer Zusammenarbeit (Beratungsgremien etc.), wie diese in Umweltrichtlinien geregelt ist. Auffällig ist die geringe Rolle, die dabei den untergeordneten Behörden zukommt. In diesem Zusammenhang ist anzumerken, daß untergeordnete Behörden trotz ihrer wichtigen umweltrechtlichen Aufgaben bei einer grenzüberschrejtenden Zusammenarbeit das Nachsehen haben. Es sind oft übergeordnete Behörden, die (außer in den Richtlinien der Europäischen Gemeinschaften) auch in internationalen Umweltabkommen, etwa im Rahmen der Wirtschaftskommission der Vereinten Nationen für Europa, explizit genannt werden und deutlich angeben müssen, wo und wie sie oder die ihnen unterstellten Behörden verpflichtet sind, die Bestimmungen der betreffenden Abkommen zu erfülen. Dabei behalten sich die übergeordneten Behörden oft und meines Erachtens nicht immer zu Recht das formelle Recht der grenzüberschreitenden Zusammenarbeit vor. Die Regelung, alles den "Vertragsparteien" (also bei den Europäischen Gemeinschaften den Mitgliedstaaten) zu überlassen, ist dort, wo die Ausführung auf dezentraller Ebene liegt, nicht immer sehr wirkungs voll.

Die Rolle der Europäischen Gemeinschaften kann wor allem für die Harmonisierung des materiellen Rechts, das selbstverständlich eine große Rolle für die grenzüberschreitende Zusammenarbeit spielen kann, von Bedeutung sein. Diese Harmonisierung der fachgesetzlichen Regelungen ist allerdings nicht Gegenstand dieser Erörterung.

In Kapitel 4 wird das aus der Verfassung abgeleitete Recht in Sachen belgische, deutsche und niederländische untergeordnete Behörden, die zu einer öffentlich-rechtlïchen grenzüberschreitenden Zusammenarbeit berechtigt sind, beschrieben. Die Darstellung der Organisation dieser dezentralen Stellen sowie ilhre (autonomen) Befugnisse stellen eine relevante Einführung für die in den Kapiteln 5 und 6 behandelten Punkte dar. Es hat sich herausgestelit, daß sicherlich auf kommunaler Ebene die belgisch-niederländische und die deutsch-niederländische dezentrale Zusammenarbeit nicht infolge von Unterschieden in dem aus der Verfassung abgeleiteten Recht behindert werden. Für die niederländischen Provinzen gilt in diesem Punkt dasselbe wie in niederländisch-belgischer Beziehung. Übrigens kann als Folge der Kompetenzunterschiede auf der Grundlage der Fachgesetzgebung die interprovinzielle Zusammenarbeit über die belgisch-niederländische Grenze hinweg problematisch werden. Probleme furr die Zusammenarbeit zwischen miederländischen Provinzen und deutschen Behörden gibt es ebenfalls. Im Rahmen der dezentralen grenzüberschreitenden Zusammenarbeit liegen die deutschen Äquivalenteder niederländischen Provinzen nicht direkt auf der Hand.

In den Kapiteln 5 und 6 steht die nationalrechtliche Dimension grenzüberschreitender öffentlich-rechtlicher Vereinbarungen zwischen untergeordneten Behörden im Mittelpunkt. Diese nationalrechtliche Dimension ist hier viel offensichtlicher als die internationalrechtiliche (vgl. Kapitel 2). Dies ergibt sich aus der untergeordneten Behörden- 
ebene, auf der zusammengearbeitet wird, aus den kommunalen/regionalen Themen der Zusammenarbeit, aber vor allem aus dem für diese Zusammenarbeit anwendbaren Recht. Zwischen den Niederlanden und Belgien (Kapitel 5) gillt seit gut zwei Jahren das bereits erwähnte Benelux-Abkommen über dezentrale grenzüberschreitende Zusammenarbeit. Für die dezentrale grenzüberschreitende Zusammenarbeit zwischen den Niederlanden und Deutschland (Nordrhein-Westfalen und Niedersachsen) gilt seit Anfang 1993 das bereits genannte deutsch-niederländische Abkommen über dezentrale grenzüberschreitende Zusammenarbeit. Beide Abkommen schaffen Kompetenzen für untergeordnete Behörden im Hinblick auf grenzüberschreitende offentlich-rechthiche Vereinbarungen. Die Kooperations formen auf der Grundlage des Benelux-Abkommens, nämlich der Zweckverband (openbaar lichaam), die kommunale Arbeitsgemeinschaft (gemeenschappelijk orgaan) und die Verwaltungsvereinbarung (administratieve afspraak), gehen vom Anwendungsbereich her etwas weiter als die Kooperations formen auf der Grundlage des deutsch-niederländischen Abkommens (Zweckverband, kommunale Arbeitsgemeinschaft, offentllich-rechtliche Vereinbarung). Beide Abkommen verweisen bei einer Reihe von Punkten, etwa der Aufsicht, auf das nationale Recht der teinehmenden Staaten. Bei dem diesbezüglichen Benelux-Abkommen wurde nicht oder nur am Rande der Unterschied zwischen der Zusammenarbeit in den Niederlanden auf der Grundlage des "Wet gemeenschappelijke regelingen" und der Zusammenarbeit in Belgien auf der Grundlage des "Wet betreffende de intercommunales" berücksichtigt. Da die Zusammenarbeit auf der Basis des nationalen Rechts in hohem Maße richtungsweisend für die grenzüberschreitende Zusammenarbeit ist, muß das Benelux-Abkommen sehr extensiv ausgelegt werden, um seiner Zielsetzung, nämlich der rechtlichen Grundlage für eine öffentlich-rechtliche Zusammenarbeit, entsprechen zu können.

Für das diesbezügliche deutsch-niederländische Abkommen entstehen durch die Verweisung auf das niederländische und deutsche Recht hierbei weniger Probleme. Dies hängt mit der Tatsache zusammen, daß das innerstaatliche Recht von Deutschland (der Bundesländer Nordrhein-Westfalen und Niedersachsen) und von den Niederlanden in bezug auf die öffentlich-rechtliche Zusammenarbeit größtenteils übereinstimmt. Hierdurch wird die geringere Reichweite der Zusammenarbeit auf der Basis des deutschniederländischen Abkommens gegenüber dem Benelux-Abkommen kompensiert.

Übrigens bestehen im Hinblick auf die Zusammenarbeit auf der Grundlage dieser beiden Abkommen noch einige Unklarheiten und Probleme. So wurde in das deutsch-niederländische Abkommen im Gegensatz zum Benelux-Abkommen explizit die Kollisionsregelung (bei Streitigkeiten zwischen Behörden) aufgenommen, die bestimmt, daß eine Behörde nur durch die eigenen Gerichte zu einem Tun oder Unterlassen verurteilt werden kann. Hierdurch entsteht eine Hin- und Herverweisung zu den Gerichten. Dieses Problem wird im deutsch-niederländischen Abkommen (teilweise) durch die Môglichkeit: einer informellen Beilegung von Konflikten (Schiedsvereinbarung) zwischen Behörden gelöst. Obwohl diese Kollisionsregelung nicht ausdrücklich in das Benelux-Abkommen aufgenommen wurde, ist sie wahrscheinlich anwendbar, weil es sich hierbei um eine allgemeine völkerrechtliche Regellung handelt. Es ist abzuwarten, ob und inwieweit der "supranationale" Benelux-Gerichtshof diese Kollisionsregelung (teilweise) zu durchbrechen vermag.

Andere Probleme können sich ergeben aufgrund einer Aufsichtshäufung und der Reichweite der Bindung der teilnehmenden Behörden durch den Zweckverband. In dieser 
Hinsicht wird sich die Zusammenarbeit zumindest zu Beginn auf die nicht-bindende BeschluBfassung in den Beratungsgremien oder aber auf Vereinbarungen über Befugnisse mit Ermessenssplelraum konzentrieren.

Abschllekend ist zu sagen, daß vor allem die formale Seite der grenzuberschreitenden öffentlich-rechtlichen Zusammenarbeit beschrieben wurde, nämlich die Befugnis zur Zusammenarbeit und der diesbezïgliche juristische Rahmen. Selbstverständlich können die zu bericksichtigenden materiellen fachgesetzlichen Kompetenzen sich derart unterscheiden, dal letztlich die Vornahme öfentlich-rechtlicher Vereinbarungen behindert wird. In diesen Fällen wird eine Harmonisierung der Fachgesetzgebung notwendig sein. Hilerauf wird an dieser Stelle nicht näher eingegangen.

Kapitel 7 enthălt eine kurze Zusammenfassung, einige Schlußfolgerungen und Empfehlungen bezüglich der Grundlagen und juristischen Rahmenbedingungen einer dezentralen grenzüberschreitenden Zusammenarbeit, insbesondere in bezug auf offentlichrechtliche Vereinbarungen niederländischer dezentraler Behörden mit Ihren "Counter-

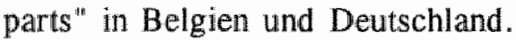

Angesichts dieser Ausfühungen und der in der Einleitung angezeigten gesellschaftlichen Relevanz der dezentralen grenzuberschreitenden Zusammenarbeit, insbesondere der öffentlich-rechtlichen Vereinbarungen, werden abschließend folgende Empfehlungen gegeben.

1. Zur Betonung der eigenen Position und der Bedeutung der dezentralen grenzüberschreitenden Zusammenarbeit müßte in den Niederlanden (und auch in europäischer Hinsicht) die Befugnis für untergeordnete Behörden zum Abschluß von öffentlichrechillichen Vereinbarungen mit ihren "Counterparts" im Ausland verfassungsmäßig verankert werden, wobei die diesbezügliche nähere Ausarbeitung des rechtlichen Rahmens in Gesetzen und internationalen Abkommen zu regeln ist.

2. Die Position der untergeordneten Behörden zur grenzüberschreitenden Zusammenarbeit muß auch außerhalb der Anwendung der Zusammenarbeit auf der Grundlage des Benelux-Abkommens und des deutsch-niederländischen Abkommens einen mehr fundamentalen Charakter erhalten. Dort, wo diese Behörden bestimmte Kompetenzen ausführen, müssen sie (und nicht unbedingt die übergeordneten Behörden) im Prinzip über das entsprechende Recht für eine grenzüberschreitende Zusammenarbeit verfügen. Vor allem bei der Erstellung von Verträgen und Richtinien der Europäischen Gemeinschaften muß die Rolle der untergeordneten Behörden stärker betont werden.

3. Eine Ausdehnung des Wirkungsgrades des Benelux-Abkommens und des deutschniederlăndischen Abkommens über die dezentrale grenzüberschreitende Zusammenarbeit im Hinblick auf "Gemesten/Gemeenschappen" bzw. die Länder mulf untersucht werden. Dies wäre sicherlich unter dem Aspekt der jüngsten belgischen und deutschen Grundgesetzänderungen in Sachen Vertragsabschluß möglich.

4. Im Zusammenhang mit der Verweisung des Benelux-Abkommens und des deutschniederländischen Abkommens über die dezentrale grenzüberschreitende Zusammenarbeit auf das wechselseitig anwendbare nationale Recht und insbesondere auf die Verwaltungsaufsicht sind in beiden Abkommen nähere Bestimmungen uber die Koordination - sicherlich bei Aufsichtsverfahren - angebracht. 
5. Angesichts der Problematik der Konfrontation von Rechtssystemen bei dezentraler grenzuberschreitender Zusammenarbeit ist, gerade in bezug auf die Beilegung von Rechtsstreitigkeiten zwischen Behörden, eine klarere Rechtsstreitigkeitenregelung gewünscht. Dabei ist bei Streiträllen, die nicht die Rechte und Pfichten Dritter beeinflussen, eine Schiedsregelung zu erwägen, die den Rechtsweg zum Gericht ausschließst.

6. Öffentlich-rechtliche grenzüberschreitende Vereinbarungen zwischen untergeordneten Behörden, vor allem solche, durch die Zweckverbände ins Leben gerufen werden, müssen von der Bevölkerung mitgetragen werden. Ein Fehlen der Einbezichung/des Einflusses der Bevölkerung kann dazu führen, daß diese Vereinbarungen auf lange Sicht Schifforuch erleiden. Die Tatsache, da.B z.B. der Gemeinderat bei einer kommunalen Zusammenarbeit zumindest der Errichtung eines grenzüberschreitenden Zweckverbandes zustimmen muß, reicht vielleicht noch nicht aus. Es muB eine meBbare Zustimmung des Volkes stattfinden, z.B. durch Referenda. Handelt es sich um weniger sichtbare Formen der Zusammenarbeit, etwa um offentlich-rechtliche Vereinbarungen über die Erteilung von Befugnissen mit Ermessensspiciraum, ist eine diesbezügliche Veröffentlichung Voraussetzung für Offenheit und Kontrolle durch die Bürger.

7. Da die Initiativen bezüglich einer grenzüberschreitenden Zusammenarbeit und damit auch die diesbezüglichen Formen und Variationen zunehmen, ist aus Kontinuitätsgründen eine Strukturierung der Zusammenarbeit (Wer ist mit was wie befaßt?) auf Dauer notwendig. Wildwuchs der grenzüberschreitenden Zusammenarbeit muß vermieden werden.

8. Da es für jede Form der grenzüberschreitenden Zusammenarbeit eine optimale GröBenordnung gibt, muß die angestrebte Form von Fall zu Fall bestimmt werden. Für eine gelegentliche Zusammenarbeit zwischen z.B. zwei aneinandergrenzenden Behörden ist in der Regel die Schaffung eines öffentlichen Zweckverbandes nicht erforderlich, vielmehr reicht hier zum Beispiel ein Kompetenzvertrag aus.

Für eine strukturellere Zusammenarbeit zwischen mehreren Behörden könnten grenzüberschreitende Zweckverbände gebildet werden, etwa durch Umformung der bestehenden Grenz-/Euregios. Da diese Grenz-/Euregios noch nicht sehr stark in das Bewußtsein der Bürger eingedrungen sind, müssen diese Zweckverbände im Prinzip an der Basis, also bei den Bürgern auf kommunaler Ebene, eingerichtet werden. Eine direkte Wahl des vertretenden Organs dieser Grenz/Euregios ist angesichts der vielen bestehenden Wahlen vielleicht nicht ohne weiteres wünschenswert. Die einzelnen gewählten Gemeinderatsmitglieder oder die Vertreter in den nationalen kommunalen Kooperations verbänden könnten den Grenz-/Euregiorat bilden. Die Vertretung kann z.B. anhand der Einwohnerzahlen bestimmt werden. In diesen kommunalen Kooperationsverbänden können höhere Behörden, z.B. in den Niederlanden die "Provincies" in Deutschland die Länder und in Belgien die "Gewesten/Gemeenschappew", als (ko. ordinierende) Beratungsinstanz auftreten. Eine vergleichbare Beteiligung von anderen (privatrechtlichen) Instanzen kann vorgesehen sein.

9. Eine Ordnung für eine Grenz-/Euregio, durch die diese über Zuständigkeiten verfügt, die Bürger und Behörden binden, impliziert eine Übertragung von Befugnissen der beteiligten Gemeinden. Da diese Form der Zusammenarbeit (auf der Grundlage des Benelux-Abkommens bzw. des deutsch-niederländischen Abkommens über dezentrale 
grenzïberschreitende Zusammenarbeit) zur Anwendung des innerstaatlichen Rechis der Teilnehmer führt, können Probleme im Zusammenhang mit der (unterschiedlichen) Aufsicht und dem (unterschiedlichen) Rechtsschutz entstehen.

Diese Divergenzen können auf drei Arten reduziert werden. In erster Linie kann eine Abstimmung (Koordination und Harmonisierung) der Aufsichts- und Rechtsschutzverfahren durchgeführt werden. Darüber hinaus geht die Entscheidung zugunsten der Anwendbarkeit eines nationalen Rechtssystems. Die Divergenzen könnten wahrscheinlich am stärksten durch die Schaffung einer eigenen rechtlichen Ordnung für die Grenz-/Euregio, unabhängig von der der teilnehmenden Behörden, aufgehoben werden. Diese eigene Ordnung impliziert den Wegfallen der (nationalen) Grenze innerhalb der Euregio. Da in diesem Fall die rechtliche Ordnung innerhalb der Grenz-/Euregio von der nationalen Ordnung abweicht, entsteht ein vergleichbares Divergenzproblem bei der Zusammenarbeit zwischen den Grenz-/Euregios und dem angrenzenden nationalen Gebiet. Letzteres gilt auch für die Zusammenarbeit zwischen Grenz-/Euregios untereinander, falls ihre rechtliche Ordnung nicht dieselbe ist. Bei der Anwendbarkeit eines nationalen Rechtssystems ist dies auch der Fall bei der Zusammenarbeit zwischen der Grenz-/Euregio und dem angrenzenden Gebiet des Staates des nicht anwendbaren Rechtssystems sowie zwischen Grenz-JEuregios untereinander, wenn sich die jeweiligen Rechtssysteme unterscheiden. Anders ausgedrückt: Dort, wo die Staaten zugunsten der Grenz/-Euregios Souveränität einbüßen, werden die heutigen nationalen Grenzen lediglich auf die Außengrenzen der Grenz-/Euregios verlegt. Die Entscheidung zugunsten einer eigenen rechtlichen Ordnung bzw. die Anwendung der nationalen Rechtssysteme hat in dieser Hinsicht demnach nicht so viel Sinn.

Falls (noch) nicht zu einer Übertragung von Befugnissen auf Grenz-/Euregios übergegangen wird, die die Bürger oder die Behörden binden, kann eine Zusammenarbeit mit einer vergleichbaren rechtlichen Reiclwweite bewerkstelligt werden, indem innerhalb der Grenz-/Euregios ad hoc Vereinbarungen über die Ausübung von Befugnissen gemacht werden, die danach "im eigenen Hause" von den teilnehmenden Behörden aufgegriffen und ausgeführt werden.

10. Die Finanzierung ist sücherlich ebenso wichtig für das Zustandekommen und Ausführen von öffentlich-rechtlichen Vereinbarungen (Schaffung der diesbezüglichen gesetzlichen Grundlagen). In diesem Zusammenhang muß die Interreg-Förderung, die die politische Bereitschaft zur Zusammenarbeit und den "Euregiogeist" unterstützt, gleichzeitig aber einen Beitrag der teilnehmenden Behörden erfordert, sicherlich noch einige Jahre aufrechterhalten werden.

11. Für das Zustandekommen won öffentlich-rechtlichen Absprachen zwischen belgischen, deutschen und niederländischen untergeordneten Behörden in der Euregio Maas-Rhein ist neben einer Abstimmung des Benelux-Abkommens und des deutschniederländischen Abkommens gleichzeitig ein vergleichbarer Vertrag zwischen Beigien und Deutschland erforderlich. 


\section{Summary}

\section{Public law transfrontier co-operation between local authorities Legal aspects of public law agreements between Dutch local authorities and their counterparts in Belgium and Germany}

\section{INTRODUCTION}

Many of the territories of Dutch local authorities - to be defined for this purpose as all governmental authorities below the national level - border directly on Belgium or Germany. The territories concerned involve more than half of the Dutch provinces, about one-eighth of the Dutch municipalities, approximately one-fifth of the Dutch water control corporations and more than one-third of the territorial communities created under the Wet gemeenschappelijke regelingen (Act on Public Law Cooperation between Local Authorities). Up to the present day, however, the provincial, municipal and regional authorities and their counterparts on the other side of the border have concluded virtually no public law agreements. The national borders apparently form an obstacle in this respect, as a reasonable degree of co-operation of a public law nature does exist within the individual countries themselves. Transfrontier co-operation between local authorities is predominantly established on an official and administrative scale and is, so to speak, of a factual nature. In this framework, transfrontier co-operation manifests itself at various administrative levels: between only a few municipalities, between a large number of municipalities and - possibly - provinces (border regions/Euroregions) and, at a higher interregional level, between Dutch provinces and (services of) Belgian Gewesten/Gemeenschappen (Districts/Communities), as well as German Länder (the States of the Federal Republic). In the past few years, an increasing number of crossborder initiatives have been launched in the field of public duties and powers.

This growing practice of transfrontier co-operation between local authorities and the increasing need for more far-reaching agreements in a legall sense already justify a more detailed investigation into the legal principles and the legal framework of this issue. For a number of other reasons, however, it is also (socially) important in this respect to give a description of the administrative powers for transfrontier co-operation and an indication of possible forms of such co-operation.

First and foremost, transfrontier co-operation between local authorities must be viewed from the perspective of internationalisation, due to the disappearance of the internal 
borders within the European Community. Transfrontier co-operation on public powers, established between the authorities most closely linked with the citizens, can particularly contribute to the development of a single Europe. Furthermore, in the context of the removal of frontiers, the local authorities in the border regions will become increasingly inter-dependent. To resolve any problems and to optimise administration, it may become necessary to comoperate with 'foreign' authorities. Consideration might, for instance, be given to jointly adopting plans and permit rules, but also to assigning the powers involwed to newly formed transfrontier associations. It seems quite possible that a process of institutionalisation will take place in the cross-border regions. The opportunity to establish far-reaching co-operation in (certain) policy areas may in particular expedite the creation of such cross-border regions and reinforce their internal and external position. The following should also be noted at this point. The legal scope of transfrontier co-operation does not yet extend beyond that of co-operation between the local authorities within the relevant countries. For instance, the Netherlands and Germany and, to a lesser extent, Belgium have legislation on co-operation between local authorities, allowing them to devolve public powers to newly created public entities, to give a mandate to neighbour municipalities to exercise public powers and to make other agreements within the framework of their discretionary powers. As this dissertation compares Dutch, German and Belgian laws on local authorities and co-operation between such authorities, it should be possible to determine whether or not the laws of these countries are similar and whether this similarity may promote (European) integration. Obviously, if the laws conform to each other, co-operation will be easier to achieve than if the legal systems are at variance. However, I believe that the (similarity of law as a possible catalyst of integration should not be overestimated. Similarities/distinctions in the fields of language, administrative culture, conflict of interest, etc., may infuence co-operation more than similarities/distinctions in legislation. On the other hand, if transfrontier co-operation is institutionalised and formalised (and, thus, if rules are adopted in this respect), this may contribute to a co-ordination of governmental policies and powers where it concerns bottlenecks and opportunities for border regions.

Establishing transfrontier co-operation is also important with a view to avoiding liability in the absence of such co-operation. Reference should be made to the "reflexive" effect of legislation. The Dutch courts have held that decision-making processes (especially in the field of environmental permits and plans) must take account of foreign effects and/or circumstances. In the light of this duty to protect foreign rights and interests, it seems sensible to achteve co-operation in advance in the form of mutual co-ordination (by means of agreements between authorities). This is to be preferred over any subsequent liability for or reversal of decisions on grounds of a lack of co-ordination. Making farreaching public law agreements particularly ensures the coming into being of obligations (not only rights) for foreign governmental authorities and citizens, among others. As it is, apart from the Dutch court decisions referred to above, there are several statutory provisions which expressly provide for co-ordination with foreign authorities.

The advantage of co-operation is, of course, that it is more efficient than actions undertaken (differently) by the individual authorities of their own accord or actions undertaken by one authority, but omitted by another. 


\section{DEFINTTION OF THE PROBLEM}

The legal regime governing the various possibilities open to local authorities to make transfrontier public law agreements is currently taking shape. The purpose of this dissertation is to provide an analysis of what is legaily possible (in terms of powers and legal framework) in making transfrontier public law agreements between Dutch local authorities and their counterparts in Belgium and Germany.

As concems local transfrontier co-operation, the key question can be described as follows:

Do Dutch local authorities have the power to make public law agreements with their counterparts in Belgium and Germany and, if so, what is the legal framework in which such public law agreements can manifest themselves?

Within the individual States, there are statutory bases for co-operation in the form of agreements which provide for (the assignment of) administrative and regulatory powers between local authorities. Indeed, co-operation between local authorities within the State is specifically regulated by domestic law: in the Netherlands by the Wet gemeenschappelijke regelingen, in Belgium by the Wet betreffende de intercommunales and the Wet houdende organisatie van agglomeraties en federaties van gemeenten and in the German federal states of North Rhime-Westphalia and Lower Saxony by the Gesetz iber kommunale Gemeinschaftsarbeit and the Zweckverbandsgesetz, respectively.

The major forms of public law agreements between authorities, indicated by the relevant domestic laws are:

- the creation of a new public corporation with regulatory andior administrative powers:

- the assignment of public powers from one governmental authority to the other (delegation of powers);

- the assigmment of the exercise of public powers from one governmental authority to the other (mandate).

Furthermore, public law agreements may consist of agreements which do not necessarily require a(n additional) statutory basis (apart from the freedom of contract under private law). Such agreements concern, e.g., agreements between authorities on the manner in which certain public powers are exercised or on the co-ordination of decisions, etc. Such agreements are often based on discretionary public powers. For that reason, I would like to define such agreements, especially as a delineation from private law agreements, as being of a public law nature. The relevant (organic) legislation and, in many cases, other (sector-related) legislation is usually confined to provisions on internal co-ordination and contains no sections on similar transfrontier co-operation between local authorities. The statutory forms of co-operation are territory-bound. If the relevant public law agreements cross the borders of the State, the requirement of a statutory basis becomes even more pertinent. There are, on an incidental basis, transfrontier co-operative powers for local authorities which are based on directives of the European Communities and international treaties. However, these directives generally - save for a few exceptions - contain obli- 
gations to enter into consultations. They do not provide for more far-reaching forms of co-operation, analogous to those set out in said domestic Jaws. The Netherlands and Belgium, as well as the Netherlands and Germany, have recently concluded treaties or transfrontier co-operation between local authorities. These treaties elaborate on the European Outline Conwention on Transfrontier Co-operation between Territorial Communities or Authorities (Madrid, 1980) drawn up by the Council of Europe. The objective of these treaties is to enable public law agreements between local authorities. The local co-operation between the Netherlands and Belgium has been regulated in the Benelux Agreement on Transfromtier Co-operation between Territorial Associations or: Authorities, Brussels, 1986 (Benelux Owereenkomst inzake grensoverschrijdende samenwerking tussen territoriale samenwerkingsverbanden of autoriteiten). As concerns local co-operation between the Netherlands and Germany, this is governed by the Agreement between the Kingdom of the Netherlands, the Federal Republic of Germany, the State of North Rhine-Westphalia and the State of Lower Saxony on Transfrontier Co-operation between Territorial Communities or Authorities, Isselburg-Anholt, 1991 (Overeenkomst tussen het Koninkrijk der Nederlanden, de Bondsrepubliek Duitsland, het Land Nedersaksen en het Land Noordrijn-Westfalen inzake grensoverschrijdende samenwerking tussen territoriale gemeenschappen of autoriteiten). Both treaties are of major significance in relation to the powers of local authorities and the legal framework for the conclusion of public law transfrontier agreements.

\section{SUMMARY BY CHAPTER}

The key question in Chapter 2 is whether sovereignty/territoriality implies that international law should govern the public law agreements which are made between local authorities on both sides of the border with respect to the delegation/exercise of public law powers. As explained in Chapter 2, international law only applies to transfrontier public law agreements involving an assignment of powers between local authorities (that is, powers which are binding on citizens and governmental authorities) insofar as this law allows the States to provide a legal basis for such agreements. Such a basis is mainly required for public law agreements under which powers are assigned to foreign authorities or newly created cross-border associations (having powers that are binding on citizens and governmental authorities). I believe, however, that public law agreements concerning $\mathrm{e} g$. discretionary powers or the establishment of consultative forums without any decision-making powers require no additional underlying treaty. Even if international treaties constitute the basis of concluding public transfrontier co-operation between local authorities, this does not imply that international law applies to (the contents of) the relevant agreements. The applicability of international law to transfrontier-cooperation between local authorities has been placed predominantly in a perspective of international administrative agreements. The legal status of these agreements must in principle be sought in international law and the requirements prescribed for the conclusion of treaties and the law governing such treaties. In general, the conclusion may be drawn that the (possible) applicability of national (public) law to international administrative agreements is more often the case. In other words: apart from treaties, other binding agreements can exist at the international level. 
Following the above line of reasoning, transfrontier co-operation of a public law nature between local authorities does not fit in with the constitutional systems governing external affairs. This ensues from the (local) level of government at which the authorities cooperate and from the fact that the authorities act within their local and regional, autonomous and sector-related powers, as well as from the fact that the (nutual) national laws apply to the transfrontier co-operation. On the other hand, it has been established in Chapter 6 that there is always a possibility that the central government reverses decisions of local authorities on the basis of their general administrative/constitutional powers of supervision. The ground for such a reversal will probably be a violation of law (the lack of any statutory basis) or an infringement of public and/or municipal interest rather than a violation of the constifutional prerogative of the central government in the field of external (international) affairs.

Chapter 3 is devoted to the role to be played by a number of European organisations with respect to transfrontier co-operation between local authorities and, particularly, to the provision of a legal basis for such co-operation. Particular attention has been paid to the weak legal basis of the European Outline Convention on Transfrontier Co-operation between Territorial Communities or Authorities drawn up by the Council of Europe. A supplementary Protocol is currently in preparation, providing for more extensive powers for local authorities in this respect. The Protocol will consequently conform to the rights acknowledged by the European Charter on Local Autonomy. The supranational nature of the European Communities has not yet resulted in the drafting of general EC rules governing transfrontier co-operation between local authorities. Such a general set of rules could be desirable, for instance in the light of the development of a single Europe at the very basis (close to the citizens) and the uniformization of local forms of co-operation (in the border regions) in the various Member States. At present, the European Communities mainly play a role in financing transfrontier co-operation and in respect of some weaker forms of co-operation (consultation, etc.) provided for in environmental directives. In this perspective, the minor role reserved for the local authorities is rather striking. Local authorities, though having significant environmental duties, seem to be missing the boat where it concerns transfrontier comoperation. Central government is the body explicitly mentioned (not only in the EC directives, but also) in international environmental treaties, for instance, the treaties concluded in the framework of the Economic Commission for Europe of the United Nations. Central government is also the body which must clearly indicate where and how they or their subordinate authorities are obliged to satisfy the provisions of the relevant treaties. The central authorities often, though not always justifiably, reserve the formal right to establish transfrontier co-operation. It is not always effectual to leave all matcers to the States Signatories (or, as concerns the European Communities, the Member States) if the performance of the treaties is left to the local authorities.

The role of the European Communities can be of particular significance where it concerns the harmonisation of substantive law, which is of extreme importance for transfrontier co-operation. However, the harmonisation of sector legislation will not be addressed in this dissertation. 
Chapter 4 gives a description of the organic laws with respect to Belgian, German and Dutch local authorities which are authorised to establish transfrontier co-operation. The organisation of these local authorities, as well as their (autonomous) powers, are mainly relevant ass an introduction to the issues addressed in Chapters 5 and 6 . It has been established that, at least at a municipal level, the distinctions in organic laws form no impediment to local co-operation between Belgian-Dutch and German-Dutch authorities. Neither do they form an impediment to co-operation for the Dutch provinces in the Dutch-Belgian relations. However, due to distinctions in powers under the sector legislation, inter-provincial transfrontier co-operation between Belgium and the Netherlands may pose some problems. Simillar problems exist with regard to co-operation between Dutch provinces and German authorities. In the framework of transfrontier co-operation, it is diffcult to determine the German equivalents of Dutch provinces.

The centrall issue of Chapters 5 and 6 is the national law dimension of ransfrontier public law agreements between local authorities. This national law dimension is much more obvious in this respect than the international law perspective (see Chapter 2). This ensues from the local government level at which co-operation is created, the munici$\mathrm{pal} / \mathrm{regional}$ subjects of co-operation, but especially the law that applies to the co-operation. The Benelux Agreement on transfrontier co-operation between local authorities has been applicable to the Netherlands and Belgium for more than two years (see Chapter 5). With respect to transfrontier comoperation between the Netherlands and Germany (North Rhine-Westphalia and Lower Saxony), this co-operation has been regulated since early 1993 by the German-Dutch Agreement on transfrontier co-operation between local authorities. Both agreements confer powers on lacal authorities to enter into transfrontier public law agreements. The forms of co-operation allowed on the basis of the Benelux Agreement - that is, the creation of a public corporation, a community body and administrative agreements - are more far-reaching, in terms of legal scope, than the forms of co-operation allowed on the basis of the German-Dutch Agreement - that is, the creation of a public corporation, a communiry body and public law agreements. For a number of issues, such as supervision, both agreements refer to the applicability of the domestic laws governing the participating authoricies. The relevant Benelux Agreement (almost completely) failed to consider the differences between co-operation in the Netherlands under the Wet gemeenschappelike regelingen and that in Belgium under the Wet betreffende de incercommunales. As co-operation on the basis of domestic law is decisive for transfrontier co-operation, the Benelux Agreement must be interpreted rather extensively to be able to meet the objective of the Agreement: providing a legal basis for transfrontier co-operation under public law.

The references to German and Dutch laws in the relevant German-Dutch Agreenent involve fewer problems in this respect. This is due to the fact that the domestic law of Germany (North Rhine-Westphalia and Lower Saxony) in respect of public law cooperation largely conforms to that of the Netherlands. Consequently, this factor compensates for the less far-reaching legal scope of the co-operation under the German-Dutch Agreement, if compared with the Benelux Agreement. 
However, there are several uncertainties and problems concerning the co-operation under the two agreements referred to above. For instance, contrary to the Benelux Agreement, the German-Dutch Agreement contains a specific conflict of laws provision (in the event of any disputes between the participating authorities) stating that an authority may only be ordered to perform any act or omission pursuant to a judgment of its own national court. "This results in references back-and-forth to the individual courts. In the GermanDutch Agreement, this problem is (partly) resolved by the option of drafting an informal dispute settlement arrangement (arbitration agreement) between the authorities. Although this conflict of laws provision has not been expressly incorporated in the Benelux Agree. ment, it will probably apply nevertheless, since it concerns a general rule of international law. It remains to be seen whether and to what extent the "supranational" Benelux Court of Justice can (partly) break this conflict of laws rule.

Other problems may arise from the accumulation of supervisory powers and from the extent to which the participating authorities are bound by the public corporation. In this perspective, co-operation will perhaps - certainly at the beginning - focus on non-binding decision-making processes or on agreements on discretionary powers.

Finally, the dissertation particularly describes the formal aspects of co-operation, that is, the power to co-operate and the legal framework in which this co-operation is to take place. It may, of course, be so that the substantive sector-related powers differ to such an extent that they preclude the making of public law agreements. In such cases, the sector-related legislation will have to be harmonised. This aspect is not discussed in further detail.

Chapter 7 contains a brief summary, some conclusions and recommendations on the powers to co-operate and the legal framework of this transfrontier co-operation, particularly where it concerns the conclusion of public law agreements between Dutch local authorities and their counterparts in Belgium and Germany.

In the light of the issues discussed and the social relevance of local transfrontier cooperation referred to in the introduction and, particularly, in view of the conclusion of public law agreements, I refer to the following recommendations.

1. To emphasise the domestic position and the significance of transfrontier co-operation between local authorities, the powers of the local authorities to conclude public law agreements with their counterparts on the other side of the border should be embedded in the Dutch constitution (and, preferably, provided for from a European perspective). The relevant provision should indicate that the legal framework is to be regulated in further detail in laws or treaties.

2. The position of local authorities with respect to transfrontier co-operation should be given a more fundamental basis, even apart from applicability under the Benelux Agreement and the German-Dutch Agreement. When exercising certain substantive powers, the local authorities (and not, by definition, the central government) should in principle be granted the related right to establish transfrontier co-operation. The 
role of local authorities should be enhanced especially where it concerns the drafting of treaties and directives of the European Communities.

3. Consideration should be given to an extension of the effect of the Benelux Agreement and the German-Dutch Agreement on transfrontier 00 -operation where it concerns the Gewesten/Gemeenschappen and the Lander, respectively. This should be possible in view of the recent constitutional revisions that have taken place in Belgium and Germany with respect to the conclusion of treaties.

4. In view of the references, included in the Benelux Agreement and the German-Dutch Agrement on transfrontier co-operation, to the applicable national laws of the states signatories and especially to the administrative supervision, more detailed provisions on co-ordination, particularly in the supervisory procedures, seem to be in order in both treaties.

5. In the light of the problems involved in confrontations between legal systems in the field of transfrontier co-operation, particularly with respect to the settlement of disputes existing between the participating authorities, a more clearly defined dispute settlement arrangement seems desirable. With respect to disputes not affecting the rights and duties of third parties, consideration may be given to an arbitration procedure, precluding the parties from initiating national court proceedings.

6. The conclusion of transfrontier public law agreements between local authorities, particularly such agreements which create public corporations, should be supported by the population. If the citizens are not involved or cannot exercise any influence on the agreements, the agreements may fail in the end. The fact that, for instance, municipal co-operation requires the consent of the Municipal Council for the establishment of a transfrontier public corporation may be insufficient in this respect. What seems necessary is the measurable consent of the people, e.g. by means of referendums. If the comoperation concerns less visible forms, such as public law agreements on the manner in which discretionary powers are exercised, publication is a precondition for openness and control by the citizens.

7. Since the initiatives in the field of transfrontier co-operation are increasing and, cortsequemtry, the rorms and variations of co-operation, it will be necessary in the end, for purposes of continuity, to structure the co-operation - who is doing what and how is this done. Proliferation of transfrontier co-operation should be avoided.

8. Since each form of transfrontier co-operation has its own optimal scale, the form to be chosen must be determined on a case-by-case basis. For instance, co-operation on an incidental basis between two neighbourly authorities does not require the creation of a public corporation, but can be settled by means of an agreement concerning the exercise of powers. More structural forms of co-operation between several authorities may be regulated by creating transfrontier public corporations (transformation of existing border regions/Euroregions. As the citizens have no real interest in border regions/Euroregions, these regions should be established at the basis, as close as possible to the citizens, at a municipal level. The idea of direct elections of the representative organ of the border region/Euroregion is maybe not the correct procedure, in view of the many elections already being held. The various, elected municipal councils or the representatives in the domestic municipal associations could form the council of the border region/Euroregion. Representation could be based on population. Higher authorities, for instance the Dutch Provincies, the German Lander and 
the Belgian Gewesten/Gemeenschappen, could act as (comordinating) consultative committees in the municipal associations. Moreover, ofher (private law) institutions could participate on a similar basis.

9. A regime for a border region/Euroregion with powers which are binding upon citim zens and/or authorities implies a transfer of powers by the participating municipalities. As this form of co-operation (under the Benelux Agreement and the GermanDutch Agreement, respectively) results in the applicability of the participants internal laws, problems may arise in connection with (divergent) supervisory powers and (divergent) legal protection.

This divergence can be limited in three ways. First, the parties may opt for co-ordination and harmonisation of supervisory and legal protection procedures. The choice to apply only one of the national legal systems would be one step further, but the most far-reaching method of limiting the divergence would be to create a separate legal regime for the border region/Euroregion, operating independently from the participating authorities. Such a separate regime would involve the non-applicability of the legal regimes of the participating authorities and, thus, the elimination of the (national) frontiers within the Euroregion. Since the legal regime of the border region/Euroregion would consequently deviate from the national regimes, an identical divergence problem would arise in the event of co-operation between the border region/Euroregion and the national neighbour area. This also applies to co-operation between more border regions/Euroregions with different legal regimes. If only one domestic legal system were to be applied, the same situation would occur in the event of co-operation between the border region/Euroregion and the adjacent territory of the State whose legal system is not applicable, or between several border regions/Euroregions who have different legal regimes. In other words, whenever States lose their sovereignty to border regions/Euroregions, the present national borders will merely be shifted to the outer frontiers of the border regions/Euroregions. Therefore, it seems rather useless to opt for a separate legal regime or to apply one of the national legal systems.

If powers binding on the citizens and/or the authorities have not (yet) been assigned to border regions/Euroregions, co-operation with a similar legal scope can be achieved by making ad-hoc agreements within the border region/Euroregion about the exercise of powers. These agreements can subsequently be assumed and performed in-house by the participating authorities.

10. Financing is just as important for concluding and performing public law agreements as is the provision of legal bases for the agreements. In this respect, the subsidies granted in the framework of Interreg, a programme which promotes the political willingness to co-operate and the creation of a "Euroregion spirit", but which also requires a contribution from the participating authorities, will have to be continued for at least a few more years.

11. The conclusion of public agreements between Belgian, German and Dutch local authorities in the Meuse-Rhine Euroregion not only requires co-ordination between the Benelux Agreement and the German-Dutch Agreement, but also the conclusion of a similar treaty between Belgium and Germany. 

Résumé

\begin{abstract}
Les cooperations transfrontalières de droit public entre autorités locales Aspects juridiques des accords de droit public entre les autorités llocales néerlandaises et leurs équivalents belges et allemands
\end{abstract}

\title{
INTRODUCTYON
}

Un grand nombre d'autorités locales des Pays-Bas partage des frontières avec les deux pays voisins, Beligique et Allemagne. Plus de la moitié des provinces néerlandaises sont concernées, soit près d'un huitième des communes du pays, plus ou moins un cinquième des "waterschappen" (entité néerlandaise chargée de la gestion des eaux) et un bon liers des domaines de coopération définis par la Wet Gemeenschappelijke Regelingen (loi néerlandaise fixant les modalités de coopération de droit public entre autorités locales). Jusqu'ici, on a pu relever peu d'accords de droit public entre les autorités provinciales, locales et régionales néenlandaises et leurs homologues belges et allemands. Les frontières nationales semblent constituer en l'espèce une barrière effective, alors que, au sein de chacun des trois pays concernés, de tels types de coopération font florès. A ce jour, les initiatives de coopération transfrontalière restent le fait de fonctionnaires et d'admimistrations et se traduisent souvent dans des coopérations de facto. Différents niveaux administratifs sont alors impliqués: coopérations entre quelques communes, entre un grand nombre de communes et les provinces (régions frontalières et eurégions) et, à un niveau interrégional administrativement plus élevé entre les provinces néerlandaises ê les Régions/Communautés belges ou les Luänder allemands. Ces dernières annés ont néanmoins connu, du moins dans la pratique, une multiplication des initiatives transfrontalières relevant des missions et des compétences publiques.

L'augmentation de ces coopérations transfrontalières et le besoin grandissant de les doter d'une stature juridique montrent l'intérêt d'une recherche plus avancée dans le domaine de leurs fondements juridiques et de leur cadre légal. II serait également d'intérết (public) de dresser l'inventaire des différentes formes que peuvent revêtir ces accords ainsi que des différentes compétences impliquées.

Tout d'abord, ill faut situer ces liens transfrontaliers établis entre autorités locales dans la droite ligne de l'abolition des frontières nationales au sein de la Communauté Européenne. La construction de l'Europe passe par ces accords portant sur les compétences de droit public passés entre les autorités qui sont les plus proches du citoyen.

Ensuite, cette même disparition des frontières européennes resserre encore les liens de dépendance entre les autorités des régions frontalières. Certains problèmes pourraient 
trouver une solution via une collaboration de droit public entre les autorités locales concernées et les autorités "étrangères". On évoquera bien sûr la possibilitể d'élaborer conjointement certains projets ou d'accorder de concert certaines autorisations, mais il pourrait être également question de transférer certaines compétences à des associations transfrontalières qui restent encore à créer. Les différentes "régions" à cheval sur les frontières pourraient un jour se voir attribuer le statut d'institutions de plein droit. Néanmoins, ce n'est que lorsqu'il sera possible de collaborer en profondeur dans certains domaines politiques qu'il sera êgalement possible de créer (plus vite) de telles entités et de leur donner une stature crếdible tant en leur sein que vis-à-vis de l'extérieur. A ce propos "il faut tenir compte de ce qui suit: la portée juridique des accords transfrontaliers en question reste bien en deçà du cadre légal des accords équivalents entre autorités locales dans chacun des trois pays. Ainsi, les Pays-Bas, l'Allemagne -et, dans une moindre mesure, la Belgique- se sont dotés d'une législation en matière de coopération entre autorités locales; celle-ci leur confère le droit de transférer des compétences de droit public vers des organismes publics restant à instituer, de confier lesdites compétences à des communes voisines ou de passer des accords relatifs à l'exercice des prérogatives discrétionnaires.

On trouvera dans le présent travail une comparaison entre les trois législations -néerlandaise, belge et allemande- en matière d'autorités locales et de coopérations de droit public entre ceux-ci. Fort du résultat de cette comparaison, il sera donc possible de constater l'éventuelle communauté de droit en l'espèce et de démontrer si celle-ci peut favoriser l'intégration au sein de la Communauté Européenne. Les parallèles entre les différentes législations ne peuvent que favoriser l'éclosion de coopérations, au même titre que les divergences entre les cadres légaux constituent autant d'obstacles pour celles-ci. Par ailleurs, nous pensons qu'il ne faut pas surestimer l'importance de l'identité entre les droits néerlandais, belges et allemands comme vecteur d'intégration. II est probable que les différences/ressemblances entre langues, cultures politiques, les conflits d'intérêts, etc., dictent plus les modalités de coopération transfrontalière que l'existence ou l'absence d'éventuels parallèles légaux. Par contre, c"est en donnant une stature formelle, institutionnalisée, à cette coopération (et partant en les normalisant via une réglementation) que l'on obtiendra une unité de vues, tant au niveau politique qu'au niveau des compétences à propos des points délicats soulevés par le dossier des régions frontalières.

Autre problème important lié à ces initiatives transfrontalières: le partage des responsabilités lorsque la coopération n'a pas lieu. Dans ce domaine, il importe de relever que certaines réglementations néerlandaises tiennent également compte des intérêts étrangers. La jurisprudence néerlandaise, par exemple, invite les autorités amenées à prendre des décisions en matière d'environnement (autorisations ou projets) à considérer les éventuelles retombées à l'étranger. Cette obligation de tenir compte et de protéger les intérêts et les droits des tiers au-delà des frontières nationales ne peut, bien évidemment, que rendre plus souhaitable tout effort d'entente préalable (par le biais d'accords entre les autorités des pays concernés). On préférera rechercher un compromis initial à devoir, en cas de désaccord ultérieur, établir a posteriori les responsabilités mutuelles ou réformer une décision prise. En cela, la seule possibilitě d'aller plus loin dans l'élaboration juridique desdits accords de clroit public permettrait de faire reconnaitre de plein droit, tant les droits que les obligations des autorités ou des citoyens des pays limi- 
trohpes. Le droit néerlandais contient en outre des dispositions légales prểvoyant explicitement la nécessité de parvenir à un consensus avec les autorités étrangères concernées. En outre, il est évidemment préférable de collaborer plutôt que d'agir indiwiduellement (diffêremment) ou de ne rien faire du tout.

\section{ProblématiQue}

Le cadre légal en matière d'accords de droit public transfrontaliers entre autorités locales est en train de se cristalliser. Le but de cette thèse est d'analyser les aspects juridiques (faculté de conclure des accords de droit public et cadre juridique de ceux-ci) de ces accords de droit public transfrontaliers entre les autorités locales néerlandaises et leurs pairs belges et allemands.

Au coeur de cette problematique, apparaît alors la question:

les autorités locales néerlandaises ont-elles la faculté de conclure des accords de droit public avec leurs pendants belges et allemands et, dans l'affimative, de quel cadre juridique relèvent ces accords de droit public?

Chacune des lois nationales préwoit les coopérations intra fines entre pouvoirs publics visant les (transferts de) compétences en matière d'administration et de réglementation. Ainsi, les autorités locales néerlandaises peuvent collaborer au sein du cadre légal défini par la Wet Gemeenschappelijke Regelingen. La Belgique, elle, s'est dotée d'une loi sur les intercommunales et d'une loi portant organisation des agglomérations et fédérations de communes. En Allemagne, les Länder de Rhenanie-Westphalie et de Basse-Saxe ne sont pas en reste avec, respectivement, le Gesetz über kommunale Gemeinschaftsarbeit et le Zweckverbandgesetz.

Les principaux accords de droit public de coopération entre autoritếs, conformément aux lois nationales des trois pays dont question, prennent donc une des formes suivantes:

- création d'un nouvel organisme public commun revêtu de compétences en matière d'administration ou de réglementation:

- transfert de compétences de droit public d'whe autorité à whe autré (délégation):

- transfert de l'exercice de compétences de droit public d'une autorité à une autre (mandat).

Pour certains types d'accords, le législateur n'a pas estimé nécessaire de prếvoir đe fondement légal (outre la libertê contractuelle qui est de droit privé). II s"agit, par exemple, d'accords portant sur l'exercice d'une compétence de droit public ou sur la coordination de décisions, etc. Ce type d'accords relève dès lors plutôt de pouvoirs discrétionnaires de droit public. Les besoins de ce travail et, plus précisément, la nécessité de délimiter un terrain de recherche pour cette étude des accords de droit public, ont amené l'auteur à examiner d'emblée cette dernière catégorie d'accords assimilés à des conventions de droit privé comme des accords de droit public proprement dit. En l'espèce, la législation (organique) -et souvent d'autres réglementations (sectorielles)- se limite en principe à fixer les coopérations internes et ne mentionne aucune possibilité d'établir des modes de coopération similaires entre autorités locales par delà les frontières. Les possibilités de coopération évoquées ci-avant restent limitées aux territoires nationaux. Aussi, chaque fois que les accords en question impliquent un passage de fron- 
tiêres, le besoin d'un cadre lëgal appropriế se fait d"autant plus cruellement sentir. A un autre niveau, certaines directives europénnes et certains traités internationaux attribuent aux autorites locales certaines compétences transfrontalières. Mais ces rểglementations wont rarement plus loin que l'obligation de consultation mutuelle: il n'y est pas question de modes de coopération similäres à ceux que prévolent les législations nationales. Récemment néanmoins, des traitếs de coopération décentralisếe ont vu le jour, unissant les. Pays-Bas à la Belgique, d'une part, et à l'Allemagne, d'autre part. On peut considérer ces documents une application pratique de la Convention-Cadre Européenne sur la Coopération Transfrontalière des Collectivités ou Autorités Territoriales (Conseil de l'Europe - Madrid 1980). L'objectif poursuivi est bel et bien de rendre possibles les accords de droit public entre autorités locales. Sont concernées:

a. pour les accords Belgique/Pays-Bas en matière de coopération décentralisée: la Convention Benelux concernant la Coopération Transfrontalière entre Collectivités ou. Autorités Territoriales (Bruxelles 1986);

b. pour les accords Allemagne/Pays-Bas en matière de coopération décentralisée: la Convention signée par le Royaume des Pays-Bas, la République Fédérale d'Allemagne, le Land de Basse-Saxe et celui de Rhénanie-Westphalie portant sur les coopérations transfrontalières entre communautés ou autorités territoriales (Isselburg-Anholt 1991).

Les deux conventions sont d'une importance capitale quant à la définition des compétences de droit public des autorités locales et au cadre juridique des échanges transfrontaliers.

\section{CONTENU DES CHAPITRES}

Le deuxième chapitre est principalement consacré à une problématique rếsultant du principe de souveraineté/territorialité: l'exercice/transfert des compétences découlant des accords transfrontaliers de droit public entre autorités locales relève-t-il du droit public international?

Ce chapitre établit que l'applicabilité du droit public international sur ces accords et ce, dans le cas où il y a transfert de competences (engageant citoyens et administration) entre autorités locales, se limite en principe à la possibilité qu'ont les états nationaux de leur donner un tondement juridique. Cette base légale est surtout nécessaire dans le cas de coopérations de droil public impliquant un transfert de compétences vers des autorités étrangères ou vers de nouveaux organismes publics encore à créer (et revêtus de compétences engageant citoyens et autorités). Il ne sera pas, par contre, nécessaire de réglementer via des traités les accords de droit public portant sur (l'exercice) des compétences discrétionnaires et sur la création de forums de concertation sans pouvoir décisionnel propre. L'existence de traités relevant du droit public international et posant les fondements d"accords transfrontaliers de droit public entre autorités locales, n'implique pas nécessairement 『'applicabillité du droit public international sur lesdits accords (ou leur contenu). Dans ce chapitre deuxième, l'auteur a surtout évoqué l'applicabilité du droit public international sur les accords transfrontaliers décentralisés dans le cas d'accords internationaux administratifs. Le statut juridique de ces derniers impliquera que l'on se tourne en principe vers le droit international en respectant les exigences en matière de 
signature de traités proprement dits et le droit qui leur est applicable. A ce propos, on pourrait vraisemblablement conclure qu'il serait plus souvent pertinent de remettre en question l'applicabilité du droit (public) national sur ces accords administratifs internationaux. En d'autres termes: sur le plan international, il existe d'autres moyens de conclure des accords obligatoires que les traités proprement dits.

Par conséquent, on pourrait, selon l'auteur, poser que la signature d'accords transfrontaliers de droit public entre autorités locales ne relève pas du dispositif constitutionnel en matière de relations extérieures (internationales). Nous en voulons pour preuve le niveau administratif (local) où se situe la coopération, le fait que les compétences concernées soient régionales ou locales, autonomes et sectorielles, et enfin que le(s) droit(s) natio. nal/aux solient d'application sur ces cooperations. D'autre part, il ne faut pas perdre de vue, cormme l'auteur l'évoque dans le chapitre 6, que le pouvoir central garde naturellement la faculté de casser des décisions prises par les autorités locales dans ce contexte et ce, dans le cadre de sa mission de contrôle administratif prévue légalement. La motivation d'une telle intervention serait la contrariété avec la loi (absence de fondements légaux) ou avec l'intêrêt public (ou communal) plutôt que la contrariété avec la primauté constitutionnelle de l'êtat en matière de relations extérieures (internationales).

Le chapitre trois est consacré au rôle joué par un certain nombre d'organisations européennes quant aux coopérations transfrontalières décentral isées et à l'établissement de leurs fondements juridiques. L'auteur y montre la faiblesse de la base juridique établie dans ce domaine par la Convention-Cadre Européenne sur la Coopération Transfrontalière des Collectivités ou Autorités Territoriales (Conseil de l'Europe). Un Protocole est actuellement en préparation qui offrirait aux autorités locales des possibilités juridiquement plus avancées; ce nouveau document serait conforme aux droits prévus par la Charte Européenne de l'Autonomie Locale. Les Communautés Européennes, malgré leur caractère supranational, n'ont pas encore établi de réglementation globale portant sur les accords transfrontaliers de droit public entre autorites locales. D'une part, dans l'optique d'une Europe plus proche du citoyen et, d'autre part, vu l'intérêt d'une uniformisation des procédures de coopération décentralisée (dans les régions frontalières des différents états-membres), on ne peut que souhaiter l'apparition d'une reglementation globale en matière d'accords transfrontaliers décentralisés. Du reste, la Communauté Européenne semble plutôt intervenir au niveau du financement des cooperations transfrontalières et dans le cadre de formes plus légères de coopération (concertation, etc.) comme c*est. régulièrement le cas pour les directives en matière d'environnement. A ce titre, le rôle dévolu aux autorités locales reste fort limité. II faut bien dire que, dans ce contexte, les autorités locales en général, si leur mission en matière d'environnement reste importante, n'en occupent pas moins les seconds rangs dès qu'il s'agit de coopểrations transfrontalières. En effet, ce sont les pouvoirs centraux qui sont explicitement cités dans les traités internationaux en matière d'environnement (outre dans les directives européennes) comme, par exemple, les traités signés dans le cadre de la Commission Economique pour l'Europe des Nations Unies et c'est également à eux que rewient de déterminer en quoi et comment ils s'engagent, eux et leurs administrations qui leur sont subordonnées, à respecter les dispositions desdits traitês. A cela s'ajoute que les pouvoirs centraux se réservent souvent, et selon l'auteur pas toujours à raison, la procédure d'établissement des accords transfrontaliers de droit public. Néanmoins, laisser aux mains des signataires 
des traités (pour la $\mathrm{CE}$, il s'agira des Etats-membres) la réalisation au niveau local desdits accords n'est pas toujours synonyme d'efficacité.

La Communauté pourrait remplir une fonction capitale en l'espèce, à savoir l'harmonisation du fond du droit, ce qui, dans le cadre des accords transfrontaliers, est de la plus haute importance. L'harmonisation de cette branche de la législation n'est pas discutée danis le présent ouvrage.

Le chapitre quatre explore la teneur des droits organiques belges, allemands et néerlandais en matière d"autorités locales possédant la facultê d"engager des coopérations transfrontalières. Ce portrait de l'organisation des autorités locales ainsi que de leurs compétences (autonomes) constitue avant tout une introduction nécessaire aux éléments développés dans les chapitres cinq et six. On peut y constater que, au niveau communal, les coopérations éventuelles entre Belgique et Pays-Bas et entre Pays-Bas et Allemagne ne devraient pas être entravêes par des différences entre les législations organiques nationales. Ill en va de même, au niveau provincial néerlandais, pour les relations unissant la Belgique et les Pays-Bas. Par contre, les différences de législation sectorielle en matière de compétences sont susceptibles de poser problème quant aux relations interprovinciales par delà la frontière belgo-néerlandaise. Il existe également des problèmes liés aux relations entre les provinces néerlandaises et les autorités locales allemandes. Dès qu'ill s'agit de nouer des accords transfrontaliers entre les Pays-Bas et la République Fédérale, on bute hélas sur la difficulté de trouver des équivalents allemands aux provinces néerlandaises.

Les chapitres cinq et six ont été entièrement consacrés à l'êtude de la dimension légalle nationale des accords transfrontaliers de droit public entre autorités locales. Cette dimension nationale tombe bien évidemment sous le sens, plus que la dimension internationale évoquée au chapitre deux, si l'on pense au niveau administratif décentralisé concerné, aux objets locaux/régionaux des cooperations dont question et au droit applicable en la matière. Les Pays-Bas et la Belgique se sont déjà dotés il y a deux ans de la Convention Benelux en matière de coopération transfrontalière entre autorités locales (chapitre 5). Le mểme type de relation transfrontalière mais, cette fois, entre les Pays-Bas et l'Allemagne (Rhénanie-Westphalie et Basse-Saxe) est couvert depuis le début 1993 par la convention mentionnée plus haut. Les deux conventions accordent aux autorités locales lles compétences nécessaires à la signature d'accords de droit public par delà les frontières. La Convention Benelux va juridiquement plus loin que la convention germanonéerlandaise quant aux formes que peuvent revêtir les coopérations (l'organisme public, l'organe commun et les accords administratifs), à savoir au niveau de l'organisme public, de l'organe commun et des accords de droit public. Les deux conventions renwoient au droit national des parties pour certains points de la coopération, par exemple en matière de contrôle. Cette mëme Convention Benelux ne tient peu, ou pas, compte des différences existant entre les modalités des accords intra fines régis, aux Pays-Bas, par la Wet Gemeenschappelijke Regelingen et, en Belgique, par la Loi sur les Intercommunales. Dans la mesure où les coopérations au sein de chacun des pays régies par le droit national servent souvent de modèles lors de l'établissement d'accords transfrontaliers, il s'agit de donner une interprétation "élargie" de la Convention Benelux, eu égard à son 
objectif réel, à savoir l'élaboration d"un fondement juridique pour les coopérations de droit public.

Dans le cadre de la convention germano-néerlandaise, le renvoi au droit national simplifie les choses vu la relative similitude entre le droit interne allenand (législation des Länder de Rhénanie-Westphalie et de Basse-saxe) et le droit néerlandais en matière de coopérations de droit public. Ceci compensant l'apparente réserve juridique de cette convention lorsqu'on la compare à la précédente.

Du reste, ces deux conventions ne résolvent pas tous les problèmes liés aux coopérations transfrontalières et certains points délicats y restent en suspens. C'est ainsi que, au contraire de la Convention Benelux, la convention germano-néerlandaise mentionne explicitement la règle de conflit de lois (en cas de litiges partageant les autorités engagées), règle qui prévoit qu'une autorité ne peut être condamnếe que par ses propres juges. Cette règle débouche souvent sur un va-et-vient de renvois entre juges. Le problème est (partiellement) résolu dans la convention en question en ce qu'elle prévoit la possibilité d'un règlement arbitral du litige entre les autorités concernées. Bien que cette règle de conflit des lois ne soit pas explicitement reprise dans la Convention Benelux, elle reste probablement d'application en ce qu'elle relève du droit public international. Il reste à voir si et dans quelle mesure la Cour de Justice "supra-nationale" du Benelux pourra dépasser en tout ou en partie cette règle de conflit de lois.

L'auteur évoque en outre les difficultés liées à l'accumulation des contrôles ainsi qu'au degré d'engagement au sein de l'organisme public des pouvoirs signataires de l'accord. C'est à ce titre que les éventuelles coopérations se concentreront peut-être d'abord sur des décisions impliquant un moindre engagement et ce, dans le cadre de forums de consultation, et sur des accords portant sur l'exercice des compétences discrétionnaires. Le lecteur aura donc trouvé dans ces deux chapitres une description de l'aspect formel de ce type de coopération transfrontalière, à savoir la compétence nécessaire pour conclure lesdits accords de droit public et le cadre juridique de ceux-ci. Il pourra évidemment s'avérer que les compétences matérielles concernées (sectorielles) soient tellement différentes que tout accord de droit public soit difficile à conclure; auquel cas, une harmonisation des réglementations sectorielles sera nécessaire. L'auteur a choisi de ne pas s'étendre plus avant sur cet aspect.

Le lecteur trouvera dans le chapitre septième: un bref résumé, quelques conclusions et recommandations quant à l'établissement des fondements et du cadre juridique des coopérations transfrontalières décentralisées, plus particulièrement en ce qui concerne les accords de droit public entre les autorités locales néerlandaises et leurs pairs belges et allemands.

Après avoir établi ce qui précède et rappelé dans l'introduction l'intérêt des coopérations transfrontalières décentralisées et plus particulièrement des accords de droit public dans ce cadre, l"auteur propose, pour conclure, les recommandations suivantes.

1. Afin de mieux asseoir la position et l'intérêt des pouvoirs locaux dans le cadre des coopérations transfrontalières décentralisées, les Pays-Bas (et ce, de préférence dans une perspective européenne) devraient se doter d'une caution constitutionnelle établ issant les compétences des autorités locales en matière d'accords de droit public avec 
leurs pairs étrangers; ledit texte devrait explicitement prếwoir que la conclusion desdits accords doit être régie soit par une législation, soil par des traités;

2. Il faut renforcer la position des autoritës locales en matiète d'accords transfrontaliers hors du cadre d'application de la Convention Benelux et de celle unissant Pays-Bas et Allemagne. Dans les domaines où ces autorités exercent certaines compétences matérielles, elles (et non le pouvoir central) doivent disposer des droits attachés à l"établissement de relations transfrontalières; il s'agirait donc, lors de la rédaction des différents traités et des directives européennes en la matière, d'insister plus sur le rôle des autorités locales;

3. Il faudrait examiner la possibilité d'étendre le champ d'application des conventions précitées (Benelux + Pays-Bas/Allemagne) en matière de coopération transfrontalière décentralisée awec, d'une part, les Régions/Communautés belges et, d"autre part, les Lănder allemands. La chose est aujourd'hui d'autant plus possible que tant la Belgique que l'Allemagne viennent de connaître des révisions de leur constitution en matière de conclusion de traités;

4. En matière de coopérations transfrontalières entre pouvoirs locaux, les deux conventions précitées renvoient également au droit national applicable à chacune des parties, plus particulièrement en ce qui concerne la fonction de contrôle administratif; ill s'agirait ici de prévoir des dispositions plus précises quant à la coordination et, assurément, aux procédures de contrôle;

5. Vu la problématique de la confrontation des différents systèmes juridiques en matière de coopérations transfrontalières, plus précisément dans les cas de litiges opposant les autorités concernées, il reste des progrès à accomplir dans le domaine du règlement de litiges. Pour les litiges sans influence sur les droits et devoirs de tiers, pourquoi ne pas prévoir une procédure d'arbitrage excluant l'intervention d'un juge national ?

6. La réalisation d'accords de droit public entre autorités locales et par delà les frontières (et plus particulièrement, la création d'un organisme public dans ce contexte) doit être supportée par la population. A long terme, aucune influence de l'opinion publique ne doit pouvoir mener au naufrage desdits accords. Le fait que, par exemple en cas de coopération au niveau communal, la création d'un organisme public à cheval sur les frontières doive être entérinée par le conseil communal n'est pas suffsant. Il s'agit ici de mesurer l'approbation de la population, par exemple, par le biais de consultations populaires. D'autres formes de coopération plus discrètes (par exemple, dans le cas d'accords portant sur l'exercice des compétences discrétionnaires) devraient néanmoins faire l'objet d'une publication par souci de transparence et afin d'être soumises au contrôle populaire;

7. Vu la multiplication constante des initiatives transfrontalières et vu la variété croissante de leurs formes, il deviendra rapidement nécessaire de garantir une certaine continuité en structurant les coopérations, en établissant qui fait quoi et comment. L'objectif avoué serait d'éviter une prolifération sauvage de ces accords.

8. La pertinence d'une forme de coopération est liêe à une logique d'échelle; c'est pourquoi la forme optimale devra être choisie au cas par cas. Pour des coopérations occasionnelles entre, par exemple, deux autorités locales voisines, la création d'un organisme public n'est pas nécessaire; il leur suffira d'établir une convention fixant les modalités d'exercice des compétences mutuelles. 
Des accords à portée plus structurelle entre plus de parties différentes entraîneront probablement la création d'organismes publics transfrontaliers (mutation des régions frontalières/eurégions actuelles). Puisque ces entités, eurégions et consorts, ne sont pas encore vécues au quotidien par les citoyens, leurs nouvelles formes devront être créées tout près du citoyen, c'est à dire, au niveau communal. L'électeur étant déjà si souvent sollicité, il n'est peut-être pas souhaitable de constituer l'organe de représentation de cette eurégion exclusivement par le biais d'élections directes. Les divers élus des conseils communaux ou les représentants nationaux des associations d'inté rêts communaux pourraient constituer le conseill de l"eurégion concernée. La représentation pourrait $y$ être proportionnelle au nombre d"habitants. Les institutions supérieures (aux Pays-Bas, les provinces, en Allemagne, les Länder, en Belgique, les Communautés/Régions) pourraient intervenir à titre consultatif. Il pourrait en aller de même pour une représentation d'autres instances (de droit privé);

9. L'existence d'une eurégion revêtue de compétences de droit public engageant autorités ou citoyens implique un transfert de compétences de droit public au départ des communes signataires de l'accord. Ce type de coopertation (basé sur les deux conventions -Benelux et Pays-bas/Allemagne- décrites plus haut) induisant l'applicabilité des droits internes à l'accord, des problèmes peuvent surgir en cas de divergences en termes de contrôle et de protection des droits des parties ou des tiers.

On peut pallier, ou téduire, ces divergences de trois manières différentes. Les signataires peuvent d'abord essayer de $s^{\prime}$ accorder (coordination et harmonisation) sur des procédures de contrôle et de protection des droits des parties ou des tiers. Ils peuvent ensuite opter pour la législation d'une des parties applicable à leur accord. Le moyen le plus sûr de réduire ces divergences à leur portion congrue serait évidemment la création d'un régime légal propre à l'eurégion et indépendant des régimes légaux des parties. Donc, ce régime légal propre, en induisant la caducité des législations dont dépendent les autorités signataires, induit la disparition des frontières (nationales) au sein de l'eurégion en question. Mais, apparaît alors une nouvelle source de divergences, à savoir la différence entre le régime légal propre à l'eurégion et celui/ceux des parties signataires avec qui l'eurégion peut être amenée à collaborer. Idem, dans le cas de coopérations réunissant des eurégions dont les régimes légaux diffèrent. En cas de choix du régime légal d'une des parties applicable à la coopération, le problème se pose à nouveau entre l'eurégion et l'entité territoriale voisine, si cette dernière failt partie de l'état dont le régime légal n'a pas été retenu pour l'accord; le problème est similairement posé entre eurégions dont les régimes légaux applicables diffèrent. En d'autres termes: lorsque les états nationaux perdent leur souveraineté au profit des eurégions, les frontières nationales initiales sont déplacées pour correspondre aux frontières extérieures de l'eurégion concernée. Dans cette perspective, le choix du système juridique d'une des parties ou d'un système propre devient moins nécessaire. Au cas où on ne procède pas (dans un premier temps) au transfert vers l'eurégion de compétences engageant citoyens et autorités, la coopération peut avoir une teneur juridique similaire si, au sein de l'eurégion, des dispositions conjointes sont prises visant à l'exécution des compétences en question et laissant aux autorités signataires de l'accord le soin d'exercer "chez elles" lesdites compétences de droit public. 
10. Dans le cadre de la conclusion d"accords de droit public entre les autorités locales belges, néerlandaises et allemandes de l'eurégion Meuse-Rhin, un traité signé par la Belgique et l'Allemagne serait également souhaitable, outre la réelle nécessité dharmoniser la Convention Benelux et la convention germano-néerlandaise précitées.

11. Le financement de ces coopếrations est assurément aussi important que les fondements juridiques ếwoqués cî-avant. Il faudra, à ce propos, continuer pendant quelques annees encore à subsidier ces accords via lnterreg, promoteur de ces initiatives transfrontalières et soutien actif de l'esprit eurégional, qui, il ne faut pas l'oublier, exige une participation financière des autorités prenant part à ces échanges. 


\section{Curriculum vitae}

René Seerden werd op 8 mei 1962 te Heell geboren. Na afronding van het gymnasium aan de Scholengemeenschap St. Ursula te Horn (1980), heeft hij Nederlands Recht, met als specialisatie het staats- en bestuursrecht alsmede het sociaal recht, gestudeerd aan de Rijksuniversiteit Utrecht (1986).

$\mathrm{Na}$ enige tijd als juridisch medewerker te hebben gewerkt bij de gemeente Weert, is hij per 1 oktober 1987 in dienst getreden als assistent in opleiding bij de vakgroep Publiekrecht, Faculteit der Rechtsgeleerdheid Rijksuniversiteit Limburg. Gedurende zijn assistentschap heeft hij onderzoek gedaan in Brussel, Den Haag, Straatsburg en Edinburgh. Gedurende de jaren 1986-1990 was hij lid van de gemeenteraad van Heel. Sinds 1990 is hij aan de Rijksuniversiteit Limburg verbonden als universitair docent in het recht, in het bijzonder het staats- en bestuursrecht. Hij houdt zich wooral bezig met onderzoek en onderwijs in het milieurecht. 